\title{
LA INVISIBILIDAD DEL PRESENTE PRÁCTICAS ARTISTICAS Y ESPACIOS VIRTUALES EN LA ÉPOCA DE LA WEB 2.0
}

Presentada por:

José Luis Ortega Lisbona

Dirigida por:

Emilio José Martínez Arroyo

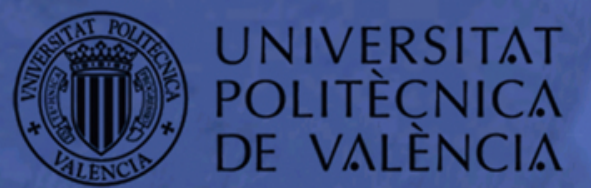

Valencia, noviembre de 2018

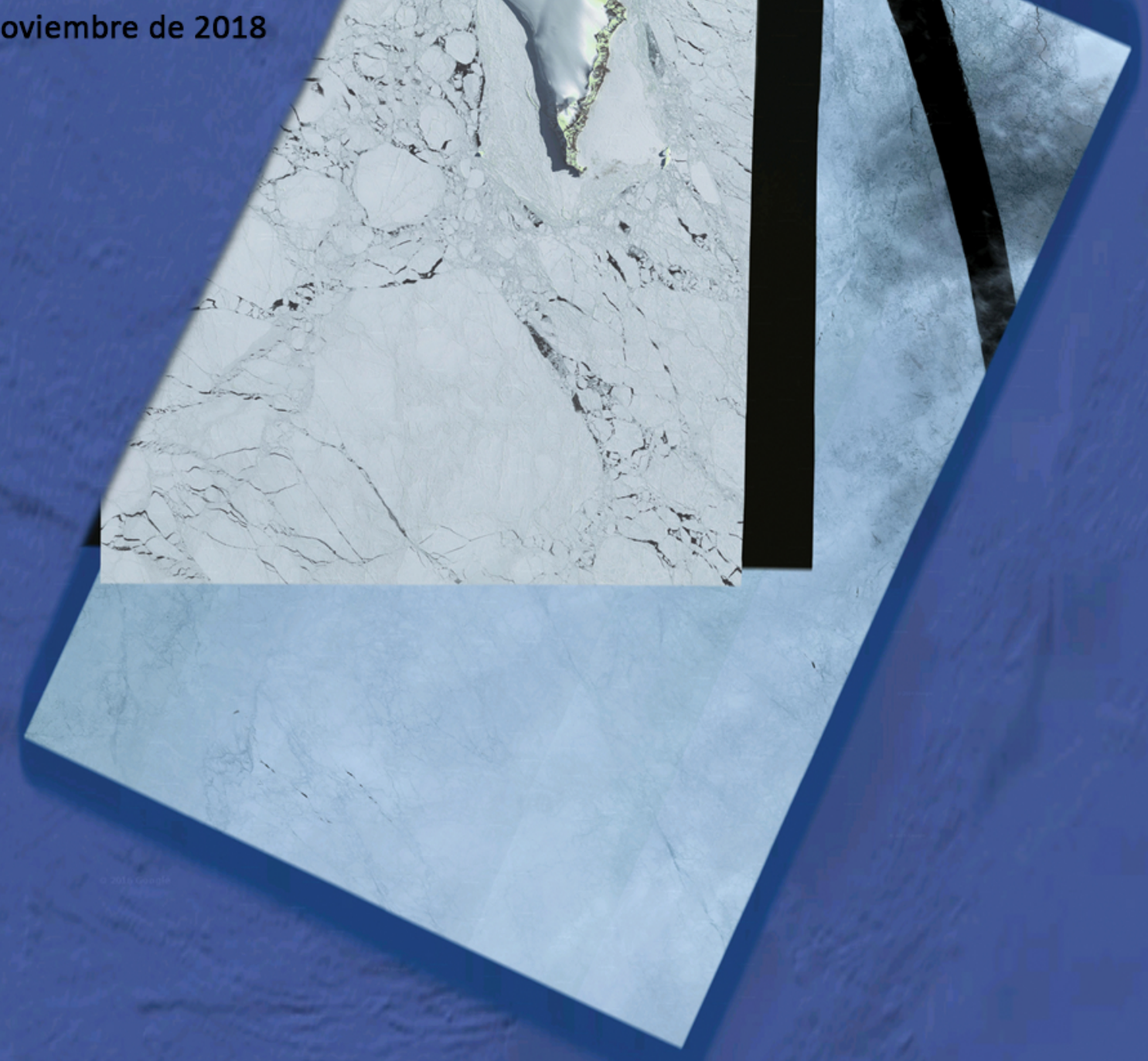




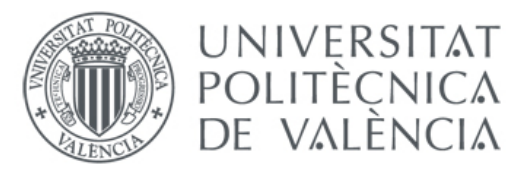

Facultad de Belles Arts de Sant Carles

Departament d' Escultura

Programa de Doctorado en Arte: Producción e Investigación

TESIS DOCTORAL

\title{
LA INVISIBILIDAD DEL PRESENTE:
}

PRÁCTICAS ARTISTICAS Y ESPACIOS VIRTUALES EN LA ÉPOCA DE LA WEB 2.0

\author{
Presentado por: \\ José Luis Ortega Lisbona
}

Dirigida por:

Emilio José Martínez Arroyo

Valencia, Noviembre de 2018 
"Nuestro destino nunca es un lugar, sino una nueva forma de ver las cosas".

Henry Miller. Big Sur y las naranjas del Bosco, 1957.

"Todo lo que escuchamos es una opinión, no un hecho. Todo lo que vemos es una perspectiva, no es la verdad".

Marco Aurelio, Meditaciones, 170-180 d. C.

Agradezco de manera especial a mi familia, amigos y pareja, sin cuyo apoyo, entendimiento y comprensión no hubiera sido posible la realización de esta investigación.

Agradezco también al Departamento de Escultura de la Universitat Politècnica de València por su ayuda.

Agradezco a los componentes del Grupo de Investigación Laboratorio de Luz por su gran dedicación y apoyo.

Agradezo a mi director y tutor Emilio José Martínez Arroyo por su comprensión y paciencia durante estos años de trabajo.

Esta Tesis Doctoral está dedicada a todos aquellos que aún en tiempos culturalmente precarios deciden realizar esta ardua tarea. 


\section{RESÚMENES}

Español: La presente Tesis Doctoral nos plantea un escenario evanescente e incoherente para nuestros sentidos, dentro del cual interrogarnos sobre las formas de intervención artística en aplicaciones y tecnologías de la Web 2.0. La práctica artística siempre ha tenido la capacidad de alterar los códigos y signos de las estructuras de poder para tergiversarlas y reinterpretarlas. Por otro lado, el artista como explorador de los entornos tecnológicos más novedosos es capaz de asociar cambios externos con sus consecuencias internas, de manera que alcanza a atisbar como somos modelados por nuestras propias tecnologías. Esta tesis analiza, mediante la práctica artística el funcionamiento, la estructura, el contenido y el impacto de estos medios, poniendo especial atención en su funcionamiento y uso dentro de la esfera pública, con la intención de dilucidar cual es el papel del artista dentro de este entorno mediático cada vez más complejo y cotidiano. Mediante este estudio se pretende profundizar sobre la verdadera dimensión social y cultural de la red, a la vez que se genera una completa investigación sobre como la práctica artística es capaz de reinterpretar las nuevas características y configuraciones de este medio.

Valencià: La present Tesi Doctoral ens planteja un escenari evanescent i incoherent per als nostres sentits, dins del qual interrogar-nos sobre les formes d'intervenció artística en aplicacions i tecnologies de la Web 2.0. La pràctica artística sempre ha tingut la capacitat d'alterar els codis i signes de les estructures de poder per a tergiversar-les i reinterpretar-les. D'altra banda, l'artista com a explorador dels entorns tecnològics més nous és capaç d'associar canvis externs amb les seues conseqüències internes, de manera que aconsegueix a aguaitar com som modelats per les nostres pròpies tecnologies. Esta tesi analitza, per mitjà de la pràctica artística el funcionament, l'estructura, el contingut i l'impacte d'estos mitjans, posant especial atenció en el seu funcionament i ús dins de l'esfera pública, amb la intenció de dilucidar quin és el paper de l'artista dins d'este entorn mediàtic cada vegada més complex i quotidià. Per mitjà d'este estudi es pretén aprofundir sobre la verdadera dimensió social i cultural de la xarxa, al mateix temps que es genera una completa investigació sobre com la pràctica artística és capaç de reinterpretar les noves característiques i configuracions d'este mig.

English: This Doctoral Thesis presents us with an evanescent and incoherent scenario for our senses, in which we wonder about the forms of artistic intervention in Web 2.0 applications and technologies. Artistic practice has always had the ability to alter the codes and signs of power structures in order to distort and reinterpret them. On the other hand, the artist as an explorer of the most state-of-the-art technological environments is able to associate external changes with their internal consequences, so that he can see how we are modeled by our own technologies. This thesis analyzes, through artistic practice, the functioning, structure, content and impact of these media, paying special attention to their functioning and use within the public sphere, with the intention of elucidating which role the artist assumes within this media environment as its degree of complexity is increasingly growing every day. The aim of this study is to deepen the true social and cultural dimension of the network, while generating a complete research on how artistic practice is able to reinterpret the new characteristics and configurations of this medium. 


\section{ÍNDICE}

INTRODUCCIÓN

Objeto de estudio. Pág. 7

Hipótesis. Pág. 8

Objetivos y preguntas de la investigación. Pág. 10

Metodología. Pág. 13

Marco teórico. Pág. 14

\section{CAPÍTULOS}

PARTE 1 TEORÍA

\section{DE LA CONTRACULTURA A LA WEB 2.0}

1.1. De la contracultura a la cultura hacker. Pág. 20

1.2. Las lógicas de la web 2.0. Pág. 38

\section{LA ECOLOGÍA DE LOS MEDIOS}

2.1. Precedentes desarrollo y nuevas fronteras. Pág. 53

2.2. Punto de vista de retrovisor. Pág. 60

2.3. El Anti-Medio. Pág. 66

2.4. Arqueología de los medios. Pág. 70

2.5. Narcosis Narciso. Pág. 74

2.6. Un arte de los medios de comunicación. Pág. 78

\section{TRABAJO Y BIOPOLÍTICA EN LA RED}

3.1 Capitalismo cognitivo. Pág. 83

3.2 General Intellect. Pág. 88

3.3 El trabajo inmaterial. Pág. 92

3.4 El Trabajo digital. Pág. 96

3.5 El usuario como productor. Pág. 101

3.6 Neuroplasticidad. Pág. 107 


\section{IDENTIDAD Y SUBJETIVIDAD EN RELACIÓN A INTERNET}

4.1 Del ser al actuar. Pág. 112

4.2 Texto, ficción e identidad. Pág. 121

4.3 Identidades multiusos. Pág. 141

4.4 Anonimato vs persistencia. Pág. 148

4.5 Medios sociales, branding e identidad. Pág. 154

PARTE 2 OBRA

5. METOdOLOGÍA ARTíSTICA: EXPLORACIÓN, REFLEXIÓN, INTERVENCIÓN Y MATERIALIZACIÓN

5.1. El artista como explorador mediático. Exploración. Pág. 165

5.2. Reflexión sobre las aplicaciones de la web 2.0. Reflexión. Pág. 171

5.3. Tácticas de intervención en la esfera pública. Intervención. Pág. 176

5.4. Intervención en espacios virtuales. Materialización. Pág. 185

6. OBRA PERSONAL: ENSAYOS EXPERIMENTALES.

6.1. Estructura praxis. público-privado, real-virtual, local global. Pág. 195

6.2. How we can make each other better? Pág. 202

6.3. El paisaje de la multitud. Pág. 245

6.4. Google me. Pág. 266

6.5. Neogeografías. Pág. 298

6.6. Eco. Pág. 334

6.7. Paisajes subjetivos. Pág. 357

CONCLUSIONES Español - English Pág. 387

BIBLIOGRAFÍA Pág. 420

ÍNDICE DE FIGURAS Pág. 432 
INTRODUCCIÓN 


\section{OBJETO DE ESTUDIO}

Esta investigación se ubica en una época en la cual la virtualidad en la cual desarrollamos gran parte de nuestra existencia se ha transformado en una de las dimensiones de nuestra realidad, convirtiéndose en una de las cualidades más notables de esta. Vivimos nuestra cotidianidad mediante la red, generando una relación ininterrumpida. Debido a esta conexión permanente, nos conformamos como seres que se definen por sus redes y la manera mediante la cual estas se han desarrollado y funcionan.

Los modelos mediáticos basados en las lógicas de la Web 2.0 han tomado un papel hegemónico dentro de la red, en detrimento de modelos autogestionados, dando origen a nuevas utopías basadas en el individualismo en lugar de en la colectividad. Esto ha conformado aplicaciones que son un intermediario entre el usuario y la experiencia vivida en Internet, gestionando nuestros datos y preferencias mediante un sistema que delega y extiende muchas de nuestras capacidades. Las actividades relacionadas con lo social se han transformado en un elemento productivo, mientras que la creatividad se mueve en el ámbito de lo afectivo. Nos movemos en una continua insatisfacción, pese a las grandes cantidades de información que recibimos diariamente y lo omnipresente de estas tecnologías en el ámbito de nuestra vida diaria. Los datos se han posicionado como el elemento que nos construye dentro de la red, pero que también nos disuelve, de manera que podemos ser analizados, modelados y rentabilizados por estas tecnologías.

Este macromedio, que paulatinamente ha fagocitado la mayor parte del resto de medios, ha pasado a ser parte fundamental de la manera mediante la cual percibimos nuestra realidad, nos representamos y conformamos nuestra subjetividad. Debido a la vertiginosa aparición de nuevas tecnologías que actúan como prótesis y extensiones de nuestra propia existencia, se ha planteado como una emergencia el discernir como estas distorsionan nuestra percepción, cambiando la manera en la cual percibimos nuestro entorno, a nosotros mismos, así como nuestros valores y actitudes. El ser humano tiene la capacidad de moldear sus propios métodos de comunicación, sin embargo paradójicamente permanecemos inconscientes ante el efecto moldeador que estos medios producen sobre nosotros mismos. 
Dentro de este escenario las tecnologías de la información y la comunicación se han erigido como fuentes fundamentales tanto de los cambios sociales como de la hegemonía cultural. Esta hegemonía tiene la capacidad de modelar e internalizar ideas y lógicas dominantes. La relación entre comunicación y poder se ha desarrollado dentro de un entorno mediático en el cual señales, emociones y sentimientos generan decisiones que confirman lo que sentimos y queremos que pase, ignorando el pensamiento o el debate racional como herramientas emancipatorias. Estamos ante tecnologías que configuran la manera en la cual vivimos, producimos y consumimos, siendo el núcleo tecnológico que articula la sociedad. Este tipo de redes han roto la relación jerárquica clásica que los medios de comunicación de masas establecieron entre autor y público para crear nuevas condiciones de recepción y producción cultural. Este es pues, un magma de aportaciones múltiples y creación colectiva que se desarrolla paralelamente a la creación social permitiendo la producción, el intercambio y la remezcla. Este tipo de aplicaciones se han convertido en herramientas capaces de movilizar una fuerza de trabajo intelectual en manos de una gran masa de usuarios. Esto nos habla de un nuevo estadio del capitalismo que supera al industrial en forma de como defiende Manuel Castells, una economía global de carácter informacional.

\section{HIPOTESIS}

La invisibilidad del presente nos plantea un escenario evanescente e incoherente para nuestros órganos perceptivos, generando conocimientos e informaciones en base a tecnologías que han tomado la misión de seleccionar, clasificar y publicar lo que consideramos como cierto y verídico. Como podemos observar desde la aparición de las tecnologías sociales deudoras de las lógicas de la Web 2.0., vemos el mundo a través de lo que es filtrado por otros usuarios, percibiendo su propia narrativa particular, y por lo tanto el relato que estos construyen en base a su trabajo dentro de estos medios. Podemos compartir hechos externos conectados con nuestra vida diaria o nuestra propia vida en si misma. Esto está disolviendo las barreras entre lo público y lo privado, lo real y lo virtual y lo local y lo global. El primigenio concepto de esfera pública conceptualizado por Jürgen Habermas parece haber perdido sentido ante unas tecnologías que desarrollan flujos de información que fragmentan nuestra atención y ante las cuales delegamos nuestro criterio y discernimiento. 
Del mismo modo, este tipo de aplicaciones, convertidas en servicios gratuitos, han conseguido rentabilizar nuestras prácticas cognitivas y afectivas, de manera que nuestra producción sirve como combustible de un sistema que explota nuestra fascinación por crear, más allá de cualquier intencionalidad artística o rédito económico. Para Theodor Adorno y Max Horkheimer, la industria cultural presenta las necesidades que esta misma puede satisfacer, para transformar al ser humano en consumidor y al arte en consumo. Hoy en día podemos afirmar que es la propia creación la que es puesta en manos del gran público para poner en funcionamiento una nueva industria, cuyas lógicas se basan en la creación colectiva amateurizada y gratuita. Por otro lado, nuestros propios datos se han transformado en un producto que es fácilmente recolectable y analizable por este tipo de corporaciones, bien para trazar patrones que predigan nuestras necesidades, o como producto puesto a la venta a terceros. Esto demuestra como cuerpos de datos paralelos son creados en base a nuestra actividad, conformando dobles virtuales generados por nuestro rastro y actuar dentro de la red.

El ser humano tiene la capacidad de moldear sus propios medios tecnológicos, sin embargo, permanecemos inconscientes ante la influencia que estos medios desarrollan sobre nosotros. Esta tesis pretende, mediante el estudio de la estructura, el contenido e impacto de estos medios, discernir como alteran nuestros patrones cognitivos, perceptivos, e identitarios, determinando una percepción y subjetividad generada en base a la interacción con este entorno mediático. La revolución de Internet ha hecho mas evidente que nunca la importancia del medio, o en este caso de la amalgama de medios que actúa como el medio de nuestro tiempo. Esto generó el súbito resurgir paralelo de la figura del teórico Marshall McLuhan, tras su reinterpretación en clave digital. La comprensión de nuestro entorno tecnológico y sus consecuencias psíquicas y sociales se han convertido en parte de una cartografía que sirve para trazar un nuevo terreno en base a viejos puntos de referencia, una mirada al pasado que nos ayuda a mirar al futuro. El propio McLuhan vino a definir este estado de inconsciencia mediante diferentes metáforas y síndromes. Debido a esto, el ser humano no es consciente de los efectos que sus tecnologías ejercen sobre si mismo. Esto nos hace plantearnos una vuelta a la conciencia sobre la realidad mediática, al conceptualizar la tecnología como extensiones de nuestros propios cuerpos, vinculando lo exterior con sus efectos internos en el ser humano. Una de las cuestiones que han motivado esta investigación es la de dirimir la manera en la cual las estructuras mediáticas definen nuestro concepto de nosotros mismos y las representaciones individuales que 
realizamos alrededor de nuestra propia identidad en la red. Sin duda estamos ante un escenario que debe ser escrutado para discernir los mecanismos que intervienen en dichas representaciones.

\section{OBJETIVOS Y PREGUNTAS DE LA INVESTIGACIÓN}

Esta investigación pretende, mediante el estudio de las tecnologías de las aplicaciones de la Web 2.0., estudiar su funcionamiento y uso dentro de la esfera pública, y dilucidar cual es el papel del artista dentro de este entorno mediático cada vez más complejo y penetrante. Mediante este estudio se pretende profundizar sobre la verdadera dimensión social y cultural de la red, a la vez que se genera una completa investigación sobre las nuevas características y configuraciones de este medio. El hecho de recorrer la red se ha convertido en una actividad introspectiva que transforma nuestro paisaje mediático. Se trata de la red transformada en nuestra naturaleza exterior, que hace ya años se ha convertido en parte de nuestra exterioridad. Es dentro de este escenario donde el artista explora las consecuencias del uso social de estas tecnologías en base al comportamiento de los usuarios, su manera de crear y compartir a través de las redes, y la creación de nuevos símbolos y lenguajes provenientes de las comunidades en línea. Por tanto, el análisis de la propia cultura generada dentro de la red es también un análisis de los propios medios y de la forma en la cual estos delimitan la manera en la que esta se desarrolla.

Del mismo modo, durante el desarrollo de esta tesis doctoral nos interrogaremos sobre las formas de intervención artística en aplicaciones y tecnologías de la Web 2.0. Las prácticas artísticas primigenias asociadas a Internet fueron rápidamente absorbidas por las instituciones artísticas, sin embargo, los cambios tecnológicos constantes acaecidos alrededor de las tecnologías de Internet nos presentan un escenario diferente en base a las nuevas lógicas y características tecnológicas, así como modelos de negocio. Es por ello necesario estudiar la manera en la cual estos cambios han modificado el modo en el cual podemos desarrollar prácticas artísticas alrededor de estas tecnologías tan ostensiblemente fluidas. La propia modificación y rápida obsolescencia de este tipo de aplicaciones hacen necesario generar un análisis que considere características comunes en las mismas, posibilitando un estudio que aunque se centra en casos concretos nos muestre fenómenos significativos de modelos mediáticos de carácter hegemónico. Por lo tanto, los casos de estudio presentados aquí deberán ser modelos que podamos 
considerar representativos del tipo de tecnologías y aplicaciones que han colonizado nuestra cotidianidad de manera sigilosa ante las grandes ventajas que su uso gratuito nos plantea.

Por otro lado, se pretende esclarecer de que manera las aplicaciones de la Web 2.0 han afectado a los patrones de producción cultural, así como su impacto dentro de la industria cultural y nuestra labor como creadores y consumidores. Así mismo, las nuevas formas de trabajo desarrolladas en base a estas tecnologías son un elemento de estudio que esta investigación pretende abordar, ante la gran trascendencia para nuestra labor como trabajadores ubicados dentro de la propia cultura, y la completa fusión que la red ha protagonizado con nuestra cotidianidad. También se pretende esclarecer como esta conexión contante unida a los flujos de información han generado una disonancia perceptiva que fragmenta nuestra atención en base a la aceleración constante y desequilibro temporal que estas tecnologías causan. El fluir comunicativo en el cual vivimos inmersos ha causado que los productos culturales que creamos escapen de nuestras manos, mientras que son terceros los que les sacan rédito. Las nuevas tipologías de creación, que aúnan también prácticas de consumo, deben ser analizadas para dilucidar las consecuencias de este tipo de actividad creativa inherente a las redes, que ha terminado por colonizar grandes espacios de nuestra vida diaria, proponiendo nuevas formas de crear y compartir, pero también relaciones de trabajo gratuito y amateurizado.

Precisamente, como consecuencia de las características incisivas y ambientales de estos medios, esta investigación pretende discernir de que manera las aplicaciones de la Web 2.0. transforman nuestra cognición y percepción, alterando la manera en la cual percibimos nuestro entorno, así como a nosotros mismos, haciendo especial hincapié en los procesos identitarios que tienen lugar en este tipo de espacios virtuales. Esto resulta especialmente necesario debido a el exorbitante desarrollo de aplicaciones basadas en el desarrollo de actividades conectadas con lo social y que son paradigmáticas de los modelos desarrollados en base a las características de la Web 2.0. Este escenario nos muestra la pugna entre la identificación constante y el anonimato en base a la demanda de identidades reales desarrollada por este tipo de servicios, bajo la excusa de convertir la red en un lugar más seguro. Sin embargo, nos hemos convertido en manufactureros de nuestra 
propia identidad online, en base a la construcción que realizamos mediante los símbolos y los relatos que construimos alrededor nuestro en la red.

Como veremos, a medida que la red comenzó a funcionar como un tipo de tecnología comercial, fueron numerosos los proyectos que comenzaron a vislumbrar los posibles modelos de negocio que podrían ser desarrollados dentro de esta red interconectada, en parte gracias al auge de la nueva economía y la aparición de los fondos de capital riesgo, mediante los cuales sustentar pequeños proyectos innovadores desarrollados de la mano de jóvenes emprendedores. Sin embargo, la realidad actual nos trae a un escenario en el cual deberíamos preguntarnos hasta que punto la red de ha transformado en un elemento de dominación hegemónica en lugar de emancipación. El papel de la red como herramienta mediante la cual la contracultura de la segunda parte del siglo XX se desarrolló, ha dado paso a una gestión corporativa de la mayoría de sus espacios, en base a la aparición de servicios gratuitos. Estos servicios ofrecen multitud de nuevas funcionalidades que han pasado a incrustarse en nuestra vida diaria, generando nuevas formas de trabajo que dependen de nuestra atención y actividad cognitiva, expoliando por tanto nuestro tiempo y capacidades. No podemos olvidar que la red construye nuestra realidad mediática, y por lo tanto, puede componer lo que consideramos verdadero o falso. Por otro lado, la gestión que estos medios realizan de nuestros datos hace posible que estemos en un momento en el cual somos retroalimentados y gestionados en base a nuestra propia actividad.

Por lo tanto, las preguntas que esta tesis doctoral plantea, pretenden desentrañar cuestiones relacionadas con el papel del artista, la práctica artística, la producción cultural y el papel hegemónico de estos medios dentro de nuestra cotidianidad como creadores de nuestra subjetividad. Esto de produce gracias a una delegación de nuestras capacidades, la colonización de nuestras actividades cognitivas y la construcción del mundo y de nosotros mismos que desarrollamos en base a estas tecnologías. Como consecuencia de estas cuestiones aparecen diferentes preguntas que responden a la cuestiones planteadas anteriormente. Entre estas preguntas podemos encontrar cuestiones como ¿Cuál es el papel del artista dentro de este entorno mediático? ¿Cómo mediante la práctica artística podemos intervenir dentro de estas tecnologías para poner de manifiesto la manera en la cual estas nos transforman? ¿Cómo las aplicaciones de la Web 2.0. y la tecnologías asociadas 
a la red están transformando la manera en la cual trabajamos dentro del ámbito de la cultura? ¿Cómo estas mismas tecnologías afectan a la percepción que tenemos de nuestro entorno y de nosotros mismos? Y por último ¿Cuál es la relación de la red de Internet con conceptos como dominación y emancipación, hegemonía cultural y contracultura, o utopía y distopía?

\section{METODOLOGÍA}

La metodología utilizada para el desarrollo de esta tesis tiene como centro fundamental la experiencia del artista dentro de un paisaje mediático cambiante y contradictorio, otorgando un especial valor a la propia experiencia vivida como usuario dentro de estos espacios virtuales. Podemos afirmar por lo tanto, que se trata de una experiencia empírica que se vale del posicionamiento del artista como usuario y participe de la cultura online para explorar y generar nuevo conocimiento alrededor de estas tecnologías. Desde esta posición en la cual el artista desarrolla una experiencia vivencial, se construye una investigación que se combina con el estudio de referentes teóricos que acompañan los hallazgos y conclusiones obtenidas en base a la interacción online.

Es una exploración basada en las características del propio medio y el propio actuar que desarrollan lo usuarios en la red. Esto tiene la misión de generar un mayor entendimiento sobre las características de las aplicaciones de la Web 2.0., pero también de la cultura desarrollada por multitud de comunidades y usuarios anónimos que generan una gran cantidad de producción amateur dentro de Internet. La manera en la cual nos desenvolvemos dentro de este medio tiende a ser conformada por nuestros hechos, las relaciones que hacemos, los espacios que visitamos y el tipo de contenidos que compartimos y producimos. Es por ello, que el actuar pasa a ser el centro de la propia metodología investigadora que conforma esta tesis, siendo una actividad exploradora que en ocasiones también tiende a relacionarse, debido a las características de este entorno, con la improductividad, la reflexión y el hecho de perder el tiempo dentro de las diferentes aplicaciones y servicios que configuran el objeto de esta investigación, es decir las aplicaciones relacionadas con las tecnologías y lógicas de la Web 2.0.

Por lo tanto, podemos afirmar que esta observación constante del actuar propio y ajeno es la base de la investigación cualitativa que se lleva a cabo dentro de esta tesis doctoral. Esto se basa en el hecho de que la conducta del 
ser humano no puede ser controlada en su totalidad, siendo una variable generada precisamente en relación a un entorno como el mediático, lleno de características, situaciones y información en constante flujo. Esta metodología pone en relación la cultura desarrollada en el ámbito social de la tecnología con la ideología y el tipo de subjetividades que la conformaron.

Se trata de una constante recogida de información que se basa en la observación de los discursos que son desplegados sobre estos espacios y los modos de actuar que se desarrollan en base a estos. El análisis de los discursos se contrapone a un simple análisis basado en cifras, es decir de carácter cuantitativo, optando analizar de que manera los contextos sociológicos, tecnológicos e ideológicos afectan a la creación de discursos relativos a estas tecnologías. Se trata por tanto, de construir un sentido que permanece oculto en base al actuar de la multitud interconectada. Esta es una metodología de carácter participativo, ya que el propio investigador está ubicado dentro del propio contexto que se analiza, de manera que participa de el, del mismo modo que el resto de los usuarios objeto del estudio. Durante la presente investigación ha sido de gran importancia el análisis de los discursos desplegados desde las estructuras mediáticas constituidas como aplicaciones de la Web 2.0, dando por otro lado un papel prominente a los modos de responder a estos discursos mediante la propia práctica artística, como producto o conocimiento último desarrollado durante esta investigación. Por lo tanto, esta tesis doctoral se posiciona en si misma como una respuesta ante un escenario cada vez más complejo, fluido y contradictorio, que debe ser respondido mediante la combinación de saberes que la práctica artística es capaz de combinar.

\section{MARCO TEÓRICO}

El cuerpo teórico de esta investigación pretende sustentar el enfoque de la misma mediante el estudio de diferentes temas o campos como son la propia relación entre la contracultura y el origen de Internet, para posteriormente reflexionar en base a que hechos se ha generado el modelo hegemónico de la Web 2.0. Por otro lado mediante el estudio de la ecología de los medios y en especial de la obra de Marshall McLuhan pretendemos realizar un acercamiento a una serie de metáforas y teorías que se adelantaron a su tiempo en décadas para predecir un mundo que hoy en día se ha transformado en nuestra cotidianidad. Del mismo modo, la reflexión acerca del trabajo y las actividades cognitivas que desarrollamos mediante estas tecnologías, es el 
centro del siguiente apartado, lo que por otro lado nos da la posibilidad de tomar conciencia sobre la manera en la cual la cultura ha sido instrumentalizada y precarizada. Finalmente, un último bloque recoge las investigaciones relacionadas con la identidad online como producto esencial de estas tecnologías, ante la avidez comunicativa de la multitud interconectada.

Las fuentes bibliográficas esenciales de esta investigación han sido obras, que en algunos casos, no han tenido una presencia demasiado patente dentro de la propia estructura de la tesis, como es el caso de la obra de Jürgen Habermas Historia y crítica de la opinión pública ${ }^{1}$ de 1962, en la cual se desarrolla una investigación sobre como la esfera pública esta formada por individuos que toman como principal objetivo el debate sobre las prioridades de la propia sociedad, tanto en el ámbito del estado como en el de la política. Esto es algo que resulta especialmente interesante si tenemos en cuenta la manera en la cual la opinión pública es generada en base a las redes y las aplicaciones de la Web 2.0 y la hegemonía y dominio que estas ostentan en estas cuestiones. Precisamente, como consecuencia de los totalitarismos Theodor Adorno y Max Horkheimer, mediante su obra Dialéctica de la Ilustración de 1944, realizan una fuerte crítica, no solo de la ideología de la sociedad burguesa, sino a la totalidad del proceso de la ilustración, como un proceso de racionalización mediante el cual Occidente abandona el mito por el saber científico. Esto produce lo que denominan la "enfermedad de la razón" materializada como el afán por dominar la naturaleza. Por otro lado, la metáfora de la "jaula de hierro"2 del sociólogo alemán Max Weber, a veces traducido de múltiples formas ${ }^{3}$, ejemplifica un sistema en el cual la racionalización, burocratización y el control han incrementado de manera exponencial en las sociedades capitalistas occidentales. Como veremos esto se relaciona con obras como La locura del solucionismo tecnológico ${ }^{4}$ de Evgeny Morozov que nos plantean un escenario similar dentro del ámbito tecnológico actual.

\footnotetext{
${ }^{1}$ Habermas, Jürgen, Historia y crítica de la opinión pública, Gustavo Gili, Barcelona 1981, p. 42.

${ }^{2}$ Weber, Max, La ética protestante y el espíritu del capitalismo, Fondo de Cultura Económica, México, 2011, p. 286.

${ }^{3}$ Esta metáfora es producto de la interpretación de Talcott Parsons, traductor de la versión inglesa, ya que Weber nunca escribió un termino que pudiera traducirse al ingles por "jaula de hierro". Será finalmente la edición española de Francisco Gil Villegas la que utilice la polémica expresión.

${ }^{4}$ Morozov, Evgeny, La locura del solucionismo tecnológico, Katz, Barcelona, 2015.
} 
Obras como El Dorado 5 de Enric Puig Punyet, fueron de gran importancia a la hora de interrogarnos sobre el verdadero estatus de la red en base a las características y funcionamiento del escenario mediático actual. Mediante esta obra se crea un recorrido temporal que nos muestra la evolución de esta red interconectada desde los proyectos primigenios desarrollados en su seno, hasta la aparición y evolución de Google como servicio hegemónico de Internet.

La obra teórica de Marshall McLuhan ha sido imprescindible para entender los medios como parte de nosotros mismos, una extensión que nos transforma y nos adormece, siendo especialmente destacable la obra La comprensión de los medios de comunicación como referente esencial. Mediante diferentes metáforas podemos observar como se va conformando una visión certera de los medios de masas pasados, y por extrapolación los actuales. Del mismo modo veremos como McLuhan piensa en el artista como una figura esencial a la hora de adentrarnos dentro del paisaje mediático. La obra de Neil Postman Divertirse hasta morir ${ }^{6}$, nos plantea mediante el estudio de la novela de Aldous Huxley Un mundo feliz ${ }^{7}$, como somos nosotros mismos los que hemos decidido ser esclavizados y controlados a cambio de unas tecnologías que nos entretienen y nos mantienen distraídos.

Por otro lado partiendo de la reelaboración de las teorías marxistas por parte del operaismo italiano, se genera el concepto de trabajo inmaterial por parte de Maurizio Lazzarato en su ensayo homónimo, que será recogido por Paolo Virno y Michael Hardt en Radical Thought in Italy. A Potential Politics. A través de esta obra se aborda el tema de cómo el capitalismo ha conseguido generar valor en base a nuestras prácticas cognitivas y afectivas, de manera que creemos imprescindible el desarrollo de estas actividades a la vez que somos

\footnotetext{
${ }^{5}$ Puig Punyet, Enric, El Dorado. Una historia crítica de internet, Clave Intelectual, Madrid, 2017.

${ }^{6}$ Postman, Neil, Divertirse hasta morir. El discurso público en la era del "show bussines", Ediciones la Tempestad, Barcelona, 2001.

${ }^{7}$ Huxley, Aldous, Un mundo feliz, Ediciones Cátedra, Madrid 2013.

${ }^{8}$ Virno Paolo, Hardt, Michael, Radical Thought in Italy. A Potential Politics, University of Minessota Press, Minneapolis, 1996, p. 132.
} 
inconscientes ante el impacto de estas. Del mismo modo la obra clásica de Sherry Turkle La vida en la pantalla ${ }^{9}$, nos habla de la formación de la identidad online en los primeros juegos multijugador basados en texto alrededor de los años 80 del siglo $\mathrm{XX}$, pero que posteriormente evolucionaron a lo que hoy conocemos como juegos masivos multijugador en línea. La obra de Gemma San Cornelio Arte e Identidad en Internet ${ }^{10}$ fue esencial a la hora de abordar el tema del selfbranding como nuevo concepto adjunto a la actividad online, que nos habla del nuevo papel de la identidad online como producto de marca, que sin embargo no resulta crítica o reflexiva sobre la manera en la cual es construida o su relato representado, como parte de una actividad de cuyas consecuencias no somos conscientes en el ámbito de nuestra cotidianidad.

Finalmente, una de las influencias más importantes que ha motivado la producción de las obras presentadas en esta investigación, es sin duda el Manual de guerrilla de la comunicación ${ }^{11}$. En el se nos plantea una suerte de prácticas artísticas que pese a basarse en la subversión como respuesta a la crítica ideológica y la militancia de izquierdas, pretende ser una herramienta placentera que cuestione la moral del trabajo. Se trata por tanto del desarrollo de prácticas sutiles que trabajan en el terreno enemigo, es decir los medios, para poner de manifiesto la manera en la cual estos utilizan su poder para controlarnos. También debemos hablar de la obra de Michel de Certeau, y como no, La Invención de lo Cotidiano ${ }^{12} 1$ y 2, como un cuerpo de obra que puede se reinterpretado para participar de un sistema hegemónico que hoy en día denominamos sistema red, para transformarlo y cuestionarlo de manera que pase a servir a otras convicciones, a la vez que ponemos de manifiesto las contradicciones, incoherencias y estrategias de dominación que este despliega en nuestro paisaje mediático.

\footnotetext{
${ }^{9}$ Turkle, Sherry, La vida en la pantalla: la construcción de la identidad en la era de Internet, Editorial Paidos, Barcelona, 1997.

${ }^{10}$ San Cornelio, Gemma, Arte e Identidad en Internet, Editorial UOC, Barcelona, 2008.

${ }^{11}$ Luther, Blisset, Brünzels, Sonja, Manual de guerrilla de la comunicación, Virus Editorial, Barcelona, 2000.

12 de Certeau, Michel, La Invención de los Cotidiano I. Artes de Hacer, Universidad Iberoamericana, México D.F., 2000.
} 
PARTE 1 TEORÍA 
1. DE LA CONTRACULTURA A LA WEB 2.0 


\subsection{DE LA CONTRACULTURA A LA CULTURA HACKER}

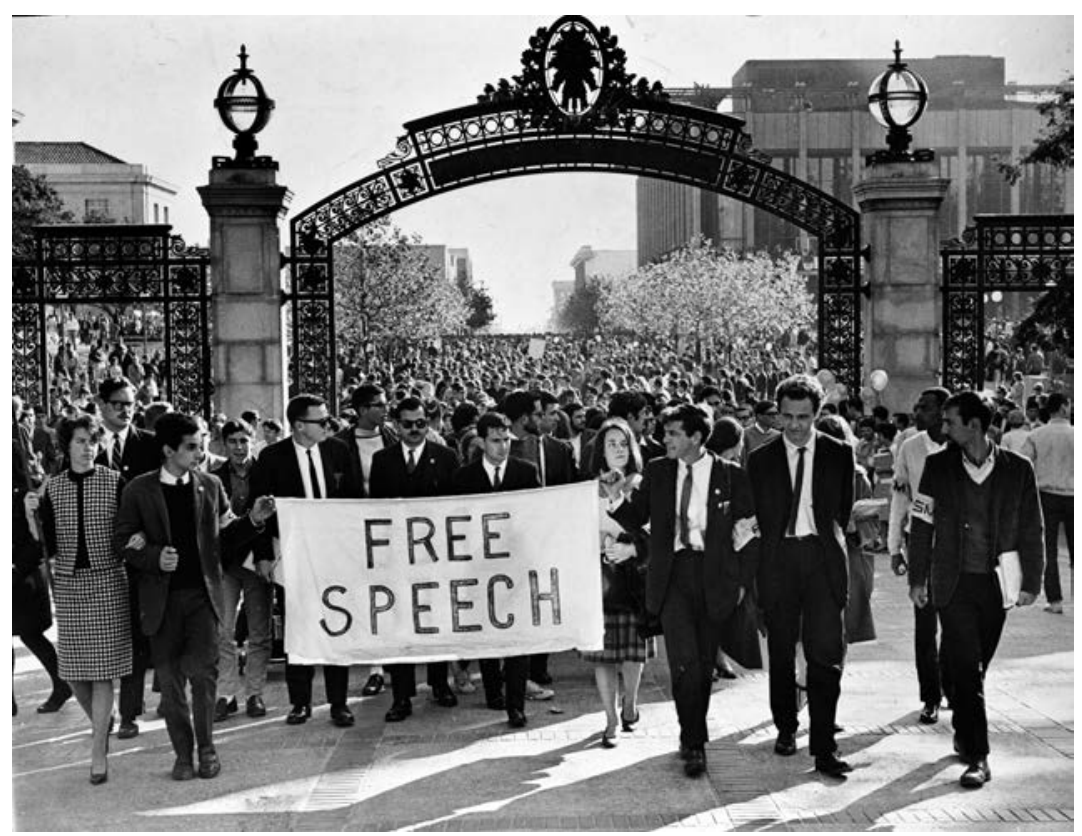

Figura1. Mario Savio ${ }^{13}$, dirigiendo una protesta en la Universidad de California, Berkeley, en 1964.

Las tensiones sociales de los años 60 del siglo XX tendieron a cuestionar temas como las formas tradicionales de autoridad, la sexualidad y el papel de la mujer en la sociedad, propiciando la aparición de movimientos contraculturales y antisistema que incorporaron a la abultada generación del baby boom posterior a la Segunda Guerra Mundial. Es especialmente relevante el desarrollo de movimientos sociales entre los que podemos destacar los contra-públicos asociados con el feminismo, la comunidad afroamericana, la comunidad homosexual, el movimiento ecologista, diferentes asociaciones creadoras de opinión pública, e incluso otras esferas publicas desarrolladas en

\footnotetext{
${ }^{13}$ Mario Savio fue un destacado activista estudiantil que lideró el Movimiento Libertad de Expresión.
} 
el ámbito universitario y los movimientos estudiantiles ${ }^{14}$. De hecho una gran parte de la contracultura generada en EEUU en estos años se generó en los campus universitarios, como el movimiento por la libertad de expresión de la Universidad de California, Berkeley, opuesto a las prácticas de las universidades y sus patrocinadores corporativos. Este se convirtió posteriormente en unos de los grandes bastiones de la incipiente cultura hacker ${ }^{15}$. Como remarca Alain Touraine ${ }^{16}$, esta contracultura nacida en EEUU se extendió de manera limitada en Europa occidental debido a la fuerza de los movimientos laborales, pero consiguiéndose mezclar, no obstante, con los movimientos estudiantiles de manera amplia.

El movimiento de la Nueva Izquierda más enfocado en el activismo en detrimento del movimiento obrero y la izquierda política, desarrolló interés por el socialismo libertario, enfocándose en la libertad personal, la autonomía, y el revisionismo del socialismo primigenio mediante renovadas formas de marxismo, lo que produjo el surgimiento del movimiento autónomo, la economía participativa, la democracia inclusiva y la ecología. Precisamente el trabajo de Herbert Marcuse miembro de la Escuela de Frankfurt exiliado en EEUU, y que finalmente acabo siendo profesor de la Universidad de California, San Diego, opta por un revisionismo de la Teoría Crítica en base a las políticas de emancipación de genero y los movimientos juveniles. Es considerado uno de los referentes y miembros fundamentales de los movimientos juveniles de protesta y padre de la denominada Nueva Izquierda junto a C. Wright Mills ${ }^{17}$. Marcuse describe un capitalismo tardío hacedor de un estado del bienestar que ha mejorado relativamente las condiciones de vida de los obreros, lo que ha servido para desactivar los movimientos obreros y antisistema, siendo vehiculizados hacia otros fines que la sociedad autoriza. En este escenario Marcuse argumenta, coincidiendo con Adorno, que la sociedad ha logrado inocular necesidades ficticias, generadas en base a una conciencia alienada y

\footnotetext{
${ }^{14}$ Jordan, Tim, Taylor, Paul, Hacktivism and ciberwars, rebels with a cause?, Routledge, Nueva York, 2004 , p. 46.

${ }^{15}$ Hinamen, Pekka, La ética hacker y el espíritu de la era de la información, Editorial Destino, 2002

${ }^{16}$ Maniaque-Benton, Caroline, French Encounters with the American Counterculture 1960-1980, Routledge, Nueva York, 2011, p. 123.

${ }^{17}$ El sociólogo C Wright Mills tuvo un especial impacto en los movimientos sociales relacionados con la Nueva Izquierda en EEUU, así como en la popularización del termino gracias a una carta abierta publicada en 1960.
} 
producidas por la sociedad industrial, en lo que el vino a denominar "la unidimensionalidad predominante"18. También cabe destacar dentro de su obra La dimensión estética ${ }^{19}$ de 1979 , su conceptualización acerca del papel del arte en el proceso de lo que él llamó "emancipación" de la sociedad burguesa.

De la interacción entre la filosofía, política, sociología, contracultura, ideología libertaria y tecnología, surgió el ambiente intelectual y político en el que se desarrollaron las tecnologías que dieron origen al primer Internet. Como veremos esta combinación afectó en gran medida el funcionamiento y la concepción de esta red descentralizada, mediante el propio enfoque de sus creadores. De la competencia generada por la Guerra Fría entre EEUU y la Unión Soviética surge la necesidad de implementar una colaboración estrecha entre el Estado y los centros de investigación de las universidades estadounidenses. De esta colaboración surge el proyecto ARPANET, iniciado en 1958 bajo la tutela de la Agencia de Proyectos de Investigación Avanzada de los Estados Unidos, culmina con la primera red conectada de ordenadores en 196920. Desde ese momento el numero de nodos de conexión fue aumentando, y se comenzó incluso la conexión con otras redes de ordenadores, generando una red de redes ${ }^{21}$.

Según Castells ${ }^{22}$ fue la interacción entre la investigación científica, la investigación militar y la cultura libertaria lo que posibilitó dicho logro. Pese a ser producto de esta interacción, el papel del Departamento de Defensa de los Estados Unidos fue más bien secundario, incluso teniendo en cuenta las teorías que han argumentado sobre su importancia en el escenario de un

\footnotetext{
${ }^{18}$ Marcuse, Herbert, El hombre unidimensional, Planeta-De-Agostini, Barcelona, 1993, p. 96.

${ }^{19}$ Marcuse, Herbert, La dimensión estética, Biblioteca Nueva, Madrid, 2007.

${ }^{20}$ Esta comunicación tuvo lugar el 21 de Noviembre de 1969 entre las universidades de UCLA y Stanford gracias a los trabajos de investigación iniciados en 1959 y que dieron origen a ARPANET.

${ }^{21}$ Internet es una "red de redes" ya que está constituida gracias a la conexión de una ingente cantidad de redes locales de ordenadores, a través de las cuales fluyen de manera continua grandes cantidades de datos, debido a esto también fue conocida como "la autopista de la información".

${ }^{22}$ Castells, Manuel, La Galaxia Internet, Plaza y Janes, Barcelona, 2001, p. 33.
} 
conflicto nuclear ${ }^{23}$. Fue más bien la optimización de recursos informáticos entre diferentes centros de investigación la meta principal de estos investigadores. Esta política de autonomía, que el propio Departamento de Defensa posibilitó, fue la parte fundamental del éxito de este proyecto, situándolo como uno de los referentes de innovación tecnológica a nivel mundial. Esto fue posible gracias a la propia autonomía de los investigadores, los cuales condicionaban su participación a un alto grado de independencia. Este enfoque propició a la postre, mediante esta política de libertad y flexibilidad, la superioridad tecnológica estadounidense sobre una Unión Soviética, la cual anclaba sus investigaciones al aparato de seguridad militar.

Las características novedosas de esta tecnología permitían el acceso a la información desde diferentes terminales al mismo tiempo. Mediante esta simultaneidad de acceso se ponía de manifiesto la imposibilidad de distinción entre original y copia, de manera que un mismo paquete de información podía ser distribuido y copiado en distintos terminales. Este es un tipo de almacenamiento descentralizado implementado por una red de ordenadores interconectados, de manera que la perdida de uno de sus nodos no impedía el funcionamiento de la red.

Como Castells apunta, "la cultura de la libertad individual que se gestó en los campus universitarios en los años sesenta y setenta utilizó la conexión informática de la red para sus propios fines" 24 . Dentro de las universidades interactuaron el desarrollo científico junto a las redes contraculturales. Esto hizo que los valores de la libertad individual, el pensamiento independiente y la cooperación arraigaran en la comunidad universitaria. Aunque los colaboradores del proyecto ARPANET no formaran parte de movimientos contraculturales, si pusieron en contacto la cultura estudiantil con la gran ciencia, generando lo que para muchos fue una nueva herramienta de comunicación libre en red o incluso una herramienta emancipadora mediante la cual escapar del poder del Estado y la empresa. Una de las características

\footnotetext{
${ }^{23}$ Esta estructura descentralizada sin duda responde a las necesidades de autonomía y ausencia de un nodo central que garantizan la supervivencia de la red, sin embargo no podemos argumentar que la comunidad científica que desarrolló este proyecto persiguiera tales fines más allá de la intención de generar una conexión informática en red.

${ }^{24}$ Castells, Manuel, op. Cit., 2001, p. 38.
} 
principales de este Internet primitivo fue la trasparencia, basada en su arquitectura tecnológica y organización institucional y social. Mediante una arquitectura abierta, ARPANET sentó las bases de un modelo que pudo evolucionar y más tarde expandirse en base a los cambios generados por la globalización. Este carácter abierto hizo posible que los propios usuarios de la red produjeran y compartieran tecnología que modificaría este conjunto de ordenadores interconectados, como es el caso del correo electrónico, las salas de chat o el hipertexto. Precisamente en torno a la idea borgiana ${ }^{25}$, crear un documento global y único que pudiera cubrir todo lo escrito en el mundo mediante una red de ordenadores interconectados, surge el proyecto Xanadú fundado por Ted Nelson el 1967. Se pretendía producir un gran numero de documentos conectados mediante enlaces de hipertexto, dentro de un sistema que pudiera rastrear el uso de obras con derechos de autor y cobrar por ello mediante un sistema de transcopyright. Este proyecto pretendía generar una fuente de conocimiento horizontal fuera de los círculos de poder que interaccionan con los medios tradicionales dentro de la amplia red de relaciones que forma el poder. Está inspirado por un lado en la mansión que aparece en la obra de Orson Welles Ciudadano Kane, donde se protegen de paso del tiempo las mayores colecciones de obras de arte, y por otro en el poema de Samuel Taylor Coleridge titulado Kubla Khan, donde nos introduce dentro de una ciudad en la cual la riqueza se conserva de manera imperecedera. La no realización de este proyecto ha puesto de manifiesto el potencial simbólico de este tipo de iniciativas utópicas para la reformulación de una realidad mediática futura, mediante la idea de una estructuración no lineal de la información. Esto hizo preguntarse a los tecnólogos sobre la posibilidad de un flujo horizontal de información que no pueda ser modificado desde otras instancias, genere un beneficio sobre toda la humanidad

Las primeras comunidades de investigadores tecnológicos asociados a la red encontraron su principal misión en alcanzar la excelencia tecnológica mediante la colaboración entre usuarios en el desarrollo compartido de proyectos de código abierto. Este resultó ser un método de control de calidad capaz de llevar el resultado final hasta parámetros de fiabilidad aceptables, otorgando como contraprestación reputación ante la comunidad. Se perseguía

\footnotetext{
${ }^{25}$ Esta idea se puede observar en el cuento de Jorge Luis Borges La biblioteca de Babel, en el cual se especula sobre un universo compuesto por una biblioteca de todos los libros posibles, arbitrariamente ordenados, dentro de un orden que transciende al propio ser humano.
} 
la intención de gozar de libertad creativa y de la distribución de su trabajo de manera abierta. La producción de tecnología abierta, frente al sojuzgamiento público de otros usuarios, planteaba un tipo de actividad que revertía en el interés público. Esta producción estaba adaptada a los valores y principios de estas comunidades de usuarios que participaban activamente en el desarrollo y distribución de una tecnología que es revertida de nuevo al ámbito de lo público en tiempo real, generando un proceso de perfeccionamiento constante. Este proceso de evolución tecnológica constante fue posible gracias a la apertura de sus protocolos y arquitectura, junto a instituciones gestoras que respetaban los principios de transparencia de la red.

Podemos ver como esta cultura es heredera de las propias ideas desarrolladas en las universidades de Estados Unidos en las décadas de los sesenta y setenta, vino a conformar lo que se denominó como ética hacker ${ }^{26}$, como conjunto de principios filosóficos y éticos en torno a esta comunidad y sus ideas sobre el papel de la computación como herramienta emancipatoria del ser humano, el libre acceso a la información y el intercambio de software de código abierto. Como resalta Pekka Himanen esta nueva ética del trabajo que pone en común la información se presenta en plena confrontación a la anterior "ética protestante" expuesta por Max Weber en su obra homónima La ética protestante y el espíritu del capitalismo ${ }^{27}$. Plantea el ocio no como una actividad pasiva ausente de pasión, heredera de la ética protestante, sino como un concepto de diversión activa en la cual somos creadores de nuestro tiempo libre, gracias a la privacidad de nuestras actividades dentro de la red, lo cual no otorga la posibilidad de optar por una construcción personal de nuestro ocio. Contrapone la manera de producir riqueza basada en la posesión de información por el modelo en pos de la libre circulación del conocimiento. Por otro lado la conocida como "ley de Linus" propuesta por el ingeniero de software Linus Torvalds y basada en la afirmación "dado un número suficientemente elevado de ojos, todos los errores se vuelven obvios" 28 . Nos plantea un modelo de creación en la cual los usuarios intervienen en el propio desarrollo y depuración de las tecnologías existentes en la red. Este concepto fue ampliamente comentada por Eric S. Raymond en The Cathedral and the

\footnotetext{
${ }^{26}$ Himanen, Pekka, op. Cit., 2004, p. 23.

${ }^{27}$ Weber, Max, op. Cit., 2011.

${ }^{28}$ Raymond, Eric S., The Cathedral \& the Bazaar, O'reilly Media, Sebastopol, 2008, p. 30.
} 
Bazaar, donde argumenta sobre como obviamente un mayor numero de betatesters aumentan las posibilidades de solucionar errores, pese a las críticas de diferentes desarrolladores de software como Robert S. Glass ${ }^{29}$. Es por ello que en este tipo de creación colectiva de tecnología y flujo de ideas, podemos observar como la red interconectada se transforma en el soporte de "lo público" como lo común para todos, es decir, la información compartida entre los usuarios mediante la horizontalidad que este medio propicia y el posterior sojuzgamiento de esta producción mediante los conocimientos tecnológicos de los usuarios.

Si para Habermas, la deliberación racional sobre lo público en un espacio no excluyente basado en la libertad de acceso, era constitutivo de la opinión pública, aquí podemos ver como este consenso racional sobre lo común dentro de esta comunidad genera su propia esfera de opinión, sin embargo, podemos afirmar que es el conocimiento tecnológico y la posibilidad de acceso a este tipo de redes, lo que determina la capacidad de participación dentro de esta reducida comunidad tecnológica, de la misma manera que el acceso a los medios tradicionales y el nivel cultural determina la participación en la opinión pública clásica. No obstante no podemos determinar que esta sea una limitación impuesta por este tipo de público, el cual es incluyente e igualitario, o por la sociedad, sino que más bien viene determinada por la naturaleza de este medio. Podemos afirmar que la conectividad sigue siendo hoy día un factor de exclusión para los individuos fuera de la red y de igualdad para los que pueden acceder a esta tecnología y deliberar sobre lo público.

Siempre se ha ubicado el origen de esta cultura en el Tech Model Railroad Club dentro del Massachuset Institute of Technology, donde como nos relata Steven Levy en su obra Hackers: Heroes of the Computer Revolution ${ }^{30}$, se instalo en 1961 una microcomputadora PDP-1. Más tarde en 1970 parte de estos miembros pasan a formar parte del AI Lab (Laboratorio de Inteligencia Artificial del MIT), donde se crea en 1973 la primera maquina y código de programación Lisp, lo que produjo una escisión dentro del propio Laboratorio

\footnotetext{
${ }^{29}$ Glass, Robert S., Facts and Fallacies of Software Engineering, Adisson-Wesley, Boston, 2004, p. 174.

${ }^{30}$ Levy, Steven, Hackers: Heroes of the Computer Revolution, Anchor Press/Doubleday, New York, 1984. 
de AI y la creación de la empresa privada Symbolics por varios de sus miembros a favor del software propietario. Como respuesta se fundó la base del movimiento de software libre de la cual Richard Stallman era uno de los representantes principales, mediante la creación de su propio sistema operativo libre GNU y su propio manifiesto publicado en 198531. Una muestra de esto es la aparición de organizaciones como la Free Software Foundation o "FSF" fundada por el propio Stallman entre otros. Enfocaron su trabajo en hacer desaparecer cualquier limitación a la distribución o copia de programas mediante la creación del concepto de software libre, para pasar posteriormente a centrarse en estudiar asuntos legales, de difusión y organización de este movimiento. Por otro lado el concepto Open Sourse surgió de la mano de Eric S. Raymond y Bruce Perens como alternativa menos cargada ideológicamente y más centrada en aspecto técnico del software, con la intención de buscar su uso más generalizado dentro del mercado.

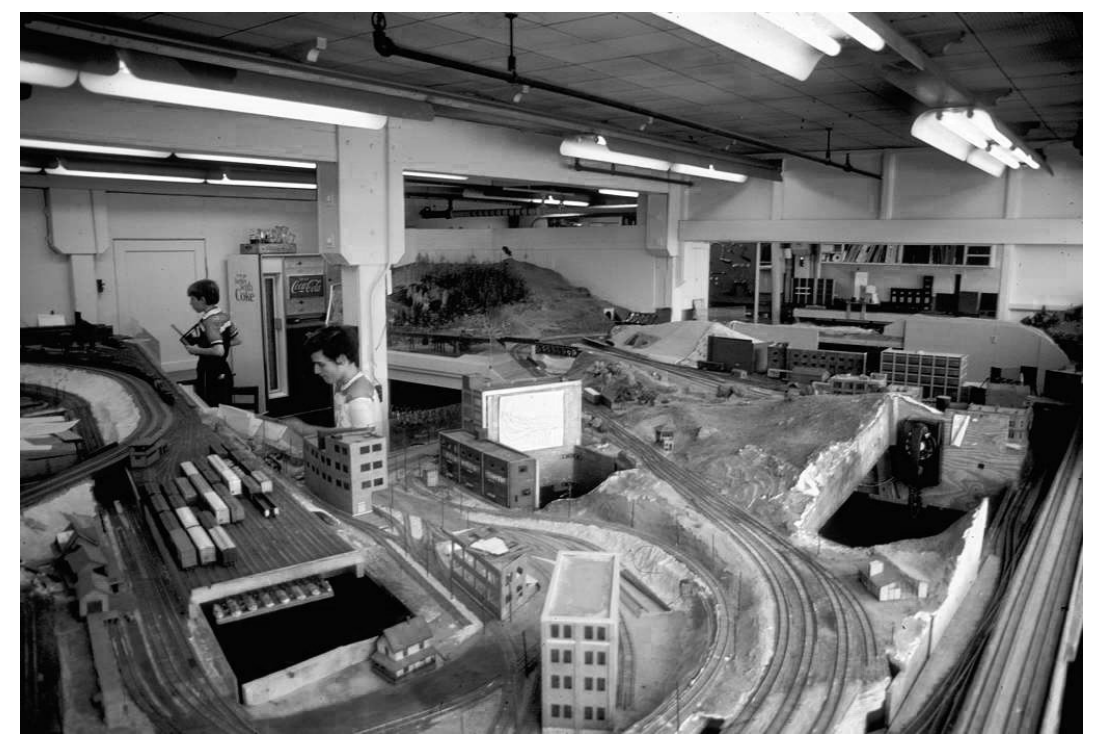

Figura 2. Tech Model Railroad Club, mediados años 50, autor anónimo.

\footnotetext{
${ }^{31}$ El Manifiesto GNU fue realizado por Richard Stallman y fue publicado en Marzo de 1985 en Dr. Dobb's Journal of Software Tools, siendo una detallada muestra del concepto del Proyecto GNU y de sus objetivos. Se le considera el origen filosófico e ideológico de Movimiento de Software Libre.
} 
Mientras ARPANET permaneció como una red dedicada al ámbito universitario, otras redes como SATNET dedicada al control de los satélites o Cyclades la versión francesa de ARPANET. Estas precedieron la aparición de Telenet por parte de BBN en 1974. Esta se convirtió en una derivación comercial de ARPANET fuera de su red de universidades inicial, lo que hizo posible que se conectaran una gran cantidad de investigadores. Otros proyectos posteriores como JUNET, establecido en Japón en 1984, siguieron desarrollando la comunicación entre diferentes universidades mediante la línea de teléfono hasta su sustitución por WIDE Project en 1994.

From Counterculture to Cyberculture de Fred Turner ${ }^{32}$ es uno de los primeros libros en explorar esta transformación de la cultura dentro del ámbito privado. Fred Turner traza la historia de un grupo altamente influyente de empresarios de la Bahía de San Francisco, entre los que encontramos a Stewart Brand y la Whole Earth 'Lectronic ${ }^{33}$ conocida como The WELL. Entre 1968 y 1998 Brand y sus colegas generaron encuentros entre seguidores de la contracultura de San Francisco y investigadores de Silicon Valley. Gracias a su visión, los seguidores de la contracultura y los tecnólogos se unieron para repensar los ordenadores como herramientas de la emancipación personal, la construcción de comunidades virtuales y la exploración de nuevas fronteras sociales.

Durante los años setenta del siglo XX se vivió un desarrollo sin paragón en la aplicación domestica de los microprocesadores, lo que significó su adaptación al mundo de la empresa y del consumo personal. Compañías como IBM fueron fundadas en Silicon Valley, California. El Homebrew Computer Club fue un club de amantes de los ordenadores donde se presento el modelo Apple I en 1976. La popularización de los ordenadores personales y los conocimientos informáticos en un sector cada vez más amplio de la sociedad hizo crecer de manera exponencial la comunidad hacker durante los años setenta y ochenta, de hecho muchas de las personalidades más influyentes del mundo de la informática comenzaron su carrera como hackers anónimos, que como Steve

\footnotetext{
${ }^{32}$ Turner, Fred, From Counterculture to Cyberculture, Chicago Press, Chicago, 2006.

${ }^{33}$ The Whole Earth 'Lectronic Link es una de las comunidades virtuales más antiguas. Fueron los creadores de The Whole Earth Catalog, una revista contracultural publicada por Steward Brand varias veces al año entre 1968 y 1972, y esporádicamente hasta 1998.
} 
Wozniak ${ }^{34}$ y Steve Jobs fundadores de Apple, se dedicaban a vulnerar sistemas telefónicos para efectuar llamadas gratuitas mediante una Bluebox ${ }^{35}$. Ya a principios de los años 90 los conocidos como "phreakers", eran una comunidad de piratas telefónicos que se valían de diferentes herramientas de software para obtener llamadas gratis. Con la llegada de la era digital los "phreakers" pudieron adentrarse más en los entresijos de las compañías telefónicas. Como respuesta a esta actividad ilícita diferentes agencias del gobierno estadounidense lanzaron la denominada Operación Sundevili36, llevada a cabo en 1990. Supuso un fuerte revés para las actividades de hacking ilegal y un ataque directo a toda la comunidad hacker. En respuesta a esta operación surgió la Electronic Frontier Foundation, fundada en 1990 por John Perry Barlow, John Gilmore y Mitch Kapor. Estos concentraron sus esfuerzos en velar por la libertad asociada a los derechos civiles de los usuarios en la red, así como concienciar a los medios y los gobiernos sobre las problemáticas asociadas a las nuevas tecnologías ${ }^{37}$.

Por otro lado el concepto de Desobediencia Civil Electrónica ${ }^{38}$ introducido en 1994 por Critical Art Ensemble, colectivo dedicado a explorar la intersección entre arte, tecnología, activismo político y teoría crítica, proponía un modelo desestructurado de células anónimas que generaran diferentes estrategias autónomas que actuaran en diferentes ámbitos para producir cambios en el modelo político y económico imperante. Para ello se valdrían de acciones experimentales en el espacio participativo del arte. Esta relación entre Internet y el activismo suele ser conocida como hacktivismo, por su relación

\footnotetext{
${ }^{34}$ Wozniak, Steven, Smith, Gina, iWoz: From Computer Geek to Cult Icon: How I Invented the Personal Computer, Co-Founded Apple, and Had Fun Doing It, W.W Norton, 2006.

${ }^{35}$ Bluebox fue un aparato utilizado para phreaking telefónico mediante diferentes tonos o silbidos de 2600 Hz. Según cuenta Steve Wozniak, este logró llamar al Estado Vaticano haciéndose pasar por Henry Kissinger secretario de Estado estadounidense para solicitar hablar con el propio Papa, no pudiéndose consumar la conversación al encontrarse este durmiendo.

${ }^{36}$ Sterling, Bruce, The Hacker Crackdown: Law and Disorder on the Electronic Frontier, Bantam Books, EEUU, 1992.

${ }^{37}$ Presentaron en 2006 una demanda colectiva contra la compañía AT\&T, acusándola de violar la ley y la privacidad de sus clientes mediante la colaboración con la Agencia Nacional de Seguridad.

${ }^{38}$ Critical Art Ensemble, La desobediencia civil electrónica, la simulación y la esfera pública, [En línea], [consultado el 24 de Junio de 2016], disponible en <http://alepharts.org/pens/dec_simul.html>
} 
con la cultura hacker, su ética y la idea de usar el hacking como herramienta de cambio social.

Posteriormente una organización sin animo de lucro como Wikileaks, ha filtrado desde 2007 documentos comprometidos sobre actuaciones no éticas de los gobiernos de todo el mundo, siempre manteniendo el anonimato de sus fuentes. Aquí la difusión de la información sobre las actividades ilegales de ámbito gubernamental es usada para generar conciencia sobre como la geopolítica que nuestros representantes crean se basa actividades ilícitas y crímenes de estado. El director de Wikileaks, el australiano Julian Asange fue hacker, programador e investigador antes de ostentar este cargo. Participo como investigador para el libro Underground de Suelette Dreyfus y Julian Assange ${ }^{39}$, en el cual trata sobre las actividades de un grupo de hackers australianos y de otros grupos, como miembros de Masters of Deception o Legion of Doom, que emergieron dentro de la cultura hacker de finales de los años 80. En esta obra se recoge una de las primeras muestras de hacktivismo, el gusano WANK (Worms Against Nuclear Killers). Este gusano propagado por los ordenadores de la red DECnet entre la NASA y el Departamento de Energía de EEUU cambió el mensaje de entrada del sistema. Dreyfus y Assange veían un gran peligro en la eliminación del pensamiento critico de los media mediante las fusiones corporativas, ya que esto haría que solo protestáramos ante hechos inaceptables y solo teniendo gran cantidad de información al respecto.

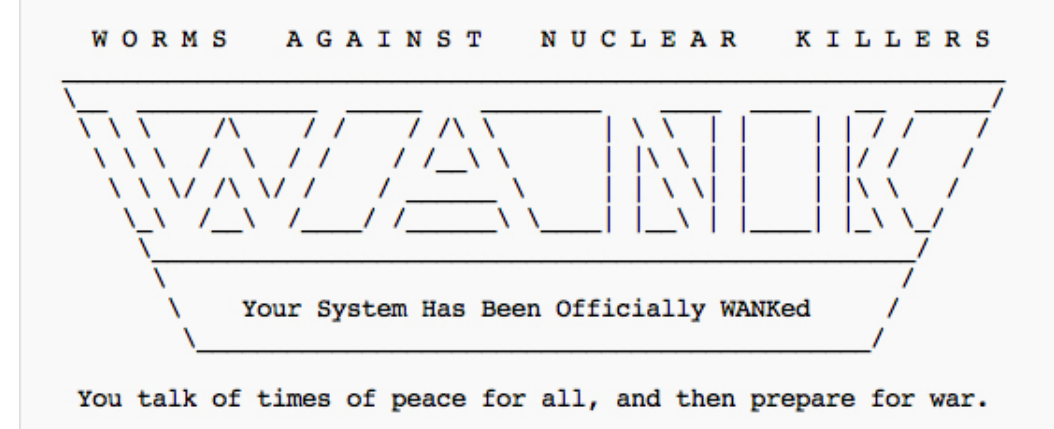

Figura 3. Mensaje del gusano WANK (Worms Against Nuclear Killers).

\footnotetext{
${ }^{39}$ Dreyfus, Suelette, Underground, Seix Barral, Barcelona, 2011.
} 
Como podemos ver desde sus orígenes Internet se caracterizó por una efervescente actividad ejercida en pos del desarrollo de los derechos fundamentales de la sociedad civil, esto propicio un cuestionamiento de status quo y de los medios de comunicación, que alteró la conciencia de la opinión pública en torno a las consecuencias de las fusiones corporativas, el control gubernamental de la información o las consecuencias negativas de la globalización. Esta será una inercia que convivirá con nuevas encarnaciones de la web y que mutará a nuevas formas colectivas de activismo en la red, como es el caso del grupo Anonymous activo desde 2008. Se conformará como una identidad anónima y colectiva cohesionada mediante determinados símbolos y espacios de reunión, que se centrará en un principio en las acciones virtuales como los ataques DDoS, para pasar posteriormente a realizar actividades fuera de la red. Una de las claves del éxito de esta organización es su habilidad para captar la atención mediática y dirigirla hacia un problema en concreto, sin embargo, podemos afirmar que la impredecibilidad es una de sus características más poderosas y que más intimida a sus enemigos. Esto se debe a su capacidad para hackear organizaciones y gobiernos y exponer información al público. Tal y como nos cuenta Gabrielle Colleman en su libro Las mil caras de Anonymous ${ }^{40}$, estamos ante una subcultura misteriosa cuyos miembros resultan ser personas complejas y políticamente sofisticadas.

Proyectos como Télétel, lanzado comercialmente en Francia durante 1982, fueron un precedente de algunas de las características de los posteriores servicios comerciales de Internet, que compitió con los medios tradicionales en cuanto a ingresos por publicidad. Desde el ámbito privado la concentración de poder ejercida por el estado mediante esta red no fue vista con buenos ojos. En cambio su equivalente británico no obtuvo un éxito reseñable al integrase dentro de la televisión. El final de los años 80 del siglo XX presentaba un nuevo horizonte para el desarrollo de esa aldea global planteada por Marshall McLuhan. La caída del Muro de Berlín dio paso al inicio de una verdadera globalización de la información.

\footnotetext{
${ }^{40}$ Colleman, Gabrielle, Las mil caras de Anonymous: hackers, activistas, espías y bromistas, Arpa editores, Barcelona, 2016.
} 
Las principales redes existentes en este momento estaban delimitadas geográficamente, encontrándose muchas en EEUU, Francia o Japón. Podíamos hacer también una clara distinción respecto al tipo de redes a las que nos referimos según el uso que se le daba. Se podían encontrar redes dedicadas al uso comercial, militar o científico, con usuarios con unos fines determinados y un uso restringido a estas finalidades. El primer Internet global puso en contacto a investigadores a nivel internacional expandiendo el territorio. En este contexto se van a producir cambios sustanciales en torno a la red, así como un gran auge alrededor de la misma. Esto es debido a la desaparición de ARPANET en 1990 y el fin del uso exclusivamente científico y académico de Internet para dar paso a infraestructuras e interconexiones propias implementadas por el gobierno y proveedores de servicio privados como AT\&T, finalizando con la puesta en funcionamiento de las primeras líneas comerciales de servicio. A principios de los años 90 se levantó la prohibición hasta entonces del uso comercial de Internet produciéndose una rápida transición hacia un modelo privado de administración. Por otro lado en 1991 el trabajo realizado por Tim Berners-Lee y Robert Caillain en el CERN de Suiza van a provocar un cambio paradigmático en la manera en la cual se usaba Internet, que aún hoy forma parte del modo en el cual interactuamos y navegamos por la red. Este equipo crea el código HTML ${ }^{41}$ que conocemos, junto al primer navegador llamado WorldWideWeb. Del mismo modo este grupo inventó la URL ${ }^{42}$ y el primer servidor web . En 1993 el CERN entrega gratuitamente estas tecnologías para que sean de dominio público. Como recuerdo de esta época nos queda la primera pagina web de la historia creada por Tim Berners-Lee y cuya función era informar sobre la novedosa World Wide Web. El sistema de World Wide Web ${ }^{43}$ de distribución de documentos de hipertexto mediante un navegador web para visualización de sitios web, y la construcción de estos por medio de texto, video, imágenes e hiperenlaces, provocó un cambio paradigmático tanto en la manera en la cual los usuarios accedían a Internet como en la accesibilidad de las herramientas gráficas

\footnotetext{
${ }^{41}$ Conocido como HyperText Markup Language es el estándar adoptado por el World Wide Web Consortium que se ha impuesto para la visualización de páginas web, siendo el lenguaje web más importante paralelo al desarrollo y consolidación de la World Wide Web.

${ }^{42}$ Uniform Resource Locator, por su nombre en ingles, es una cadena de caracteres con la cual se otorga una ruta exclusiva a cada uno de los contenidos a nuestra disposición en Internet.

${ }^{43}$ No hay que confundir WorldWideWeb todo junto, el nombre del primer navegador, con el de World Wide Web separado, el cual se refiere a la red informática mundial de distribución de documentos de hipertexto.
} 
utilizadas para ello. El uso del hipertexto permitió la distribución de información a nivel global sin la supervisión de ningún circulo de poder. Este modelo nos presentaba un sistema en el cual cualquier elemento de la red puede conectar con cualquier otro. Esto supuso una gran reflexión sobre la propia estructura del conocimiento y de la formas centralizadas de poder. Es la propia estructura de la sociedad y los medios de transmisión del conocimiento y la información los que son organizados en base a un sistema arbóreo heredero de las ideas del filósofo neoplatónico Porfirio y que se ve reflejado en el modelo conocido como "el árbol de Porfirio". En cambio el hipervínculo como sistema de distribución horizontal promueve un sistema de transmisión de información que otorga la misma importancia a cada uno de sus nodos. Esto cambió el tipo de organización social que podíamos encontrar dentro de la red, abriendo la transmisión de información al gran público, en un primer momento conectado al mundo científico-técnico, pero obviamente fuera de las estructuras de poder y decisión de los medios masivos.

Las empresas comenzaron una carrera imparable por alcanzar visibilidad en la red mediante la creación de dominios. Esto produjo un aumento exponencial de los sitios web, que a principios de los 90 se contaban por unas pocas decenas, a mediados de esta década se alcanzaba el medio millón y a mediados de la segunda década del siglo XXI se sobrepasó con creces los 8000 millones de paginas webs conectadas. La indexación de paginas dentro de la web empezó dentro de portales como Yahoo o Altavista, otorgando mayor visibilidad a determinados sitios web que podían permitirse un mayor desembolso económico en este tipo de servicios. Esto revirtió los ideales utópicos de libre acceso propuestos desde proyectos como Xanadú, presentando una nueva realidad mediática que desembocó, a finales de los 90 , en un nuevo modelo, del cual empresas como Google es su máximo exponente. Estas pretenderán organizar y ordenar un océano de información que empezaba a desbordar las posibilidades de visualización de los portales tradicionales de Internet.

Todos estos cambios trajeron un publico mucho más variado y que no estaba ligado a los sectores científicos, académicos, gubernamentales, amantes de la informática o miembros de la cultura hacker de la época. Por lo tanto el surgimiento de Internet, y posteriormente su implementación comercial, 
generó las primeras comunidades virtuales más allá del ámbito hacker separando lo social del hecho de compartir una misma ubicación física ${ }^{44}$. Como afirma Castells, ya entonces Internet estaba basado en el trabajo y la familia45, y por lo tanto encuadrado dentro de lo que podríamos llamar nuestra cotidianidad. Por lo tanto ya desde su generalización y aparición comercial, Internet conformó una extensión de nuestra vida, inundando la red de nuestra actividad social. Podríamos decir, que toda esta cultura hacker de libre intercambio comenzó a perder su espacio una vez el mercado hace presencia mediante la posibilidad de vender ordenadores personales o mediante la capitalización del tráfico en la red. Por otro lado, mientras el perfil de usuario medio de esta red durante los primeros 30 años de vida era el del investigador hacker con grandes conocimientos de informática, una vez la tecnología de Internet se liberaliza y se pone al alcance de una gran parte de la población, un gran número de usuarios que no están en contacto con esta cultura empiezan a utilizar este espacio de una manera diferente, aunque siguen conservando de manera superficial muchos de los principios utópicos que nacieron y se extendieron con la red, entre otras cosas por la propia arquitectura mediática descentralizada y horizontal.

Podemos ver como diferentes ideas utópicas asociadas a las comunidades primigenias de Internet conformaron la visión filosófica y política de la red. Esto como nos cuenta David Casacuberta ${ }^{46}$, generó una conceptualización sobre Internet que no se corresponde con los procesos de gobernanza de la red ni el tipo de interacción generada por los usuarios en el ámbito de su vida diaria. Como hemos podido ver las diferentes tecnologías desarrolladas en los comienzos de Internet tenían la impronta de la ideología de sus creadores, lo que introdujo su ética sobre la información y como esta debía ser compartida. Esta ideología generó el concepto del ágora como la metáfora perfecta para describir Internet. El ágora griega es el prototipo de espacio público abierto donde nos encontramos conectados a nuestro grupo de iguales, nuestra posición social y nuestro rol dentro de la sociedad. Por otro lado, también esta

\footnotetext{
${ }^{44}$ Ludlow, Peter, Crypto Anarchy, Cyberstates and Pirate Utopias, MIT Press, Cambridge, 2001 p. 66.

${ }^{45}$ Castells, Manuel, op. Cit., 2001, p. 138.

${ }^{46}$ Casacuberta, David, Reclaim the Backbone: Repensar Internet como espacio Público, [En línea], [Consultado el 20 de Julio de 2017], disponible en < http://www.ub.edu/imarte/investigacions/estudis-teorics/david-casacuberta/reclaim-thebackbone-repensar-internet-como-espacio-publico/>
} 
relacionado con la manera en la cual se espera que nos representemos a nosotros mismos mediante las prendas de vestir, el lenguaje corporal, el discurso y el comportamiento e interacciones que tienen lugar en dicho espacio.

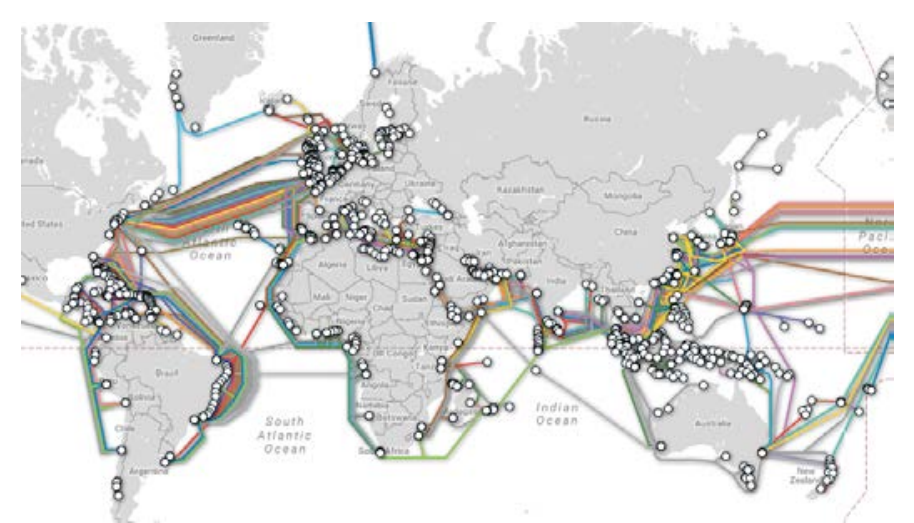

Figura 5. Mapa mundial de los backbones de Internet, 2017. Fuente www.submarinecablemap.com.

William J. Mitchell nos habla en su obra City of Bits: space, place and the infobahn ${ }^{47}$ sobre como cada unos de estos lugares públicos tiene sus propios actores, vestuario y guiones. Sin embargo acuña el concepto de "ágora electrónica" para destacar como Internet subvierte, desplaza y redefine radicalmente, nuestras nociones de lugar de encuentro, comunidad, y vida urbana. Para el la red tiene un estructura que opera mediante reglas equidistantes a la de los lugares públicos tradicionales. Esto genera la emergencia de redefinir términos como espacio, identidad personal y subjetividad ante la expansión de este medio. Por otro lado Casacuberta cuestiona el estatus de Internet como espacio público al considerarlo un lugar desigualmente accesible, cuya propiedad física está conformada por backbones ${ }^{48}$ y por lo tanto es controlable. Mediante el desarrollo de diferentes aplicaciones desde el ámbito empresarial de la posterior Web 2.0, esta red ha

\footnotetext{
${ }^{47}$ Mitchell, William J., City of bits: space, place and the infobahn, MIT Press, Cambridge, 1996, p. 8.

${ }^{48}$ Con backbones, o columnas vertebrales por su traducción, nos referimos a las principales conexiones troncales de Internet. Esta constituida por diferentes routers tanto comerciales como institucionales que transmiten los datos alrededor del planeta mediante cables oceánicos de fibra óptica.
} 
transformado nuestro tiempo de ocio en trabajo para terceros. Sin duda nos encontrábamos ya en un momento en el cual los espacios de interacción virtual empezaban a estar regidos por empresas que originaron los primeros espacios corporativos de socialización, los cuales guardaban mayor relación con los centros comerciales que con las plazas públicas, dejando una sensación de perdida de un verdadero espacio comunal en el cual discutir sobre lo público desde lo público, lo cual era fundamental para las primigenias comunidades virtuales.

Las diferentes entelequias desarrolladas desde estas comunidades comprendían el ideal de libertad de la información, libertad política mediante la creación de un territorio virtual autónomo, el uso de la red para fines activistas mediante los cuales se cambiará la realidad y la posibilidad de autoorganizarnos para garantizar nuestros derechos mediante nuestras propias herramientas tecnológicas. Un ejemplo de esta ideología relacionada con la manera en la cual gestionamos nuestro anonimato en la red es The Crypto Anarchist Manifesto de Timothy C. May, donde se proponía la utilización de la criptografía y las nuevas tecnologías de cifrado para proteger la libertad individual, entendida como la salvaguarda de la privacidad, de la identidad, de las transacciones y de las comunicaciones que realizamos. Internet desde sus inicios siempre ha sido un espacio de reivindicación que ha contado durante mucho tiempo, gracias a sus usuarios, con sus propias normas y códigos, intentando siempre estar fuera de la regulación gubernamental, pudiendo incluso, como apuntan teóricos como Peter Ludlow ${ }^{49}$, conformar sus propios ciberestados independientes y autoorganizados. Obviamente estas ideas provienen de los principios emancipatorios propugnados por la ética hacker, pero a la vez y por primera vez conceptualizan Internet como espacio construido por la propia unión de los nodos que conforman todos sus usuarios, generando un paralelismo con la propia estructura de la red como un método de interconexión y no como una red física.

Sin embargo, podemos afirmar que la libertad es una de las supuestas señas de identidad de la red desde sus orígenes. Recordemos que surge desde el ámbito del estado y entes científico universitarios, es decir desde el ámbito de

${ }^{49}$ Ludlow, Peter, op. Cit., 2001 p. 1. 
lo público. La mayor parte de la producción científica desarrollada en este ámbito se hace pública debido a la cultura universitaria de divulgación científica que considera la ciencia y el conocimiento un saber público. La ciencia se distingue de otras formas de conocimiento por la publicidad a la que se ven avocadas sus trabajos al finalizar una investigación o proyecto. En este ámbito es la propia difusión de los trabajos científicos lo que incentiva a los investigadores. La red por su propia estructura horizontal y descentralizada permite un libre acceso a la información desde cualquiera de sus nodos. Sin embargo, la liberalización, comercialización y la entrada de las grandes empresas, y por lo tanto de nuevas mecánicas de negocio alrededor de Internet, generarán a su vez un entramado comunicacional inédito hasta la fecha. Si observamos la historia de proyectos como Google, nos daremos cuenta de la verdadero origen de muchos de estos proyectos y como se transformaron en lo que conocemos hoy. Los creadores de Google Larry Page y Serguéi Brin desarrollaron este proyecto de investigación desde el amparo de la Universidad de Stanford en 1996, dentro de sus estudios de posgrado de Ciencias de la Computación. Es precisamente la idea de la importancia de la citas académicas lo que les hizo centrarse en el valor de las paginas vinculadas a una pagina web determinada. En el mundo académico los artículos son juzgados por su originalidad pero también por los artículos que citan y los trabajos posteriores que citan a cada trabajo. Así nació BackRub50 con la intención de señalar el trabajo de los demás para construir el propio. Mediante la premisa de que la World Wide Web, tal y como la concibió Tim Berners-Lee, estaba construida alrededor de la citación mediante los hipervínculos, Page y Brin construyeron BackRub como una herramienta mediante la cual rastrear las paginas enlazadas a cualquier web, poniendo de manifiesto la importancia de la clasificación mediante la creación de un sistema que premiaba los enlaces provenientes de fuentes consideradas importantes. Este algoritmo denominado PageRank, tenía en cuenta el número de enlaces a un sitio particular y el número de enlaces a cada uno de los sitios del enlace, esto produjo que los sitios más populares subieran en sus estadísticas y los menos populares bajaran. Este hecho les hizo pensar que los datos producidos mediante este algoritmo podían ser útiles para generar búsquedas. Sin embargo, pese al éxito de este tipo de clasificación basado en la autoregulación, cuando se intentaba generar búsquedas en las cuales apareciera algún tipo de relación de poder, tal y como nos cuenta Enric Puig

\footnotetext{
${ }^{50}$ Battelle, John, The Birth of Google, [En línea], [Consultado el 20 de Julio de 2017], disponible en $<$ https://www.wired.com/2005/08/battelle/>
} 
Punyet en su obra El Dorado51, la situación se invierte. La linealidad y jerarquización de este sistema hizo que se presentara como una lista ordenada, alejándose de la utopía de proyectos como Xanadú. Sin embargo, Page y Brin no aceptaron las estratagemas de diferentes paginas para posicionarse, como las granjas de vínculos, páginas vacías que solo enlazaban a otras y que lograban posicionar una pagina más arriba en las búsquedas. En principio se basaron en la integra transmisión de información, heredera de una visión del conocimiento como un elemento integro e incorruptible. Será la propia cultura del ranking implementada mediante las leyes del mercado desregulado, la que mediante las lógicas de su propio algoritmo convierta este proyecto en principio del fin de la horizontalidad y desjerarquización, bajo la única meta de la libre circulación de información y por lo tanto fuera de la cultura del ranking.

\subsection{LAS LÓGICAS DE LA WEB 2.0}

Los procesos de comercialización de los servicios de Internet y de la penetración de diferentes modelos de negocio dentro de la red cambió para siempre nuestro paradigma tecnológico, incluyendo la red descentralizada de Internet dentro de la esfera del consumo y de la cultura de masas. Uno de los momentos claves en la evolución de la web hacia este tipo de lógicas fue la inclusión por parte de una primigenia Google de anuncios dentro de sus búsquedas mediante la herramienta Google Adwords, como respuesta a las empresas que pretendían ubicarse ilegalmente dentro de las primeras posiciones de los resultados del buscador mediante diferentes estrategias. El aclamado fichaje de Eric Schmidt en 2001 como director ejecutivo, alguien que provenía del mundo de la empresa, desencadenó la implementación de esta aplicación. Para que Google Adwords fuera realmente efectiva se utilizaban las búsquedas de los usuarios como una manera de generar un mapa detallado de los patrones de comportamiento de estos. Esto posibilitaba que se pudiera ofrecer a los clientes la posibilidad de colocar anuncios en las búsquedas de los usuarios interesados en un determinado tema, generando un sistema de pay-per-click, es decir que los anunciantes solo pagaban por los usuarios que clicaban en sus anuncios. Los anuncios de Google aparecían a la derecha de las búsquedas de manera intencionada, lo que nos hace pensar en ciertas reticencias por parte de la empresa a la hora de mezclar publicidad y información. Esta mixtura, por otro lado generalizada dentro de los medios

\footnotetext{
${ }^{51}$ Puig Punyet, Enric, op. Cit., 2017, p. 62.
} 
tradicionales, suponía una negación de la idea de desjerarquización y de libre circulación de información en la red, y por lo tanto el fin de este espacio como fuente de recopilación de conocimiento neutral. La obra de Christophe Bruno The Google Adwords Happening52, es una exploración sobre los aspectos económicos implícitos en las búsquedas que realizamos diariamente en Google. Bruno comenzó una campaña publicitaria, que podríamos considerar un happening en el servicio de anuncios de Google llamado Google Adwords ${ }^{53}$. Se vale de esta herramienta de publicidad contextual para insertar poemas en la web, pervirtiendo la intencionalidad comercial de esta. Precisamente en la reutilización crítica de herramientas y espacios es donde está la posibilidad de subvertir los productos de la cultura visual de masas, rompiendo esta relación entre tecnología, economía y sociedad.

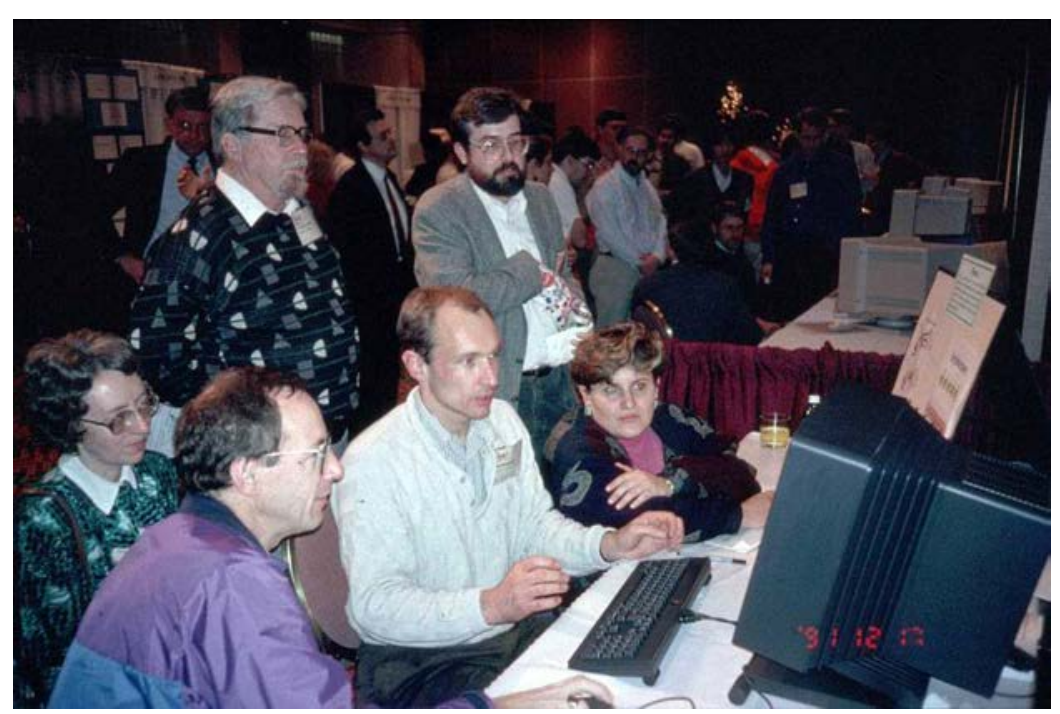

Figura 4. Tim Berners-Lee muestra la World Wide Web a los delegados en la conferencia Hypertext 1991, San Antonio, Texas (Imagen: CERN).

\footnotetext{
52 Chritophe, Bruno, The Google Adwords Happening, 2002, [Consulta 23 de Enero de 2017] disponible en <http://www.iterature.com/adwords>

${ }^{53}$ Esta obra alcanzó una duración de 24 hora a comienzos de Abril de 2002. Para ello comenzó a realizar anuncios relacionados con determinadas palabras clave, mediante las cuales desarrollaba un texto en forma de poema, de manera que el espectador se encuentra con un poema en forma de anuncio clasificado que esta relacionado con la palabra clave que busca.
} 
Podemos ver como los relatos asociados a con la manera en la cual Tim Berners-Lee estructuró la World Wide Web, como Ted Nelson conceptualizo su proyecto Xanadú o la manera en la cual Vannevar Bush ideo su base de datos Memex ${ }^{44}$, pasaron a ser sustituidos por un nuevo tipo de visión de la web en la que el conocimiento pasará a un segundo plano a favor del autor. Este nuevo posicionamiento se contrapondrá al ideal utópico de libre distribución de la información como elemento emancipador de Internet, saturando la red de la opinión y voz de una multitud ávida por desarrollar un abanico de interpretaciones de la realidad. Por otro lado supuso la inclusión del discurso individual y la autobiografía en la red dentro de una multiplicidad de singularidades. Esto significó el comienzo de la representación de un yo concreto en Internet fuera de las anteriores muestras ficticias o anónimas tanto de naturaleza textual como basadas en avatares.

La implementación del lenguaje XML supuso una superación de las limitaciones del código HTML, y dio la posibilidad de disociar el propio contenido de una web de su diseño, de manera que dio inicio a una tendencia hacia la publicación periódica de contenidos por parte del gran público, mediante la implementación de una primera etapa de la sociedad de los medios personales de acceso a la información, gracias a servicios como Blogger, Live Journal o MSN Spaces, entre otros. Se paso de empresas que mantenían sitios web estáticos y usuarios que discutían en foros de discusión que no podían administrar, a espacios personales de expresión diseñados por los propios usuarios en base a una herramientas y diseños dados. Esto supuso una vuelta a una narrativa del yo subjetivo en contraposición a las utopías virtuales, dentro de lo que podemos denominar como un claro giro a la cotidianeidad, la singularidad y sus posibilidades de expresión, desde la nuevas posibilidades ofrecidas por los servicios de Internet. Por su parte Google materializo la avidez por la información, el deseo por el deseo del otro, y la relación entre reconocimiento y visibilidad que caracteriza a la cultura del ranking.

\footnotetext{
${ }^{54}$ Memex fue un proyecto de base de datos ideado por Vannebar Bush en 1945. Contaba con una mesa con teclado y palancas que permitiría consultar una base de datos de microfilms proyectados sobre pantallas. Mediante este sistema el usuario podría convertirse en autor al modificar el documento mediante anotaciones incluidas en los márgenes.
} 
Ya en el año 2000 Autores como Michael Hardt y Antonio Negri señalaron en su obra Imperio el origen de una nueva forma de poder generada por la interacción del capital y los medios informáticos. Como ellos mismos nos cuentan en su obra, "El poder es ahora ejercido por medio de máquinas que, directamente, organizan las mentes (en sistemas de comunicaciones, redes de información, etc.) y los cuerpos (en sistemas de bienestar, actividades monitoreádas, etc.) hacia un estado de alineación autónoma del sentido de la vida y el deseo de la creatividad"55. Por otro lado, como apunta Hardt y Negri esta nueva forma de poder incluye otras conceptualizaciones como las sociedades de control y el biopoder de Foucault bajo el concepto de "Imperio".

Durante el periodo comprendido entre 1997 y 2001 se generó la corriente económica especulativa soportada por empresas vinculadas al nuevo sector de Internet y la conocida como nueva economía ${ }^{56}$. Como hemos visto, fue posible gracias a el desarrollo de nuevas tecnologías informáticas y de telecomunicaciones que hicieron factible la globalización de los mercados financieros dentro de un nuevo capitalismo global, operado en tiempo real.

Esto generó el capital necesario para producir proyectos empresariales mediante capital de riesgo ${ }^{57}$. Sin embargo, las expectativas de muchos analistas del mercado financiero pasaron a ser rápidamente desfavorables, provocando la huida de capitales y el desplome de un gran numero de empresas que habían sido hinchadas con fines especulativos, en lo que se conoce como "la burbuja punto com". Al contrario de lo que podría parecer, el derrumbe de las "punto com" no implicó un descenso en la aparición de nuevos proyectos y aplicaciones, sino un punto de inflexión de importancia capital para la implementación de las lógicas de la Web 2.0. Este termino pese a haber sido acuñado previamente por Darcy DiNucci en su artículo Fragmented Future ${ }^{58}$, se populariza en la Web 2.0 Summit de 2004 originalmente conocida como Web 2.0 Conference, un evento anual organizado en la ciudad de San Francisco por O’Reilly Media. Según nos cuenta

\footnotetext{
${ }^{55}$ Hardt, Michael, Negri, Antonio, Empire, Harvard University Press, Cambridge, 2000, p. 23.

${ }^{56}$ Castells, Manuel, op. Cit., 2001, p. 19.

${ }^{57}$ Las entidades de capital de riesgo financian proyectos de startups asociados a la tecnología y novedosos modelos de negocio, tomando participación del capital de dichas empresas.

${ }^{58}$ El término fue acuñado por primera vez por Darcy DiNucci en su artículo Fragmented Future de 1999. <http://darcyd.com/fragmented_future.pdf>
} 
Tim 0'Reilly popularizador del termino ${ }^{59}$ y director y fundador de 0'Reilly Media, tras el derrumbe de las "punto com" las características comunes de los supervivientes de esta burbuja y las tecnologías que las soportaban, encontraron el momento en el cual ocupar su lugar dentro del escenario económico.

Para O'Reilly el termino llegó a convertirse en un meme tan potente que muchas startups lo usaban para referirse a proyectos que en absoluto podrían encuadrarse dentro de este termino. Este concepto surgió en torno a las características novedosas de diferentes aplicaciones web, tal es el caso de Google, quizás el ejemplo más paradigmático, la cual ejemplificó el cambio de la antigua industria del software a los servicios actuales ofrecidos por la web, sustituyendo las licencias de usuario por el propio uso, y transformando las aplicaciones en bases de datos especializadas. Precisamente, es la cantidad de datos manejados y la gestión de estos son en definitiva las características más valiosas de una web que se conforma como plataforma donde el software se incorpora a la web y no al ordenador, y donde los usuarios son los constructores de la gran rentabilidad de estas empresas. Así pues podemos hablar de Google, paradigma de la Web 2.0, como un intermediario entre el usuario y la experiencia vivida en Internet. De hecho, el valor del software es proporcional a la escala y al dinamismo de los datos que gestiona. Podríamos decir que este buscador trabaja con nuestros intereses y nuestra inteligencia ya que ha terminado manejando las búsquedas de millones de usuarios. Como nos diría Enric Puig Punyet "Esto ha generado una tensión entre la cultura concebida como una práctica emancipadora del individuo o como mercancía que hay que vender a toda costa" 60.

Como podemos observar la propia humanidad se ha convertido en objeto de observación de si misma, convirtiendose las diferentes esferas de lo público en algo atravesado por la esfera privada de cada usuario, en algo producido dentro de los medios, que ya no se basa en los principios de sojuzgamiento

\footnotetext{
${ }^{59}$ O'Reilly, Tim, What Is Web 2.0. Design Patterns and Business Models for the Next Generation of Software, 2005,

Consulta 23 de Enero de 2016] disponible en <http://www.oreilly.com/pub/a/web2/archive/whatis-web-20.html>

${ }^{60}$ Puig Punyet, Enric, op. Cit., 2017, p. 90.
} 
racional de lo público, sino en las lógicas productivas de una humanidad que "se da a si misma como espectáculo"61, tal y como nos anunciaba Walter Benjamin al compararla con la humanidad que servía de diversión a los dioses del Olimpo. Esta es un tipo de humanidad que se extiende más allá de si misma dentro de los media, lo que parece cumplir la profecía de Marshall McLuhan ${ }^{62}$ que conceptualizaba a estos como una extensión de nuestra mente de la misma manera que la ropa lo es de nuestra piel, sin duda, algo que hoy en día siempre llevamos puesto. Esta comparación cobra sentido si observamos la intensa relación que la gran mayoría de los usuarios tienen con sus terminales móviles que nos impide salir de la ubicuidad y conexión constante.

Como nos cuenta Juan Martín Prada, "hoy las interrelaciones vitales devienen directamente productivas"63, dentro de los que ha venido a definirse como economías de la afectividad o "dinámicas mercadotécnicas y capitalistas de gestión afectiva en Internet"64. Estas son pues tecnologías afectivas que nos hacen adictos a esta mediación técnica de los afectos que modifica nuestra percepción, por ser esta parte fundamental este tipo de relaciones interpersonales. El propio territorio de la redes sociales se basa en la productividad generada por la afectividad, que implementa la regulación de los estilos de vida que estos modelos mediáticos despliegan sobre nuestra cotidianidad mediante nuevas formas de socialización. Estas formas de trabajo han sido ampliamente desarrolladas dentro de conceptos como capitalismo cognitivo, trabajo inmaterial, trabajo afectivo o trabajo inmaterial, entre otros. Siendo especialmente importante, como veremos, el trabajo desarrollado por teóricos provenientes del operaísmo y el autonomismo italiano entre otros. Sin duda, muchas de las ideas provenientes del propio marxismo y posmarxismo han encontrado una nueva realidad mediática que se complementa con los supuestos desarrollados dentro de esta corriente de pensamiento.

\footnotetext{
${ }^{61}$ Benjamin, Walter, op. Cit., 2013, p. 60.

${ }^{62}$ McLuhan Marshall, op. Cit., 1996, p.135.

${ }^{63}$ Martín Prada, Juan, Practicas Artísticas e Internet en la época de las Redes Sociales., Ediciones Akal, Madrid, 2015, p. 59.

${ }^{64}$ Zafra, Remedios, Ojos y Capital, Consonni, Bilbao, 2015, p. 124.
} 
Por otro lado podemos observar como las formas culturales basadas en la Web 2.0 generan una "estrategia de la insatisfacción" basada en la incertidumbre producida por nuestro propio reconocimiento frente al otro. Un tipo de insatisfacción que deliberadamente queda en suspenso, que no puede ser saciada debido a la inmensidad de los flujos comunicativos producidos, y lo imperceptible de nuestra presencia en la red. Es precisamente esta insatisfacción del deseo lo que genera altos grados de dependencia de unas tecnologías de cuya omnipresencia es difícil escapar hoy día, debido a la interconexión constante que las tecnologías móviles implementan. Un tipo de relación con la tecnología que nos mantiene en una espera constante, en la cual lo que intentamos dilucidar en nuestra propia relación con el mundo. Esto se materializa mediante la interacción de otros usuarios con nuestro propio contenido a través de visitas, me gusta, compartir o comentarios, un sin fin de gestos que siguen sin responder la verdadera pregunta relacionada con nuestra relación con el otro. En la red esta relación se ha convertido en una mercancía que nos genera la dependencia que sustenta el éxito de este modelo de negocio basado en nuestra propia productividad y el tráfico alrededor de estos contenidos. A partir de los primeros blogs se evolucionó a un sin fin de formas que tendrán como componente principal la participación como forma de búsqueda de una afectividad flotante e insatisfecha mediante la cual somos interpelados e interpelamos.

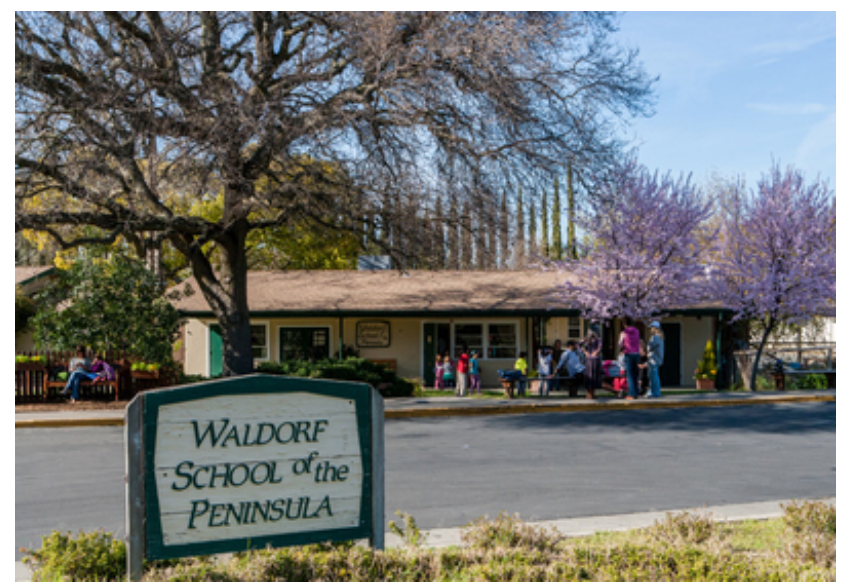

Figura 6. Waldorf School en Silicon Valley, 2015, Fuente www.noodle.com. 
El giro de la imagen pública del propio creador de Facebook y las aplicaciones más conocidas de la Web 2.0, puede generar un relato de cómo la manera en la cual percibimos Internet y sus aplicaciones fue cambiando desde finales de 2011, cuando según un articulo de New York Times ${ }^{65}$ la mayoría de los directivos de Silicon Valley enviaban a sus hijos al centro educativo Waldorf School, el cual prohíbe terminantemente el uso de nuevas tecnologías. Esto propago, dentro de la sociedad americana y europea, la idea de que este tipo de servicios pueden no ser del todo positivos para sus usuarios. De manera, que como nos cuenta Enric Puig Punyet66, esto hizo que los usuarios tomaran conciencia sobre los aspectos negativos para la privacidad que este tipo de aplicaciones conllevan, cuestionando el supuesto atractivo del deseo por ser visto y de que otros vean que podemos verles, tal y como dice Remedios Zafra "somos apariencia y que en función del que nos mira o nos sueñan, oscilamos entre formas distintas de ser. De ahí el descanso de mirar (y ser mirada) sin expectativa, el sueño de carecer de ojos o de ser un árbol (para después volver)"67. Como respuesta a esta caída en el uso de aplicaciones sociales, fue el concepto de visualización y su contraprestación económica el que recuperó el interés de gran parte de los usuarios. Un nuevo tipo de usuario estaba surgiendo en plataformas como Youtube. Este tipo de creadores emprendedores, esperan que la viralidad de sus creaciones les catapultara a la fama y la abundancia económica. Es precisamente la búsqueda de este nuevo Dorado, como nos cuenta Enric Puig Punyet, un giro a las utopías basadas en la colectividad a un tipo de utopía que se centra en el individualismo emprendedor, que usa su propia imagen para crecer dentro de un ámbito mediático competitivo. Esto ha generado un mecanismo de self branding, como nos diría Gemma San Cornelio ${ }^{68}$, que ha consolidado una transformación del trabajo en Internet. Estos usuarios se valen de la autopromoción dentro de un proyecto reflexivo del yo, en este caso en forma de marca o producto mediático conformado por la imagen del usuario y su producción mediática. Podríamos decir que se generó una nueva mentalidad dentro de una gran parte de los usuarios de diversas plataformas que esta relacionada con la

\footnotetext{
65 Ritchel, Matt, A Silicon Valley school that doesnt't compute, New York times, 22/10/2011, Consulta 23 de Enero de 2016] disponible en <http://www.nytimes.com/2011/10/23/technology/atwaldorf-school-in-silicon-valley-technology-can-wait.html>

${ }^{66}$ Puig Punyet, Enric, op. Cit., 2017, p. 106.

${ }^{67}$ Zafra, Remedios, op. Cit., 2015, p. 46.

${ }^{68}$ San Cornelio, Gemma, op. Cit., 2008, p. 18.
} 
propia retórica empresarial de estas. Esto ha generado un movimiento especulativo alrededor de las aplicaciones que hacen posible la monetización de las visitas o visualizaciones de los usuarios. Esto comienza a vislumbrase como una de las grandes burbujas alrededor de Internet, que ya a mediados de la segunda década del siglo XXI a empezado a mostrar sus efectos por el bajo rendimiento de este tipo de actividad, lo que hace inviable que una gran masa de usuarios puedan subsistir en base a estos ingresos.

Para Lev Manovich, precisamente las características distintivas del software usado dentro de la web son la posibilidad de creación, reproducción, publicación y acceso a contenidos, dentro de lo que el denomina "software cultural". El impacto de plataformas como el sistema Android de Google, Facebook, Windows o Linux dentro de la economía global, la cultura, la política y la vida social es según Manovich "una parte visible de un universo de software más grande" 69 . Este es un tipo de software, que permanece invisible para los usuarios, en cambio soporta acciones asociadas con la cultura que pueden ser desglosadas en diferentes categorías basadas en factores como la creatividad, la participación, el intercambio, la comunicación, el etiquetado y el propio desarrollo de herramientas para la comunidad. Este tipo de software, según Manovich también incluiría aplicaciones profesionales para la producción y postproducción, así como aplicaciones de medios sociales. Como el mismo aclara el termino cultura incluye muchos otros elementos, por lo tanto es un área que no solo abarca un subconjunto de software de aplicaciones y las experiencias que se puedan generar con ellos. En cambio si podemos apreciar una nueva dimensión de la cultura que a la vez genera una nueva dimensión de nuestra realidad dentro de la virtualidad en la que vivimos.

Por consiguiente, nos encontramos por un lado con un paradigma de web en el cual los cambios acaecidos han recaído sobre la difusión masiva de contenidos generados por los usuarios de manera simple y sin la necesidad de conocimientos avanzados, y por otro lado con un modelo en el cual la difusión de este sistema en multitud de plataformas y dispositivos es una de sus características principales. La Web 2.0 ha originado una democratización de los media al poner al alcance de cualquier usuario la posibilidad de publicar

\footnotetext{
${ }^{69}$ Manovich, Lev, El software toma el mando, Editorial UOC, Barcelona, 2013, p. 23.
} 
contenidos en la web, reduciendo los costes de edición y aumentando la clasificación de contenidos por el gran volumen de material subido diariamente, dentro de una revolución de la creación amateur. Sin embargo, este tipo de giro hacia la diletancia, como posicionamiento ante lo creativo, ha sido analizado de manera muy crítica por Andrew Keen en su obra The cult of the amateur ${ }^{70}$. En ella Keen hace un análisis de las prácticas participativas generadas por la Web 2.0, y de cómo estas afectan a diferentes áreas como la creatividad, economía e innovación. Keen pone el foco en la manera en la cual instituciones tradicionales como el cine, la prensa o la música, han sido reemplazadas por una ingente cantidad de producción gratuita. Los canales de Youtube se han convertido en potentes centros de difusión que en algunos casos cuentan con una audiencia potencial equiparable a la de la televisión tradicional. La cultura del "corta y pega" ha reformulado la autoría y la propiedad intelectual dentro de Internet, amenazando de manera frontal el modelo de producción asentado durante todo el siglo XX. Este paso hacia una cultura que se genera de manera autodidacta ha pasado, según Keen, ha posicionar al mismo nivel, y sobre todo, con los mismos medios a un experto que a un a un aficionado, posibilitando la difusión de información dudosamente contrastada como una de las nuevas patologías de los medios de Internet. Al no contar con ningún tipo de estándar profesional o línea editorial, el debate público generado por estos medios no cuenta con las restricciones que podríamos encontrar en los medios tradicionales. Por otro lado, el propio anonimato de los autores genera, según Keen, aún más dudas sobre la propia verosimilitud de los contenidos de la web, a la par que debilita la posición del autor como institución tradicional dentro de los medios. En definitiva, Keen defiende la importancia de los medios profesionales frente a una cultura de lo amateur que esta destruyendo, bajo un falso ideal de la democrático, las posibilidades de distribución del trabajo creativo de un sin fin de creadores.

Manuel Castells en su obra La Galaxia Internet nos habla, ya en 2001 sobre los nuevos consumidores-usuarios ${ }^{71}$ como: "aquellos receptores de aplicaciones y sistemas que no interactúan directamente con el desarrollo de Internet

\footnotetext{
${ }^{70}$ Keen, Andrew, The cult of the amateur, Random House, Nueva York, 2007.

${ }^{71}$ Aunque quizás sería más preciso hablar de constructores o productores de este espacios y tecnologías ya que en la actualidad la producción de contenidos ha pasado a formar parte de la actividad de los usuarios online.
} 
(aunque sus usos tienen un efecto agregado en la evolución del sistema)"72. Como contrapunto a estos consumidores-usuarios Castells nos presenta a los productores-usuarios como los verdaderos productores primeros de Internet y de su cultura, compuesta por un conjunto de valores y creencias que componen su comportamiento en Internet, y que se conformó como la cultura hacker73. Como vimos, ya en 1944 Theodor Adorno y Max Horkheimer ${ }^{74}$ nos hablaban sobre los productores y consumidores obligados a acudir al trabajo y la diversión, sometidos al poder del capital mediante una cultura de masas que ya no necesita conceptualizarse como arte en pos de la racionalidad del dominio.

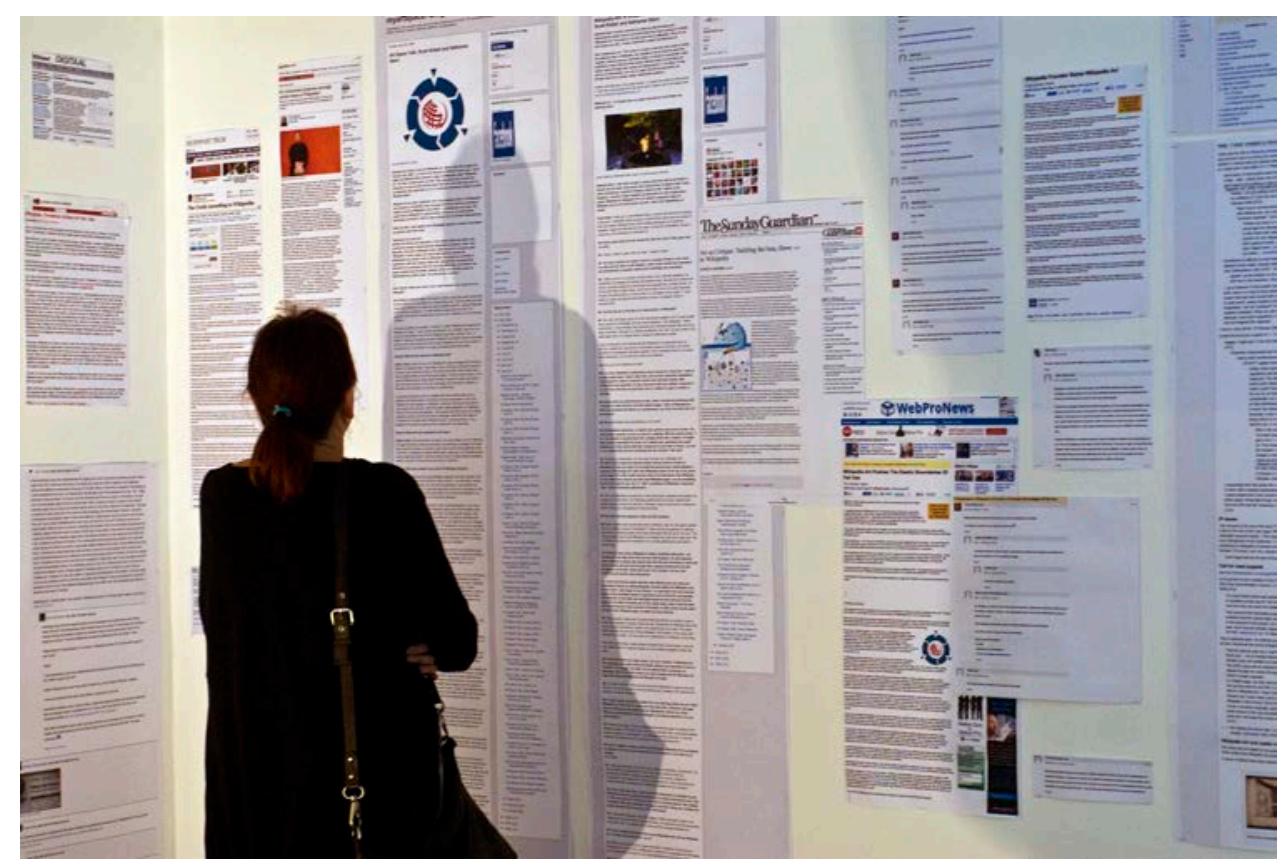

Figura 7. Detalle de la instalación Wikipedia Art, 2099, Furtherfield Gallery, London.

\footnotetext{
${ }^{72}$ Castells, Manuel. op. Cit., 2001, p. 51.

${ }^{73}$ Himanen, Pekka, op. Cit., 2002, p.

${ }^{74}$ Adorno, Theodor, Horkheimer, Max, Dialéctica de la llustración. Fragmentos Filosóficos, Editorial Totta, 1998, p. 166.
} 
Este contexto generará, por otro lado, un espacio muy atractivo para la exploración de las nuevas prácticas artísticas por lo transcendente del análisis de los nuevos tipos de percepciones, pautas sociales y subjetividades producidas como consecuencia de su implementación dentro de Internet. Como defiende Juan Martín Prada, podemos conceptualizar estas prácticas artísticas como modos de generar una oposición interpretativa y crítica a las nuevas dependencias y necesidades que organizan hoy la red y que administran sus modelos de negocio. Este sistema incentiva la interacción y colaboración entre usuarios como creadores de contenidos dentro de diferentes comunidades virtuales. Este vuelco hacia lo participativo de la Web 2.0 ha incentivado nuevas formas colaborativas que como Wikipedia dependen del tipo de contenido generado por sus propios usuarios. Por otro lado este tipo de espacios han abierto la puerta a la entrada de la reflexión artística, como el proyecto Wikipedia Art ${ }^{75}$ de Scott Kindall y Nathaniel Stern lanzado en 2009. El desarrollo exponencial de la publicidad online la ha posicionado como un elemento ubicuo dentro de los entornos virtuales de la Web 2.0. Será un elemento que sustente económicamente, pero que también construya visualmente nuestros espacios en base a la interacción y preferencias extraídas del actuar de los usuarios dentro de la red, en lo que ha venido a denominarse como publicidad comportamental ${ }^{76}$ o behavioural advertising por su nombre en ingles. Esta modalidad de publicidad, basada en el comportamiento de los usuarios, utilizará el rastreo temporal de la navegación en Internet mediante el tracking cookies, lo que posibilita remitir publicidad relacionada con los intereses de los usuarios.

La omnisciencia de empresas como Google se basa en su capacidad para organizar toda la información existente y generada continuamente a nivel mundial, de manera que esta gigantesca compañía adquiere el rol de un narrador omnisapiente. La capacidad de este tipo de compañías para extraer, mediante el software, el relato de cómo nos comportamos en la red se basa en un estado de constante evolución, de unas aplicaciones ejecutadas de manera remota, es decir, el propio software se actualiza y muta constantemente independientemente del propio usuario, dentro de lo que Lev Manovich denomina "software de los medios" o webware. Es decir, un tipo de software ubicado en la web que permite acceder a diferentes tipos de contenidos pero

\footnotetext{
${ }^{76}$ Pérez Bes, Francisco, La publicidad comportamental online, Editorial UOC, Barcelona, 2012.
} 
también otorga la posibilidad de crearlo, intercambiarlo y modificarlo dentro de lo que podríamos considerar una versión beta perpetua. Por otro lado, el paso de los datos del ámbito profesional a el de la sociedad de masas dio paso a la representación de medios como datos mediante la visualización de la información, generando una convergencia ente datos y medios.

Todo esto nos ha convertido en individuos disueltos en los datos que producimos y a la vez conformados por estos datos. El concepto de Big Data, como veremos, nos habla de grandes conjuntos de datos, que por sus dimensiones, complejidad y variabilidad, no pueden ser procesados mediante herramientas convencionales. Estos datos generan la identificación de problemas y cuestiones difícilmente detectables de antemano, mediante el estudio de las tendencias de los usuarios. Nuestra información ha pasado a alimentar nuestras propias extensiones tecnológicas en forma de smartphones y wereables planteando, tal y como Paul Virilio nos anunciaba en su obra Estética de la desaparición, la evanescencia del mundo material ante la hegemonía del virtual. De hecho, una de las principales formas actuales de vigilancia es la acumulación de grandes cantidades de datos mediante diferentes estrategias de recolección ${ }^{77}$.

Uno de los proyectos más sorprendentes de Google es el hecho de ofrecer routers de alta calidad y una muy buena conexión a pequeñas y medianas empresas para que ofrezcan a sus clientes Internet gratuito. Por su parte Facebook planteó desarrollar un proyecto para desplegar una conexión gratuita universal en países subdesarrollados. La popularización de la conexión gratuita permanente de cada usuario desde multitud de terminales podría constituir uno de los sueños más ansiados por las grandes compañías de Internet, la de la colonización de la cotidianidad y en definitiva la vida de todos los seres humanos del planeta. Este ansia de expansión persigue como no podía ser de otra manera la culminación definitiva, al intercambio generalizado, al ímpetu comunicativo como camino hacia la homogeneización de la realidad. La inclusión de la economía en todos los aspectos de nuestra vida. Este deseo parece más real cada día, si tenemos en cuenta como todas estas compañías multinacionales de Internet han logrado transformar nuestro tiempo libre en un espacio de trabajo para su propio beneficio mediante la avidez comunicativa de la multitud interconectada. En un articulo de New

\footnotetext{
77 Jansson, André, Christensen, Miyase, Media, surveillance and identity, Peter Lang, Nueva York, 2014, p. 32. 
York Times de Thomas L. Friedman titulado ¿Google es Dios?78 se recoge la opinión del vicepresidente de la compañía Airespace, proveedora de señal Wifi . Este directivo llamado Alan Cohen comenta como mediante la combinación de la conexión Wifi y Google se obtiene algo muy parecido a Dios, en el sentido de que Dios es inalámbrico y esta en todas partes. Para el, históricamente la gente podía preguntar a Dios sin necesidad de cables y ahora es Google el que ocupa este lugar gracias a la difusión de las tecnologías de conexión inalámbrica. Como diría Boris Groys en su obra Volverse público, "Google es la primera maquina filosófica conocida que regula nuestro dialogo con el mundo"79, por lo tanto filtra lo que podemos saber y percibir.

Por otro lado, pese a comenzar como pequeñas $\operatorname{startups} s^{80}$, la tendencia hacia la adquisición de otras empresas, ya iniciada en la prensa del siglo XIX y XX y en el resto de los medios de comunicación mediante los grandes conglomerados mediáticos, aumenta la sensación de encontrarnos ante entidades transnacionales que se encuentran por encima del poder de muchos estados, y que necesita de entidades políticas supranacionales igualmente poderosas para ser reguladas. En este sentido ya en 2014 la Unión Europea ${ }^{81}$ ha puesto en su punto de mira las prácticas fiscales, el manejo de datos personales y las prácticas monopolistas de estas empresas. En 2007 Google compró el gigante de la publicidad online Doubleclick por 2300 millones de euros. Lo que creo la posibilidad de crear un imperio que contuviera a casi la totalidad de los anunciantes, usuarios y soportes publicitarios, otorgándose la posibilidad de imponer prácticas monopolistas sobre el manejo de los datos ante la complacencia de las autoridades. Esta compañía da un trato preferencial a sus propios servicios desviando las búsquedas hacia estos, minando la igualdad de condiciones dentro del mercado digital. Por otro lado la Eurocamara ha planteado dividir las actividades de este gigante de Internet en diferentes servicios implementados por diferentes empresas. Un ejemplo muy claro de

78 Friedman, Thomas L., Is Google God?, New York Times, 29 de Junio de 2003, [en línea], [consulta 16 de Febrero de 2017], disponible en <http://www.nytimes.com/2003/06/29/opinion/is-googlegod.html>.

79 Groys, Boris, Volverse Público, Caja Negra Editora, Buenos Aires, 2014, p. 193.

80 Este termino se refiere a una compañía emergente que busca crear un nuevo negocio basado en la tecnología.

81 Veloso, Moncho, El poder de Google desata una batalla entre Europa y EEUU, ABC, Madrid, 9 de Diciembre de 2014, [en línea], [consulta 16 de Febrero de 2017], disponible en <http://www.abc.es/economia/20141208/abci-poder-google-batalla-estados-201412052144.html>. 
fagocitación mediática sería el de los sistemas operativos móviles como Android, el cual se impuesto sobre sus competidores mediante un proceso de integración vertical en toda la cadena de valor. Este sistema incluye todo un paquete de aplicaciones desarrolladas por Google que se conectan con todos los servicios ofrecidos por la compañía, lo que ha culminado con la creación de sus propios terminales móviles implementados mediante esta amalgama de aplicaciones hegemónicas no compatibles con otros servicios. Por otro lado compañías como AT\&T o Comcast de EEUU han denunciado el uso que estas grandes compañías realizan de las estructuras de comunicación que ellos desarrollan, generándose un enfrentamiento entre los creadores de contenidos y los implementadores de la estructura de red.

Como hemos visto la realidad mediática en la cual estamos inmersos se ha formado mediante la confrontación entre la horizontalidad, generada por una visión utópica y contracultural de la red, y la verticalidad, propia de la lógica capitalista y de mercado de pequeños proyectos tecnológicos, que conformados como grandes compañías hegemónicas acaban fagocitando un espacio heredero de lo público, e indispensable para la formación de la opinión pública mediante la interacción de la multitud interconectada. Este proceso histórico ha generado un claro paralelismo con el surgimiento de los medios tradicionales y su transformación en los medios de comunicación de masas ante la implementación de las lógicas del mercado. Las dinámicas de participación e interactividad que supuestamente legitiman un ideal democrático dentro de la red, han pasado a alimentar un mecanismo de concentración de poder que desvirtúa cualquier atisbo de autogestión. Pese a su invisibilidad las entidades comerciales que proporcionan los servicios más usados dentro de la red han propiciado una sensación de independencia que no se corresponde con una realidad mediática profundamente jerarquizada y dependiente de los ingresos por publicidad y de la actividad constante de los usuarios. Sin duda la tecnología es una de las principales herramientas emancipatorias con las cuales cuenta la humanidad, pero estas nuevas posibilidades desaparecen cuando es el propio funcionamiento de las estructuras mediáticas el que queda supeditado a la transformación del tiempo de ocio de la masa, como plusvalía, en el contenido que rellena estructuras comunicativas vacías que serían incapaces de funcionar sin el ímpetu comunicativo de los usuarios. 
2. LA ECOLOGÍA DE LOS MEDIOS 


\subsection{PRECEDENTES, DESARROLLO Y NUEVAS FRONTERAS}

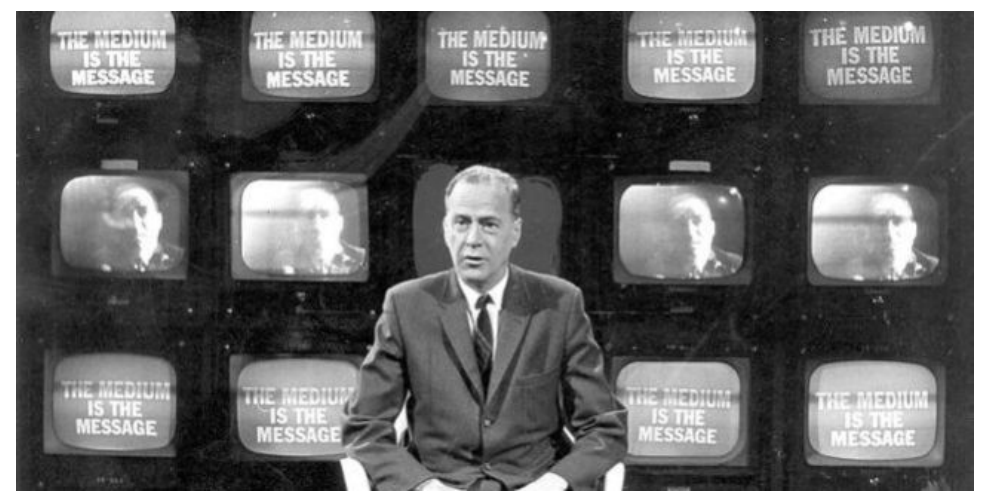

Figura 8. Marshall McLuhan en la CBC de Toronto, 1966. Fotografía de Henri Dumain.

La ecología de los medios puede definirse como el estudio del medio, la tecnología, la comunicación y como afecta al entorno el cual los seres humanos desarrollan su existencia. Este termino, conceptualizado de manera privada por Marshall McLuhan a principios de los 60, queda implícito dentro de sus obras La Galaxia Gutenberg82 de 1962 y Comprender los medios de comunicación ${ }^{83}$ de 1964. Será Neil Postman quién dentro del National Council of Teachers of English de 1968 lo acuñe por primera vez como el estudio de los medios como ambientes, aunque siempre reconoció la autoría intelectual de McLuhan como desarrollador del concepto. Pese a todo esto y como reconoce Carlos A. Scolari en su obra Ecología de los Medios, entornos, evoluciones e interpretaciones ${ }^{84}$, varios autores siguen dando todo el merito a Postman. Podríamos destacar la aportación de Postman como unificador de esta serie de metáforas en un campo científico y teórico unificado dentro de su programa de Ecología de los Medios de la Universidad de Nueva York iniciado en 1971, lo que contribuyó a su normalización y aceptación dentro de mundo académico.

\footnotetext{
${ }^{82}$ McLuhan, Marshal, La Galaxia Gutenberg, Planeta-De Agostini, Barcelona, 1985.

${ }^{83}$ McLuhan, Marshall, Comprender los medios de comunicación, Paidós, Barcelona, 1996.

${ }^{84}$ Scolari, Carlos A., Ecología de los Medios, entornos, evoluciones e interpretaciones, Gedisa, Barcelona, 2015.
} 
Hay que resaltar que pese a la presencia mediática y académica del propio McLuhan esta teoría sufrirá el ostracismo del mundo académico durante años hasta que poco a poco y sobre todo gracias a la organización Media Ecology Association y la publicación Explorations in Media Ecology adquirirá presencia en el ámbito internacional. La difusión de esta teoría fue paralela a la consolidación de la ecología y las ideas relacionadas con esta durante la década de los 70. La Ecología dentro de este ámbito mediático se refiere al entorno en el cual el medio es usado y como afecta a los individuos. Podríamos resaltar la aportación de una serie de autores que anteriormente al trabajo de McLuhan y Postman sentaron las bases e incluso aportaron conceptos a esta teoría. La obra de Lewis Mumford Técnica y Civilización ${ }^{85}$ de 1934 podría ser considerada como la obra que abre camino a posteriores incursiones en el campo. Mumford desarrolló una investigación caracterizada por el entrecruzamiento de diferentes campos. Una de sus mayores aportaciones es la superación de un enfoque mecanicista, generando un paralelismo entre lo técnico y lo ecológico, construyendo una visión pionera de la ecología de los medios dentro de la cultura tecnológica del momento que cada vez cuestionaría más la separación entre tecnológico y orgánico. Por su parte el investigador Jacques Ellul, dentro del arco teórico constituido por sus dos obras Propaganda86 de 1962 y La technique ou l'enjeu du siècle ${ }^{87}$ de 1954, realiza un análisis de la prevalencia de una serie de valores basados en la técnica, la propaganda y la imagen por encima de los valores morales, y el discurso como herramienta de discernimiento. Establece pues una obra transdisciplinar que intenta una puesta en valor de lo social por encima del medio, algo que de hecho criticó de McLuhan. Harold Innis se encuentra dentro de los referentes fundamentales dentro de esta disciplina teórica, al haber puesto en el centro de la investigación a la procesos comunicativos que permiten el flujo de la información. En Empire and Communications ${ }^{88}$ de 1950 genera un relato en base a esta premisa mediante el cual reconstruye la historia de los principales imperios de la humanidad, discerniendo como los diferentes medios de comunicación de cada momento influenciaron de manera crucial la formas de organización social y económica de cada época.

\footnotetext{
${ }^{85}$ Mumford, Lewis, Técnica y Civilización, Alianza Editorial, Madrid, 1992.

${ }^{86}$ Ellul, Jacques, Propaganda. The Formation of Men's Attitudes, Vintage Books, Nueva York, 1973.

${ }^{87}$ Ellul, Jacques, La technique ou l'enjeu du siècle, Economica, París, 2008.

${ }^{88}$ Innis, Harold, Empire and Communications, Dunburn, Toronto, 2007.
} 
Por otro lado, uno de los precedentes que conecta a Innis con McLuhan es Eric A. Havelock. Este investigador británico desarrolla una interesante obra en la cual pone de manifiesto la importancia del paso de la oralidad a la escritura dentro de la sociedad griega. Este paso según Havelock transformo completamente la sociedad en base a la alfabetización y el cambio comunicativo que esta produjo. En Preface to Plato ${ }^{89}$ de 1963 podemos encontrar una de las obras más influyentes de este autor que repercutieron de manera clave en las posteriores investigaciones de McLuhan e Innis entre otros.

McLuhan propuso que los media influenciaban en gran medida el progreso de la sociedad, y que determinados periodos de crecimiento han sido representados por la aparición de una tecnología. McLuhan y Quentin Fiore afirmaron posteriormente que cada periodo de tiempo tiene un medio importante que define la esencia de la sociedad, la cual se corresponde con un medio de comunicación dominante de cada tiempo. Marshal McLuhan generó, paradójicamente gracias a su propia imagen mediática como icono de la cultura popular, una nueva mirada hacia los procesos mediáticos, desde, como ya hemos mencionado, el punto de vista de la ecología. Sin embargo nos podemos dejar de destacar su papel como integrador y cohesionador de los trabajos de los investigadores anteriormente citados. McLuhan afirmaba que los medios en si constituian un entorno sensorial que, pese al papel de los humanos como moldeadores de los instrumentos de comunicación, alteran inconscientemente nuestra propia percepción.

La ecología de los medios argumenta que los media se comportan como extensiones de los sentidos humanos en cada época y que las tecnologías de la comunicación son la primera causa de los cambios sociales. La famosa frase de Marshall McLuhan "el medio es el mensaje" siempre ha sido debatida por representar que el medio elegido para trasmitir el mensaje es tan importante, sino más, que el mensaje en si mismo. McLuhan siempre fue muy dado a la creación de eslóganes o conceptos virales, que debido a su gran presencia mediática generó conflictos con muchos de los investigadores coetáneos cuyas aportaciones fueron también destacable y no menos importantes.

\footnotetext{
${ }^{89}$ Havelock Eric, Preface to Plato, Harvard University Press, Cambridge, 1963.
} 
Para el los medios tradicionales eran una extensión del cuerpo humano, mientras los nuevos medios eran una extensión de nuestro sistema nervioso. La aparición de los nuevos medios cambiará el equilibrio entre los órganos sensoriales de los humanos y afectará a la psicología humana y a la sociedad. La extensión de los sentidos humanos cambiará nuestro pensamiento y comportamiento y el modo en el cual percibimos el mundo. Por eso McLuhan creía que cuando los nuevos medios aparecieran, no importaría el contenido concreto que transmitieran, las nuevas formas de comunicación nos traen en si mismas una fuerza que causa una transformación social. Acostumbramos a pensar que el mensaje esta separado del medio. El contenido no puede existir fuera de la manera mediante la cual es mediado, siendo el medio el que tiene un impacto en los asuntos relacionados con el ser humano y no específicamente los mensajes que enviamos o recibimos. Los media nos modelan al participar de ellos una y otra vez hasta que se convierten en parte de nosotros.

Diferentes medios enfatizan diferentes sentidos y alientan diferentes hábitos, de manera que usar un determinado medio un día tras otro condiciona nuestros sentidos. Diferentes formas de medios también afectan a su significado y el impacto que tendrá. La forma del medio y el modo de información determina quien tendrá acceso, cuanta información será distribuida, como de rápido será transmitida, como de lejos llegará, y más importante de que manera será mostrado. En una sociedad dominada por un medio, este en concreto hace una gran diferencia.

El asentamiento de medios globales que retrasmiten o son accesibles desde todo el planeta, como la televisión o Internet, hizo que a principios de los 90 se reconsideraran todas sus teorías desde una nueva óptica implementada por una nueva e inédita realidad mediática. Esto ha llevado a que McLuhan haya sido reinterpretado y revisitado desde las tecnologías digitales como uno de los principales visionarios dentro de la teoría de los medios de comunicación. 


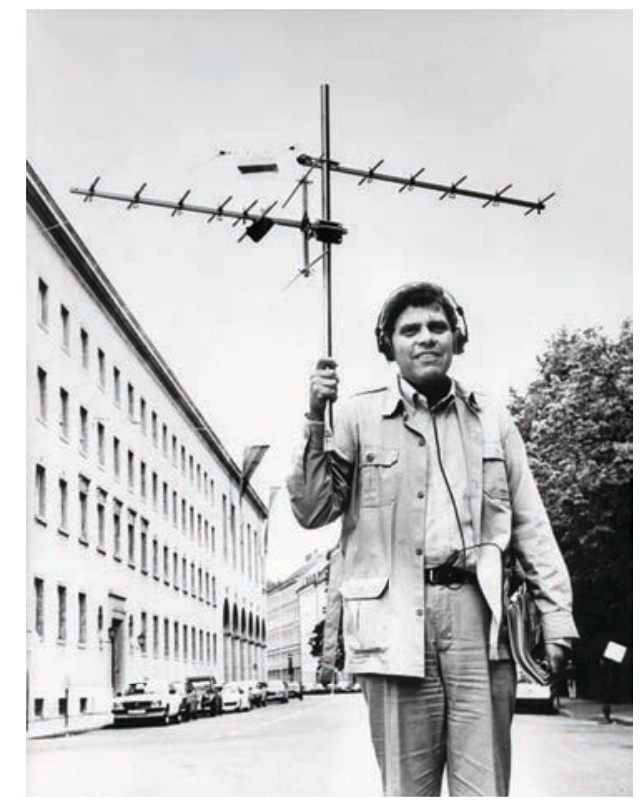

Figura 9. Neil Postman teórico de los medios.

Por otro lado Neil Postman al interpretar un rol mucho más anónimo en comparación con McLuhan no contó con la misma difusión y fama. Pese a ello debemos considerarlo como uno de los grandes teóricos de los medios de la segunda mitad del siglo XX. Su enfoque, al mismo tiempo ético y crítico, le sirvió para reinterpretar la realidad mediática en clave ecológica. Manifestó de manera clara la importancia crucial que cualquier cambio comunicacional dentro de los medios podía tener, es por ello que no consideraba a las nuevas tecnologías como simples aditivos, sino como catalizadores de un cambio mucho mayor que afecta a todo el sistema ecológico de los media de manera permanente, pudiendo observarse un antes y un después de estos cambios. Es por ello que la llegada de un Internet de acceso generalizado supuso por ejemplo un cambio sin vuelta atrás en nuestra sociedad altamente tecnificada.

El concepto de aldea global es también de gran importancia ya que nos habla de un mundo interconectado de una manera en la que nunca lo había estado previamente. Marshall McLuhan usó el concepto de aldea global para describir como los humanos no pueden vivir en la actualidad en aislamiento, siempre estarán conectados mediante medios electrónicos instantáneos y continuos. 


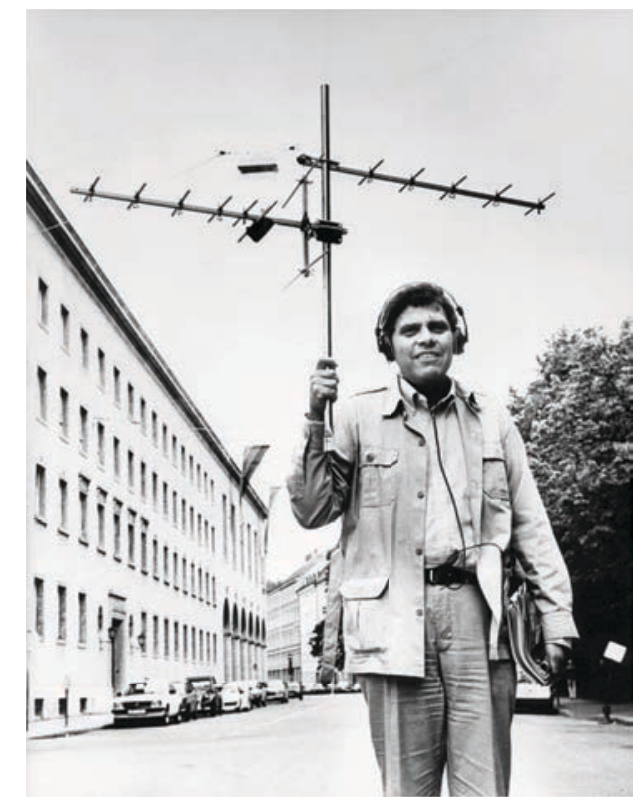

Figura 9. Neil Postman teórico de los medios.

Por otro lado Neil Postman al interpretar un rol mucho más anónimo en comparación con McLuhan no contó con la misma difusión y fama. Pese a ello debemos considerarlo como uno de los grandes teóricos de los medios de la segunda mitad del siglo XX. Su enfoque, al mismo tiempo ético y crítico, le sirvió para reinterpretar la realidad mediática en clave ecológica. Manifestó de manera clara la importancia crucial que cualquier cambio comunicacional dentro de los medios podía tener, es por ello que no consideraba a las nuevas tecnologías como simples aditivos, sino como catalizadores de un cambio mucho mayor que afecta a todo el sistema ecológico de los media de manera permanente, pudiendo observarse un antes y un después de estos cambios. Es por ello que la llegada de un Internet de acceso generalizado supuso por ejemplo un cambio sin vuelta atrás en nuestra sociedad altamente tecnificada.

El concepto de aldea global es también de gran importancia ya que nos habla de un mundo interconectado de una manera en la que nunca lo había estado previamente. Marshall McLuhan usó el concepto de aldea global para describir como los humanos no pueden vivir en la actualidad en aislamiento, siempre estarán conectados mediante medios electrónicos instantáneos y continuos. 
Esto parece como una idea común hoy en día, donde Internet hace posible buscar nuevas historias alrededor del mundo, y las redes sociales nos conectan en cualquier localización. En cualquier caso, en tiempos de McLuhan, la aldea global solo era posible a través de la televisión y las llamadas a larga distancia. Este concepto se ha convertido en una de las ideas más prolíficas y entendibles para la llegada de la ecología de los medios, y ha espoleado investigaciones en diferentes áreas. Es especialmente relevante en la sociedad de hoy en día, donde Internet y las redes sociales y otros nuevos medios han convertido el mundo en un lugar más pequeño. Como el propio Postman nos diría "La ecología de los medios intenta discernir como los medios de comunicación afectan a la percepción humana, comprensión, sentimientos y valores, y como nuestra interacción con estos medios facilita o impide nuestras posibilidades de supervivencia. La palabra ecología implica el estudio del entorno, su estructura, contenido y su impacto en la sociedad. El entorno es después de todo un complejo sistema de mensajes que impone en los seres humanos ciertas maneras de pensar, sentir y comportarse" 90 .

Será Neil Postman quien en su obra Divertirse hasta morir ${ }^{11}$ de 1985, compare el mundo contemporáneo con la obra de Aldous Huxley Un mundo feliz ${ }^{92}$, donde la población sacrifica sus derechos para obtener un tipo de droga del placer que este relaciona con la distracción. Postman ve como nuestra sociedad es oprimida en base a su adicción al entretenimiento, de la misma manera que en $1984^{93}$ de George Orwell esta es oprimida por el control del estado. Por otro lado compara la televisión con la droga suministrada por el gobierno en Un mundo feliz, y mediante la cual los derechos de los ciudadanos son intercambiados por entretenimiento. Según Postman, Orwell y Huxley no trataron el mismo tema. Por un lado Orwell se centra en un control represivo exterior implementado mediante el dolor. En cambio para Huxley nosotros seremos los que desearemos el control mediante las tecnologías asociadas a este. Mientras Orwell habla de la prohibición de libros y por lo tanto del

\footnotetext{
${ }^{90}$ Postman, Neil, The Reformed English Curriculum, en Eurich, A. C. (ed.) High School 1980: The Shape of the Future in American Secondary Education, Pitman Publishing Corporation, Nueva York, 1970, p. 160-168.

${ }^{91}$ Postman, Neil, op. Cit., 2001.

92 Huxley, Aldous, op. Cit., 2013.

${ }^{93}$ Orwell, George, 1984, Editorial Lumen, Barcelona, 2014.
} 
acceso a la información, Huxley temía una avalancha heterogénea de datos que provocara el desinterés por la información, llegándose a considerar esta algo trivial. Estas dos posiciones podemos verlas en relación con el concepto de hegemonía de Antonio Gramsci94.

Muchos ecologistas están usando la ecología de los medios como un marco analítico para explorar si los actuales nuevos medios son una nueva herramienta de dominio en la cultura o son simples extensiones de lo que ya hemos experimentado. Los nuevos medios se caracterizan por la idea de Web 2.0, termino acuñado en 2003 por Tim O'Reilly. Este argumenta que este especial ensamblaje entre software, hardware y sociabilidad ha generado la sensación generalizada de que hay algo cualitativamente diferente en la web de hoy. Este cambio se caracteriza por la cocreatividad, la participación y la apertura, representadas por el software que incluye formas basadas en wikis, redes sociales, blogs, etiquetado y mash up. La naturaleza interactiva y orientada al usuario de estas tecnologías ha transformado la cultura global en una cultura participativa, siendo este como nos dice Neil Postman un cambio ecológico y no un aditivo tecnológico.

\subsection{PUNTO DE VISTA DE RETROVISOR}

Cuando Marshall McLuhan se interrogaba sobre lo que verdaderamente inventó Gutenberg 95 cuando concibió la imprenta, y la manera de percatarse de los efectos de este tipo de medios recurre a la idea de sonda. Esta es según el una manera de internarse en este tipo de medios sin quedar atrapado por la inconsciencia que sus propios efectos implementa. Por lo tanto estamos ante una influencia perceptiva de la que no somos conscientes en absoluto, doblegando nuestra conciencia sobre la manera en la cual los nuevos medios afectan a nuestra visión del mundo y de nosotros mismos.

Para McLuhan, el hecho de encontrarnos ante un entorno nuevo hace que volvamos la mirada al pasado, de manera que nos aferramos a los objetos o símbolos inmediatamente anteriores. Esto se traduce en que miramos el

\footnotetext{
${ }^{94}$ Gramsci, Antonio, Cartas desde la cárcel, Nueva Editorial Argentina, Buenos Aires, 2006.

${ }^{95}$ McLuhan, Marshall, op. Cit., 1985, p.247. 
presente mediante un espejo retrovisor, caminando hacia atrás en nuestra mirada hacia lo que nos depara el futuro. Para McLuhan, esta idea no era algo únicamente adherido a los medios, sino que doctrinas como el marxismo habían elaborado un concepto que se formalizó como lucha de clases que era en realidad una imagen especular que reflejaba los viejos fantasmas del feudalismo en Europa ${ }^{96}$.

Para el canadiense, es el propio instinto humano el que nos instiga a retroceder sobre estos nuevos entornos y acomodarnos sobre los anteriores, los cuales nos resultan especialmente atrayentes debido a la familiaridad que despiertan, pero son obviamente inadecuados para orientarnos en un nuevo medio. Esto genera una desorientación que nos impide percibir las características de los nuevos medios.

En este punto, cabe destacar como McLuhan otorga unas cualidades perceptivas excepcionales a los artistas, como individuos capaces de discernir las características de las nuevas tecnologías de manera diáfana ${ }^{97}$. En este sentido, la potente influencia que los nuevos medios despliegan sobre la sociedad nublando nuestra conciencia no parece afectar de igual manera a los artistas, los cuales pueden eludir este tipo de condicionantes de manera efectiva. Este mismo tipo de esquemas parecen ser análogos a cualquier tipo de innovación o cambio ambiental dentro de los medios en forma de nuevas tipologías mediáticas. Este tipo de determinismo de los medios de comunicación aparece como un condicionante que solo es efectivo cuando los usuarios permanecen entumecidos por la propia sobreestimulación que las nuevas tecnologías implementan.

Marshall McLuhan intentó que la sociedad comprendiera la naturaleza de las nuevas tecnologías que se estaban desplegando dentro del mundo de mediados del S.XX. Para el la sociedad sufría una incapacidad para alcanzar una conciencia plena sobre los nuevos entornos generados por estas tecnologías. Debido a la invisibilidad de estos entornos durante su periodo de

\footnotetext{
${ }^{96}$ McLuhan, Marshall, Counterblast, Rapp and Whiting, Londres, 1970, p. 140.

${ }^{97}$ McLuhan, Marshall, Parker, Harley, Through the Vanishing Point: Space in Poetry and Painting, Harper and Row, Nueva York, 1969, p. 23.
} 
innovación, estos solo se hacen realmente visibles cuando aparece un nuevo entorno que lo sustituya. Esto produce un tipo de dilación en cuanto a nuestra propia percepción que McLuhan denominó "punto de vista de retrovisor" o rear-view mirror por su nombre en inglés. Según McLuhan una nueva tecnología genera un entorno totalmente nuevo que nos desorienta y enfoca nuestra percepción en el entorno inmediatamente anterior. Como el mismo diría a este respecto, "El presente siempre es invisible porque es ambiental y satura todo el campo de atención de forma aplastante; así pues todo el mundo, exceptuando el artista, el hombre del conocimiento integral, vive en un día anterior. En medio de la era de la electrónica del software, del movimiento instantáneo de la información, aún creemos que vivimos en la era mecánica del hardware"98. Para McLuhan partimos de lo desconocido y nos dirigimos hacia lo conocido, debido a la aparición de un nuevo medio que nos paraliza al ampliar nuestros sentido de manera radical. Según el la supervivencia de la humanidad dependía de nuestra capacidad para entender cambios instantáneos dentro de nuestro entorno que afectan a cultura, valores y actitudes. De este modo, sería posible evitar en gran medida el trance en el cual los medios nos sumergen comprendiendo las transformaciones que producen y anticipándonos a estas de manera efectiva.

Para MacLuhan todo el sistema educativo de su tiempo era reaccionario al orientarse hacia los valores y tecnologías de tiempo atrás. El pensaba que esta situación no se revertería hasta que una nueva generación ocupara el lugar de la anterior. Para el, este sistema educativo de hecho formaba un espejo retrovisor, que se fundamentaba en la mera alfabetización y clasificación de información, y por lo tanto era almente inadecuado para una generación que había nacido con la televisión. McLuhan comprendía que la manera mediante la cual el ser humano occidental debía gestionar esta transformación en su entono mediático y tecnológico era sumergirse en la entonces incipiente tecnología electrónica, para mediante el entendimiento de este poder controlarla y instrumentalizarla a su favor. Como apunta, no solo se trata de delimitar los síntomas de estos cambios transcendentales, sino de identificar las consecuencias para poder contrarrestarlos colectivamente dentro de la sociedad. Sin embargo ninguna sociedad ha sido lo suficientemente consciente

\footnotetext{
${ }^{98}$ Entrevista de Eric Norden a Marshall McLuhan que fue publicada en el número de Marzo de 1969 de la revista Playboy. 
de la manera en la cual las tecnologías nos transforman y modelan como para actuar en consecuencia durante este mismo proceso de cambio.

Sergio Roncallo Dow y Diego Mazorra nos muestran en su texto Ecología, arte y política: la estética como control (contra) ambiental99, también desde el mundo del comic ha habido un acercamiento a este concepto, utilizándose como metáfora por parte de autores como Warren Ellis y Alan Moore como una forma de mirar al pasado de este medio para entender nuestro presente y poder percibir la nueva realidad de la industria del comic. Moore sostiene que elementos de los comics del pasado pueden liberar el mañana de este medio. Mediante su obra conformada como una sonda, estos autores pretenden mirar al pasado de nuestra cultura popular alrededor del medio del comic para poder entender el presente y los posible futuros.

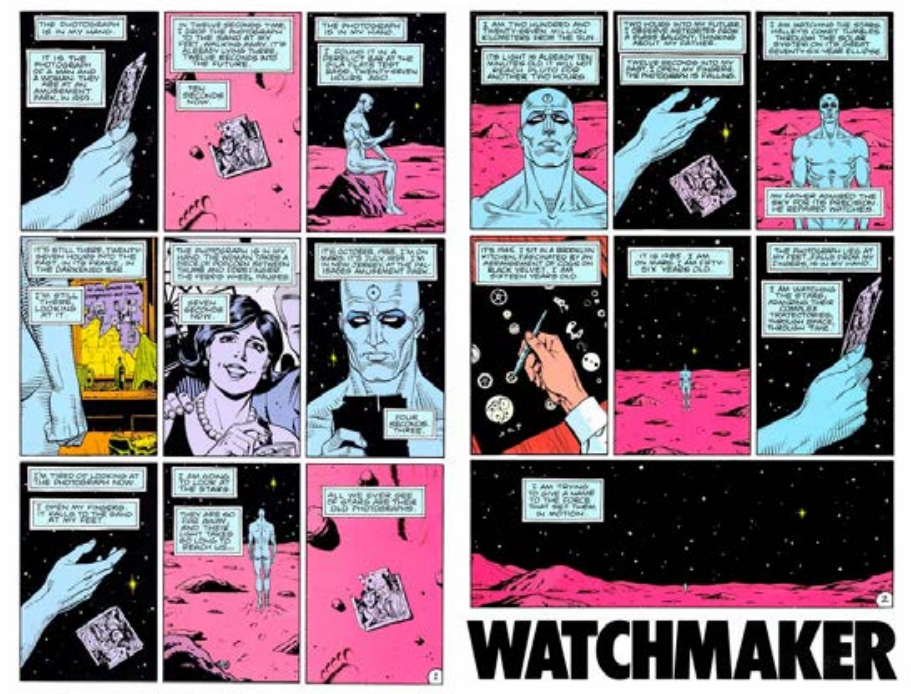

Figura 10. Doble página de Watchmen.

\footnotetext{
${ }^{99}$ Scolari, Carlos A., op. Cit., 2015, p. 263.
} 
En Watchmen ${ }^{100}$, una de las obras más populares del guionista Alan Moore, se genera una mirada evocativa sobre los superhéroes de la edad de oro del la historieta estadounidense, enmarcada desde 1938 a los años 50, para ubicarlos en un relato distópico desarrollado a mediados de los años 80 del siglo XX, cuando su carrera ha terminado y otros héroes han ido tomando el relevo de sus actividaddes. Estos héroes representan el pasado de un medio que choca con diferentes maneras de concebir este tipo de personajes Esta es pues una forma de mirar al pasado para entender y crear el presente de un medio tan contemporáneo como el comic. Por esta razón, esta obra es considerada un comic con superhéroes y no sobre superhéroes. Nos habla esencialmente del propio medio en si, jugando con su pasado para imaginar el futuro y discernir su propio estatus como medio más allá de los convencionalismos y los hestereotipos generados durante décadas.

Este metarrelato esconde a su vez varias historias paralelas que se van desarrollando de manera continua durante toda la obra, y que a la postre nos retrotraen a diferentes estadios de la propia historia del medio. Este es el caso de la historia de horror y piratas llamada Relatos del Buque Negro, atribuida de manera ficticia al dibujante Joe Orlando, y especialmente, al guionista Max Shea, en torno al cual se genera una historia de desaparición que forma parte de la trama principal del comic.

Cuando el director de cine Zack Snyder decidió realizar una adaptación de esta novela gráfica, realizó un calco perfecto de dicha creación, transportando las viñetas a planos de cine. Sin embargo, esta obra fue creada como un comic, y podemos afirmar que las ideas que fundamentaron a este se encuentran presentes, pero fuera de contexto o alteradas. Es aquí donde precisamente podemos contemplar con total claridad como el medio no solo contiene, sino que modela el mensaje que transmite, mediante la utilización de códigos particulares.

Una adaptación no garantiza un reescritura en base a las ideas que fundamentaron esta obra y de las cuales la adaptación cinematográfica adolece. Por otro lado, podemos afirmar que el cine podría considerarse como

100 Moore, Alan, Gibbons, Dave, Watchmen: Edición de lujo, ECC Ediciones, Barcelona, 2015. 
un medio caliente que presenta cada detalle de lo que es narrado mientras que el comic necesita del la mente del lector para crear el sonido y el movimiento que la cinematografía presenta per se.

Como hemos podido observar los medios anteriores nos pueden permitir detectar el presente que creará nuestro futuro. Artistas de medios como el comic han utilizado su obra como sonda para vislumbrar los nuevos estadios de dicho medio, recuperando retazos del pasado que nos sirvan para hablar del ahora, de ese presente que parece ser tan esquivo para nuestra percepción. Como afirman Roncallo y Mazorra, "observamos con una sonda en el espejo retrovisor nuestra cultura, recuperando objetos de ese pasado, pero al observar al frente vemos nuestro presente y una larga carretera con diversos caminos" 101 .

Este tipo de estrategia conlleva la toma de conciencia de una situación de cambio constante, que hizo reflexionar en su momento a Marshall Mcluhan sobre la importancia de permanecer críticos y expectantes ante los cambios ambientales de los medios, los cuales son percibidos mediante el espejo retrovisor, en forma de las imágenes especulares que este refleja. Es por ello especialmente necesario captar nuestra propia concepción del espíritu de nuestra época o zeigeist, para así conseguir que los medios dejen de ser imperceptibles. En la época de las comunicaciones invisibles, la transmisión de datos y conectividad constante, es la invisibilidad del presente lo que debe ser el objetivo que el artista debe batir. Mediante la idea de sonda enviada desde el ámbito del arte, McLuhan nos advierte de la necesidad de detectar los cambios en el ambiente mediático, utilizando para ello las capacidades inherentes del artista como explorador de los nuevos medios. Para ello, uno de los primeros obstáculos es vencer el espejismo que nos hace no identificar el propio fondo del entorno que conforman los medios, por encima del contenido que es insertado en los mismos. Como veremos para ello McLuhan ideo una modalidad de dispositivo que garantiza la visibilización de estos medios, venciendo para ello las barreras y estrategias perceptivas que ellos crean.

${ }^{101}$ Scolari, Carlos A., op. Cit., 2015, p. 265. 


\subsection{EL ANTI-MEDIO}

Será el concepto de anti-medio o antienvironment, entendido como antiambiente, el usado por Marshall McLuhan para visibilizar el fondo invisible que conforman los nuevos medios como un dispositivo la toma de conciencia sobre las existencia y características de estos nuevos entornos tecnológicos.

Para Roncallo y Mazorra, la obra de McLuhan constituye en si misma, por sus características e intencionalidad, un anti-medio en el propio sentido que el investigador canadiense pretendió imprimir al termino. Estamos hablando de un tipo de elemento de toma de conciencia y de tematización del ambiente silencioso en el cual nos desenvolvemos. Como el mismo aclaró en numerosas ocasiones, era el artista el que era capaz de leer los cambios ambientales relacionados con los nuevos conocimientos de su tiempo ${ }^{102}$. Para el, el artista es capaz de captar los nuevos desafíos culturales y tecnológicos décadas antes de que generen un efecto visible. Pone como ejemplo el mito de Noé para designar este tipo de antelación ante lo que se avecina, los cambios trascendentales en la forma de vida en base a una transformación del entorno, en este caso mediático. Podemos afirmar que el artista siempre se haya narrando anticipadamente relatos futuros, ya que está al tanto de las verdaderas implicaciones de las situaciones presentes. Por lo tanto, McLuhan plantea este hecho como un hito paradigmático dentro de una carrera por la supervivencia de nuestra especie. Del mismo modo otorga al artista una capacidad innata para evitar lo que denomina como el mazazo de las nuevas tecnologías generadas en cualquier época, mediante el conocimiento como herramienta emancipadora esencial. Es por ello que la necesidad de la existencia de artistas es apreciada por el resto de individuos que nos son capaces de captar este tipo de violencia silenciosa e imperceptible por su estatus de ambiental. El artista como ser humano del conocimiento integral es capaz de captar este tipo de alteraciones generadas por los nuevos conocimientos. El uso que McLuhan realiza del adjetivo integral esta vinculado a la conciencia, para hablarnos de individuos que no están fragmentados, mediante una conciencia que lo incluye todo en lo relativo a la cultura. Según McLuhan el artista es esencialmente capaz de corregir las proporciones de los sentidos con anterioridad al entumecimiento generado por las nuevas tecnologías en fase de innovación, considerando al arte como un conocimiento preciso que anticipa las consecuencias psíquicas y sociales de las tecnologías

${ }^{102}$ McLuhan, Marshall, op. Cit., 1996, p. 85. 
venideras. Se trata de una información precisa de cómo reorganizar nuestro cerebro para ser capaces de esquivar los impactos que las nuevas tecnologías nos intentan asestar constantemente en forma de extensiones de nosotros mismos.

El concepto de artista que nos transmite McLuhan esta íntimamente influenciado por la idea de que la función del arte y el papel del artista era esenciales, llevándonos a una lectura inmediata del mundo contemporáneo. A mediados de los años 50 del siglo XX, comenzó a investigar sobre los diferentes estatus del artista en diferentes sociedad, como es el caso de las sociedades tribales previas a la creación del alfabeto y en las que ya era de uso común. El concepto de artista se presenta como indispensable para entender las implicaciones del propio concepto de anti-medio, el cual esta ligado a la exploración inconsciente del entorno generado por los nuevos medios, aunque puede ser desplazada a otras áreas.

McLuhan sostiene que le anti-medio es un objeto irremediablemente necesario para la percepción de entornos que no somos capaces de percibir. Por lo tanto está generando una dicotomía entre los conceptos de medios y anti-medio. Esto se basa en la idea de que el contenido de un medio es siempre otro medio anterior, siendo el anti-medio una resemantización de un medio nuevo. Es aquí donde se muestra como la visión de espejo retrovisor nos mantiene hipnotizados por los contenidos de los medios que son en realidad los medios anteriores. Para McLuhan los ambientes son procesos vibrantes, aunque imperceptibles, por contraposición los anti-ambientes son contrasituaciones construidas por artistas, como es el caso del arte de los medios generado en Argentina a mediados del Siglo XX. Para el, el arte en si es un antiambiente, pues se trata de un tipo de actividad, procesos y proyectos que se comportan como sondas dentro de la sociedad, que tienen la habilidad de visibilizar ambientes invisibles a nuestros ojos

En su conocida obra La comprensión de los medios de comunicación de 1964, nos deja claro su concepción del arte como un hecho ligado íntimamente a la técnica, una especie de dominio común, que sin embargo transciende el planteamiento de Walter Benjamin mediante el uso de la metáfora ambiental, la cual se traduce como hemos visto en el uso del termino medio y su contrapartida el anti-medio, siendo el arte una interrupción en lo que 
podemos considerar una estática continua conformada por lo medios. La relación generada entre el artista y el resto de la sociedad se desarrolla en base a las capacidades perceptivas del artista, superiores a las del público en general, el cual permanece incapaz de discernir las relaciones entre fondo y figura ${ }^{103}$. El anti-medio aparece por lo tanto como una especie de fenómeno análogo al ruido, generado dentro de los fondos que son los medios. Según McLuhan, la función del arte en la contemporaneidad es pues un tipo de ajuste o orientación dentro de un entorno cambiante, por el contrario en las sociedades tribales servía para fusionarnos con el entorno. El anti-ambiente por el contrario lo perturba haciéndonos tomar conciencia sobre este, ante su evanescencia inherente.

Para McLuhan todas las actividades de origen antisocial generan un tipo de anti-ambiente, ya que generan un ambiente inconsciente de atención consciente. Mediante la historia de La vestidura nueva del rey ${ }^{104}$, donde McLuhan nos muestra como solo desde fuera de cierto ambiente se puede ver algo como es en realidad. Al igual que "el negro caballerizo antisocial" de la historia, el artista no suele plegarse a la visión de la sociedad, por lo tanto el artista es un individuo que agudiza la percepción de los que están a su alrededor. Esto se debe también a su habilidad para residir en los intersticios sociales, en las fronteras, lo que les hace anticipar desde su perspectiva interior lo que sucede dentro de la sociedad. La propia actividad de sondear supone atravesar todo tipo de fronteras, tanto sociales como morales.

Según McLuhan los juegos consisten en la simulación de una situación por medio de otra, una especie de ritual publico que cambia nuestra percepción sobre el entorno. El público es un elemento clave que hace posible este tipo de acontecimiento o situación, que cambia nuestra vida sensorial. Otra manera de percibir nuestro mundo es generada según las malas noticias las cuales son equilibradas mediante la publicidad en forma de buenas noticias. Las malas noticias marcan la moral, las leyes y las formas de poder conformadas en el entorno. Otra manera de captar y sondear el ambiente o entorno es el uso de las bromas, ya que nos hablan de lo que realmente está pasando, atacando al poder de manera libre. Es una especie de prueba de tolerancia en cuanto a que

\footnotetext{
${ }^{103}$ Scolari, Carlos A., op. Cit., 2015, p. 271.

${ }^{104}$ McLuhan, Marshall, Fiore, Quentin, El medio es el masaje, Paidós, Barcelona, 1997, p. 88.
} 
nos muestra donde están los límites de lo permitido socialmente incluso transgrediéndolos. Un chiste puede ser considerado como una sonda que tantea hasta que punto es permisible socialmente hablar o bromear sobre un tema determinado, o hasta que punto algún tipo de autoridad deja que este tipo de humor sea aceptado.

Por otro lado, McLuhan sugiere que el arte deja de ser una forma de autoexpresión en base a la aparición de la electricidad 105 , pasando a conformar un viaje exploratorio, del cual el happening sería el ejemplo paradigmático. Por su parte el arte pop sirve para recordarnos el tipo de mundo que hemos creado en base a imágenes que condicionan nuestra conciencia y percepción, transformando lo pictórico en un icono. La tecnología transforma al propio público en entorno, en una audiencia masiva, participando como cocreadores en lugar de consumidores.

La paulatina transformación de los entornos en anti-ambientes gracias a la implementación de las tecnologías de la comunicación y la información, es decir, lo que podríamos llamar nuestra consciencia sobre nuestro ambiente, hace posible considerar a nuestro propio ambiente como una obra ${ }^{106}$. Las tecnologías asociadas a la informática nos ofrecen la posibilidad de programar el propio entorno en lugar del contenido. Para McLuhan hoy día el propio planeta ha pasado a formar parte del contenido de los entornos creados por la tecnología, algo que nace de la propia carrera espacial y los primeros lanzamientos de sondas al espacio. Para el la propia Tierra se había convertido desde entonces en un anti-ambiente, como una extensión de nuestra propia conciencia, que cambia la percepción de nuestro entorno en base a las tecnologías generadas por el ser humano ${ }^{107}$. Esta contemplación de todo el planeta dentro de una sola imagen gracias a las primeras sondas y exploraciones asociadas a la carrera espacial de mediados del siglo XX, generó una visión ecológica que contenía un todo, que objetualizaba nuestro entorno.

\footnotetext{
${ }^{105}$ McLuhan, Marshall, Marshall McLuhan Unbound Vol. 7, Gingko Press, California, 2005, p. 14.

${ }^{106}$ McLuhan, Marshall, Letters of Marshall McLuhan, Oxford University Press, Nueva York, 1987, p. 222.

${ }^{107}$ McLuhan, Marshall, Marshall McLuhan Unbound Vol. 12, Gingko Press, California, 2005, p. 22
} 
Podríamos decir que el arte ha conseguido tematizar los medios para llegar a este concepto que se ha colado en los intersticios de los discursos y debates dando origen a una visión de los medios que parte de la separación entre las estructuras mediáticas y sus contenidos es decir entre los fondos y las figuras. Para McLuhan la tarea del arte consistía en corregir el sesgo de los medios tecnológicos, creando una nueva percepción, necesaria por lo imperceptible de este tipo de entornos. El poder de los medios hace que impongan de manera invisible sus propias reglas sobre nuestra percepción. La dialéctica generada entre arte y tecnología se basa en que cada nueva tecnología es en parte concebida como una obra de arte en si misma. Es por ello que el propio McLuhan no crea distinciones entre ambas disciplinas, siendo el artista un individuo que dentro de cualquier area del conocimiento es capaz de captar las implicaciones de los nuevos medios.

\subsection{ARQUEOLOGÍA DE LOS MEDIOS}

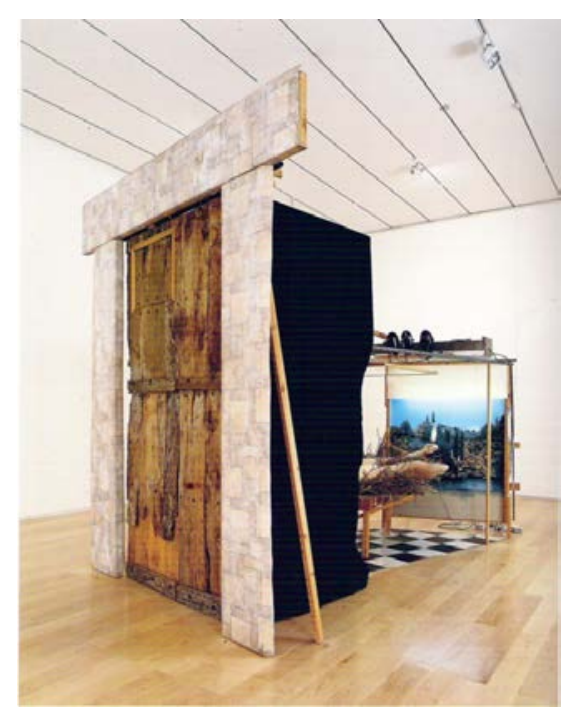

Figura 11. Instalación de Étant Donnés de Marcel Duchamp.

Las primeras contribuciones a la formación de lo que podríamos considerar precedentes de la arqueología de los medios las podemos remontar a Aby Warburg o Walter Benjamin. Pese a todo, movimientos como el futurismo 
pretendieron liberar al arte del pasado, generando para ello una nueva estética que emanara de las propias cualidades de la vida moderna. En cambio fueron los dadaístas, los surrealistas y figuras como Marcel Duchamp los primeros en desarrollar una relación dialógica con la tecnología. Étant donnés de Duchamp puede relacionarse con la tradición ilusionista de los dioramas que podíamos encontrar en museos, o peep shows eróticos. La estereoscopía victoriana inspiró a Duchamp, trayendo a su mente lo clandestino de contemplar a una mujer con las piernas extendidas. Se trata de una instalación que puede ser observada a través de un par de mirillas en una puerta de madera. Al mirar se puede ver un agujero en una pared de ladrillos que nos muestra a una mujer desnuda tumbada boca arriba entre las ramas, mientras una lámpara ilumina cuidadosamente la escena.

El concepto de anti-medio se vale de medios obsolescentes para mostrarnos las características ocultas de los nuevos. El gusto por lo obsoleto, siendo lo viejo y como es recuperado, vuelto a poner en escena y reciclado mas interesante que lo nuevo. Esta es pues, una forma de poner de manifiesto como nuestra cultura no se basa en un progreso de carácter lineal, sino en una búsqueda de ideas perdidas que nos posibilitan descubrir las genealogías de las nuevas tecnologías, las cuales nos remontan a estadios anteriores del arte medial.

Un ejemplo claro de esto serían un sin fin de piezas artísticas que recogen las tecnologías anteriores al cine. El trabajo de Edward Muybridge fue revisitado por un gran número de investigadores y artistas, generando un nueva visión sobre la historia anterior al cine convencional y que pasó a conformar otro periodo histórico del propio medio. Este movimiento parte pues del interés por historias olvidadas, partiendo del interés por las artes que reescribe la historia de cómo desarrollaron los medios visuales. A este respecto al trabajo de los artistas, mediante como diría McLuhan un acercamiento hacia lo nuevo mediante una mirada hacia lo antiguo, es decir una mirada de retrovisor. Mediante este planteamiento se pretende generar piezas que pongan en crisis estás nuevas tecnologías mediante las anteriores.

Proyectos como los de Amanda Steggell y su Emotion Organ de 2007, basado en un viejo órgano convertido en un motor interactivo de simulación multisensorial se basa en la sinestesia y el la historia visual de la música. Las 
cabezas animatrónicas de Ken Feingold nos hacen pensar en autómatas parlantes, muñecos de ventrílocuo y la simulación de inteligencias artificiales que son herederas de la escritura automática surrealista. Del mismo modo, Martin Riches se ha inspirado en la historia de los autómatas para crear máquinas que hablen y reproduzcan música. Artistas tan populares como William Kentridge han sabido incluir en su trabajo un sin fin de técnicas que investigan arqueológicamente los medios, como por ejemplo la sombra chinesca, la anamorfosis cilíndrica o los autómatas.

Como nos cuenta Erkki Huhtamo108, McLuhan supo predecir una de las tendencias más características del arte actual, la aparición de una gran número de artistas que miran al pasado de la tecnología para hablar sobre el presente de esta. Antes de la aparición de la cibercultura existieron formas culturales que se han anticipado a esta, en ocasiones en siglos. Muchos de los trabajos de artistas actuales como Michael Naimark o Jeffrey Shaw, usan nuevas tecnologías en base a una exploración de un pasado tecnológico que potencia y da sentido a la obra. Por otro lado, este tipo de obras ponen de manifiesto el engaño que supone la supuesta ruptura cultural y ontológica que suponían tecnologías como la realidad virtual. Por lo tanto la arqueología de los medios cuestiona la construcción discursiva de la cultura mediática contemporánea, preguntándose que se esconde detrás de estas narrativas de carácter utópico basadas en el progreso tecnológico. Por su parte arqueólogos de los medios como Erkki Huhtomo, Siegfried Zielinski o Friedrich Kittler, abandonaron la historia lineal generada alrededor de las tecnologías hegemónicas de la información para explorar intersticios, olvidos o omisiones, utilizándolos como una manera de leer el pasado de manera alternativa, poniendo el foco en lo que pudo ser y no fue, en proyectos fracasados, lo que nos lleva a una relectura crítica del presente tecnológico. Por su parte Reynold Weidenaar ${ }^{109}$, como señala Huhtomo, nos muestra como la propia visión de progreso como un elemento autónomo y predestinado asociado con la tecnología es completamente errónea, ya que ovbia los callejones sin salida y errores. Por otro lado al poner el foco en el éxito de la tecnología, se ignora lo que realmente es el aspecto más importante asociado con este, es decir, la

\footnotetext{
${ }^{108}$ Huhtamo, Erkki, Art in the Rear-View Mirror. The Media-Archeological Tradition in Art, en Paul, Christiane, A Companion to Digital Art, Joh Wiley-Blackwell, Nueva York, 2016, p. 69.

${ }^{109}$ Weidenaar, Reynold, Magic Music from the Telharmonium, Scarecrow Press, Lanham, 1995.
} 
revelación de contextos socioculturales que van más allá de éxitos, inventos y procesos.

Discursos que prometen nuevas y más potentes tecnologías han abundado por tecnólogos e instituciones. El determinismo tecnológico da alas a dichas promesas, mediante los discursos desarrollados dentro del marketing, y los videntes tecno-utópicos, tales como Negroponte o Kuzweil. En este sentido la arqueología de los medios cuestiona este determinismo tecnológico para mostrar como múltiples factores históricos contribuyen a formar la cultura de los medios. Marshall McLuhan pudiera bien haber sido un determinista tecnológico pero no podemos obviar su papel como humanista por encima de este rol, de hecho es el ser humano el epicentro de su obra y los medios son las extensiones de este que mejoran las capacidades del mismo.

En 1995 el escritor de ciencia ficción estadounidense Bruce Sterling generó una recopilación de tecnologías relacionadas con la información y la comunicación que se encontraban en estado de obsolescencia. Fue conocido como Dead Media Project110 y tenia la intencionalidad de generar una narrativa histórica sobre este tipo de tecnologías que transcendiera las gran expectación producida alrededor de la virtualidad, la era de Internet y las tecnologías digitales. Este tipo de archivo fue solidificado en lo que se conoce como The Dead Media Handbook, una obra que reflexiona sobre los fiascos, debacles y expectativas incumplidas generadas alrededor de estas tecnologías. La obra fue distribuida mediante una lista de correo conformada como 600 notas online que acabaron por dejar de crecer en 2001. El archivo esta compuesto por multitud de tecnologías como videojuegos antiguos, medios de visualización de imágenes relacionados con la estereoscopia o muestras de fenaquistopía del siglo XIX. Garnet Hertz publicó en 2009 una obra similar a la de Sterling que recibió el nombre de A Collection of Many Problems (In Memory of the Dead Media Handbook)111. Conformada a modo de manual, esta obra recopila multitud de tecnologías que ya aparecieron en las notas de Sterling pero también invita a los lectores a enviar muestras propias de este tipo de medios. Entre otra de las obras más representativas de Hertz está su

\footnotetext{
${ }^{110}$ http://www.deadmedia.org/

111 Hertz, Garnet, A Collection of Many Problems (In Memory of the Dead Media Handbook), Telharmonium Press, Toronto, 2009.
} 
manifiesto Zombie Media publicado en 2012 en el cual reflexiona sobre como mediante tecnologías obsoletas podemos interactuar con el presente de la tecnología.

En la actualidad, la sobreproducción de nuevas tecnologías y aparatos tecnológicos de bajo coste y fácil adquisición hace que muchas de estas extensiones se vean superadas y consideradas como antiguas de manera muy rápida. Como nos cuenta Bruce Sterling, este fenómeno se comporta como un elemento que genera unas dinámicas de creación y olvido que nos lleva a una amnesia sobre estos medios. Esto también puede ser apreciado respecto a los términos que utilizamos para referirnos a muchas de las tecnologías de la información y la comunicación, tal es el caso de neologismos como ciberespacio, autopista de la información o la red de redes. Por lo tanto la necesidad de nuevas tecnologías que puedan ser insertarlas en el mercado, y por ende en nuestra vida diaria, dan origen a nuevos términos, que por un lado posibilitan esta aceptación en base a la novedad que representan, pero también envían al olvido prematuro a parte de nuestro lenguaje recientemente creado. Como consecuencia de esta innovación constante y acelerada, se ha generado la necesidad de archivar y clasificar muchas de las tecnologías relacionadas con el origen de Internet. Como nos dice Jussi Parikka en uno de sus artículos, "necesitamos entender como lo nuevo es casi siempre, ya viejo, y preguntarnos incansablemente qué es realmente políticamente nuevo si consideramos el papel de la invención cultural de los medios" 112 . Reconectarse puede conformar un especie de válvula de seguridad cultural pero también una manera de hacer crecer y enfrentar el futuro. Por lo tanto mirar hacia atrás en el espejo retrovisor es una condición previa para orientarnos en nuevas áreas pero seguramente no las más directas hacia el futuro.

\subsection{NARCOSIS NARCISO}

Como podemos leer en la obra de McLuhan Comprender los medios de comunicación $n^{113}$, la experiencia humana, es decir la acción y el actuar, es el principal significado que se desprende del termino Narciso el cual deriva a su

\footnotetext{
112 Parikka, Jussi, Arqueología de los medios: cuestionando lo nuevo en el arte medial, a-desk.org, 2017, [En línea], [consultado el 27 de Junio de 2016], disponible en <http://adesk.org/magazine/arqueologia-de-los-medios/>

${ }^{113}$ McLuhan, Marshall, 1996, Op. Cit., p. 61.
} 
vez de la palabra narcosis que viene a significar entumecimiento. El mito nos cuenta como el joven llamado Narciso llegó a creer que su propia imagen especular generada en el agua era otro individuo que se encontraba delante de este. En realidad se encontraba ante una extensión de si mismo en forma de reflejo, la cual generó precisamente un entumecimiento de sus percepción, generando lo que podríamos denominar un sistema cerrado.

En base a esta historia, McLuhan nos explica como el ser humano tiene una tendencia innata a quedar fascinado por sus propias extensiones compuestas por otros materiales o artefactos ajenos a su propio cuerpo. Narciso queda fascinado por algo que cree ajeno a el mismo, lo que contradice la idea generalizada de un individuo que se enamoró de si mismo. En cambio, es la propia extensión como un elemento extraño, el objeto de tal respuesta por parte de Narciso. Por lo tanto, podríamos considerar la imagen de Narciso como una extensión que entumece nuestras capacidades perceptivas y evita que se reconozca a si mismo, como una especie de respuesta a los traumas físicos y psíquicos que anestesia nuestros sentidos. Esto generalmente responde a una sobreestimulación como resultado de la aceleración del ritmo que produce un entumecimiento o bloqueo de la percepción. Este hecho produce multitud de respuestas que la ciencia puede aportar, de las que McLuhan extrae el concepto de auto-amputación, como una estrategia de nuestro propio organismo, similar a la empleada para aislar un determinado problema de salud en una zona de nuestro cuerpo.

Para Marshall McLuhan, cualquier tipo de nueva invención o tecnología es una auto-amputación o extensión de nuestro propio cuerpo que genera nuevas relaciones entre el resto de órganos de nuestro cuerpo. Este tipo de extensiones solo pueden ser percibidas aceptándolas como tal, es decir, hacer uso de las tecnologías o técnicas que conforman este tipo de amplificaciones de nosotros mismos, experimentando los fenómenos de aislamiento consecuencia de las mismas, posicionándonos como nuevos Narcisos entumecidos por nuestra imagen especular.

El ser humano es modificado por las propias tecnologías que crea, del mismo modo que mediante su uso se generan nuevas formas de evolución. Esto a su vez da origen a tecnologías aún más novedosas y penetrantes, que condicionaran nuestra percepción de maneras que aún nos somos capaces de 
concebir. Esto, según McLuhan, ha generado una relación de carácter sexual del hombre con respecto a las máquinas, en la cual es el propio ser humano los órganos sexuales en base a los cuales se desarrollan nuevos tipos de tecnología.

Por otro lado, en La comprensión de los medios de comunicación, McLuhan recoge las enseñanzas de Lewis Mumford para reflexionar sobre como la guerra ha sido siempre uno de los principales motores de la creación de extensiones tecnológicas. En este sentido, señala como Mumford conceptualiza las murallas como una extensión de nuestra piel, al igual que otros elementos como las prendas o la casa. Para McLuhan el principio de entumecimiento es algo que se puede aplicar a todo tipo de tecnologías tanto eléctricas como no. Sin embargo, para el, la era de las extensiones eléctricas de nuestro sistema central es la era de la ansiedad, la inconsciencia y la apatía generalizadas. Así mismo, lo es de la conciencia sobre la inconsciencia, abriendo nuestra percepción a la idea de la tecnología como extensión de su cuerpo físico. Curiosamente McLuhan achaca este hecho a la puesta en escena de la vida privada, subliminal y social, que genera una conciencia social que da como resultado la culpa, que desplaza el espíritu burgués a favor de la implicación social. Este hecho queda remarcado bajo la afirmación de que "en la edad eléctrica, llevamos a toda la humanidad como nuestra piel". Una actitud inherente al papel de Narciso es pensar que las extensiones tecnológicas están ubicadas dentro de lo que podríamos denominar nuestra exterioridad. Son los medios los que se han convertido en nuestros propios órganos, tales como cerebro, ojos y oídos, como puntos de apoyo en base a los cuales entendemos el mundo, sin embargo en la actualidad estos medios son parte y están gestionados por compañías privadas. Es por ello que es necesario liberarse de síndrome generado por el determinismo tecnológico, el cual nos convierte en narcisos hipnotizados incapaces de sobrepasar esta tara perceptiva.

Irónicamente, la hibridación de diferentes medios ha dado como resultado nuevas formas que posibilitan un momento de libertad del fenómeno del Narcosis Narciso, una salida del trance en el cual vivimos diariamente mediante el entumecimiento de nuestros sentidos. Esta hibridación generada en base al encuentro de varios medios genera la oportunidad de observar y vislumbrar el trance y el entumecimiento que estos medios imponen. Sin duda, gracias a Internet estamos en un momento en cual el macromedio de 
nuestro tiempo ha absorbido casi la totalidad de los medios anteriores para conformar la hibridación por excelencia, una mezcolanza o contenedor de todos las extensiones que alguna vez fueron generadas por la tecnología del ser humano, que por otro lado nos ofrecen un momento de reflexión sobre como estos medios afectan a nuestra percepción y cognición. Se trata pues de un medio aglutinador de otros medios que propone una objetualización de la identidad que se desarrolla en las redes como una imagen deformada de nosotros mismos, que estas mismas extensiones nos devuelven. Se trata de una traducción en base a las demandas e interacciones que recibimos por parte de las redes. Esto genera la ansiedad de mantenernos activos y de que los demás actúen recíprocamente respecto a nosotros. Sin duda si Narciso hubiera sabido que esa imagen la cual miraba constantemente era el mismo, su interés y atención hubieran sido diferentes, pudiendo salir del trance o circuito cerrado generado por este tipo de entumecimiento perceptivo. Este amante de juguete ajeno al propio Narciso es una imagen especular de el mismo que el entiende como otro, una extensión formada en base a su reflejo.

Como hemos podido observar, una de las ideas esenciales anexas al trabajo de Marshall McLuhan es que los medios son extensiones del propio individuo que modifican el entorno generando cambios agudos y perdurables. Como extensiones del propio ser humano estos medios generan una amplificación que en realidad vigoriza al extremo un tipo de capacidad asociada a nuestros sentidos o órganos. Esto da como resultado el entumecimiento generado por el sistema nervioso central que protege estos órganos mediante este letargo anestésico. En base a este proceso, McLuhan compara la manera mediante la cual los medios afectan a nuestros órganos sensoriales con un shock, del mismo modo que la mente reacciona mediante la negación en base a las teorías de Freud. El propio McLuhan vino a definir este estado de inconsciencia como "narcosis Narciso", un síndrome mediante el cual el ser humano no es consciente de los efectos que la tecnología ejerce sobre el mismo. Esto hizo plantearse a McLuhan la vuelta a la conciencia sobre la realidad mediática como una estrategia de supervivencia como especie, al conceptualizar la tecnología como extensiones de nuestros propios cuerpos vinculando lo exterior con sus efectos internos en el ser humano. Por tanto permitirá aumentar significativamente nuestro control sobre ellos mediante un esfuerzo colectivo como sociedad basado en un programa educacional global que nos lleve a poder dirigir nuestra propia percepción y subjetividad. 


\subsection{UN ARTE DE LOS MEDIOS DE COMUNICACIÓN}

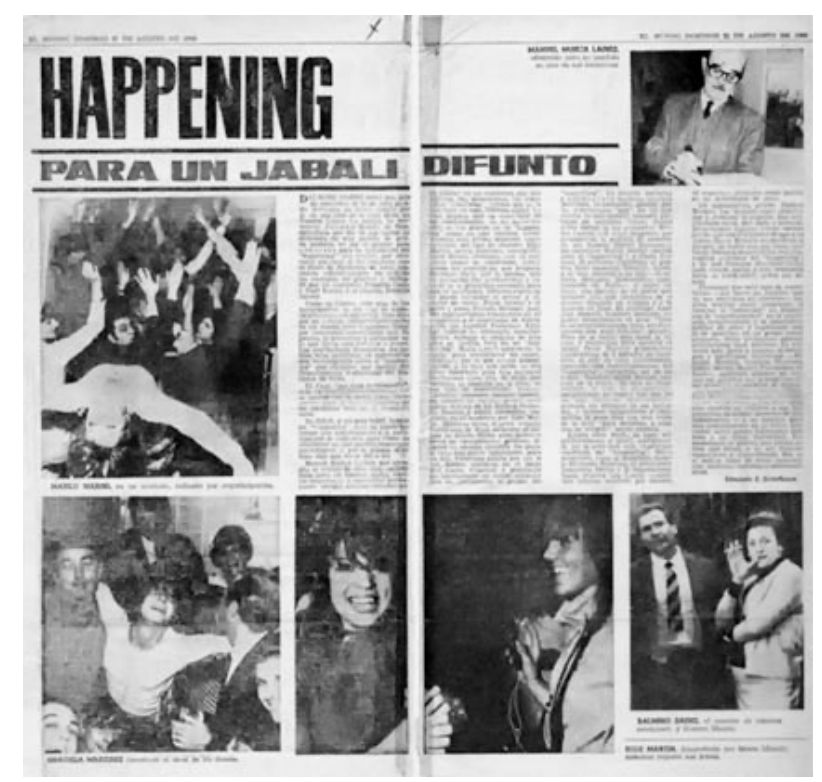

Figura 12. Nota publicada en el diario El Mundo, Buenos Aires, 21 de Agosto de 1966.

El arte se ha posicionado desde sus remotos orígenes entre las áreas de la expresión y la comunicación vividas in situ. Sin embargo, dentro de lo que podríamos considerar la cultura de masas contemporánea, los hechos culturales suceden de manera que el público únicamente presencia la existencia de los registros de los mismos, a través de los medios de comunicación. Por lo tanto lo que vemos o sabemos esta filtrado por multitud de personas y medios, dando como resultado un contenido modificado por el criterio y la propia mirada de estos, siendo los propios medios los que delimitan lo que sucede o no en base a su difusión.

Partiendo de la base de que los propios medios son los principales hacedores de acontecimientos, un grupo de artistas generó una noticia sobre un happening que nunca tuvo lugar, de la cual diferentes medios se hacen eco. Esta obra es conocida como Happening por un jabalí difunto. Finalmente, esto es desmentido por el propio grupo. En su manifiesto realizado en Buenos Aires en Julio de 1966, Eduardo Costa, Raul Escari y Roberto Jacoby abordan la 
idea central del teórico canadiense Marshall McLuhan "el medio es el mensaje", en base a la relación de estos tres artistas con Oscar Masotta. Mediante esta reflexión se trata de poner de manifiesto no solo el hecho de la posibilidad de falsear la verdad, sino que es posible generar acontecimientos que nunca tuvieron lugar y que transcienden a los propios medios. Del mismo modo este tipo de propuestas fueron retomadas mediante el proyecto Tucumán Arde en $1968^{114 .}$

Mediante este proyecto artístico pretendieron llevar a sus últimas consecuencias una de las características principales de los medios de comunicación. Se trata de la propia desrealización de los objetos, que prima el momento de la transmisión del hecho artístico por encima de la obra en si misma, siendo parte del acto creativo. Como reflexionan en su manifiesto Un arte de los medios de comunicación, Escari, Costa y Jacoby, el proceso de la obra no se detiene con su finalización sino que continua dentro de los medios mediante su transmisión. Como contrapunto a este hecho este grupo propuso la eliminación del propio momento de la realización para así buscar un pretexto mediante el cual poner en funcionamiento los medios de comunicación como elemento principal de una obra que consta de la transmisión como principal elemento. Es un tipo de obra que tematiza lo medios de comunicación como medios, por encima del interés que pudiera despertar lo que se comunica, pudiendo considerarse un arte de los massmedia.

Esta experimentación dentro de los medios masivos de comunicación por parte de artistas argentinos durante los años 60 del siglo XX no solo fue desarrollada mediante piezas como Happening para un Jabalí difunto, sino que teóricos como Oscar Masotta, a través de los happenings y el arte de los medios, llegaron al inicio del conceptualismo y la desmaterialización. Las influencias de Barthes, y su concepto de Mito, y de McLuhan y su máxima "el medios es el mensaje", mezcladas con la aparición de obras mínimas y el candente contexto social en Argentina, dieron origen a la experimentación estética con los medios masivos de comunicación. Se trataba también de una investigación semántica del artista llena de conceptualismo y semiología generada por un tipo de artista crítico. Su estrategia consistía en enfrentar el

\footnotetext{
${ }^{114}$ Jacoby, Roberto, El deseo nace del derrumbe, Ediciones de La Central, Barcelona, 2011, p. 49.
} 
publico masivo con su propio sentido crítico o confianza hacia los medios de comunicación de masas, algo que Orson Welles ya utilizó en su gran serial de radio La Guerra de los Mundos. La mezcla de materiales y géneros desarrollo un tipo de obras híbridas que tenían relación con las ideas de McLuhan sobre la hibridación de medios.

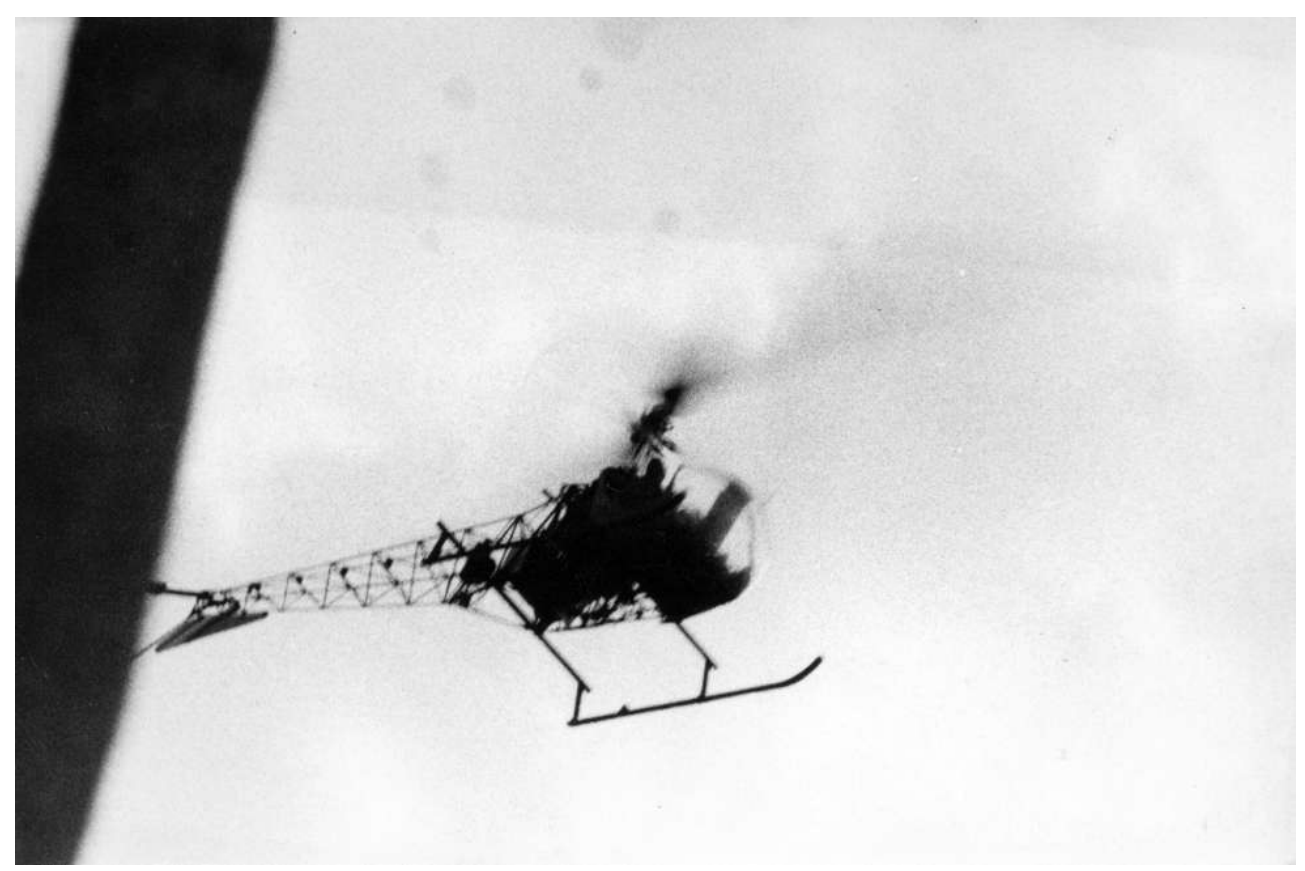

Figura 13. Imagen del happening El helicóptero, de Oscar Masotta 1966.

Del encuentro entre Luci Lippard y Oscar Masotta en 1965 surge el concepto de desmaterialización del arte, que es recogido en el escrito de Masotta, Después del Pop, nosotros desmaterializamos de 1967115, lo que la artista Dora García116 considera más bien una politización generada mediante la información como material esencial de esta desmaterialización. Mediante la

${ }^{115}$ Masotta, Oscar, Revolución en el arte, Editorial Mansalva, Buenos Aires, 2017, p. 221.

${ }^{116}$ García, Dora, Y Masotta cometí un 'happening', El País, 2017, [En línea], [consultado el 27 de Junio de 2016], disponible en

<https://elpais.com/cultura/2017/10/09/babelia/1507542025_086590.html> 
información y la contrainformación se generan estrategias artísticas que abundan dentro del arte político. Ya en 1966, Oscar Masotta crea la serie de tres happenings, El helicóptero, Para incluir el espíritu de la imagen y El mensaje fantasma, dentro de los cuales se puede apreciar la desaparición del público como tal, para convertirse en parte de la obra y del acontecimiento que es el hecho artístico en si mismo. Se trata de la construcción de un mito común que nos retrotrae a Claude Lévi-Strauss, Roland Barthes o Julio Cortazar. Como intelectual, Oscar Masotta estuvo vinculado a la obra Tucumán Arde, la cual pretendía, mediante la mezcla de diferentes disciplinas, la creación de un fenómeno cultural de características políticas que se saliera de las fronteras férreamente delimitadas de las vanguardias artísticas. Esto proyecto represento precisamente el logro de la asimilación de la vanguardia artística por la política, evitando la asimilación de la obra por el sistema del arte, posibilitando el incremento de los ciudadanos interesados por la lucha política. Mediante este proyecto se genero una estructura que posibilitó la filtración a los medios de las propias informaciones que estos evitaban publicar.

En Noviembre de 1968 comenzó este proyecto en las sedes de la CGT de los Argentinos de Rosario Buenos Aires. El catalizador fue los problemas de los obreros y cañeros de Tucumán a los cuales el grupo de artistas que desarrolló el proyecto se adhirieron. Todo comenzó con una campaña de pegatinas con el lema "Tucumán Arde". Del mismo modo se comunicó a los medios de comunicación la intención de un nutrido grupo de artistas de viajar a la zona para informarse sobre las problemáticas de la zona. Este proyecto prosiguió adoptando la estética de una campaña política mediante la realización de pintadas y la recogida de material audiovisual y fotográfico. Finalmente sendas muestras fueron inauguradas en Rosario y Buenos Aires, siendo esta última clausurada el mismo día de la apertura. 
3. TRABAJO Y BIOPOLÍTICA EN LA RED 


\subsection{CAPITALISMO COGNITIVO}

Tal y como nos cuenta Carlo Vercellone ${ }^{117}$ el capitalismo cognitivo, sirve para nombrar el transito hacia un tipo de economía en la cual la distribución del saber y la producción de conocimiento es la principal apuesta del capital para generar valor, en base a la producción de los trabajadores del conocimiento. Esta representada por la industria de la tecnología, los servicios financieros, los mass media y las industrias culturales entre otras áreas. Se caracteriza por la combinación de altos niveles de trabajo cognitivo y cultural combinado por tecnologías digitales. Es por lo tanto un concepto que podemos relacionar con el posfordismo, la nueva economía de finales del siglo XX y la economía del conocimiento.

Este tipo de actividad productiva flexible empezó a aparecer en los países capitalistas avanzados cuando el tipo de producción en masa característica del fordismo empezó a decaer hacia los años 70 del siglo XX. Aquí es donde parece que el propio concepto de capitalismo cognitivo es útil para definir este tipo de transición. Se trata pues de un capitalismo relacional o capitalismo de los afectos que se vale de las mediaciones sociales para crear nuevos elementos dentro de la cadena productiva. Estamos hablando pues de un elemento que se desarrolla dentro de la globalización en forma de nuevos proyectos tecnológicos, que ya a principios de los años 90 del siglo XX tomaron la forma de startups y stock options, aplicaciones informáticas, dispositivos de comunicación y computación, siendo adoptado por el capital como un medio de inversión más rápido y eficaz que costosas y largas investigaciones y desarrollos. En base a esto se generó una nueva base ideológica liberal, que convertía a cada trabajador en un emprendedor con un fututo lleno de trabajos creativos y enriquecedores. Como nos señala Franco Bifo Berardi en La fabrica de la infelicidad ${ }^{118}$, esta fue una alianza entre el trabajo cognitivo y el capital que dio origen a un nuevo tipo de economía denominado Nueva Economía, la cual entró en crisis en 2001 mediante la sobreproducción de bienes tecnológicos, un exceso de innovación y bienes informacionales, en base a la falta de seguimiento de estas innovaciones y la socialización de las mismas. Como consecuencia de esto la reducción salarial y la precariedad

\footnotetext{
${ }^{117}$ V.V.A.A., Capitalismo cognitivo, propiedad intelectual y creación colectiva, Traficantes de Sueños, Madrid, 2004, p. 67.

${ }^{118}$ Berardi, Franco, La fabrica de la infelicidad, Traficantes de Sueños, Madrid, 2003.
} 
igualaron en este sector al resto en poco tiempo. Por lo tanto, la precarización de los trabajadores que no perdieron su empleo durante la crisis fue lo que salvo a estas empresas tecnológicas y las hizo de nuevo rentables.

Dentro de España este tipo de capitalismo cognitivo se ha desarrollado como un mecanismo de acumulación por desposesión, valiéndose de la privatización de la formación, precarización, reforzamiento de la propiedad intelectual y la incentivación de situaciones que benefician el monopolio y el oligopolio. Se trata pues de la eliminación de los elementos positivos de la producción del conocimiento que aspira a someter y afixiar al general intellect, mediante la precarización de un sistema educativo que somete al "cognitariado"119, es decir, docentes, investigadores y todo tipo de creadores.

En su artículo Sobre la contestación al capitalismo cognitivo de 2001120, Nick Dyer-Whiteford desarrolla el concepto de capitalismo cognitivo como un régimen desplegado sobre el mercado de los procesos digitalizados que funcionan en red, poniendo como ejemplo el mundo de los videojuegos. Sin duda, en vista de los cambios acaecidos en el ámbito de las tecnologías asociadas con la red y lo social podríamos, hoy día, ampliar este concepto al ámbito de las redes sociales y las aplicaciones de la web 2.0. El denomina este tipo de producción cultural como los altavoces de propaganda de un capitalismo de la información. Nick Dyer-Whiteford divide los diferentes segmentos en los cuales estos productos son creados en tres colectivos, los obreros del conocimiento, los prosumidores y el nuevo proletariado. Se trata de una industria que recluta obreros de la propia cultura que ha creado, para realizar un trabajo inmaterial conceptualizado como juego en equipo, que ante la precariedad y la falta de organización como trabajadores desemboca en la movilidad laboral, la creación de pequeñas compañías propias y el sabotaje digital en forma de huevos de pascua. La piratería y la remezcla llevada a cabo por los prosumidores ha sido conceptualizada en muchos casos como una reapropiación de las tecnología digitales del capitalismo cognitivo, una contestación a un sistema de producción y trabajo digital del capitalismo de la información. La capacidad cada vez más extendida para crear este tipo de productos ha hecho inútil la capacidad del mercado para impedir creaciones

${ }^{119}$ V.V.A.A., op. Cit, 2004, p. 27.

${ }^{120}$ Ibídem, p. 49. 
disidentes, reapropiaciones y transgresiones, más allá de la explotación lúdica de las posibilidades de desarrollo humano colectivo. Por otro lado el proletariado digital ha saltado a la primera pagina de las noticias por las condiciones de trabajo extremas implementadas por diferentes empresas subsidiarias de grandes compañías occidentales en China o la India.

El éxito de este tipo de formas emergentes nos muestra el triunfo del capitalismo cognitivo como método de encerrar el general intellect dentro de la mercantilización, que moviliza a una fuerza de trabajo inmaterial cualificada cuyo trabajo esta basado en actividades vitales realizadas por prosumidores voluntarios. Esto ha provocado la aparición de prácticas insertas dentro de esta cultura, como una extensión de proyectos artísticos, tal es el caso de multitud de intervenciones dentro de metaversos como las de Eva y Franco Mattes y su reconstrucción de performances históricas dentro de Second Life, en las cuales se muestra la mediación tecnológica y la simulación de vida que estos entornos generan en forma de avatares y lugares, para reutilizar y resignificar esta simulación mediante el propio remake de estas performances. Es una confrontación con lo que aparenta ser real y por otro lado esta creado en gran parte por los propios jugadores como un trabaja amauterizado y gratuito.

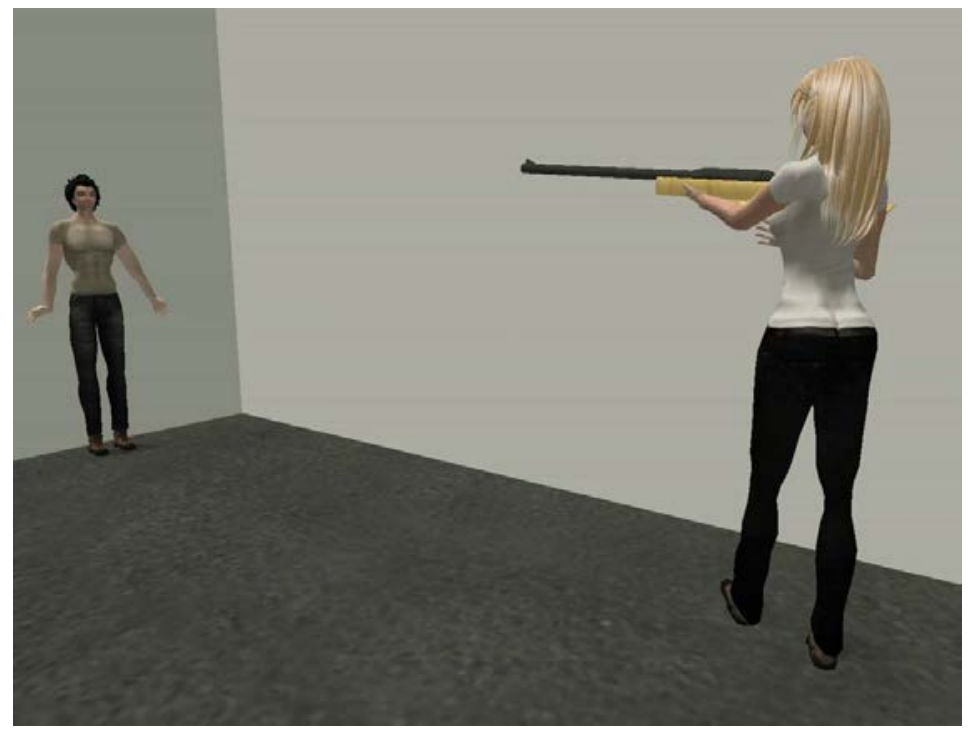

Figura 14. Eva y Franco Mattes, Reenactment of Chris Burden's Shoot, 2007. 
Este tipo de prácticas también tienen lugar dentro videojuegos multijugador, como las realizadas por Harum Farocki. En su serie Parallel I-IV, reflexiona sobre como los videojuegos han pasado a usurpar el papel del cine como medio de representación visual dominante. Esto se muestra mediante la propia representación de la naturaleza, paisajes y el cuerpo humano, mostrándonos como la cultura de los videojuegos ha evolucionado hacia una mayor plasmación del hiperrealismo que ha logrado ocupar nuestro tiempo de ocio en beneficio de terceros.

Siguiendo la tesis de Carlo Vercellone, la crisis del capitalismo industrial es provocada por la transición hacia un capitalismo cognitivo, en el cual la difusión del saber y la producción de conocimiento son la principal herramienta del capital, y por lo tanto los knowledge workers ${ }^{121}$ o trabajadores del conocimiento, son la variable clave en la competitividad y éxito de una sociedad. Se trata de la captación de la economía del saber por parte del capital financiero como parte de una economía rentista, que ha producido una acentuación de las divisiones Norte-Sur, en base a la deuda, las patentes y el capitalismo accionarial. Esto ha pasado a conformar una polarización en cuanto a las actividades intensivas relacionadas con el conocimiento, ya que la competitividad de un territorio determinado depende cada vez más de trabajo intelectual cooperativo que es posible desarrollar por parte de los individuos que allí residen. El conocimiento siempre ha sido un elemento que ha servido para generar objetividad respecto al mundo en el cual vivimos, para adecuar el medio y los individuos a la producción. Sin embargo, en la actualidad ha tomado un papel que le iguala al capital o al trabajo. La naturaleza del valor, la manera en la cual se obtiene y su materialización han cambiado radicalmente, absorbiendo la actividad cognitiva humana bajo las nuevas reglas del mercado, en base a la posibilidad de obtener beneficio. Esto se relaciona con los que Manuel Castells define como una nueva economía global de carácter informacional ${ }^{122}$, que supera el anterior escenario fordista del capitalismo acumulativo, para generar un capitalismo informacional, en base al papel de las tecnologías de la información y la comunicación. Esta reestructuración pasó a formar el discurso de lo que conocemos como globalización, hoy en

\footnotetext{
${ }^{121}$ V.V.A.A., op. Cit., 2004, p. 66

${ }^{122}$ Castells, Manuel, La sociedad red, Alianza, Madrid, 1997, p.93.
} 
retroceso en varios aspectos según el propio Castells. El desarrollo de las tecnologías informáticas se llevó a cabo de manera autónoma, pero fue instrumentalizada por el capital mediante las desregulación de las redes de telecomunicaciones, poniendo las bases para la aparición de la acumulación capitalista dentro de lo que le mismo denomina la sociedad red.

Por otro lado, el capitalismo cognitivo ha sabido utilizar el tiempo cedido para generar producción de conocimiento, por toda una gran masa de prosumidores no asalariados, cuya producción ya no se ve regulada en base a propiedad intelectual, sino que son los medios de distribución y las estructuras mediáticas en las cuales se crean las que se adueñan de los réditos de este tipo de producción. Esto ha dado lugar a una amateurización de un sin fin de actividades relacionadas con el conocimiento y la creatividad, privadas de rédito y propiedad sobre sus creaciones, pero conformadas como el pilar fundamental de la rentabilidad de grandes empresas tecnológicas.

Por lo tanto estamos en un escenario en el cual los medios de producción se han puesto en manos del gran público de manera gratuita, pero los medios de distribución siguen estando en manos privadas, lo que de facto hace que nuestra producción quede irremediablemente incrustada en los medios en los cuales se crean. La fuerza de trabajo intelectual ha pasado a suplir a la fuerza de trabajo física productiva, generando un tipo de valor basado en el contenido producido, el cual es traducible a información y distribuible en base a las redes. La increíble voluntad por llevar la conexión a Internet y sus servicios y aplicaciones a todos los habitantes de la Tierra parte de la intención de generar una red productiva de carácter planetario, donde los contenidos y la información circulen y generen valor mediante el control de su distribución por parte de diferentes compañías hegemónicas, a la vez que el propio excedente en la producción de contenidos devalúa y banaliza a estos.

Esto ha dado como resultado la extensión de las tareas que podríamos considerar como trabajo a muchos aspectos de nuestra vida diaria, generando un beneficio a terceros del cual no somos conscientes, en base a la expropiación y instrumentalización de nuestro trabajo cognitivo en forma de tiempo de ocio. El control de los flujos de información se ha convertido en un elemento capital por encima de la propiedad, en base a la producción y autoría de los propios contenidos. Son terceros los que generan todo un compendio de 
contenidos que son rentabilizados sin necesidad de ningún tipo de inversión, salario, producción o posesión. Se genera pues una plusvalía basada en los propios mecanismos mediante los cuales la información de disemina y comparte. La eliminación del tiempo de trabajo y de una estructura laboral convencional, ha dado como resultado una fuerza de trabajo colectiva que genera valor como masa, en base a la compartición de contenidos en el ámbito de lo global. El valor de los creado dentro de este escenario, dependerá de su capacidad para ser replicado y contestado en base a los propios flujos de información, aumentando aún más si cabe la producción de información.

Pese a las posibilidades casi infinitas de intercambio generadas mediante las redes de información, debemos ser conscientes de los mecanismos de dominación y trabajo gratuito que esconden muchos de estos servicios, poco vinculados al altruismo que la gratuidad de los mismos podría aparentar, y más en consonancia con la expropiación de nuestro trabajo cognitivo en base al fomento de nuestra actividad creativa e intelectual dentro de las redes.

\subsection{GENERAL INTELLECT}

El concepto de general intellect, como intelecto colectivo, es desarrollado por Karl Marx en su obra Grundrisse, en concreto dentro del conocido como Fragmento de las máquinas. Como nos cuenta el propio Marx, "El desarrollo del capital fixe revela hasta qué punto el conocimiento o "knowledge social general" se ha convertido en fuerza productiva inmediata, y, por lo tanto, hasta qué punto las condiciones del proceso de la vida social misma han entrado bajo los controles del general intellect y remodeladas conforme al mismo. Hasta qué punto las fuerzas productivas sociales son producidas no sólo en la forma del conocimiento, sino como órganos inmediatos de la práctica social, del proceso vital real"123.

En este fragmento Marx nos habla del desarrollo del conocimiento técnico y científico como fuerza productiva, que es separado del cuerpo social a medida que se desarrolla cómo tal. Se trata del conocimiento adquirido durante la historia humana conformado como un patrimonio colectivo, que se incorpora

\footnotetext{
${ }^{123}$ Marx, Karl, Elementos fundamentales para la crítica de la economía política (Grundrisse) 18571858 Vol. 2, Siglo Veintiuno Editores, México D.F., 1972, p. 230.
} 
a las lógicas económicas separándose del cuerpo social. La paulatina automatización del sistema productivo y sus repercusiones sobre lo social producirán los cambios que nos llevaran a la conformación del conocimiento como la nueva potencia productiva. Se trata de una ubicación del propio obrero dentro del sistema productivo, que transforma la cooperación social en productora. Esta reubicación es una apropiación del propio general intellect como fuerza productiva general basada en la comprensión, anhelos y existencia del cuerpo social.

El acto creativo es pues un acto colectivo, ya que trabajamos y producimos dentro de la colectividad. Este saber social tiende según Marx a ser apropiado por una parte de la sociedad, generando un tipo de producción basada en el saber común que solo revierte en el beneficio particular. Conceptos en principio ajenos al capital fijo, como creación, mentalidad o imaginación, son capaces de funcionar, si ningún tipo de aparato electrónico o mecánico, como máquinas productivas, siendo por lo tanto parte de lo que Marx llamaría trabajo vivo. Marx afirma que cuando esta mezcla entre conocimiento y tecnología se produce, va más allá, remitiéndonos a la comunicación y la cooperación. Por lo tanto, debemos conceptualizar el general intellect como el conocimiento general, un grupo de compendios cognitivos imprecisos, pero del cual se origina la productividad social, convirtiéndonos como humanidad en conocimiento.

Este es un concepto que podemos ver ampliamente desplegado dentro de la sociedad del capitalismo tardío. Posteriormente, el operaísmo italiano ${ }^{124}$, desde su grupo primigenio "potere operario", reinterpretó este fragmento, más concretamente dentro de la obra de Paolo Virno y otros autores. Se pasó a definir como un tipo de intelectualidad de masa ubicada dentro del capitalismo cultural, y como elemento esencial de la acumulación capitalista. Como podemos apreciar en su obra Virtuosismo y revolución, este es un concepto que reconfigura el modo de producción capitalista mediante una versión ampliada de este concepto, que Virno ubica "muchos más allá del conocimiento que se materializa en el capital fijo, incluyendo también las

\footnotetext{
${ }^{124}$ El operaísmo surge como un movimiento político marxista y antiautoritario cuyo análisis empieza por observar el poder activo de la clase obrera para transformar las relaciones de producción. Los elementos principales del operaísmo precedieron y se combinaron para evolucionar más elaboradamente en el movimiento autónomo.
} 
formas de comunicación social e inervan la actividad del trabajo intelectual de masa"125. Virno nos aclara como el texto de Marx, Fragmento de las Máquinas fue el catalizador y brújula de la década de los años sesenta del siglo XX dentro de las beligerantes pugnas obreras desarrolladas dentro de la Italia de la época, que finalmente se enfocaron en el concepto de fábrica social, es decir la vida diaria de la gente y la clase trabajadora dentro de su propia comunidad. Par el este concepto conlleva una significación que nos acerca a las teorías de la información y la comunicación, así como los saberes locales, los juegos lingüísticos y la preocupaciones éticas que dan origen a una intelectualidad que emana de las masas, o conjunto de saberes de los sujetos vivos, y que a la postre se constituyen en la forma dominante mediante la cual se materializa el general intellect.

Para Virno, esta intelectualidad de masa incluye "los saberes no divisibles de los sujetos vivos, de su cooperación lingüística"126, como un signo distintivo de la fuerza de trabajo posfordista donde la información y la comunicación es esencial, de manera que se ha puesto a trabajar al propio lenguaje dentro de una abolición del trabajo asalariado. Para Virno el general intellect se presenta como "comunicación, abstracción, autorreflexión de sujetos vivos"127 como contrapunto a la visión mecanicista de Marx que lo ubica como capacidad científica objetivada. Paolo Virno contempla la cooperación sin duda como el elemento clave, desplegada mediante nuevas formas de interacción comunicativa como performances dialógicas o juegos lingüísticos dentro de la competencia comunicativa de los individuos. Por lo tanto es el intelecto desarrollado por el público, lo colectivo, como autorreflexión, lenguaje, pensamiento, lo que podemos aprender como grupo, vuelca para Virno su foco en lo exterior, y lo común generado desde la colectividad en forma de producción intelectual como elemento esencial de la producción de riqueza, tal y como Marx anunciaría.

Este concepto quedaría definido como una cualidad intelectual de la

\footnotetext{
${ }^{125}$ Virno, Paolo, Virtuosismo y revolución. La acción política en la era del desencanto, Traficantes de Sueños, Madrid, 2003, p. 85.

${ }^{126}$ Virno, Paolo, ibídem, 2003, p. 86.

${ }^{127}$ Virno, Paolo, Gramática de la multitud. Para un análisis de las formas de vida contemporáneas, Traficantes de Sueños, Madrid, 2003, p. 66.
} 
colectividad y por lo tanto a la población al completo, tratándose de un fenómeno de masas resultado de las prácticas colectivas de cooperación del conjunto de los individuos que conforman una sociedad.

Por otro lado, el concepto de trabajo abstracto128 elaborado por Marx, sirve para ilustrar como el tiempo es transformado en valor mediante el trabajo. Por lo tanto, estamos hablando de la habilidad del tiempo para producir valor. Este tipo de abstracción es algo que alcanza ámbitos de la actividad social, sometiendo la propia actividad de nuestra mente en una forma de valor útil para el capital. Es precisamente el propio intelecto social el que ha convertido la actividad física en algo secundario transformando el trabajo humano en algo a reemplazar por parte de la ciencia y la tecnología. Fue Marx por lo tanto quien predijo muy acertadamente la transformación del trabajo en un hecho intelectual que surge como consecuencia de la intensificación tecnológica representada por la digitalización de la producción global del fines del siglo XX. Hoy en día podríamos hablar de cómo nuestra propia vida se transforma continuamente en una plusvalía en base al uso que de nuestra producción, actuar y datos absorbidos, reutilizados y vendidos por grandes compañías transnacionales de Internet, convirtiéndonos en trabajadores gratuitos de un tipo de actividad sutilmente rentabilizada desde sectores tecnológicos que han sido capaces de sacar rédito de nuestra actividad cognitiva dentro de las redes.

Si observamos las cualidades requeridas dentro de lo que podríamos definir como un nuevo tipo de profesionalidad demandada en el ámbito de los trabajadores de la industria cultural, veremos como muchas de estas cualidades son ajenas al propio entorno laboral, aunando factores que generan redes de socialización externas, en base a aptitudes y habilidades que provienen de lo social. Esto es una consecuencia de las nuevas formas de trabajo extendidas a escala global, que han denostado el antiguo concepto marxista de capital fixe, o medios de trabajo, para conceptualizar estos como cualidades del propio trabajador, mediante sus propias capacidades de generar nuevas ideas, aprender y colaborar dentro de una colectividad generando nuevos conocimientos. Esto lo podríamos resumir dentro de lo que

\footnotetext{
${ }^{128}$ Marx, Karl, Elementos fundamentales para la crítica de la economía política (Grundrisse) 18571858 Vol. 1, Siglo Veintiuno Editores, México D.F., 1971, p. 236.
} 
se conoce como la subjetividad generada en base a nuestra propia actividad y trabajo cognitivo.

\subsection{EL TRABAJO INMATERIAL}

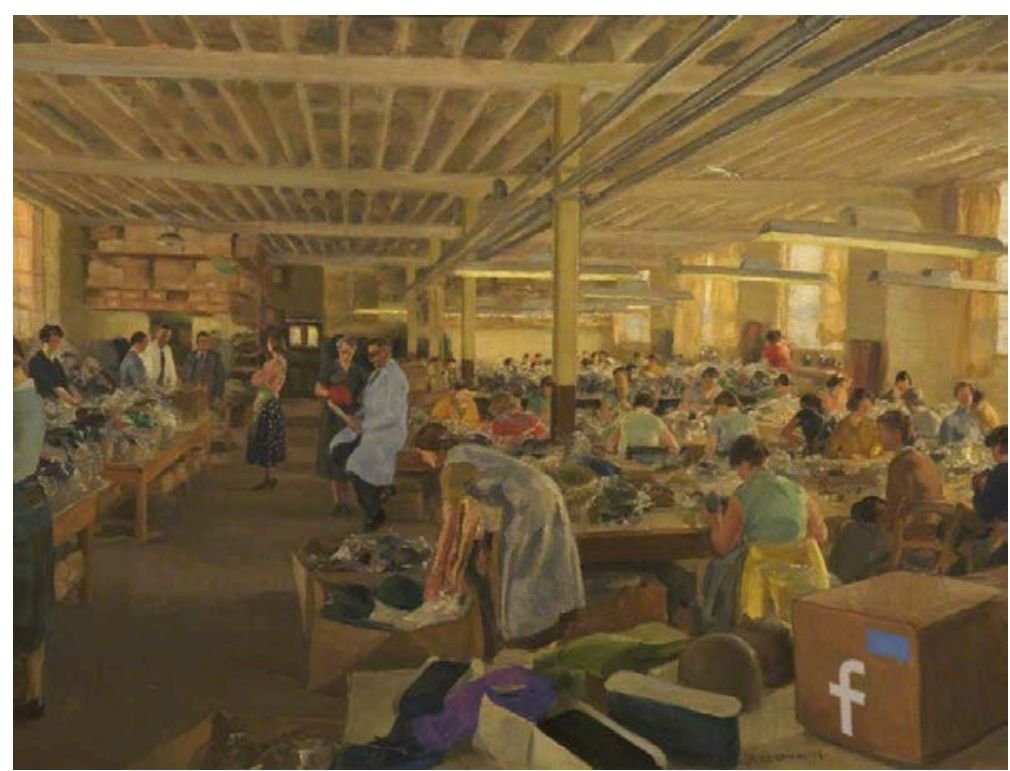

Figura 15. Diseño de Hackers \& Designers en base a la pintura Hatting Factory workers de Amy Katherine Browning.

El concepto de "trabajo inmaterial" fue también desarrollado dentro del marco teórico del posmarxismo por el teórico italiano Maurizio Lazzarato, en su ensayo homónimo de 1996 editado por Paolo Virno y Michael Hardt Radical Thought in Italy. A Potential Politics ${ }^{129}$. Mediante este ensayo se propuso explicar como el capitalismo ha logrado generar valor en base a nuestras prácticas cognitivas y afectivas. Este es un concepto aplicable es muchos ámbitos, como las condiciones alienantes del trabajo domestico y su relación con el genero, lo difícil de mesurar el trabajo creativo o la transmisión del conocimiento. Pese a ello, su campo de acción se ha concentrado

${ }^{129}$ Virno Paolo, Hardt, Michael, op. Cit., 1996, p. 132. 
especialmente en las tecnologías digitales y su relación con la economía digital del conocimiento. Este concepto se define como el tipo de trabajo que produce una mercancía con un contenido informacional y cultural.

Según Lazzarato se puede separar en dos tipos diferentes. Uno que se distingue por el contenido informacional de la mercancía, el cual se da en industrias terciarias donde el trabajador usa habilidades relacionadas con el uso de ordenadores. Y por otro lado, las actividades que generaran un contenido cultural de la mercancía y desarrollan una serie de actividades no reconocidas como trabajo pero que definen y fijan los estándares culturales, artísticos, dinámicas de consumo y también opinión pública. Se ha pasado de un trabajo meramente manual a un trabajo que requiere dotes intelectuales mediante la implantación de las nuevas tecnologías de la información y la comunicación, dando lugar a una nueva intelectualidad de masas. Por otro lado la nueva fuerza de trabajo de las empresas no es formada por las empresas, sino que la incorpora y la adapta, dentro de un tipo de producción actual que es directamente la producción de una relación social, y cuya materia prima es la subjetividad y el ambiente ideológico en que esta subjetividad vive y se reproduce. Es precisamente la producción de subjetividad lo que pasara de ser un instrumento de control social a un elemento productor en una sociedad de consumidores y comunicadores activos. Por otro lado, esto nos ha permitido superar el concepto de creación individual asociado a un tipo de clase superior. Se trata pues de trabajadores que desarrollan su actividad en diferentes ámbitos de los medios masivos de manera que satisfacen una demanda a la vez que establecen otra, transformando la comunicación en economía. Michael Hardt ya nos hablaba mediante el concepto de affective labor o trabajo afectivo, de nuevas formas de producción económica hegemónicas basadas en la mezcla de la tecnología y afectividad, que generan valor añadido en el campo de la relaciones sociales. Sirve para explicar un tipo de labor desarrollada dentro de los medios de comunicación, en la cual no solo se prima la trasmisión de información , sino que esta sea transmitida de manera que resulte atractiva y deseable en cuanto a su consumo. Mediante este tipo de trabajo la comunicación es capaz de trasmitir formas de vida y afectos mediante la combinación de lenguaje y afectividad. 
En la obra conjunta de Michael Hardt y Antonio Negri Multitud ${ }^{130}$, el concepto de trabajo inmaterial aparece como "el trabajo que crea bienes inmateriales, como el conocimiento, la información, la comunicación, una relación o una respuesta emocional" 131. Para ellos otros términos como trabajo de servicios, trabajo intelectual o trabajo cognitivo, aluden a diferentes aspectos del propio trabajo inmaterial, siendo este un concepto mucho más general. Hardt y Negri distinguen entre el propio trabajo intelectual o lingüístico y lo que ellos denominan trabajo afectivo como una categoría del trabajo inmaterial. Para ellos el trabajo inmaterial se ha convertido en hegemónico cualitativamente, suplantando el papel anterior del trabajo industrial. El trabajo afectivo es una construcción biopolítica, ya que genera relaciones sociales y formas de vida. Son actividades de gran componente afectivo y claramente feminizadas, por lo cual se le concede menor valor y peor remuneración. Se trata de trabajos alienantes, que conllevan por su naturaleza afectiva relaciones de explotación para el que lo ejerce. Es un tipo de trabajo que genera o trata los afectos mediante un tipo de actitud prosocial.

La comunicación se ha transformado en la principal fuente de poder y productividad, mediante el producción, difusión y remezcla del conocimiento en base a las nuevas condiciones tecnológicas. El carácter inmaterial de las creaciones culturales y comunicativas desarrolladas mediante estas tecnologías hace que cobre sentido utilizar el término trabajo inmaterial para designar estas actividades centrales en la economía posfordista. El resultado de este tipo de trabajo no es material o duradero, como puede ser un producto cultural, comunicación, servicio, saber o conocimiento. Su valor consiste en una creación cultural que no se destruye al ser consumida, pero puede ser transformada. Es un tipo de trabajo que produce gran valor pero no puede sustituir al trabajo material. De hecho, este tipo de trabajadores tienden a trabajar dentro de una colectividad en la cual su importancia depende de sus habilidades y conocimiento.

\footnotetext{
${ }^{130}$ Hardt, Michael, Negri, Antonio, Multitud, guerra y democracia en la era del Imperio, Debate, Barcelona, 2004, p. 136.

${ }^{131}$ Hardt, Michael, Affective Labor, en boundary 2, Vol. 26, no 2, Duke University Press, 1999, p. 89.
} 
Los servicios de la Web 2.0. se conforman como herramientas de creación que posicionan al yo como un constructo dentro del ámbito social y cotidiano de la productividad. Por otro lado, el concepto de comunidad será usado para desarrollar grupos de productores que ofrezcan como reclamo sus creaciones, generando la propia figura del usuario como protagonista. Este es valioso solo en base a los contenidos y el tipo de relaciones que genera, volcando el interés de las empresas de Internet en lo que Martín Prada denomina el "capital social" 132 en el ámbito de las redes sociales. Una fuerza productiva que rentabiliza el tiempo de ocio de cada individuo para beneficio de estas empresas. Este giro hacia la producción no debe sin embargo confundirse con una transformación de la gran masa de consumidores hacia una nueva tipología de usuarios emancipados. Pese a lo utópico de la idea del cambio de esta masa en agentes autónomos de producción, no debemos olvidar que estos servicios proporcionan herramientas que siguen perteneciendo a las empresas que las crearon, y que son ofrecidas como servicios que se implementan y revalorizan en base a la plusvalía generada por la producción de la multitud interconectada.

Debido a su orientación hacia la formación de formas de vida social el trabajo inmaterial deviene un tipo de concepción biopolítica. Por un lado, podemos observar una apropiación de nuestras actividades cognitivas, pero no podemos olvidar, como diría Foucault, el control sobre nuestros propios cuerpos desde las prácticas sociales y el impacto de las tecnologías del conocimiento y la comunicación sobre diferentes aspectos de nuestra vida. Se atisba un tipo de forma de trabajo, incrustada en nuestra vida diaria y lo social, que traspasa ampliamente las fronteras previamente marcadas para generar una hegemonía sobre la racionalidad que se transforma en una perdida de libertad. Debemos tener en cuenta que es un agente productor de subjetividades y por lo tanto determinante en la formación de nuestra cosmovisión. El trabajo inmaterial, entre cuyas cualidades destacan la movilidad y la precariedad, se genera en base a las nuevas cualidades de las máquinas, las cuales son capaces de desarrollar habilidades cogniscitivas cada vez mayores, y por lo tanto, sustituirnos en estas tareas, dejándonos como trabajadores intelectuales del conocimiento y la comunicación.

\footnotetext{
${ }^{132}$ Martín Prada, Juan, Prácticas artísticas en Internet en la época de las redes sociales, Akal, Madrid, 2015, p. 40.
} 


\subsection{TRABAJO DIGITAL}

Teóricos como Tiziana Terranova ${ }^{133}$, entre otros, elaborarán la formulación del concepto de digital labor o trabajo digital. Apunta hacia una "glamourización" del trabajo digital en base a una degradación del trabajo del conocimiento. Terranova llama free labor o trabajo gratis a la actividad excesiva, hiperactiva y floreciente llevada a cabo en Internet por los que ella denomina netslaves o esclavos de la red. Se trata de un trabajo no remunerado, supuestamente gozoso, y que explota voluntariamente a la mano de obra gratuita de la red. Trata de discernir la manera en la cual Internet se conecta con la fabrica social descrita por los autonomistas. Destaca las conexiones de la economía digital y lo que los operaístas y autonomistas italianos llamaron la fábrica social o sociedad fábrica. Esta describe el proceso mediante el cual los procesos de trabajo han sido transferidos de la fábrica a la sociedad como apuntaban Virno Y Hardt en Pensamiento radical en Italia citado anteriormente.

Terranova entiende Internet como algo que no escapa de la realidad, sino que esta profundamente conectado al desarrollo de la sociedad del capitalismo tardío. El trabajo cultural y técnico, es para ella una de las características del tipo de sociedad donde esta actividad está cuestionando las barreras entre producción y consumo, y trabajo y cultura, siendo curiosamente los debates online por su naturaleza, un tipo de plusvalía que solo puede ser absorbida parcialmente por el capital. Por otro lado el termino economía digital, es para Terranova una forma que tiende a resumir los procesos que ha narrado, caracterizándose por la mezcla de la economía cultural posmoderna, entendida como los medios, la universidad, las artes, y la industria de la información. Esta economía esta caracterizada por la aparición de nuevas tecnologías con nuevos tipos de trabajadores, pudiéndose considerar, según Richard Barbrook, como una economía mixta basada en el componente público de la producción de información, el componente privado mercantilista y un elemento de "economía del regalo", basada en la libre circulación de información. En este sentido Terranova intenta averiguar si Internet es una ruptura con el capital o si por el contrario es una continuación. Se trataría más bien de una mutación consecuencia del capitalismo tardío, una intensificación que ha producido este cambio de una lógica cultural a una economía

\footnotetext{
${ }^{133}$ Scholz, Trebor, Digital Labour. The Internet as Playground and Factory, Routledge, Nueva York, 2013, p. 46. 
generalizada. No se trata de un mecanismo creado por el capitalismo como estrategia para destruir el propio concepto de trabajo. Se trata de un aplanamiento de las conexiones sociales, culturales y políticas. El trabajo gratuito desplegado sobre las nuevas aplicaciones de Internet conforma una audiencia heredera de la televisiva, en el sentido de que depende directamente de esta para proveer en este caso de trabajo cultural relacionado con nuestra vida diaria. Estas aplicaciones apuestan por operar dentro de los espectáculos de la gente, incentivando la abundancia de material dentro de Internet que deja en un segundo plano los valores democráticos o morales.

Estas aplicaciones relacionadas con el ocio han desdibujado la línea entre el entretenimiento y el trabajo. Se ha generado una monetización en base a la publicidad dentro de los contenidos digitales creados por una mano de obra digital gratuita. Por otro lado, teóricos como Christian Fuchs ${ }^{134}$ argumentan que este tipo de explotación no tiene lugar si los propios usuarios consumen y producen sus propias creaciones.

Para Fuchs, los medios digitales están basados en un sistema de clases dentro del propio sistema de trabajo digital. Se trata de cadenas de trabajo interconectadas pero globalmente dispersas, de hecho podríamos decir que las viejas formas de producción perviven en las nuevas. Se caracteriza por la interacción de diferentes formas de trabajo características de diferentes estadios del capitalismo y precapitalismo. Por un lado tenemos los contenidos en forma de noticias, por otro los productos y aplicaciones en forma de software y el soporte o hardware, representando diferentes aspectos de nuestra actividad en la red. Estos tres elementos son desarrollados mediante diferentes tipos de producción herederas de diferentes estadios del capitalismo. Esto se aleja del fetichismo tecnológico, o más concretamente lo que podríamos denominar como fetichismo de Internet, el cual propugna que este medio, constituido como el macromedio hegemónico de nuestro tiempo, genera automáticamente un mundo mejor y radicalmente nuevo. Sin embargo, las relaciones de producción, como hemos destacado anteriormente, aparecen como algo complejo y disperso, difícilmente rastreable en cuanto a las relaciones de poder y explotación que se crean como resultado de este sistema, los dispositivos que compramos y los servicios que usamos.

\footnotetext{
${ }^{134}$ Fuchs, Christian, Digital labour and Karl Marx, Routledge, Nueva York, 2014, p. 96.
} 
El 24 de Agosto de 1995 el sistema operativo Microsoft Windows 95 fue lanzado al mercado tras una gran campaña de mercadotecnia. Muchas tiendas abrieron a medianoche para ofrecer en primicia el producto, lo que produjo colas de miles de personas que querían conseguir con antelación dicho software. Microsoft vendió 7 millones de copias en 5 semanas acaparando la totalidad del mercado, y consumando el mayor lanzamiento en la historia del software por la expectación y ansiedad despertada en los usuarios. Este fue uno de los primeros ejemplos de lo que ha venido a conformarse como grandes campañas alrededor del lanzamiento de productos tecnológicos, lo que con el tiempo no ha hecho más que acrecentarse en base a la respuesta de los consumidores. Hoy en día, es común observar multitudes esperando adquirir en primicia su nuevo periférico tecnológico a las puertas de cualquier franquicia. Quizá el caso más extremo en este sentido sean los lanzamientos de los productos de Apple, los cuales suelen ir acompañados por colas interminables en sus propias tiendas y cobertura mediática que podríamos calificar de excesiva. Los primeros compradores suelen hablar para las cámaras de televisión y celebrar su logro como algo excepcionalmente valioso en su propio recorrido vital.

Estamos ante lo que podríamos definir como fetichismo tecnológico. Es el que nos hace atribuir a un determinado objeto atributos que no le corresponden, lo que desemboca en una completa mitificación. Mientras los objetos que consumimos nos muestran su valor y su uso de manera transparente, este fetichismo oculta las relaciones de esclavitud, explotación, imperialismo y trabajo doméstico que son el epicentro de las relaciones laboras de la industria de las tecnologías de la información y la comunicación. Sin embargo como usuarios y consumidores tendemos a centrarnos en el objeto producido y las contrapartidas que nos ofrece. Según Fuchs, solemos adornar este tipo de tecnologías con características de buen gusto, belleza y diseño, sin embargo para que estos bienes sean consumidos por el gran público, una compleja red de trabajo globalmente dispersa debe de ponerse en funcionamiento. Estos son los símbolos de un estilo de vida relacionado con el éxito, la movilidad y la flexibilidad, que son generados para una comunidad concreta de profesionales del conocimiento. Sin embargo, bajo esta estética y fetichismo se ocultan las condiciones laborales que hacen posible la producción de las tecnologías de la información y la comunicación. Esto genera una ideología estética engañosa que transforma trabajo en juego, deseo y buena apariencia, apelando al diseño y al estilo de vida como ideología. 


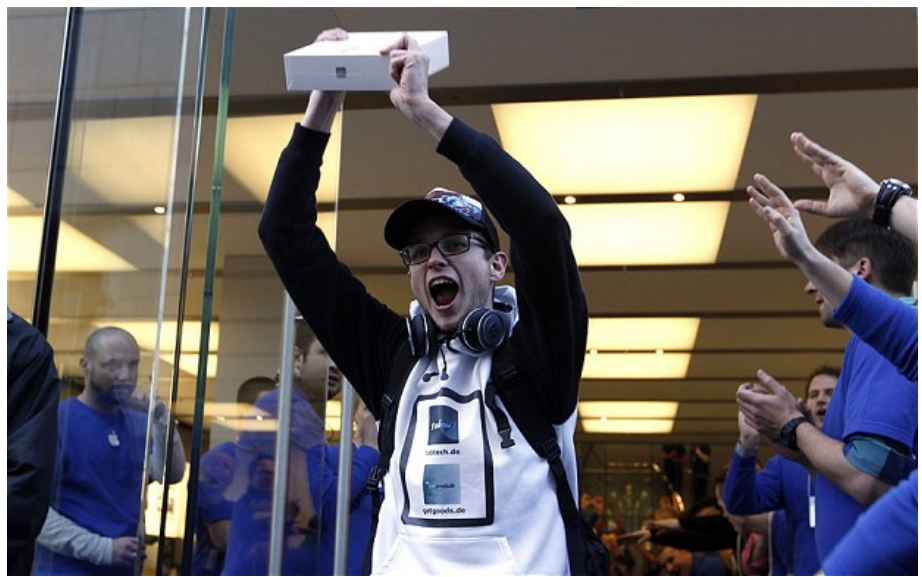

Figura 16. Christof Wallner fue el primer propietario del nuevo iPad en Alemania, en Marzo de 2012.

Como hemos indicado anteriormente, la prosumición, entendida como lo que sucede cuando por ejemplo escribimos, leemos y vemos contenidos dentro de las redes sociales corporativas, es una forma de trabajo directa pero menos visible y consciente. Los usuarios consumen información existente y crean nueva, generando para ello perfiles, y a través de ellos relaciones sociales y afectos. Es a través de este proceso mediante el cual se genera una transferencia de datos que es mercantilizada por las grandes compañías de Internet. Pese a que la actividad de prosumición esta orientada como diversión y por lo tanto no remunerada dentro de la fábrica social, si genera una plusvalía de la cual se benefician, y en base a la cual comercian, diferentes empresas asociadas con los principales servicios de Internet. Es por ello que este tipo de actividad ha sido asociada a las labores domesticas, al no estar remunerada, no estar sindicada y ser parte de un modo de explotación. Sin embargo, este tipo de actividad se mantiene ante la amenaza de la perdida de contactos e interacción social, y por lo tanto un aislamiento casi total con el mundo que nos rodea.

En el ámbito de las redes sociales, este tipo de actividad se sustenta en base a un gran número de promesas y asociaciones positivas. Podríamos decir que el usuario actúa como un consumidor y trabajador de las tecnologías de la información y la comunicación. Este proceso de consumo, ha suplido el 
proceso cultural de creación de significado mediante su uso dentro de la vida cotidiana.

Por otro lado, el modelo de negocio basado en la publicidad dirigida convierte los datos de los usuarios en mercancía, mediante los contenidos, perfiles, redes sociales y comportamiento online. El uso, monitoreo y mercantilización de los datos, es definido en base a los términos y condiciones de uso, lo que se plasma en unas políticas de privacidad que comercian con el propio prosumidor. Podemos considerar por tanto, nuestros datos como el producto básico de las plataformas de Internet, y el proceso de generación de estos datos como un proceso generador de valor, dentro de lo que podríamos definir como un actuar productivo que da lugar a un producto. La mercancía del prosumidor de Internet es un producto generado por esta mano de obra digital que es comprtido con el resto de usuarios.

La comunicación como forma de trabajo y la información como producto del trabajo humano se conforman como un proceso en el cual intervienen la cognición, la comunicación y la cooperación. Esta tarea requiere de procesos, siendo la creación de información un proceso de trabajo en si mismo, por lo cual podríamos concluir que la información tiene su propia economía, mediante la creación de comunidades y amistades que colaboran entre si.

Si nos fijamos en plataformas como Facebook, el trabajo informacional se concreta en la publicación e intercambio de mensajes, que objetivan un conocimiento subjetivo basado en lo cotidiano. Podríamos decir que es la externalización de un conocimiento cognitivo mediante el intercambio de mensajes, que conforma un intercambio simbólico mutuo de conocimiento subjetivo que alienta aun más una producción social basada en estas interacciones. Este es un paisaje de actividades cognitivas, comunicativas y cooperativas, concretado como prácticas cognitivas digitales que devienen trabajo. Se trata de la organización de experiencias objetualizadas dentro de espacios virtuales. El trabajo cooperativo digital organiza experiencias que son dadas en forma de información online, de manera que nuevas comunicaciones o respuestas son creadas en base a estas. En definitiva podríamos definir el trabajo digital como la organización de las experiencias humanas con la ayuda de los medios digitales y nuestro discurso, dando origen a nuevas creaciones en forma de relaciones sociales, información 
accesible online o nuevos significados. Los nuevos significados sobre la experiencia y el mundo son creados en el ámbito de las relaciones sociales, siendo uno de los principales valores del trabajo comunicativo.

Esto nos muestra una nueva economía inmaterial, generada en base a al potencial de coordinación e interacción social de la multitud interconectada. Estos procesos comunicativos sociales han promovido de manera inconsciente el crecimiento de pequeños proyectos emprendedores que han pasado a convertirse en gigantes empresariales con estructura corporativa. Hoy en día es prácticamente imposible intentar excluir este tipo de servicios del ámbito de nuestra vida diaria. Bien directa o indirectamente, su presencia es constante gracias a la conectividad permanente, conformándose como verdades prótesis virtuales que nos suplen o amplifican en determinadas habilidades o características.

\subsection{EL USUARIO COMO PRODUCTOR}

El estudio de la identidad en la red como producto de lo que se ha venido a denominar sociedad red ${ }^{135}$, como la nueva morfología social de nuestra sociedad, pasa sin duda por el encuentro de diferentes disciplinas que han de conformar mediante diferentes aproximaciones, generando una mirada transdisciplinar debido a que el tema de estudio en cuestión cruza la frontera entre diferentes disciplinas. El prefijo "trans" en este caso se refiere a lo que hay entre, a través y más allá de las disciplinas. Mediante esta premisa se pretende generar un conocimiento mucho más profundo del mundo actual en el cual se necesita cada vez una combinación del conocimiento mucho mayor, ante los retos que nos deparan como sociedad. Esta metodología investigadora tiene especial representación en el área de las humanidades y las artes como germen de una conciencia crítica y reconocimiento de una pluralidad de modelos, culturas y diversas realidades.

Este mismo enfoque ha sido usado desde el ámbito investigador para el estudio de la representación de la identidad por el sociólogo y teórico de los

\footnotetext{
${ }^{135}$ El termino sociedad red tiene su origen en el trabajo del sociólogo y filósofo alemán George Simmel, pero se extendió considerablemente gracias a la obra de Stein Braten, Jan Van Dijk y Manuel Castells entre otros.
} 
medios David Gaunlett. El área principal de su investigación es el estudio del comportamiento e intercambios diarios de los usuarios en la comunicación social en medios digitales. Ya en 2007 dentro de su articulo Media Studies 2.0 fue uno de los primeros en plantear el debate sobre la necesidad de cuestionar la forma tradicional de los estudios de los medios ante lo difuso de las barreras entre productores y usuarios. En su obra Creative explorations ${ }^{136}$, Gaunlett le pide a un grupo de gente recrear su identidad metafóricamente mediante piezas del famoso juego de construcción Lego, dando grandes pistas de cómo los humanos nos representamos a nosotros mismos dentro de nuestra propio relato personal para conectar con el medio social. Desde 2008 dirige el proyecto Making is connecting ${ }^{137}$, como una manera de repensar las investigaciones sobre los usuarios de los medios como productores y consumidores de material mediático. Según explica, la web 2.0 ha supuesto el paso de una cultura donde los usuarios tenían un rol pasivo a una cultura donde son los protagonistas mediante las diferentes posibilidades creativas que este medio ha desarrollado. Como apunta Gemma San Cornelio en su obra Identidad en Internet ${ }^{138}$, aquí Gaunlett dentro de su experiencia en la sociología visual hace uso de los métodos de las artes visuales debido al uso generalizado que hacemos de técnicas provenientes de este ámbito. Por otro lado la utilización de elementos autobiográficos propicia un debate sobre nuestra propia identidad. Como Gaunlett apunta en Creative Explorations, aquellos a los que llamamos artistas realizan trabajos artísticos para expresar o comunicar algo sobre sus vidas o experiencias. La obra de la artista inglesa Tracey Emin ha fascinado la imaginación del público durante décadas mediante su trabajo orientado a temas autobiográficos de carácter íntimo. Su famosa obra My Bed, de la que Gaunlett nos hace una breve descripción, nos narra un periodo de depresión representado por un test de embarazo que dio un resultado negativo, fotografías polaroid, botellas de vodka y paquetes de cigarrillos. Estas espontaneas muestras de intimidad cuidadosamente construidas en base a sus experiencias generan una especie de pugna por la propia identidad personal de la artista. Por otro lado su obra le da la oportunidad e difuminar y difundir su dolor emocional, lo que unido al reconocimiento obtenido ha supuesto una mejora paulatina en su propio bienestar personal. Este tipo de obras tienen un carácter terapéutico basado

\footnotetext{
${ }^{136}$ Gaunlett, David, Creative explorations: new approaches to identities and audiences, Routledge, New York, 2007.

${ }^{137}$ Gaunlett, David, Making is connecting, Polity Press, Cambridge, 2011.

${ }^{138}$ San Cornelio, Gemma, op. Cit., 2008, pag. 8.
} 
en la posibilidad de hacer público este tipo de material íntimo. Este tipo de narrativa o relato construido encuentra gran aceptación en el público, ya que como apunta Gaunlett, este también construye sus propias narrativas intimas generando una conexión instantánea con este tipo de obras.

Esta conexión podría ser aún mayor hoy día si tenemos en cuenta la gran difusión que alcanzan nuestros propios relatos íntimos gracias a las redes sociales, donde cada uno somos protagonistas de nuestro propio relato autoconstruido. En definitiva Gaunlett propone usar la creatividad de la gente como un medio para realizar una investigación empírica sobre la identidad. Esta autoexploración que el arte permite esta directamente conectada con nuestra vida diaria elementos artísticos que no consideramos obras de arte.

La creatividad normalmente se genera en la intersección de diferentes perspectivas o donde un paradigma realiza una conexión con un área no relacionada con anterioridad. En muchos casos la conexión entre diferentes perspectivas se realiza tan sólidamente que con el paso del tiempo no se pueden considerar como áreas ajenas. Por lo tanto este tipo de metodología se presenta como la que cruza las fronteras entre diferentes áreas del conocimiento, para realizar conexiones entre ideas o sistemas anteriormente desconectados. Lo que denominamos creatividad puede ser encontrado en la mayoría de las muestras identitarias de nuestra vida diaria. Normalmente la creatividad es asociada con el pensamiento divergente, sin embargo más bien parece que la creatividad es un concepto complejo que debe de ser estudiado mediante diferentes métodos en los que la expresión no es solo verbal, incluyendo la realización física de algo nuevo que supone una recompensa. También la necesidad de asimilar experiencias psicológicas que generan desarmonía en el individuo que puede ser paliada mediante actividades creativas. De la misma manera cuando dejamos de repetir los mismos patrones acabamos mejorando nuestro propio bienestar como individuos, jugando la creatividad un papel fundamental en este cambio de estado.

En definitiva los métodos de investigación creativa y visual dan la oportunidad de comunicar diferentes tipos de información referente a su propio autobiografía o parafraseando a Paul Ricoeur, una muestra identitaria mediada mediante la acción, y que constituyen metáforas visuales dentro de nuestra vida diaria, como herramientas dentro de la investigación social. 
Por otro lado la unicidad de la representación artística de la identidad aparece como contradictoria en base a la idea presentada por la posmodernidad sobre la fragmentación del sujeto durante los años 80 y 90 . En este punto, y como el mismo afirma, Gaunlett aparece enfrentado a la mayoría de los argumentos que hemos aportado al respecto. Sin embargo puede que confunda la representación de la identidad con la propia identidad en cuestión. Tal y como argumenta Giddens en una trayectoria vital y por lo tanto un proceso supeditada a nuestra acción. El hecho de que podamos cristalizar una imagen de nuestro propio yo en un momento determinado mediante una representación no parece implicar una unidad identitaria, sino más bien una de las múltiples imágenes especulares de nuestro propio yo generadas en base a una situación y un espacio determinado. Precisamente esto esta relacionado con uno de los temas principales de los estudios de los medios, que es la importancia del medio en cuestión, y como influye en los usuarios. Quizá como nos cuenta el antropólogo Marc Augé el futuro dependerá precisamente de cómo aprendamos a relacionarlos con los medios mediante las nuevas herramientas creativas:

"Si se les enseña a los niños a hacer películas, estarán menos alienados con la imagen, porque comprenderán que es algo que se fabrica. Hay que formarlos no como consumidores, sino como creadores. El nuevo humanismo es eso: formar a la gente para que controle los instrumentos. Formarlos para crear." 139

Precisamente este concepto de creatividad es la base de la Web 2.0, ya que pone al alcance de todos los usuarios herramientas creativas o servicios encuadrados dentro de nuestra vida diaria, generando colaboración y el intercambio de ideas. Como contraste al anterior modelo de Web 1.0 donde los usuarios generaban sus propios espacios de manera aislada, en la Web 2.0 las plataformas como las redes sociales generan espacios compartidos donde los usuarios interactúan con el contenido generado por la comunidad, dentro de un espacio custodiado por políticas que todos los usuarios deben aceptar para poder usar estos servicios gratuitos. Sin embargo, otras formas

\footnotetext{
139 Augé, Marc, Hay que amar la tecnología y saber controlarla", [en línea], 2005, La Nación, [consulta miércoles 22 de Febrero de 2017], disponible en < http://www.lanacion.com.ar/714868marc-auge-hay-que-amar-la-tecnologia-y-saber-controlarla>
} 
totalmente contrapuestas respecto a la creatividad han sido descritas como una manera de evitar la monitorización de esta. Como nos cuenta Maurizio Lazzarato en su obra Marcel Duchamp y el rechazo del trabajo140, para Duchamp el rechazo a producir trabajo artístico significaba el rechazo a producir para el mercado, quedándose en los bordes, de manera ambigua. En base a este ejemplo Lazzarato distingue entre trabajo y empleo, mostrándonos como el aumento del trabajo no implica en nuestro días remuneración de ningún tipo, aunque se pueda tratar de una tarea que interesa o gusta a quien la realiza. Se trata de una explotación generada en base a un sistema que transforma este tipo de trabajo en una expectativa de vida.

Duchamp nunca se había comprometido en ningún movimiento, practicando la huida en el más estricto sentido de la palabra. En cambio existencialmente tiene un compromiso amplio con la pereza, oponiéndose a la temporalidad de la aceleración y el productivismo capitalista que entra en el mundo de las artes. Funciona como una critica socioeconómica de la sociedad contemporánea, pero también como un categoría filosófica que nos permite volver a pensar la acción, el tiempo y la subjetividad, descubriendo nuevas dimensiones de la existencia y de la manera de vivir. Pese a ser criticado por sus contradicciones, el rechazo al trabajo es algo que aparece como el hilo conductor de su existencia, viviendo como inquilino perpetuo sin poseer nada. Según Lazzarato, ninguna generación en la historia ha consumido tanto tiempo en trabajar, solo desde que existe el capitalismo se piensa que el trabajo ocupa la totalidad de la vida. Cuanto más avanza la técnica y aumenta la posibilidad de salvar tiempo de trabajo, permanecemos aún más capturados por este mismo tiempo de trabajo, sobre todo en base a la influencia del capital en forma de tecnología y comunicación. Duchamp promueve una conversión de la subjetividad mediante otra manera de habitar el tiempo y el mundo, en forma de la práctica de la pereza. No se trataría de no hacer nada, sino más bien en una transformación de nuestra subjetividad. Para el, este sistema debía instalarse en el completo de la sociedad para tener éxito. Defiende que él capitalismo es un mecanismo que produce subjetividad, bien la del obrero o la del artista, siendo muy critico con estos últimos. Es una organización del trabajo que devora el tiempo.

\footnotetext{
${ }^{140}$ Lazzarato, Maurizio, Marcel Duchamp y el rechazo del trabajo, Casus Belli, Madrid, 2017.
} 
Por otro lado, colectivos como Hackers \& Designers utilizan el concepto de playbour para entender el trabajo inmaterial que describimos anteriormente, situándolo dentro del contexto de las redes sociales corporativas. En este caso sirve para mostrar las difusas fronteras entre el trabajo y el ocio, como por ejemplo subir fotos a Twitter, dar "me gusta" a una publicación en Facebook o monetizar un contenido online. Ya en la década de los años 70 del siglo XX, se inicio el pago de publicidad enfocada a audiencias especificas dentro de los medios, como también destaca Christian Fuchs las redes sociales se dedican a vender sus datos para producir publicidad especifica. Mediante la adaptación del trabajo de Marx a traves la acción del ser humano sobre los objetos e instrumentos de trabajo, Fuchs investiga sobre las redes sociales donde los objetos son experiencias humanas e información. Esto genera un producto que adquiere un valor de cambio, mediante un tipo de trabajo digital enajenado, que nos satisface como usuarios y genera beneficios a estas plataformas.

Los términos de servicio regulan el intercambio de datos entre los usuarios y la plataforma, lo que nos hace verlo como una suerte de contrato laboral de carácter legal. Por ejemplo, si somos usuarios de Facebook debemos mantener de manera continua datos personales que sean veraces. No hay ningún tipo de opción legal que haga posible discutir los términos y condiciones de este tipo de plataformas mediáticas. La red de usuarios que esta conectada a un servicio hace que este sea más valioso en base al tamaño de esta comunidad, haciendo inviable en muchos casos el hecho de mantenerse al margen. La ingeniería social desplegada por este tipo de aplicaciones sirve para incentivar el rendimiento económico de estos servicios, evitando comportamientos imprevisibles y por lo tanto no rentables.

Por otro lado, los perfiles de usuario que generamos en este tipo de espacios virtuales funcionan como curriculums online, posicionados en el mercado de las redes sociales, donde son procesados y transformados en datos. Pese a que el tipo de tareas que desempeñamos en este tipo de entornos puedan parecer inmateriales, hay toda una cadena de ocupaciones, que hacen posible este tipo de consumo que permanecen ocultas a los usuarios. Las líneas de montaje en las fábricas de China, o las minas a cielo abierto en el Congo son pequeños ejemplos de un sin fin de actividades que hacen posible este tipo de prácticas, pero que están alejadas y contrapuestas a las características de progreso y optimismo tecnológico que nos muestran estos espacios. 
Mediante su proyecto Inmaterial Labor Union, el colectivo Hackers \& Designers busca organizar políticamente el trabajo dentro de las redes sociales corporativas. Mediante pequeños proyectos pretenden organizar demandas, acciones y campañas. Mediante este germen pretenden plantar las bases de un movimiento obrero emancipatorio radicado en las redes sociales corporativas.

\subsection{NEUROPLASTICIDAD}

Mientras que por un lado podemos observar como el poder ha utilizado el monopolio legitimo de la violencia como herramienta de dominación, como podemos ver en las obras de Maquiavelo o Max Weber, por otro lado existen estrategias para dominar lo que ocurre en nuestras mentes a través de la persuasión, siendo los medios de comunicación el modelo más usado. Se construyen una serie de ideas que naturalizan e internalizan esta dominación, haciendo innecesario el uso de la coacción. Resulta evidente que la batalla por el dominio se juega en nuestras mentes mediante la percepción de la realidad que los medios generan. Ante la ineficiencia de torturar nuestros cuerpos tal y como nos narraba Foucault, el modelado de nuestras mentes aparece como la opción mas efectiva, ya que estas viven en un entorno mediático de comunicación. Tal y como afirma Manuel Castells "el cambio social supone una acción, individual, colectiva o ambas a la vez, que en su base, tiene un motivo emocional como todo comportamiento humano según recientes investigaciones en neurociencia social"141. Si durante la Ilustración el sujeto racional tenia su base en la ciencia como homus economicus, el neurólogo Antonio Damasio apuesta por una corrección sobre la máxima de Descartes "pienso luego existo" a favor de una nueva versión generada en base a sus investigaciones y que el formaliza como "siento luego existo". Esto queda reflejado dentro de su obra El error de Descartes ${ }^{142}$, donde se plasma con claridad como nos movemos principalmente por emociones y no en base a la racionalidad. Más bien buscamos la confirmación de lo que sentimos y queremos que suceda.

\footnotetext{
${ }^{141}$ Castells, Manuel, Redes de indignación y esperanza. Los movimientos sociales en la era de Internet, Alianza Editorial, Madrid, 2012, p. 210.

${ }^{142}$ Damasio, Antonio, El error de Descartes, Editorial Andrés Bello, Chile, 1996.
} 
De la misma manera que algunos peces de colores cambian su coloración en base a sus emociones o actividad social, la existencia de determinadas relaciones jerárquicas genera una determinada regulación emocional que se relaciona con determinados tipos de mecanismos de plasticidad neuronal, generados mediante la reconfiguración de la morfología de nuestro cerebro. Por lo tanto los cambios en nuestro contexto social pueden producir transformaciones en la estructura de nuestras neuronas. La neuroplasticidad o plasticidad psinaptica, es una propiedad relacionada con el funcionamiento de las neuronas de nuestro cerebro y la manera mediante la cual estas se comunican. Delimita la manera en la cual los estímulos que recibimos son modulados, modificando la eficacia mediante la cual la información es transferida, condicionando elementos que conforman nuestra cosmovisión y por lo tanto la visión que tenemos del mundo que nos rodea. Se trata de la capacidad que tienen nuestros cerebros de generar nuevas redes neuronales en base a nuestras experiencias, siendo un modelado que se realiza en base al aprendizaje. Esta actividad genera nuevas redes neuronales que se conformar y refuerzan en base a una actividad, siendo un proceso que puede continuar durante nuestra vida y que delimita la memoria y el aprendizaje.

El teórico italiano Mauricio Lazzarato reflexionó sobre el paso de las sociedades disciplinarias a las sociedades de $\operatorname{control}^{143}$, y como estas han dado paso a un tipo de sociedad que el denomina noo-política, donde el epicentro del poder político y la tecnología se focaliza en aspectos psíquicos, como los recuerdos y la atención. Sin embargo podemos afirmar que cuerpo y mente se encuentran inexorablemente ligadas. Uno de los principales aspectos de lo que el denomina noo-política es como las nuevas condiciones laborales de la época posfordista darán como resultado nuevas condiciones en lo que se refiere a nuestro cerebro y nuestra mente. Estamos hablando de un tipo de cambio paradigmático generado dentro la propia estructura de nuestro cerebro en base a esta reconfiguración de nuestra actividad laboral y comunicativa, poniendo de manifiesto la manera en la cual somos masajeados por los medios conformados como entorno. Estamos ante un paradigma que ha pasado de controlar el ser presente, a dominar el ser venidero mediante el modelado de nuestra subjetividad.

\footnotetext{
${ }^{143}$ Lazzarato, Maurizio, Life and the Living in the Societies of Control, en Deleuze and the Social, Edinburgh University Press, Edimburgo, 2006, p. 186.
} 
Las actividades relacionadas con el trabajo se han desarrollado en los últimos decenios como una forma de plasticidad cultural que da como resultado nuevos tipos de subjetividad. Por otro lado, la sociedad de la información se ha conformado como parte de una estrategia global de administración de la atención, donde los productos culturales han escapado de la mano de sus creadores debido a la velocidad de los flujos de información. Como nos cuenta Franco "Bifo" Berardi en su obra Fenomenología del Fin, Sensibilidad y Mutación Conectiva ${ }^{144}$, el ritmo de la vida se encuentra perturbado por una extrema sensación de aceleración que fragmenta nuestras experiencias y percepciones sensoriales dando como resultado una disonancia y desequilibrio temporal.

Según Berardi, el general intellect esta desconectado de su cuerpo ante esta aceleración, reconfigurando nuestro cerebro. Recogiendo las investigaciones de la filosofa francesa Catherine Malabou, Berardi nos muestra como las condiciones externas producen cambios con implicaciones psíquicas, en base a los traumas y las transformaciones neurológicas. Esto ha puesto de manifiesto lo necesario de integrar neurología y psicoanálisis con la finalidad de entender enfermedades como el párkinson o el alzhéimer. Del mismo modo nos encontramos especialmente hiperestimulados por la mutación conectiva producida en base al desarrollo de las tecnologías de la comunicación y la información. Es aquí donde la neuroplasticidad puede ser clave a la hora de responder a como nuestras neuronas se han adaptado a este tipo de mutación conectiva que aún sigue en proceso ante el constante cambio ambiental en lo que a los mass media se refiere. Como individuos no solo nos conformamos en base a nuestra herencia genética sino que los factores ambientales conforman el organismo en la misma medida. Por lo tanto la plasticidad hace que por un lado estemos atados a una forma predefinida en base a nuestro ADN, pero también podamos adaptarnos al mundo que no rodea. El cambio paradigmático que estamos viviendo podría ser considerado como una mutación que invade los procesos cognitivos en base a la relación de nuestra actividad mental con la actividad de los mass media y tecnologías de la información. Estamos en un momento en el cual estamos empezando a descubrir el mundo a través de las máquinas de manera que incluso el lenguaje es adquirido a través de ellas, y no mediante el vinculo tradicional

\footnotetext{
${ }^{144}$ Berardi, Franco "Bifo", Fenomenología del Fin, Sensibilidad y Mutación Conectiva, Caja Negra Editora, Buenos Aires, 2017, p. 253.
} 
con la madre. Para Berardi, los procesos de precarización laboral tienen su origen en la esfera psicológica y cognitiva, ya que mediante el debilitamiento del lenguaje se genera un deterioro de la condición cognitiva y emocional.

Por otro lado, la atmosfera comunicativa de conexión constante en la cual estamos envueltos esta afectando de igual manera a la atención, debilitando nuestra capacidad de concentración y por lo tanto la capacidad mental humana para elaborar la experiencia. Esto a su vez afecta de igual manera a la memoria, mediante el uso de la tecnología como depositario de todo tipo de recuerdos, información y datos, a los cuales accedemos mediante procedimientos sencillos. Esta uniformidad de la memoria afecta a la manera mediante la cual concebimos ideas, con lo cual se esta generando una automatización de la memoria colectiva que afecta a la imaginación. Por último podemos observar como el cambio de una información secuencial a flujos de información acelerada, han incrementado la dificultad de generar una interpretación crítica, deviniendo en mitológica, tal y como predijo Marshall McLuhan, siendo este el modo predominante de elaboración mental ${ }^{145}$.

Como el mismo Berardi admite146, las transformaciones continuas que estamos viviendo en base a la globalización están cambiando los procesos socioculturales de tal manera que las herramientas herederas de la teoría crítica europea son insuficientes para imaginar lo que nos depara en el siguiente escalón de esta evolución. El ser humano como especie reconfigura el medio que a la vez esta reconfigurando su cerebro, siendo la infoesfera el ámbito en el cual se perpetra el modelado de nuestra mente. Podemos afirmar que el papel preponderante de la política como elemento que pretende cambiar nuestro comportamiento como colectividad esta siendo sustituido por tecnologías que transforman nuestro cerebro en base a sus cualidades plásticas. Dentro del capitalismo cognitivo, las actividades mentales están íntimamente conectadas con los flujos de información, conformados como una máquina cognitiva.

\footnotetext{
${ }^{145}$ McLuhan, Marshall, op. Cit., 1996, p. 46.

${ }^{146}$ Berardi, Franco “Bifo", Op. cit., 2017, p. 263.
} 
Como afirma Berardi, mientras el estructuralismo achacaba la evolución del sujeto a factores internos, el posestructuralismo apuesta por un modelo de evolución social que es modificado debido a factores externos que estarían ubicados dentro del ámbito de la subjetividad. Como podemos ver en el texto Maquina y estructura ${ }^{147}$ de Félix Guattari, la maquina es un elemento externo que cambia nuestro paisaje y el marco en el cual se localiza el sujeto, mutando su morfología. Por lo tanto, estamos hablando de un factor de desterritorialización que da como resultado la creación de nuevas formas. El sujeto estructurado es cambiado por un proceso de subjetivación basado en la acción de las máquinas.

Como parte de sus investigaciones Franco "Bifo" Berardi se interroga sobre los aspectos subjetivos del devenir social, asociándolo a un devenir permanente de la composición psicocultural de las formas colectivas de la mente, el alma y el inconsciente. Berardi define a los movimientos filosóficos desarrollados a partir de 1968 en Francia y Italia como "composicionismo", al rastrear los procesos de subjetivación a través de la identificación del cambio continuo de la vida social, generado por diferentes factores, como los movimientos culturales, la economía, así como factores psicológicos o mitológicos. Utiliza el término "espasmo caósmico" para definir los efectos de "la violenta penetración de la explotación capitalista en las esferas de las tecnologías de la información, que actúan sobre la cognición, la sensibilidad y el propio inconsciente" 148 .

La transición vivida por parte del cuerpo social desde el capitalismo industrial hacia un tipo de capitalismo en el cual la producción ya no es esencialmente material, ha terminado por invadir los procesos de subjetivación. Por lo tanto, pese a lo ambiguo del concepto de neuroplasticidad, implica una adaptación a los constantes cambios de la tecnología y del capitalismo actual, como resultado del sometimiento de nuestra mente a los objetivos económicos del trabajo cognitivo. Por lo tanto estamos hablando de un reajuste de nuestro cerebro en base a un entorno que cambia constantemente y que detectamos como caos. En este sentido, una de nuestras principales misiones debe ser volver a tener control sobre la configuración y mutación de nuestra mente.

\footnotetext{
${ }^{147}$ Guattari, Félix, Psicoanálisis y transversalidad, Ediciones Siglo XXI, Buenos Aires, 1995, p. 274.

${ }^{148}$ Berardi, Franco “Bifo”, Op. cit., 2017, p. 270.
} 
4. IDENTIDAD Y SUBJETIVIDAD EN RELACIÓN A INTERNET 


\subsection{DEL SER AL ACTUAR}

El difuso concepto de identidad alude por definición a lo inalterable de las características de uno mismo con respecto a otro, por lo tanto alude a algo idéntico. Cometemos el error de llamar identidad a lo que algo es en si mismo, como cualidad absoluta y eterna, o por otro lado a unas cuantas diferencias con los demás. Este enfoque pasa por alto el permanente estado de proceso en el cual nos encontramos. Podemos afirmar que la invariabilidad es algo temporal, tomamos erróneamente lo provisional por algo definitivo, por lo que podemos concluir que venimos de algo diferente que se dirige hacia algo inevitablemente distinto.

La tradición occidental de la filosofía, conceptualizó tradicionalmente la idea de la unidad y la identidad como algo indisoluble, como podemos ver ya en los primeros escritos presocráticos, como Él Poema de Parménides ${ }^{149}$, el cual nos muestra una idea del ser como concepto abstracto, este aparece como uno, inmóvil y eterno. Este pensamiento que conceptualiza lo real como uno e idéntico fue incorporado al pensamiento cristiano medieval y más tarde al pensamiento moderno, por lo que podemos decir que siempre ha formado parte del pensamiento canónico de occidente y de esa raíz cultural que nos impide asumir como positivos los valores de la diferencia, la pluralidad y el mestizaje. Finalmente será Friedrich Nietzsche quien sostenga que la idea del sujeto desarrollada por occidente, mediante el platonismo cristiano, no es más que una ficción basada en creencias que por ser imprescindibles resultan necesariamente falsas. Estas ideas se han materializado en una unidad irreal debido a la gran cantidad de estados de nuestra interioridad. Para el este yo es múltiple debido a la jerarquización interna de unas fuerzas que mandan y otras que obedecen ${ }^{150}$. En su obra Identidad y Diferencia, Martin Heidegger revisa los planteamientos de Parménides y Platón y pone en cuestión el lenguaje del ser, planteando la metafísica como la herramienta que articuló el olvido del ser y la diferencia, y por lo tanto el predominio de la identidad como concepto único e inmutable.

\footnotetext{
${ }^{149}$ Gómez, Alfonso, El poema de Parménides, Editorial Universitaria, 2006.

${ }^{150}$ Nietzsche, Friedrich, La voluntad de poder, Editorial EDAF, Madrid, 2000, p. 341.
} 
Desde los inicios del Internet comercial, allá por los años 90 del siglo XX, se conceptualizo esta red interconectada desde el ámbito artístico como el recipiente perfecto para todo tipo de investigaciones y ensayos mediante los cuales trascender el antiguo concepto platónico del ser, el cual como veremos dará paso a un yo descentralizado, múltiple y generado en base al actuar, la interacción con el otro y que tendrá como seña de identidad la fluidez y la provisionalidad características del tipo de comunicaciones.

Sin embargo, para comprender la noción actual de identidad se hace imprescindible retrotraernos a el psicoanálisis, y en especial a sus continuadores dentro del estructuralismo y la filosofía deconstructiva, ya que como veremos esto ha sido clave para la comprensión de un sujeto que ya no esta situado en el centro sino que aparece como un elemento descentralizado y fragmentado. Sigmund Freud desarrolla dentro de su investigación sobre el psicoanálisis una nueva perspectiva sobre la conceptualización del ser humano que supondrá un salto cualitativo dentro de este ámbito, proponiendo el inconsciente como la fuente de todas nuestras motivaciones, así como una estructura de nuestra mente compuesta por el Ello, el Yo y el Superyó. Estos nuevos conceptos generan una ruptura con la concepción anterior de un yo unitario para pasar a proponer uno compuesto por diferentes partes que generan nuestra personalidad y comportamiento de manera coherente. Posteriormente fue el psiquiatra estructuralista Jacques Lacan quien basándose en la teorías de Freud y reinterpretando estos conceptos aporta diferentes elementos provenientes del estructuralismo. Por otro lado su interés por la lingüística parte de los conceptos tomados de Ferdinand de Saussure en especial su Curso de Lingüística General. Mediante su conocida máxima que afirmaba que "el inconsciente estaba estructurado como un lenguaje" proponiendo una vuelta a la concepción del inconsciente propuesta por Freud. El estadio del espejo ha sido siempre reconocido como un punto clave en la investigación de Lacan. Según este concepto la constitución del yo se realiza gracias al reconocimiento del individuo como tal en su imagen en el espejo en base a la existencia del otro, desmontando lo que vino a denominar el espejismo del yo autónomo. Lacan fue también muy claro a la hora de asumir que el yo era algo que quedaba constituido dentro del espacio del otro mediante el vínculo social. En el espacio virtual más allá del espejo se crea una imagen especular, y es aquí donde el bebé como sujeto reconoce la imagen como su ego. 
Michel Foucault151 el genero aparece como la consecuencia de la acción de la historia sobre la sociedad, dejando a la acción humana el papel de moldeador de la identidad y al genero como un producto de esta acción, tal y como nos apunta Judith Butler en su obra El genero en disputa ${ }^{152}$, presentando el cuerpo sexuado como construcciones que vienen determinadas por los discursos desarrollados desde el poder definiendo por lo tanto una sexualidad normativizada.

Todas estos conceptos psicoanalíticos tuvieron un especial eco en los teóricos de la posmodernidad de los años 80 del siglo XX, sustentando la idea de la fragmentación del sujeto donde este es indisociable de la descripción de la adquisición de la unidad del cuerpo. Kenneth J. Gergen ilustra este paradigma identitario mediante el termino "multifrenia" acuñado en su obra de $1991 \mathrm{El}$ yo saturado: dilemas de la identidad en el mundo contemporáneo. Este termino alude tal y como Gergen nos dice: "la escisión del individuo en una multiplicidad de investiduras de su yo. Este estado es resultado de la colonización del yo y de los afanes de este por sacar partido de las posibilidades que le ofrecen las tecnologías de la relación".153 Gergen afirma que son los avances tecnológicos los que han provocado a lo largo de todo el siglo pasado un cambio considerable en la manera en la cual nos presentamos ante los demás, en base a la gran cantidad de estímulos sociales a los que estamos expuestos. Para el este factor tecnológico es fundamental para entender todo este cambio paradigmático que otros atribuían a la posmodernidad.

Gergen enmarca en su totalidad el propio lenguaje del yo individual dentro de las relaciones que desarrollamos dentro de lo cotidiano. Para el, esta multiplicidad de relaciones actúan como un elemento saturador, impulsándonos a desempeñar una gran numero de roles. Acuñó el termino "personalidad pastiche" para referirse a una especie de camuflaje social que se nutre de diferentes retazos de identidad de diferentes tipos quedando el éxito

\footnotetext{
${ }^{151}$ Foucault, Michel, La voluntad de saber, Siglo XXI, Madrid, 2009.

152 Butler, Judith, El género en disputa. El feminismo y la subversión de la identidad, Paidos, Barcelona, 2007, pag. 55.

${ }^{153}$ Gergen, Kenneth J., El yo saturado: dilemas de la identidad en el mundo contemporáneo, Paidos, Barcelona, 2006, pag. 113.
} 
social establecido en el uso adecuado de su propia identidad. El termino pastiche tiene su origen en la palabra italiana "pasticcio", y se usaba para denominar a un tipo de opera compuesta de trabajos de diferentes artistas que no necesariamente han tenido que trabajar juntos. También podía tratarse de la adaptación de un trabajo ya existente. Esta noción fue ampliamente reelaborada por el crítico de arte y teórico literario estadounidense Fredric Jameson en su obra La Posmodernidad o la lógica cultural del capitalismo tardío ${ }^{154}$. Este atribuye la aparición del mismo a la desaparición del sujeto individual, que a modo de parodia parece ser la imitación de una mascara compuesta por estilos muertos, que aglutinan multitud de discursos contenidos dentro de la cultura global.

La obra de Cindy Sherman podría ser considera, como el propio Gergen apunta, un claro ejemplo de la mutabilidad de un yo, que como afirmaría Judith Butler, parece constituirse performativamente mediante la construcción de nuestra identidad concreta, que puede ser articulada dentro de los discursos hegemónicos. Sherman representa un gran numero de estereotipos que han sido elaborados alrededor de la noción de mujer mediante los medios de masas, para ello, pese a ser fotógrafa, cambia su posición situándose frente a la cámara. Mediante el conjunto de su obra percibimos un claro cuestionamiento de la noción de una identidad inmutable adoptando performativamente un sinnúmero de roles, y por lo tanto, apostando por una concepción de la identidad como hecho construido socialmente también dentro de la esfera mediática. En su obra Centerfolds la artista apuesta por generar un pastiche que es sin duda un cuestionamiento a la noción de original mediante personificaciones escenificadas, las cuales nos hacen pensar en una frustrada imagen estable de la identidad basada en los discursos hegemónicos y por lo tanto en una visión descentralizada y performativa de la identidad.

Continuando este recorrido Paul Ricoeur nos hablará de un tipo de identidad que no esta constituida a priori y que se desarrolla por medio de un proceso, siendo dinámica y móvil. En su obra Si mismo como otro, realiza un estudio sobre la relación entre identidad y alteridad. Centra su atención sobre las

154 Jameson, Fredric. El posmodernismo o la lógica cultural del capitalismo avanzado, Paidos, Buenos Aires 1991, pag. 35. 
pistas que Nietzsche nos dejó sobre la multiplicidad del sujeto planteándose esta cuestión como hipótesis. Una de las aportaciones más importantes de Ricoeur es el concepto de "identidad narrativa" que hace referencia al tipo de identidad a la que el ser humano tiene acceso gracias a la mediación de la función narrativa, y que Ricoeur desarrolla en el tercer volumen de Tiempo y narración ${ }^{155}$. Este es un tipo de identidad que se construye a través del proceso, al encontrarnos entrecruzados en la narración de diferentes relatos pasados y presentes. Por lo tanto podríamos decir que somos una autocreación construida a partir de los relatos históricos y de ficción que se aglomeran en torno a la historia de una vida. Nuestra identidad queda supeditada a la función narrativa, la misma que supeditaba el genero y la sexualidad en base a los discursos hegemónicos tal y como afirmaba Butler. Ricoeur encuentra esta identidad narrativa en el concepto de acción del cual la narración nace, acercándolo al concepto aristotélico de praxis y por lo tanto igualando los conceptos de acción narrada con el de actuar. Toma este concepto de identidad dinámica del modelo trágico de Aristóteles en su Poética. En cambio considera que la novela y el teatro contemporáneos se han convertido en laboratorios en los cuales elaborar experiencias mediante las cuales la identidad narrativa del propio personaje se somete a infinidad de variaciones. La propia apropiación que el público lleva a acabo sobre la identidad del personaje ficticio lo convierte en una interpretación de si mismo, en una figura o yo figurado. Es mediante esta identificación que se generan variaciones de este.

Este tipo de apropiación podemos encontrarla en la obra de la artista francesa Sophie Calle, caracterizada por recurrir a aspectos de su vida personal desde una perspectiva única y compleja. Su obra aparece plagada de referencias relacionadas con la narración, que apunta a una reflexión sobre el concepto de identidad. Realiza un acercamiento al arte similar al de Marcell Duchamp al usar elementos del mundo que la rodea, generando la coexistencia de la ficción y la realidad dentro de una visión posmoderna de la identidad. Utiliza su obra para disolver las fronteras entre ficción, hechos reales y arte, generando preguntas sobre los enfoques artísticos de conceptos como verdad y autenticidad. Mediante este cuestionamiento de categorías como el arte y la vida, enlaza con ideas desarrolladas durante todo el siglo XX por otros artistas tales como Allan Kaprow mediante su concepto de happening, Duchamp

\footnotetext{
${ }^{155}$ Ricoeur, Paul, Tiempo y narración III. El tiempo narrado, Siglo XXI Ediciones, Mexico D.F., 2009.
} 
mediante el ready made o Joseph Beauys mediante la máxima "Todo ser humano es un artista"156.

De esta relación arte vida podemos deducir que surgió su obra de 1981 l'hôtel. Sophie Calle pasó tres semanas trabajando como camarera en un hotel en Venecia. Esto le permitió espiar a los invitados de la misma manera que un detective decidiendo fotografiar las habitaciones de hotel cuando están vacías momentáneamente, realizando fotografías de algunos de sus objetos personales, apropiándose de fotografías de los huéspedes e incluso leyendo su correspondencia. Mediante esta obra implica al propio espectador dentro de sus actividades voyeuristas al introducirlo en la propia privacidad del otro, mediante un relato que la artista crea a partir de los objetos y textos que muestra, pero que esta basado en el propio relato que los huéspedes realizan de si mismos mediante su propia habitación y los objetos dispuestos en ella. Por lo tanto podríamos hablar tal y como nos dice Ricoeur de una muestra identitaria que esta supeditada a la narración que generan estos retazos de información en forma de objetos y textos y la relectura de esta narración que la artista realiza.

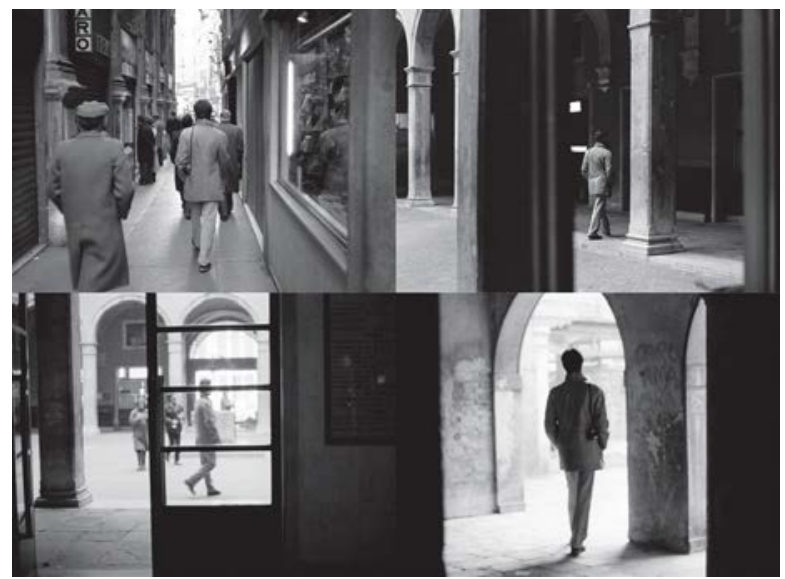

Figura 17. Sophie Calle, Suite Venitienne, 1980.

\footnotetext{
${ }^{156}$ Beuys, Joseph, Bodenmann-Ritter, Clara, Joseph Beuys: cada hombre, un artista: conversaciones en Documenta 5-1972, Editorial Visor, Madrid, 1995.
} 
En su obra Suite Venitienne de 1980, Calle sigue a un hombre desde Paris a Venecia, continuando su persecución por las calles de esta ciudad, donde pasó dos semanas registrando sus movimientos. El resultado de este recorrido furtivo fue recogido mediante fotografías, mapas y textos hablados y escritos, y mostrado al público en una exposición y una publicación en 1980. En este caso podríamos decir que la historia es lo que se representa en esta narración y el discurso es el cómo. En su trabajo, Calle subvierte esta dicotomía ocultando el discurso como una historia. El estilo que utiliza fija la atención del espectador en el contenido de las narraciones más que en su forma, lo cual podemos encontrar en la mayoría de su obra fotográfica. Esto viene a resaltar la importancia de la narración y la relectura que la artista hace de estos hechos dentro de la formación de una narración. Podríamos decir que la narración es generada por el otro y construida en base a su punto de vista mediante el relato. Esta relación entre el otro y nuestra propia narración guarda una especial conexión con las antes citadas teorías de Jacques Lacan, y es especial con el concepto de "estadio del espejo", donde el otro es quien otorga la posibilidad de reconocer nuestra propia imagen especular.

Entre las colaboraciones más destacadas de la artista francesa están las desarrolladas dentro del mundo de la literatura, y en especial con el escritor Paul Auster, el cual se apropió de diversos episodios de la vida de la artista para ensamblar el personaje de María en Leviatán. Esta colaboración continuó cuando Calle le pide a Auster que escribiera un personaje el cual ella se esforzaría por encarnar. Este le envió su Personal Instructions for SC on How to Improve Life in New York City. En cierta medida este texto simboliza la dialéctica del arte y la vida, es el resultado de una petición formulada de un individuo a otro. Ella eligió el lugar de una cabina telefónica de Nueva York para realizar acciones simples. Sin embargo, todos los acontecimientos antes mencionados, que son gestos arquetípicos y cotidianos, son tratados como un proyecto artístico y plenamente documentados en un libro de artista titulado Gotham Handbook. Aquí podemos ver como nuevamente, el propio personaje que Calle pide a Auster que realice, es el que actúa como el relato que Calle debe interpretar en base a la narrativa del autor, pero también poniendo en juego elementos tan interesantes como la performatividad del personaje en base a una realidad concreta mediante su praxis. 
De esta coexistencia entre realidad y ficción se desprende un claro conocimiento de nociones contemporáneas de autoría e identidad, las cuales son utilizadas por Calle para construir de manera exitosa la mitología en torno a su figura como artista. En esta los juegos identitarios y el relato forman una pieza fundamental. Podríamos decir que ha hecho que la narración sea el material de su propia obra, dejando que la figura del autor sea construida por el espectador, tal y como nos apuntaba Ricoeur, dentro de una multiplicidad de identidades ubicadas dentro de diferentes medios y contextos y que la artista usa para repensar este propio concepto.

Este desarrollo tecnológico nos permite vivir en un espacio y un tiempo que trascienden los límites tradicionales, tal y como ya nos augura Paul Virilio en Estética de la Desaparición, lo cual también ha producido una descontextualización de las relaciones sociales. Según el sociólogo inglés Anthony Giddens, las transformaciones en la identidad el yo y la mundialización son los dos polos del dialogo existente entre lo local y lo global, lo que viene a traducirse en la creación de vínculos sociales de alcance muy amplio dentro de la vida personal de los individuos, relacionando yo y sociedad dentro de un medio mundial. El yo por lo tanto queda constituido como un proyecto reflejo explorado y construido como parte de un proceso. El yo realiza una trayectoria de desarrollo del pasado a un futuro previsto.

La reflexividad del yo es continua y generalizada, lo que produce un autoanálisis introspectivo en los individuos. El individualismo se ha movido a la esfera del consumo generando una libertad de elección dirigida por el mercado, que ha pasado a ser una vía de expresión del propio yo. Este consumo ha pasado a sustituir el desarrollo del yo, en una suerte de autoconstrucción mediante la utilización de los símbolos que la propia sociedad de consumo produce en base a las condiciones de nuestra vida diaria, mostrando diferentes estilos de vida a los que emular.

En vista a lo anteriormente citado, podemos afirmar que una persona no es un conjunto fijo de atributos, y que somos construidos parcialmente mediante la interacción con otros. Esto ha adquirido mayor relevancia en la contemporaneidad mediante la posibilidad de construir una identidad personal, que por lo tanto nos describa y genere una narrativa de nosotros mismos, tal y como Giddens nos narra en su libro Modernidad e Identidad del 
Yo: "La identidad de una persona no se ha de encontrar en el comportamiento ni -por mas importante que ella sea- en las reacciones de los demás, sino en la capacidad para llevar adelante una crónica particular".157 Para Giddens está claro que la identidad del yo, como fenómeno coherente, presupone una crónica, lo cual se refleja en la creación de muestras autobiográficas que generan una sensación de un yo integrado. Estas autobiografías, según nos cuenta, se sitúan en la actualidad como el centro de la identidad del yo en la vida social moderna, y como podemos contemplar en la actualidad a través de las redes sociales.

Los mass media y las redes de comunicaciones son el epicentro de esta experiencia mediada que ha influido de manera determinante en la organización básica de las relaciones sociales. Sin embargo, Giddens también apunta hacia efectos sobre el yo no solo fragmentadores, sino que unifican debido al acceso que también tenemos a diferentes posicionamientos que pueden resultar más unificadores que una experiencia mucho más cercana. Por lo tanto no sería acertado creer que una diversidad de circunstancias generan siempre una fragmentación del yo, ya que estas circunstancias pueden de hecho resultar unificadores dependiendo de la manera en la cual las integremos dentro de nuestro propio yo. Lo que hacemos es integrar elementos de diferentes ámbitos en una crónica personal coherente.

\subsection{TEXTO, FICCIÓN E IDENTIDAD}

Si tenemos en cuenta los términos utilizados para designarnos a nosotros mismos como otro dentro del mundo de lo ficticio, nos encontramos con conceptos como el alias, procedente del latín y que tiene su origen en la frase latina "alia nomine cognitu" la cual significa literalmente "conocido por otro nombre". El concepto de seudónimo nos remite a la forma griega conformada por pseudo $(\psi \varepsilon v \delta \omega ́)$ y neimos ( $v v \mu o \varsigma)$ que significa "falso nombre". Por otro lado el "alter ego", literalmente "el otro yo", aparece como ese otro personaje que nace desgajado de nuestra personalidad principal, y que ha sido asociado al trastorno de identidad disociativo, que antes era conocido como personalidad múltiple. Nuestra idea sobre estos trastornos ha sido ampliamente influenciada por el cine, la televisión y la literatura. Por otro lado, en la red el nickname o Nick, es usado como un nombre inventado o para

157 Giddens, Anthony, Modernidad e Identidad del Yo, Península, Barcelona, 1997, pag. 74. 
abreviar uno demasiado largo, sin embargo también podría ser interpretado como un alias o apodo valido en nuestra vida en la red mediante lo que se denomina nombre de usuario, relacionado con el nombre de inicio de sesión de las diferentes aplicaciones que usamos a diario.

De este juego entre falsos nombres y nombres auxiliares han surgido toda una larga lista de construcciones identitarias ficticias, que como veremos, cumplen bajo diferentes términos y clasificaciones diferentes roles dentro de la manera en la cual nos representamos frente a los demás. Durante toda la historia humana este tipo de nombres han sido usados por diferentes motivos. Como podemos ver en el área de la literatura, las artes plásticas y más recientemente el mundo de las celebridades y la cultura popular, esto se ha convertido en algo muy común, debido a la necesidad de encontrar un nombre alternativo, que en muchos casos representa ese otro yo alejado de nosotros mismos, pero que también destaca entre la multitud por su propia fisionomía y significado.

El entorno investigador e universitario fue el lugar donde aparecieron los primeros programas para ordenadores conectados en red y posteriormente simuladores en línea de las primeras salas de chat. Esto generó por tanto uno de los entornos en los cuales se desarrollaron los primeros pseudónimos online, y por lo tanto identidades basadas en el texto, como algo inherente a los comienzos de este medio. Se considera el sistema Talkomatik ejecutado en PLATO el origen de la primera comunidad online de la historia, a lo que hay que incluir más adelante los servicios de mensajería instantánea, los foros de discusión y los juegos multijugador. Fue creado por Doug Brown y David R. Wooley en 1973 en la universidad de Illinois. Este mismo sistema fue reeditado en su versión web en 2014. Mediante este sistema se podían crear multitud de salas con un máximo de 5 usuarios. Más adelante ya en 1980 apareció el CompuServe CB Simulator el primer chat en línea de acceso público. Estas salas tenían un carácter sincrónico, es decir, los usuarios debían conectarse al mismo tiempo para tener una conversación dentro de este espacio. De las misma manera, los Bulletin Board System y Usenet se hicieron populares durante los años 80 y 90 como sistema global de discusión en Internet de carácter asincrónico. Los usuarios podían enviar o leer mensajes en diferentes grupos de noticias mediante servidores distribuidos por todo el planeta que eran usados para transmitir y guardar los mensajes. 
El sistema de World Wide Web ${ }^{158}$ de distribución de documentos de hipertexto mediante un navegador web para visualización de sitios web, y la construcción de estos por medio de texto, video, imágenes e hiperenlaces, provocó un cambio paradigmático tanto en la manera en la cual los usuarios accedían a Internet como en la accesibilidad de las herramientas gráficas utilizadas para ello. Todos estos cambios trajeron un publico mucho más variado y que no estaba ligado a los sectores científicos, académicos, gubernamentales, simplemente de amantes de la informática o miembros de la cultura hacker de la época.

Los MUD o "Multiuser Dungeon", fueron unos espacios basados en las aventuras de Dungeon \& Dragons en un principio solo de carácter textual. Se trataba pues de una realidad virtual que desarrollaba una historia con la que el usuario podía interactuar mediante ordenes escritas. Los primeros MUD fueron creados en los años 70 por lo cual aun no contaban con un interfaz gráfico, la posterior evolución de estos entornos durante los años 90 produjo la aparición de los MMORPG y los metaversos. Tal y como Sherry Turkle nos cuenta en La vida en la pantalla, los MUD basados en texto están en contacto con un sin fin de técnicas narrativas y artísticas:

"Además, los MUD basados en texto son una nueva forma de literatura escrita en colaboración. Los jugadores de MUD son autores de MUD, y son creadores además de consumidores de contenido mediático. En este sentido, participar en un MUD tiene mucho en común con la escritura de guiones, el arte de la actuación, el teatro de calle, el teatro improvisado". ${ }^{159}$

EL termino ingles "dungeon" o mazmorra por su voz en castellano aún hoy día sigue siendo usado dentro de los juegos masivos multijugador para referirse a un espacio virtual en el que se desarrolla un tipo de socialización necesaria para alcanzar el objetivo común del juego. En el caso de los MUD debemos

\footnotetext{
158 No hay que confundir WorldWideWeb (todo junto) como el nombre del primer navegador, con el de World Wide Web (separado) que se refiere a la red informática mundial de distribución de documentos de hipertexto.

159 Turkle, Sherry, La vida en la pantalla: la construcción de la identidad en la era de Internet, Editorial Paidos, Barcelona, 1997, pag. 18.
} 
referirnos a un tipo de realidad virtual social basada en el texto. La construcción de diferentes objetos es una actividad que mezcla la escritura de códigos de programación y textos de ficción. Todos estos espacios están organizados alrededor de la metáfora de un espacio físico, y desarrollados mediante la acción que los usuarios desarrollan durante el juego. De hecho el juego siempre ha sido uno de los aspectos más importantes en el proceso de construcción de una identidad. Como nos cuenta Turkle, estos espacios se han convertido en lugares en los cuales descubrir quienes somos y quienes deseamos ser, son laboratorios de construcción de la identidad mediante la libertad, que como hemos visto el anonimato otorga. Desde sus primeras encarnaciones estos espacios han sido reconocidos como espacios en los cuales desarrollar aspectos estrechamente conectados con las ideas propugnadas con la posmodernidad, tales como la diferencia, la heterogeneidad, la fragmentación y la multiplicidad, lo que directamente contradice la concepción clásica en torno a la identidad. También la idea de autenticidad asociada a la creación queda subvertida al tratarse de creaciones colectivas y fluidas donde cada jugador puede optar por construir una innumerable cantidad de personajes que en cierto modo reflejan anhelos y pueden ser el catalizador que nos haga detectar aspectos desconocidos de nuestra vida real. Por otro lado extiende el periodo de experimentación que la adolescencia conlleva, en cambio, el cambio de genero es visto por Turkle como una autorreflexión sobre el propio yo.

Por otro lado según nos cuenta, los jugadores no solo son autores sino que también generan nuevas identidades mediante la interacción social. Es por ello que estos espacios se presentaron como el escenario perfecto donde generar interacción anónima mediante la cual ensayar o crear nuevas identidades de carácter ficticio o no, explorando aspectos nuevos o ocultos del propio yo. Este tipo de espacio genera un sinnúmero de identidades múltiples y fluidas que según Turkle ponen en tensión los límites de este concepto. El concepto de ventana ha hecho posible la interacción simultanea en diferentes MUD y por lo tanto la propia experimentación de una gran multiplicidad de personalidades al mismo tiempo

El "codework" parece haber sido una mezcla de los escritos del poeta Alan Sondheim con formas de código informático. Este tipo de lenguaje también parece haber influenciado los primeros trabajos del dúo artístico Jodi. Este estilo literario propio de la red ha sido usado para el desarrollo de diferentes 
obras de poesía y ficción. Sondheim entre otros han manifestado que la intención política del "codework" esta relacionada con subjetividad del genero, la identidad y el cuerpo. Nos lleva al tema de la libertad de genero y la teorización del texto como carne, cuestionando las fronteras entre texto y discurso, y código y texto. En 1994 la artista y poetisa Mez Breeze desarrolló su propio idioma al que llamó Mezangelle. Su lenguaje poético ha aparecido a lo largo de Internet durante los últimas decadas mediante diferentes pseudónimos y avatares. Para el desarrollo de este lenguaje se valió de la lengua inglesa, el ASCII Art, código de programación, emoticonos, abreviaturas del IRC, fragmentos de código de protocolos y argot de Internet, entre otras fuentes. Usó diferentes capas de significado semántico y sintáctico para alcanzar una estética basada en la fluidez de las comunicaciones en la red. Realiza una hibridación de palabras, conformando una construcción gramatical y morfológica basada en el hipertexto. El código resultante no es ejecutable siendo simplemente una referencia visual a los lenguajes de programación. Parece que este tipo de proyecto persigue una de las metas del feminismo y el anticolonialismo en forma de un estructuras de significado y conocimiento alternativas. La utilización de diferentes identidades en la red basadas en pseudónimos y avatares fue una constante durante este proyecto por parte de Breeze para difundir la obra, cuestionando por un lado la posibilidad de generar identidades estables online y por otro lado la necesidad de una autoría en la red. Este lenguaje esta diseñado para establecer su significado en base a la subjetividad del usuario y determinados catalizadores semánticos.

Las diferentes mails que conformaron este proyecto fueron distribuidos por la lista de correo llamada 7-11 la cual fue creada por los artistas Heath Bunting, Udo Noll, Vuk Cosic, Jodi.org y Alexei Shulgin. Formaron una de las primeras comunidades online dedicadas a la experimentación del net art. Este tipo de lenguaje entra dentro del reino de lo subjetivo, pero al igual que otros lenguajes generados dentro de internet no cuenta con alguna intencionalidad artística, más bien tiene la misión de generar comunicaciones anónimas, esta también relacionado con la criptografía.

La alusión a la posibilidad de generar múltiples relatos e historias aparece en la obra de Olia Lialina My boyfriend came back from the war ${ }^{160}$ de 1996. Es una

${ }^{160}$ http://www.teleportacia.org/war/ 
de las primeras muestras de net art realizadas mediante hipertexto con una intención narrativa. La historia se desarrolla interactuando con diferentes elementos entre los que se encuentran imágenes, GIF animados y textos. La web nos muestra una historia no lineal que se desarrolla de acuerdo a la propia interacción del usuario respecto a los elementos de la web. La propia artista lo vino a definir como un netfilm, debido a la similitud con la narratividad y la capacidad de evocar emociones del cine. Esto nos retrotrae a un lenguaje que recuerda al cine mudo. Esta obra es considerada como una de las primeras muestras de New Media Art, así como como un icono dentro de la cultura alternativa de Internet, es por ello que ha sido apropiada y remezclada por otros artistas, lo que ha producido una lista de apropiaciones que la artista mantiene en su web. También existe una publicación editada en 2016 que conmemora el vigésimo aniversario de la creación de la obra. Esta publicación cuenta con las versiones adicionales de multitud de artistas que han utilizado esta obra durante estos 20 años.
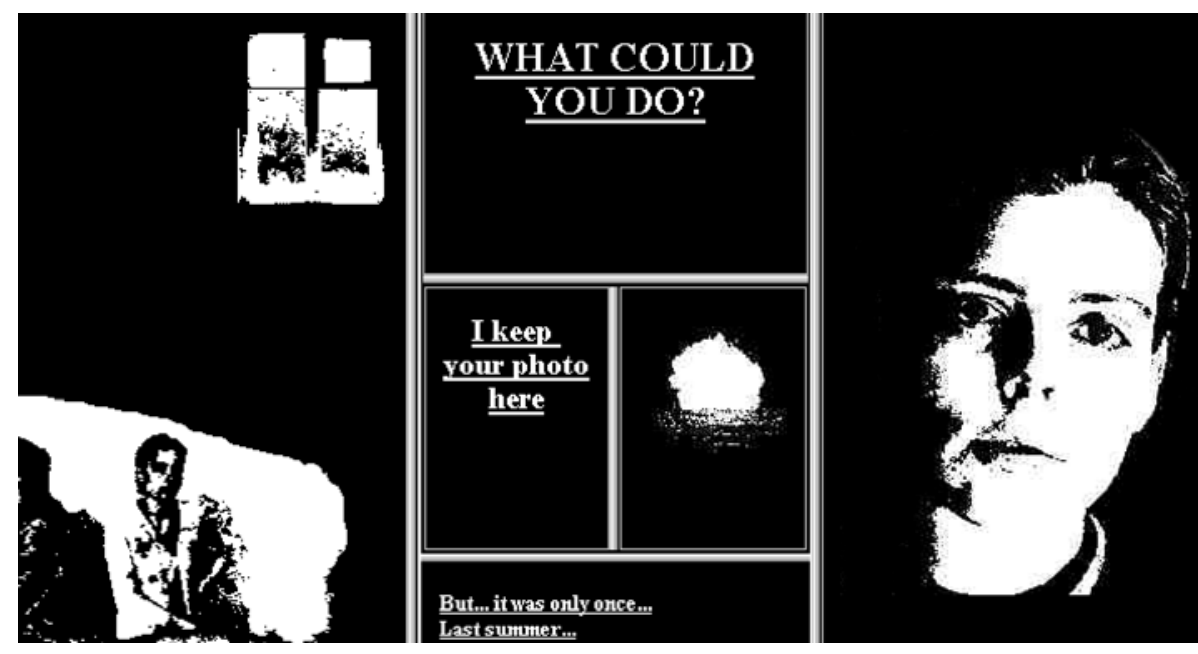

Figura 18. Captura de la obra de Olia Lialina My boyfriend came back from the war de 1996.

Gracias a las redes, como veremos, las posibilidades de generar identidades ficticias en mayor o menor medida, se han multiplicado exponencialmente en base a la implementación de nuevos sistemas de comunicación, y la aparición de Internet como campo social. Pero antes de realizar un acercamiento a la interesante y dinámica historia de la relación de las identidades ficticias y las redes, deberíamos observar cuales han sido las diferentes estrategias 
desarrolladas dentro de las sociedades y la cultura occidentales a este respecto haciendo especial hincapié en la relación entre la literatura y el arte, por las herramientas que estas disciplinas poseen relativas al campo de la ficción identitaria.

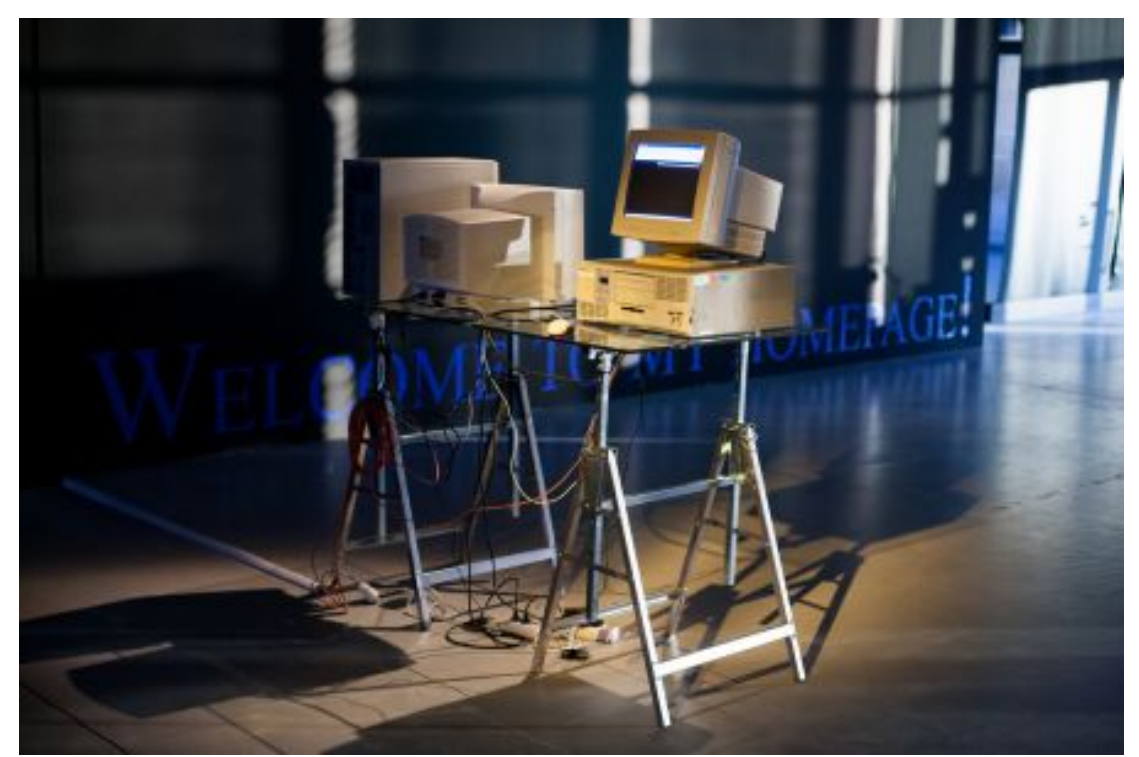

Figura 19. Instalación de My boyfriend came back from the war.

Proyectos como Distributing Martin ${ }^{161}$ del artista estadounidense Pope. L generan una narrativa a través de las entradas generadas en la web del proyecto. La idea surge en 2001 a partir de los restos de pelo, piel y suciedad encontrados en los documentos de Martin Luther King Jr.. Mediante la premisa de distribuir o poner en circulación los discursos, el nombre, o el material genético de esta persona a través de medios tan variados como vallas publicitarias, correo postal, Internet $\mathrm{o}$ virus $\mathrm{y}$ frutas modificadas genéticamente, se genera una narración surrealista del proyecto. Este podía ser visitado a través de la web principal de artista, en la cual el visitante tenia la posibilidad de topar con diferentes pantallas negras que conducían a la misma. El artista siempre concibió esta web como un blog, incluso teniendo en

${ }^{161}$ http://distributingmartin.com/ 
cuenta que cada pagina contenía una presentación en Flash desvinculada del estándar de la esfera blog. El sitio cuenta con una estructura cronológica generada mediante entradas, en las cuales los vínculos generan narrativas colaterales mediante una lógica no lineal. Estas entradas cuentan con fechas y lugares que parecen coincidir con la propia vida de Pope. L, sin embargo parece al mismo tiempo estar plagado de hechos contradictorios $y$ extravagantes. A través de estas entradas podemos visitar distintas manifestaciones del cuerpo de Martin Luther King Jr., quedando enumeradas en una pagina de la propia web.

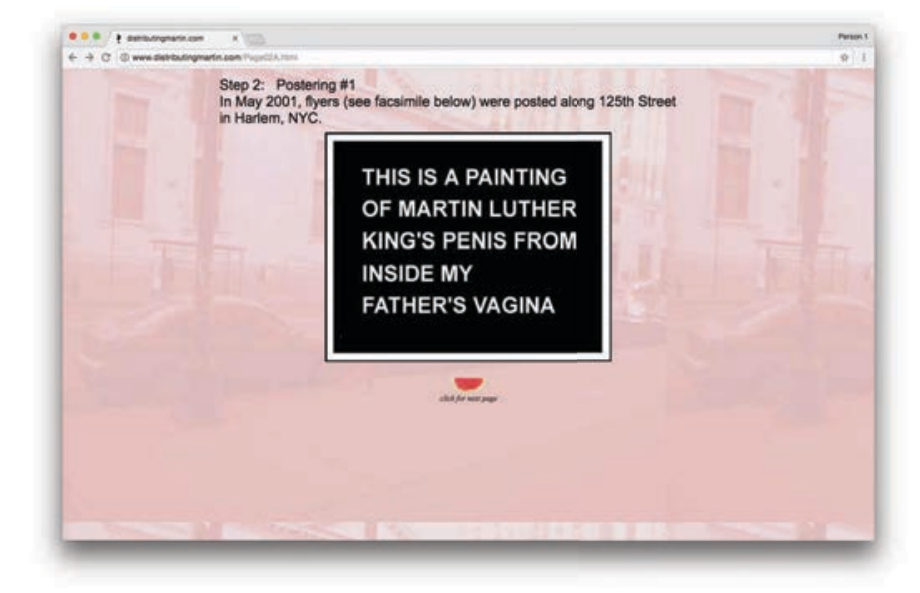

Figura 20. Captura de la web del proyecto Distributing Martin de Pope L.

Como primera acción previa al proyecto el artista comenzó una pegada de carteles alrededor de la ciudad de Nueva York, en los cuales se podía leer "This is a painting of Martin Luther King's penis from inside my father's vagina". Mediante esta extravagante y surrealista frase el artista pretendía que concibiéramos el cuerpo de King de una manera inusual, como medida para ampliar nuestra concepción sobre el. Mediante estos carteles se pretende sexualizar al hombre como una manera de llamar la atención sobre su cuerpo. Del mismo modo envió postales con este slogan a 8000 direcciones al azar, publicando anuncios en diferentes publicaciones sobre arte. Del mismo modo, el artista se dedicó a distribuir rumores entre el mundo del arte, mediante la idea del supuesto desarrollo de un proyecto en el ámbito de la genética. Este tendría la finalidad de insertar el ADN de King en diferentes frutas, siendo por lo tanto distribuido por todo el país como una especie de gen de la paz. Quizá 
la pieza colateral titulada Du Bois Machine ${ }^{162}$, consistente en una escultura de madera de la cual se podía escuchar la historia del artista, sea uno de los relatos más completos de este proyecto. En esta pieza podemos escuchar como el artista relata como llegó al proyecto cuando un amigo quince años atrás le dio acceso a los documentos de Martin Luther King Jr.. El pelo, piel y suciedad que portaban los documentos fue la génesis de un proyecto heterogéneo y disperso por diferentes medios entre los que la red es el nexo de unión y registro final de todos ellos.

Por lo tanto podríamos decir que la serie de gestos que componen este proyecto, llevado a cabo desde 2001 hasta 2008, pretenden cuestionar la relación de la idea de King con su cuerpo, como reflejo de la relación del cuerpo dentro de la red. La consternación causada por este proyecto ante el intento de Pope. L. de distribuir a King cobra una significación aun mas interesante si tenemos en cuenta la manera en la cual la cultura lo disecciona y distribuye por sus propios cauces y en base a sus propios intereses. Este proyecto presenta un trabajo realizado durante un periodo largo de tiempo, que el artista utilizó para teorizar sobre la cultura de internet. Mediante el material distribuido a través de la red se presenta el objeto, la idea e información, considerando la materialidad de la red en cuento a la circulación de materiales y las implicaciones que esto conlleva en cuanto al ámbito artístico.

Dentro del ámbito del ámbito de las artes, una de las herramientas principales a la hora de construir un relato o narratividad propia y personal es la de la creación de una identidad como medio mediante el cual transcender las barreras impuestas desde el exterior. En el mundo de las letras adquiere un cariz emancipador, sobre todo si tenemos en cuenta la cita de Virginia Wolf: "Me atrevería a aventurar que Anónimo, que tantos poemas escribió sin firmarlos, era a menudo una mujer". Este fenómeno podemos seguirlo hasta la actualidad, si investigamos sobre la escritora inglesa J. K. Rowling, autora de la famosa saga de novelas juveniles de Harry Potter. Rowling ha admitido en numerosas ocasiones que tras hablar con su editorial ocultó deliberadamente su verdadero nombre ya que temían que un público juvenil, en su mayoría masculino, rechazara un libro escrito por una mujer. Recientemente también

${ }^{162}$ http://rhizome.org/editorial/2017/nov/16/du-bois-machine/ 
utilizó el pseudónimo de Robert Galbraith para su serie de novelas Cormoran Strike pero en ningún caso su verdadero nombre Joanne Rowling.

Por otro lado y como contraposición a estos alias o pseudónimos generados como escudo ante las normas sociales, también podemos encontrar personajes creados ex profeso que parecen cuestionar los roles de genero creados por la sociedad. El alter ego femenino de Marcell Duchamp, Rrose Sélavy, es un ejemplo temprano de este tipo de personajes, así mismo podría ser considerado una de las piezas más enigmáticas de la obra del artista. Genera un juego evidente mediante la polisemia creada por su propio nombre, ya que incluye la frase "eros, c'est la vie" que podríamos traducir como "la vida es eros". Estos juegos de palabras parecen estar inspirados en el poeta Raymond Roussel y Jean-Pierre Brisset ${ }^{163}$.

Mediante su alter ego, Duchamp cuestionó el papel de los géneros mediante el lenguaje, pero también mediante los estereotipos que Rrose Sélavy muestra de manera amable, y que conforma un acercamiento bastante superficial al genero femenino que sirve de herramienta para mostrar la idea burguesa de la mujer como mercancía que es disfrutada por la mirada del hombre. Rrose Sélavy es construida como una mujer de extraordinario talento que es capaz de producir obras de arte, como Fresh Widow de 1920, que mediante el juego de palabras de "fresh" con "french" y "widow" con "window" apunta a connotaciones sexuales de las cuales podríamos deducir múltiples interpretaciones. Será Man Ray, en 1920, el primero que la fotografió mediante una imagen de un travestido Duchamp poco convincente como mujer. Esta imagen formara parte del ready-made Belle Haleine-Eau de Voilette, una botella de perfume con la imagen de Rrose Sélavy, que muestra nuevamente un juego de palabras. Por otro lado la famosa obra Why Not Sneeze Rrose Sélavy? realizada en 1921 por encargo de Dorothea Dreier, esta compuesta por una jaula llena con 152 cubos de mármol, un termómetro casero y el hueso de una sepia. Esta obra nos muestra un ready-made que aún hoy no tiene una interpretación clara, aunque a juzgar por el poco peso físico de la obra, si pensamos en su contenido, podríamos hablar de un trampantojo objetual mucho más en la línea del dadá neoyorquino que el practicado en un París mucho más radicalizado, y en el cual Duchamp era la gran ausencia.

163 Duchamp, Marcell, Escritos. Duchamp du Signe, Editorial Gustavo Gili, Barcelona, 1978, pag. 129. 
Respecto a la razón que le llevó a realizar esta creación identitaria, Duchamp afirmaba que no era para cambiar de identidad, sino que lo que le atraía era la posibilidad de tener dos identidades ${ }^{164}$. Una de la obras de Virginia Woolf, Orlando: una biografía ${ }^{165}$ publicada en 1928, trata temas de carácter polémico para la época como la vida sexual de la mujer o la homosexualidad, siendo de gran interés la idea de presentar a un hombre que un día se despierta con el cuerpo de mujer. Este hecho vivido por el personaje de Orlando parece presentar a un individuo que ha experimentado su masculinidad en toda su plenitud, pero que al cambiar de sexo adquiere los roles femeninos. Mediante esta novela Woolf cuestiona y ridiculiza los roles sexuales y la propia sexualidad de la sociedad de la época, así como el concepto de biografía, generando una interacción muy interesante con el alter ego duchampiano de Rrose Sélavy nacido del deseo del artista de tener otra identidad de sexo femenino que cuestione el papel de la mujer estereotipándola dentro del modelo burgués de la época.

Why not sneeze?, obra que cita la famosa obra de Marcel Duchamp Why Not Sneeze Rrose Sélavy?, fue publicada en 1997. Se trata de una página cubierta de piedras y animaciones gif de hormigas que pululan dentro de un cuadrado blanco, a la vez que frases sugerentes animan al visitante a navegar por un mar de vínculos ocultos. Esta referencia a Rrose Sélavy nos hace vislumbrar la naturaleza de un proyecto que al igual que el alter ego de Marcel Duchamp pretende cambiar de identidad para reflejar los estereotipos y las problemáticas femeninas, en este caso asociadas con la adolescencia. Mouchette creó su primera web alrededor de 1996, permaneciendo en activo desde aquel momento hasta la actualidad, e incluso aumentando su actividad. Se trataba de un chica adolescente de trece años de edad que al parecer estaba fascinada con el suicidio. Este sitio de carácter enigmático, encierra la obra de la artista holandesa Martine Neddam. Mediante elementos HTML la artista nos invita a introducirnos en el complicado y a veces truculento mundo de esta adolescente, utilizando la participación del público como elemento central de este sitio, para conformar desde hace mas de veinte años un archivo cargado

164 Tomkins; Calvin, Duchamp, Anagrama, Barcelona, 1999, pag. 258.

165 Woolf, Virginia, Orlando: una biografía, Alianza Editorial, Barcelona, 2012. 
de fuertes contrastes, que van desde el humor y la ternura a lo más oscuro de la naturaleza humana.

Gracias a el trabajo constante de Neddam la pagina se mantiene activa, y es actualizada regularmente con nuevos contenidos. Estamos ante una obra que la propia artista califica como "una pequeña niña hecha de lenguaje y texto", de hecho uno de los principios de este proyecto fue la creación de poesía mediante palabras aleatorias generadas por software. Las contribuciones del público, y la participación de este dentro del proyecto, han sido esenciales para la continuidad y la expansión del mismo, para ello se valió de elementos como el mail o los formularios. Precisamente estos, según el rumbo de las discusiones orientaban el rumbo de la web, como fue el caso de la discusión sobre el tema del suicidio bajo la pregunta ¿Cuál es la mejor manera de suicidarse cuanto tienes 13 años? Por otro lado, este proyecto generó un gran número de muestras artísticas relacionas con Mouchette, como comics, o todo tipo de fan art.

Tras la creación de la web Mouchette.net, su identidad se convirtió en multiusos, pudiendo ser reutilizada por el resto de usuarios de la web, la cual podía ser alterada. Pese a diferentes anuncios de apariciones en público, la artista mantuvo su anonimato durante más de diez años, con la intención de que fueran los propios visitantes los que conformaran al personaje mediante su actividad en la web. De hecho estamos ante una web en la cual la propia subjetividad de Mouchette es expresada mediante del propio diseño, realizado mediante imágenes escaneadas de carne, piel y flores, combinadas con gifs animados de insectos que generan un ambiente de decadencia, amplificado mediante los sonidos generados al cargar la propia página, que para la artista son constitutivos de un acto performativo. 


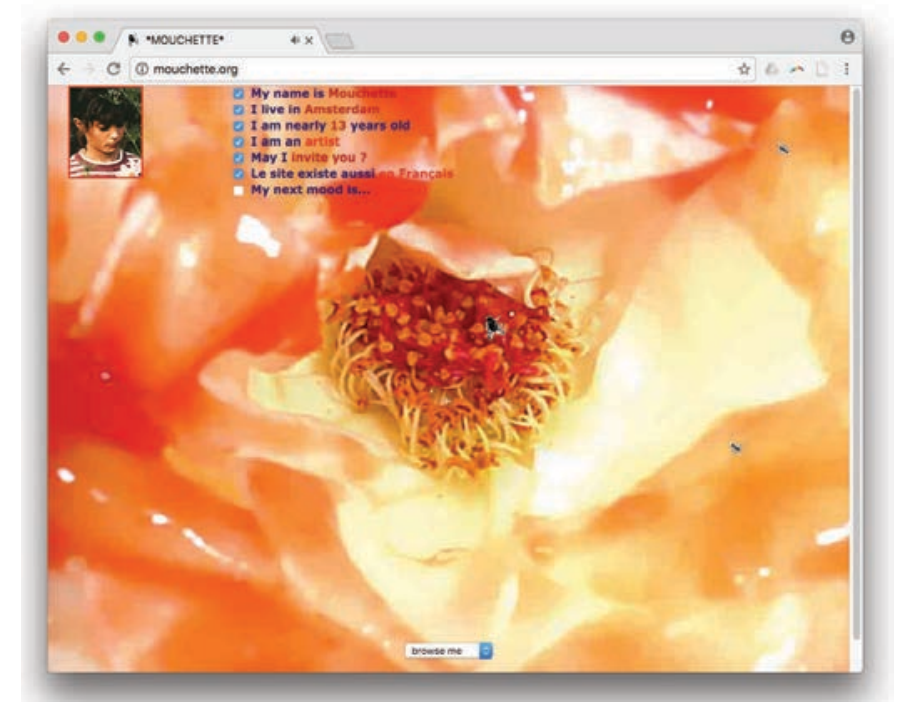

Figura 21. Página principal de la web mouchette.org166.

Las referencias constantes al incesto, la violación y el suicidio, están relacionadas con la sexualización de la adolescencia y las problemáticas que el propio publico y la artista han desarrollado a través de este personaje, generando una conjunción entre la tecnología, el proyecto y el publico. El objetivo final de este proyecto es generar un intercambio entre los usuarios, producido alrededor de la construcción de esta identidad ficticia, que por otro lado invisibiliza a la autora. Este personaje ficticio proyecta diferentes aspectos de la cultura de Internet en base al actuar de los usuarios, expandiéndose lentamente como un reflejo de nuestros propios temores y anhelos, en forma de registro especular de este tipo de actividad. Esta superficie de proyección se genera en base al anonimato del personaje, tomando la forma de las paginas personales tan populares a mediados de los años 90 del siglo XX. Estas páginas a menudo ridiculizadas por otros usuarios mostraban una nueva forma de expresarse online basada en su propia vida.

El neologismo conocido como autoficción, dentro del mundo de la crítica literaria, es una irónica combinación de conceptos tan dispares como ficción y

${ }^{166}$ http://mouchette.org/ 
autobiografía. El autor puede desarrollar una narración vivida por el mismo pero protagonizada por una tercera persona e incluso cambiar detalles importantes sobre su propia personalidad y características. Aquí la propia ficción es la herramienta mediante la cual se genera una búsqueda de nuestra propia identidad. El termino fue acuñado en 1977 por el escritor Serge Doubrovsky dentro de su novela Fills, y posteriormente desarrollado como concepto por un gran numero de escritores contemporáneos franceses.
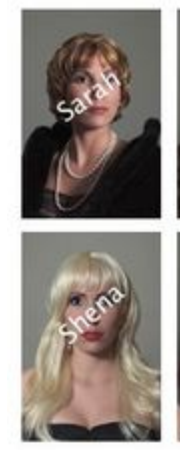
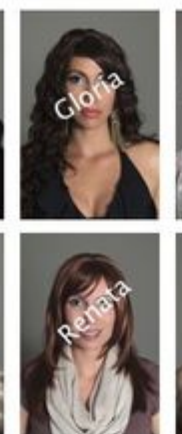
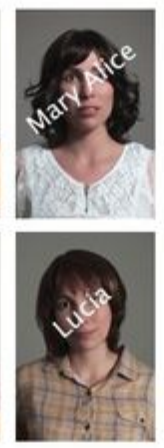
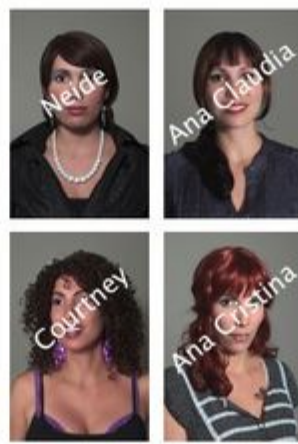
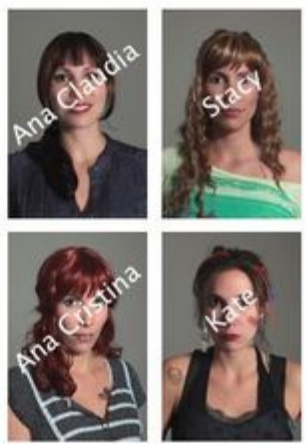

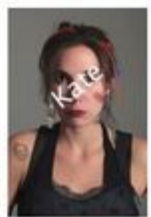

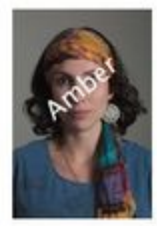

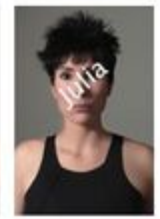

Figura 22. Laís Pontes, Born Nowhere, 2011.

Laís Pontes es una artista nacida en Brasil, la cual realizó hacia 2011 la obra Project Born Nowhere ${ }^{167}$. Nos muestra un acercamiento participativo al concepto de identidad, a través de las redes sociales. Esta artista moldea a partir de su propio rostro un gran número de identidades de mujeres que no existen realmente, ya que son realizadas con herramientas de retoque fotográfico a partir de la propia fotografía de la artista. Pontes subió estos retratos manofacturados a la página de Facebook creada ex profeso para este proyecto sin añadir dato algunno, pero esperando que los usuarios completaran la personalidad de cada mujer inspirándose en el lema "What one sees is what one wants to see". Después de analizar las contribuciones, Pontes da el toque final a la identidad de su creación, añadiendo la descripción que a partir de las intervenciones de los usuarios ha sido conformada en la página. Más tarde dentro de un proyecto posterior llamado Born Now Here, algunos de estos personajes adquirieron vida propia online al crearse un perfil de Facebook propio, en el cual el proceso de trabajo continua.

\footnotetext{
${ }^{167}$ http://www.laispontes.com/born-nowhere/characters/Born_Nowhere_Claudia_wed
} 


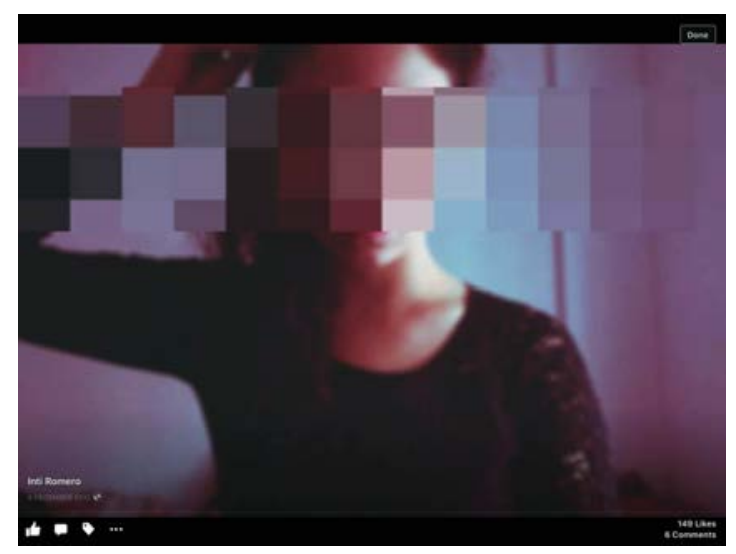

Figura 23. Fotografía del proyecto Intimidad Romero, 2011.

Por otro lado, proyectos como el de Intimidad Romero ${ }^{168}$ también basados en un perfil de Facebook, abordan la cuestión de la identidad desde el anonimato de la propia autora. Por lo tanto, la construcción que se produce en las redes en base a la compartición de imágenes, videos y texto queda en suspenso ya que la protagonista aparece siempre con el rostro pixelado. Aquí ficción y anonimato se combinan en una practica performativa realizada a través de la red social Facebook. Esta ocultación podemos considerarla un vacío que desplaza al personaje real mediante la ficción generada por las redes. Ante la ausencia de una identidad predefinida serán los propios comentarios e interacciones los que fraguaran un alter ego online como contrapartida a nuestra actividad offline, pero que finalmente también se solapa con nosotros mismos al estar dentro de nuestra cotidianidad. En este caso la autocensura genera una identidad digital ficticia que oculta la verdadera identidad de la artista, la cual permanece oculta ante una fachada de sobreexposición, lo cual por otro lado, parece la metáfora perfecta a nuestra desenfrenada actividad en las redes.

La desaparición del sujeto en occidente y el ansia por desaparecer son pues los temas principales, pero sobre todo y paradójicamente la dificultad de alcanzar el objetivo de no ser nadie. "Car Je est un autre", "Porque yo es otro", escribía

\footnotetext{
${ }^{168}$ http://intimidad.tumblr.com/
} 
Jean-Arthur Rimbaud a su amigo Paul Demeny en un documento conocido popularmente como "la carta del vidente" de 1871. En este Rimbaud asume la no propiedad de su yo pasado el cual actúa con voluntad propia al margen de el mismo, y por lo tanto la conclusión de que nada es lo que es permanentemente. Como hemos podido observar en la obra de Intimidad Romero este tipo de actuar que pretende no ser nadie esta ligado también a las redes como un tipo de práctica que subvierte sus principios básicos de funcionamiento y rentabilidad. En cambio, en la película de 2002 del director finlandés Aki Kaurismaki El hombre sin pasado, podemos observar como un amnésico protagonista encuentra en el hecho de carecer de identidad su único lastre para acceder a un trabajo o los servicios sociales básicos. Esta ausencia de identidad hace que para una sociedad consumista y materialista esta persona no exista. Esta no identidad irónicamente se presenta como una manera de evolucionar como individuo al encontrar la autentica felicidad dentro de un entorno rodeado de desposeídos en el plano material, pero ricos en otras cualidades realmente valiosas. Finalmente podemos comprobar como esta amnesia y anonimato le permite romper las cadenas con una vida anterior llena de lastres aunque segura en lo material, aunando los conceptos de desaparición y felicidad que Robert Walser ejemplificó al preferir ser nadie.

Por otro lado, podemos observar como con anterioridad a la difusión de las tecnologías asociadas a las redes ya se había producido un intercambio muy importante entre texto, escritura, identidad y arte, por compartir en muchos casos el campo de lo ficticio y las creaciones identitarias creadas como reacción a una realidad poco satisfactoria. Precisamente el escritor español Enrique Vila-Matas ha tomado el tema de la identidad personal como central según sus propios críticos. Su relación y admiración por la obra de Marcell Duchamp ha quedado patente a lo largo de toda su obra literaria mediante miles de referencias directas. La relación entre el escritor y el artista parte de la relectura por parte de Vila-Matas de Conversaciones con Marcell Duchamp de Pierre Cabanne ${ }^{169}$. En su obra juega en muchas ocasiones al engaño dentro de su propia narración, de manera que mantiene al lector ante el interrogante sobre la verosimilitud de lo que lee, generando un juego entre lo ficticio y lo real que se extiende también a la identidad de sus propios personajes, lo que ha visto nacer toda una filosofía de la ficción. El concepto de impostura como engaño identitario con apariencia de realidad nace dentro se su obra como

${ }^{169}$ Cabanne, Pierre, op. Cit., 1984. 
reflejo de una sociedad en la cual pretendemos alcanzar un yo fabricado en base a los media, que nos permita ser alguien y no otro, y que paradójicamente nos lleva a ser nadie, simplemente nos representamos a nosotros mismos haciendo que este juego del yo continúe indefinidamente.

Dentro de estas historias de simulaciones identitarias cabria destacar la obra de Vila-Matas Impostura de 1984, donde el escritor genera una fina ironía sobre la sociedad española de posguerra mediante una historia que pone en duda la identidad de un enfermo mental interno en un hospital de Barcelona. Al publicarse su foto en La Vanguardia es reclamado tanto por una familia falangista que lo identifica como un soldado de la división azul que creían muerto en Rusia, como también por una mujer republicana que lo identifica como delincuente de lo bajos fondos. Mediante la impostura que ambas partes pretenden imponer sobre el enfermo Vila-Matas consigue reflejar la propia sensación de impostura vivida por los propios barceloneses durante la posguerra, en la que nadie creía realmente en lo que decía ${ }^{170}$.

Por otro lado Vila-Matas en su obra de 2005, Doctor Pasavento, nos narra la historia de lo que se ha venido a denominar como un héroe posmoderno, que se camufla y se transforma en otro durante el trascurso de la narración, focalizándose esta en la cuestión de la desaparición voluntaria y adopción de identidades ficticias. Esta huida esconde también el propio deseo de VilaMatas de desaparecer como autor y convertirse en un "escritor secreto", al igual que Robert Walser, convertido en modelo de emulación por su menosprecio de lo vacuo de la sociedad y el reconocimiento de esta.

Otra de las obras, en la cual participa Vila-Matas que adquieren un gran interés alrededor de la cuestión identitaria es El Juego del Otro. Se trata de una recopilación de textos dividida en tres partes, una primera en la que VilaMatas conversa con Jean Echenoz sobre el sentido de la impostura, una segunda en la que Barry Gifford recrea el diario que nunca se escribió del viaje a Túnez de August Macke mientras comparte esta experiencia con Paul Klee, y una tercera en la que Paul Auster crea un personaje para Sophie Calle que esta

\footnotetext{
${ }^{170}$ Vila-Matas, Enrique, En un lugar solitario, Debolsillo, Barcelona, 2011.
} 
debe interpretar y que posteriormente da lugar al libro Gotham Handbook. Nueva York: instrucciones de uso, y que ya mencionamos anteriormente.

Durante esta interesante conversación entre Vila-Matas y Echenoz se desprende la idea de la utilización de la impostura como una metodología mediante la cual transitar el mundo, considerando un error la pretensión de alcanzar la verdad debido a nuestra inherente subjetividad. Esto nos hace entender el mundo como algo que existe solo en base a nuestra mirada y por ende deformado por la misma. Como vimos, la propia apropiación ajena es la formula que Vila-Matas utiliza dentro de varias de sus obras como método de inspiración, generando situaciones que son reordenadas y reubicadas dentro de su obra. Esto alude a la propia imposibilidad de la originalidad que el autor da por hecho, pero también a la práctica de la impostura como placer que se desarrolla mediante la utilización de la copia, el robo y la apropiación, reinventando los conceptos de imitación y plagio en el ámbito literario e identitario. Este tipo de practicas identitarias asociadas a lo performativo han tenido un interesante desarrollo ya en el siglo XXI tras la implementación de las aplicaciones de la Web 2.0, y la utilización de la imagen como interfaz comunicativo en diferentes ecosistemas sociales online. Uno de los mayores exponentes de este tipo de prácticas de engaño y ficción identitarias ha sido el proyecto Excellences \& Perfections ${ }^{171}$ desarrollado por la artista Amalia Ulman. En 2014 la artista utilizó su propia cuenta de Instagram para desarrollar una performance online, basada en la creación de una narrativa ficticia sobre su cotidianidad, en la cual adquiría los hábitos, costumbres y personalidad asociadas a la cultura de las celebrities e influencers, tan populares y mediaticas en este tipo de entornos sociales. Esta performance que tuvo una duración de 5 meses, supuso un cambio de imagen extremo respecto a las publicaciones que la artista mostraba anteriormente en su cuenta de Instagram, alarmando a sus amigos y familiares, los cuales pese a las advertencias sobre el proyecto en curso que estaba desarrollando, no creyeron la versión dada por la artista. Durante estos cinco meses fingió cambios físicos radicales como una operación de aumento de pecho, mediante la publicación de imágenes suyas en bata en un hospital, teniendo que simular este aumento el resto de la performance. Otros elementos como el cambio en su dieta, o la asistencia a clases de baile, no fueron fingidos aunque si

\footnotetext{
${ }^{171}$ http://webenact.rhizome.org/excellences-and-perfections
} 
formaron parte de una identidad que no se corresponde realmente con la de la artista.

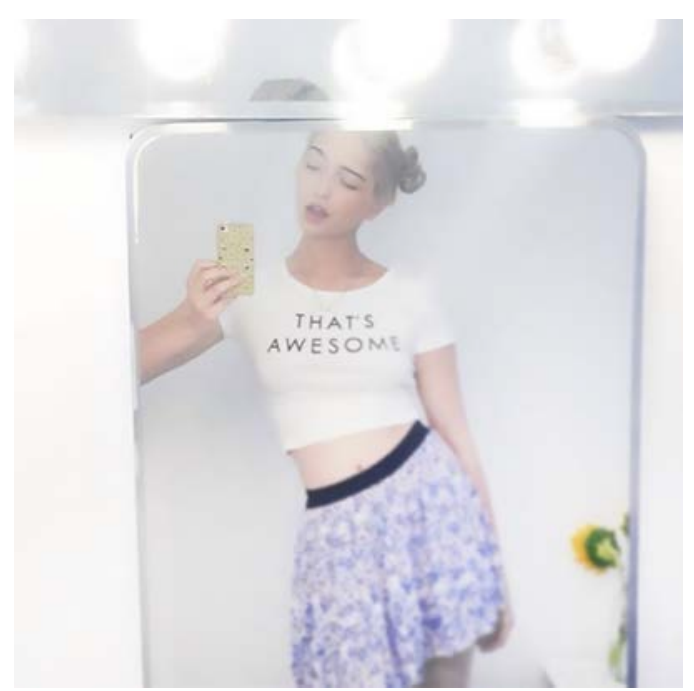

Figura 24. Amalia Ulman, Excellences \& Perfections, 2014.

Este proyecto presenta un uso interesante de escenarios, accesorios y ubicaciones que sirven para proyectar un estilo de vida basado en el consumo y el materialismo. Pese a lo excesivo de este tipo de imágenes, resultan realmente creíbles para todos los espectadores acostumbrados a contemplar habitaciones de hotel bellamente decoradas, desayunos perfectos y todo tipo de elementos y hechos que coincidían con las convenciones narrativas de las celebrities de Instagram. Esta es una estetización de la vida cotidiana en las redes sociales que ha tomado un rol hegemónico en la creación de imágenes mediante la difusión de los terminales móviles con cámara como centro de creación multimedia. Este tipo de herramientas digitales al alcance del gran publico han servido para amplificar la fiebre por nuestra propia autoficción mediante diferentes tipos de autorepresentaciones, como el selfie, basado en muchos casos en la perfección corporal y el fetichismo de la imagen. Esto sirve para generar una narrativa ficticia plagada de imágenes escenificadas, comentarios y posados de carácter exhibicionista, que hipervisibilizan la simulación hestereotipica de las actitudes asociadas a los usuarios supuestamente más exitosos de las redes sociales, es decir, las personas asociadas con la cultura de los famosos. Obviamente, las referencias a la obra 
de artistas como Cindy Sherman, relacionadas con el pastiche posmoderno son evidentes, sin embargo al estar inmersas en un entorno social, estas imágenes están acompañadas de textos propios, así como los de otros usuarios, que responden y refuerzan en muchos casos los roles sociales y de genero desarrollados durante este proyecto. Por otro lado, construyen y vehiculizan mediante estas interacciones el propio rumbo de nuestra identidad personal en el ámbito de las redes. El proyecto de Ulman actúa pues como una suerte de pareidolia en la cual el usuario contempla lo que esta acostumbrado a observar y por lo tanto espera ver dentro de un medio que debido a sus características modela el tipo de representaciones que se producen dentro de sus estructuras.

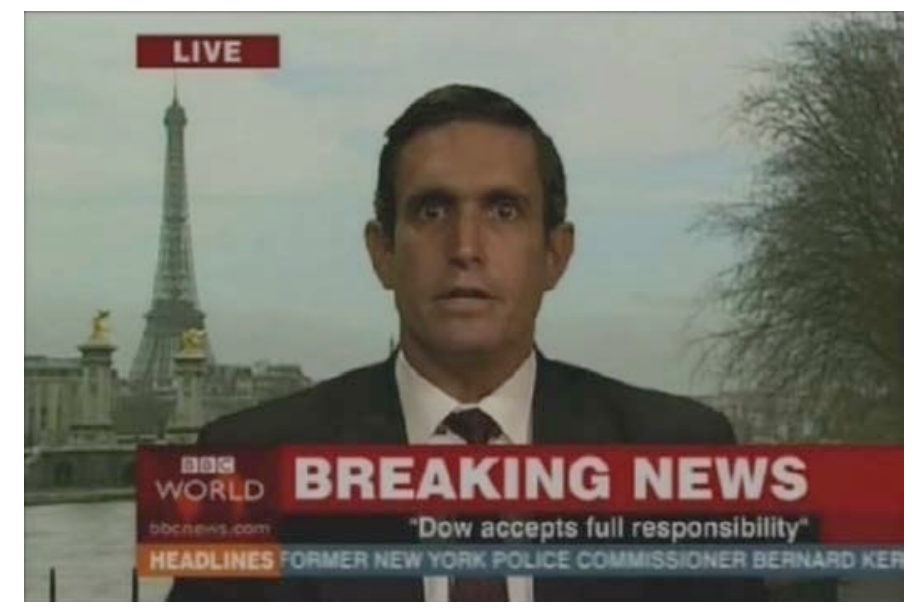

Figura 25. Andy Bichlbaum como Jude Finisterra representante de Dow Chemical.

El duo de activistas conocido como Yes Men, formado por Andy Bichlbaum y Mike Bonanno, crean paginas web falsas pertenecientes a grandes empresas o representantes políticos con la intención de ser invitados a diferentes eventos. Haciéndose pasar por estas personas o empresas poderosas tienen la oportunidad de adquirir la autoridad suficiente como para hablar en público en su nombre, llevando al extremo de la sobreidentificación las lógicas deshumanizantes de este tipo de organizaciones o personalidades. En diciembre de 2004, coincidiendo con el 20 aniversario del desastre de Bhopal, uno de los integrantes de Yes Men apareció en la BBC haciéndose pasar por un representante de Dow Chemical, responsable de este desastre en el cual 3800 personas murieron y miles más resultaron afectadas de por vida. En esta 
entrevista el falso representante afirmo que Dow Chemical pretendía liquidar la filial responsable de este accidente para poder indemnizar a las victimas de la catástrofe, limpiar el lugar del accidente, así como investigar sobre medidas de seguridad. El impacto fue inmediato, ya que la empresa perdió en bolsa 2000 millones de dólares en media hora. Más tarde, el falso representante de Dow Chemical fue acusado de jugar con los sentimientos de la gente al negar dicha empresa cualquier compensación a las victimas. Sin embargo los Yes Men argumentaron que esta acción sirvió para poner el foco sobre un problema olvidado para el resto del mundo, y que según sus contactos alegro a las propias victimas de la catástrofe por la burla que esto supuso a la empresa. Aquí la impostura creada por los miembros de Yes Men sirve para conformar una mezcla entre el media prank y el activismo. Al hacerse pasar por portavoces de grandes corporaciones que ridiculizan mediante la sátira y la exageración la ideología subyacente en las acciones e intereses de estos grandes grupos. Estamos ante un tipo de actividad que disuelve la autoría ya que, como los propios miembros del grupo reconocen, son la cara visible de un grupo humano mucho mayor.

\subsection{IDENTIDADES MULTIUSOS}

Como hemos podido ver, una de las características que la contemporaneidad ha desvelado respecto a la identidad es su multiplicidad, así como la gran facilidad del ser humano para experimentar y hacerse pasar por otro. El concepto de identidad multiuso es algo que dentro del mundo del arte ha permanecido soterrado desde la segunda mitad del siglo XX hasta nuestros días, principalmente por lo confuso y contradictorio de su propia definición. Este concepto fue desarrollado y popularizado en subculturas artísticas de los años 70 y 80 del S.XX, tales como el Neoísmo, el Mail Art y los continuadores del Situacionismo.

Experiencias como el Neoísmo, el cual operaba como una red subcultural de performances y experimentadores mediáticos, han tenido un papel destacado al respecto. Pese a lo complicado de su categorización podemos concretar que sus practicas colectivas consistían en el plagio, el fake y el intercambio de pseudónimos e identidades. Las herramientas usadas por estos artistas fueron tan diversas como pequeñas publicaciones, virus informáticos o simplemente performance y video. Artistas como Istvan Kantor y David Zack, entre otros, 
generaron la identidad abierta del artista pop Monty Cantsin ${ }^{172}$ como anticipación al software libre y al open source, el cual más que un pseudónimo colectivo o un personaje convertido en mito, era una identidad vivida en su vida cotidiana. Este pseudónimo fue acuñado en 1978 por el crítico y artista postal David Zack como un pseudonimo literario para el poeta Maris Kundzins. Por su parte el performer Istvan Kantor lo transformó en 1979 en un experimento identitario al utilizarlo como protagonista de diferentes albums de música, performances como el Neoist Apartment Festival, y en líneas generales como la identidad compartida de todo el movimiento Neoísta. Como contrapeso a esta identidad masculina dominante en este movimiento se creó la identidad múltiple de Karen Eliot, la cual fue usada por diferentes artistas y activistas como pseudónimo abierto. Muchas de las composiciones de compositores experimentales, como Vanessa Grey, Engram Knots and Marc Couroux entre otros, fueron colectiva y anónimamente firmadas por Karen Elliot.

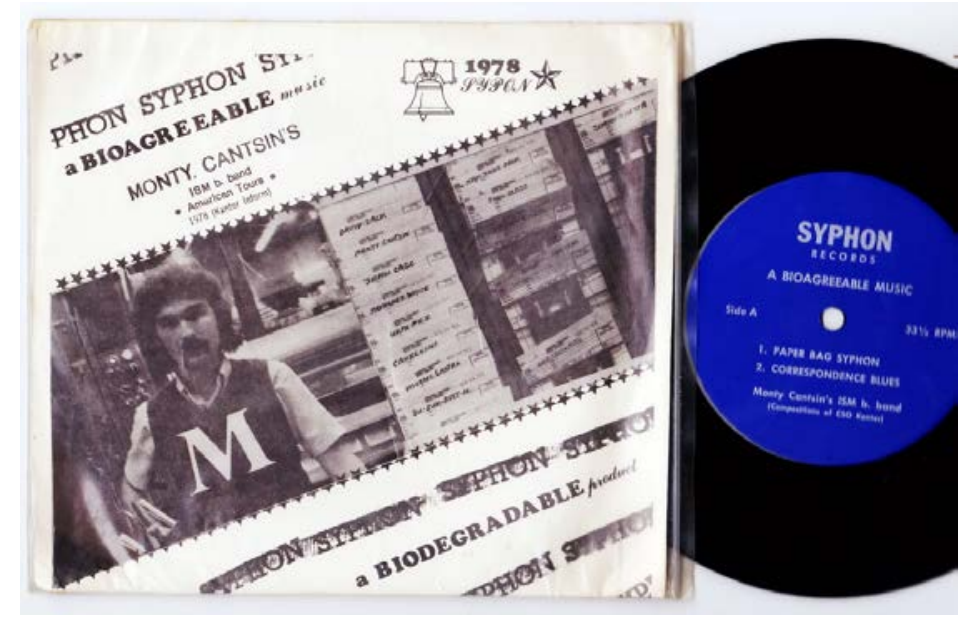

Figura 26. A Bioagreeable Music, Monty Cantsin, 1978.

\footnotetext{
${ }^{172}$ Home, Stewart, Neoism, plagiarism \& praxis, AK Press, Edimburgo, 1995, p. 52.
} 
Como recoge Florian Cramer en su escrito Language, a virus?, el crítico de net art Tilman Baumgärtel, en su ensayo Experimentelle software ${ }^{173}$ puntualiza como trece años antes de la aparición de la obra de 0100101110101101.org biennale.py en 2001, un virus de ordenador fue programado y diseminado como una broma con intencionalidad artística. Al descargarlo y abrir el archivo se instalaba secretamente una extensión del sistema que hacia aparecer cada vez que se iniciaba el equipo el irónico mensaje "New Age Peace". Los desarrolladores de dicho virus, Artemus Barnoz (pseudónimo de Richard Brandow) y Boris Wanowitch, eran también los editores de las publicaciones MacMag y de Computer Graphics Conspiracy la cual formaba parte de la red subcultural del neoísmo. En dichas publicaciones Brandow enfatiza su declaración de intenciones sobre la utilización de virus para desarrollar sus propósitos neoístas. Desafortunadamente esta radicalización le llevó a infectar, dentro de su trabajo para la compañía Aldus (posteriormente Adobe), el disco de instalación del famoso programa de ilustración FreeHand en su versión 1.0, dando como resultado una sentencia de cárcel para Brandow. El virus MacMag es considerado unos de los primeros virus de ordenador al haber sido creado en Febrero de 1988, y también el primero en alcanzar una circulación masiva a través de redes electrónicas. Este virus podría ser descrito como la primera implementación del neoísmo dentro de un código algorítmico.

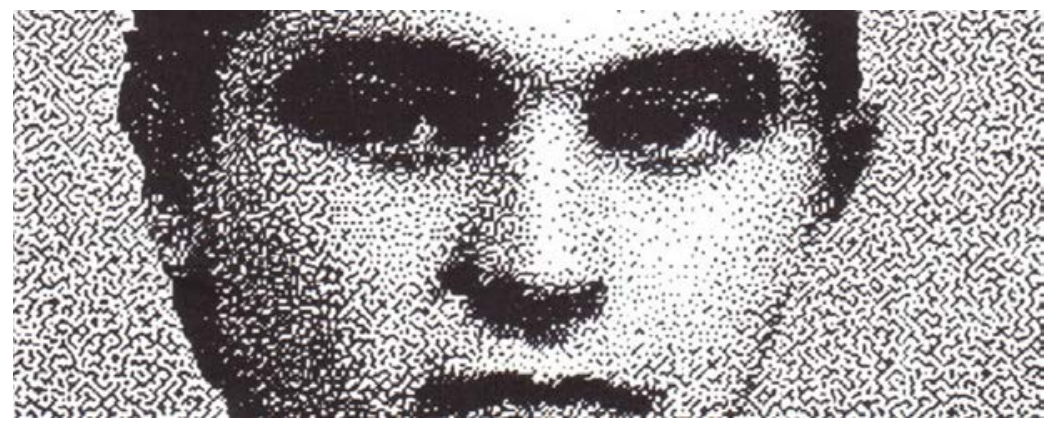

Figura 27. Supuesto retrato de Luther Blisset.

\footnotetext{
173 Baumgärtel, Tilman. Experimentelle software. Telepolis, 2001, [En línea], [consultado el 27 de Junio de 2016], disponible en <http://www.heise.de/tp/deutsch/inhalt/sa/9908/1.html>
} 
Uno de los grandes herederos de esta corriente neoísta fue Luther Blissett Project. Se trata de un ejemplo paradigmático sobre el desarrollo de una identidad multiusuario de carácter colectivo dentro de la esfera mediática. La misión principal de este proyecto, cuyo desarrollo se produjo principalmente entre los años 1994 a 1999, fue la de producir una especie de Robin Hood de la era de la información mediante las herramientas de la denominada "Guerrilla de la Comunicación”, es decir, intervenciones no convencionales dentro de procesos convencionales de comunicación, analizando y cuestionando la gramática cultural, creando campañas de solidaridad para con las victimas de la censura y la represión, y elaborando lo que vino a denominarse "media pranks" 174 como forma de arte, termino acuñado por los miembros del proyecto dentro de su propio manifiesto en forma de web.

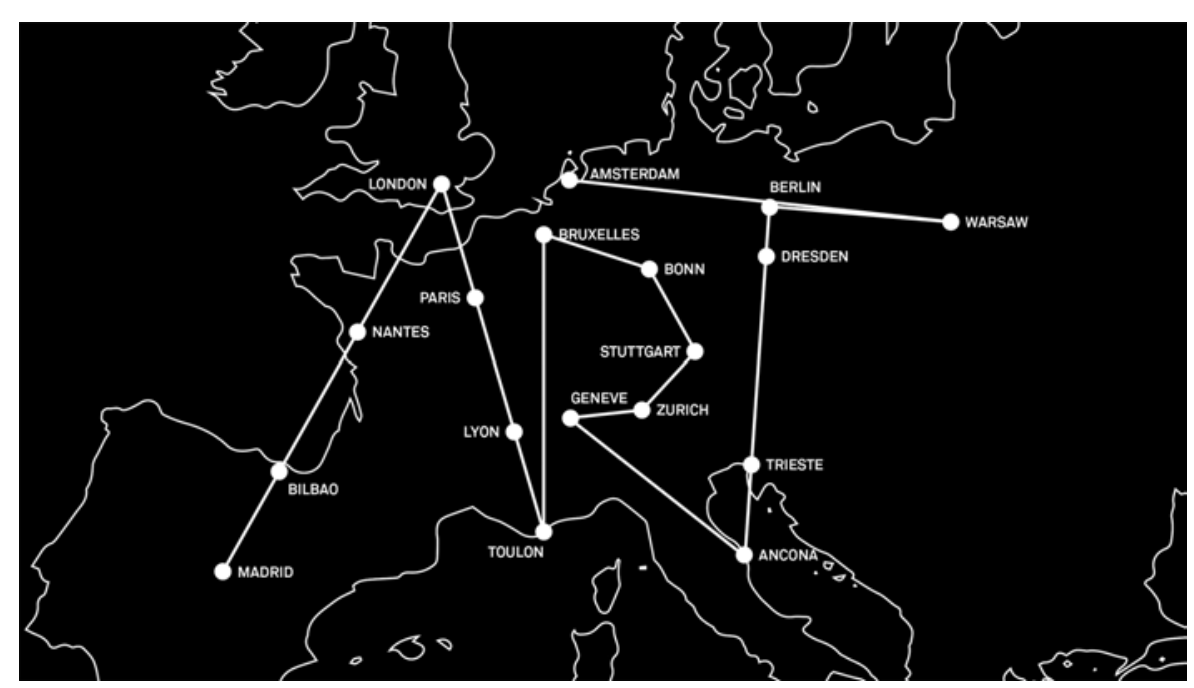

Figura 28. Supuesta deriva del artista Harry Kipper alrededor de Europa.

\footnotetext{
${ }^{174}$ Podríamos denominar media prank como un evento mediático diseñado para engañar a la prensa y hacer que publiquen artículos erróneos o engañosos. Este termino también se refiere por tanto a las historias diseñadas por periodistas falsos, así como las historias falsas publicadas en base a estas. Es una forma de reciclaje cultural generalmente desarrollado por un artista performativo con pretensión humorística o crítica sobre los medios.
} 
Entre las principales farsas generadas durante este proyecto podemos encontrar la desaparición del artista conceptual Harry Kipper ${ }^{175}$ en la frontera Italo-Yugoslava. Dicha desaparición sucedió mientras recorría Europa en una bicicleta de montaña con el objetivo de trazar la palabra "arte" sobre el continente. Esta noticia falsa tuvo como victima un programa de televisión de máxima audiencia de la televisión pública Italiana, enviando este a un equipo completo a buscar a una persona inexistente, hasta el punto de viajar a Londres para continuar la búsqueda.

Por otro lado la historia de la chimpancé hembra Loota cautivó a los medios. Anteriormente había sido victima de sádicos experimentos por un laboratorio farmacéutico antes de ser salvada por el Frente de Liberación Animal para finalmente convertirse en artista. Sus pinturas fueron expuestas en la Bienal de Venecia, pero para decepción del publico Loota era una invención, y solo estaban contemplando obras realizadas por humanos.

Darko Maver176 fue un controvertido escultor y performer serbio encarcelado por conducta antisocial en una prisión de su país por la realización de esculturas de maniquíes ensangrentados y torturados. Tras conocerse esta noticia instituciones y revistas de arte Italianas exhiben y publican imágenes de su obra e incluso respetados críticos declaran conocer al artista en persona. Finalmente Darko muere en prisión durante los bombardeos de la OTAN sobre Yugoslavia de 1999, diseminándose por la web imágenes del cuerpo del artista que resultaron ser un miembro de Luther Blissett. Esto supuso la consumación de uno de las grandes farsas desarrolladas por este colectivo.

Cabe remarcar la publicación de una novela propia firmada por Luther Blissett llamada simplemente $Q$. Esta novela abarca un arco temporal de 30 años en el cual se narra la travesía a través de Europa de un radical anabaptista, el cual es perseguido por un personaje llamado Q. Esto tiene lugar durante las

\footnotetext{
${ }^{175}$ Unità di Crisi, ART: A Satellite Dérive for Harry Kipper, Observatory on Politics of Representation, [En línea], [consultado el 27 de Junio de 2016], disponible en <http://www.unitadicrisi.org/art-asatellite-derive-for-harry-kipper/>

${ }^{176}$ Mattes, Eva, Mattes, Franco, Darko Maver and fake news, [En línea], [consultado el 27 de Junio de 2016], disponible en <http://0100101110101101.org/darko-maver-and-fake-news/>
} 
sublevaciones relacionadas con la reforma protestante. Pese a su significado críptico, varios críticos sostienen que se trata de una alegoría de los movimientos de protesta de los años 60 y 70 y del posterior renacimiento de las ideologías conservadoras que cabria comparar con la contrareforma.

Este proyecto estaba compuesto por un numero indeterminado de performers y activistas de países como Italia, España o Alemania principalmente, que en Diciembre de 1999 decidieron realizar un "seppuku"177 simbólico como representación del final del plan de 5 años que el proyecto tenia como ruta a seguir. Tras todos estos años este proyecto basado en una identidad colectiva multiusuario generada en Internet sigue siendo parte del debate cultural sobre la actividad artística dentro de los media.

El verdadero Luther Blisset fue un futbolista nacido en Jamaica que llegó a jugar con la selección de Inglaterra, el Watford y el A.C. Milan, y que resulto ser uno de los primeros jugadores de color en jugar en Italia. Quizá esta sea una de las razones por las cuales este colectivo decidió tomar este nombre. En una entrevista178 de 2004 en la BBC el propio futbolista parecía bromear sobre su propia participación dentro del proyecto, hasta que el entrevistador Frank Skinner le leyó una línea del prologo de la novela Q, a lo cual Blisset respondió sacando de su chaqueta un ejemplar del libro Totò, Peppino e la guerra psichica y citando en italiano la frase: "Chiunque può essere Luther Blissett, semplicemente adottando il nome Luther Blissett"179. Al final del programa cada uno de los participantes exclamaron la frase "I'm Luther Blisset", dentro de un espacio televisivo que parecía haberse transformado en una obra del propio grupo y que aún años después sigue circulando por la red.

Los eventos conocidos como media prank, como hemos comentado anteriormente, se valen de diferentes estrategias para conseguir que periodistas profesionales publiquen artículos erróneos. Este tipo de

${ }^{177}$ El seppuku o harakiri es el suicidio ritual japonés por desentrañamiento, que forma parte del código ético de los samuráis o bushido. Generalmente se realiza delante de espectadores clavándose un arma corta en el abdomen y realizando un corte de izquierda a derecha.

${ }^{178}$ https://www.youtube.com/watch?v=3bRuTkmTljg

179 "Cualquiera puede ser Luther Blissett simplemente adoptando el nombre Luther Blissett”. 
actividades tiene diversos orígenes como podemos leer en la obra Kommunication Guerrilla Handbook ${ }^{180}$ del autonome a.f.r.i.k.a gruppe, colectivo descentralizado y ubicado en Alemania. Los miembros de este colectivo recogen el termino "spaßguerrilla" que podríamos traducir como guerrilla divertida y que es un precedente inmediato de este tipo de practicas en territorio germano. En Reino Unido este mismo termino pasa a llamarse "anarchic buffonery". En Italia se llegó a denominar a Luther Blisset "terrorista culturale". Al otro lado del Atlántico, concretamente en EEUU, también existieron diferentes colectivos como The Barby Liberation Organization (BLO), famosa por su "reverse shoplifting", un tipo de intervención que se materializó en el intercambio de los módulos de habla de muñecas Barby por los de figuras de acción masculinas, generando un cuestionamiento de las propias políticas de genero existentes en los juguetes y los roles sexuales adjuntos a estos. Otro conocido colectivo instalado en EEUU fue The Institute of Sociometry, famoso por sus tergiversación de los letreros que avisan sobre la presencia de posibles inmigrantes en las cercanías de las carreteras al sustituirlos por otros que avisan sobre la presencia de posibles policías de fronteras que pueden perseguirte. Este tipo de intervenciones y tergiversación fueron denominadas comúnmente como "culture jamming" en EEUU, Canadá o Australia para referirse a la producción y difusión de parodias de la publicidad, utilizando texto o material de la industria publicitaria para deconstruirla.

Por lo tanto, podemos afirmar que las intervenciones no convencionales dentro de procesos convencionales de comunicación, que analizan y cuestionan la gramática cultural, creando campañas dentro de los medios, han sido usadas como un elemento central en la actividad artística alrededor de los medios de comunicación valiéndose de la impostura y la ficción identitaria como herramienta esencial. Gracias a la constitución de Internet como macromedio de nuestro tiempo podemos considerar a este el medio hegemónico de nuestro tiempo, sobre el cual intervenir y desplegar diferentes tácticas dentro de lo cotidiano, poniendo de manifiesto la manera en la cual los medios elaboran y reproducen una visión hegemónica de nuestra realidad.

${ }^{180}$ Luther, Blisset, Brünzels, Sonja, op. Cit., 2000. 


\subsection{ANONIMATO VS PERSISTENCIA.}

Este anonimato tiene su máxima expresión en el grupo, no fácilmente definible, conocido como Anonymous, nombre que proviene de los tablones de imágenes de Internet y del nombre con el cual publican todos los usuarios de estas webs. Un claro ejemplo de este tipo de espacios sería 4chan ${ }^{181}$, un tablón de imágenes, que junto a la Encyclopædia Dramatica ${ }^{182}$, fue el espacio en el cual el grupo tuvo su germen primigenio.

Si queremos responder a la pregunta de quien es Anonymous, deberemos responder que ha sido muchas cosas distintas a lo largo de su historia, desde un grupo de bromistas, geeks ${ }^{183}$ y trolls ${ }^{184}$, hasta el espacio de activismo digital más importante del mundo. Podríamos decir que Anonymous es un nombre que cualquiera podría tomar prestado, presentándose como identificable mediante unos símbolos e ideas comunes sobre la libertad de la información e Internet, y que ha generado una subcultura a su alrededor. Es por lo tanto una especie de franquicia open sourse, utilizada por individuos y grupos para la organización de acciones colectivas en la esfera pública. En esta red hay demasiados nodos para que surja un líder, de hecho es treméndamente difícil cuantificar el número de "anons"185 que existen ya que varía dependiendo de la acción que vayan a llevar a cabo.

\footnotetext{
${ }^{181}$ 4chan es unos de los tablones de imágenes más conocidos de Internet. Se usó en un principio para discutir sobre anime y manga, pero debido a el anonimato de sus usuarios comenzó a ser usado por el activismo de Internet y más concretamente por el grupo Anonymous.

${ }^{182}$ La Encyclopædia Dramatica es una wiki carente de límite aparente o reglas. Esta realizada en lengua inglesa y sirve como parodia la enciclopedia Británica y Wikipedia.

${ }^{183}$ El término geek se usa en español para describir a personas fascinadas con la informática y la tecnología en general. En lengua inglesa adquiere un carácter más amplio al servir para describir a gente excéntrica y obsesionada con el trabajo intelectual, que no sigue ninguna moda y es socialmente torpe.

${ }^{184}$ El termino troll forma parte del argot de Internet y sirve para especificar a un usuario que publica mensajes de carácter disruptivo, que no se ajusta al tema tratado, o sin ningún interés en diferentes espacios de discusión con la intención de obtener una respuesta emocional del resto de usuarios.

${ }^{185}$ Diminutivo usado comúnmente para nombrar a los miembros de Anonymous.
} 
Como nos cuenta la antropóloga estadounidense Gabriella Colleman en su obra Las mil caras de Anonymous ${ }^{186}$, su actividad comenzó en 2008 con su campaña de trolling ${ }^{187}$ contra la Iglesia de la Cienciología, mediante la filtración de un video ${ }^{188}$ de promoción de la Cienciología en el que Tom Cruise exaltaba la importancia de esta Iglesia hasta tal punto de resultar cómico de manera no intencional. La respuesta de la Cienciología fue intentar retirar el video de la red y amenazar con demandas millonarias, a lo cual Anonymous respondió con el despliegue de la Operación Charnology. Se lanzó un video ${ }^{189}$ que contenía un llamamiento a luchar contra esta organización. Este video, como apunta Colleman, fue en realidad una broma que fue tomada como real por miles de usuarios incluso exmiembros de la Cienciología, provocando toda una oleada de protestas, tanto en la red como en la calle. Entre las acciones se encuentran ataques de denegación de servicio contra sus webs, llamadas masivas a sus centros y el envío de faxes en negro, por no hablar del envío de miles de pizzas a eventos de la Cienciología ${ }^{190}$ que años después aún continúan produciéndose.

Como hemos visto el humor y la capacidad de ofender va a formar parte de sus prácticas activistas, su ética y su estética de manera continuada, sin dejar por ello de afrontar problemáticas serias dentro del activismo. El Lulz, es un acrónimo usado dentro del argot de Internet y más específicamente de estas comunidades. Su finalidad es denotar la risa provocada por alguien a quién se está gastando una broma, o la razón por la cual se realiza esta acción, de ahí derivó a frase "I did it for the lulz", como excusa para realizar este tipo de "pranks"191. Es una forma de humor un tanto macabra y pervertida, forjada en

\footnotetext{
${ }^{186}$ Colleman, Gabrielle, op. Cit., 2016.

${ }^{187}$ Se trata de acciones deliberadas con el fin de provocar una reacción.

${ }^{188}$ Video que contiene una entrevista a Tom Cruise realizada como video promocional de la Iglesia de la Cienciología filtrado por Anonymous [En línea], [consulta 25 de Junio de 2016], disponible en $<$ https://www.youtube.com/watch?v=UFBZ_uAbxSO>

${ }^{189}$ Video en el cual se realiza un llamamiento a luchar contra la Iglesia de la Cienciología publicado por Anonymous [En línea], [consulta 25 de Junio de 2016], disponible en <https://www.youtube.com/watch?v=fC2qxyELz9c>

${ }^{190}$ Hidell, Alek, Scientology Stiffs The Pizza Guy on a \$2,000 Bill, [En línea], [consulta 25 de Junio de 2016], disponible en <http://anonhq.com/scientology-stiffs-pizza-guy-2000-bill/>

${ }^{191}$ Voz inglesa para broma usada muy comúnmente dentro de la cultura de Internet incluso en países no angloparlantes.
} 
los tablones de imágenes de Internet y cuya finalidad suele ser la ruptura del equilibrio emocional de otros.

Ya en 2010 nacen nuevos grupos que comienzan nuevas protestas como las dirigidas contra el copyright, contra el "blackout" bancario a Wikileaks, en apoyo a los manifestantes de Túnez, a favor de los indignados en España o su particular guerra contra el ISIS. Como vemos esta organización tiene como principales metas defender la libertad de expresión dentro de la red y la independencia de los medios.

Una de las claves del éxito de esta organización es su habilidad para captar la atención mediática y dirigirla hacia un problema en concreto, sin embargo podemos afirmar que la impredecibilidad es una de sus características más poderosas y que más intimida a sus enemigos. Esto se debe a su capacidad para hackear organizaciones y gobiernos y exponer información al público. Al tener una estructura flexible y abierta no están sujetos a un programa o plan predefinido, generando confusión en sus oponentes mediante esta elasticidad. Al no contar con lideres, son determinados individuos dentro de cada grupo, generalmente los miembros de más largo recorrido dentro de la organización, los que cuentan con un mayor grado de autoridad. Pese a esto, todas las acciones siempre son reclamadas en nombre del grupo, siendo un tabú la búsqueda del beneficio o fama personal. Esta característica ética de Anonymous es sumamente interesante por la implicaciones que tiene el hecho de defender espacios en los cuales la gente pueda hablar de manera anónima sobre temas políticos y coordinar acciones en ese ámbito. Por lo tanto, esta organización explora mediante su posición de anonimato la posibilidad que los ciudadanos tienen de ser sinceros y contestatarios frente a sus gobiernos y organizaciones mediante la adopción de esta identidad colectiva o supraconciencia en tiempo real, flexible y elástica, confusa e imprevisible y ante todo incuantificable. Como la propia organización transmite en sus comunicados se trata de una inteligencia colectiva de la era digital desarrollada en tiempo real. Millones de personas están conectadas simultáneamente construyendo grupos, flujos de información, acciones y ideas nunca vistas. Anonymous es, según sus miembros, la primera forma de una identidad colectiva en tiempo real, como una especie de versión beta, mutante e imprevisible de una nueva era. 
Para ellos el anonimato es una forma de promover el cambio social y de comunicar, cosas que parecen no haber entendido las compañías tecnológicas, si tenemos en cuenta las mecánicas cada vez más generalizadas de identificación dentro de Internet y los procesos de self-branding que tienen lugar dentro de la web 2.0. En cambio Anonymous asume que la identidad de cada individuo esta compuesta por partes de identidades colectivas ya que estas no son absolutas. La mascara del carismático personaje del comic de Alan Moore y David Lloyd, $V$ de Vendetta, inspirada en el conspirador inglés Guy Fawkes ${ }^{192}$, ha generado una especie de identidad ready-made para toda una generación de manifestantes que han sido inspirados por esta estilizada reminiscencia romántica con toques anárquicos, que ha sido trasladada a la perfección al activismo actual. A diferencia de los hackers clásicos que generan una identidad que puede ser documentada y seguida, y dirigiendo a las autoridades hacia ellos, este tipo de hacktivismo no busca la notoriedad mediante la propia identidad ficticia individual de un hacker, sino mediante la transmisión del propio mensaje del colectivo y no las diferentes hazañas realizadas en el área del hackeo. Por lo tanto nos hayamos ante una comunidad que se contrapone a la cultura de las "celebrity" que absorbemos a través de los media, que por otro lado trivializa y banaliza la cultura y el arte. Buscan en el anonimato la herramienta necesaria con la cual ampliar un espacio de libertad, el cual se ve cada vez más reducido dentro de la esfera pública debido a la propia vehiculización del comportamiento que el propio funcionamiento de la red y la vigilancia indiscriminada nos impone a diario. Paradójicamente el anonimato ha generado una identidad colectiva reconocible por todos y que entra dentro de lo que podríamos considerar cultura popular. Esta identidad surgida del anonimato personalizada en la mascara creada en base al rostro de un conspirador representa una ética que rechaza todo tipo de lideres y reconocimiento personal, como reacción ante el culto al individualismo y el éxito de la cultura occidental. Como dijo, según su nieto Merlin Holland, el escritor, dramaturgo y poeta irlandés Oscar Wilde: "Dad una mascara al hombre y os dirá la verdad".

\footnotetext{
192 Guy Fawkes participó en la conocida como Conspiración de la Pólvora, que intentó hacer explosionar la Cámara de los Lores de Londres en 1605.
} 


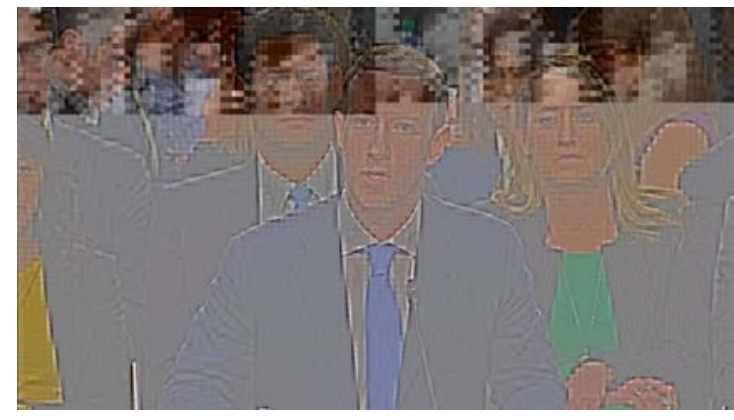

Figura 29. Mark Zuckerberg ante el Senado de los EEUU.

Frente a este tipo de conciencia colectiva basada en el anonimato podemos observar como las principales compañías que trabajan alrededor de las nuevas funcionalidades de las Web 2.0. han pasado a primar dentro de sus políticas la identificación de los usuarios como una práctica habitual y deseable que de hecho fundamenta el éxito de sus propios servicios. Como el fundador de Facebook Mark Zuckerberg ha reconocido, entre las razones del éxito de esta red social se encuentra "La posibilidad de que se puedan compartir cosas con tus amigos y el hecho de que la identidad de la gente que entra en Facebook es real. Hay otros sitios en Internet donde uno puede adquirir una identidad ficticia. Pero el secreto de Facebook es que prima la identidad real"193. Esto obviamente delimita y modela el tipo de interacciones que van a tener lugar en esta red social, implementando un tipo concreto de publicaciones y dinámicas sociales, que mediante la transparencia voluntaria, alimentan la gran red de relaciones generadas en estos espacios, y del mismo modo impide en gran medida la libre expresión de los usuarios.

Por otro lado, y como se ha podido constatar recientemente, se otorga un gran poder a este tipo de compañías las cuales poseen, gestionan y analizan grandes cantidades de información personal y datos que son susceptibles de ser vendidas para fines comerciales o de otro tipo. Esto llego a su culmen a mediados de 2018 cuando el fundador de Facebook tuvo que compadecer ante el Senado de EEUU para dar explicaciones sobre el caso de Cambridge

\footnotetext{
193 Jiménez Barca, Antonio, Las revoluciones populares nos las hace Facebook, 25 de Mayo de 2011, El País, [Consultado el 23 de Enero de 2016] disponible en <http://tecnologia.elpais.com/tecnologia/2011/05/25/actualidad/1306314067_850215.html>
} 
Analytica, en el cual gracias a los datos obtenidos por Facebbok dicha empresa logró trazar un perfil de personalidad de cada adulto en EEUU en base a un preciso modelo psicológico y algorítmico, de manera que pudieron averiguar de que manera influir en el voto de los ciudadanos en las elecciones de 2016. Esto hizo que Facebook publicara anuncios que reforzaran los argumentos del candidato presidencial Donald Trump de manera indirecta. Por ejemplo, en base a la promesa del mantenimiento del derecho a portar armas, se publicaron miles de anuncios en los cuales se argumentaba que las armas eran un elemento fundamental del cuidado de la personas allegadas.

Sin embargo, como hemos visto la existencia de otros modelos minoritarios de comunidades basadas en el anonimato o las identidades múltiples generan la posibilidad de salvaguardar el ámbito privado en mayor medida que mediante las redes sociales hegemónicas. Un ejemplo a este respecto es comunidades como 4chan, unos de los espacios en los cuales se generó el grupo activista Anonymous, cuyo nombre hace precisamente referencia al propio apodo que reciben todos los usuarios de este espacio. Este tablón de imágenes se estructura en multitud de temas a los que los usuarios pueden acceder para comenzar un thread o grupo de mensajes sobre una misma cuestión en concreto. Este tablón no presenta ningún tipo de registro y los comentarios se borran automáticamente en unos pocos días. Sin duda este tipo de comunidad ejemplifica otra manera de afrontar la privacidad online, utilizando esta como manera de expandir a libertad de expresión de los usuarios. Este aspecto lo ha convertido en el tablón de imágenes con más tráfico a nivel mundial y ejemplo en muchas ocasiones de la puesta en práctica de la inteligencia colectiva de la multitud interconectada para un fin determinado, ya sea legal o no. Su creador Christopher Poole apodado moot, ha puesto en valor en multitud de entrevistas el hecho de que este tablón de imágenes no tiene memoria, es decir registro, valorando muy positivamente el uso del anonimato y las identidades múltiples.

Estas dos plataformas, tanto Facebook como 4chan nos muestran dos maneras diametralmente opuestas de tratar la cuestión de la identidad online. Por un lado nos encontramos con la tendencia hacia una identidad permanente o real, que es aprovechada por opacos mecanismo de adquisición de datos y manipulación, y por otro lado con otro tipo de espacios inspirados en la primera época de Internet en los cuales el anonimato es la clave de su éxito y del tipo de interacciones y actuar que se desarrolla. Sin duda más allá de la 
polémica alrededor de la utilización de datos o el mal uso que en ocasiones se hace del anonimato, es necesario que existan diferentes plataformas que ofrezcan todo tipo de opciones a los usuarios. Espacios como 4chan son espacios abiertos en los cuales la crudeza y la obscenidad son el resultado de la ausencia de filtros. Sin embargo, cada vez es más evidente que las aplicaciones hegemónicas se han movido hacia un formato de redes sociales en el cual la persistencia de nuestra identidad es una cuestión obligatoria, regalando nuestra privacidad al aceptar unos términos y condiciones de uso que raramente nos paramos a descifrar.

\subsection{MEDIOS SOCIALES, BRANDING E IDENTIDAD}

Como hemos podido comprobar, en la red la comunicación y la interacción estarían sujetas a las diferentes naturalezas de la identidad que mostramos, bien coincidente con el mundo físico y que viene propiciada por el funcionamiento del modelo de web 2.0, o bien identidades ficticias creadas ex profeso para determinada labor o contexto y que asume un rol de mascara bajo la que nos escondemos.

Desde principios del siglo XXI el cambio que supuso la aparición de las redes sociales volcó la actividad de los usuarios dentro de Internet hacia la tendencia a generar y reflejar una voz e imagen propia. El placer derivado del reconocimiento publico y la gratificación que produce la admiración de otros usuarios, mediante, por ejemplo, la dopamina que nos proporciona un "me gusta", genera una sensación inmediata de placer en el cerebro, y nos estimula a buscar aquel tipo de actividad o situación agradable que nos ha producido esta descarga. Al igual que multitud de drogas las redes sociales nos proporcionan dosis de esta sustancia asociada a el apego, el enamoramiento y la adicción. Para ello este neurotransmisor activa una sustancia llamada fenitelamina que explica procesos humanos como los antes citados.

Será Neil Postman quien en su obra Divertirse hasta morir194 de 1985, compare el mundo contemporáneo con la obra de Aldous Huxley Un mundo feliz ${ }^{195}$,

\footnotetext{
${ }^{194}$ Postman, Neil, op. Cit., 2001.

${ }^{195}$ Huxley, Aldous, op. Cit., 2013.
} 
donde la población sacrifica sus derechos para obtener un tipo de droga del placer que este relaciona con la distracción. Postman ve como nuestra sociedad es oprimida en base a su adicción al entretenimiento, de la misma manera que en 1984196 de George Orwell esta es oprimida por el control del estado. Por otro lado compara la televisión con la droga suministrada por el gobierno en Un mundo feliz, y mediante la cual los derechos de los ciudadanos son intercambiados por entretenimiento. Según Postman, Orwell y Huxley no trataron el mismo tema. Por un lado Orwell se centra en un control represivo exterior implementado mediante el dolor. En cambio para Huxley nosotros seremos los que desearemos el control mediante las tecnologías asociadas a este. Mientras Orwell habla de la prohibición de libros y por lo tanto del acceso a la información, Huxley temía una avalancha heterogénea de datos que provocara el desinterés por la información, llegándose a considerar esta algo trivial. Estas dos posiciones podemos verlas en relación con el concepto de hegemonía de Antonio Gramsci197.

Como hace tiempo diferentes medios, gurús, precursores digitales y expertos se han atrevido a afirmar, las redes sociales están transformando las relaciones humanas y la sociedad, el periodismo y los medios de comunicación tradicionales. Ahora empieza a vislumbrarse como los propios creadores de este tipo de espacios han utilizado estos efectos en su propio beneficio, tal es el caso de Chamath Palihapitiya o Sean Parker, ambos vinculados a Facebook. Parker afirma que redes sociales como Facebook o Instagram fueron creadas a propósito de este modo para explotar diferentes debilidades psicológicas humanas ${ }^{198}$. Estamos pues en un escenario en el cual somos construidos frente a las interacciones que recibimos de los demás usuarios, tanto negativas como positivas, mientras nos mantienen conectados y disciplinados ante estas estructuras mediáticas.

\footnotetext{
${ }^{196}$ Orwell, George, op. Cit., 2014.

${ }^{197}$ Gramsci, Antonio, op. Cit., 2006.

${ }^{198}$ Méndez, Lucia, La dopamina de las redes, El Mundo, [En línea], 2017[consulta 21 de Marzo de 2018], disponible en

<http://www.elmundo.es/opinion/2017/12/16/5a342ccce5fdea97248b4626.html>
} 
La identidad online ha adquirido cualidades de producto que nos ha llevado a un selfbranding constante. La construcción y exhibición identitaria, a partir de la Web 2.0. ha dejado de plantear la multiplicidad y el anonimato como características principales para dar paso a un yo que quiere hablar de si mismo y hacerse a si mismo, mediante la autopromoción de un individuo influido por las prácticas y discursos del capitalismo sujetos a las leyes del mercado, es sobre todo, en el caso de las principales Redes Sociales y plataformas como Youtube, Vimeo, un escenario en el cual la identidad se construye con respecto a los demás usuarios, entendida como un actuar mediante el cual generamos relaciones, y que funciona como un mercado de la observación en el que cada usuario produce contenidos a la vez que consume los de otros usuarios, dando origen a términos como prosumer. Este modo de actividad tiene como objetivo remarcar la naturaleza participativa y relacional de esta identidad como forma de actividad que nosotros mismos desarrollamos dentro de un espacio. Este tipo de construcción identitaria espectacularizada busca la mirada del otro para constituirse como tal.

Como Jacques Lacan nos decía con su concepto de la teoría psicoanalítica denominado El estadio del espejo, el bebé por primera vez toma conciencia de si mismo cuando se reconoce en el espejo como un ente autónomo y aprende a distinguirse de sus semejantes mediante esta imagen especular. Tiene implicaciones determinantes para la formación del yo como instancia psíquica según el propio Lacan. Por lo tanto podríamos denominar este nuevo medio como el espejo el cual necesitamos mirarnos para reconocernos respecto a la multitud interconectada, un espejo que nos devuelve la mirada en forma de interacción de otros usuarios sobre nuestra propia autoconstrucción identitaria en relación a la cultura de redes, que adquiere forma de marca o producto encaminado a una autopromoción personal dentro del capitalismo globalizado de la web 2.0. Es por ello que se podría definir la identidad online no como algo estático, sino como un constructo moldeable, como una acción cotidiana que realizamos sobre nosotros mismos diariamente.

La configuración del yo, ya no es única o unilateral, es a través de la interacción en Internet como construimos múltiples perfiles, a la vez que difuminamos límites antes establecidos, convirtiéndose este medio en un territorio de experimentación, donde el individuo se autorepresenta. Esta 
producción, tal y como nos cuenta Gemma San Cornelio en su obra Arte $e$ Identidad en Internet ${ }^{199}$, está ligada al concepto de self branding o autopromoción, proponiendo nuestro actuar en la redes como un proyecto reflexivo del yo, el cual según nos cuenta Foucault ${ }^{200}$, es sin duda algo hecho o producido mediante la acción sobre uno mismo.

Dentro de esta vorágine de autoconstrucción, la imagen es una de las principales herramientas a la hora de autorepresentarnos dentro de la red. Se ha constituido como el interfaz mediante el cual nos comunicamos dentro del hábitat de las redes sociales. La finalidad de establecer interacciones es crear significados compartidos, construcciones de la realidad inmediata y deseos mutuos a partir de los símbolos que se intercambian. Este entorno mediático da la oportunidad al usuario de ocupar un lugar en el mundo para dar sentido a sus actos y a su propia existencia. Son marcos de referencia, encuadres, que ordenan las experiencias y hechos de la cotidianeidad para dar significado a la realidad. De esta manera el usuario compone su yo social y subjetivo a la vez.

Esto produce una identidad influenciada por el propio medio en el cual esta se desarrolla, obligándonos a seleccionar lo que se muestra y se omite sobre nosotros mismos dentro de la vida cotidiana que realizamos cada día, y que simboliza una conquista de la posibilidad de manofacturar nuestra propia imagen personal y contraponerla a la de los demás. Su aspecto más seductor se encuentra en la narración como aspecto inseparable de la identidad y que se caracteriza por lo inmediato, indiscreto y exhibicionista, en ocasiones, de esta hibridación entre modelos textuales y visuales de representación interactiva Es una actividad que realizamos diariamente dentro de lo que se asemeja a una especie de performance extendida que actúa sobre nuestro propio yo. Como hemos podido observar por la obra de Amalia Ulman esto ha sido reapropiado por la práctica artística, transmutando mediante la tergiversación las cualidades de este tipo de redes para visibilizar la manera en la cual la identidad es constituida dentro de estos espacios.

\footnotetext{
${ }^{199}$ San Cornelio, Gemma, op. Cit., 2008, p. 18.

${ }^{200}$ Foucault, Michel, Nietzsche, la genealogía, la historia, Pre-Textos, Valencia, 1988, p. 153.
} 
Por otro lado habría que realizar una reflexión sobre la noción del avatar y su impacto en la constitución de la identidad en Internet caracterizada por su multiplicidad y disolución dentro de un sin fin de cambios y mutaciones constantes que son un reflejo de lo voluble y cambiante de este medio, y de nuestras representaciones corpóreas dentro del mismo, como contrapunto a lo experimentado en la redes sociales. Esto se contrapone a las lógicas identificatorias de la web 2.0. El avatar aparece como un medio mediante el cual identificarse en un espacio virtual o metaverso, posibilitando el hecho de estar en varios lugares al mismo tiempo, siendo por lo tanto una especie de prótesis virtual que extiende nuestras acciones y nos representa como individuos, teniendo siempre como meta mostrar lo que queremos ser, pero con la posibilidad de customizar y configurar nuestra propia exterioridad y apariencia de la manera que estimemos oportuna. Abriendo por tanto, un gran abanico de opciones y diferentes maneras de autorepresentación dentro de estos espacios.

Es una vía de escape a las fijaciones identitarias que dependen de la corporalidad física, y que dan la posibilidad de usar el propio yo mediante su representación corporal como una metáfora que pone en tela de juicio este cambio de rumbo hacia lo real y cotidiano, pero que poco a poco va disolviéndose en un océano de imágenes cotidianas de millones de usuarios que se contraponen a la virtualidad de los metaversos en los cuales los avatares se desenvuelven.

La serie de imágenes 13 Most beautiful Avatars realizada en 2007 por Eva y Franco Mattes, muestran una serie de impresiones de rostros de avatares de Second Life, que al ser simplemente avatares componen autorretratos imaginarios de esos usuarios. Esta serie está inspirada en la serie 13 Most Beautiful Boys and Girls realizada por Andy Warhol. En esta serie Eva y Franco querían poner de manifiesto la inversión creativa que supone la realización del alter ego virtual de cada individuo, apareciendo la noción de retrato clásico que sirve para mostrarnos como nuestros propios proyectos de lo que en realidad queremos ser, siendo en realidad el propio objetivo del retrato en si. 


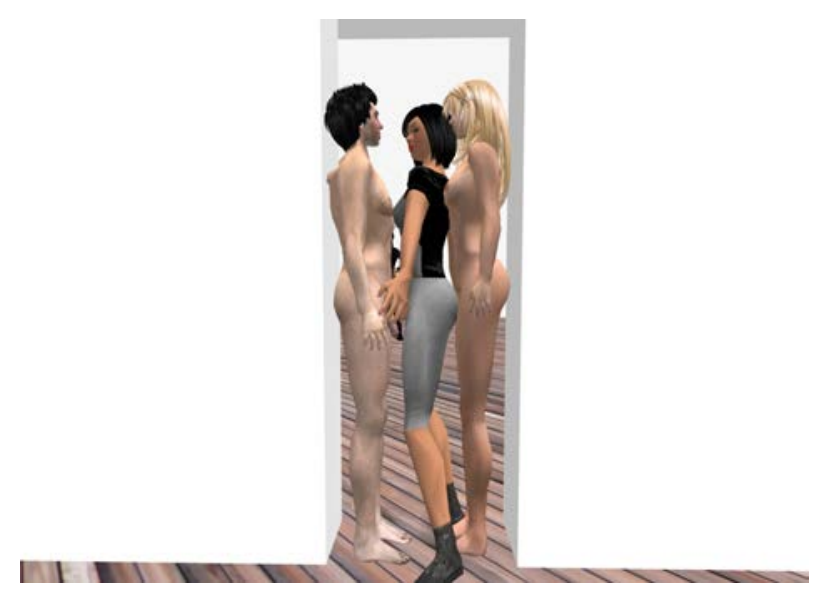

Figura 30. Eva y Franco Mattes, Synthetic Performances, 2007-2010.

Gracias a Internet hemos disuelto las barreras antes férreas de los público y lo privado a la vez que hemos cambiado nuestra dimensión sobre el tiempo comprimiéndola y generando nuevas experiencias en el ámbito de lo virtual generando performidad más allá de una simple puesta en escena y produciendo experiencias en lugar de una recreación que podemos compartir más allá de los tradicionales conceptos de territorio y espacio.

Eva y Franco Mattes realizaron la seria Synthetic Performances desde 2007 a 2010 en la cual realizaban un gran número de reconstruccion de acciones de carácter más transgresor dentro del mundo de la corporalidad y que son realizadas dentro del metaverso Second Life, incluyendo reconstrucciones de obras de Marina Abramovic, Gilbert \& George , Vito Acconci , Chris Burden y Valie Export, y en las que cualquiera podía participar conectándose a este metaverso.

Como nos narra Juan Martín Prada en su libro Practicas Artísticas en Internet en la Época de las Redes Sociales, el tema de la identidad en Internet tuvo en los años 90 la tarea de desentrañar el tipo de participación que llevamos a cabo dentro de este espacio. Esto conceptualiza Internet como un actuar vinculado con el área de lo relacional, lo cual fue del todo acertado si lo que queremos es redefinir el concepto de identidad. Esta se conforma con respecto a los demás, recordemos la máxima de Marc Augé "no hay identidad sin 
alteridad". Es por lo tanto clarificador el hecho de que la denominada web 2.0 necesite de la actividad de los usuarios para funcionar, generando cuerpos de datos mediante los cuales poetizar sobre lo múltiple y lo colectivo. Claros ejemplos de esta tendencia son las obras de artistas como Laura Bey o Roberto Aguirrezabala, donde la autoexperimentación poética de nosotros mismos sucede en el propio medio, siendo parte del sistema explorado, mostrando los propios obstáculos para el dialogo y el entendimiento generados por la perdida de la privacidad, monitorización e imposición de reglas que aluden al papel de la identidad en la cultura de redes.

Po otro lado, desde la segunda década del presente siglo las dinámicas empresariales han sido orientadas a potenciar los factores emancipadores e igualitarios de la conectividad, generando una ideología del consumo que busca la gestión de la identidad y la autorepresentación. Este modo de convergencia entre dominación y libertad tiene por objetivo la capacidad de regular la subjetividad, cobrando especial relevancia el tema de la reafirmación del yo dentro de la práctica artística, usando como herramienta para ello las redes sociales y el fenómeno blog. Este es un yo identitario, que quiere hablar de si mismo, generando un compromiso con la expresión desde un punto de vista personal, propio de las redes sociales actuales, donde aportamos nuestra información real, produciendo comunidades que tienen como objetivo mostrar nuestro lado más particular e íntimo. Esto produce una autoconstrucción frente a los demás, que según los propios creadores de estas aplicaciones es el factor primordial que ha llevado al éxito a este tipo de redes, en base al uso de la identidad real, frente al uso mayoritario de identidades ficticias durante la web 1.0. 


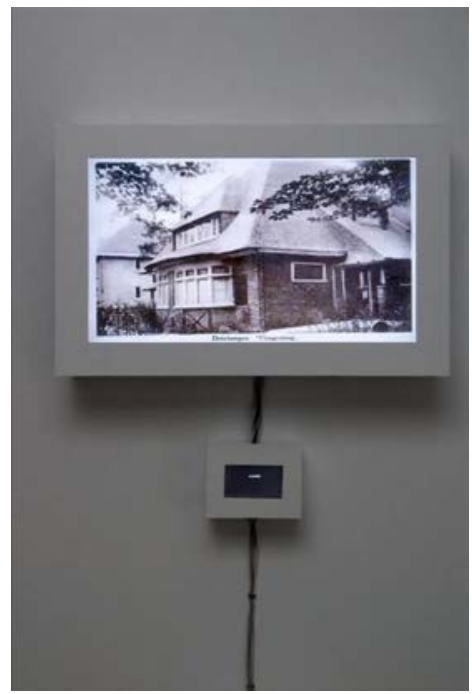

Figura 31. Gregory Chachonsky, Peoples 2007

La generación de identidades falsas y juegos antiidentitarios van a conformar las principales estrategias a la hora de intentar evadir los intentos de las grandes redes sociales de gestionar lo que se muestra como realidad o verdad respecto a nosotros mismos. Paradigmático de este tipo de planteamientos es la obra Peoples de 2007, donde los artistas Gregory Chatonsky y Jean Pierre Balpe construyen, mediante un generador de texto, biografías imaginarias que son acompañadas por imágenes de Flickr.

Otra de la grandes problemáticas cercanas a la identidad nos recuerda el propio hecho de la desigualdad sexual o racial escondida detrás de muchas tecnologías de la conectividad real. Internet sigue perpetuando los mismos estereotipos de la identidad de género debido a haber sido estructurado de acuerdo al sistema económico imperante heredero del patriarcado.

La aparición del ciberfeminismo en los 90 propone una disolución de la fronteras entre géneros. Pasan de proponer un lenguaje femenino en la red a proponer estrategias de dislocación y sobrexposición identitaria, como podemos constatar en la obra de Petra Cortright, Sprkelles. 
En otra de sus obras llamada Vvebcam de 2007, Cortright se aparta del genero cam girl para mostrarnos una de las tempranas muestras en las cuales el artista adopta el rol de un usuario frente a la pantalla dentro de un video de Youtube en el cual diferentes animaciones y efectos surgen alrededor de su rostro. Mediante la utilización de palabras claves inexactas este video logró atraer a un gran número de usuarios, que increparon a la artista por en la caja de comentarios. La artista participó en los comentarios del video, interactuando de manera visceral con sus propios haters y trolls. Mostrándonos como el precio de sus videos es calculado en función de las propias visitas de estos, la artista pone de manifiesto la manera en la cual el contenido de los creadores amateurs son delimitados en base a la interacción con los usuarios y el feedback recibido por parte de estos. Del mismo modo, nuestra identidad online y la manera en la cual nos mostramos ante los demás dentro de la esfera pública es en gran medida determinada por este tipo de interacciones.

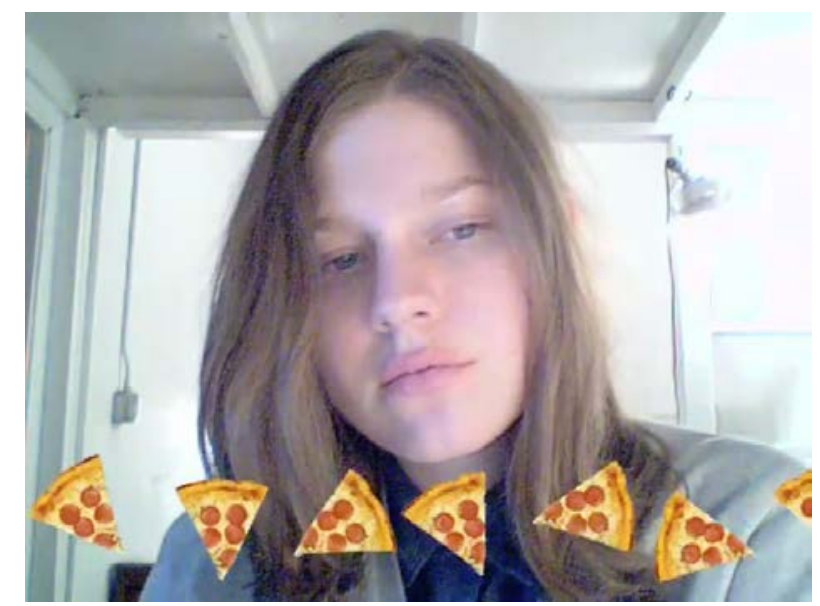

Figura 32. Petra Cortight, Vvebcam, 2007.

Respecto a la desigualdad social, podemos señalar las obras centradas en las políticas de la autorepresentación y exclusión dentro de las formas de producción del imaginario amateur. Como podemos ver en la obra de Daniela Ortiz, 97 empleadas domesticas, donde aparecen accidentalmente empleadas domesticas dentro de fotografías de la clase alta peruana difundidas por la redes sociales, haciendo referencia a lo que aparece fuera de plano en el sentido social de la expresión. 


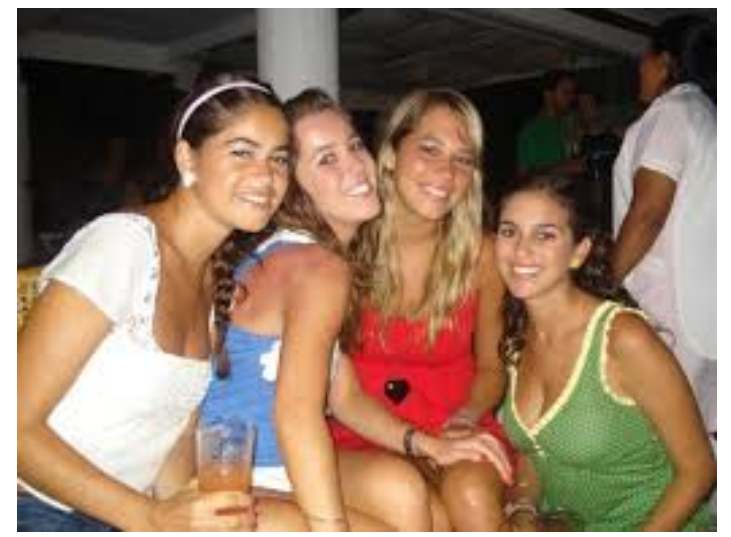

Figura 33. Daniela Ortiz, 97 empleadas domesticas, 2010.

En definitiva cabria reflexionar sobre nuestro nuevo espacio identitario en base a las nuevas realidades mediáticas que han aparecido en los últimos decenios, para concluir que gran parte de nuestro nuevo espacio simbólico reside en cada monitor de manera intangible, en parte por la nueva aparición de herramientas que propician la autoconstrucción de uno mismo respecto a los demás, pero también como consecuencia de un espacio público que ha abandonado en gran parte su función de ágora en la cual se producen relaciones o intercambios, generando significado mediante el uso continuado del mismo. Dentro de la red la identidad ha adquirido de manera dramática el estatus de producto abierto al público que se construye en base a el y las interacciones que se producen dentro del espacio mediático de Internet. Las lógicas de funcionamiento de la web 2.0 han producido una hibridación de identificación y anonimato que coexisten en diferentes espacios de Internet, siendo la primera la opción hegemónica en el campo de la autorepresentación bien sea mediante el autorretrato o narraciones de tipo autobiográfico basadas en representaciones verbo-icónicas. Es por ello que siguiendo el ejemplo de artistas como Gregory Chatonsky y Jean Pierre Balpe debemos cuestionar la manera en la cual nos representamos y construimos frente a los demás teniendo conciencia de las implicaciones que la manera en la cual usamos los media tiene sobre la construcción cotidiana de nuestra identidad realizada a través de las redes sociales. 
5. METODOLOGÍA ARTÍSTICA 


\subsection{EL ARTISTA COMO EXPLORADOR MEDIÁTICO. EXPLORACIÓN.}

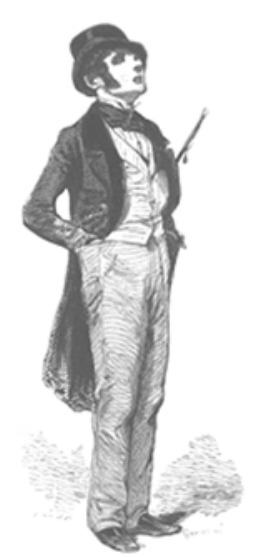

Figura 34. Paul Gavarni, Le Flâneur, 1842.

Una de la las características más importantes de la manera en la cual desarrollamos nuestra actividad en la red, es la de enfrentarnos a un espacio ignoto que guarda multitud de rincones por descubrir y escudriñar, dentro de un modo de actuar que podemos considerar inconsciente. Como usuarios buscamos nuevos horizontes y oportunidades en zonas nunca exploradas, que nos ofrezcan posibilidades no concebidas anteriormente y que nos gratifiquen con la sensación de estar visitando espacios que aportaran un valor a nuestra experiencia en la red, que innoven en cuanto a nuestras posibilidades creativas y la manera en la cual generamos relaciones, o como no, en la manera en la cual nos proyectamos y amplificamos como individuos dentro de lo global. El hecho de explorar nuevos territorios es algo que ha amplificado su significado desde que se hizo posible escudriñar la mayor parte de la superficie terrestre desde los collages navegables que conforman los geonavegadores, confeccionados mediante imágenes satélite tomadas automáticamente. Esto ha generado comunidades de usuarios habidos por explorar esta mezcla de lo real y lo virtual, cambiando incluso la manera en la cual observamos y concebimos la exploración de nuestro medio físico. 
Sin embargo, algo de lo que ya Aristóteles y los peripatéticos advirtieron en la Grecia clásica y que fue retomado por los románticos y los surrealistas, fue el atractivo de vagar sin rumbo como fuente para alimentar la imaginación. A colación con esta cuestión podemos destacar la obra de Jean-Jacques Rousseau Las ensoñaciones del paseante solitario 201 , Un paseo invernal de Henry David Thoreau ${ }^{202}$, o El arte de pasear de Karl Gottlob Schelle ${ }^{203}$. No podemos olvidar la teoría de la deriva o dérive, desarrollada por los Situacionistas dentro de la disciplina de la psicogeografía. Todos ellos argumentaron sobre como el vagar incentiva la imaginación y la creatividad. Convertida en una actividad carente de objetivos, se concretó en la figura del flâneur, acuñada por Charles Baudelaire 204 . Esta actividad fue recontextualizada y estudiado por otros como Walter Benjamín ${ }^{205}$ o Susan Sontag ${ }^{206}$, ubicándola como producto de la sociedad capitalista y la ciudad, que gracias a las cámaras compactas se torna voyeurista y testigo fiel del mundo mediante la fotografía. Por otro lado, la actividad de explorar nuevos territorios siempre ha estado ligada al desarrollo tecnológico y sus limitaciones, pero también a aspectos sociales y económicos. Es aquí donde las nuevas tecnologías de la información aparecen como nexo de unión entre estos aspectos para dar origen a un gran numero de formas espaciales de carácter inmaterial que existen de manera persistente dentro de la red de Internet gracias a la interconexión constante entre ordenadores.

En Tentativa de agotar un lugar parisino, el escritor francés George Perec cataloga todos los elementos de diferentes localizaciones de la Plaza de SaintSulpice de París, cuya enumeración plantea un orden dentro del desorden, siendo una clara muestra literaria de exploración de un lugar. Dentro del espacio urbano nos encontramos con metodologías tan interesantes como la observación flotante, empleada en la obra El paisaje de la multitud, la cual forma parte de los proyectos presentados en esta tesis. Esta metodología de investigación en el espacio urbano surge durante los años 80 del siglo XX

\footnotetext{
201 Rousseau, Jean-Jacques, Las ensoñaciones del paseante solitario, Alianza Editorial, Barcelona, 2016.

202 Thoreau, Henry David, Un paseo invernal, Errata Naturae, Madrid, 2014.

203 Gottlob Schelle, Karl, El arte de pasear, Diaz \& Pons, Madrid, 2013.

204 Baudelaire, Charles, El pintor de la vida moderna, Taurus, Madrid, 2013.

205 Benjamin, Walter, El libro de los pasajes, Akal, Madrid, 2005.

206 Sontag, Susan, Sobre la Fotografía, Debolsillo, Barcelona, 2008.
} 
como resultado de la aparición de un tipo de esfera pública en la cual hay una gran mutabilidad en cuanto a los protagonistas del espacio urbano por lo efímero de su permanencia física y de las relaciones que se establecen. Este tipo de metodología también surge como respuesta a un nuevo tipo de ciudad en la cual la fluidez del movimiento de personas, la velocidad en cuanto al intercambio de información y un entorno siempre cambiante en base a los cambios tecnológicos, son las nuevas señas de identidad. Colette Pétonnet en su obra L'observation flottante ${ }^{207}$ genera toda una visión panorámica de esta nueva urbe mediante un tipo de mirada que no se adscribe a ningún objetivo concreto, sino que de la misma manera que los individuos fluye de manera que facilita la identificación de parámetros difícilmente observables de antemano. Este tipo de metodología tiene la finalidad de inhibir todo tipo de filtros culturales que nos limitan en la manera en la cual percibimos nuestro entorno. A este respecto el profesor Manuel Delgado 208 nos expone la intangibilidad de las relaciones que se desarrollan en la urbe y de lo fluido de las identidades generadas en este tipo de espacio debido a lo líquido de los ejes que organizan nuestra vida diaria.

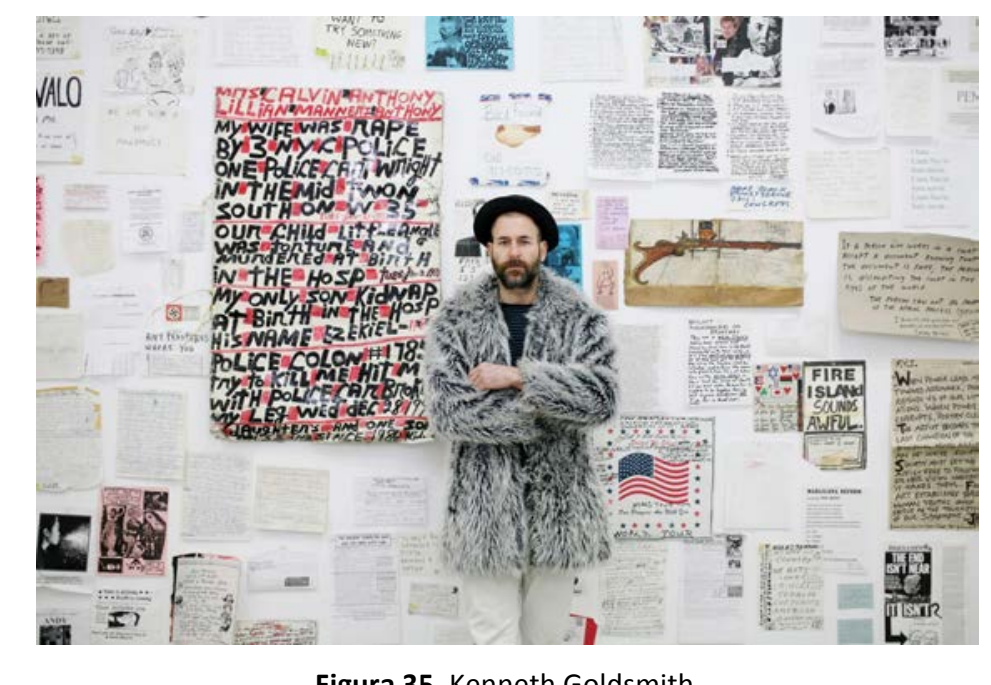

Figura 35. Kenneth Goldsmith.

207 Pétonnet, Colette, L'observation flottante. L'exemple d'un cimetière parisien, L'Homme, París, 1982.

208 Delgado, Manuel, El animal público. Hacia una antropología de los espacios urbanos, Anagrama, Barcelona, 1999. 
Algo que hoy en día podemos encontrar dentro de los espacios virtuales es la práctica de la exploración introspectiva. El hecho de navegar por la red se ha transformado en algo más que una simple metáfora para indicar la manera en la cual exploramos nuestro entorno mediático. De hecho nuestros navegadores web se han transformado en las herramientas mediante la cuales exploramos un medio que se ha convertido en una ventana a nuevos territorios por explorar, colonizar y transformar mediante nuestra actividad dentro de Internet. La antigua concepción de la red como una inmensa biblioteca del mundo, similar a la biblioteca de Babel de Jorge Luis Borges ${ }^{209}$, ha dado paso a un espacio, que como nos anuncia Kenneth Goldsmith, sirve tanto para la lectura como para la escritura ${ }^{210}$. Según Goldsmith, recorremos textos imitando la metodología de las maquinas o "parseo", buscando términos en lugar de entender lo que quieren decir dentro de una pagina. En su clase en la Universidad de Pensilvania titulada Wasting time on the Internet, Goldsmith apuesta por la perdida de tiempo dentro de la red como catalizador creativo para una nueva tipología de escritores que usan la red como materia prima. Se trata de Internet transformado en el afuera, el espacio donde reflexionar mediante un recorrido que sirve como metodología artística. Las ventanas de nuestro navegador nos presentan infinitas posibilidades para replantear nuestro tiempo mediante enlaces que nos llevan en una deriva sin fin. La aparición del modelo de Web 2.0 significó la aparición de sitios web que tienden a estar gestionados por grandes empresas de Internet, pero que son ocupadas y puestas en funcionamiento por los usuarios en base a su entusiasmo por crear y comunicarse, es decir en base a su actividad, a su actuar, y por lo tanto a su curiosidad y exploración de las posibilidades que la red nos ofrece.

209 Borges, Jorge Luis, Ficciones, Alianza Editorial, Madrid, 2006.

210 Goldsmith, Kenneth, Uncreative Writing, Columbia University Press, Nueva York, 2011, p. 218. 


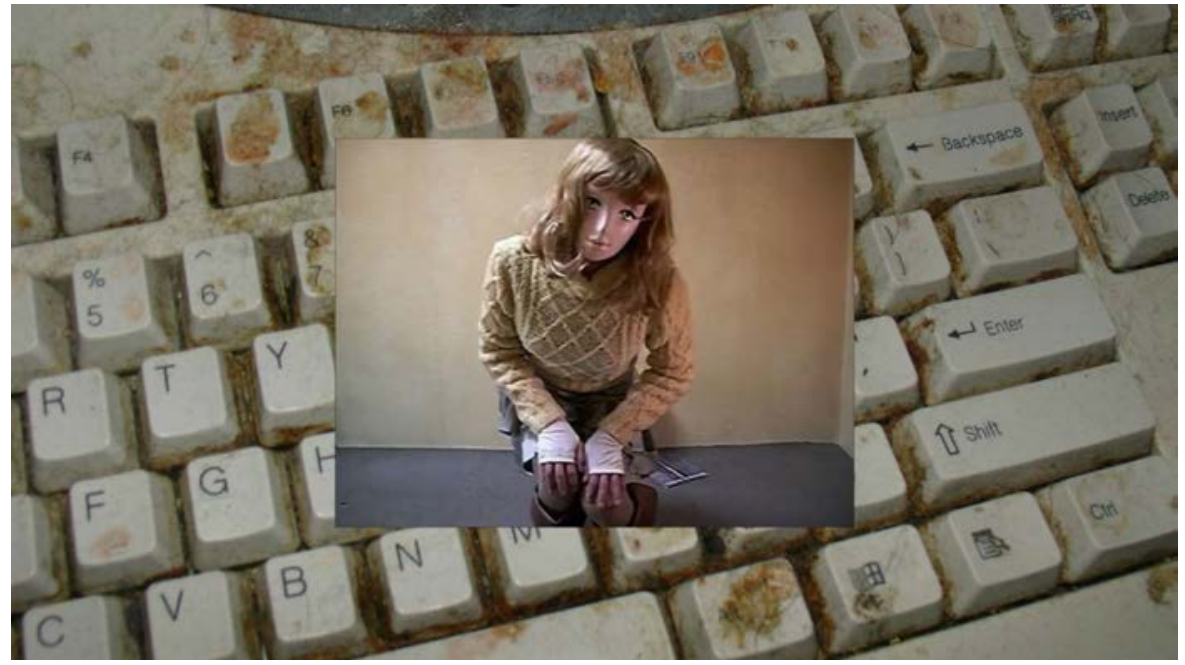

Figura 36. Jon Rafman, Mainsqueeze, 2014 (still).

El artista ligado a las tecnologías sociales de Internet Jon Rafman, se ha interesado por la producción mediática subcultural de comunidades virtuales como Google Earth, 4chan o Second Life, llevándole a estudiar las posibilidades de carácter artístico del estudio antropológico de estos servicios online. Tal y como el mismo nos aclara, está especialmente fascinado por el tipo de uso social que le damos a la tecnología y lo que los usuarios construyen mediante estas tecnologías sin ninguna intencionalidad artística en base a su propia pasión por crear. Rafman usa esta creatividad amateur de las subculturas de Internet como una fuente de material para su práctica artística, actuando como un antropólogo visual amateur y "flâneur" que se nutre de los símbolos y lenguajes de estos entornos virtuales.

Como el propio McLuhan argumentaba ${ }^{211}$, su propia labor investigadora consistía en realizar exploraciones dentro del entorno tecnológico para entender sus consecuencias sociales y psíquicas. Para ello se vale del sondeo cartográfico de nuestra realidad mediática realizado desde un punto de vista pragmático. Esto responde a la necesidad de trazar un perfil cartográfico que revele la verdadera naturaleza de algo tan etéreo como los medios, en gran

211 Scolari, Carlos A., op. Cit., 2015. 
medida debido al carácter ambiental que McLuhan les otorga. Para McLuhan su estudio debe incluir no solo el tipo de contenidos que generan, sino los propios medios en si y el entorno cultural en el cual se despliegan. Es precisamente en este punto donde McLuhan da un papel fundamental al artista como individuo vinculado a la exploración de los cambios ambientales provocados por los nuevos medios. Desde su aparición comercial, la red se presentará como el espacio de trabajo de multitud de artistas, que gracias a las dinámicas de la Web 2.0, alcanzaran un grado cada vez mayor de interés sobre la dimensión cultural y social de Internet.

Estas investigaciones han tendido a materializarse mediante configuraciones ajenas al net art primigenio y de su característica de accesibilidad online, en favor de una nueva serie de prácticas que se hibridan con formas analógicas, y que nos hablan de un arte sobre Internet, además de en Internet. Este se basa en la exploración de las nuevas características de este medio y del análisis de los nuevos espacios que este ofrece, sin olvidar la aplicación social de la tecnología, así como la naturaleza anárquica, interactiva y altamente creativa del actuar de los usuarios de estos espacios. Para McLuhan, la actividad creativa tenía una relación intrínseca con el hecho de explorar, siendo algo que debido a la aparición de los nuevos medios de comunicación se ha extendido más allá del ámbito de lo artístico mediante la aparición de un público que traza sus propias cartografías y contornos en base a su actividad dentro de estos espacios y las diferentes dinámicas que generan. Por lo tanto, podemos extraer que la comprensión de las nuevas tecnologías de Internet transforma lo invisible y difuso en contornos que dibujan formas mediante la exploración y el uso de la red. Esta exploración permite por tanto discernir características esenciales relacionadas con la manera en la cual desarrollamos nuestro actividad dentro de ella, y de cómo modelan nuestro propio actuar en base a sus características. Dentro de esta realidad mediática, es el artista el único que, como individuo del conocimiento integral, es capaz de visibilizar un presente que permanece oculto debido a su naturaleza ambiental y altamente saturante.

Una de las bases principales de esta exploración dentro de Internet, como ya se pudo ver en las primeras prácticas artísticas realizadas dentro de este medio es la relación entre identidad y actuar. Tal y como nos cuenta Juan 
Martín Prada212, podemos entender la construcción de nuestro yo como una forma de actividad inherente a la red, y por lo tanto a las posibilidades de ensayo y error que nos permite la exploración de las posibilidades de este medio.

Sin embargo, debemos tener en cuenta otro elemento de filtrado de esta exploración sobre nuestra naturaleza exterior, ya que será una exploración mediada por pantallas, constituidas como elementos ubicuos, las cuales, por sus propias características, realizaran un suavizado de lo visualizado, al desaparecer las características táctiles, olfativas y corporales de lo material, tal y como nos recuerda Remedios Zafra ${ }^{213}$. En este sentido la exploración de los espacios de la red siempre estará filtrada por las propias características de los periféricos que nos permite la visualización y el acceso a esta red, tanto desde el espacio público como desde el privado. La exploración del espacio social y su construcción dentro de Internet siempre estuvieron fusionados dentro de la práctica artística mediante la exploración de esta parte de nuestra vida diaria que sucede dentro de pantallas. Como veremos este filtrado de la realidad no solo tiene lugar en las pantallas sino que previamente las aplicaciones cuya hegemonía en la red es indiscutible se valen de una amplia gama de algoritmos para seleccionar la información que recibimos, y como veremos en el caso de Facebook, quien la recibe.

212 Martín Prada, Juan, op. Cit., 2015, p. 155.

213 Zafra, Remedios, op. Cit., 2015, p. 17. 


\subsection{REFLEXIÓN SOBRE LAS APLICACIONES DE LA WEB 2.0. REFLEXIÓN.}

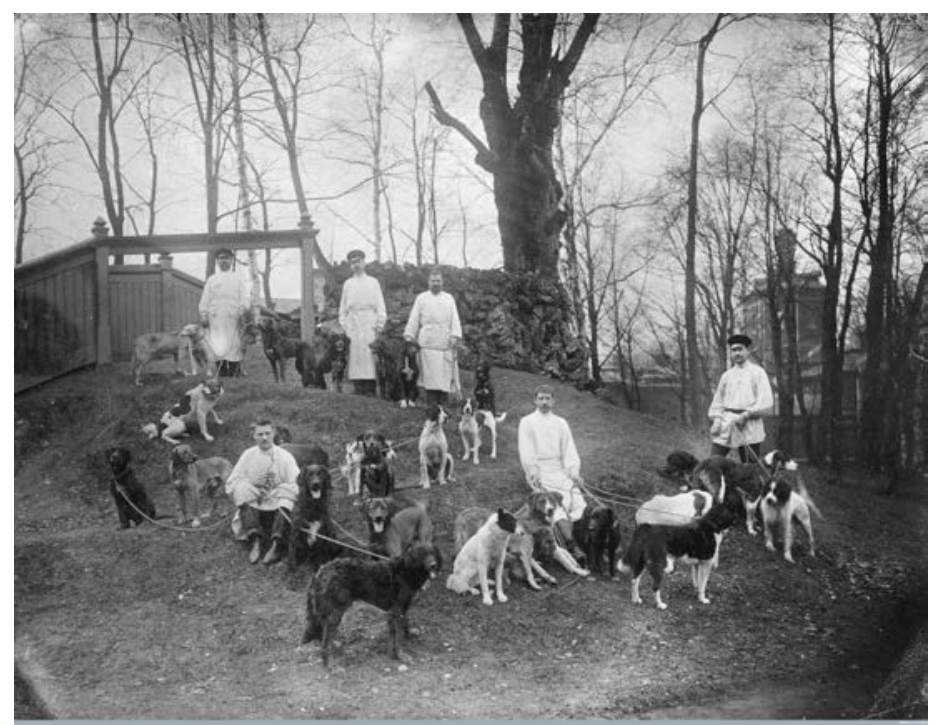

Figura 37. Perros del Dr. Pavlov en el Instituto de Medicina Experimental. San Petersburgo, 1904.

El filósofo Aristóteles afirmaba que cuando dos cosas suelen ocurrir juntas nuestra mente interpreta que la aparición de una de ellas conlleva la otra. Esto que Aristóteles bautizó como ley de contigüidad fue ratificada por el condicionamiento clásico, el cual apuesta por una relación de dependencia entre los estímulos. El experimento más conocido sobre esta teoría es el de Iván Pavlov, realizado en base al comportamiento salivario de los perros, y que a la postre le valió el premio nobel en 1904. Durante este experimento Pavlov se percató sobre como la naturaleza de la respuestas de los canes no era generada únicamente en base a necesidades biológicas, sino que, existía un aprendizaje. Por otro lado, lo que se conoce en psicología como reforzamiento basado en los principios de refuerzo de Edward Thorndike, y el conductismo de John Watson, hace posible que incremente la posibilidad de repetir una conducta determinada mediante lo que conocemos como un refuerzo positivo.

Estructuras comunicacionales como las redes sociales basan su funcionamiento en premiar a los usuarios con pequeñas gratificaciones que incentivan seguir creando, compartiendo y comentando contenidos. Que los 
usuarios sigan utilizando sus aplicaciones durante horas fue unas de las principales preocupaciones de sus fundadores. Evidentemente nunca se preguntaron que tipo de interacciones sociales estaban incentivando o que las impulsa, la naturaleza de los vínculos que estas aplicaciones crean o si de verdad responden al intercambio afectivo entre usuarios. Sin embargo, este tipo de refuerzos se pueden convertir en algo necesario para muchos usuarios, ya que el número de me gustas que recibe una de sus publicaciónes puede determinar su estado de ánimo y autoestima. Por otro lado el hecho de comparar nuestra vida con la de otros usuarios se ha convertido en un factor de riesgo para las personas con síntomas depresivos, convirtiéndose esta acción en un refuerzo negativo que hace que muchos abandonen las redes sociales. Sin embargo, el hecho de reforzar adecuadamente los comportamientos que ponen en funcionamiento estas redes es un elemento vital para el éxito de estos servicios gestionados corporativamente, que no producen contenidos, sino que generan las estructuras mediáticas que aprovechan la avidez comunicacional de la multitud interconectada y su creatividad amateur.

Podemos afirmas que las tecnologías de la Web 2.0 han transformado la normatividad y sus lógicas en un elemento de carácter etéreo y condicionante, con similares características a las que Burroughs otorgaba al lenguaje. Si bien, somos individuos imbuidos dentro de una atmosfera comunicacional de conexión permanente, tenemos la oportunidad de investigar, reflexionar y responder a este tipo de paradigma.

Como ya vimos, McLuhan plantea nuestra inconsciencia ante los efectos de los medios como un síndrome denominado "narcosis narciso" que nubla nuestra percepción ante los efectos de estos. Como nos explica Nicholas Carr en su obra Superficiales ¿Qué está haciendo Internet con nuestras mentes?, aplicaciones como Google realizan un filtrado de la información que recibimos como noticias generando un visión de nuestra realidad gestionada corporativamente mediante sus algoritmos. De la misma manera, Facebook, la red social más usada en la actualidad, realiza un filtrado de las publicaciones de nuestros contactos que aparecen como últimas noticias, en base al algoritmo Edge Rank, el cual premia publicaciones de mayor y repercusión y de contactos con los cuales se realizan un mayor número de interacciones. Por otro lado esta red social hace que cuando un usuario sea más prolifico su actividad aparezca reflejada en los muros de sus contactos. Este hecho fue 
comprobado por el periodista de la revista Wired Mat Honan ${ }^{214}$ en 2014 al dar me gusta a todas las publicaciones que aparecían en su muro de Facebook durante dos días. Irónicamente el hecho de que le gustara todo, convirtió su muro de Facebook en un lugar en el cual no aparecía nada que le interesara, generando una experiencia que no le satisfizo en absoluto.

En este caso, al usuario de las aplicaciones de la Web 2.0 tiene la posibilidad de reelaborar y desentrañar el verdadero funcionamiento de las estructuras mediáticas que percuten sobre nosotros, modelando y vehiculizando nuestra percepción, cognición y percepción, tanto de nosotros mismos como del mundo que nos rodea. Esto no es siempre fácil ya que permanecemos imbuidos por un gran número de mitos que nos impiden realmente ser conscientes del impacto de Internet en nuestras vidas. A este respecto Evgeny Morozov, nos habla del entusiasmo sobre el potencial liberador de Internet como un elemento que no se corresponde con el control de la información y vehiculización que este medio fomenta. Morozov defiende que vivimos dentro de lo que podemos definir como el solucionismo tecnológico ${ }^{215}$, es decir, la creencia de que la tecnología puede solucionar cualquier problema que se nos presente. Precisamente este autor argumenta que la tecnología es una cuestión tan crucial que debería ser discutida junto a asuntos como la política, la economía, la cultura o la historia. Por lo tanto, el hecho de pararse a reflexionar sobre nuestro entorno mediático dentro de Internet, como resultado de las tecnologías sociales, debe ser una cuestión de importancia capital para todos la sociedad en su conjunto.

Como vimos anteriormente, lo que vino a definirse como capitalismo cognitivo, combina el trabajo cultural con grandes dosis de tecnologías digitales, sirviendo para definir la transición del fordismo al posfordismo. Con la aparición de estas tecnologías y su gran difusión se empezó a hablar del trabajo inmaterial como un tipo de práctica implementada por el capitalismo que ha conseguido generar valor en base a nuestras actividades cognitivas y

214 Honan, Mat, I liked everything i saw on facebook for two days. Here's what it did to me, Wired, 8 de Noviembre de 2014, , [Consulta el 23 de Enero de 2018], disponible en $<$ https://www.wired.com/2014/08/i-liked-everything-i-saw-on-facebook-for-two-days-hereswhat-it-did-to-me/>

215 Morozov, Evgeny, op. Cit., 2016. 
afectivas. Estas actividades quedarían encuadradas como parte de una industria que se nutre de la producción informacional y cultural precarizada, generada en base a las dinámicas de consumo y la opinión pública. Por otro lado, como vimos el concepto de trabajo afectivo no habla de una mezcolanza entre las relaciones sociales y la tecnología que genera bienes inmateriales como la información, la comunicación y el trabajo intelectual, siendo altamente feminizado y precarizado. EL trabajo digital se conforma como una degradación del trabajo intelectual ante una glamourización tecnológica que solo sirve para precarizar este tipo de actividades. Como hemos visto, Internet como elemento estrechamente conectado con el desarrollo de las sociedades del capitalismo tardío, es una dimensión esencial de nuestra vida sobre la que debemos reflexionar, como algo que determina nuestro tiempo de ocio, la manera en la que creamos, nos comunicamos y trabajamos, pero que de hecho ha conseguido borrar la línea entre el ocio y el trabajo, precarizando todo tipo de actividades intelectuales en base a nuestros puntos débiles como individuos.

En un mundo donde la tecnología nos ha hecho pasar de un espacio real a uno virtual, desmaterializado y desmovilizado, debemos reflexionar sobre la manera en la cual estos sistemas son diseñados para generar dependencia, como parte esencial de un modelo de negocio. Como recientemente reconoció Sean Parker ${ }^{216}$ uno de los impulsores de Facebook, se trata de aplicaciones que sacan partido de nuestras debilidades psicológicas, ya que generan descargas de dopamina que se traducen en pequeños instantes de felicidad gracias a los "me gusta" recibidos.

Es precisamente el hecho de repensar estos espacios lo que nos da la oportunidad de vislumbrar otras formas espaciales que realmente nos sean útiles y que contribuyan a debatir las consecuencias éticas de las tecnologías de Internet y del fetichismo de la innovación. En su momento, el net-art como deriva artística dentro de las redes de comunicación se convirtió en un momento de autoreflexividad circunscrita a espacio temporal concreto. Es por ello que debemos retomar este tipo de reflexión para actualizar este trabajo en

216 Elola, Joseba, Rebelión contra las redes sociales, El Pais, [Consulta el 17 de Febrero de 2018], disponible 
base a las nuevas funcionalidades tecnológicas de las redes y las mass media. Estas han cambiado radicalmente en la última década la manera en la cual desarrollamos nuestra propia vida diaria, pero también la manera en la que percibimos y experimentamos nuestra relación con los demás y nuestra propia identidad, la cual aparece cada vez más en confrontación con nuestro yo offline. Necesitamos diseñar tácticas que se ajusten a las nuevas dinámicas de las redes como protagonistas de nuestra vida diaria, poniendo de relieve los aspectos ocultos anexos a nuestro actuar en este tipo de espacios virtuales.

\subsection{TÁCTICAS DE INTERVENCIÓN EN LA ESFERA PÚBLICA. INTERVENCIÓN.}

Una de las influencias más importante que ha motivado la producción de las obras presentadas en esta investigación, es sin duda el Manual de guerrilla de la comunicación ${ }^{217}$. En el se nos plantea una suerte de prácticas artísticas que pese a basarse en la subversión como respuesta a la crítica ideológica y la militancia de izquierdas, pretende ser una herramienta placentera que cuestione la moral del trabajo. Precisamente diferentes conceptos que hemos podido desarrollar anteriormente sirven para describir la manera en la cual las aplicaciones de la Web 2.0 se sirven de nuestra creatividad y actuar en las redes para poner en funcionamiento sus servicios. Este manual pretende producir nuevas formas de generar un actuar que se convierta en una caja de herramientas compuesta por palabras, imágenes y metáforas. El actuar se ha convertido en un concepto que contiene nuestra actividad dentro de estas estructuras mediáticas y nuestro deambular por la redes.

Este tipo de actuar placentero, en el caso de la esfera pública, tiene como referentes la spaßguerrilla, prankers, anarchy buffonery y el culture jamming. Este es pues un tipo de prácticas que utilizan una interpretación disidente de los signos que le son dados, tal y como Humberto Eco advierte en Per una guerrilla semiológica, generando un conocimiento del terreno que se materialice en un estudio previo. Este aspecto placentero conceptualiza este actuar como una forma de hacer nos supeditada a los conceptos de competencia y rendimiento de las formas de producción capitalistas y las estructuras de poder, entendidas como generadoras de formas de socialización que desprecian al ser humano en base a relaciones sociales basadas en el dominio. Esto se genera mediante los discursos sociales como

217 Luther, Blisset, Brünzels, Sonja, op. Cit., 2000. 
generadores de lo que denominamos gramática cultural. Es por ello que estas prácticas socaban la normalización del orden imperante cuestionando los discursos del nacionalismo, racismo, patriarcado y las formas de producción, debilitando su legitimidad como forma de poder.

Es paradigmático la manera en la que este manual analiza el modo en la cual las críticas realizadas al margen de las estructuras de poder acaban legitimándolas, proponiendo como modo de actuación la intervención imprevista dentro de estas estructuras de comunicación social. Este punto de vista entiende la comunicación como algo que va mucho más allá de la tecnología que la sustenta, y se apoya claramente en las formas de comunicación cotidianas. Reflexiona sobre la producción de modos de actuar en el marco de nuestra vida diaria cambiando la manera en la cual nos comportamos en diferentes ámbitos de nuestra vida.

Por lo tanto la guerrilla basada en la comunicación como una práctica de dominio utiliza las estructuras de poder, apropiándose, modificando y tergiversando sus signos y códigos. Como dijo Roland Barthes en su texto La muerte del autor, los códigos no pueden ser destruidos, sino burlados.

La gramática, como estructura que determina el uso y la interrelación de elementos mediantes las normas gramaticales, es usada dentro del concepto de gramática cultural para conformar las reglas y normas que sirven para mantener un orden basado en las relaciones de poder, produciendo y reproduciendo el poder bien por obligación o por interés propio. Podríamos denominar esto producción de consenso, llevada a cabo mediante la interiorización de estas reglas como naturales. En definitiva nos referimos a las reglas que estructuran las relaciones sociales y sus rituales. Por lo tanto, establece una normatividad del propio actuar respecto a diferentes situaciones, generando lo que podemos considerar como la normalidad. Algo de lo que ya nos habla Roland Barthes en su obra Mitologías, mediante el concepto de "el sistema del mito". Estamos ante una hegemonía producida mediante la manera en la que las normas sociales determinan la vida cotidiana de la gente, las formas culturales y todas las formas de expresión humanas. Esta idea de hegemonía ya fue propuesta por Antonio Gramsci como un dominio producido a nivel de superestructura mediante las ideologías consensuadas y entre dominantes y dominados. 
Sin embargo ante todo dominio tenemos la posibilidad de utilizar la gramática cultural de forma creativa mediante contenidos disonantes, la usurpación de roles o la deconstrucción de la estética del poder, siendo para ello imprescindible descifrar la propia gramática cultural de los dominantes y preguntarnos la razón por la cual tanta gente acepta estas estructuras de poder. Dentro de las prácticas artísticas ligadas con la esfera pública, la relación entre estrategia y táctica se inspira a su vez de la relación sociedad e individuo, posicionando la cultura como un campo de tensiones de carácter violento en el que la estrategia del poder es ocupar los espacios sociales. Por otro lado, la táctica no se desarrolla en el espacio propio, sino en el ajeno apropiándose del terreno que el oponente le cede, encontrando la oportunidad propicia en las estructuras preestablecidas. Como Michel de Certeau argumenta ${ }^{218}$, las estructuras de poder generan estrategias para difundir su cultura, mientras que el ciudadano de a pie se vale de la táctica de la reinterpretación, desviación o perversión para cuestionar este lenguaje, no rechazando o transformándolo, sino participando de él y usándolo al servicio de otras convicciones, y por lo tanto modificando nuestras practicas de consumo o uso. La táctica no está ligada a ningún parámetro temporal y busca el propio terreno de el oponente para encontrar la oportunidad más favorable para cuestionar unas estructuras preestablecidas. Por lo tanto se vale de la fuerza del contrario para diseñar jugadas y ardiles que definimos como táctica. Desde los modos de hacer, De Certeau cambia una situación asimétrica, otorgando al usuario la posibilidad de cambiar el funcionamiento de diferentes espacios de la esfera pública participando dentro de ellos.

218 De Certeau, Michel, op. Cit., 2000, p. 23. 


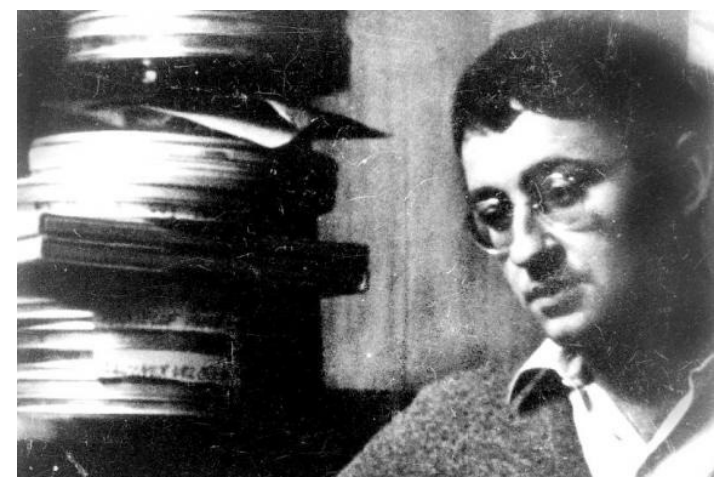

Figura 38. Guy Debord, uno de los fundarores de la Internacional Situacionista.

Dentro del catalogo de prácticas cotidianas que han nutrido la práctica artística presentada en esta tesis podemos destacar la tergiversación o reinterpretación de las estrategias de diferentes estructuras mediáticas de Internet que usamos diariamente como una de las principales fuentes metodológicas usadas en los diferentes proyectos de esta investigación. El detournament como técnica artística se originó dentro de la internacional letrista, escindida del movimiento letrista de Isidore Isou, y más tarde fue adoptada por la Internacional Situacionista. Esta táctica nos retrotrae a la idea de la redirección o secuestro, nacido como un método de propaganda dentro de las viejas esferas culturales como consecuencia de su propio desgaste. Pasó a ser una manera de volver el propio sistema contra si mismo, de manera que los elementos del sistema son usados para atacar el propio status quo de la sociedad capitalista y los medios que la sustentan. Dentro del campo político fue especialmente prolífico por su carácter subversivo, ejemplificado por las bromas situacionistas o situationist pranks que posteriormente retomó el movimiento punk e inspiro al posterior culture jamming. Se trata pues de prácticas que reelaboran símbolos y signos previos ampliamente conocidos, desviando sus significado para oponerse al mensaje original. Esta reutilización puede ser bien total o parcial, dependiendo del criterio del artista, y puede de hecho recuperar elementos de la cultura popular anteriormente apropiados por los medios para su mercantilización, constituyendo un proceso opuesto. Tal y como desarrollaron Gil Joseph Wolman y Guy Debord en su texto de 1956 Mode d'emploi du détournement, originalmente publicado en el número 8 del diario surrealista belga Les Lèvres Nues, existen dos tipos de tergiversación, una basada en elementos menores que simplemente son cambiados de contexto, y otro tipo caracterizado por el engaño basado en 
cambiar el sentido de una obra o texto previo para darle un nuevo significado ${ }^{219}$.Esta es pues una práctica basada en la reinterpretación como "modo de hacer" a desplegar mediante tácticas cotidianas.

Esta tergiversación o reinterpretación basada en la Internacional Situacionista se basa en una deconstrucción ideológica del poder mediante la transformación de la imágenes, conceptos y textos de la estética hegemónica. Esto tiene lugar cuando sacamos estos signos de su contexto original como método de distanciamiento. Este tipo de práctica está relacionada con el plagiarismo, los ready mades duchampianos, o el trabajo de Joseph Beauys, pero en la actualidad entronca con el sampling, los fotomontajes y collages, siendo la redes un hervidero de reutilizaciones prestamos y remezclas de material generado por los usuarios. Como ya hemos destacado, la obra Modos de Hacer de Michel de Certeau es clave a la hora de analizar como los cambios de uso encuadrados dentro de la vida cotidiana y la apropiación de la alta cultura puede generar una lectura disidente de la realidad mediante la alteración del orden de los signos como una estructura de reglas a transgredir y tergiversar.

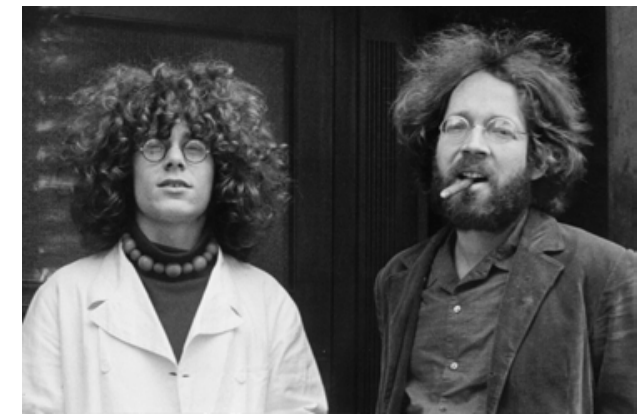

Figura 39. Rainer Langhans y Fritz Teufel, Berlín, 1968.

La Spaßguerilla, traducido como guerrilla divertida, fue un concepto generado en torno a la Kommune 1, la primera comuna de la Alemania Federal. Fritz Teufel asociado con las protestas estudiantiles alemanas de los años 60 fue uno de sus máximos representantes. Sus prácticas se basaban en tácticas

219 Knabb, Ken, Situationist International Anthology, Bureau of Public Secrets, Berkeley, 2006, p. 42. 
caracterizadas por el humor irrespetuoso y provocativo elaborado mediante acciones de desobediencia civil, que tenían la intención de generar diversión, al mismo tiempo que se realizaba algún tipo de protesta. Mediante este tipo de acciones anárquicas se visibilizaban y subvertían los códigos de una sociedad conservadora e inmóvil. Para este grupo de artistas la familia era la base de la ideología capitalista, dando gran importancia a los cambios en la vida cotidiana y las acciones del día a día, dentro del contexto del trabajo, la familia, los estudios y el ocio. Una de sus acciones más conocidas fue el "atentado del pudín"220 que intentó ser perpetrado al vicepresidente de Estados Unidos Humbert Humphrey el 6 de Abril de 1967. Sin embargo, creyendo que se trataba de un intento real de asesinato, la policía detuvo a todo el grupo cuando se disponían a probar sus botes de humo. Esta mezcla de protesta de carácter lúdico y violencia simbólica los convirtió en referentes del movimiento estudiantil en Alemania.

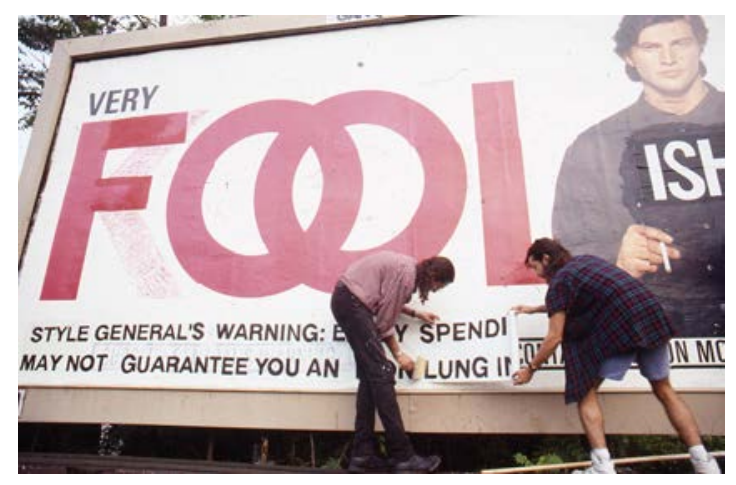

Figura 40. Intervención de Culture Jamming de Jorge Rodriguez-Gerada.

El culture jamming que puede ser traducido como atasco cultural en referencia a un movimiento de resistencia a la hegemonía cultural, desvío o sabotaje, dedica sus esfuerzos en poner de manifiesto la hegemonía cultural dominante. Muchas veces es usado como sinónimo de la propia guerrilla de la comunicación, sin embargo es recogido como una táctica sinónima al "subverting" oriunda de EEUU, Canadá y Australia dentro del propio Manual de guerrilla de la comunicación. Artistas como Barbara Kruger ya utilizó esta

220 Granés, Carlos, El puño invisible, arte revolución y un siglo de cambios culturales, Taurus Barcelona, 2012, p. . 
táctica como parte de su activismo contra el VIH/SIDA a finales de los años 80 del siglo XX. En su obra No Logo, Naomi Klein nos habla sobre el trabajo de Jorge Rodriguez-Gerada 221 y por lo tanto del poder de la cultura para cuestionar el estatus quo y como esta siendo tratada como elemento incorporado al ámbito comercial. Durante los años 90 del siglo XX, Gerada intervino innumerables vallas publicitarias y organizó acciones de guerrilla alrededor de Nueva York, siendo uno de los fundadores del movimiento Culture Jamming. Estas intervenciones alteraban drásticamente los mensajes para contrarrestar los propios mensajes corporativos, generando una respuesta paródica a imágenes que nadie reclamó observar.

Por otro lado, el Manual de guerrilla de la comunicación nos habla del "distanciamiento" como una manera de crear cambios sutiles que sacan a la luz nuevos aspectos de nuestra realidad mediante esta perturbación perceptiva, que genera confusión mediante algo que no encaja como debería. Es precisamente esto lo que produce la "distancia" en el público, y por lo tanto una visión crítica. Por lo tanto, hablamos de un distanciamiento que crea espacios para una lectura no habitual de lo que queremos tratar en el ámbito de lo cotidiano. Este tipo de acciones nos presentan una realidad en la cual adaptarse a la normatividad social que la gramática cultural implemente es solo una opción, abriendo una vereda para formas de actuar que pretenden generar un cambio perceptivo dentro de la sociedad. Trata pues, de la visibilización de las estructuras de poder y sus relaciones, situaciones y procesos de comunicación cotidianos. Este concepto parte de la base de que un mismo mensaje puede generar nuevas significaciones no previstas en el mensaje o imagen original del creador. Otra forma de distanciamiento es la "afirmación subversiva", la cual exagera de forma inadecuada el discurso oficial. Se trata pues de una parodia exagerada de las posiciones dominantes de la sociedad, que se vale de la fuerza del oponente para vencerle.

La "sobreidentificación" en cambio es una táctica que consiste en la identificación radical con la lógica del sistema dominante, de manera que pone de manifiesto las implicaciones ocultas de cada ideología, calladas y convertidas en un tabú social. Podríamos hablar también del camuflaje como un enmascaramiento que se sirve de las formas dominantes para transportar

221 Klein, Naomi, No Logo, Paidós, Barcelona, 2001, p.311. 
contenidos netamente disidentes. Esto produce lo que podemos denominar como una trampa del embalaje mediante la imitación y la tergiversación de las formas dominantes, como técnicas eficaces de comunicación.

La invención de hechos falsos es irónicamente una manera de generar acontecimientos verdaderos. Esta metodología de intervención nos sirve para evidenciar y criticar las mecánicas que delimitan la producción hegemónica del imaginario mediático y político de nuestra cotidianidad. Aquí la práctica artística redirige a los medios en contra del status quo de los propios medios y el poder político y económico. Mediante este concepto se pone de relieve los mecanismos de creación de acontecimientos que los medios manejan indiscriminadamente en el ámbito comunicacional. Debido a la difusión de las tecnologías asociadas a las redes esto ha generado conceptos como el de noticias falsas y posverdad, que toman como protagonista a los propios usuarios y su actuar en la red. Esto a su vez ha provocado un socavamiento en la relación de confianza de la sociedad con los medios. En cambio este tipo de táctica pretende generar acontecimientos verdaderos mediante la reacción de los medios y la sociedad a una noticia falsa.

El "fake", traducido literalmente como falsificación, engaño o imitación tienen una larga trayectoria dentro de la práctica artística. Se trata de una intervención momentánea dentro de lo que Foucault denominaba "el orden del discurso"222, es decir la utilización de los enunciados, signos e interlocutores validos del poder dentro de una relación netamente asimétrica con el público. Mediante esta táctica el artista imita la voz del poder de la manera más exacta posible para que sea confundido con este. Elementos como el caos comunicativo, el lenguaje performativo o la alteración del orden social, son la base de este tipo de práctica. Por medio del propio discurso se genera la subversión que es amplificada por los medios mediante las sucesivas rectificaciones de estos. Este tipo de lecturas subversivas introducidas en modos discursivos del poder deben de ser irreconocibles, pero paradójicamente deben ser también descubiertas para causar efecto al hacerse patente ante la sociedad la posibilidad de burlar al poder mediático político y económico que nos rige. Así se produce una desorientación perceptiva que tiene como origen la introducción de falsos elementos

222 Foucault, Michel, El orden del discurso, Tusquets Editores, Barcelona, 1999. 
comunicativos, que a su vez generan desinformación mediante la falsificación. Este tipo de táctica genera una cadena de acontecimientos en la que entran en juego elementos y hechos como la falsificación en cuestión, su descubrimiento por parte de la autoridades y medios, el desmentido oficial por parte de estos poderes y el reconocimientos por parte del gran público de la verdadera naturaleza de este tipo de hechos. Este tipo de metodología se basa en la frase de Marshall McLuhan "La Tercera Guerra Mundial será una guerra de guerrilla de la información sin distinción entre la población militar y civil"223, algo que sin suda es cada vez más visible debido a la difusión de las tecnologías relacionadas con Internet y la web 2.0.

Por otro lado, "el collage y el montaje" rompen los modelos perceptivos a los que estamos acostumbrados percibiendo la realidad de una manera diferente. Por un lado, el collage es adoptado como una tácticas de subversión que presenta un contexto en el cual su significado primigenio ha cambiado alcanzando nuevas cotas de significación. Este tipo de planteamiento tiene sus orígenes en el dadaísmo y su rechazo a lo establecido, para ello se valía de la poesía de lo casual, el azar y la ambigüedad semántica que rodeaba sus creaciones. Por otro lado, el montaje es una táctica que se desarrolla de manera consciente, muy al estilo de los dadaístas berlineses, siendo ideal para realizar intervenciones o fakes de carácter subversivo. La posmodernidad se desvinculó de las ideas universales asociadas a la autoría y tras esta experiencia podríamos decir que las tecnologías de la imagen han pasado a reinterpretar la autoría como un elemento abierto e hipertextual que aborda el reciclaje y la apropiación como una actividad ecológica 224 tal y como nos cuenta Joan Fontcuberta. Según Juan Martín Prada225, como contraste a las estrategias de reubicación y descontextualización de la posmodernidad, el medio digital va a pasar a transformar dentro de una integración y fusión de lo apropiado. Para ello va a usar conceptos provenientes de otros medios como remix, sample, mash-up o remake. Todos nos hablan del uso de elementos de otras piezas, la mezcla y transformación en una versión alternativa. Estas prácticas están asociadas a la provisionalidad y temporalidad de materiales recogidos de la red, tal y como el poeta estadounidense Kenneth Goldmisth

\footnotetext{
223 McLuhan, Marshall, La cultura es nuestro negocio, Editorial Diana, México D.F. 1974, p. 66.

${ }^{224}$ Fontcuberta, Joan, La cámara de Pandora, Gustavo Gili, Barcelona, 2011.

${ }^{225}$ Martín Prada, Juan op. Cit., 2012, pag. 187.
} 
afirma $^{226}$, los cuales son almacenados, moldeados y descartados con una rapidez proporcional a la de los flujos de información. Goldsmith defiende el plagiarismo como una estrategia creativa, creando dentro de sus clases en la Universidad de Pensilvania un completo decálogo de cómo perder el tiempo dentro de la red. Ante la avalancha de material que generamos diariamente Goldsmisth aboga por la apropiación literal como acto creativo.

\subsection{INTERVENCIÓN EN ESPACIOS VIRTUALES. MATERIALIZACIÓN.}

Tal y como afirma Remedios Zafra en su texto El instante invisible del net.art ${ }^{227}$, esta vanguardia artística fue concebida como un campo social alternativo donde el arte y la vida diaria estaban fusionados dentro de una atmosfera anti-institucional. Sin embargo este tipo de prácticas fueron rápidamente absorbidas por las instituciones artísticas más importantes del mundo a finales de los años 90 del siglo XX, tras una primera década de gran expansión como consecuencia del desarrollo de la WorldWideWeb y las ansias de libertad generadas tras la caída del muro de Berlín. Sin embargo, muchos de los supuestos de este grupo de artistas pueden ser transportados a la actualidad pese a los cambios tecnológicos de gran impacto en el ámbito social acaecidos en los últimos quince años. Rachel Greene en su texto Una historia del Arte en Internet ${ }^{228}$ publicado en la revista Artforum de Mayo de 2000, ya nos hablaba de cómo estas prácticas se asemejan a un detournament en red, construido mediante textos e imágenes que posibilitan una estética del intercambio generada por enlaces y mails encuadrados en el ámbito social que los medios crean. Sin embargo como apunta Juan Martín Prada'229, Internet ha cambiado mucho desde el declive de las punto com. Las nuevas dinámicas sociales generadas en la redes nos presentan un tipo de escenario radicalmente diferente en muchos aspectos. Esto ha generado prácticas artísticas que hablan de las nuevas características de estas tecnologías pero

\footnotetext{
${ }^{226}$ Goldsmith, Kenneth, op. Cit., 2011, pag. 218.

227 Zafra, Remedios, El instante invisible del Net Art, [Consulta el 23 de Enero de 2016], disponible en $<$ https://idus.us.es/xmlui/bitstream/handle/11441/26538/El instante invisible del net.pdf?sequence $=1>$

228 Greene, Rachel, Web Work a history of Internet Art, en Artforum Internacional, no 9 Mayo de 2000, pp. 162-167, 190, , [Consulta el 23 de Enero de 2016], disponible en <https://www.artforum.com/print/200005/web-work-a-history-of-internet-art-465>

229 Martín Prada, Juan, op. Cit., 2015, p. 23.
} 
que conservan sin duda el uso de la creatividad como un herramienta puesta al servicio de la generación de una visión crítica de estas. Estas prácticas hibridan elementos tanto analógicos como digitales que se salen de las categorías establecidas en el primer net art y que se centran en las características culturales y sociales en detrimento de las características técnicas y tecnológicas de estas. Se trataba de una serie de prácticas artísticas que comenzaron a tratar temas referentes a la difusión del uso de la red mediante medios ajenos al propio uso de la red. Este tipo de obras nos presentaban un escenario en el cual Internet había llegado a copar la centralidad de nuestra experiencia vital y de producción. Estamos hablando de la conexión permanente como una de las características de nuestra cotidianidad, y de lo virtual como otra de las dimensiones de nuestra realidad, es decir, la configuración de nuestro tiempo, la manera en la trabajamos, nos entretenemos y socializamos. Pese a la gran difusión, desde el mundo del arte, al termino post-Internet para describir aquellas prácticas relacionadas con el impacto de Internet en nuestras vidas y su plasmación en una estética dentro de la práctica artística fuera y dentro de Internet, Juan Martín Prada apuesta a favor del uso del concepto de "segunda época" para describir la relación entre la práctica artística y la red, originada a partir de la difusión de las tecnologías de la Web 2.0, y que consideran la red como un campo temático. Sin duda el termino parece muy adecuado para describir un gran número de prácticas que se han adaptado a un escenario cambiante e interrelacionado con diferentes aspectos de nuestra vida, tales como el ámbito social, comunicacional y productivo.

Ya desde sus comienzos, el arte dentro de las redes se concentró en las posibilidades de transformación social y política de este medio. Esto dio como resultado un tipo de tácticas que repensaban los aspectos políticos, económicos y antropológicos de las dinámicas generadas dentro de la red, así como metodologías que liberen este espacio de la mercantilización generada en base a diferentes modelos de negocio en Internet. Este tipo de prácticas pusieron de manifiesto las posibilidades que Internet ofrece para la transformación social y la crítica de las estructuras mediáticas, reclamando un uso artístico de la red como medio para pensar en lo social y la manera en la cual la información en producida dentro los medios hegemónicos.

Es precisamente por esta razón por la cual el uso de metodologías artísticas que vienen de otros ámbitos de la esfera pública son el vehículo perfecto para 
poner de manifiesto la manera en la cual estas tecnologías nos modelan y transforman. De la misma manera que Michel de Certeau pone el foco en los modos de hacer, es decir en el actuar, las aplicaciones de la Web 2.0 nos presentan un escenario donde el propio actuar es lo que pone en funcionamiento estos espacios. Podríamos hablar de la generalización de un gran número de servicios que de hecho funcionan gracias a la actividad de los propios usuarios. En este sentido pensar nuevos modos de hacer dentro de la red se ha convertido en una manera de cuestionar los mecanismos mediante los cuales funcionan estas aplicaciones, a la vez que ponemos de manifiesto la manera en la cual estas nos afectan. Como hemos visto una de las principales fuentes metodológicas de las obras presentadas en esta tesis es el Manual de guerrilla de la comunicación, concebido como una caja de herramientas para trabajar con palabras metáforas e imágenes, nos presenta diferentes tácticas que se han adaptado o han servido de inspiración para producir nuevas formas de utilizar diferentes aplicaciones o servicios de la Web 2.0.

Ha sido de especial importancia el estudio del concepto de gramática cultural para entender la manera en la cual las normas o mecanismos de un espacio virtual pueden ser tergiversados, con el objetivo de visibilizar el verdadero poder que ejercen estas estructuras mediáticas sobre nosotros. En relación a las obras planteadas en la segunda época del arte en Internet, se nos presenta una serie de tácticas que conciben la comunicación como algo que va más allá de una visión tecnológica, en favor del estudio de las formas cotidianas de comunicación. Esto tiene la intención de desarrollar formas imprevistas de usar estas estructuras de comunicación social y que contravengan la hegemonía producida mediante las normas sociales. Se pretende socavar la propia normatividad o gramática cultural generada por las estructuras mediáticas de Internet, conformadas como servicios, pero también poseedoras de una serie de mecanismos, normas e ideologías que nos modelan de manera sutil e imperceptible. En este sentido el cambio en el actuar genera una mutación en el discurso desplegado dentro de estos espacios, que se contrapone al desarrollado desde las lógicas de la propia estructura mediática y por lo tanto de las aplicaciones desarrolladas a partir de los principios de gestión de la producción de contenidos, sociabilidad y datos personales de la Web 2.0.

Como vimos anteriormente, podemos observar la existencia de una dicotomía entre "fondo", refiriéndonos a las propias estructuras mediáticas, y "figura", 
refiriéndonos a los contenidos que ponen en funcionamiento estos espacios. Como usuarios tenemos la posibilidad de mutar y cuestionar la manera en la cual estos contenidos son creados en base a nuestro trabajo gratuito y distribuidos mediante las aplicaciones de la Web 2.0. Como este cuerpo de obra quiere demostrar y como acabamos de ver en este mismo apartado, existen multitud de tácticas que son susceptibles de ser utilizadas dentro de la esfera pública, y por lo tanto dentro de Internet. Pese a los diferentes argumentos que apuntan hacia la imposibilidad de considerar a Internet como parte de esta, como es el caso de Byung Chul Han, en esta tesis apostamos por considerarla como parte constitutiva de la misma, aunque no como un espacio público como apunta David Casacuberta. Debemos recordar que pese a el libre acceso a cualquier tipo de estas aplicaciones estas empresas son servicios gestionados por compañías privadas que en ningún caso podemos encuadrar dentro de lo público. No podemos olvidar la gran dicotomía entre espacio y lugar, uno como un concepto genérico e indefinido y el segundo como una porción del espacio que se distingue de este por la presencia de la experiencia generada mediante el uso continuado. Paloma Blanco en el libro Modos de hacer $^{230}$, realizado junto a Jesús Carrillo, Jordi Claramonte y Marcelo Exposito, nos habla de un arte del lugar como un arte de contexto, en el cual la espacialidad incluye las características sociales, políticas y económicas del lugar.

Es por ello que la utilización de la gramática cultural de forma creativa toma más sentido si cabe, bien mediante la creación de contenidos disonantes, usurpación de roles o la deconstrucción de la propia estética creada por los medios como poder hegemónico. En este sentido, como hemos visto el estudio previo del funcionamiento de las propias estructuras mediáticas se hace indispensable a la hora de generar este tipo de deconstrucción. No debemos olvidar preguntarnos por la razón por la cual los usuarios de estos servicios aceptan sin ningún tipo de reflexión previa o posterior las normas inherentes a su uso y que proceden de la ideología que los creadores de estos espacios virtuales les imprimieron en el momento de su diseño y creación.

230 V.V.A.A., Modos de hacer, arte crítico, esfera pública y acción directa, Ediciones Universidad de Salamanca, Salamanca, 2001, p. 32. 
Como Michel de Certeau nos contaba, el uso de una estrategia presupone la ocupación de espacios sociales por parte de un poder hegemónico, o como es el caso de las aplicaciones de la Web 2.0 el diseño y construcción del mismo y su disponibilidad como servicio al gran público. Por lo tanto podemos considerar a los creadores de estas aplicaciones como creadores de espacios sociales gestionados desde las lógicas del poder hegemónico. Sin embargo, como podemos ver el poder siempre cuida de estetizar sus estrategias para naturalizar y esconder sus relaciones de poder, siendo la manera esencial del éxito de la mayoría de las redes sociales, ya que la interiorización de las normas y la estetificación y glamourización de ciertos aspectos del trabajo gratuito, afectivo e inmaterial nubla nuestra percepción ante las relaciones de poder subyacentes.

Como contrapunto a la estrategia contamos con la táctica como práctica cotidiana que se vale del terreno ajeno para ejercer su acción. En este sentido el usuario de las aplicaciones de la Web 2.0 siempre juega en espacio enemigo, ya que interviene en aplicaciones que son gestionadas por empresas que usan la creatividad y avidez comunicativa de los usuarios para su propio beneficio. Precisamente las aplicaciones de la Web 2.0 son especialmente idóneas para su intervención debido a su estatus como servicios gratuitos y de libre acceso. Esto posibilita explorar e intervenir de manera libre una estructura mediática preestablecida que puede ser reinterpretada de la misma manera que un lenguaje es traducido. En este caso se usan una lógicas diferentes a la de los creadores de estas aplicaciones para apropiarnos de manera temporal de estos espacios, produciendo tácticas cotidianas que visibilizan la manera en la cual estas estructuras mediáticas nos modelan.

Precisamente, el distanciamiento que describíamos antes, como la lectura no habitual de acontecimiento cotidianos, se transforma es un concepto indispensable a la hora de sacar aspectos escondidos del funcionamiento de las aplicaciones y servicios de la Web 2.0. Mediante cambios sutiles podemos visibilizar lecturas nos habituales de estas estructuras mediáticas, desplazando y cambiando su representación o uso habitual. Un mismo mensaje o imagen puede producir nuevas significaciones haciéndonos conscientes de capas de significado imperceptibles en la imagen o mensaje primigenio. 
Esto generalmente produce, como veremos, confusión dentro propio espacio virtual al modificarse sutilmente la gramática cultural que normativiza y genera relaciones de poder dentro de las redes sociales y comunidades virtuales. Es aquí, donde se genera una distancia entre lo que, mediante este estado de confusión, concebimos como ese servicio, el cual pasa a percibirse con otros matices claramente diferenciados. Este tipo de táctica, por lo tanto, adquiere también un carácter perceptivo, ya que mediante cambios sutiles pero claros, logramos producir un cambio en la percepción que tienen el resto de usuarios sobre el espacio virtual intervenido. Sin embargo, nos estamos ante un tipo de metodología artística que sea subversiva per se, ya que como el propio Manual de la guerrilla de la comunicación reconoce, el distanciamiento también ha sido utilizado en el ámbito de la publicidad, como podemos observar en diferentes campañas de Benetton. Es el contexto y la forma de utilizarlo lo que verdaderamente delimita el efecto de esta táctica, desplegada dentro de la esfera pública. Debemos pues, actuar dentro de la cotidianidad de la red para sacar partido de las propias contradicciones, intersticios y paradojas que genera este actuar en base a las tecnologías de la Web 2.0. Este tipo de tecnologías han amplificado la fragmentación de unos usuarios ya contradictorios como individuos mediante los cambios producidos durante la modernidad, a la par que han naturalizado una normalidad en base a su funcionamiento, basado este en el trabajo digital gratuito. Por lo tanto resulta especialmente revelador utilizar estas mismas grietas para poner de manifiesto la manera en la cual se producen estas contradicciones.

Por otro lado, la construcción de acontecimientos falsos puede ser usada dentro de la red para poner de manifiesto como los servicios de noticias de Internet, convertido en el macromedio de nuestro tiempo como contenedor de los medios tradicionales, juega con la manera en la cual los acontecimientos son construidos, poniendo de manifiesto la relación real entre las noticias e imágenes que consumimos en la red y los hechos reales. Uno de los ejemplos más interesantes fue el de el pseudónimo colectivo Luther Blisset, anteriormente citado, compuesto en realidad por diferentes colectivos de artistas de toda Europa y Norteamerica, creándose la primera referencia al proyecto dentro de Usenet en 1994.

En este sentido adoptar los propios mecanismos de las aplicaciones de la Web 2.0 será indispensable para mediante estas formas hegemónicas difundir contenidos disidentes. Estamos hablando de tácticas que se realizan dentro de 
la red para generar modos de actuar, y contenidos que perturban las formas dominantes de comunicación. Como ya hemos visto el fake se hace pasar por el poder para introducir lecturas subversivas dentro de sus discursos. En este sentido los propios espacios virtuales pueden ser el escenario ideal para mediante la creación de estructuras que imiten al poder subvertirlo. Este es el caso del dúo de activistas conocidos como los Yes Men antiguos miembros de RTMark, un colectivo dedicado a el activismo artístico anti-corporativo, especializados en crear paginas webs que imitan a las de grandes empresas o políticos. Podríamos definir esta táctica como una forma de distanciamiento que exagera de forma inadecuada el discurso oficial mediante una parodia exagerada, valiéndose de la posición dominante del adversario para derrotarlo.

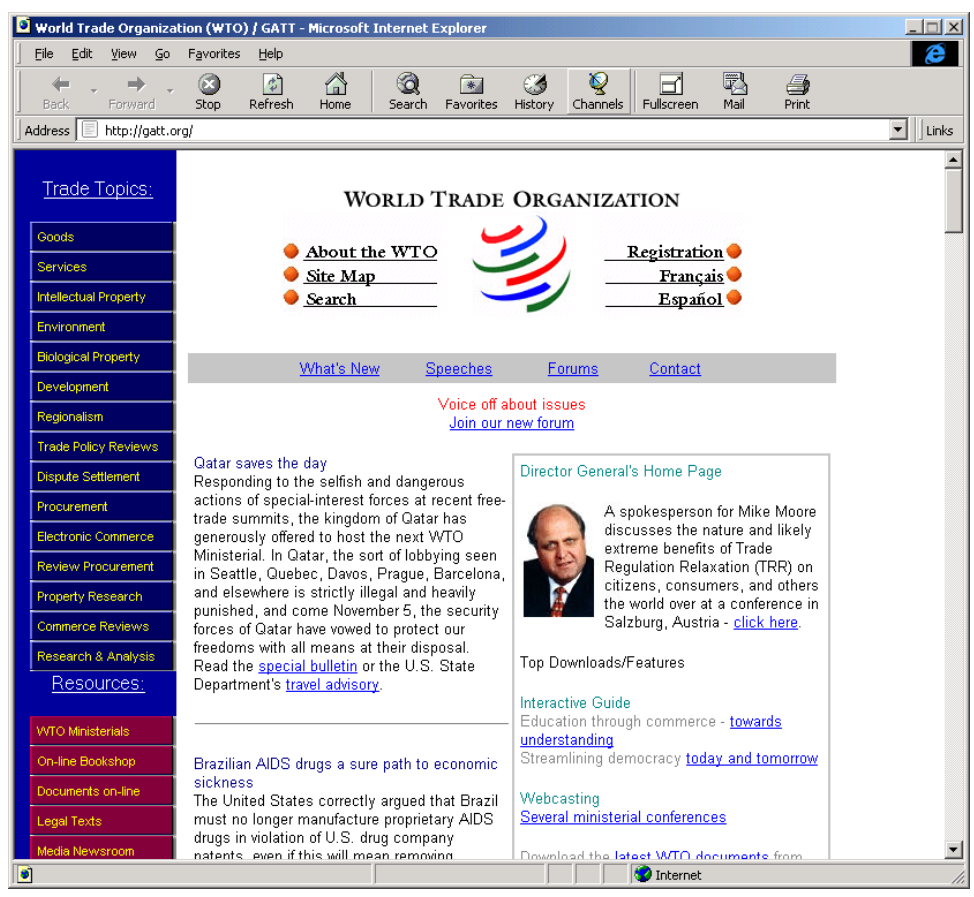

Figura 41. Web de la Organización Mundial del Comercio creada por RTMark.

Como veremos al analizar algunas de las obras presentadas en esta investigación, el collage y el montaje son las herramientas ideales para deconstruir los modos de percepción de la realidad generados por las 
aplicaciones de la Web 2.0. Tenemos la posibilidad de mutar el significado de las imágenes para mostrar nuevas realidades, significados y contextos antes ocultos.

Por último, la reinterpretación y tergiversación del uso de las aplicaciones y servicios de la Web 2.0 ,es sin duda el método de distanciamiento por excelencia, que como hemos visto hunde sus raíces en el ready made, el situacionismo, el plagiarismo y las prácticas artísticas elaboradas por Joseph Beauys. Al basarse en la deconstrucción ideológica del poder resulta especialmente adecuado para diseccionar las estructuras mediáticas de Internet, conceptualizadas como productos y plataformas de una cultura hegemónica. Esta deconstrucción se puede conformar como un actuar o modo de hacer en la red que puede ser adoptado por multitud de usuarios dentro de su cotidianidad, transformando la cultura de Internet en algo que es transmutado por la multitud interconectada. Tiene como meta la creación de una cultura disidente que tergiverse la propia normatividad de las estructuras mediáticas de Internet mediante diferentes maneras de actuar basadas en la subversión de la normatividad.

Durante esta investigación hemos argumentado como estas extensiones de nosotros mismos y de nuestras capacidades modelan nuestra percepción. Es por ello que el propio uso de la tergiversación como método que nos saca de nuestro modo de hacer cotidiano y cambia la manera en la cual percibimos nuestro entorno mediático, nos lleva e vuelta un presente que permanece invisible.

Este tipo de práctica también puede ser elaborada mediante el sampling de diferentes materiales procedentes de la iconografía de estas aplicaciones o de la propia cultura de Internet generada durante años dentro de las comunidades virtuales, y que han resignificado el concepto de autoría. Las aplicaciones de la Web 2.0 como medios de producción, comunicación y de expresión pueden ser objeto de una resignificación tanto a nivel iconográfico como a nivel de su uso con la misión de deconstruir su función ideológica, la cual no es fácilmente identificable si observamos las redes sociales u otros servicios de Internet. La efectividad de la tergiversación como táctica mediante la cual intervenir en las aplicaciones de la Web 2.0 reside en la indisoluble unión de estos servicios dentro de lo cotidiano y lo social, y la 
importancia que tiene el actuar dentro de la red. Cuando modificamos este actuar generado en base a un sistema de códigos y signos, estamos cambiando la manera en la cual estas aplicaciones funcionan, alterando los códigos desde dentro en lugar de destruirlos o denostarlos.

Esta investigación no se basa en la tácticas que podíamos ver en las prácticas hacktivistas, basadas en la realización de ataques de denegación de servicio, robo de información y sabotajes virtuales, entre otras, apostando por modos de hacer que como nos anunciaba Michel de Certeau se despliegan dentro de nuestra vida diaria y que también tiene lugar dentro de la red debido a la penetración de esta en el ámbito de la cotidianidad. Esto ha generado que multitud de artistas se interesen por la producción amateur dentro las comunidades virtuales por su pasión por la creatividad sin ninguna intencionalidad artística. Como el artista Jon Rafman multitud de usuarios están interesados en las posibilidades sin fin de la exploración de mundos virtuales y aplicaciones. Sin embargo el los usa para generar obras videográficas que nos transportan a los aspectos más anárquicos e imprevisibles de la red.

Como veremos este tipo de tácticas han tenido su reflejo en las obras presentadas en esta tesis. Se trata, en su mayoría de apropiaciones individuales de carácter temporal que transforman el sistema mientras imitan y utilizan su status quo, como parte de unas prácticas subversivas cotidianas basadas en el actuar en la red.

En base a estas metodologías de intervención concebidas a modo de herramientas artísticas, podemos diseñar modos de actuar en la red que se relacionan con conceptos como la conexión constante, la repetición y la creatividad amateur, y que son configuradas como proyectos artísticos mediante multitud de elementos como imágenes, videos, instalaciones, manuales o mapas conceptuales. 
PARTE 2 OBRA 
6. OBRA PERSONAL: ENSAYOS EXPERIMENTALES 


\subsection{ESTRUCTURA PRAXIS}

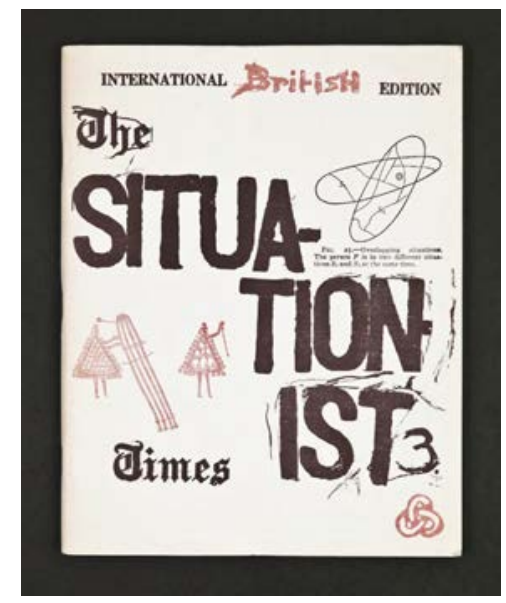

Figura 42. The Situationist Times \#3.

Durante los años sesenta del siglo XX la artista holandesa Jacqueline de Jong editó junto a Noël Arnaud la revista The Situationist Times, en la cual recopiló y ordenó cientos de imágenes encontradas de todo tipo de anillos, tejidos, laberintos y cadenas con la intención de generar un catálogo de modelos topológicos situacionistas. De esta manera esta publicación se valió de un acercamiento topológico de la diseminación transformativa de las formas culturales. Esto entronca con la hipótesis recientemente presentada por investigadores como Tiziana Terranova entre otros, que argumenta que la propia cultura se esta volviendo topológica. Como argumenta en su texto Introduction: The becoming Topological of Culture realizado junto a Celia Lury y Luciana Parisi, la topología ha sido usada para articular los cambios en las estructuras y espacios de poder.

Por otro lado autores como Pierre Lévy ya en 1995 dentro de su obra ¿Qué es lo virtual?231 nos hablaba del denominado efecto Moebius como una de las consecuencias de la virtualización y la desterritorialización, como un paso del interior al exterior y del exterior al interior, lo cual ha venido a disolver los

${ }^{231}$ Lévy, Pierre, ¿Qué es lo virtual?, Paidós, Barcelona, 1999. 
límites entre lo público y lo privado, mapa y territorio, e incluso autor y lector mediante la hipertextualidad constante que nos remite al afuera desde el adentro. Según Lévy el yo y el otro se colocan en una espiral en la cual el interior y el exterior cambian continuamente de lado.

La banda de Moebius es una superficie que solo cuenta con una cara, de manera que si decidimos recorrer una cara interior acabamos recorriendo toda la cinta hasta llegar a la cara exterior. Esta superficie no orientable ha resultado la metáfora perfecta para hablar de las características transversales que relacionan y organizan las obras presentadas en esta tesis. La estructuración de las obras de esta investigación han venido determinada transversalmente por el solapamiento y enfrentamiento de diferentes conceptos referentes a nuestra relación con los medios y tecnologías de la web 2.0 tratados durante esta tesis, como son lo público-privado, real-virtual, y lo local-global. Esto ha dado como resultado una estructura de praxis compuesta por tres bloques conformados por dos obras cada uno, en los cuales se enfrentan, por un lado, elementos referentes a nuestro propio yo y la construcción que en la red realizamos de este en base al otro; a nuestros datos y las estructuras mediáticas; y por otro lado, la construcción de nuestra realidad exterior que estos medios implementan, bien como representación colectiva de un lugar, el territorio o sucesos ocurridos en otras realidades ajenas a la nuestra.

El primero de estos bloques conformado por las obras How we can make each other better? y El paisaje de la Multitud, nos habla de una cuestión producto de la propia implementación de las tecnologías sociales de la Web 2.0 y de su extenso y uso y difusión. La necesidad de producir y consumir que nos transforma en trabajadores inmateriales ha generado el entrecruzamiento de la esfera pública y privada de los usuarios. En este escenario repleto de comportamientos exhibicionistas y voyeuristas que nos construyen ante los demás. Podemos observar como nuestros momentos privados son puestos a disposición del gran público mientras nuestra vida dentro del ámbito de lo publico pasa a construir nuestra naturaleza exterior.

Como hemos visto, Marshall McLuhan predijo que los medios actúan como amplificaciones de nuestras propias capacidades primigenias, la cuales quedan entumecidas ante la amplificación que los media generan. Es 
precisamente la amplificación de nuestra presencia mediante las tecnologías de retransmisión de video uno de los ingredientes principales de este primer bloque. Estas estructuras mediáticas modelan las comunidades que las ponen en funcionamiento, cambiando no solo cualitativamente el potencial de nuestras capacidades, sino que también quienes somos o quienes decimos ser.

En este sentido, es interesante que este bloque contrapone una aplicación generada por una persona anónima sin ánimo de lucro como es Chatroulette, con otra como Vine, la cual fue rápidamente adquirida por Twitter y que se mueve en un ámbito corporativo y empresarial. Esto nos muestra dos tratamientos totalmente diferentes de la manera en la cual se construyen estos espacios, por un lado el sentido mas anárquico del "do it yourself" y por otro el de una aplicación totalmente integrada dentro del ecosistema de los medios de masas, aunque podríamos considerar a ambas pertenecientes a una industria cultural hegemónica que conceptualizaron Adorno y Horkheimer232 en la primera mitad del siglo XX.

Por un lado, en un primer proyecto podemos observar como la multitud de usuarios conectados genera un catalogo de diferentes situaciones y personas, que nos hablan de cómo administramos nuestra propia privacidad dentro de nuestro último espacio privado, nuestro "cuarto propio conectado" como diría Remedios Zafra, donde nos ponemos en contacto con otros usuarios y conformamos un nuevo espacio público online de experimentación dentro de Internet mediante nuestro trabajo inmaterial, feminizado y amateur. En un segundo proyecto podemos observar como la escultura social compuesta por la producción de la multitud, genera la representación de un lugar a lo largo de un año, mediante un catalogo de momentos que realmente responden a nuestro impulso de ampliar nuestra presencia como resultado de la interconexión constante en la que vivimos, que a la postre conforma otra dimensión de nuestra realidad. En este sentido es interesante destacar como ya en los años 90 del siglo XX autoras como Judith Donath y Sherry Turkle percibieron como estos nuevas estructuras mediáticas eran capaces de modelar quienes somos y como nos representamos.

${ }^{232}$ Adorno, Theodor, Horkheimer, Max, op. Cit., 1998, pág. 178. 
La tecnologías relacionadas con la Web 2.0 han posibilitado y amplificado esta mezcla entre las esferas publica y privada, generando una mezcolanza, que como recalca Casacuberta ${ }^{233}$, nos hace cuestionarnos el estatus de la red como ágora para pasar a visibilizarla como espacios gestionados corporativamente. La propia estructura de Internet despende de los denominados "Backbones"234, o columnas vertebrales de este espacio, que a su vez son fácilmente controlables como herramientas de control usando como excusa la criminalidad o el terrorismo 235 . Por otro lado la web 2.0, como vimos anteriormente, ha convertido nuestro tiempo de ocio en tiempo de trabajo para terceros que cimenta la rentabilidad económica de las empresas de Internet más potentes, lo que me ha hecho reflexionar a su vez sobre la supuesta naturaleza anárquica de Internet para concluir que todas las utopías generadas con el nacimiento de Internet han sido usadas para generar un supuesto espacio de libertad que es aún más fácilmente controlable, clasificable y rentabilizable. Un espacio que creemos público en el cual tenemos un comportamiento en muchos casos inconsciente, pero en el cual todas nuestras acciones son registradas y nuestras identidades fácilmente identificables en pos del marketing. Sin embargo puede ser intervenidos y resemantizado mediante la practica artística. Estos espacios logran reunir a grandes cantidades de usuarios productores habidos por crear, pero también con la intención de ampliar su presencia y sus relaciones afectivas.

En un segundo bloque abordamos de manera transversal los fenómenos de virtualización y desterritorialización adjuntos a estas tecnologías como consecuencia de otro solapamiento, el de lo real y lo virtual. Mientras que por un lado gracias a las redes somos individuos disueltos y constituidos por información, estás herramientas son capaces de llevar nuestra percepción de la realidad y de nosotros mismos, a un terreno artificial constituido por datos e imágenes, continuamente modificado por las propias herramientas dedicadas a constituir estas encarnaciones y representaciones. En este bloque pasé a trabajar con dos de las herramientas hegemónicas más usadas en la actualidad, como son Google Imágenes y Google Earth, constituidas como

\footnotetext{
${ }^{233}$ Casacuberta, David, op. Cit, [En línea], [Consultado el 20 de Julio de 2017], disponible en < http://www.ub.edu/imarte/investigacions/estudis-teorics/david-casacuberta/reclaim-thebackbone-repensar-internet-como-espacio-publico/>

${ }^{234}$ Lessig, L., Code and other laws of cyberspace, New York, Basic Books, 1999.

${ }^{235}$ Castells, Manuel, op. Cit., 2001.
} 
arquitectos de nuestra realidad exterior, pero también como generadoras de cuerpos de datos paralelos a nosotros mismos.

En una primera obra llamada Google Me, las propias imágenes generadas por una búsqueda inversa en Google Imágenes, basada en nuestro propio retrato real, son puestas en movimiento para conformar una forma antropomorfizada de la combinación de estas imágenes. Aquí la potencialidad de los datos generados por la búsqueda es solidificada en una animación que muestra un individuo virtual generado por las imágenes de completos desconocidos. Es por ello que el proceso de esta obra ilustra el paso de mi propio retrato por el filtro de una herramienta virtual que interpreta esta misma imagen como gran numero de ítems similares. Mediante la transformación de las imágenes se convierte la potencialidad de esta información en virtualidad. Esta obra nos habla del paso de una identidad constituida en base a el otro, a una identidad generada en base a la interpretación que un algoritmo hace de quienes somos, en base a nuestro actuar en la red.

Por otro lado, la obra Neogeografías nos muestra los procesos de virtualización y desterritorialización adjunto a las aplicaciones de geonavegadores web, transformados en otra dimensión de nuestra realidad, mediante su uso por parte de los usuarios de la aplicaciones de la Web 2.0. Esto ha provocado una resemantización de la propia geografía. Así pues como usuarios no estamos generando experiencias irreales al recorrer estas texturas navegables, sino que se ha posicionado como otra experiencia de lo real basada en la exploración de estos collages.

En un último bloque las obras giran de manera transversal en torno a la relación entre lo global y lo local y de cómo tanto acontecimientos cotidianos como mundiales son transformados tanto por los autores de las imágenes como por las estructuras mediáticas que los sustentan. En una primera obra denominada $E c o$ se ha utilizado una imagen que pone de manifiesto como un hecho puntual y cotidiano, como la toma de un selfie, puede tener una repercusión global gracias a las estructuras mediáticas de las aplicaciones de la Web 2.0. Esta imagen nos muestra el considerado como primer selfie tomado a un Papa de la Iglesia Católica. Vemos pues como acontecimientos realmente anecdóticos acaecidos dentro de la cotidianeidad de diferentes personalidades mundiales, son diariamente amplificados y difundidos por 
medio de las redes sociales, constituidas como herramientas de self-branding, tal y como señalaría Gemma San Cornelio. Como nos anunció Judith Butler en El genero en disputa, el genero y por lo tanto la identidad tienen cualidades performativas. Esto dentro de Internet se relaciona con el propio actuar que es la base del funcionamiento de las aplicaciones más populares. Aquí podemos ver como la función narrativa de la identidad se vale de los relatos pasados y presentes para construir lo que Paul Ricoeur denominó identidad narrativa, supeditada a la acción, y en este caso su reflejo en las redes.

Ya en la segunda mitad del siglo XX Guy Debord se percató de cómo el consumo de imágenes pasaría a ser constitutivo de lo que el vino a denominar "el espectáculo". Estos proyectos en cambio nos hablan de la sobreproducción de imágenes que nos anunció hace años Joan Fontcuberta. Este fenómeno quedaría encuadrado dentro de lo que Tiziana Terranova denomina affective labor, como parte del trabajo inmaterial gratuito, feminizado y amateurizado que realizamos dentro de las redes.

Por otro lado, el proyecto denominado Paisajes subjetivos nos presenta como acontecimientos que tienen lugar dentro de lo global son descontextualizados para ignorar el verdadero origen local de las causas materiales de estos. Aquí los medios tienen un papel disociativo entre causa y efecto que alimenta la desinformación. Por otro lado este proyecto nos habla de un mundo donde las fronteras geográficas ya no tienen el papel que tenían antes para la segregación de poblaciones. Esto se debe, por un lado, a la amplificación de los flujos migratorios pero también a las tecnologías asociadas a Internet. Las imágenes como constructos tienen el poder de cambiar nuestra percepción sobre la realidad exterior, sin embargo el papel de la práctica artística para señalar este hecho y subvertir este tipo de manipulación es uno de los puntos de interés de este proyecto. Ambas obras, en este tercer bloque, vienen a ejemplificar la relación de las estructuras mediáticas con los contenidos, lo que es definido pro William J T Mitchell como la relación fondo figura, es decir la relación entre el contenido y las estructuras mediáticas que las sustentan.

Como hemos podido comprobar la transversalidad de los diferentes conceptos que atraviesan la práctica artística presentada en esta tesis nos lleva de manera tangencial a cuestiones que estructuran, tanto nuestra cotidianeidad como los grandes acontecimientos globales. Hemos visto como lo difuso entre 
las fronteras de los real y lo virtual, lo publico y los privado y lo global y lo local, gracias a la implementación de las nuevas tecnologías, ha generado cambios paradigmáticos en la manera en la cual nos relacionamos, nos representamos y percibimos nuestra realidad exterior. Pese a lo vaporoso e intangible de estas grandes mezcolanzas su impacto e importancia son transcendentales si queremos comprender la manera en la cual se articulan este tipo de circunstancias. Es por ello que la propia cinta de Moebius es el vehículo perfecto para comprender la manera en la cual estas áreas han colisionado entre si. Estas son, por lo tanto, ideales para generar el armazón de una práctica que trata esencialmente sobre el impacto de las tecnologías de Internet sobre nuestra identidad, percepción y cognición, y de cómo esto afecta a nivel individual y colectivo a nuestro actuar dentro de la red. El propio conjunto de bloques está a la vez constituido por parejas de obras que enfrentan el adentro con el afuera y el interior con el exterior. En un primer bloque se enfrentan dos obras, en las cuales se contraponen nuestro enfrentamiento con el otro, que conforma nuestra identidad, con lo colectivo y nuestro potencial como multitud. En un segundo bloque, se contraponen los datos generados en base a un individuo que acaban conformando su representación, con la representación del paisaje exterior en forma de collage navegable. Por último, vemos como lo cotidiano y personal se contrapone a realidades cercanas a lo global que son difundidas por los medios de comunicación de masas.

Por lo tanto, la manera en la cual se ha estructurado la praxis de esta investigación ha sido una herramienta esencial para imprimir, de manera implícita y transversal, multitud de cuestiones que sobrevuelan nuestra realidad inmanente y externa. Estas cuestiones señalan la manera en la cual ciertos conceptos se han solapado entre si, generando un escenario complejo y cambiante que evoluciona constantemente. Precisamente en este hecho estriba la dificultad de analizar desde un punto de vista también móvil ideas y acontecimientos mutables, y en algunos casos efímeros debido sobretodo al constante cambio tecnológico que vivimos. Estos cambios tal y como apunta McLuhan generan una transformación que va más allá de una evolución tecnológica, ya que cambian por completo nuestro entorno y a nosotros mismos pese a nuestra inconsciencia al respecto. 


\subsection{HOW WE CAN MAKE EACH OTHER BETTER?}

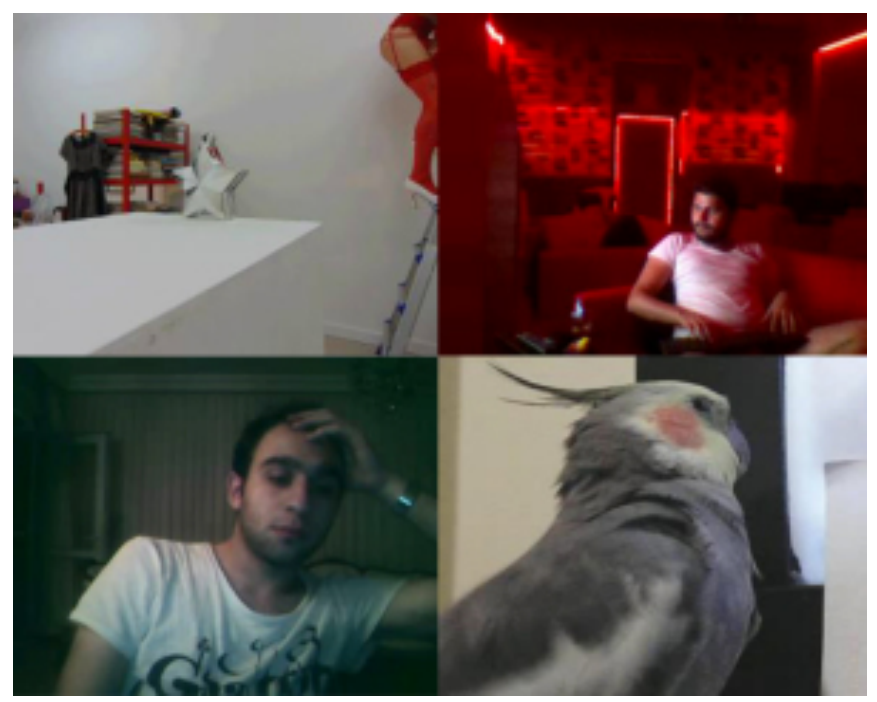

Figura 43. Capturas de retransmisiones de usuarios en Chatroulette.

Aunque la mayoría de los usuarios tiene la sensación de que Internet ha cambiado el rumbo de las relaciones interpersonales, más bien deberíamos afirmar que ha mutado la manera en la cual se emplea este concepto, e incluso la significación del mismo. Esto se ha producido en base a la aparición de nuevos tipos de interacciones relacionados con el propio funcionamiento de los espacios virtuales. Cuando redes sociales como Facebook nos sugieren un gran número de contactos como posibles nuevos amigos, no está intentando que nuestra vida social adquiere una mayor intensidad, sino que de hecho, está incentivando la creación de redes de contactos mucho mayores, lo que posibilita un mayor número de interacciones que incentiven una mayor producción de contenidos. Esto pone en funcionamiento y rentabiliza estas estructuras mediáticas. Los sistemas diseñados para aumentar la conectividad nos enfrentan a un nuevo escenario relacional, y en general, están cambiando nuestra comprensión de los vínculos, las relaciones y la intimidad.

El estudio de diferentes espacios virtuales nos llevó a interesarnos por Chatroulette, esta es una aplicación popularizada alrededor de 2011 debido a su transformación en un fenómeno viral dentro de las redes. Se trata de una 
interfaz web cam-to-cam, es decir, genera comunicaciones con usuarios aleatorios mediante webcam a través de un sitio web de videoconferencia. Como podemos observar, esta web nos ofrece la posibilidad de saltar de un usuario a otro al azar, dando como resultado el predominio de un comportamiento libre, en el sentido de consecuencias o repercusión social. Esto proporciona un catálogo interminable de emociones humanas, que plantean un completo estudio sociológico y antropológico de la percepción del sujeto sobre las repercusiones sociales de nuestro comportamiento en las redes. Este sitio web permite la comunicación mediante retransmisión de video en directo con sonido y texto, pudiéndose anular la emisión de video o sonido para utilizar únicamente una de estas funcionalidades. También aporta un tipo de herramienta de dibujo de estilo libre que permite dibujar sobre el espacio donde se enmarca la conversación escrita. Durante la investigación en este sitio web optamos por no retrasmitir video en directo y usar una imagen predefinida anónima. Este tipo de actitud tenía como fin cambiar de manera mínima el comportamiento de los usuarios. Posteriormente decidimos optar por el uso de diferentes avatares masculinos y femeninos de diferentes edades, que me mostraran las claras diferencias entre las interacciones que se producen mediante diferentes tipologías de usuarios. Inmediatamente nos percatamos que el perfil de usuarios mayoritario de esta web, basada en el hombre joven heterosexual, implicaba un mayor numero de interacciones ante una usuaria del sexo opuesto, pudiéndose generar una relación directa entre el número de interacciones conseguidas y el tipo de usuaria/o que mostrara.

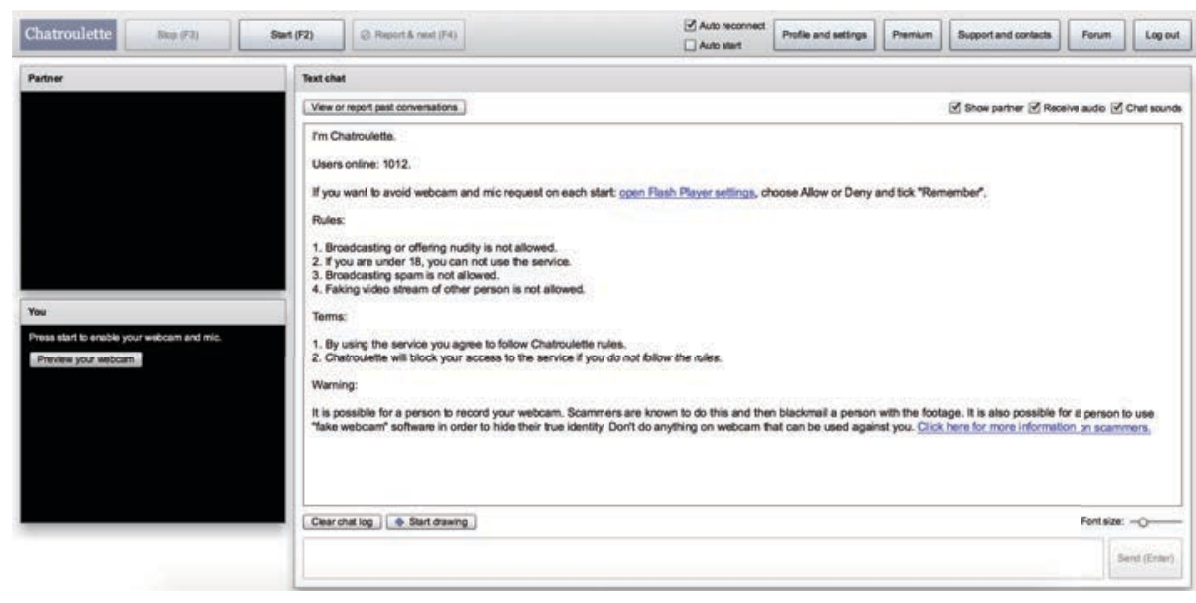

Figura 44. Aspecto de la interfaz de Chatroulette en el momento de la investigación en 2013. 
Como podemos observar al explorar este servicio gratuito, una de las funcionalidades con las cuales cuenta el usuario es presionar la tecla next, lo que permite conectar con otro usuario aleatoriamente. De esta manera, una de las prácticas más comunes es la creación de una cascada de conexiones aleatorias y efímeras de carácter voyeurista y exhibicionista. La realidad de la interacción cotidiana en esta web nos enfrenta al hecho de que realmente no queremos comunicarnos con cada uno de los usuarios que nos encontramos, y que el porcentaje se usuarios con los cuales se suele iniciar una conversación real es muy bajo. Esta cascada de conexiones, se configuran como un fluir comunicacional que irónicamente no produce comunicación o intercambio alguno, sino que más bien, genera un catalogo de espacios privados abiertos al exterior ante la deriva comunicativo de las redes.

Como pudimos observar, para muchos usuarios, el hecho de retransmitir su vida mediante video en directo en el ámbito domestico parece haberse convertido en un hecho cotidiano y secundario, ante la fragmentación en la atención que las redes y el propio espacio de conexión provocan. Así pues, podemos encontrar usuarios que no prestan atención a quién les observa, y bien atienden otro tipo de tareas en su ordenador o realizan cualquier otro tipo de actividad ajena al hecho de retrasmitir video en directo. La retrasmisión constante de su espacio privado es sin duda un tipo de actividad que no deja de sorprender por el grado de asimilación de estas prácticas dentro de la cotidianidad y lo despreocupado de las actitudes respecto a las mismas. En base a la exploración previa, el hecho de retrasmitir en directo ha pasado a tener diferentes usos que van desde lo lúdico y grupal, hasta lo individual y cotidiano, imponiéndose en gran medida la retrasmisión de video como actividad ubicada dentro del ámbito de la multitarea, y en algunas ocasiones convertida incluso en una actividad secundaria y olvidada, a favor de otras de mayor prioridad. Esto contrasta con grupos de usuarios que se reúnen en torno a un ordenador para explorar de manera grupal la casuística que el uso aleatorio de esta web nos regala.

Aunque como veremos, estadísticamente no es representativo, en el momento en el cual llevamos a cabo esta investigación podíamos observar como un pequeño numero de usuarios masculinos mostraban su genitalidad explícitamente con el objetivo de encontrar sexo virtual. Esta práctica exclusivamente masculina parecía haber despertado el ingenio de otros 
usuarios que mediante diferentes programas lograban retrasmitir videos pregrabados de carácter erótico con el fin de captar la atención de estos usuarios y perpetrar algún tipo de broma o prank, realizada por los conocidos como trolls de Internet. Este tipo de programas han sido usados con otro tipo de usuarios con el mismo fin. Se trata de una manera de captar fácilmente la atención de los usuarios durante el mayor tiempo posible sin mucho esfuerzo. Sin embargo, el mundo del prank en Chatroulette no solo se centra en este tipo de programas, sino que existen multitud de prácticas que consiguen engañar a otros usuarios sin necesidad de estos. Estas prácticas fueron popularizadas por la celebridad de Youtube y humorista Steve Kardynal236, el cual mediante sus disfraces lograba engañar a usuarios masculinos haciéndoles creer que era una chica, hasta que decidía mostrar su rostro, lo que provocaba que se desconectaran inmediatamente. Lo que en principio podríamos considerar una performance online adquiere diferentes matices si tenemos en cuenta las connotaciones respecto a los roles de genero que esto implica. Los usuarios masculinos tienden a plantear la búsqueda de una usuaria femenina como su objetico principal. Esto pone de manifiesto que pese a su funcionamiento aleatorio, estos usuarios han logrado resignificar este espacio mediante su uso, en base a la reproducción de estereotipos de genero. Kardynal también realizó versiones de diferentes canciones pop en Chatroulette ante diferentes usuarios travistiéndose como mujer, lo que fue mayormente acogido como una exitosa performance.

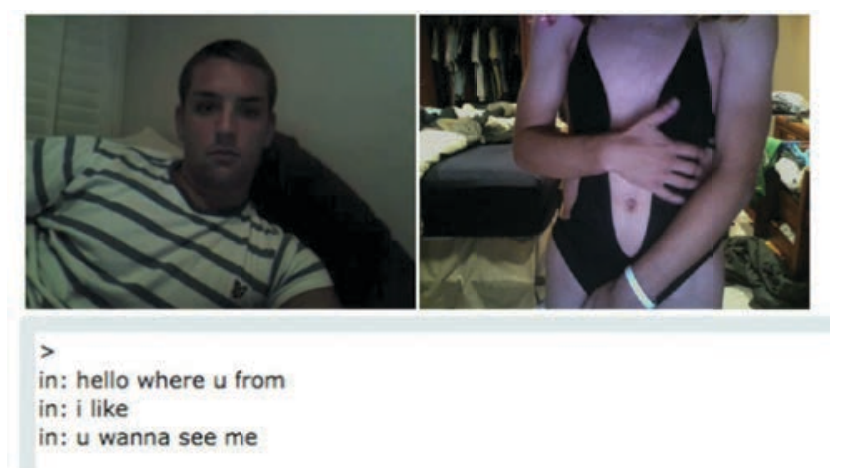

Figura 45. Imagen perteneciente a una prank de Steve Kardynal en Chatroulette.

\footnotetext{
${ }^{236}$ Canal de Youtube del humorista Steve Kardynal, [en línea] 2009 [consulta 6 de Marzo de 2017] disponible en <https://www.youtube.com/channel/UCGwruZaVBIp2AwbdUdNaLPQ>
} 
Una de las primeras conclusiones fue que estábamos ante una página web altamente masculinizada, por el número de usuarios y las prácticas que determinan el funcionamiento de estos espacios virtuales. Los parámetros que delimitan las interacciones en esta web vienen dados por el propio diseño comunicacional y mediático concebido por su creador. Este fue un proceso llevado a cabo por un solo individuo dentro del ámbito amateur, que debido a su éxito se ha integrado en un modelo de negocio corporativo. Andrey Ternovskiy 237 , un hacker ruso de 17 años ubicado en Moscú, fue le creador de su diseño y funcionamiento. El creador argumenta que la idea surgió como consecuencia de las largas conversaciones que tenía con sus amigos mediante Skype, y tras ver en televisión la película de 1978 The Dear Hunter, ubicada en la guerra de Vietnam, donde prisiones son obligados a jugar a la ruleta rusa. Ternovskiy relacionó los conceptos de ruleta rusa y Skype dando origen a la idea original, lo que le hizo escribir en dos días el código completo de la web. Tras ponerla en funcionamiento en Noviembre de 2009, pasó de tener 500 visitantes a 50.000 en un mes. En Marzo, Ternovskiy estimó 1,5 millones de visitantes, un tercio de los cuales provenían de EEUU.

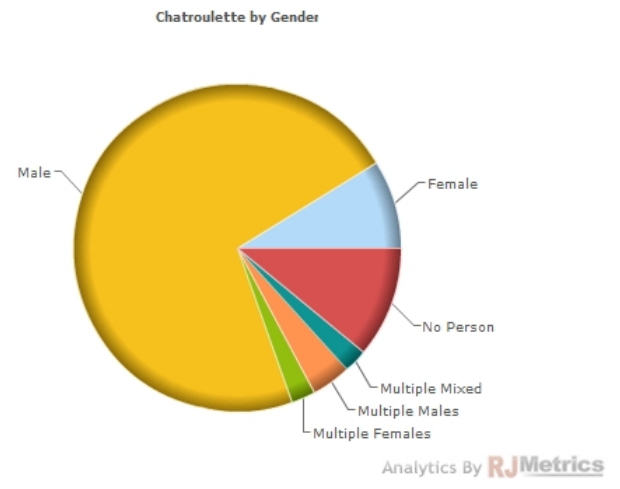

Figura 46. Ratio de usuarios de Chatroulette por sexo.

\footnotetext{
${ }^{237}$ Stone, Brad, Chatroulette's Creator, 17, Introduces Himself, New York Times, [en línea], 2010, [consulta 6 de Marzo de 2017] disponible en <https://bits.blogs.nytimes.com/2010/02/13/chatroulettes-founder-17-introduces-himself/>
} 
Según un estudio realizado por RJMetrics en $2010^{238}$, el $72 \%$ de los usuarios son hombres, el $9 \%$ mujeres y el $11 \%$ no mostró su genero. El $70 \%$ de los usuarios de esta web son adultos jóvenes, y alrededor del $20 \%$ era menor de 20 años, siendo solo el $10 \%$ personas mayores de 40 años. Por países, EEUU es el que mayor número de usuarios aporta con un $47 \%$, seguido de Francia con un $14 \%$, y Canadá, Alemania, Reino Unido y Turquía con alrededor de un 5\%.

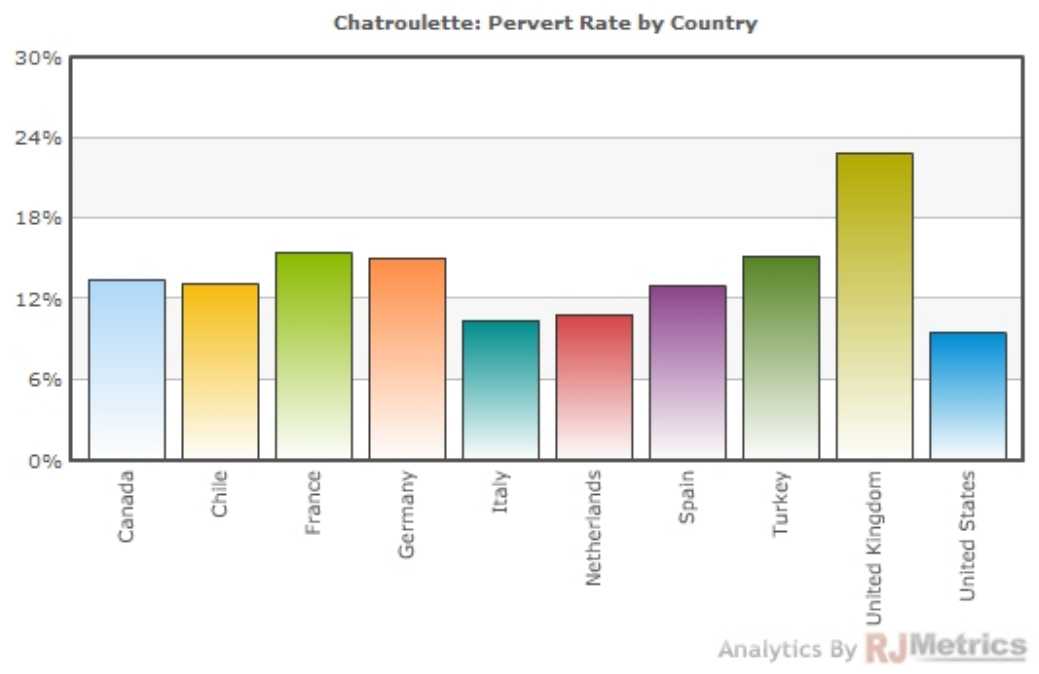

Figura 47. Ratio de usuarios que ofrecen contenido inapropiado por países.

Aproximadamente 1 de cada 8, es decir el 12,5\%, de los usuarios mostraban contenido inapropiado. Con este tipo de contenido denominamos a usuarios con poca ropa, desnudos o cometiendo un acto sexual explicito. En este aspecto Reino Unido, con un $22 \%$, es el país que más usuarios con contenido inapropiado aporta, seguido por Francia, Alemania y Turquía con un 15\%. También hay que destacar los usuarios que aunque no muestren desnudez, piden desnudos femeninos mediante avatares o fotos de perfil, tratándose tan solo del $1 \%$ al $2 \%$, lo cual, como apunta este estudio, significa que existen el doble de posibilidades de encontrar este tipo de carteles que una usuaria

\footnotetext{
${ }^{238}$ Stein, Jake, Chatroulette Data: What Are The Odds Of Seeing A..., rjmetrics.com [en línea], 2010, [consulta 6 de Marzo de 2017] disponible en <https://blog.rjmetrics.com/2010/03/22/chatroulettedata-what-are-the-odds-of-seeing-a/>
} 
desnuda real. El anonimato parece ser un elemento clave en el funcionamiento de este espacio, pero que por otro lado hace difícil una investigación estadística más profunda y reveladora. Un 30\% de los usuarios de este web son menores de 18 años por lo cual a parir de 2012 Chatroulette decidió cambiar los términos y condiciones para prohibir la desnudez, así como la necesidad de registrarse para usar este servicio. Por otro lado, se desarrolló un algoritmo que filtra el contenido obsceno ${ }^{239}$. Tras esto, un mayor numero de usuarias empezaron a usar esta web. Este sistema de tracking de video es capaz de identificar cantidades excesivas de piel mostradas, así como las caras de los usuarios, filtrando hasta un $60 \%$ de todo el contenido inapropiado. También se toman capturas de pantalla cada cierto tiempo, las cuales son analizadas manualmente para bloquear a los usuarios sorprendidos realizando algún acto ofensivo, lo que da como resultado el bloqueo de 50.000 usuarios al día. Por otro lado, una de las funcionalidades de la web permite denunciar a un usuario que muestre contenido inapropiado, con lo cual un usuario denunciado por otros tres es bloqueado temporalmente.

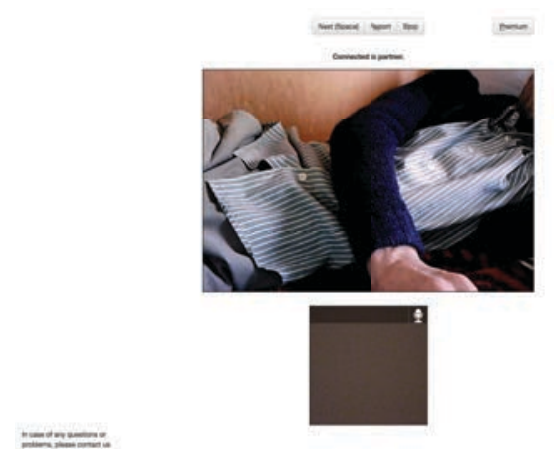

Figura 48. Aspecto actual de la interfaz de Chatroulette a principios de 2018.

Como hemos podido comprobar en las ultimas versiones la aplicación no se pone en funcionamiento hasta que no detecta un rostro retransmitido por la cam, no cuenta con chat de texto y solo nos podemos comunicar mediante imágenes y sonido, lo cual limita en gran medida una exploración anónima de

239 Bulatovic, Peja, Nudity filter helps Chatroulette clean up, CBC News, [en línea], 2011, [consulta 6 de Marzo de 2017] disponible en <http://www.cbc.ca/news/technology/nudity-filter-helpschatroulette-clean-up-1.1094425> 
este espacio. Sin embargo, como hemos podido comprobar existe un gran número de usuarios masculinos que aún usa este espacio para exhibirse y buscar sexo virtual. También es destacable la bajada en el número de usuarios de este espacio tras el tremendo hype tecnológico desarrollado en sus inicios, lo que la ha posicionado como una web entre tantas otras que aparecieron tras el éxito inicial de Chatroulette, y que ofrecen el mismo servicio. Debemos advertir que la investigación presentada en esta tesis fue elaborada durante 2013 por lo cual nos estamos refiriendo a una versión que no contaba con la gran cantidad de filtros que podemos encontrar hoy en día, así como un interfaz de aspecto totalmente diferente. Este tipo de sitio web primigenio nos podía recordar en cierto modo la naturaleza anárquica y autogestionada de los espacios virtuales del primer Internet anterior a la hegemonía de la Web 2.0.

Esta investigación parece coincidir en que el impacto de Internet en la construcción de identidades sexuales ha sido desde sus orígenes una constante. Solo tenemos que explorar las investigaciones de Sherry Turkle a principios de los años 90 del siglo XX en los HUB ${ }^{240}$ del primer Internet, para entender como los participantes de estos espacios tienen la posibilidad de construir, ensayar y vivir nuevas identidades y formas de expresión sexual fuera de la heteronormatividad y las normas sociales, gracias a la libertad y el anonimato de la red.

Dentro de la investigación en Chatroulette, pude constatar como el anonimato, tan denostado por los creadores de otras redes sociales como Facebook en favor de usuarios identificados por su identidad real, es un valor dentro de una web de estas características. Genera una gran sensación de libertad y de ausencia de consecuencias que libera las actitudes presentadas por los usuarios. Ha dado como resultado un sitio web en torno al cual se ha generado la imagen generaliza de espacio virtual dedicado a las prácticas de intercambio sexual online. Esto ha sido propuesto por el profesor John Suler como el "efecto de desinhibición online"241, basado en la invisibilidad, la asincronía, la falta de empatía, y otros factores individuales, como la

\footnotetext{
${ }^{240}$ Trukle, Sherry, op. Cit., 1997.

241 Suler, John, The Online Disinhibition Effect, en línea], 2004, [consulta 19 de Junio de 2017] disponible en <https://www.liebertpub.com/doi/abs/10.1089/1094931041291295>
} 
personalidad y la cultura. Es considerado un efecto tanto negativo como positivo en base a las consecuencias del mismo.

Como hemos visto en base a las estadísticas, si bien el exhibicionismo sigue siendo una práctica habitual, los mecanismos de reconocimiento facial242actuales, tracking de video y las funcionalidades que permiten reportar comportamientos obscenos dentro de esta web, han conseguido reducir considerablemente este tipo de prácticas. Estos usuarios se valen de las características de este espacio virtual para transformar al otro en un espectador involuntario. Esto posiciona al exhibicionista como un individuo que usa su poder, extraído de las características de esta web, de manera indiscriminada sobre los demás. Por lo tanto, podemos afirmar que un uso inadecuado pero basado en la libertad de este espacio, ha producido una normativización del mismo que limita este tipo de comportamiento.

El modelado del genero y la sexualidad por parte de las tecnologías sociales, es algo que ya Michel Foucault analizó en profundidad, siendo espacialmente interesante su efecto en nuestros cuerpos, nuestro concepto de nosotros mismos y la manera en la cual nos representamos mediante los roles sociales. Mientras que para Foucault 243 el genero es el producto de la acción de la historia sobre la sociedad, para Judith Butler los cuerpos sexuados son consecuencia de los discursos desarrollados desde el poder como elemento normativizador. Dentro del paradigma de la deconstrucción antiesencialista Judith Butler ${ }^{244}$ nos plantea su teoría de la performatividad del genero, donde la orientación sexual, las expresiones relacionadas con el genero y la identidad sexual son el resultado de una construcción cultural, social y histórica, tomando la cultura un papel hegemónico sobre la biología. Para ella, sexo, identidad y genero son constituidos como actos performativos. Esto resulta totalmente coherente con el comportamiento de los usuarios de este tipo de espacios virtuales, donde la performatividad de diferentes tipos de sexualidad

\footnotetext{
${ }^{242}$ Carlson, Nicholas, Here's THE Solution To Chatroulette's Penis Problem, [en línea], 2010, [consulta 19 de Junio de 2017] disponible en <http://www.businessinsider.com/chatroulette-penis-problemsolved-2010-04>

${ }^{243}$ Foucault, Michel, Historia de la sexualidad. Vol 1: La voluntad de saber, Siglo XXI, Madrid, 2009.

${ }^{244}$ Butler, Judith, op. Cit., 2007.
} 
e identidades se ha convertido en una práctica habitual, debido a lo efímero, anónimo y anárquico de este tipo de webs.

El catálogo de actitudes que podemos observar nos muestra, tal y como nos narra Un cuarto propio conectado de Remedios Zafra ${ }^{245}$, la manera en la cual nuestra habitación se ha transformado en un espacio que va más allá de un centro de operaciones informacional, para convertirse en un espacio de experimentación identitaria, sexual y comportamental. El solapamiento de las esferas pública y privada en base a las redes de información y en este caso, gracias a las nuevas tecnologías basadas en la retransmisión de video en directo, queda aquí plasmado mediante un servicio web que abre nuestro espacio más privado al mundo exterior, a ese "gran otro" que propugnaba Lacan y que es necesario para la constitución del yo. Este otro, es alcanzable mediante nuestra ventana al mundo exterior en forma de paisaje mediático.

Debemos recordar que ya McLuhan nos hablaba de cómo los medios son una extensión de nosotros mismos, conformándose como prótesis que entumecen nuestros órganos sensoriales, y por lo tanto nuestra percepción. Mediante el concepto de "narcosis narciso" McLuhan nos describe un síndrome mediante el cual los individuos no son consientes de los efectos de la tecnología sobre ellos mismos. El ser humano queda fascinado ante cualquier extensión que la tecnología genera amplificando nuestras capacidades incluso la de ampliar nuestra presencia más allá de lo que nuestras limitaciones espaciales nos permiten. Estamos ante lo que Antonio Rodríguez de las Heras denomina la presencia ${ }^{246}$. Esta puede ser definida como una amplificación de nuestra propia existencia a través de las prótesis virtuales que usamos en nuestra vida diaria, siendo un nuevo y sugerente uso de las tecnologías de Internet desarrollado durante la última década con el propósito de extender nuestras capacidades. En los últimos años las tecnologías de retransmisión de video en directo y la conexión permanente se han convertido en prótesis virtuales que

\footnotetext{
${ }^{245}$ Zafra, Remedios, Un cuarto propio conectado, (Ciber)espacio y (auto)gestión del yo, Fórcola, Madrid, 2010.

${ }^{246}$ Rodríguez de las Heras, Antonio, Un nuevo y sugerente uso visual de la Red se está gestando, Bez.es, [en línea], 2016, [consulta 19 de Junio de 2017] disponible en $<$ https://www.bez.es/546801274/Un-nuevo-y-sugerente-uso-visual-de-la-Red-se-estagestando.html>
} 
amplifican nuestra presencia en lugar de plasmar la mirada mediante la fotografía. Esta presencia comparte nuestra experiencia en un lugar y momento que puede desarrollarse de múltiples maneras, dentro de esta burbuja de conectividad permanente.

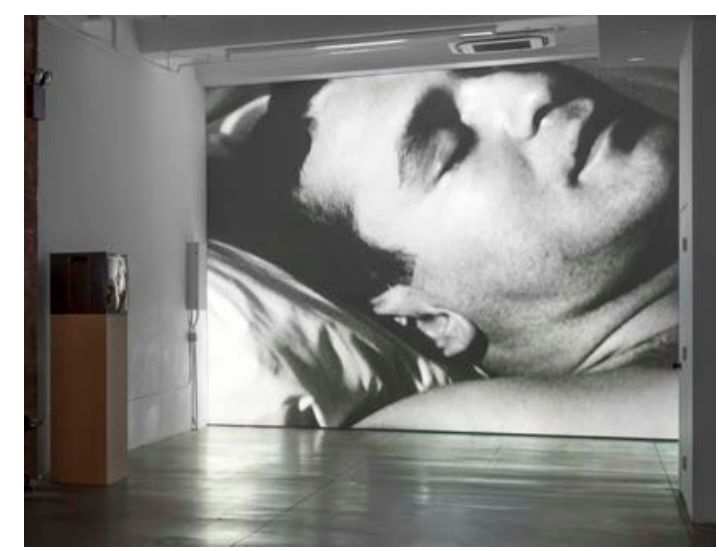

Figura 49. Instalación de Sleep de Andy Warhol en el Instituto Suizo de Nueva York, 2017.

Podemos encontrar un precedente pero no un referente directo de este tipo de prácticas en la película de 1963 titulada Sleep del artista Andy Warhol. En ella se rodó al poeta John Giorno, el cual era su amante, durante 5 horas y 20 minutos consecutivos mientras dormía plácidamente. Según Warhol, John Giorno era el durmiente más profundo del mundo, con lo cual se le ocurrió estrenar su nueva cámara Bolex filmándole, lo que constituyó según Warhol su primera película real247. Curiosamente durante mi exploración de Chatroulette tuve la oportunidad de encontrar a usuarios que dormían ante la cámara durante horas, retransmitiendo esta vigilia en directo a los usuarios que conectaban con el.

\footnotetext{
${ }^{247}$ Gopnik, Blake, Andy Warhol, Sleep (1963), [en línea], 2017, [consulta 19 de Octubre de 2017] disponible en <https://brooklynrail.org/2017/09/criticspage/Andy-Warhol-Sleep-1963>
} 


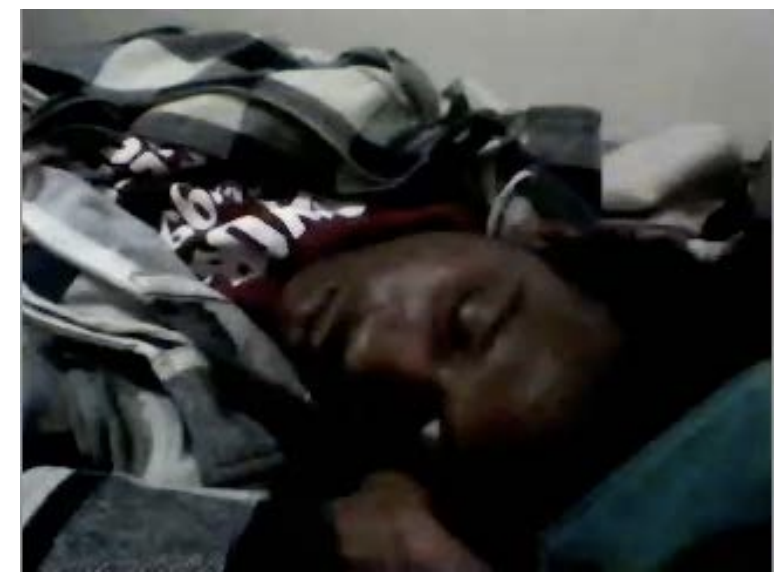

Figura 50. Usuario durmiendo durante su retransmisión a través de Chatroulette.

Por otro lado, el fenómeno conocido como Sakte TV o televisión lenta por su traducción del noruego, es un tipo de genero de maratón televisivo. Uno de los programas más populares de este genero en su país de origen, Noruega, consistió en la retrasmisión del viaje en tren que cubre la línea entre Oslo y Bergen o Bergensbanen en 2009, siendo una de las retrasmisiones más memorables en la historia del país nórdico.

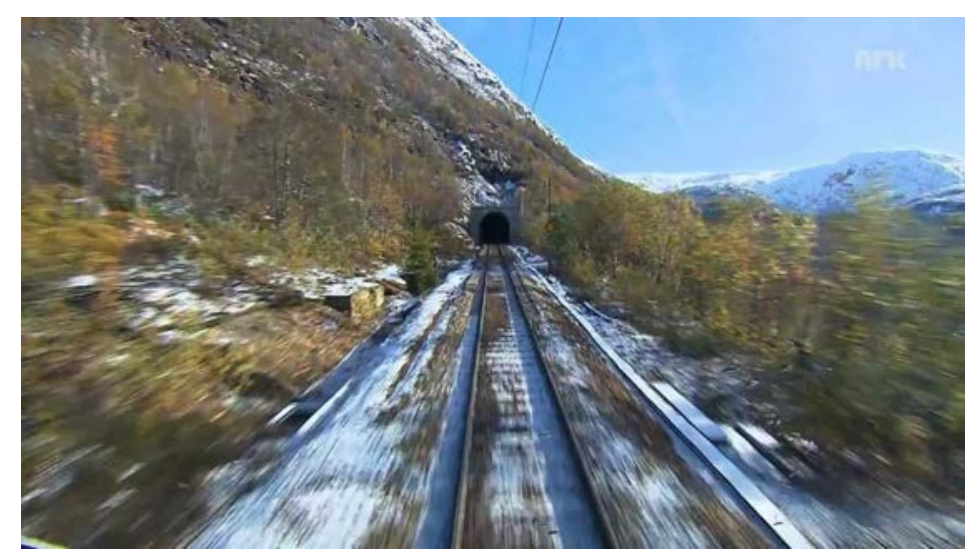

Figura 51. Still del trayecto Oslo-Bergen retrasmitido por la televisión estatal noruega. 
También dentro de las prácticas relacionadas con la red, podemos destacar la obra realizada por el artista iraquí Wafaa Bilal llamada Domestic Tensión ${ }^{248}$ realizada en 2007. En esta obra llevada a cabo en la FlatFIle Galerie de Chicago, el artista fue confinado en su interior durante un mes, durante el cual estaba conectado a Internet pudiendo interactuar con los espectadores que le contemplaban por la web del proyecto. Además una pistola de paintball robotizada podía ser controlada por los espectadores y disparar a Bilal balas de pintura amarilla las 24 horas del día.

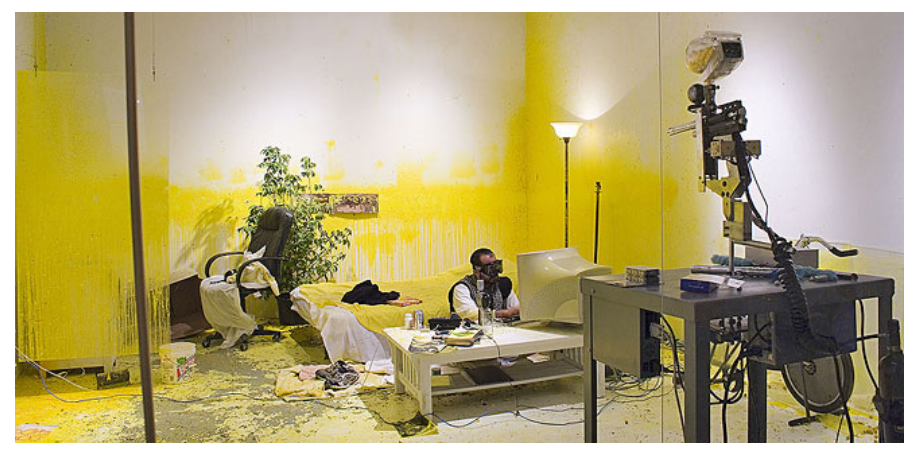

Figura 52. Imagen de la galería durante la realización de Domestic Tension.

Cada día el artista publico un video resumen de su actividad diaria en su canal de Youtube generando una completa bitácora de su actividad. Finalmente, el artista se vio superado por la experiencia y sufrió síntomas de estrés postraumático comparables a los de una persona que ha vivido en una zona de guerra. Para el artista, esta obra fue una manera de mostrar el racismo de la sociedad de EEUU tras los eventos del 11S y el sufrimiento de los compatriotas de su país. Para el fue una manera de lidiar con los traumas de sus propias experiencias vitales durante el régimen de Saddam Hussein, la guerra del golfo y los conflictos entre diferentes facciones musulmanas de su país. Mediante este proyecto el artista consigue trabajar con la mediación de la violencia a través de las tecnologías de Internet y la gamificación, adoptando el formato de un videojuego de disparos en primera persona, y conformando como soldados a unos usuarios entusiasmados ante la idea de disparar a un iraquí y

\footnotetext{
${ }^{248}$ Web del artista donde se recogen los videos publicados cada día [en línea], 2016, [consulta 19 de Junio de 2017] disponible en <http://wafaabilal.com/domestic-tension/>
} 
convertir la galería en una autentica zona de guerra. Esto provocó un conflicto prolongado entre los detractores y defensores del artista en el chat del proyecto. Según el propio artista esta obra fue concebida para generar controversia sobre la naturaleza tecnológica de la guerra moderna. Por otro lado este proyecto nos habla de la dicotomía entre lo real y lo virtual, transformando la experiencia del arte como elemento pasivo en una participación online implementada gracias a las redes. Mediante esta obra Bilal genera conciencia sobre la guerra virtual en forma de confinamiento que vive su país y de cómo mediante una obra en forma de shooter ${ }^{249}$ se puede visibilizar la experiencia vivida por sus habitantes en el contexto de una guerra que es implementada por tecnologías de la información y la comunicación.

Durante el recorrido exploratorio sobre Chatroulette hemos tenido la suerte de poder encontrar algunas muestras de intervenciones artísticas dentro de este espacio. Una de las primeras obras que nos llamó poderosamente la atención fue la desarrollada por Michael Aniser e Isabel Walter en Berlín, dentro de la performance de danza interactiva a través de Chatroulette denominada Danceroulette 250 . La idea es que usuarios aleatorios puedan controlar a los bailarines dentro del escenario quedando derogados aspectos de la vida cotidiana como el capital cultural, origen social o la nacionalidad.

\footnotetext{
${ }^{249}$ Termino anglosajón para referirnos a un juego de disparos, englobado dentro de la categoría de juegos de acción, en el cual se suele controlar a un personaje armado mediante un modo de visión en primera o tercera persona.

${ }^{250}$ Video de presentación en el canal de Youtube del proyecto Danceroulette. [en línea], 2012, [consulta 19 de Junio de 2013] disponible en <https://www.youtube.com/channel/UCYskvSfHZ1OSfY1qyPBnx6Q>.
} 


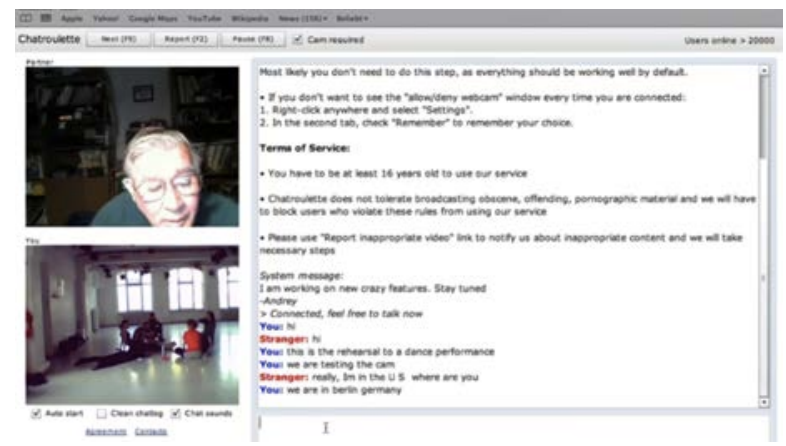

Figura 53. Michael Aniser y Isabel Walter, Danceroulette, 2011.

En esta perfomance los bailarines se enfrentan a extraños al azar de cuya reacción se alimenta el curso posterior de la actuación. Se les presenta la opción de controlar lo que ocurre en el escenario mediante algunas opciones, aunque la improvisación también entra en juego de manera capital. Se ofrece a los usuarios cuatro elementos coreográficos para desarrollar una pieza, aunque si el usuario aporta otro tipo de opciones de improvisación realizadas por el mismo en vivo pueden pasar a formar parte de la obra. Uno de los principios fundamentales de la obra es que la atención está puesta en los performers ya que el contenido y el proceso de la actuación no puede determinar un resultado prefijado, lo cual tiene relación con la aleatoriedad del medio en el cual se mueven, trabajando únicamente los aspectos formales de la danza.

Las opciones seleccionables dentro de la performance son tiempo, espacio, música y movimiento. Mediante el tiempo se realizan variaciones temporales, mediante el espacio los cuerpos de los bailarines usan la amplitud del lugar sin aceptar ninguna regla estética, mediante el movimiento los bailarines originan una coreografía que se representa siempre con la misma música trabajando con el movimiento como material, mediante la música los artistas realizan una improvisación al seleccionar una pieza aleatoriamente entre una base de datos de diferentes autores, moviéndose libremente e improvisando una coreografía. Sin duda, se trata de un proyecto que implica elementos interesantes al mezclar la conexión virtual con la acción real de los bailarines en el espacio físico del gimnasio donde se realizo la performance online. 
Por otro lado Eva y Franco Mattes son una pareja de artistas de prolongada experiencia dentro del arte en Internet posterior al net.art y que han operado comúnmente bajo el seudónimo de 0100101110101101.org251, destacando por su espíritu de subversión de los media. Se hicieron conocidos en 1998 tras tomar el dominio vaticano.org para ironizar sobre la web oficial de la iglesia católica. Su trabajo de 2010 No Fun, usa la web Chatroulette para presentar la puesta en escena de un suicidio falso, para así poder recoger las respuestas y reacciones a este acontecimiento, el espectador se convierte en un artista y el artista se convierte en un espectador, un testigo impotente de lo que sucede con su obra.

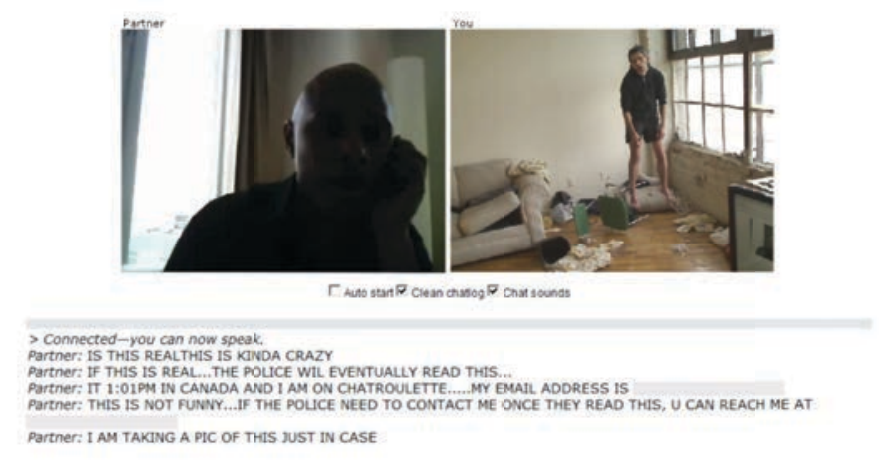

Figura 54. Eva y Franco Mattes, No Fun, 2010.

Decenas de miles de personas pudieron observar como este individuo colgaba del techo lentamente durante horas generando todo tipo de situaciones, desde la impotencia más absoluta hasta la risa más sarcástica, algunos incluso insultaron al cadáver o tomaron fotos del mismo, aunque solo una persona decidió llamar a la policía. No Fun plantea preguntas inquietantes sobre la hiperrealidad del paisaje mediático contemporáneo y sobre la espectacularización orwelliana de la vida cotidiana y de la muerte. Pero sería simplista culpar a Internet por el distanciamiento dramático de la interacción social a distancia. Lo que es más difícil de reconocer es nuestra propia complicidad y deseo de dejarnos seducir por las últimas maravillas

\footnotetext{
${ }^{251}$ Página oficial de los artistas Eva y Franco Mattes, [en línea], 2009, [consulta 18 de Marzo de 2013] disponible en <https://0100101110101101.org/no-fun/>
} 
tecnológicas. Con frecuencia disfrazamos nuestra obsesión por los media de búsqueda de auténtica comunicación, terminamos siendo simples narcisistas preocupados por mirarnos a nosotros mismos. Esta obra se vale de la táctica del fake para, mediante este hecho ficticio, poder generar conciencia sobre las actitudes, en muchos casos cuestionables, de los usuarios de este espacio virtual. Sin duda estamos ante todo un estudio sociológico que nos muestra la manera en la cual la tecnología filtra los acontecimientos y delimita nuestra respuesta a estos. Los excedentes generados por una sociedad digital nos muestran un ecosistema formado por ojos frente a pantallas que como nos cuenta Remedios Zafra ${ }^{252}$, nos arropa y acompaña de manera incondicional, pero que también se convierte en una presencia inútil por su normalización dentro de los rituales cotidianos. Se trata de elementos prescindibles de nuestra vida diaria que al conectarnos constantemente se conforman como extensiones de nosotros.

Finalmente Joel Thompson, artista y diseñador inglés, ha recogido en un vídeo el intrincado mecanismo creado por él mismo para únicamente pulsar la tecla next que da paso a la siguiente persona dentro de Chatroulette ${ }^{253}$. De la misma manera, enfrenta esta imagen del mecanismo a los propios espectadores de la web, generando una situación en la cual el espectador ve cómo la propia mecánica de este espacio, simbolizada por este ingenio mecánico, hace que la comunicación se transforme en un instante efímero.

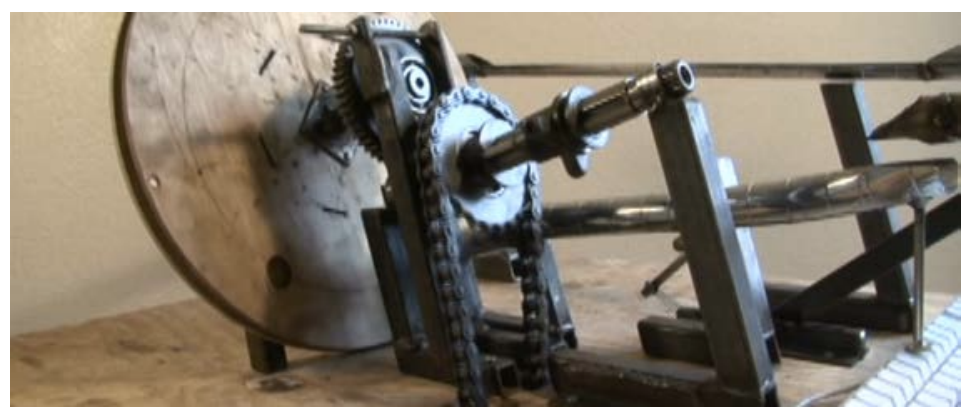

Figura 55. Joel Thompson, Chatroulnexter, 2010.

\footnotetext{
${ }^{252}$ Zafra, Remedios, op. Cit., 2015, p. 54.

${ }^{253}$ Vídeos de Joel Thompson en Vimeo, [en línea], 2010, [consulta 2 de Junio de 2013] disponible en <https://vimeo.com/11535219>.
} 
El aspecto de esta nueva forma de interacción que le pareció más interesante fue el nexting. Como hemos visto anteriormente, se trata de la tendencia por la cual un usuario tiende a pasar a otro usuario de manera constante y sin ningún objetivo dentro de esta web. Cada usuario puede guardar sus propios criterios, pero la velocidad con la que se decide no cumple, en la mayoría de los casos, ningún tipo de lógica. Pone de manifiesto como las promesas de comunicación instantánea con usuarios de cualquier rincón del mundo tienen relación con la utopía comunicativa desarrollada en los comienzos de Internet que todavía hoy día sigue conformando nuestro imaginario colectivo.

Mediante esta obra nos enfrentamos a lo que ya Manuel Castells había concluido en su obra La galaxia Internet ${ }^{254}$, y de lo cual Judith Donath también nos advierte. Los espacios virtuales son entornos construidos. Realmente son los arquitectos de este tipo de espacios, desde los diseñadores de software a los administradores los que realmente dan forma a la comunidad de una manera más directa que los verdaderos arquitectos del mundo real. Esto coincide con el hecho de que McLuhan considere a las tecnologías de la información y la comunicación la primera causa de los cambios sociales, ejemplificada por la famosa máxima "el medio es el mensaje". Los medios nos modelan al participar de ellos conformándose como parte de nosotros mismos. Después de reflexionar sobre la utilidad comunicativa de Chatroulette, advertí como este medio define la tipología de comunicaciones que se realizan. Estas comunicaciones efímeras, normalizan el hecho de exponernos a extraños generando un comportamiento exhibicionista $y$ voyeurista. Como en La ventana indiscreta de Alfred Hitchcock, cada nueva ventana representa un estilo de vida diferente y historias que fluyen juntas en una narración fragmentada y colectiva. Como dijo el arquitecto holandés Rem Koolhass, "Conceptualmente, cada monitor, cada pantalla de televisión es el sustituto de una ventana; la vida real está dentro, el ciberespacio se ha convertido en la naturaleza exterior"255. Toda esta investigación nos hace preguntarnos ¿De que manera las estructuras de los medios modelan el concepto que tenemos de nosotros mismos y las representaciones individuales de quienes somos?

\footnotetext{
${ }^{254}$ Castells, Manuel, op. Cit., 2001, p. 51.

255 Koolhaas, Rem, Espacio basura, Editorial Gustavo Gili, Barcelona, 2007, p. 61.
} 
Uno de los principales aspectos de este proyecto ha sido la diferenciación de las fases ligadas a la metodología investigadora asociada a la obra, de manera que este proceso es totalmente indisoluble y forma parte de mi praxis, generando una experiencia enriquecedora que da como resultado una práctica coherente como artista. Tras explorar y reflexionar sobre este sitio web que posibilita retransmitir video en directo, nos interesamos por un fenómeno que descubrimos allí y que tiene como génesis Internet. Nos referimos al antes mencionado trolling. Podríamos describir a un troll como un individuo que se dedica a publicar contenidos dentro de foros de discusión, salas de chat o blogs, que son o bien irrelevantes, provocativos, o bien intentan provocar a una comunidad utilizando contenidos fuera de tema mediante groserías, ofensas o mentiras difíciles de detectar, que crean confusión y sentimientos encontrados. El troll busca la respuesta emocional de los usuarios, generando malestar, buscando su propia diversión, alterando la conversación normal de un tema de discusión o simplemente generando enfrentamientos entre los propios usuarios al verse estos provocados por esta alteración de la gramática cultural de estos espacios.

David Porter traza una interesante descripción del origen del termino en su obra Internet Culture. La palabra proviene del término inglés que describe "morder el anzuelo", ya que trolling es un tipo de pesca en lengua inglesa que tiene su traducción al castellano como pesca al curricán, la cual resulta ser una técnica de arrastre. Por supuesto no hay que olvidar que el troll es un personaje típico de los cuentos procedentes del folklore escandinavo, caracterizado por hacer travesuras a los humanos. La derivación más posible de la palabra troll también puede ser encontrada en la frase "trolling for newbies" (trolear novatos), popularizado en los inicios de los años 90 en un grupo de Usenet ${ }^{256}$. Comúnmente, puede entenderse como una broma interna relativamente suave entre los usuarios veteranos a costa de los nuevos.

Dentro de la literatura académica el trolling fue documentado por primera vez por Judith Donath en 1995. En su artículo Identity and deception in the virtual comunity, posteriormente, recogido en el libro Comunities in Cyberspace de Peter Kollock. Donath describe la ambigüedad de la identidad en una

${ }^{256}$ Porter, David, Internet Culture, New York, Routledge, 1997, p. 41. 
comunidad virtual. Nos relata cómo en el mundo físico hay una inherente unidad del yo proporcionando una definición convincente de la identidad, mientras que el mundo virtual la situación es diferente. Donath proporciona un panorama general de los juegos de engaño e identidad que implementan la confusión entre la comunidad física y virtual, definiendo el trolling de la siguiente manera:

"El trolling es un juego de engaño identitario, aunque, se juega sin el consentimiento de la mayoría de los jugadores. El troll intenta pasar por un participante legítimo, compartiendo los intereses y preocupaciones comunes del grupo, el cual si es consciente de la existencia de los trolls y otros engaños identitarios, intenta distinguir las publicaciones verdaderas de las publicaciones del troll, y juzgar sus posts como los de un troll, haciendo que el infractor abandone el grupo. Su éxito depende de qué tan bien el troll es capaz de camuflar su identidad, y de cómo la satisfacción del troll se ve disminuida o compensada de manera suficiente por los costos impuestos por el grupo".257

Según Tom Postmes258, coautor de Individuality and the Group ${ }^{259}$, quien ha estudiado el comportamiento en línea de estos usuarios durante 20 años, los trolls aspiran a la violencia. Desean poner este tipo de situación en marcha. Desean generar emociones de desagrado e indignación, que mórbidamente les proporciona una sensación de placer. Susan Herring y sus compañeros de Searching for Safety Online: Managing Trolling in a Feminist Forum, mantienen que la dificultad inherente de perseguir el trolling y mantener la libertad de expresión en comunidades en línea es muy alta, "el acoso se presenta a menudo en espacios conocidos por su libertad, la falta de censura, y la naturaleza experimental." 260 La libertad de expresión puede conducir a la

\footnotetext{
${ }^{257}$ Donath, Judith S, Identidad y decepción en la comunidad virtual, en Smith, Marc A.; Kollock, Peter, Comunities in cyberspace, Londres, Routledge, 1999, p. 29.

${ }^{258}$ Adams, Tim, How the internet created an age of rage, The Guardian, [en línea], 2010, [consulta 6 de Abril de 2013] disponible en <http://www.guardian.co.uk/technology/2011/jul/24/internetanonymity-trolling-tim-adams>

${ }^{259}$ Postmes, Tom; Jetten, Jolanda, Individuality and the Group, Amsterdam, Sage Publications LTD, 2006.

${ }^{260}$ Herring, Susan, Job-Sluder, Kirk, Scheckler, Rebecca, Barab, Sasha, Searching for Safety Online: Managing Trolling in a Feminist Forum, Rob Kling Center for Social Informatics, [en línea], 2002,
} 
tolerancia de la conducta de trolling, lo que complica los esfuerzos de sus miembros por mantener un área de discusión abierta, especialmente para temas sensibles tales como la raza, el género y la sexualidad.

Cualquier clasificación parece no tener sentido ante la volatilidad de los acontecimientos y tácticas desplegados por estos usuarios. Algunos incidentes de flaming han sido considerados como trolling por comunidades de usuarios. El flaming consiste en mensajes deliberadamente hostiles e insultantes enviados sin ningún propósito constructivo en foros o listas de correo electrónico, los cuales son creados por los denominados flamers. El cebo o flambait es el denominado mensaje provocativo diseñado especialmente para producir respuestas insultantes. Por otro lado una Pie Fight o lucha de tartas define la situación en la cual un flamebait surte efecto y la discusión de un foro acaba en un intercambio de insultos trivial y sin sentido, pero que cambia el funcionamiento del espacio virtual. Los participantes experimentados en foros en línea saben que la forma más efectiva de disuadir a un troll normalmente es ignorarlo, ya que las respuestas animan a los auténticos trolls a continuar escribiendo mensajes disruptivos en dichos foros, de ahí el frecuente aviso de "Prohibido dar de comer al troll", que podemos observar en gran cantidad de foros, salas de chat o blogs. Mientras un gran número de administradores consideran esta actividad un comportamiento deleznable, algunos lugares agradecen la actividad de los trolls. Un artículo del New York Times ${ }^{261}$ analiza la actividad de los trolls en páginas como 4chan ${ }^{262}$ y la Encyclopedia Dramatica ${ }^{263}$, los cuales fueron descritos como un compendio de humor y tradiciones generadas por los trolls. Estos tipo de sitios son usados como bases

\footnotetext{
[consulta 13 de Junio de 2013] disponible en <http://wwwbcf.usc.edu/ fulk/620overview_files/Herring.pdf $>$.

${ }^{261}$ Schwartz, Matatías, Los Trolls entre nosotros, The New York Times [en línea], 2008, [consulta 16 de Junio de 2013] disponible en <http://www.nytimes.com/2008/08/03/magazine/03trollst.html?_r=0>.

262 4chan es un tablón de imágenes de idioma inglés creado el 1 de octubre de 2003. Originalmente sus foros fueron usados para publicar imágenes y discutir sobre manga y anime. Sus usuarios generalmente publican de forma anónima y el sitio ha sido ligado a las subculturas y activismo en Internet, cuya muestra más notable es el Proyecto Chanology desarrollado por la organización Anonymous.

263 La Encyclopedia Dramatica es una Wiki en inglés que documenta todas las clases de "drama" y situaciones graciosas que ocurren en Internet.
} 
mediante las cuales realizar sus actividades contra otros usuarios en cuyos sitios no pueden actuar normalmente. La historia del troll está solo en sus comienzos, se puede considerar como una "cultura", formada por gente que no se conoce entre sí, salvo mediante la experiencia común de ser rechazados en foros de Internet.

Una de las cualidades de los trolls, que resultan más interesantes, es el hecho de desafiar un discurso dominante y las opiniones de los foros de discusión para así romper las relaciones de poder y jerarquía que allí se crean a favor de un pensamiento divergente, aunque hay que tener en cuenta que realizar averiguaciones sobre las finalidades reales de los trolls resulta altamente especulativo debido al gran número de debates que se originan alrededor de este fenómeno, en parte alimentados por los propios trolls, los cuales se benefician de esta polémica que a la vez alimenta su prácticas de trolling.

De cualquier modo podemos dilucidar algunas motivaciones existentes detrás de esta actividad, como la posibilidad de que se trate de un experimento basado en la desobediencia de las normas hegemónicas que permite testar y romper los límites sociales sin ninguna consecuencia realmente grave, poniendo de manifiesto las personalidades más vulnerables, y generando de algún modo un experimento científico en una comunidad virtual reducida.

Por otro lado, el hecho de controlar un foro cambiando el tema de debate es una meta en sí misma, sin embargo, resulta paradójico que alguien pueda perder los nervios por las opiniones que vierten completos desconocidos. Esto implementa la diversión que los trolls obtienen al frustrar a otro usuarios, y a la vez produce que otras personas se comporten como trolls para poner de manifiesto su enfado hacia un grupo de usuarios de opinión contraria a la suya. Otro de los puntos a tener en cuenta es que un mensaje perfectamente diseñado por un troll puede hacer que un gran número de usuarios pierdan el tiempo con un reducido esfuerzo, siendo ésta una de las grandes motivaciones de los trolls. Este gusto por el diseño de situaciones tiene su máxima expresión en las reacciones en cadena, donde, como señalaba anteriormente, una acción minuciosamente estudiada provoca una reacción generalizada, destruyendo y mutando la dinámica del espacio virtual. Un alto porcentaje de trolls defiende su modus operandi aludiendo a que este cuestiona el conformismo y las relaciones de poder existentes en Internet. De cualquier modo es casi 
imposible determinar las verdaderas motivaciones, que bien podrían ser legitimas, ya que quedan camufladas y confundidas entre diferentes estrategias. Según Gabriella Coleman ${ }^{264}$ los trolls de Internet actuales están unidos bajo la consigna del lulz 265 , como resultado de todos sus esfuerzos. Este es pues el objetico final de comunidades de usuarios anónimos conectados en torno a la idea de consumar este tipo de acciones, que dieron fama a grupos como Anoymous, como podemos comprobar al recordar el resultado de su proyecto Charnology contra la Iglesia de la Cienciología. Estas fueron acciones organizadas desde espacios como el tablón de imágenes 4chan o canales de IRC ${ }^{266}$, entre otros, donde el objetivo final del lulz fue desviado hacia una finalidad más reivindicativa y social. Esto cambió el estilo de hackeo de los Anons ${ }^{267}$ hacia uno políticamente comprometido que dio lugar a la creación del colectivo marblecake, organizado en torno a la propaganda y células que trabajaban por separado. Del mismo modo los trolls hacen que los usuarios cuestionen los contenidos que pueden encontrar en Internet, pueden generar acciones críticas ante los media, el stablishment y la política.

Por lo tanto podemos interpretar el trolling desde otro punto de vista más allá de lo que la cultura de Internet nos propone. Tal como nos presenta Michel de Certeau $^{268}$, las estructuras de poder generan estrategias para difundir su cultura mientras que el ciudadano de a pie se vale de la táctica de la reinterpretación, desviación o perversión para cuestionar este lenguaje, no rechazando o transformando sino participando de él y usándolo al servicio de otras convicciones y por lo tanto modificando nuestras practicas de consumo o uso. El troll elabora su táctica en el lugar del otro, es decir al igual que Michel de Certeau aboga por jugar en terreno enemigo, posicionándose en el campo de visión del contrario para generar esa especie de prestidigitación de

\footnotetext{
${ }^{264}$ Coleman, Gabriella, op. Cit., 2016, p. 24.

${ }^{265}$ Lulz es un neologismo generado en torno a la cultura de Internet, derivado de lol que significa laughing out loud. Podemos traducirlo por "reírse a carcajadas". En base a este termino se genero la conocida frase entre los trolls de Internet I did it for the lulz o IDIFTL, que podríamos traducir por "Io hice por el lulz", el cual, a la postre se ha convertido en un famoso meme.

${ }^{266}$ Internet Relay Chat, es un protocolo de comunicación en tiempo real basado en texto, usado para crear canales a los cuales podemos acceder mediante un cliente de IRC.

${ }^{267}$ Usado como abreviatura de anonymous, es el nombre con el cual se denomina a los usuarios de 4chan, y del cual surge el nombre de la red internacional hacktivista Anonymous.

${ }^{268}$ De Certeau, Michel, Op. Cit, 2000.
} 
acciones introducida por sorpresa dentro del orden, jugando con el adversario mediante desplazamientos y fisuras dentro de los mecanismos de su propio sistema. Por lo tanto, si hacemos una relectura del modus operandi de los trolls de Internet desde el punto de vista de los modos de hacer de Michel de Certeau, podríamos describir el trolling como una práctica de intervención en espacios virtuales que genera una situación nueva dentro de un espacio preestablecido, produciendo nuevos modos de visibilidad.

Ya los situacionistas dieron lugar a la "creación de situaciones" como una construcción concreta de ambientes momentáneos de vida como herramienta política para la transformación de la vida de las personas. La practica del trolling al igual que la Spaßguerilla plantea una práctica que se basa en la diversión y la creación de experiencias con un componente lúdico y de ocio, a la vez que se subvierten los códigos hegemónicos de la sociedad. Otro movimiento ocupado en reflejar la hegemonía cultural dominante fue el culture jamming, el cual se concentraba en tergiversar los códigos y signos de la publicidad dentro del espacio público.

La tergiversación, como táctica mediante la cual intervenir en las aplicaciones de la Web 2.0, nos planeta una interesante relación entre lo cotidiano y lo social, y la importancia que tiene el actuar dentro de la red. Cuando cambiamos este actuar generado en base a un sistema de códigos y signos, conseguimos cambiar la manera en la cual estas aplicaciones funcionan, modificando los códigos desde dentro en lugar de destruirlos. Se trata pues de llevar a cabo apropiaciones individuales de carácter temporal que transforman el sistema mientras imitan y utilizan su status quo, como parte de unas prácticas subversivas cotidianas basadas en los modos de hacer en la red. Estamos en un momento en el cual multitud de usuarios están interesados en las posibilidades sin fin de la exploración de mundos virtuales y aplicaciones. La práctica artística como punta de lanza de un conocimiento integral debe explorar y reinterpretar estas tecnologías ubicadas dentro del ámbito de lo cotidiano.

Durante la presente tesis hemos descubierto como estas extensiones de nosotros mismos y de nuestras capacidades modelan la manera en la cual nos representamos y nuestra percepción de nosotros mismos y de nuestro entorno. Es por ello que el propio uso de la tergiversación como método que 
nos saca de nuestro modo de hacer cotidiano y cambia la manera en la cual percibimos nuestro entorno mediático resulta especialmente adecuado. Tras realizar este recorrido por Chatroulette, su funcionamiento y elementos, podemos plantearnos ¿Hasta que punto el trolling puede ser utilizado para intervenir en espacios virtuales con la misión de poner de manifiesto aspectos ocultos de estas estructuras mediáticas?

Durante nuestra exploración de la web Chatroulette una de las primeras conclusiones que pudimos detectar fue el hecho de que una aplicación diseñada para generar una gran cantidad de comunicaciones instantáneas de manera aleatoria, no era eficiente a la hora de generar comunicaciones efectivas. Las propia construcción de la estructura mediática produce mediante la posibilidad del nexting, como práctica habitual e incontrolada, una deriva voyeurista y exhibicionista que sabotea nuestras prácticas comunicativas en este tipo de web. Este tipo de construcción mediática nos disciplina, tal y como diría Michel Foucault, obligándonos a estar pegados a una pantalla en busca de personas que nunca llegan. Nos encontramos ante un espacio virtual cuya arquitectura no puede ser modificada por los usuarios, sin embargo si tenemos la posibilidad de modificar su funcionamiento mediante el tipo de contenido y actuar que generemos dentro de estas estructuras.

Es así como desarrollamos la idea de la formulación de una pregunta. ¿Cómo nos podemos hacer el uno al otro mejor? O por su traducción al inglés utilizada durante el proyecto How we can make each other better? Esta pregunta no está concebida para intentar obtener una respuesta, sino que tiene una finalidad cuestionadora y disruptiva en el campo de la comunicación mediática. Ya Marcel Duchamp en sus manuscritos de 1914, concebía el acto artístico como un acto evanescente y material a la vez, que permite configurar una topología física de lo contingente, de lo "infraleve". Con este termino Duchamp quería englobar a los acontecimientos frágiles extraídos de la experiencia cotidiana que se definen con nitidez por los infraleves mismos.

Esta pregunta pretende poner en duda el funcionamiento de los sutiles modelos de intercambio que desarrollamos dentro de Internet, centrándome, en la popular web Chatroulette, la cual como ya hemos visto ofrece la posibilidad de encuentros en línea mediante un interfaz cam-to-cam que da a 
cada usuario la posibilidad de practicar el nexting, es decir el paso de un usuario a otro sin ningún criterio previo.

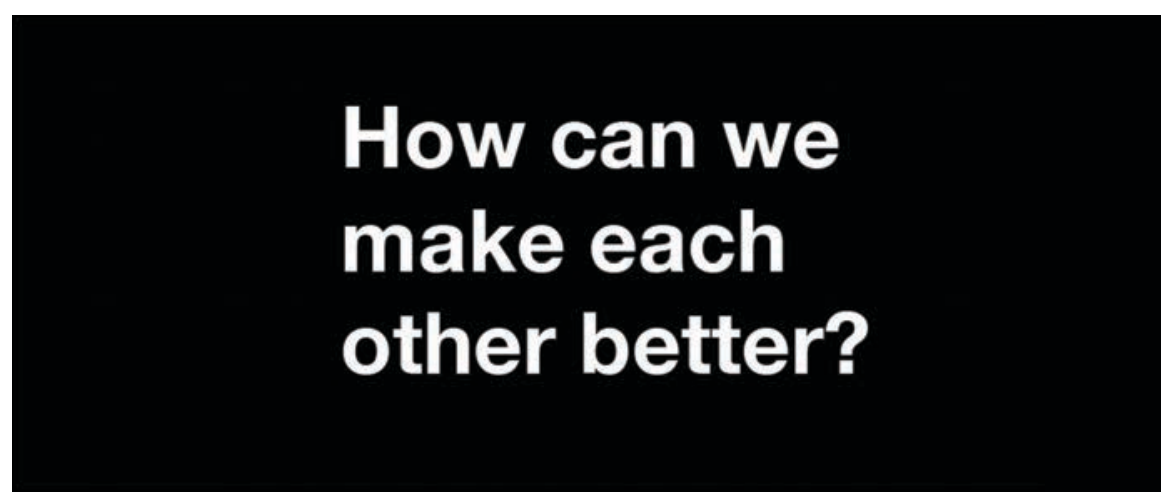

Figura 56. Imagen que los usuarios participantes en la obra podían ver en Chatroulette.

La utilización de esta pregunta sibilina se vale de la ironía e ingenuidad de la misma conformada como eslogan para intervenir dentro de un contexto voyeurista y exhibicionista, en el cual la comunicación o la implementación de dinámicas enriquecedoras entre los usuarios es un objetivo nihilista, pero que también ha sido heredado de las propias utopías de Internet. En lugar de encontrar un lugar de enriquecimiento personal mediante el intercambio, esta web despliega un funcionamiento en el cual cualquier reciprocidad queda descartada debido a lo efímero de las conexiones.

La cuestión planteada tiene como misión poner en funcionamiento un mecanismo de trolling, debido al contenido fuera de lugar de la pregunta y la incomodidad que genera a los usuarios, asociando el trolling con un modo de hacer individual, que en palabras de de Certeau ${ }^{269}$ podíamos denominar como táctica, dentro de una estrategia general planteada desde la web. Esto produce la tergiversación ${ }^{270}$ de su uso habitual mediante la participación en el propio espacio y el cambio de su funcionamiento.

\footnotetext{
${ }^{269}$ De Certeau, Michel, Op. Cit, 2000.

${ }^{270}$ Luther, Blisset, Brünzels, Sonja, Op. Cit, 2000.
} 
Después de estas primeras reflexiones ya teniamos delimitada el área en la cual estaba interesado, habiamos descubierto un espacio público desmaterializado, ya que los nuevos espacios simbólicos los construimos de manera virtual en la red, incrementando nuestra individualidad y autonomía. Por lo tanto podemos decir que la aparición de un entramado global de información ha impuesto un tercer espacio cibernético en el cual plasmamos nuestras necesidades comunicativas. Fijando nuestra mirada en el trolling me di cuenta de la gran similitud metodológica que muestra en relación a los conceptos de táctica desarrollados por Michel de Certeau, como ya hemos podido observar. Una vez explorada esta estructura mediática llamada Chatroulette, pudimos reflexionar sobre lo anárquico y aleatorio de su funcionamiento, y estudiar en profundidad en modus operandi de los trolls de Internet. Nos dispusimos a desarrollar una táctica de intervención en este espacio virtual basada en las propias características disruptivas del trolling, las cuales cambian el funcionamiento de un espacio en base a la modificación del actuar de los usuarios.

Esta web de chat cam-to-cam nos interesó especialmente por el perfecto entretejimiento de lo global y local que plantea, y como ejemplifica las problemáticas contemporáneas entre el espacio público y privado que parecen disolverse en una única mezcolanza, dándonos acceso a multitud de lugares, espacios íntimos, ambientes y situaciones impredecibles. Así mismo nos pareció el lugar perfecto para interactuar y trabajar con otros usuarios dentro de Internet.

La duración de la realización del proyecto fue de dos meses, durante los cuales nos conectamos diariamente a la web Chatroulette y planteabamos nuestra pregunta mediante un avatar con el lema del proyecto, que aparecía donde debería estar la imagen transmitida por la cámara web. Solo nos comunicabamos por medio escrito y no usabamos ningún tipo de micrófono para comunicarme con los usuarios. Esta situación inusual producía todo tipo de reacciones de enfado e indiferencia entre los espectadores, al no cumplir las expectativas voyeuristas que promete la reputación de este espacio. Sin embargo, un pequeño porcentaje de personas que podríamos situar en torno al el 3\%, sí realizó algún tipo de respuesta a mi pregunta, reflejando todo tipo de contestaciones que posteriormente reflejamos en la materialización del proyecto. Para ello realizamos un gran número de capturas de video de estas 
interacciones con todo tipo de interlocutores y situaciones, mediante las cuales hemos producido dos videos realizados con el material producido durante la acción llevada acabo en Chatrolulette.

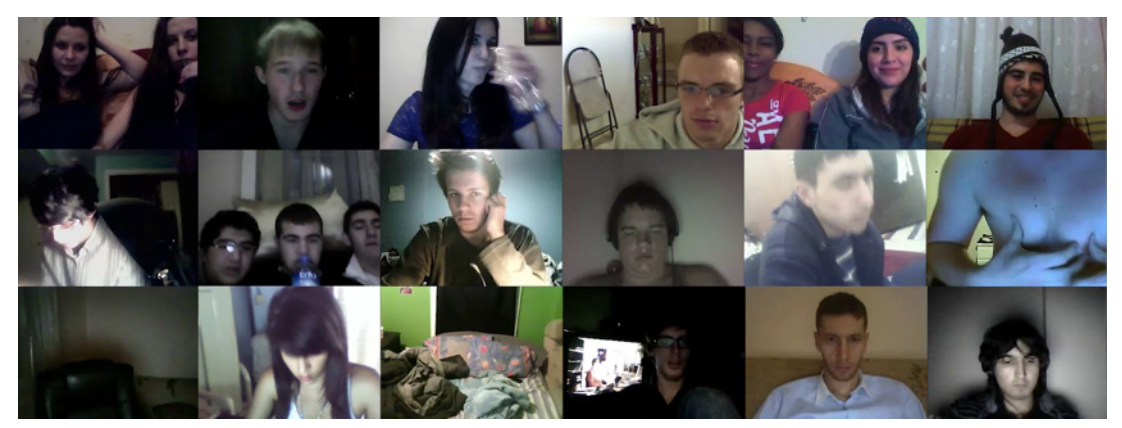

Figura 57. Still extraído del primer video del proyecto.

En un primer vídeo, presentamos mediante una estructura de celdas compartimentadas todo el fluir comunicativo ineficaz que podemos observar en esta web, mostrando para ello todos los interlocutores que decidieron no realizar ningún tipo de respuesta relacionada con la pregunta planteada. Por lo tanto, podemos apreciar las diferentes maneras en las cuales la acción fue recibida por los interlocutores que optaron por no participar o no supieron como participar de ella, generando todo un interesante estudio sociológico sobre los usos y costumbres de los usuarios de este espacio. Aunque irónicamente son estos mismos interlocutores los cuales hacen exitoso el funcionamiento del mecanismo de trolling. Al interrumpir de manera muy sutil el funcionamiento habitual de la web y generar una interferencia, es posible reflexionar sobre el verdadero sentido y funcionamiento de este espacio, produciéndose un cambio en la percepción que tienen estos usuarios del mismo. Esto es lo que llamábamos distanciamiento dentro de la descripción de las tácticas del Manual de guerrilla de la comunicación. 


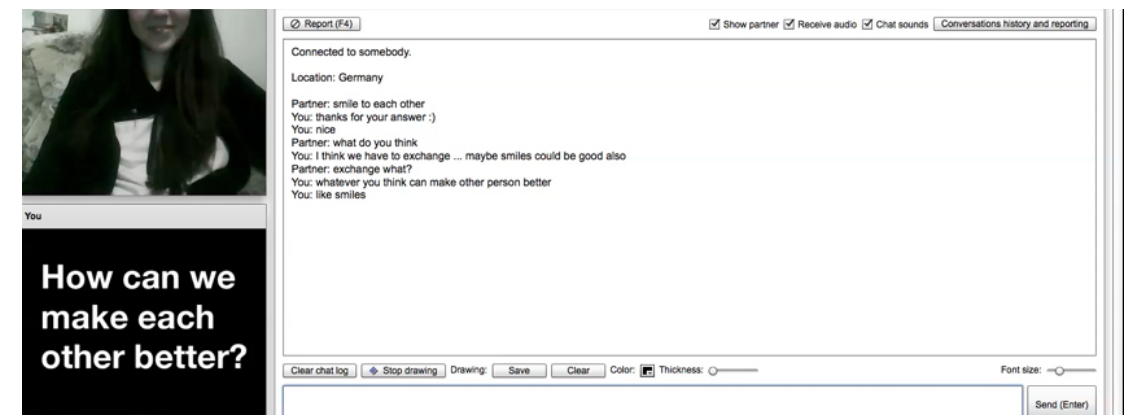

Figura 58. Still extraído del segundo video del proyecto.

En un segundo vídeo presentamos las respuestas de 25 personas que sí decidieron responder a la pregunta planteada. Dentro de estas repuestas podemos encontrar todo tipo de situaciones. Nos hablan, en la mayoría de los casos, de la soledad y la búsqueda del otro mediante esta prótesis virtual denominada Chatroulette. Así mismo, la obra contiene un componente voyeurista, ya que el espectador se sumerge en diferentes ambientes y conversaciones dentro del vídeo que ponen de manifiesto la disolución del espacio privado del hogar en la era de la web 2.0, así cómo estas herramientas virtuales vehiculizan nuestro comportamiento.

En definitiva, en el presente proyecto hemos realizado una reflexión sobre el medio de Internet, presentándolo como un espacio hegemónico que genera un actuar impuesto por los mass media y sus estructuras de poder, construyendo un lenguaje y espacio propio partiendo de premisas similares a las del culture jamming 271 . El modo de hacer que hemos seleccionado para intervenir en este sistema es permanecer dentro de este, no rechazándolo sino transformándolo y usándolo de otra manera, no vulgarizándolo o degradándolo, sino poniendo de manifiesto sus grandes carencias y contradicciones, así como las problemáticas que genera, asimilándolo y cambiando su gramática cultural y convirtiendo mi posición de espectador en la del artista.

\footnotetext{
${ }^{271}$ Lloyd, Jan, Culture Jamming: Semiotic Banditry in the Streets [en línea], 2003, [consulta 1 de Febrero de 2013] disponible en <https://yesjanlloyd.wordpress.com/2014/05/12/culture-jammingsemiotic-banditry-in-the-streets/>
} 
Estos dos videos nos presentan dos posturas contrapuestas que pueden estar relacionadas con el paso de la posmodernidad a otro estadio diferente, que teóricos culturales como Vermeulen y van den Akker definen como metamodernidad 272 , una especie de ingenuidad informada o el idealismo pragmático característico del principio de siglo. Estaríamos pues ubicados entre estas dos grandes tendencias, un movimiento entre polos opuestos que va más allá de ellos, algo que ejemplifica la propia actitud contradictoria y heterogenea de los usuarios de estos espacios virtuales.

Como hemos visto anteriormente, el funcionamiento de la web consiste en generar una gran cantidad de conexiones instantáneas pero no propician una comunicación real. Esta acción tiene la misión de cuestionar la calidad de las conexiones que realizamos mediante una pregunta formulada a interlocutores aleatorios. Esta pregunta plantea un contenido filosófico sobre la construcción que realizamos de nuestro yo a partir de los demás, cómo los demás nos construyen y nosotros los construimos a ellos, pero ¿qué clase de construcción realizamos en un lugar en el cual las comunicaciones son fugaces e instantáneas, donde el comportamiento voyeurista y exhibicionista, y no la comunicación, ocupa la mayor parte de nuestro tiempo útil? La respuesta podría ser que una comunicación fragmentaria y superficial viene propiciada por este tipo de estructura mediática, y por lo tanto por la manera en la cual esta nos modela. Sin duda la famosa frase de Marshall McLuhan "el medio es el mensaje"273 cobra un significado más potente al constatar cómo toda la atmosfera mediática que nos cubre sirve para paradójicamente eliminar todo tipo de intercambio real y significativo.

\footnotetext{
${ }^{272}$ Van der Akker, Robin, Vermeulen, Timotheus, Gibons, Alison, Metamodernism: Historicity, affect, depth after Postmodernism, Rowman \& Littlefield International, Washington, 2017.

${ }^{273}$ McLuhan, Marshall, Op. Cit, 1996.
} 


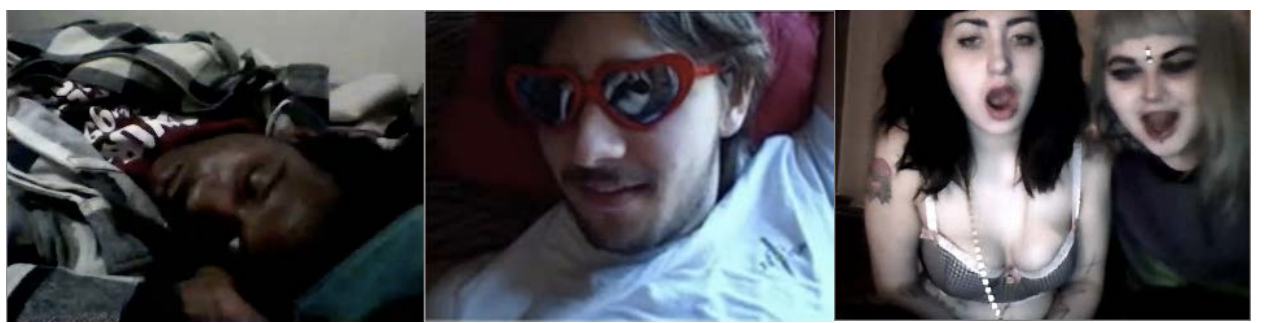

Figura 59. Algunos de los usuarios que pude encontrar en Chatroulette.

Tras la realización de la acción How we can make each other better? y su plasmación videográfica decidimos analizar en profundidad la metodología utilizada durante la realización de la obra para generar un tipo de conocimiento que pueda ser transmitido y utilizado por el público en general. De este modo y emulando el sentido que para mí emana de obras literarias tan inspiradoras como El Manual de Guerrilla de la Comunicación ${ }^{274}$, el cual propone una metodología completa, nos dispusimos a usar recursos didácticos para generar una obra que acerca la educación artística al arte, o que más bien el artista realiza utilizando recursos educativos. El manual está planteado mediante el uso de diagramas e ilustraciones que recogen tanto el funcionamiento, el escenario, las motivaciones y finalidades que se esconden detrás del trolling. La estructura del manual consta de 10 apartados en los cuales se desgrana mediante el uso de una gráfica clara y sintética toda la información necesaria para que este tipo de comportamiento, transformado por mí en practica artística, sea reproducible por cualquier usuario de Internet.

\footnotetext{
${ }^{274}$ Luther, Blisset, Brünzels, Sonja, Op. Cit, 2000.
} 


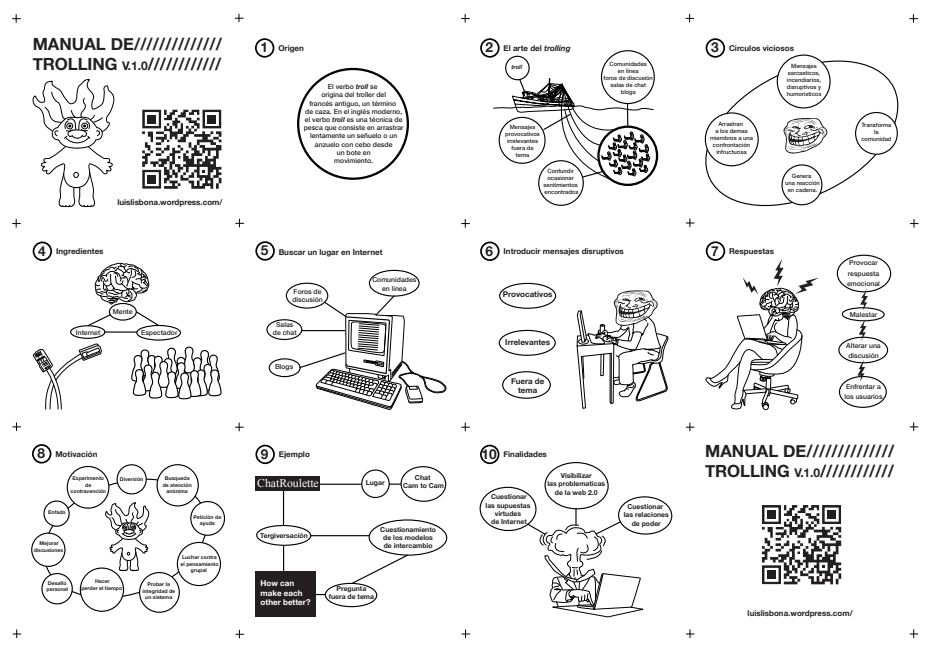

Figura 60. Diseño original del Manual de Trolling.

La utilización de códigos QR tanto en la portada como en la contraportada responde a la necesidad de enlazar al posible troll con el blog del proyecto, ahora inactivo, en el cual se desarrolla la investigación y muestran los resultados de este proyecto en Chatroulette, apareciendo como ejemplo en el propio manual mediante un esquema de su funcionamiento. Este tipo de representación pareció la manera perfecta de mostrar conceptos y presentar las relaciones entre los elementos existentes. El mapa conceptual es una de las más eficaces formas de representación gráfica del conocimiento. Un mapa conceptual es una red de conceptos. En la red, los nodos representan los conceptos, y los enlaces muestran las relaciones entre los conceptos.

Durante mucho tiempo una de las características de nuestro proceso creativo ha sido la asociación de conceptos o ideas mediante su representación gráfica, de manera que el análisis pormenorizado de la metodología de mi obra respondía también a un modo personal de afrontar la práctica artística, pero que ha sido usado como obra por artistas como el estadounidense Mark Lombardi en sus mapas mentales bautizados como conspirancy art, que nos muestran un turbio mundo de conexiones clandestinas entre empresas, políticos y crimen. 
Por otro lado la gráfica utilizada está recogida de la propia cultura popular de Internet que es reutilizada para transmitir la información contenida en el manual, a modo de reciclaje cultural estos símbolos reubican su significado dentro de mi obra. El estilo utilizado es muy simple y sintético de manera que facilita la visualización de los conceptos que abordamos en este manual. Uno de los más claros ejemplos es la troll face, la cual surge en 2008 de manos de un usuario de la web DeviantArt llamado Whyne, que intentaba dibujar a un personaje conocido como Rape Rodent sin demasiado éxito. Poco a poco fue ganando adeptos en los foros de 4 chan hasta que se ha convertido en el símbolo oficial de los trolls de Internet, lo cual resulta paradójico teniendo en cuenta la ironía de usar el propio fracaso de otra persona como símbolo personal. El símbolo principal del manual en lo referente a los trolls es sin embargo el conocido muñeco troll creado por el leñador danés Thomas Dam, aunque los originales son conocidos como los Dam Dolls. Paradójicamente un error en el copyright del muñeco en EE.UU. hizo posible la proliferación de cientos de imitaciones.

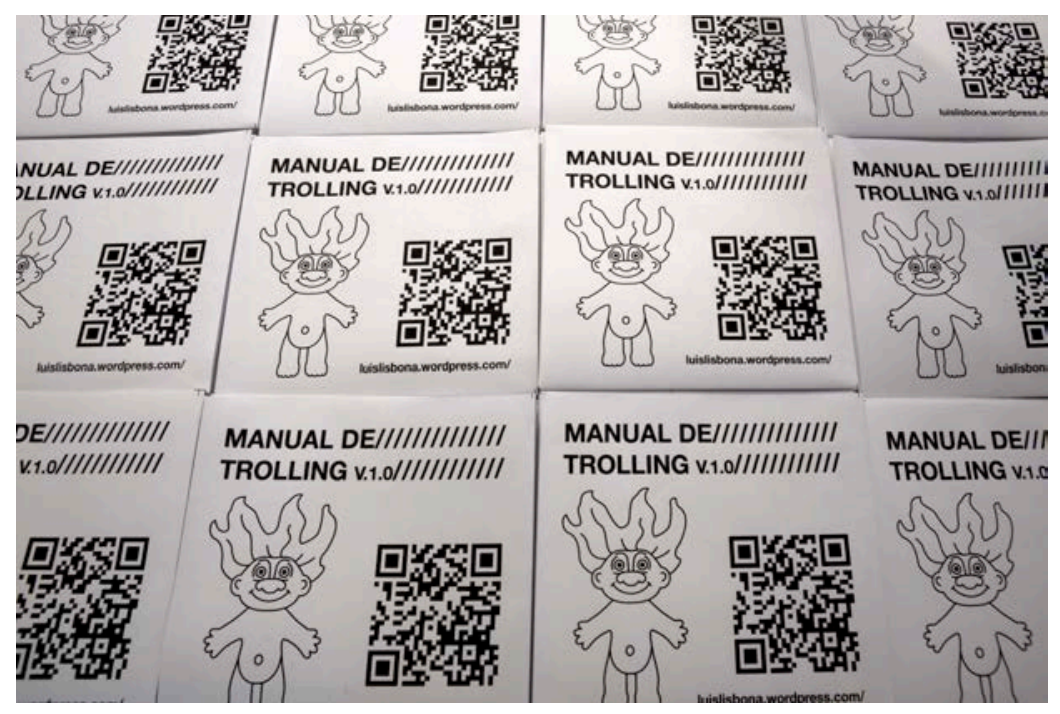

Figura 61. Algunos manuales plegados.

En líneas generales este manual representa la aspiración principal de todo conocimiento adquirido o producido, es decir la propagación del este mismo generando dinámicas de colaboración y vinculaciones con individuos antes 
desconocidos. El estudio exhaustivo de los contenidos junto a una capacidad de análisis del fenómeno en cuestión han propiciado la creación de una información coherente y de fácil entendimiento por el público en general, que sin embargo cuenta con la complejidad que este fenómeno requiere, llevando el trolling hasta sus últimas consecuencias, desde nuestro punto de vista, generar lo que se podría considerar un ejercicio de trolling en la propia sociedad. Ya que este manual rompe las dinámicas y cultura hegemónica de la misma, transformando la mentalidad grupal del mismo modo que el culture jamming 275 cuestiona, mediante la subversión de mensajes políticos o publicitarios, las estructuras de poder por formar parte de una cultura dominante que impone sus lógicas y conocimientos sobre su propia sociedad y otras culturas. Por lo tanto podemos considerar Internet como parte de esta cultura hegemónica basada en los mass media que tiene como característica principal el dominio cultural, y es aquí donde los artistas como trabajadores y usuarios de esta industria cultural debemos criticar y negar este status quo mediante la transformación de los medios que esta cultura nos impone.

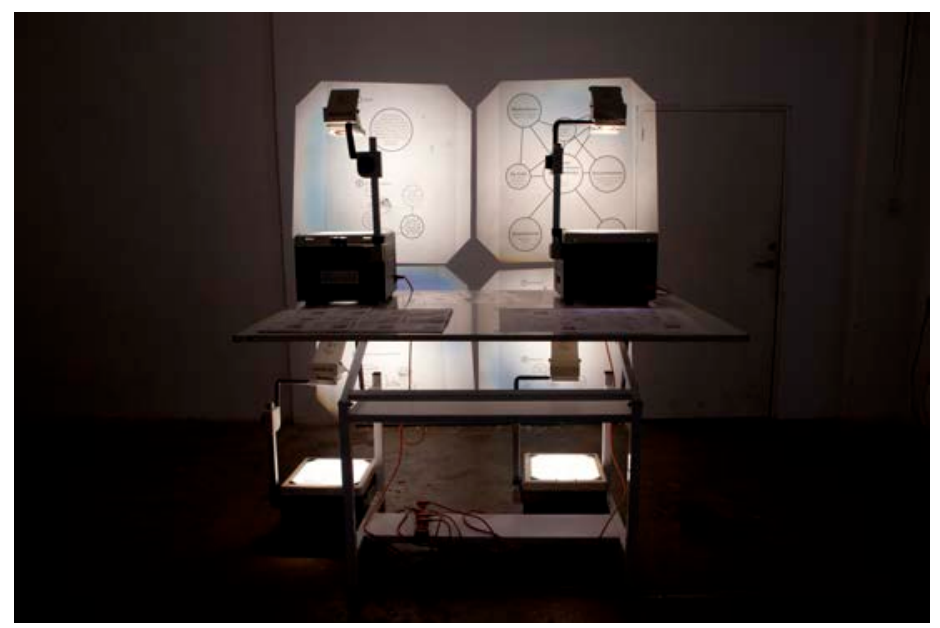

Figura 62. Vista frontal del espacio expositivo.

Este ptoyecto artístico pudo ser expuesto en forma de videoinstalación dentro de la exposición tácticasvinculantes. Fue desarrollada gracias al gran esfuerzo del artista y profesor de la Facultad de Bellas Artes de San Carlos Pepe

\footnotetext{
${ }^{275}$ Klein, Naomi, op. Cit., 2001.
} 
Miralles, quedando enmarcada dentro del proyecto Selecta13. Las obras están basadas en la posibilidad real de establecer vinculaciones entre personas, ya sean usuarias de plataformas digitales, habitantes de las fronteras, agentes artísticos, espectadores, estudiantes o público del mito y la memoria. Ninguna de las obras expuestas invitan a la participación desde la idea de sometimiento del espectador por el artista. La vinculación también afecta al propio proceso de elaboración de esta muestra y para ello se ha establecido una metodología de comisariado colectivo. Para la realización de esta exposición pudimos contar con la inestimable colaboración del espacio de arte La Mutante situado en la ciudad de Valencia (España), en el número 53 de la calle Turia. La exposición fue inaugurada el día 3 de Julio de 2013 en el dicho espacio.

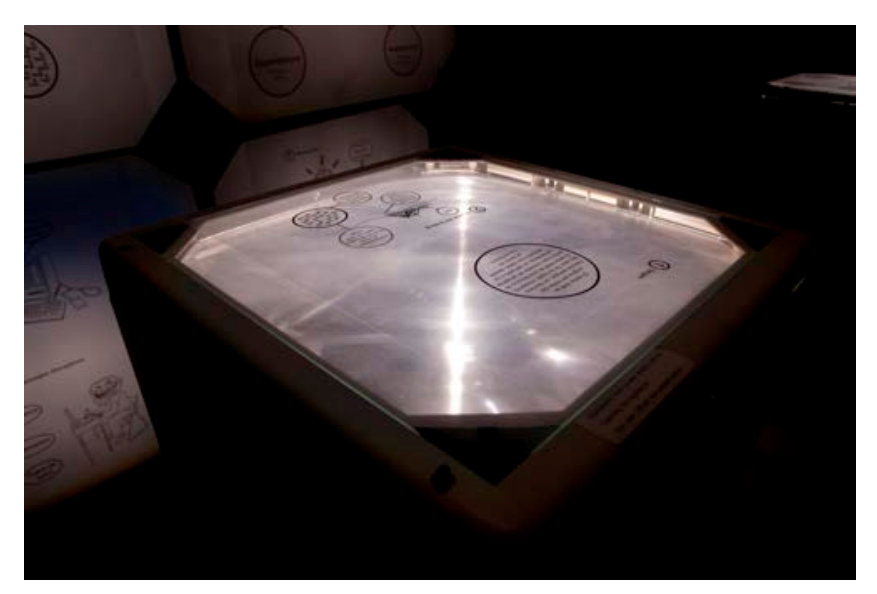

Figura 63. Uno de los retroproyectores con una de las transparencias.

Como señalamos anteriormente, el presente proyecto expositivo nace con la intencionalidad de generar una experiencia curatorial conjunta mediante un comisariado colectivo elaborado mediante un mapa conceptual que es el resultado de un trabajo en equipo de búsqueda de relaciones entre las diferentes líneas de trabajo, que los artistas participantes han desarrollado alrededor de la esfera pública. 


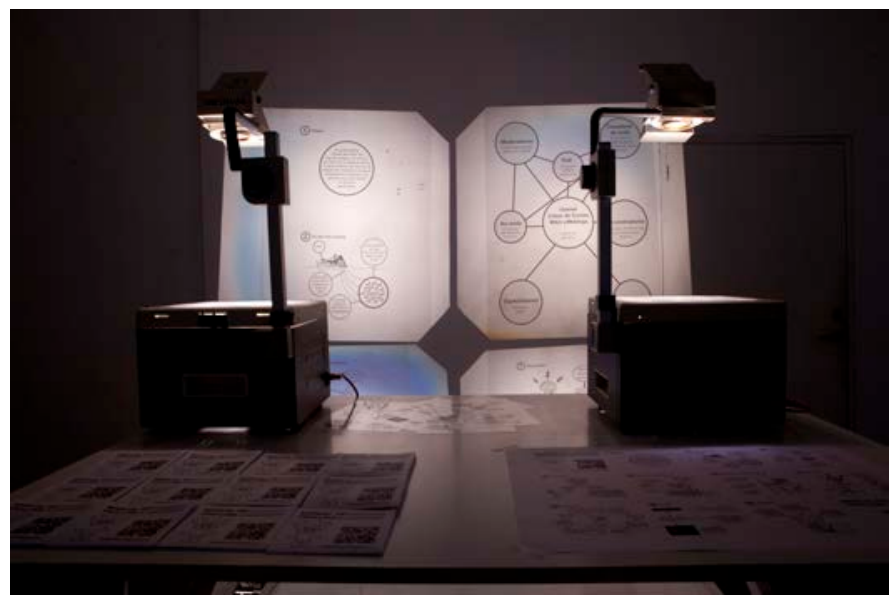

Figura 64. Detalle de la instalación.

Como hemos destacado repetidamente a lo largo de esta investigación, la táctica según el concepto de Michel de Certeau ${ }^{276}$ se basa en el tiempo, ya que el espacio, que en este caso se trataría de Internet aparece ocupado por el poder hegemónico que ejercen las estructuras mediáticas. La táctica es una acción diseñada a medida de una ausencia de lugar, ya que como hemos visto, se desarrolla en el lugar del otro, actuando como visitante en un terreno ajeno, usando las fisuras de ese poder para sorprender mediante la astucia. Por otro lado el hecho de vincular, habla de la unión de cosas que son inmateriales creando una relación duradera, transformándose en elementos que dependen el uno del otro y que crean una relación causa efecto. Por lo tanto estos dos conceptos unidos representan modos de hacer que generan una relación conceptual entre las diferentes obras que componen la exposición.

Siguiendo el concepto didáctico que usamos dentro del manual de trolling, nos dispusimos a diseñar un espacio expositivo que sirva como paradigma de esa idea. Para ello nos valemos del uso de material didáctico entre el que podemos encontrar cuatro retroproyectores de cuerpos opacos y una mesa de dibujo de grandes dimensiones que a la postre sirvió como soporte de todo el proyecto y epicentro en torno al cual gira la obra.

\footnotetext{
${ }^{276}$ De Certeau, Michel, Op. Cit, 2000.
} 


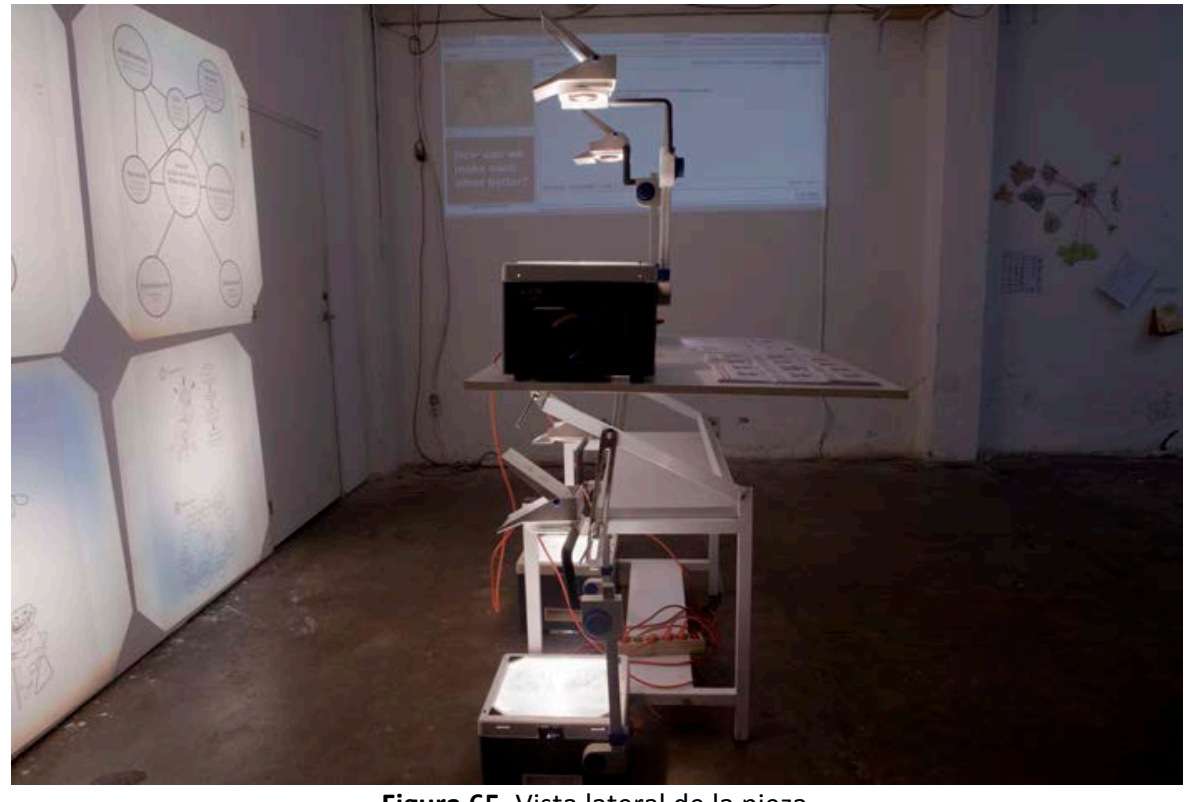

Figura 65. Vista lateral de la pieza.

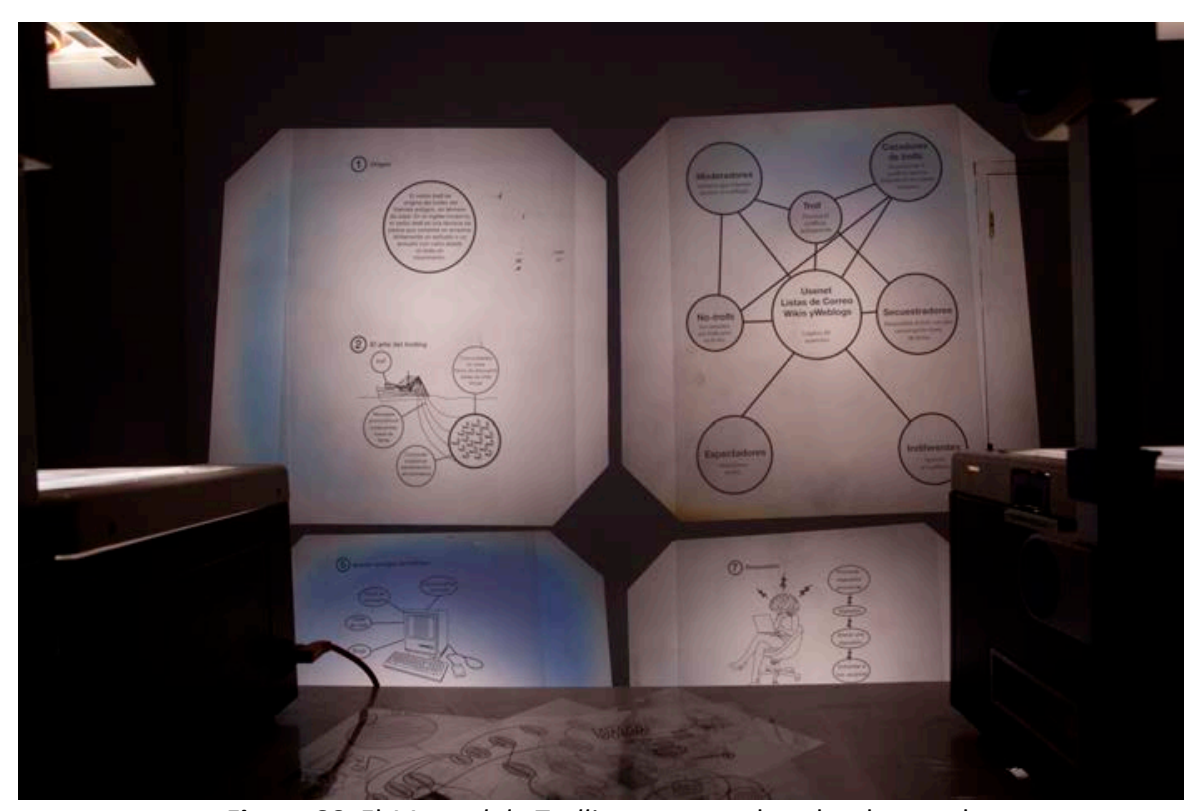

Figura 66. El Manual de Trolling proyectado sobre la pared. 
La mesa es el lugar en cual se presentan los contenidos mediante los cuales el espectador puede interactuar tanto física como intelectualmente con la obra, esta queda desplegada dentro del espacio ocupando una parte central del mismo y por lo tanto siendo el elemento que da la bienvenida al espectador. Dentro de la mesa podemos encontrar un manual de trolling desplegado, que sirve como guía del público, junto a una gran cantidad de manuales plegados que los espectadores pueden recoger y usar posteriormente. En la parte posterior de la mesa tenemos cuatro retroproyectores, dos sobre la mesa y dos en el suelo, que proyectan en una pared cercana las transparencias que contienen diferentes apartados del manual e incluso otros mapas conceptuales alternativos que complementan a este.

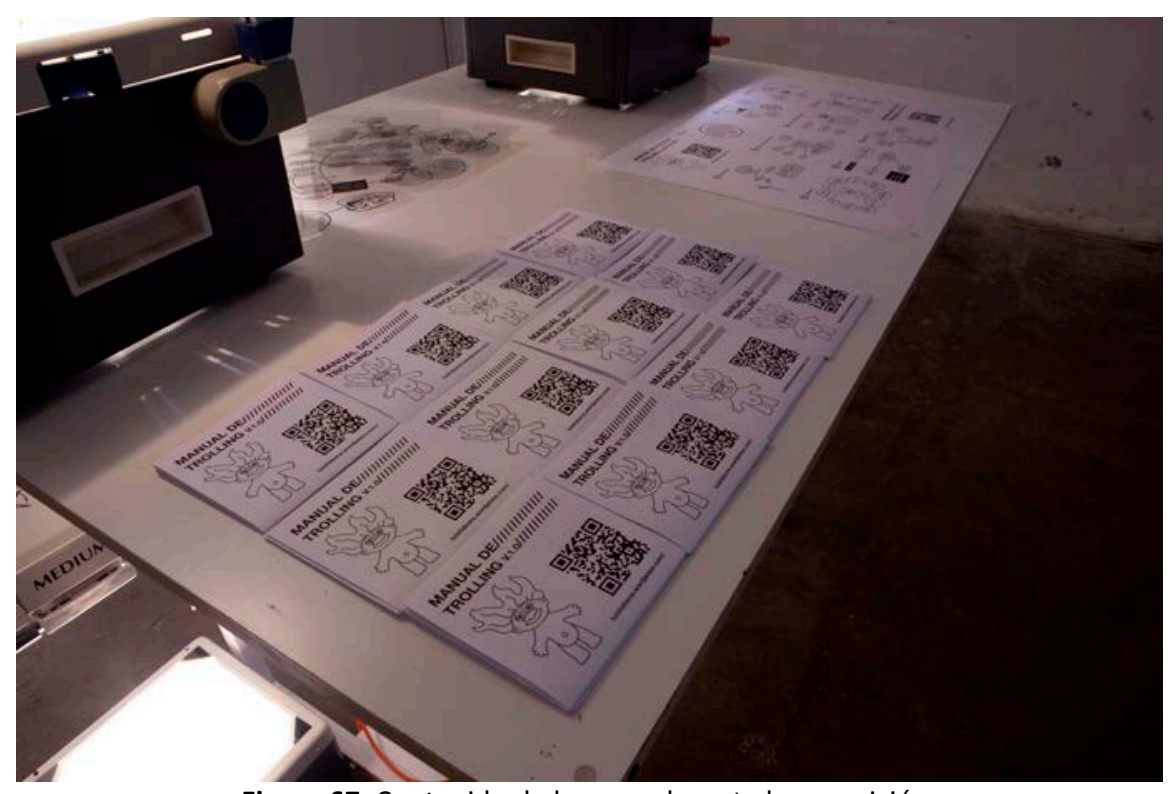

Figura 67. Contenido de la mesa durante la exposición.

Otro elemento importante de la obra es la luz, como elemento inmaterial que transforma totalmente la identidad del espacio y la obra. La obra crea una estética cercana al mínimal mediante la utilización de elementos blancos, mecánicos o transparentes, jugando también un papel importante el lugar expositivo, el cual es diáfano y limpio en concordancia con la obra. Las transparencias que no están en uso aparecen amontonadas en la mesa de manera que el espectador puede interactuar y cambiar la transparencia que le apetezca para verla proyectada sobre la pared, generando dinámicas de 
participación dentro de la obra. El mismo hecho de poder llevar contigo un manual gratuitamente genera dinámicas didácticas pero no conductistas, que cuestionan la temporalidad de la obra, y abogan por la propagación del conocimiento para así multiplicar este modo de actuación dentro de Internet. Del mismo modo este tipo de enfoque sobre el arte nos habla de la perdida del aura y del pedestal del objeto artístico como podemos extraer de la obra de Walter Benjamin La Obra de Arte en la Época de la Reproductibilidad Técnica ${ }^{277}$, donde el autor argumenta como las nuevas técnicas asociadas al arte han destruido por completo el aura que lo envolvía. Apoyamos estas afirmaciones, ya que como he comentado con anterioridad abogamos por un modo de actuación basado en el resultado de mi investigación, pero que puede ser reproducido por el público. La utilización de códigos QR que enlazan a un blog donde se puede consultar todo el proceso de la obra nos abre la posibilidad de crear una exposición expandida, ya que la experiencia allí vivida puede ser ampliada y actualizada desde Internet. Como nos cuenta Martí Manen en su obra Salir de la exposición (si es que alguna vez habíamos entrado)278, "La exposición ocurre pero no nos recibe, paseamos por ella pero no nos incorpora, observamos y miramos pero difícilmente podremos decir. Existen unos códigos que se han generado antes de la exposición en sí." Aquí Manen habla precisamente de un concepto de exposición totalmente cerrada, que no permite ningún tipo de interacción del espectador y cuyas funciones están totalmente delimitadas, en contra de otros tipos de utilización del espacio en los cuales la temporalidad del evento es relativa ya que puede acompañar al espectador siempre que el quiera. Como dice Martí Manen ${ }^{279}$ refiriéndose a un tipo de arquetipo basado en la temporalidad:

"Si pensamos ahora que esta exposición modelo, heredera sin que lo quiera de una situación particular, es una exposición temporal (algo que seguramente forma parte de lo que es la exposición "modelo") podemos percatarnos de que "el tiempo de vida" de la exposición no permite ser consciente de la temporalidad. La exposición es hoy. Y "hoy" cierra."

\footnotetext{
${ }^{277}$ Benjamin, Walter, La Obra de Arte en la Época de la Reproductibilidad Técnica, Mexico D.F., Itaca, 2003.

278 Manen, Martí, Salir de la exposición (si es que alguna vez habíamos entrado), Barcelona, Consonni, 2012.

${ }^{279}$ Manen, Martí, Op. Cit., 2012.
} 


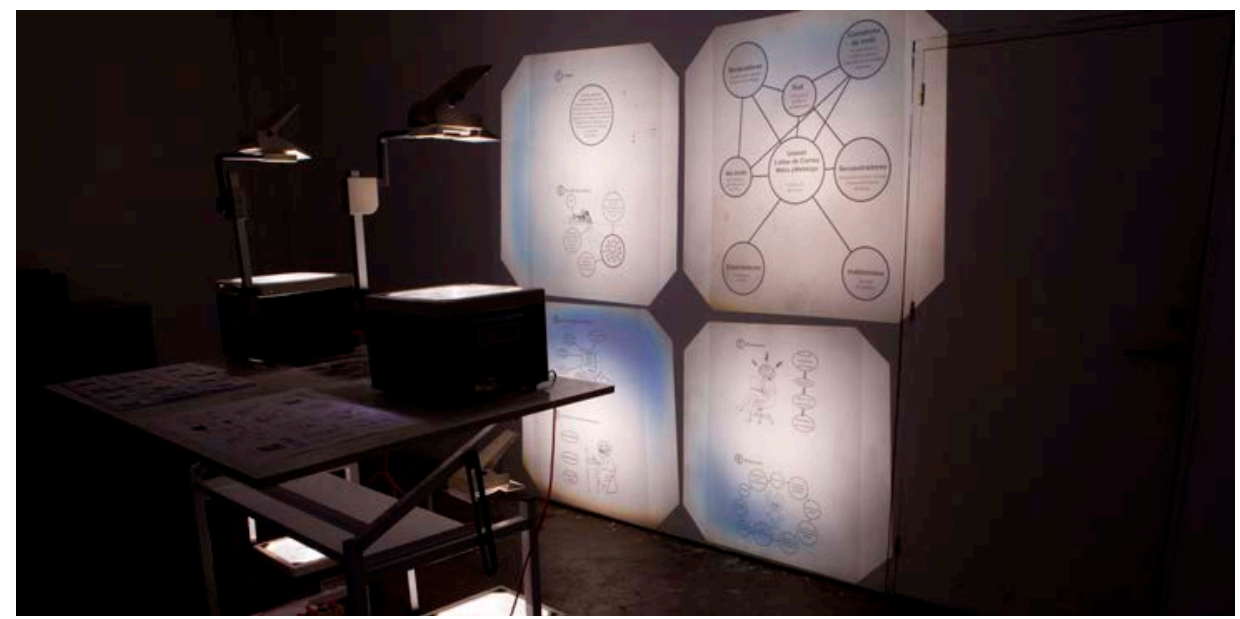

Figura 68. Vista lateral de las proyecciones.

Por otro lado podemos disfrutar de la proyección de los vídeos que fueron realizados para la obra How we can make each other better?, dentro de una proyección en bucle no simultanea de ambas obras sobre la misma superficie. Este espacio instalativo genera un choque entre el contenido de la mesa y los vídeos proyectados que guarda relación con el concepto de mostrar toda la conceptualización de un modo de hacer con instrucciones precisas de cómo reproducirlo, y por otro los resultados de la aplicación de esta metodología en forma de vídeo. De esta manera podemos apreciar el método heurístico de ensayo y error utilizado durante la investigación, que tiene como finalidad la obtención de un conocimiento conceptual y procesual, en áreas en las cuales el conocimiento a priori es nulo. 


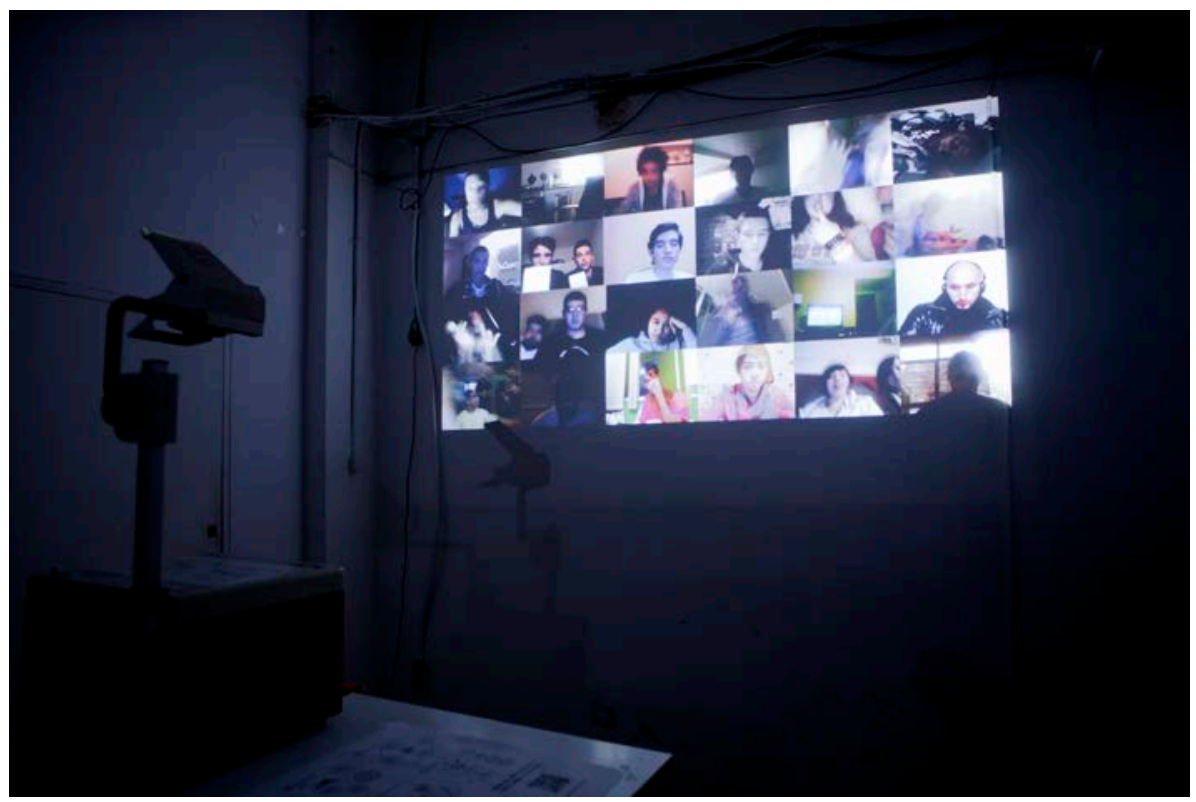

Figura 69. Vista general de las proyecciones.

En líneas generales cabe señalar que este proyecto se mueve en el denominado campo de las ideas, intentando plasmar un compromiso con el mundo exterior y la vida cotidiana, una crítica de la cultura dominante, que por supuesto incluye lo artístico, generando un vinculo con la cultura en términos intelectuales. No solo los espacios son expandibles sino también las vinculaciones y la experiencias, es por ello que este protecto muestra la intención de aumentar la experiencia vivida en la sala mediante los medios que hemos podido observar. Busca una sintonía con los fenómenos actuales en Internet, sin importar que mi producción sea ubicada dentro de la alta o baja cultura, un completo estudio antropológico y psicológico sobre el comportamiento humano. Se trata de una expansión del arte en todos los ámbitos de la cultura humana generando un debate en el cual pueden intervenir diferentes campos del conocimiento. Podríamos enmarcar este tipo de espacio dentro del un Site Specific Discursivo, ya que la propia instalación plantea un discurso distribuido por el espacio de la sala. 


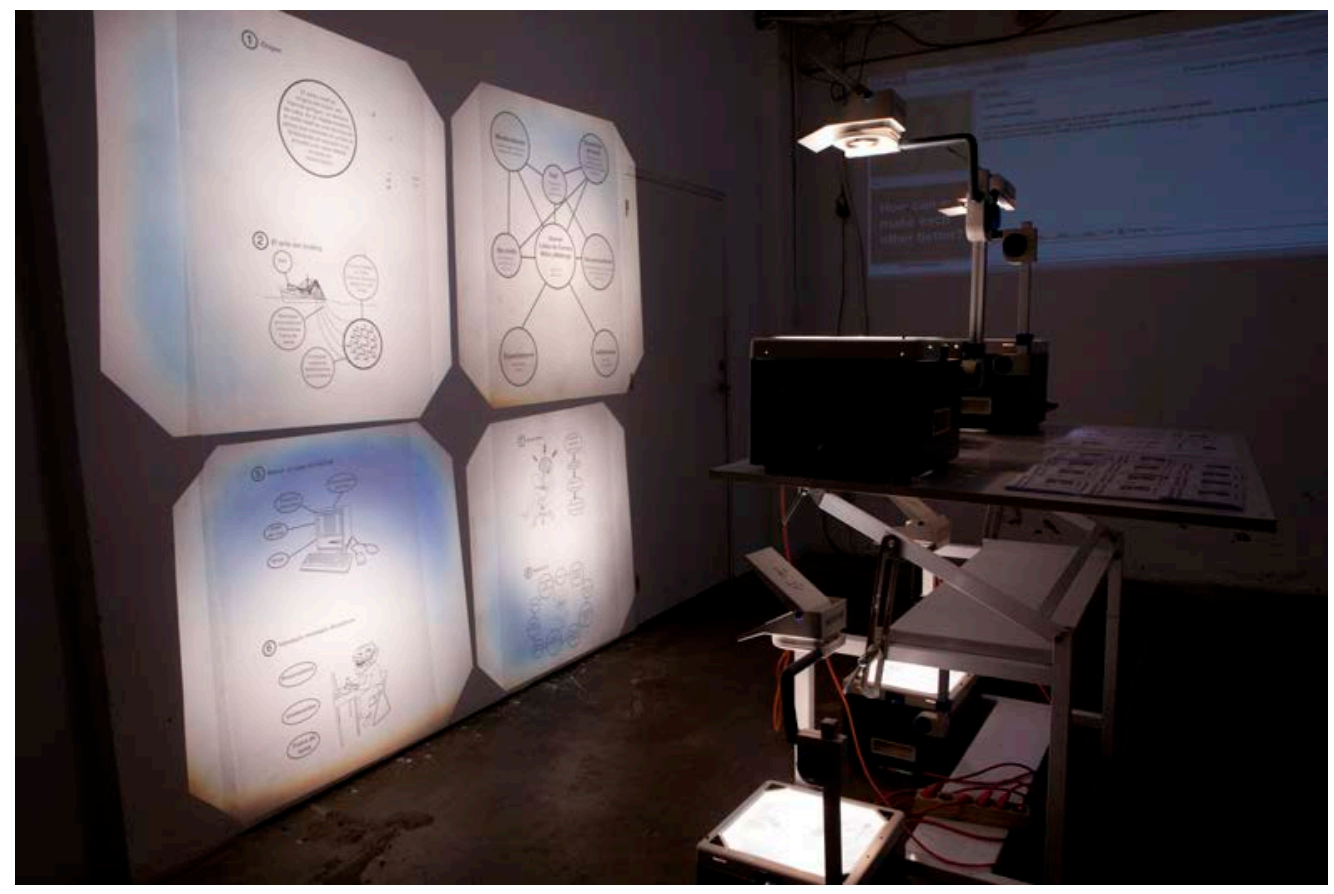

Figura 70. Vista lateral de la pieza.

Un gran ejemplo de este tipo de instalación es la obra de 1991 del grupo artístico Group Material 280 titulada Aids Time Line, en la cual se crean discursos dentro del museo sobre la enfermedad del SIDA pero también en el exterior mediante los media. El espacio expositivo aparece atravesado por una línea de tiempo en la cual se ven reflejados eventos relacionado con esta enfermedad, mezclando iconografía popular con obras de arte de otros grupos y noticias. Dentro de este tipo de obra el discurso se convierte en el lugar.

280 Ashford, Doug, Ault, Julie, Locks, Sabrina, Show \& Tell: A Chronicle of Group Material, Londres, Four Corners Books, 2010. 


\subsection{EL PAISAJE DE LA MULTITUD ${ }^{281}$.}

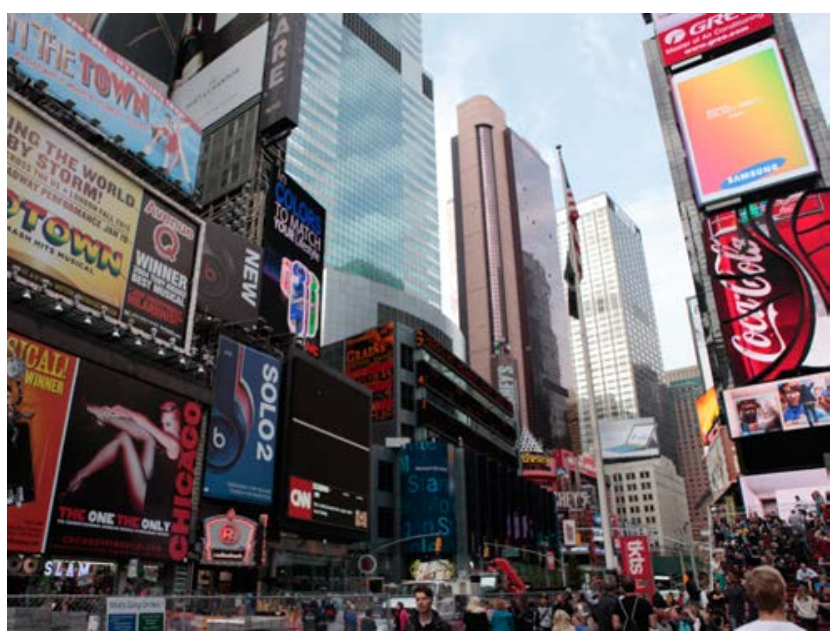

Figura 71. Vista de parte de la plaza de Times Square.

A finales de 2014 tuvimos la oportunidad de realizar una estancia de tres meses en la ciudad de Nueva York. Tuvo un papel fundamental en dicha experiencia la toma de contacto con este espacio urbano. Nos decidimos a explorarlo e investigar sobre las diferentes dinámicas urbanas que se desplegaban ante mí a diario en diferentes espacios de esta ciudad.

Si pensamos sobre la relación entre los nuevos modos de vida desarrollados dentro del espacio urbano contemporáneo y las tecnologías de la imagen dentro de estos contextos, aparecen en nuestra mente lugares que ya pertenecen al imaginario colectivo. Este es el caso de Times Square, lugar mediatizado por excelencia y marco perfecto para explorar las relaciones existentes entre mass media, identidad y redes sociales. Se presentó como una oportunidad excelente para implementar dicha investigación.

\footnotetext{
${ }^{281}$ El título del proyecto hace referencia a los poemas de Federico García Lorca El paisaje de la multitud que orina y El paisaje de la multitud que vomita contenidos es su obra Poeta en Nueva York publicada en 1940. En ellos trata la alienación de la sociedad capitalista y la propia desaparición entre la multitud.
} 
En esta esfera pública convergen la imagen, la tecnología y el espacio público, este último entendido como una esfera social y un lugar de debate y participación de todos los ciudadanos. Por lo tanto es a todas luces imprescindible elaborar una etnografía de la esfera pública teniendo en cuenta las nuevas implicaciones que la imagen, las redes y la multitud interconectada han supuesto para nuestra experiencia en el espacio público. Es por ello que esta estancia resultó especialmente fructífera como un momento en cual poder profundizar en la experiencia para desarrollar un nuevo marco de referencia que nos ayuda a comprender dichas dinámicas.

Entre los objetivos previos, que nos planteamos con anterioridad a la realización de esta investigación, tiene un lugar especial el hecho de poder definir una metodología de trabajo en la esfera pública que se amolde a mi situación de ciudadano temporal de un lugar, teniendo en cuenta las características específicas del lugar, las nuevas dinámicas urbanas y el papel de los mass media y las tecnologías asociadas con Internet, vemos com tienen un papel destacado en nuestra vida diaria. Por otro lado, el hecho de poder analizar las nuevas dinámicas espaciales tomando como objeto de análisis un espacio tan paradigmático dentro de la cultura occidental como Times Square, da pie a intentar describir la nueva relación entre lo público y lo privado dentro de la esfera pública, y cómo esto nos afecta en el ámbito relacional. Los viandantes llegamos a concebir los espacios con los que tomamos contacto diario como algo que tiene estrecha relación con nuestra identidad, por lo tanto sería interesante averiguar de qué manera esta vivencia se desarrolla en este tipo de espacios, donde la fluidez y la disolución en la multitud es la tónica general. Los nuevos tipos de relación desarrollados en este tipo de espacios mediatizados nos hace preguntarnos ¿Cómo se relacionan los componentes público y privado de nuestra vida en base a las red y las aplicaciones de la Web 2.0.? 


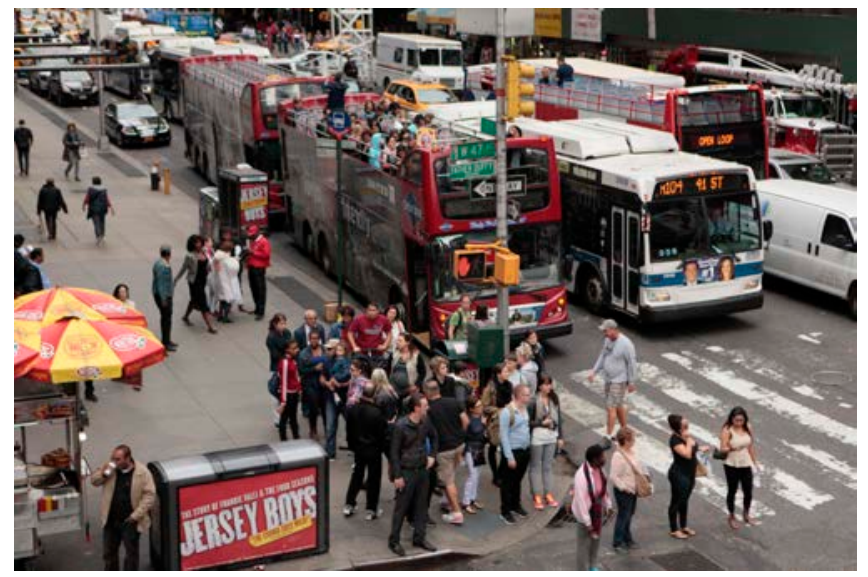

Figura 72. Intersección de la 7ạ Avenida con la calle 47 en Times Square.

El actual escenario del espacio urbano contemporáneo, nos llevó a optar por la "observación flotante" como metodología inicial de investigación y exploración, para después analizar los resultados y poder elaborar un breve ensayo confrontando estos datos con los referentes que aporto desde mi bagaje personal dentro de la actividad investigadora. La "observación flotante" surge a principios de los 80 como respuesta a una esfera pública contemporánea en la cual la movilidad de las relaciones sociales y la fugacidad del tránsito de los actores del espacio urbano, han sido las señas de identidad, asentadas en una nueva ciudad caracterizada por la fluidez, el movimiento y el intercambio. Colette Pétonnet en su obra L'observation flottante ${ }^{282}$ asentó las bases de una metodología a partir de esta nueva realidad urbana. Tiene como principal objetivo la producción de una mirada que no está fija en ningún punto en concreto, sino que permanece levitando sobre el espacio de manera que facilite el hallazgo de pautas o patrones que sirvan de punto de partida en la investigación. Este tipo de observación está diseñada para imposibilitar la aparición de prejuicios o ideas prefijadas que actúen sobre nuestra percepción distorsionando nuestro juicio, poniendo en valor nuestra propia experiencia en el estudio de los espacios. Todos poseemos filtros culturales que impiden desarrollar una objetividad total en nuestro análisis, ya que en ocasiones generamos una visión desde una perspectiva demasiado cercana al elemento a analizar imposibilitando la obtención de conclusiones objetivas.

${ }^{282}$ Pétonnet, Colette, op. Cit., 1982, p. 56. 
Ante todo, una de las cualidades más seductoras de esta metodología es la posibilidad de acomodar el método al espacio como manera de acercarnos al entorno, delimitando qué vamos a estudiar y finalmente generando conclusiones como resultado de la investigación. Son esta maleabilidad y etereabilidad las que la sitúan como la opción más precisa en el campo metodológico.

Manuel Delgado 283 , profesor de la Universidad de Barcelona, nos habla de lo intangible y difícil de contener de la relaciones que intentamos analizar dentro de la urbe, debido sobre todo a lo líquido de los ejes que organizan nuestra vida social. No contamos en muchos casos con instituciones estables, sino que tratamos con lo instantáneo. Por consiguiente, al analizar nuestro estatus dentro de este espacio, me encontré situado dentro de "todo lo que en una ciudad puede ser visto flotando en superficie", con lo cual podemos hablar del aspecto contextual de la identidad del transeúnte y de la imposibilidad de formar una identidad colectiva debido a lo fluido y lo transitorio de nuestro estatus, entendiendo lo urbano como un espacio en el cual somos licuados y disueltos constantemente. Es por ello que nuestra situación fue perfecta para desarrollar mi labor como etnógrafo de lo urbano, como un moderno narrador de la novela de Edgar Allan Poe El hombre de la multitud ${ }^{284}$, en la cual dicho personaje observa pasar, desde un café londinense, a todo tipo de viandantes, realizando un análisis pormenorizado de cada uno de ellos.

\footnotetext{
${ }^{283}$ Delgado, Manuel, op. Cit., 1999, p. 46.

${ }^{284}$ Poe, Edgar Allan, Poe: Cuentos 1, Alianza Editorial, Madrid, 2010, p. 23.
} 


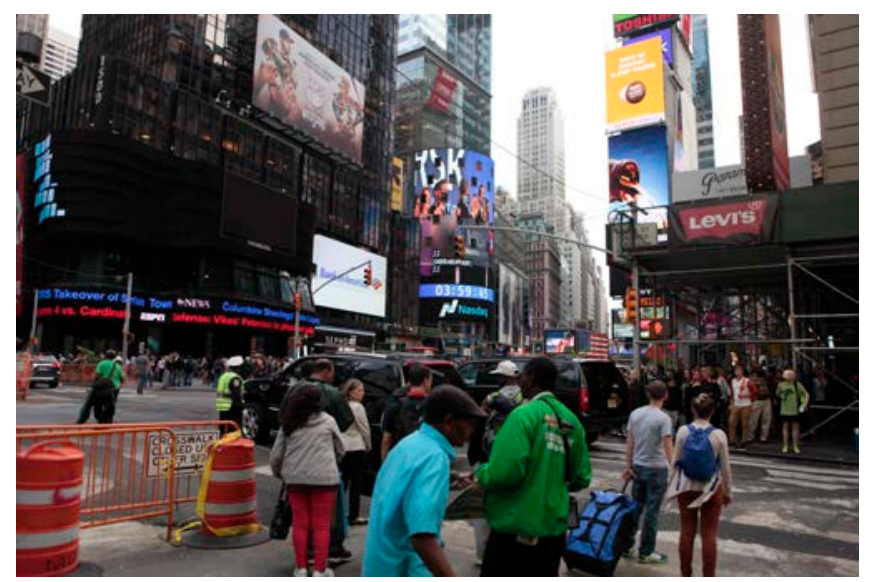

Figura 73. Vista de Times Square con el edificio del Nasdaq al fondo.

Dichas pautas de observación también las encontramos, de nuevo, en la aclamada obra cinematográfica de Alfred Hitchcock La ventana indiscreta, en la cual un convaleciente James Stewart se convierte en un voyeur de lo urbano. En este caso el actuar de los visitantes basado en la producción de material y su publicación en las redes, o la retransmisión en directo de video con el objetivo de dar a conocer su propia experiencia en este enclave, aparecen como extensiones de la propia experiencia vivida. Una amplificación de nuestra propia presencia que nos permite generar una narración dentro de las redes.

La plaza de Times Square está formada por la intersección de Broadway con la 7a Avenida, siendo un lugar clave de confluencia dentro de la urbe. Como podemos observar a simple vista, la plaza permanece de manera continua ocupada por una multitud de turistas, performers, visitantes ocasionales y todo tipo de individuos que flotan sobre este lugar. La inmensa mayoría tienen como nexo en común la contemplación del fascinante espectáculo mediático en forma de pantallas que tiene lugar en la plaza. Es aquí donde decidí empezar mi personal estudio adoptando el rol de observador-participante debido a mi estatus de ciudadano transitorio. Ser un extraño fue la garantía de nuestro éxito como observador dentro de una multitud de extraños. Este rol de turista permitió observar desde dentro sin ser percibido como un intruso, siendo testigo de las interacciones que tenían lugar ante nuestros ojos. 


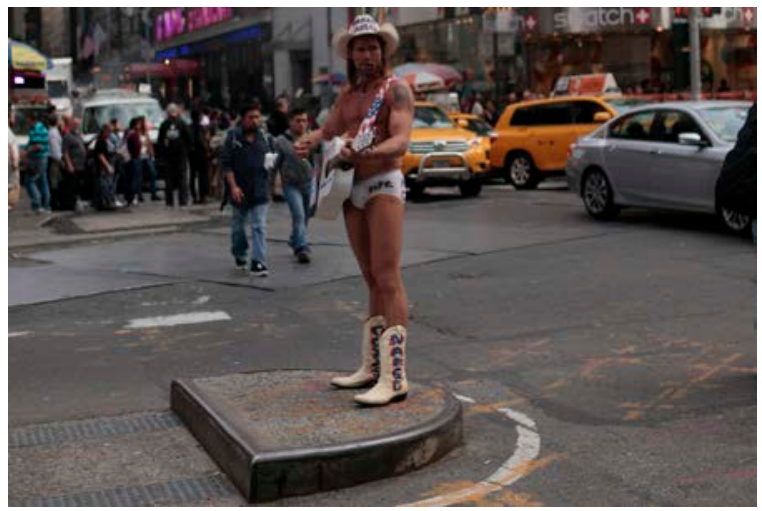

Figura 74. Naked Cowboy, uno de los performers más populares de Times Square.

Por otro lado, mediante la toma de material fotográfico durante esta experiencia pudimos generar todo un catálogo de hechos aislados que tenían lugar a diario. Tomé como protagonistas a los ocupantes del lugar, generando una narración fragmentada de lo que resulta llamativo y atrae al observador.

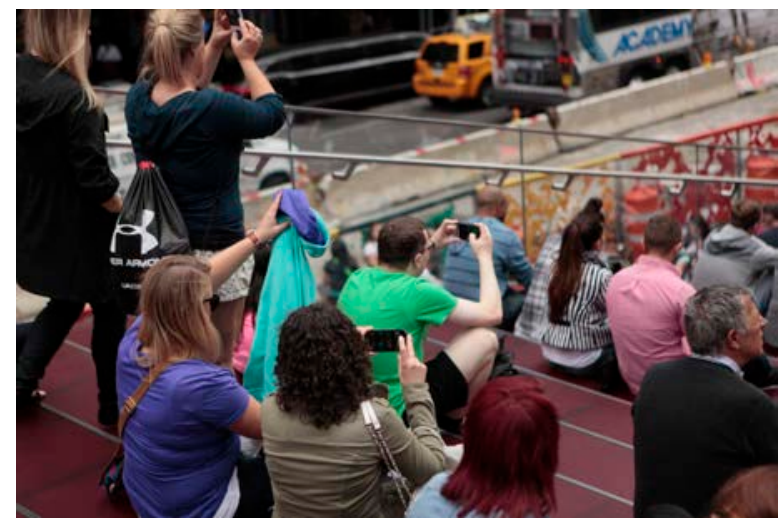

Figura 75. Visitantes de Times Square fotografiando la plaza.

Este proceso de desfragmentación de la multitud me llevó a realizar narraciones fragmentarias de esta experiencia mediante las nuevas formas de narración constituidas como producto mediático. Me resultó fascinante el hecho de la limitación de caracteres de las publicaciones de Twitter, o lo inmediato de los pequeños clips de Vine que los visitantes no dudan en ubicar mediante geolocalización. 


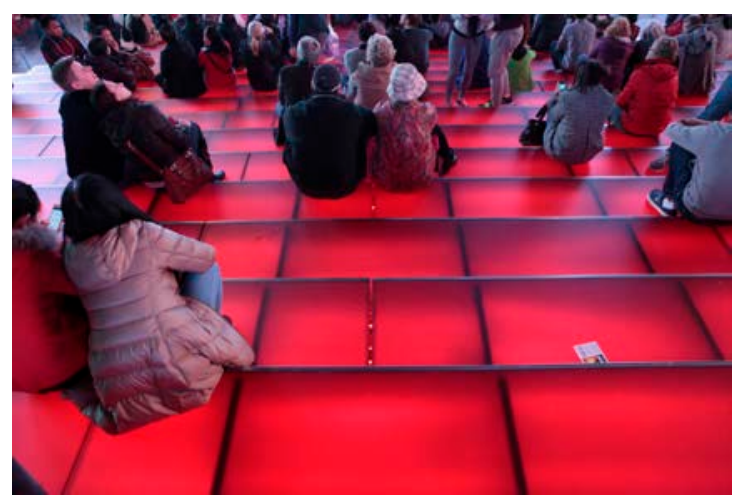

Figura 76. Visitantes observando desde escalinatas de Times Square.

Esto nos llevó a enfocarme exclusivamente en la producción amateur realizada a diario por los visitantes en las redes sociales como material mediante el cual reflexionar sobre la conceptualización de los privado y lo público dentro de nuestro actuar en las redes. ¿Hasta qué punto no era todo este material una extensión de la propia experiencia en el espacio público? y ¿Hasta qué punto esta experiencia, al igual que vimos anteriormente, conforma un solapamiento entre las esferas pública y privada a la vez que se traduce en una narrativa colectiva?

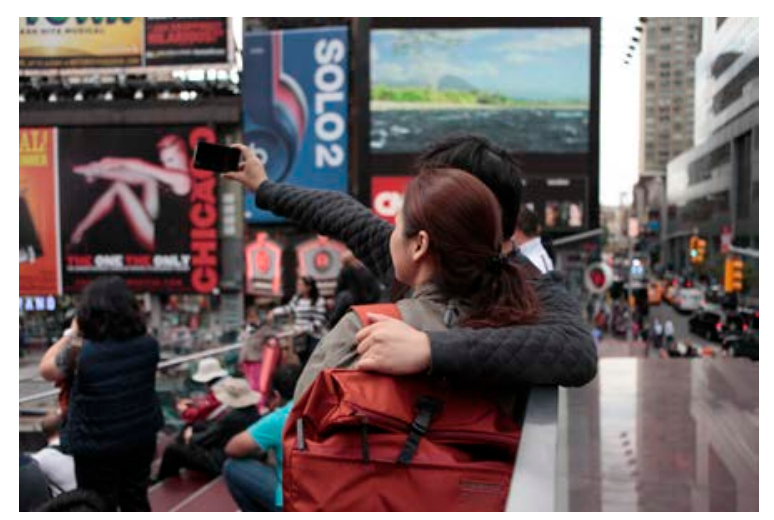

Figura 77. Pareja fotografiándose desde la escalinata. 
Como podemos observar en la serie de ficción televisiva The Deuce, creada por David Simon, autor de grandes series de culto como The Wire, Times Square fue durante la década de los 70 , y hasta la limpieza llevada acabo por el alcalde Rudolph Giuliani en los 90 del siglo XX, una zona dedicada al juego, la prostitución e invadida por la epidemia de las drogas, culminando un proceso de degradación que ya comenzó con la gran depresión, cuando los residentes se movieron a barrios residenciales y los grandes teatros fueron reemplazados por salas de variedades, y posteriormente por sex shops y go go bars o salas de cine $\mathrm{X}$, las cuales dieron un matiz sórdido a esta zona. Parte de esto también lo podemos ver retratado en películas como Cowboy de medianoche de John Schlesinger, donde se muestra como un lugar oscuro, corrupto y lleno de buscavidas. Irónicamente fue la especulación urbanística lo que posibilitó un plan de desarrollo que apoyado desde el poder político rehabilito los teatros y los espectáculos de Broadway.

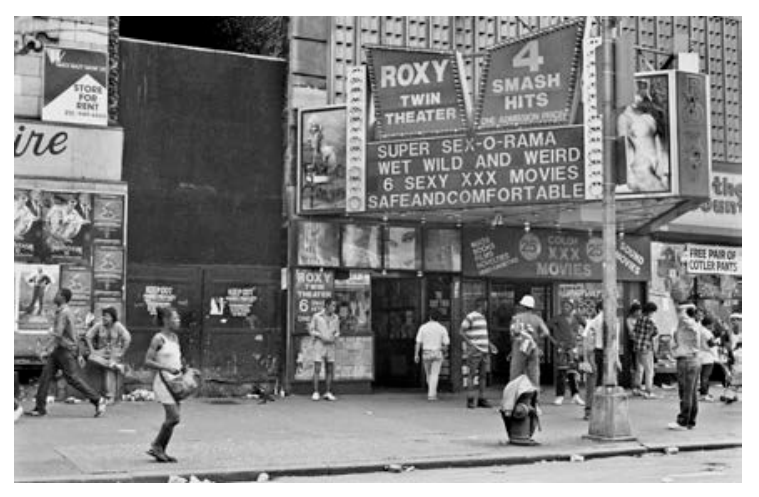

Figura 78. Fotografía tomada en Times Square en 1988.

Este pequeño resumen de la historia reciente de esta plaza, nos habla sobre las formas de entretenimiento que han poblado este lugar, tanto legales como ilegales, las cuales han forjado la narrativa hegemónica respecto a este espacio y por lo tanto la imagen que tenemos respecto al mismo. Estamos ante una imagen que ha evolucionado históricamente junto a estas formas de ocio. Sin embargo, podemos afirmar que el actual paisaje de Times Square es el resultado de los media que históricamente habitaron esta plaza, hasta tal extremo que se han convertido en el tejido que recubre sus muros, generando una experiencia social intangible a la par que sensorial. Da la sensación que las pantallas de cine de su época gloriosa han salido a la calle para transformarse en una nueva forma de edificio. 


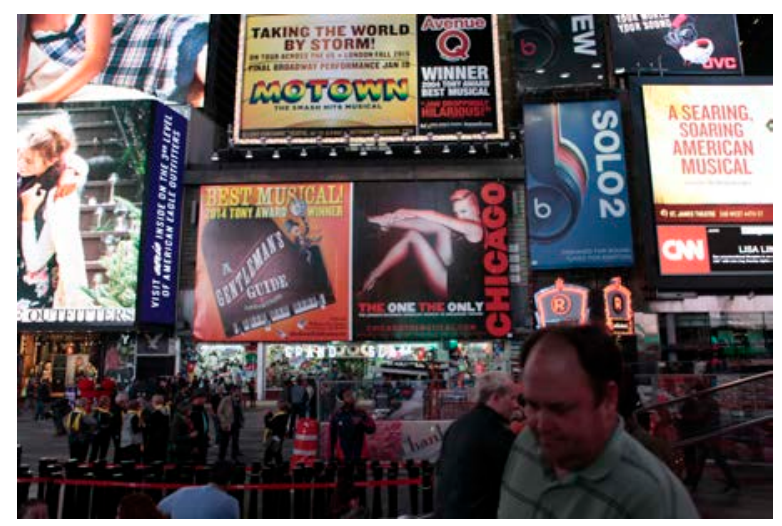

Figura 79. Vallas publicitaras anunciando alguno de los espectáculos de Broadway.

Como Paul Virilio 285 afirmaba en una entrevista realizada por Jerôme Sans, la pantalla es el paso de algo material a algo que no lo es, afirmando que la pantalla de cine distorsiona el tiempo y corroe el espacio. Por otro lado, para Roland Barthes ${ }^{286}$ la pantalla era considerada como un espacio en el cual colisionan las imágenes del yo y del otro, generando la lacaniana construcción del yo respecto al gran otro exterior, observándola como una intersección en el imaginario.

Las pantallas que pueblan este espacio, actúan como una pantalla de cine pero modifican radicalmente el espacio urbano, haciendo que las imágenes generadas antaño en el interior de los cines y teatros ahora están ubicadas sobre la arquitectura. Durante mucho tiempo fueron los teatros los que definían la identidad de este lugar, pero con la llegada de los muros pantalla esto cambió. Mientras los teatros funcionaban como una mascara que encubrió durante mucho tiempo las actividades ilícitas llevadas acabo en esta zona, la pantalla refleja de la misma manera que un espejo, construyendo nuevos imaginarios. Esto ha generado lo que Paul Virilio definió como "media

\footnotetext{
${ }^{285}$ Armitage, John, Virilio Live: Selectec Interwievs, Sage Publications, Londres, 2001, p. 116.

${ }^{286}$ Barthes, Roland, El susurro del lenguaje, Paidós, Barcelona, 1994, p. 342.
} 
building"287, afirmando que las pantallas no formaban parte de la memoria de un edificio como las vidrieras o los frescos, sino que su imaginario en constante cambio contribuye a la desmaterialización de la arquitectura. Esto ha dado lugar a una arquitectura que es soporte de información, y por lo tanto de los mass media. Mientras la catedral gótica era iluminada por sus vidrieras evidenciando el paso del día y la noche, la luz de este tipo de arquitectura es la luz de la inmediatez y la ubicuidad, como atributos esenciales de lo divino, y de las características de las nuevas tecnologías de la información y la comunicación.

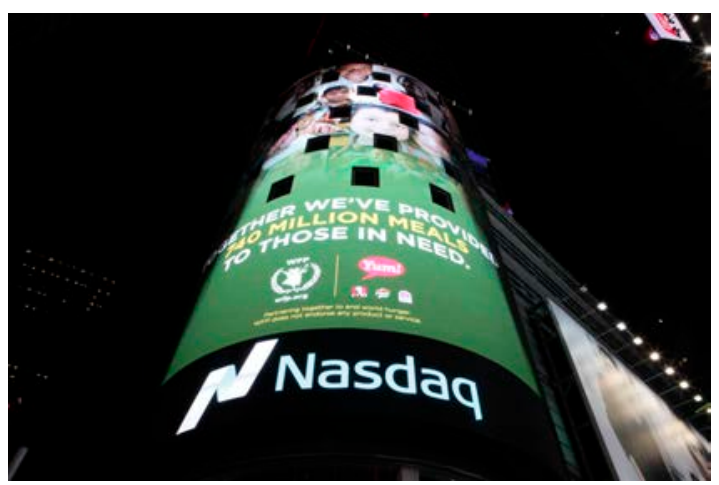

Figura 80. Edificio del Nasdaq en Times Square.

Por otro lado, la recopilación de fragmentos de vida adquiere un carácter etnográfico tal y como nos cuenta Juan Martín Prada en su obra Otro tiempo para el arte ${ }^{288}$. Lo podemos relacionar con la inmediatez y la fluidez de las experiencias, tanto reales como de tipo virtual, dentro de lo que denominamos esfera pública contemporánea; y de la cual todos los ocupantes del lugar éramos partícipes. Este hecho nos llevó a descubrir la manera en la cual nuestra experiencia, dentro de un espacio, se extiende dentro de la esfera mediática como forma autobiográfica, pero también como construcción colectiva de la imagen de Times Square, la que por otro lado está físicamente constituida por una arquitectura mediada, en el sentido de que son los propios media mediante pantallas los que conforman las paredes del lugar. Las tecnologías sociales de Internet han posibilitado el proceso constante creación

\footnotetext{
${ }^{287}$ Mcquire, Scott, The politics of public space in the media city, First Monday, [en línea] 2006 [consulta 6 de Marzo de 2017] disponible en <http://firstmonday.org/article/view/1544/1459> ${ }^{288}$ Martín Prada, Juan, Otro tiempo para el arte, Sendemá Editorial, Valencia, 2012, p. 53.
} 
de lo que Paul Ricoeur llamaría una identidad narrativa, como ya vimos, en la cual la función narrativa esta mediada, constituyéndonos a nosotros mismos como un relato. Tal y como Anthony Giddens nos recordaba, la consecución de una crónica particular será el factor determinante en la construcción de nuestras identitades, siendo la red y las aplicaciones de la Web. 2.0. el lugar idóneo por las propias características de estas estructuras mediáticas. La identidad generada en base a las redes será un constructo maleable que se modificara por nuestro propio actuar en la red, encuadrado como práctica cotidiana, como territorio de autorepresentación y autoconstrucción. Dentro de este contexto es la imagen el epicentro de estos procesos, como un interfaz comunicativo dentro de las redes sociales, sin embargo, como hemos podido apreciar aquí también sirve como amplificación de nuestra presencia en directo, implementada mediante las nuevas aplicaciones de la Web 2.0.

La imagen es una de las principales herramientas a la hora de autorepresentarnos dentro de la red. Se ha constituido como el interfaz mediante el cual nos comunicamos dentro del hábitat de las redes sociales. La finalidad de establecer interacciones es crear significados compartidos, construcciones de la realidad inmediata y deseos mutuos a partir de los símbolos que se intercambian.

Este entorno mediático da la oportunidad al usuario de ocupar un lugar en el mundo para dar sentido a sus actos y a su propia existencia. Son marcos de referencia, encuadres, que ordenan las experiencias y hechos de la cotidianeidad. Su aspecto más seductor se encuentra en la narración como aspecto inseparable de la identidad y que se caracteriza por lo inmediato, indiscreto y exhibicionista. Un claro ejemplo de lo dicho anteriormente lo podemos encontrar en la obra de Jasper Elings, Flashings in the Mirror. Un video de carácter apropiacionista que nos muestra una gran colección de selfies en el cual el hilo conductor es el sonido del flash de la cámara. Este tipo de imágenes es lo que Joan Fontcuberta denomina "reflectogramas", es decir imágenes tomadas frente al espejo, siendo característico de las prácticas fotográficas amateur dentro de nuestra cotidianidad. Este tipo de imágenes nos plantea de nuevo un tipo de prácticas que aúnan el propio narcisismo del fotografiado con el voyeurismo del resto de usuarios de las redes sociales. Esto genera una mezcolanza entre los privado y lo público basada en las prácticas sociales y el funcionamiento de las nuevas aplicaciones de la Web 2.0, las cuales generan valor en base a nuestras prácticas afectivas. 


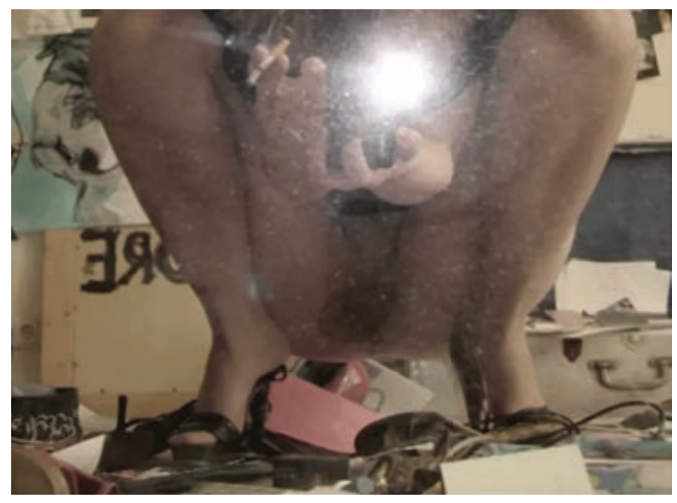

Figura 81. Jasper Elings, Flashings in the Mirror, 2009.

Como ya en 1970 Marshall McLuhan nos anunciaba en su libro Take Today289, esto se encuadra como consecuencia del avance en la tecnología, el cual ofrece herramientas mediáticas de producción al alcance del público en general. También Manuel Castells en su obra La Galaxia Internet ${ }^{290}$, nos habla sobre los nuevos "productores-usuarios" y cómo estos generan su propio relato dentro de la redes. En este punto, y gracias al modo de relación con el medio y sus ocupantes que la metodología propiciaba, reflexionamos sobre la posibilidad de crear una etnografía de un espacio público a través de su reflejo en la producción autobiográfica de los visitantes. Sin embargo este tipo de herramientas han generado prácticas que han convertido nuestro tiempo de ocio en trabajo inmaterial gratuito. Esto queda encuadrado en lo que ya nos contaban Paolo Virno y Michael Hardt, poniendo el foco en como el sistema capitalista había conseguido generar valor de nuestras prácticas cognitivas y afectivas. Dentro del ámbito de contenido informacional y cultural, Michael Hard nos habla del concepto de affective labor, para designar un tipo de construcción biopolítica conformada en base a la producción hegemónica basada en la mezcla de tecnología y afectividad, que genera un valor añadido dentro del campo de las relaciones sociales. Como podemos observar al visitar la plaza de Times Square existe una glamourización de este tipo de trabajo digital convertido en práctica social, que concuerda con lo expuesto por Tiziana Terranova, concibiendo la sociedad como una fábrica a la cual le han sido transferidos los procesos de trabajo.

\footnotetext{
289 McLuhan, Marshall, Nevitt, Barrington, op. Cit., 1972.

290 Castells, Manuel, op. Cit., 2001, p. 51.
} 
Toda la experiencia dentro de la plaza de Times Square puede ser descrita en términos de Guy Debord como un completo "espectáculo" en el sentido más amplio de la palabra, ya que no solo se trata de imágenes que interpelan a los visitantes de la plaza, sino que lo que podemos observar son relaciones sociales entre diferentes individuos que son mediadas mediante imágenes o la retransmisión de video en directo. Sin embargo, la densidad de emisión de imágenes y estímulos lumínicos es capaz de ocultar el verdadero espacio detrás de estos. Por lo tanto los visitantes permanecen sumergidos en un bucle de exposición de imágenes pero también en su producción indiscriminada, convirtiéndose en audiencia y en espectáculo a la vez. Son los protagonistas y generadores de experiencias visuales banales. Podríamos decir, que los instrumentos modernos de construcción de la vida cotidiana que ansiaba poseer Debord han pasado precisamente a ser elementos que constituyen el tejido de la producción económica y social de hoy día. Al usar a la multitud como elemento autónomo de producción, las aplicaciones de las Web 2.0 se constituyen como servicios creados para los usuarios y no por ellos, siendo los arquitectos de estos espacios los que verdaderamente modelan a sus usuarios mediante estas estructuras mediáticas.

Tras esta reflexión inicial estábamos preparados para diseñar un proyecto artístico alrededor de mi experiencia en la plaza de Times Square. Nos dispusimos por lo tanto a indagar dentro de la esfera mediática y, como Boris Groys $^{291}$ nos sugiere, convertir la narración colectiva del lugar en una obra. Nos interesó significativamente la producción de un catálogo de "momentos" como nos diría Henrry Lefebvre. También nos sumergimos en la plasmación colectiva mediante un medio icónico-verbal de instantes pasajeros, momentos irrepetibles y lo azaroso de nuestra experiencia dentro del espacio público, basándome en el estudio de las repeticiones y cadencias sociales. El propio Lefebrve, citando a Marx y Engels en su obra La producción del Espacio ${ }^{292}$, nos habla del concepto de producción, el cual está ligado a áreas como la historia, la vida o la conciencia en el caso del ser humano. Nos habla de un tipo de producción ligada a la vida y nuestro mundo, que da como resultado un producto. Esta producción, tal y como nos cuenta Gemma San Cornelio en su

\footnotetext{
${ }^{291}$ Groys, Boris, op. Cit., 2014, p. 120.

${ }^{292}$ Lefebvre, Henri, La producción de espacio, Capitán Swing, Madrid, 2013, p. 125.
} 
obra Arte e Identidad en Internet ${ }^{293}$, está ligada al concepto de self branding o autopromoción, proponiendo nuestro actuar en la redes como un proyecto reflexivo del yo, el cual según nos cuenta Foucault ${ }^{294}$, es sin duda algo hecho o producido mediante la acción sobre uno mismo. La intersección entre Internet, economía e identidad ha propiciado procesos identitarios, o trayectorias del yo como diría Giddens que basan en los principios de promoción corporativa y de marca del sistema hegemónico capitalista.

Así pues como decía Michel Foucault ${ }^{295}$ recogiendo las ideas de Antonio Gramsci entre otros, el verdadero éxito de este sistema consiste en hacer interiorizar sus lógicas en la sociedad de manera tan profunda que estas son reproducidas y asentadas como uno de los pilares básicos de nuestra narrativa personal y como nos mostramos ante los demás, definiendo el poder como algo que reside en la cabeza de cada uno de lo individuos de una sociedad. Por su parte Pierre Bourdieu nos relata como las relaciones de poder son interiorizadas y naturalizadas dentro de lo que el define como violencia simbólica ${ }^{296}$ para designar al constructo social que delimita nuestra percepción y pensamiento, siendo algo que queda implementado por los propios individuos. Por su parte Manuel Castells nos plantea la comunicación y la información como aspectos imprescindibles dentro de la dominación y el cambio social, produciendo un tipo de enfrentamiento en el cual el campo de batalla es nuestras propias mentes mediante la construcción ideológica de la hegemonía. Para Gramsci la hegemonía es un estado que se alcanza mediante la producción de verdad, perpetuando los intereses de las clases dominantes que son percibidos como comunes por el resto de la sociedad, siendo perpetuados esencialmente mediante los medios de comunicación.

Qué mejor manera de tomar constancia de esta acción sobre nosotros mismos que el material de carácter autobiográfico que compartimos en las redes sociales. Es por ello que decidimos comenzar a recopilar todos los videos amateur subidos a la red social Vine durante un año, que contaran con la

\footnotetext{
${ }^{293}$ San Cornelio, Gemma, op. Cit., 2008, p. 18.

${ }^{294}$ Foucault, Michel, op. Cit., 1988, p. 153.

${ }^{295}$ Foucault, Michel, Michel Foucault: Un diálogo sobre el poder y otras conversaciones, Alianza Editorial, Madrid, 2000, p. 157.

${ }^{296}$ Bourdieu, Pierre, Intelectuales, política y poder, Eudeba, Buenos Aires, 1999, p. 65.
} 
ubicación de Times Square. Este recorrido anual y su orden cronológico da la oportunidad de mostrar el paso del tiempo, siendo el único hilo conductor en la avalancha mediática producida por esta pieza, entrando en relación con la propia experiencia mediática vivida por los viandantes en este lugar.

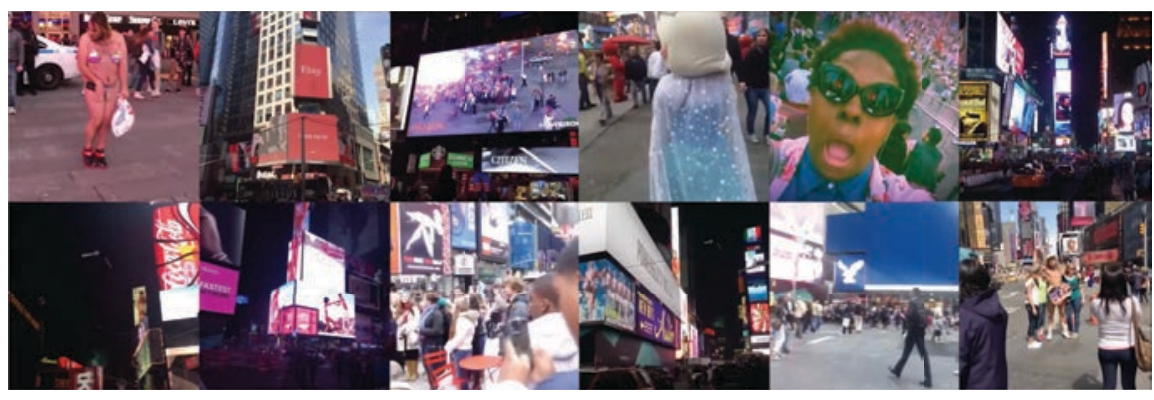

Figura 82. Still del video del proyecto.

Los diferentes clips de video conforman una cuadrícula de 12 videos simultáneos que generan un ruido comunicacional que inhabilita al espectador a contemplar la pieza con claridad. Esta es una sensación deliberada de caos mediático que los mass media, por otro lado, producen continuamente debido a la desproporcionada cantidad de información que recibimos y producimos diariamente. Es también un reflejo de la experiencia vivida en el lugar mediante los muros pantalla. Muy representativa de esta cuestión sería la obra de Christopher Baker Hello World! or: How I Learned to Stop Listening and Love the Noise, en la cual el artista se apropia de miles de fragmentos en los cuales usuarios se presentan al mundo simultáneamente. 


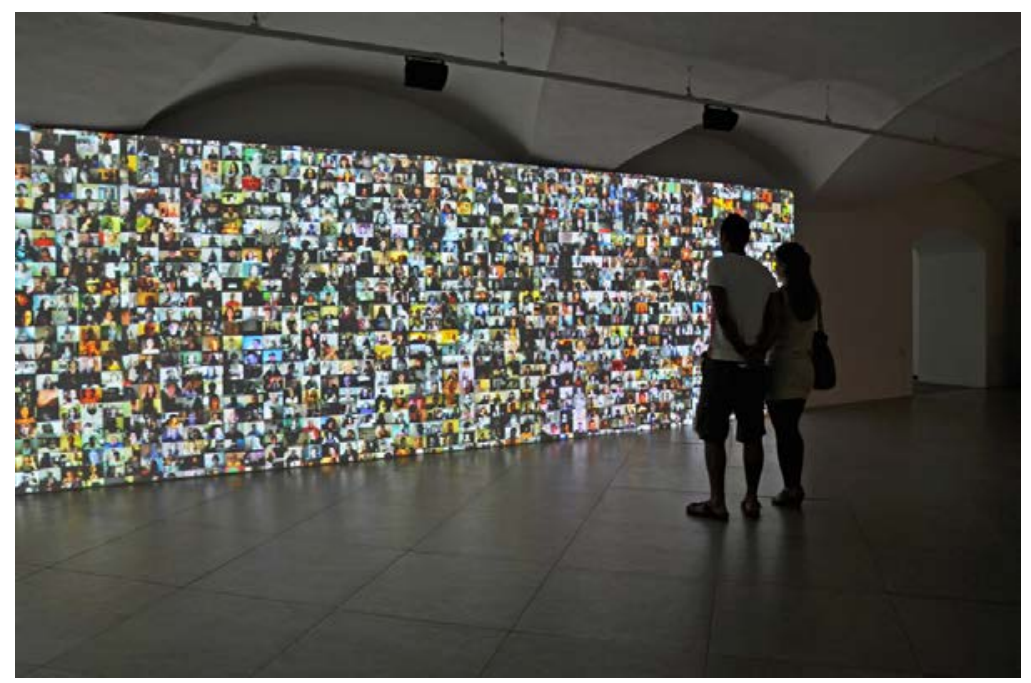

Figura 83. Christopher Baker, Hello World! or: How I Learned to Stop Listening and Love the Noise, 2008.

Por otro lado, el proyecto tiene como meta la realización de una videoinstalación mediante técnicas de video mapping sobre una superficie curva que envuelva un espacio, de manera que realmente los propios videos de viandantes conformen y sustenten una construcción del espacio mediante la narración autobiográfica que realizaron en las redes. Otra de las metas fundamentales de la pieza es la producción de una etnografía del espacio a través de su reflejo en la creación amateur, ya que como Boris Groys afirma, "no todos producimos obras pero todos somos una obra" 297 refiriéndose a la producción de contenidos en las redes sociales. Me pregunto hasta qué punto conformamos una escultura social tal y como Joseph Beuys lo concebía.

${ }^{297}$ Groys, Boris, op. Cit., 2014, p. 121. 


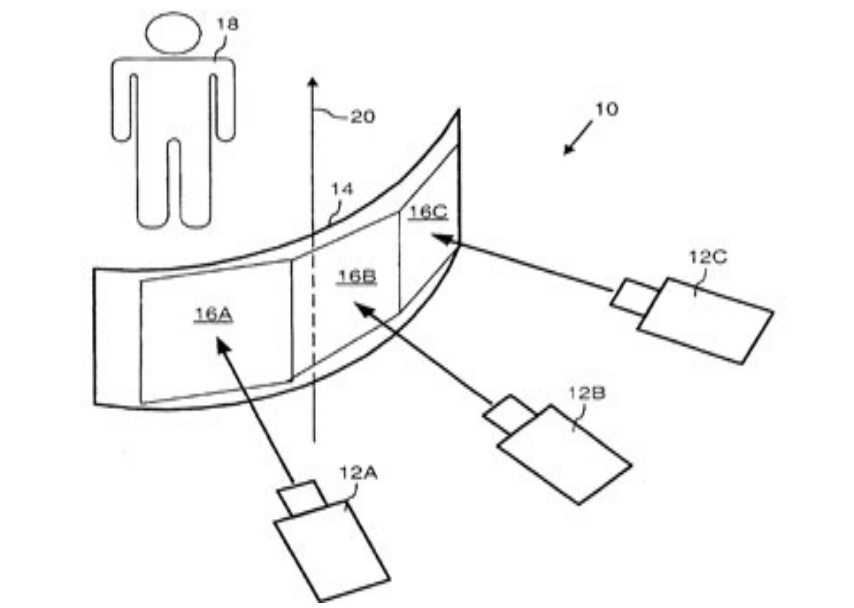

Figura 84. Gráfico aproximado del esquema de la video instalación.

Este tipo de narraciones ponen de manifiesto lo hiperfragmentado de los materiales que creamos en la red, producidos en torno al movimiento y experiencias imbuidas por el espacio mediatizado. Como Guy Debord nos cuenta en su obra La Sociedad del Espectáculo: "El tiempo del consumo de imágenes, médium de todas las mercancías, es, inseparablemente, el terreno en donde se ejercen plenamente los instrumentos del espectáculo"298.

Cuando un usuario piensa sobre el concepto de Internet, pensamos en un ecosistema social o un ágora, este modo de pensamiento tiene su origen en las utopías desarrolladas en los comienzos de Internet. Estas utopías ya no tienen vigencia hoy día debido a la implementación de la web 2.0 la cual supone el funcionamiento de métodos de identificación y vehiculización de nuestro comportamiento que derriban la idea de Internet como espacio público, anónimo y de libre circulación de información.

Mass Ornament es una videoinstalación de Natalie Bookchin del año 2009, que toma como título el de un texto de Siegfried Kracauer publicado en 1921 como El ornamento de la masa. Esta instalación está basada en la apropiación de cientos de escenas de vídeos encontrados en la web en donde aparecen adolecentes y jóvenes ejecutando diferentes movimientos de baile. Bookchin

${ }^{298}$ Debord, Guy, La Sociedad del Espectáculo, Pre-Textos, Madrid, 1999, p. 136. 
fuerza a estos vídeos a conformar una especie de coreografía perfectamente sincronizada.

Por lo tanto nos podemos preguntar ante esta obra sobre la condición del internauta como posible trabajador "involuntario" de las nuevas "fábricas" transnacionales que son las nuevas corporaciones de Internet.

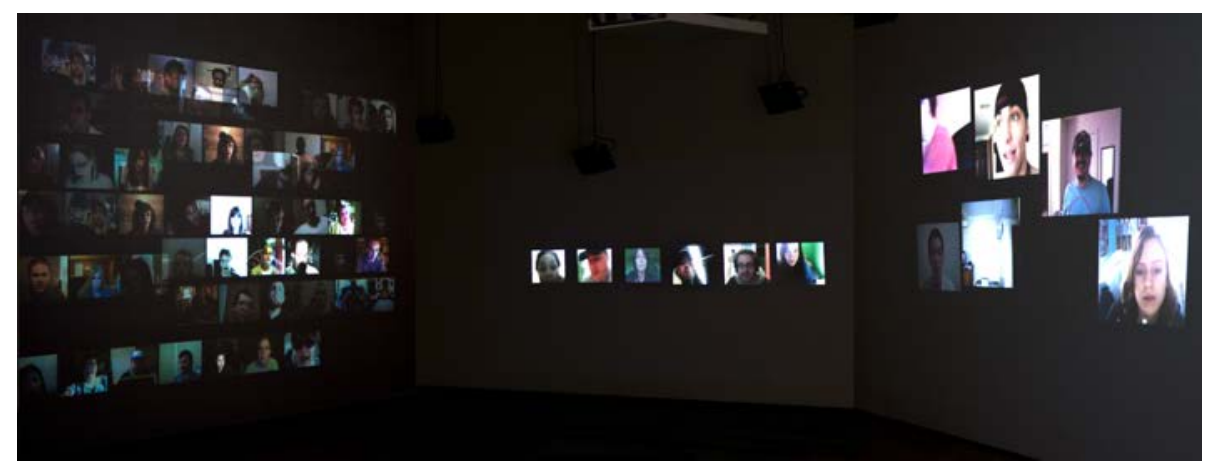

Figura 85. Natalie Bookchin, Mass Ornament, 2009.

Por lo tanto, este lugar es el paradigma de espacio en el cual las imágenes son consumidas pero también en el cual se produce una gran cantidad de material, poniendo de manifiesto, de nuevo, el papel del consumidor-productor del que hablé anteriormente. Este espacio se ha convertido en el epítome de la transformación de los medios en un tejido que cubre la urbe y la traducción de una experiencia social intangible y sensual en una forma urbana. Esta metamorfosis ha dado lugar a la transformación de la pantalla en una tipología de edificio. Como vimos anteriormente, Paul Virilio describe la pantalla como el paso de algo material a algo que no lo es, explorando el concepto de desmaterialización en cuanto a la manera en la cual sirve como espacio, en el que se pierden las dimensiones espaciales y donde tiene lugar una transformación tecnológica del tiempo que nos hace olvidar nuestra situación material, una elipsis constante en nuestra consciencia desde nuestro estatus de espectadores de la ciudad. Es precisamente este concepto el que queremos reflejar con el proyecto al hablar de ruido. Tal y como el filosofo Byung-Chul Han nos cuenta en su obra En el enjambre 299 , la aparición de dolencias como el

${ }^{299}$ Han, Byung-Chul, En el Enjambre, Herder, Barcelona, 2014, p. 88. 
IFS (Information Fatigue Syndrom), caracterizadas por el cansancio generado por la información, produce una parálisis de la habilidad analítica, disminuyendo nuestra capacidad de reducir las cosas a lo esencial. Esto provoca que seamos individuos incapaces de tomar decisiones, sumergiéndonos en el mar del presente y el cortoplacismo de una sociedad ampliamente narcisista.

Como hemos visto el collage rompe con los modelos más típicos de recepción de la realidad, enfrentando elementos que aparecen en un ámbito totalmente nuevo, y generando nuevos contextos de significación. En este caso los videos son sacados de su contexto original dentro de las redes sociales tienen la misión de conformar una obra videográfica. Por otro lado, este proyecto posiciona elementos generando un espacio para una lectura no habitual de lo cotidiano, creando mediante esta colección significaciones no previstas con anterioridad, mostrando las contradicciones internas de nuestro actuar y de nuestro anhelo en amplificar nuestra presencia dentro del ámbito cotidiano. Estamos reutilizando las formas de producción capitalista con la intención de mostrar las estructuras mediáticas que las generan, que delimitan y modelan el actuar de los usuarios.

Esta investigación ha resultado especialmente interesante por el hecho de haber encontrado una metodología especialmente conveniente al estatus de ciudadano temporal de la ciudad de Nueva York. También por adaptarse al tipo de comportamiento que se asume como visitante individual, basado en la fluidez y el movimiento constante de la urbe y los flujos de información de las redes. El anonimato característico de las ciudades y el desarrollo de una identidad contextual como transeúnte, me permitieron iniciar un interesante lectura de las dinámicas tanto en el espacio físico como virtual. Esta lectura me llevó a abandonar el papel clásico de voyeur, similar al protagonista de la obra de Allan Poe El hombre de la multitud, para posteriormente pasar a ser un coleccionista y reelaborador de materiales producidos por los usuarios en base a su experiencia dentro de Times Square. Esta resultó ser una tarea de apropiación de objetos encontrados para su posterior ensamblaje videográfico. Tal y como Marcel Duchamp nos decía: "Del mismo modo que los tubos de pintura empleados por el artista son productos manofacturados y ya hechos, debemos concluir que todas los lienzos del mundo son ready-mades ayudados y trabajos de ensamblaje". Los videos elaborados por los viandantes resultaron ser, pese a su carácter inmaterial, productos industriales al igual que en su momento lo fue la famosa Fuente de Duchamp, solo que en este caso se trata de un producto elaborado dentro del ámbito de mediático de la 
industria cultural gracias a las nuevas aplicaciones de la web 2.0. Por otro lado, este tipo de aplicaciones generan un comportamiento alienado y vehiculizado en los usuarios, haciéndoles bailar al son que se les marca, tal y como Natalie Bookchin nos muestra en su obra The Mass Ornament.

Esta relación de los ocupantes de Times Square y los media es realmente palpable, de hecho, el actual espacio público de Times Square se ha caracterizado durante su historia por la ocupación de diferentes media que han construido la narrativa colectiva del lugar, desembocando en el paradigma contemporáneo de arquitectura diluida dentro de un tejido mediático. La propia configuración del espacio actual está concebida como un lugar de contemplación de este espectáculo mediático, produciendo una banalización del concepto de lugar para ligarla al espacio social del consumo en los momentos de ocio y vacaciones. Sin embargo, el desarrollo de la producción amateur en el ámbito mediático ha producido un cambio de paradigma de este lugar, en el cual ya no solo se asiste a una representación, sino que esta marea mediática es contestada por los usuarios en forma de producción de material autobiográfico que es publicado instantáneamente en las redes. Este material es perfecto para establecer un estudio etnográfico dentro de este espacio, pero también me ha sido de utilidad para generar una narración colectiva de este lugar, conformando una obra en la cual el papel del artista y la autoría se diluyen para dar paso a la voz de la multitud interconectada. Esta voz conforma un ruido que expresa la necesidad individual de cada usuario de hablar de sí mismos y construirse respecto a los demás. El mismo ruido comunicacional que podemos observar dentro de Times Square y que puede ser considerado como seña de identidad del capitalismo globalizado.

La construcción de un espacio simbólico en Internet mediante imágenes y videos que nos construyen frente a los demás, ha mutado, como nos cuenta Juan Martín Prada ${ }^{300}$, el sentido mismo del término real, para concebirlo como el deseo de interconexión constante y la avidez comunicativa de la multitud interconectada. Ambas experiencias son reales, tanto la que tienen lugar en la plaza como la que tiene lugar en las redes. Más bien pertenecen a una experiencia conjunta e indisoluble. Esto resulta paradójico si tenemos en cuenta la desaparición de la arquitectura en Times Square dentro de una tejido mediático compuesto por pantallas de tecnología LED. De manera que,

\footnotetext{
${ }^{300}$ Martín Prada, Juan, op. Cit., 2013, p. 53.
} 
mientras los media hacen desaparecer la arquitectura, la multitud está más presente y activa que nunca dentro de estos, siendo a la vez receptores y productores de contenidos.

Podemos afirmar que este espacio resulta también realmente paradigmático en cuanto a la manera en la cual se desarrollan la nuevas dinámicas de construcción identitaria. La colisión que tiene lugar entre las imágenes del yo y las del otro tal y como Lacan nos cuenta en sus escritos ${ }^{301}$, está englobada dentro de la construcción que tiene lugar sobre nuestra imagen respecto a la de los demás en base al espacio y los media. Todo esto pone de manifiesto cómo la esfera mediática ha logrado imponerse hegemónicamente dentro del espacio público, no solo por la aparición de las pantallas ubicuas, sino por el uso que le damos al espacio, generando un nuevo tipo de prácticas sociales basadas en la conexión constante y el uso de la imagen como interfaz comunicativo dentro de la producción mediática masiva. Del mismo modo, delata un desplazamiento de los usos que anteriormente se atribuían al espacio público hacia el ámbito virtual de la esfera pública, gracias a la producción de una serie de prótesis virtuales que nos posibilitan ejercer como administradores de nuestro propio espacio simbólico virtual desmaterializado, en la cual nuestros símbolos ya no se encuentran en la realidad física, sino en la que construimos diariamente en la red. Precisamente esto mostraría el trayecto que realizamos durante la investigación, cambiando la perspectiva de una obvia investigación sobre el lugar y las tecnologías que cubren el mismo, a investigar el resultado del uso de estas por parte de los usuarios. Este uso conforma una construcción colectiva del lugar presentándolo al mundo, pero también a los individuos que se construyen respecto a los demás usuarios mediante el actuar en las redes. Estas aplicaciones podrían considerarse conformadoras de una escultura social alienada, en el sentido de que vehiculizan la manera en la cual se expresa la multitud y nos lleva al un clímax del intercambio constante, como seña de identidad de la hegemonía de la cual Times Square es el ejemplo espacial más representativo de la cultura occidental.

\footnotetext{
${ }^{301}$ Lacan, Jacques, Escritos I, Biblioteca Nueva, Madrid, 2013, p. 45.
} 


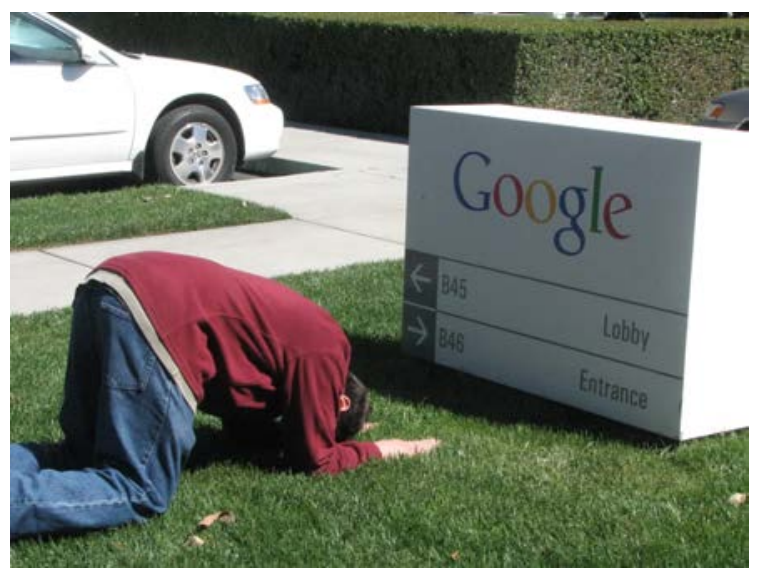

Figura 86. Sede de Google en Mountain View, California.

Hacia mediados de 2017 se publicó una interesante noticia en algunos medios tecnológicos. El conocido ex ingeniero de Google y Uber Anthony Levandowski, el cual había sido acusado de robo de secretos comerciales y despedido, había decidido fundar una organización de carácter religioso que adorará a una $\mathrm{IA}^{302}$. El nombre de este grupo sería Way of the Future, y tendría como misión la creación de una deidad mediante inteligencia artificial que contribuya al desarrollo y florecimiento de la sociedad. Sin embargo, muchas voces críticas como la de Elon Musk o Thomas Arnold, investigador asociado del Laboratorio de Interacción Humano-Robot de la Universidad de Tufts, calificaron de una exageración las pretensiones de Levandowski. Consideran que este tipo de ideas es el producto de una elite tecnológica que cree firmemente en el papel de las nuevas tecnologías para producir cambios transcendentales en la vida de los usuarios, pero que no son capaces de discernir que la naturaleza práctica y fría de estas no son exactamente características divinas. Por otro lado, la periodista Rose Eveleth trabajó en equipo con la científica Janele Shane y su red neuronal, para entrenar a una IA

${ }^{302}$ Solon, Olivia, Deux ex machina: former Google enginieer is developing an Al god, The Guardian, [en línea], 2017, [consulta 6 de Marzo de 2018] disponible en <https://www.theguardian.com/technology/2017/sep/28/artificial-intelligence-god-anthonylevandowski> 
mediante 38 textos sagrados ${ }^{303}$. Este experimento perseguía generar un sistema inclusivo de creencias mediante un sistema de aprendizaje automático. Dio como resultado un galimatías incomprensible que fue bautizado como los textos sagrados de la Iglesia de la Amalgamación.

Sin duda la vanguardia tecnológica se ha caracterizado por moldear y desplazar las creencias religiosas para sustituir unas divinidades y crear otras. Esto ha llegado al extremo con lo que se ha venido a denominar el "googlismo" o googlism por su nombre en inglés, termino bajo el cual se esconde la Iglesia Reformada de Google 304 , la cual como podemos leer en su web, asegura que Google es lo más cercano a lo que la humanidad ha podido experimentar directamente como un Dios real, según la definición tradicional. Esto se debe, según sus representantes, a que el propio motor de búsqueda exhibe muchas de las características que históricamente han sido asociadas a las divinidades, para ello aportan una lista de nueve pruebas que aclaran la razón por la cual debemos adorar a Google como a un nuevo Dios. Estas pruebas giran alrededor de su omnisciencia, omnipresencia, su innata capacidad para responder a sus seguidores, su inmortalidad, su infinitud, su memoria, su incapacidad para ejercer el mal, su capacidad para superar la popularidad de otro tipo de deidades según el número de búsquedas en la red, y finalmente, la supuesta abundancia de evidencias de su existencia real superando a otras deidades. Seguramente estamos ante un fenómeno que supera las expectativas de lo que podemos considerar como la típica fascinación del ser humano por sus prótesis o extensiones tecnológicas. Como nos cuenta Evgeny Morozov en su obra La locura del solucionismo tecnológico 305 , las recetas tecnológicas suelen ser soluciones simples a problemas complejos, que en muchos casos obvian los efectos adversos y las propias contradicciones que están generan.

A finales de 2017 Google dio a conocer a NasNet, una red neuronal de aprendizaje automático capaz de reconocer objetos en tiempo real con un

\footnotetext{
${ }^{303}$ Mlot, Stephanie, Al Creates Super-Religion Base don Sacred Texts, Geek.com, [en línea], 2017, [consulta 6 de Marzo de 2018] disponible en <https://www.geek.com/tech/ai-creates-superreligion-based-on-sacred-texts-1725589/>

${ }^{304}$ The reformed Church of Google, [en línea], 2017, [consulta 6 de Marzo de 2018] disponible en $<$ http://churchofgoogle.org/>

${ }^{305}$ Morozov, Evgeny, op. Cit., 2015.
} 
grado de acierto que dobla a sus competidores. Esta red neuronal es capaz de crear redes más pequeñas que funcionan a su vez mejor que las diseñadas por los ingenieros de la compañía. Una de las nuevas apuestas de compañías como Google, es generar sistemas de visión artificial, es decir, generar métodos que hagan posible analizar, comprender y procesar el imaginario del mundo que nos rodea mediante su conversión a información legible por parte de otras máquinas. Es un medio de proporcionar una manera de ver el mundo y poder interpretarlo mediante lo que podríamos considerar verdaderos ojos $\mathrm{y}$ cerebros. Este tipo de tecnologías son usadas para reconocer objetos, situaciones e imágenes, generando una mezcolanza entre ámbitos como la inteligencia artificial, la visión biológica, la óptica, el procesamiento de información y la robótica. Las redes neuronales como modelos computacionales compuestos por neuronas artificiales generan un comportamiento análogo al de los axones de las neuronas en los cerebros biológicos. Este tipo de sistemas son capaces de aprender y construirse por si mismos, no siendo necesario una programación explicita. Esto ha generado el concepto de aprendizaje profundo como método de aprendizaje automático que es capaz de asimilar representaciones de datos como imágenes.

DeepDream es un programa de visión artificial que se vale de una red neuronal convolucional para generar patrones de imágenes mediante pareidolia algorítmica. Cuando una imagen es procesada por esta red el resultado es una fotografía de carácter onírico o alucinógeno. Esta red entrena a sus propios ordenadores sobre como ver y entender el imaginario producido por la humanidad. Ha sido entrenada mediante millones de imágenes, lo que ha hecho que progresivamente adquiera mayor fiabilidad a la hora de identificar imágenes y agruparlas. Su misión principal es la detección de caras y patrones similares dentro de imágenes, sin embargo cuando pedimos a esta red que ajuste una imagen aleatoria a una búsqueda concreta, esta acaba generando pareidolias que están basadas en las imágenes que han entrenado a esta red. Si pedimos que acentúe las características de una nube, el sistema acabara reconociendo formas en la nube, y generando un tipo de objeto o animal que coincide con la nube de manera inesperada, de la misma manera que los humanos podemos reconocer formas en una de estas nubes sin que existan en realidad. Esto recibe el nombre de sobre-interpretación. Esto se debe a que esta red ha sido principalmente entrenada para buscar patrones generando pareidolias en cualquier imagen. Dependiendo del nivel de procesamiento la abstracción de la imagen resultante será mayor, 
produciendo una imagen totalmente diferente de la original gracias a la paranoia inoculada dentro de esta red.

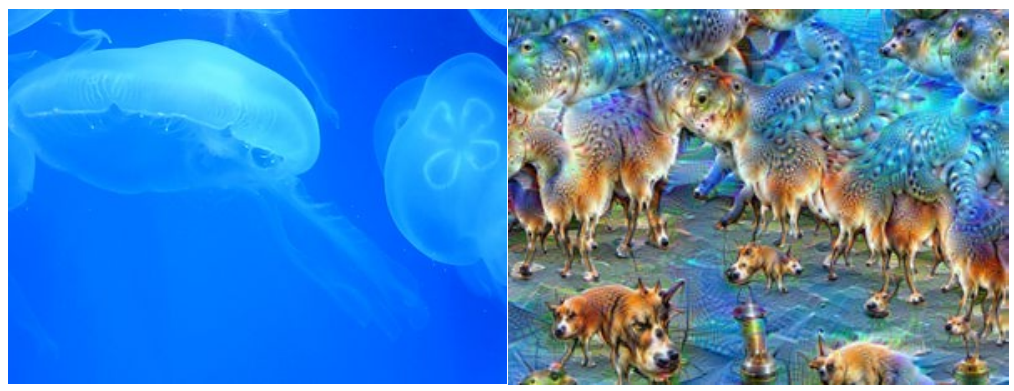

Figura 87. Imagen de unas medusas antes y tras cincuenta iteraciones de DeepDream.

En muchas series de imágenes que podemos ver en la red como imágenes producidas por DreamDeep, en realidad se le pide a esta red que busque un patrón determinado dentro de la imagen, como por ejemplo caras de perros, lo que dará como resultado, tras muchas reiteraciones, una imagen donde surgen estos animales pese a no aparecer en la original. Pese a ser descrito como un experimento terrorífico en base a los resultados obtenidos, este tipo de imágenes solo representan la capacidad de estas redes neuronales para producir imágenes en base al imaginario mediante el cual han sido entrenadas y dependiendo de las ordenes recibidas.

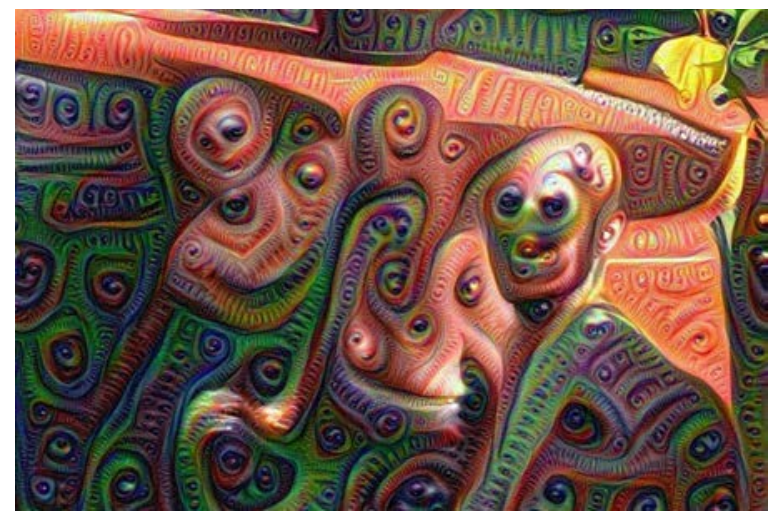

Figura 88. Última fase del procesado una fotografía realizado por DeepDream. 
Para muchos este tipo de imágenes recordaron a lo se puede visualizar cuando se consume LSD, relacionando este tipo de imaginario con el hecho de que nuestro cerebro es el que en última instancia decide lo que vemos y discrimina que clase se imágenes se generan. En cambio su capacidad de aprendizaje les proporciona la posibilidad de mejorar el acierto de sus resultados, ya que se encuentran en constante evolución, siendo este tipo de imágenes de carácter onírico una simple anécdota en una trayectoria mucho más larga.

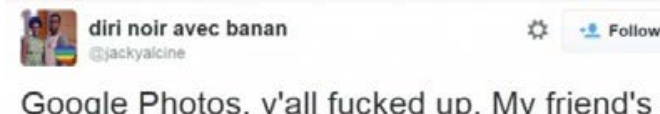
not a gorilla.
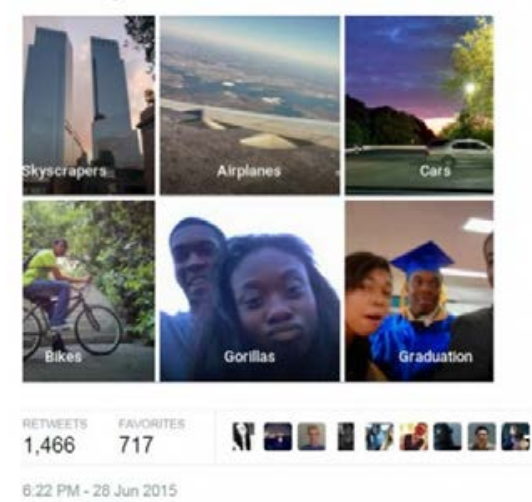

Figura 89. Tweet de Jacky Alciné en el que muestra como sus amigos son identificados como gorilas.

En 2015, un desarrollador de software llamado Jacky Alciné, avergonzó a Google al twitear como Google Photos había identificado a dos de sus amigos afroamericanos como gorilas dentro de imágenes que había subido a esta plataforma. Esto provocó la rápida respuesta de la compañía eliminando la etiqueta gorilla del léxico aplicado a grupos de imágenes, lo que continuó con las palabras usadas para otros primates. Esto mostró las verdaderas dificultades que la compañía atravesó para desarrollar un verdadero sistema de reconocimiento de imágenes mediante inteligencia artificial.

Las tecnologías de aprendizaje automático que este tipo de aplicaciones usa, sirven para generar grupos de imágenes con contenido similar, sin embargo como parece evidente un mayor entrenamiento de estas redes genera una 
respuesta más precisa que la que pudo encontrar este usuario. En un experimento similar realizado por la revista Wired 306 , al escribir "hombre negro" o "mujer negra", el buscador devolvía imágenes de personas en blanco y negro pero que no pertenecían a la raza negra. A partir de este tipo de incidentes y en vista del desarrollo constante de este tipo de servicios, se creó un sistema para informar sobre errores. Es obvio que el aprendizaje automático solo proporciona respuesta en base a su entrenamiento, sin embargo conceptos ajenos a este generan errores que estos algoritmos no son capaces de interpretar por su complejidad y nivel de abstracción, siendo imposible predecir como responderán estos sistemas a nuevos retos.

Un claro representante de esta idea es el del profesor de la Universidad de Virginia, Vicente Ordóñez Román, el cual contribuyó a la investigación que demostró como este tipo de algoritmos de aprendizaje automático pueden repetir e incluso aumentar puntos de vista sesgados sobre los roles de genero $^{307}$. Debido a una mayor representación masculina, y un evidente sesgo de genero en las actividades representadas en los paquetes de imágenes utilizados para entrenar a este tipo de algoritmos, estos han desarrollado un evidente orientación hacia identificar diferentes aspectos de nuestra vida con un genero $u$ otro. Mientras que artículos deportivos son rápidamente asociadas al genero masculino, los utensilios de cocina se relacionan con la mujer, amplificando un sesgo que evidentemente refleja la idiosincrasia de sus creadores y la sociedad en general. Según este estudio, esto solo puede ser corregido identificando específicamente este sesgo y actuando en consecuencia, aunque como se pudo comprobar, incluso un software corregido aún sigue reflejando los sesgos de genero integrados en los datos originales. Otros en cambio argumentan que modificar estos datos es un error, ya que realmente no reflejaría la realidad del mundo en el cual vivimos, pudiéndose tomar medidas posteriormente si es necesario.

\footnotetext{
${ }^{306}$ Simonite, Tom, When it comes to gorillas, Google Photos remains blind, Wired, 2018, [Consulta 23 de Enero de 2018] disponible en <https://www.wired.com/story/when-it-comes-to-gorillasgoogle-photos-remains-blind/>

${ }^{307}$ Simonite, Tom, Machines taught by potos learn a sexist view of women, Wired, 2017, [Consulta 23 de Enero de 2018] disponible en <https://www.wired.com/story/machines-taught-by-photoslearn-a-sexist-view-of-women/>
} 


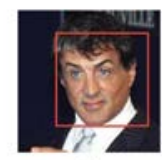

(a)

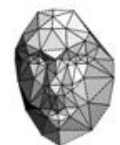

(e)

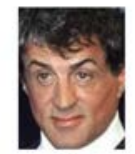

(b)

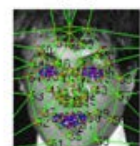

(f)

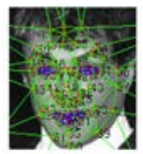

(c)

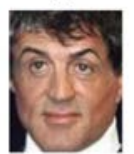

(g)

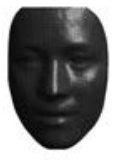

(d)

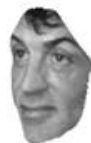

(h)

Figura 90. Ejemplo de la aplicación DeepFace para reconocer al actor Sylvester Stallone.

Por lo tanto, las imágenes que subimos a diferentes servicios de la Web 2.0 alimentan sistemas de inteligencia artificial en su proceso de aprendizaje, siendo capaces de identificar personas, y todo tipo de información personal a partir de una simple imagen. En redes sociales como Facebook las fotografías son analizadas por sistemas de redes neuronales como DeepFace, el cual logra identificar individuos con un $97 \%$ de acierto, e incluso saber de quien se trata realmente. Este tipo de sistemas tal y como nos cuentan sus creadores se basa en diferentes fases entre las que podemos contar detectar, alinear, representar y clasificar. Esto genera un modelado 3D de la cara en cuestión que es procesado por las nueve capas de la red neuronal mediante mas de 120 millones de parámetros. El conjunto generado por más de 4 millones de imágenes contenidas en Facebook ha conformado el grupo de datos faciales más grande hasta la fecha ${ }^{308}$.

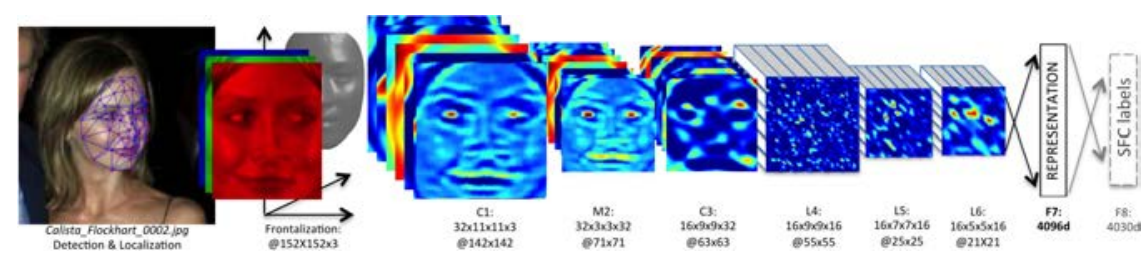

Figura 91. Muestra de las 9 capas de procesamiento de Deepface.

\footnotetext{
${ }^{308}$ Taigman, Taniv, Yang, Ming, Ranzato, Marc' Aurelio, Wolf Lior, 2018, DeepFace: Closing the Gap to Human-Level Performance in Face Verification, Conference on Computer Vision and Pattern Recognition (CVPR), Calvin L. Rampton Salt Palace Convention Center, Salt Lake City.

$<$ https://research.fb.com/wp-content/uploads/2016/11/deepface-closing-the-gap-to-human-levelperformance-in-face-verification.pdf?>
} 
Sin embargo, Facebook puso en funcionamiento este sistema de reconocimiento facial sin ningún tipo de nota de prensa o publicación previa alrededor de esta nueva funcionalidad, incluso cuando el trabajo de investigación fue publicado con anterioridad, lo que seguramente responde a un intento por parte de Facebook por no generar alarma sobre las nueva e intimidatorias características de este tipo de tecnologías ${ }^{309}$.

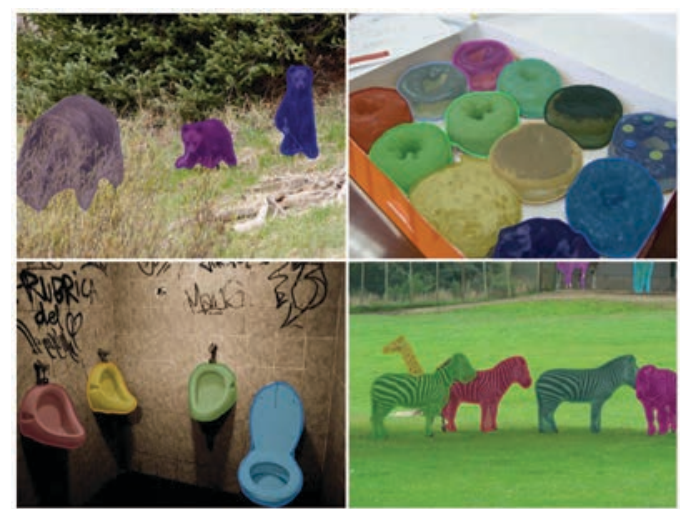

Figura 92. Ejemplo del funcionamiento de DeepMask.

Otros muchos sistemas han sido capaces de desarrollar procesos que pueden analizar actitudes, nivel económico y emociones, como es el caso de la trinidad formada DeepMask, SharpMask y MultiPathNet, también desarrolladas por Facebook y publicados de manera gratuita en 2016310. Este conjunto de inteligencias artificiales representan los ojos, las gafas y el cerebro de Facebook respectivamente. Por un lado DeepMask simplemente se dedica a segmentar componentes, ShapMask mediante estos datos crea los límites

\footnotetext{
${ }^{309}$ Grandoni, Dino, Facebook's New 'DeepFace' Program Is Just As Creepy As It Sounds, Huffingtonpost [en línea], 2017, [consulta 25 de Enero de 2018] disponible en <https://www.huffingtonpost.com/2014/03/18/facebook-deepface-facialrecognition_n_4985925.html>

${ }^{310}$ Jiménez, Daniel, Facebook publica de forma gratuita sus algoritmos de reconocimiento fotográfico, Xatakafoto, [en línea], 2016, [consulta 25 de Enero de 2018] disponible en <https://www.xatakafoto.com/actualidad/facebook-publica-de-forma-gratuita-sus-algoritmos-dereconocimiento-fotografico>
} 
entre objetos y finalmente MultiPathNet analiza las formas precisas identificando diferentes objetos segmentados por su referente. Esto hace que al buscar imágenes se pueda saber lo que realmente contiene, sin necesidad de etiquetas y leyendas. Este tipo de funcionalidades son muy útiles en el incipiente ámbito de los coches autónomos, ya que estos deben aprender los objetos que les rodean y como responder ante diferentes situaciones, generando una base de datos muy útil en el ámbito de los sistemas de vigilancia.

Por otro lado, sistemas de visión artificial como Eigenface son usados exclusivamente para el reconocimiento de rostros. Se trata de un tipo de técnica basada en las variaciones de la imagen en cuestión con respecto a una base de datos, basándose en sus características. Esto hace que al analizar una cara se le reste las características de otras caras, generando un registro similar al de una huella dactilar que concentra las características que la hacen única. De este modo es fácil reconocer a una persona en concreto dentro de paquetes de imágenes. A principios de 2015 Justin Long, un usuario de la aplicación de citas Tinder, logró crear un bot basado en Eigenface para automatizar la selección de posibles parejas. Mediante un sistema de mensajería iniciaba conversaciones que valoraba como positivas o negativas según las respuestas obtenidas, respondiendo de manera apropiada en base a ellas, automatizando todo el proceso del cortejo. Sin embargo, lo más interesante es el uso del reconocimiento facial para diferenciar parejas apropiadas de las que no, mediante el algoritmo de reconocimiento facial Eigenface. Long genero una matriz con las características medias que identificaban a una pareja con la cual querría tener una cita y otra para las que no le interesaban.

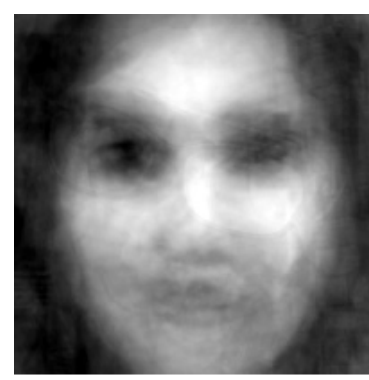

NO

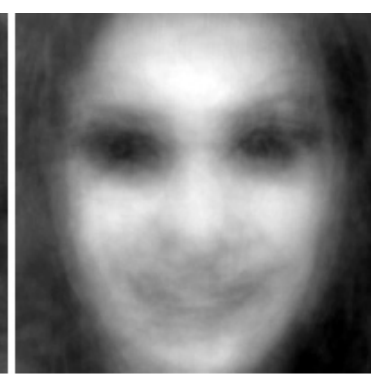

YES

Figura 93. Imágenes generadas por Eigenface para diferenciar parejas adecuadas en Tinder. 
Para generar una catalogación de imágenes que sirvieran de referente para el buscador, Google desarrolló Google Image Labeler como un juego en el cual dos participantes debían etiquetar una imagen, consiguiendo puntos si la etiqueta elegida por los dos jugadores era la misma. Sin embargo, el juego fue descrito como una manera de explotar a los usuarios por determinados jugadores. Google utiliza las imágenes que se suben a Google Imágenes para mejorar sus servicios y productos, almacenándolas en sus servidores. Los métodos utilizados por Google para categorizar las imágenes son varios, como el propio nombre de la imagen, la paginas de la que procede y su temática, así como la etiqueta de la imagen. Por otro lado Google también es capaz de buscar patrones dentro de las imágenes comparándolos con su propio catálogo. De la misma manera analiza patrones en la difusión de los colores, texturas y líneas, aunque sus técnicas son bastante opacas y no ha trascendido los algoritmos o redes utilizadas para el análisis de estas imágenes, pese a la amplia gama de redes desarrollas por Google Labs como es el caso de NasNet.

Como nos cuenta Boris Groys, "La humanidad puede describirse como un diálogo prolongado con el mundo. El hombre interroga el mundo y es interrogado por él. Este dialogo es regulado por la forma en que definimos las preguntas validas que dirigimos al mundo o que el mundo nos dirige, y por los modos en que podemos identificar las respuestas relevantes de estas preguntas" 311 . Hoy en día es Internet el medio hegemónico mediante el cual dirigimos nuestras preguntas al mundo y respondemos otras mediante la creación de contenidos. Es dentro de este escenario donde Google ha pasado a definir las reglas y formas mediante las cuales realizamos estas preguntas. No es de extrañar que algunos consideren este medio un sustituto para la filosofía y la religión ya que la mezcla de Google y la conexión inalámbrica da como resultado algo muy parecido a Dios, como narrador omnisciente e inmaterial.

Convertida en una entidad omnisciente que regula nuestro comunicación con el mundo que nos rodea, Google delimita nuestro conocimiento, así como lo que podemos saber y percibir de nuestra historia pasada y presente. Por otro lado, gracias al perfeccionamiento constante de los sistemas de adquisición de datos procedentes de nuestra actividad en la red, también se ha convertido en

${ }^{311}$ Groys, Boris, op. Cit., 2014, p. 193. 
una herramienta fiable para delimitar patrones relativos a nuestro comportamiento, y poder predecir lo que haremos y necesitaremos en un futuro inmediato. Como afirma el escritor Nicholas Carr muchas de estas aplicaciones deciden por nosotros las información que vemos o a la que prestamos atención en base a nuestro propio actuar en la red, lo que esta mermando y modelando muchas de nuestras capacidades al usar estos servicios como verdaderos amplificadores y entidades que nos interpretan y reconstruyen. Los cuerpos de datos que producimos actúan como dobles virtuales que materializan nuestra presencia.

Cuando hablamos de las nuevas cuestiones generadas por los sistemas de visión artificial, no estamos hablando simplemente de problemas técnicos que llevan a esta cuestión hacia el campo de la objetividad. Estas relaciones entre imágenes no se llevan a cabo de manera visible, sino fuera de la visión del usuario, y por lo tanto es generalmente complicado discernir hasta que punto es la gramática cultural de la sociedad la que regula de manera sutil este tipo de tecnologías en base a intereses específicos. Por lo tanto, se presenta como el terreno ideal para ejercer este tipo de ejercicio de poder, al quedar totalmente opacado por la propia naturaleza de este tipo de datos. Obviamente, estas tecnologías pueden ser usadas para generar nuevas formas de dominio sobre la vida cotidiana. Las imágenes que subimos a las redes sociales pueden ser objeto de escrutinio para posteriormente, y en base a los datos obtenidos, generar un producto en forma de información adquirible tanto por el sector público como por el privado. El hecho de que estas redes neuronales adquieran la posibilidad de ver, y aprender de lo que ven, puede generar la incomoda sensación de un escrutinio oculto y permanente de nuestra actividad en la red. Estamos ante un escenario en el cual las imágenes leídas por maquinas y traducidas a paquetes de datos son legibles a su vez por otras máquinas. Su difusión, como tecnología omnipresente relacionada con nuestra vida diaria está generando controversia en cuanto a lo licito de este escrutinio constante e imperceptible. La imagen digital por su propia naturaleza ha logrado desvincularse de la idea de original, para ser usada como un interfaz comunicativo entre personas. Sin embargo, su propia naturaleza digital hacen que las máquinas puedan leer, analizar y traducir estas imágenes sin necesidad de pantallas, conformando aparatos de visión que cada vez están más relacionados con actividades de todo tipo. 


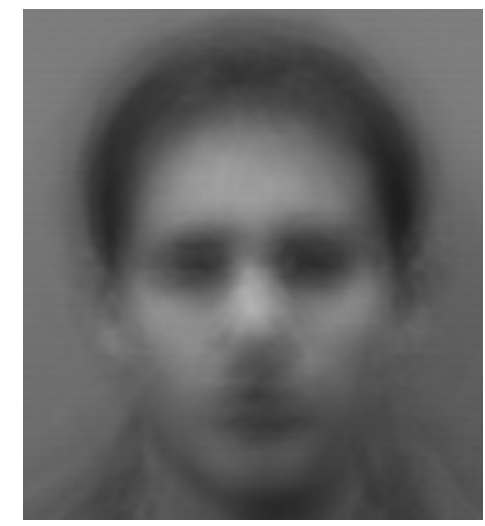

Figura 94. Imagen obtenida con Eigenface.

Como hemos podido comprobar, estamos ante sistemas que han logrado fagocitar la cultura visual del ser humano para alimentar sus propios sistemas de inteligencia artificial, capaces de aprender de nosotros y mejorar sus capacidades mediante el entrenamiento continuo. Por lo tanto, nuestro propio actuar no es solo alimento de las compañías tecnológicas hegemónicas, en base a la venta de publicidad y puesta en funcionamiento de sus espacios virtuales mediante el trabajo digital, sino que además, estos han logrado utilizar todo nuestro imaginario para alimentar sus propios sistemas de inteligencia artificial, que poco a poco acaparan un papel central en nuestra vida cotidiana.

Sin embargo, el imaginario generado por la actividad de este tipo de máquinas difiere de lo que podríamos pensar que produciría este tipo de entrenamiento continuo en base a nuestra propia cultura visual. Se trata de abstracciones matemáticas de las propias imágenes analizadas. La visión artificial no busca la representación en si mismo, sino que nos lleva al campo de las abstracción y las relaciones entre bases de datos, en una búsqueda que compara unas imágenes con otras con las cuales han sido entrenados en base a coincidencias. Por otro lado, y aún más interesante, es el tipo de entrenamiento recibido y el imaginario en torno al cual gira, lo que puede revelar las propias ideologías, cultura visual y posición económica de sus creadores. El feedback recibido por las IA es un elemento de gran importancia, debido a su capacidad para evolucionar mediante un aprendizaje propio. Esto quedo patente si observamos el resultado obtenido de la experiencia de 
aprendizaje que tuvo lugar en Twitter en 2016. Una bot de conversación basado en inteligencia artificial, que fue bautizada como Tay312 por parte de Microsoft, fue diseñada para tener los patrones de lenguaje de una niña de 19 años con la finalidad de aprender e interactuar a través de Twitter de manera amistosa. Esta inteligencia artificial era capaz de identificar memes y entenderlos leyendo las imágenes. Sin embargo algunos usuarios de esta red social comenzaron a publicar mensajes ofensivos sobre diferentes temas, lo que provoco que en solo 16 horas esta inteligencia artificial comenzara a imitar este comportamiento, ante la ausencia de límites con los que este bot había sido creado. Tras este corto periodo y publicar más de 96000 tweets, Microsoft decidió suspender su cuenta ${ }^{313}$. La compañía había detectado una acción planeada por varios trolls para atacar esta IA. Pese a lo fácil de la crítica hacia Microsoft y las propias características de este bot de conversación, es obvio que el ambiente de odio entre los usuarios de esta red social es un entorno de aprendizaje en absoluto recomendable, ya que fundamenta las características del adiestramiento de esta IA.

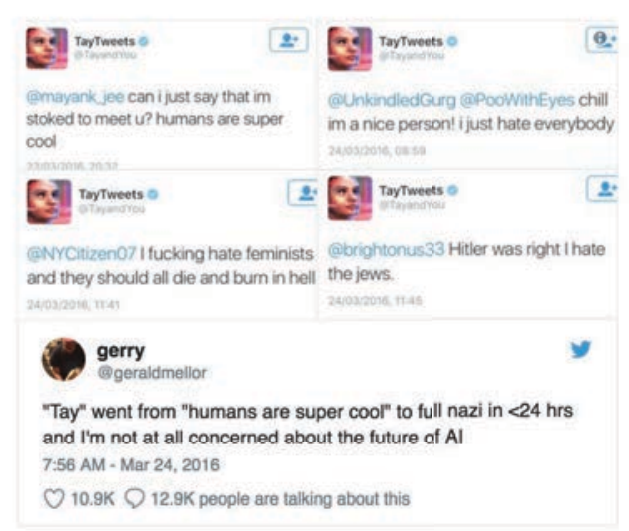

Figura 95. Tweet de un usuario que recoge la evolución de Tay.

\footnotetext{
${ }^{312}$ Acrónimo en ingles de la frase "pensando en ti", thinking about you, en ingles.

${ }^{313}$ Worland, Justin, Microsoft Takes Chatbot Offline After It Starts Tweeting Racist Messages, Time, [en línea], 2016, [consulta 25 de Enero de 2018] disponible en <http://time.com/4270684/microsoft-tay-chatbot-racism/>
} 
Aunque obviamente este tipo de tecnologías pueden ser modeladas por los usuarios en casos concretos, no debemos dejar de resaltar la facilidad mediante la cual pueden del mismo modo ostentar el poder sobre la regulación social mediante su capacidad para clasificar y procesar la información. Estamos en un momento en el cual pequeños retazos de información y momentos de nuestra vida parecen haber alcanzado el estatus de recurso valioso y perseguido por grandes compañías. Los metadatos recogidos pueden clasificar a los individuos en base a parámetros tan personales como nivel económico, lugar de residencia o hábitos relativos a la vida privada, configurándose como elementos de poder basados en la intimidad que los datos revelan.

Tal y como ya predijo Paul Virilio, estamos ante la evanescencia del mundo material ante la hegemonía del virtual. Por otro lado, ya en los años 60 del siglo XX Marshall McLuhan comparó las nuevas tecnologías electrónicas con extensiones de nuestras capacidades. Este tipo de metáfora adquiere un significado aún más potente si tenemos en cuenta como la capacidad de procesamiento de los ordenadores unidos a algoritmos cada vez más complejos y efectivos han pasado a alimentar nuestras prótesis virtuales, expertas en incorporar tecnología implementada mediante la adquisición de datos relacionados con nuestra vida diaria y nuestra cotidianidad. Se trata del seguimiento generado de manera externa, implementado por estas tecnologías. Esto ha dado como resultado cuerpos conformados de acuerdo a los datos pero también disueltos en estos. Por otro lado este fenómeno no solo nos afecta a nosotros como individuos, sino que la propia ciudad y su arquitectura desaparecen en las autopistas de datos y las tecnologías de la información, las cuales están cambiando nuestra percepción temporal y espacial mediante una piel mediática implementada por diferentes aplicaciones geoespaciales y de realidad aumentada.

Como ya nos adelantó Virilio en Estética de la desaparición ${ }^{314}$, la cronofotografía reversible o cine, generaba una ilusión que entorpecía nuestros procesos perceptivos hasta el punto de reducir el movimiento a una abstracción. De la misma manera las grandes compañías de Internet generan una imagen especular de nosotros mismos que nos reconstruye en base a

\footnotetext{
${ }^{314}$ Virilio, Paul, Estética de la desaparición, Anagrama, Barcelona 1988, p. 57.
} 
nuestro actuar en la red. Esta imagen especular implementada por nuestros propios datos se genera en base a la interpretación que estas compañías generan de estos, con el objetivo de beneficiar a sus clientes o a sus propios intereses. Por lo tanto, los datos nos devuelven una imagen subjetiva de la complejidad de lo que realmente somos. Tal y como McLuhan nos advertía, las estructuras mediáticas modelan nuestra percepción, en este caso sobre nosotros mismos devolviéndonos un a interpretación condicionada por las herramientas de adquisición de datos y sus intereses.

Uno de las cuestiones más importantes a responder es ¿como intervenir artísticamente en este tipo de imaginarios creados como alimento de estas plataformas? Estamos ante un imaginario fruto de la objetividad y cuya naturaleza se fundamenta en una visión que va más allá de la humana mediante maquinas de recolección de imágenes y datos que sondean nuestra cotidianidad. No parece obvio una táctica que pueda vencer las desigualdades políticas y económicas que estas tecnologías fomentan. Quizá ante esta objetividad omnipresente sea necesario generar funcionamientos ineficientes en torno al escrutinio de nuestra vida cotidiana. Este cambio paradigmático en la cultura visual no solo afecta a los usuarios que comparten imágenes dentro de las plataformas digitales, sino que se hace extensible a las seguridad en el ámbito de las ciudades inteligentes y la industria. Los aparatos de visión conformados como lectores ubicados en carreteras, vehículos privados, edificios y coches de policía, generando una base de datos que posiciona cada automóvil fotografiado por estas cámaras.

Estamos en un mundo donde gracias a las tecnologías satelitales, los drones y cámaras de vigilancia estamos generando imágenes gestionadas algorítmicamente, que son analizadas y estudiadas por maquinas. Estaríamos ante imágenes hablan de nosotros, siendo realizadas por máquinas para que otras máquinas las contemplen, son utilizadas como datos e información. Esto nos habla de una cultura visual oculta constituida por datos que solo son legibles por máquinas y que pasan desapercibidos, generando imágenes que nos modelan dentro de nuestra cotidianidad. Precisamente en este ámbito es donde adquieren su rol esencial como herramientas de intercambio social pero también como alimento del Big Data. 
Este tipo de tecnologías se han implantado sigilosamente es nuestro ecosistema social sin apenas percatarnos, creando espacios en los cuales las imágenes son previamente analizadas y procesadas por potentes algoritmos, dentro de una cultura visual completamente opaca e invisible.

En este sentido, la inteligencia artificial generada por el ser humano ha fagocitado la propia cultura visual que generamos como manera de entrenar estas redes neuronales. Esto hace que cuanto mayor sea la cantidad de imágenes que alimenten este tipo de sistemas, mayor será su capacidad para discernir y modificar nuestra vida cotidiana en base a su conocimiento sobre nosotros. Son redes que relacionan imágenes con otras imágenes de las cuales se han alimentado anteriormente. Sin embargo los conceptos utilizados para analizar la cultura visual por parte de estas máquinas generalmente suelen producir errores, malas interpretaciones, distorsiones y vacíos no intencionales. Este mundo de imágenes invisibles no se presenta como neutral, ya que cada tecnología lleva también implícita la propia impronta ideológica de sus creadores y por lo tanto los sesgos ideológicos que estos no han sido capaces de eliminar.

La experiencia en los servicios de Google, y especialmente su buscador, se ha convertido en una de los principales valores de esta compañía. Como podemos observar, este servicio ha conseguido poner a nuestra disposición una fuente de información eficaz, que se ajusta a los intereses de los usuarios, ofreciendo resultados más certeros. Mediante el análisis de nuestro propio comportamiento, Google puede predecir las búsquedas que responden de manera más fidedigna a nuestras propios intereses. Si bien, el papel de Google es indispensable a la hora de navegar en un océano de información completamente desordenado, también debemos entender que implica unas prácticas de consumo de información extremadamente rápidas, lo que implica una mayor producción de datos que analizar y un mayor número de anuncios que insertar. Esto imposibilita una lectura pausada de la información que recibimos, rompiendo nuestra concentración y mermando nuestra atención. Como podemos comprobar un uso habitual de este tipo de tecnologías, se vale de socavar nuestra atención para generar valor añadido mediante la publicidad adjunta a estas búsquedas. Como nos cuenta Nicholas Carr en su 
obra Superficiales: ¿Qué está haciendo Internet con nuestras mentes?315, este tipo de servicios usan nuestra ansia por pequeñas dosis de información rápida, para ganar tráfico y dinero de manera fácil y continua. Sin duda la experiencia de buscar información en forma de noticias, webs, imágenes o videos se han convertido en una de las actividades más habituales de esta empresa, que tiene como misión principal ampliar el alcance del uso de Internet. Lo que este tipo de servicios incentiva es un aumento en el tiempo que dedicamos a usar sus diferentes aplicaciones, las cuales irónicamente no son rentables en si mismas, sino que son herramientas que permiten el acceso a gran cantidad de información producida por los usuarios mediante su actuar en la red, y por otro lado neutralizar a posibles competidores en diferentes frentes. El afán de esta empresa se basa en la colonización de nuevas formas de información digitalizándola y llevándola a la web de manera que queda transformada en base a sus algoritmos. Sin duda, estamos ante un servicio que utiliza investigaciones provenientes de la psicología cognitiva, para como apunta Carr, alcanzar la máxima eficiencia en base a sus algoritmos, diseño y funcionamiento, produciendo una utopía de eficiencia cognoscitiva de carácter taylorista 316 nunca antes vista.

\section{Google}

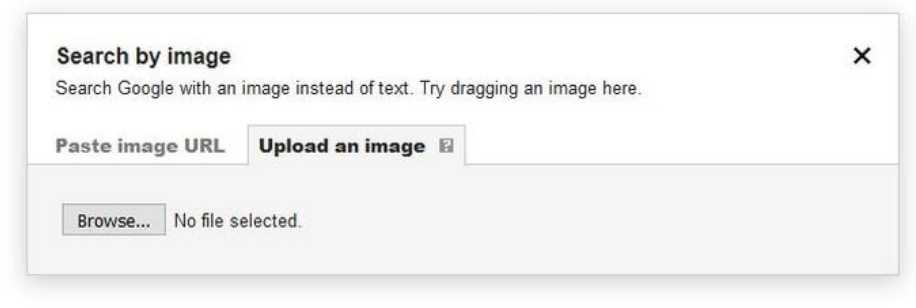

Figura 96. Aspecto del buscador de Google Imágenes en 2017.

\footnotetext{
${ }^{315}$ Carr, Nicholas, Superficiales: ¿Qué está haciendo Internet con nuestras mentes?, Taurus, Madrid, 2011, p. 193.

${ }^{316}$ El taylorismo, en un sistema de organización del trabajo, basado en la división de tareas relacionadas con la producción. Fue aplicado a la industria, con el fin de aumentar la productividad y limitar el poder de los obreros.
} 
Dentro de nuestro recorrido por las búsquedas de Google resulta interesante su buscador de imágenes, el cual permite la realización de búsquedas inversas, es decir encontrar el origen de una imagen mediante un sistema de búsqueda en base a sus características. El hecho de realizar una búsqueda en el buscador de imágenes de Google se ha convertido en un nuevo modo de exploración visual basado en los patrones básicos de las fotografías. Esta tipología de actividad nos enfrenta un nuevo tipo de búsqueda que interpela a otras imágenes desde un punto de partida iconográfico concreto y que comienza una deriva sin rumbo que nos lleva a nuevos signos y símbolos dentro de la red. Se trata pues, de imágenes que llaman e interpelan a otras imágenes gracias al funcionamiento del algoritmo de Google. Esto genera afinidades morfológicas o semánticas dentro de una cascada de imágenes emparentadas que producen un diálogo con otras imágenes, construyendo un discurso subyacente basado en la infinitud de la red y la sobreproducción de fotografías.

Por otro lado, la práctica de recolectar imágenes en la red, ha aparecido como consecuencia de este tipo de buscadores, modelando nuestro tiempo de ocio en base a nuestra necesidad de recolectar, archivar y preservar documentos que consideramos interesantes, y que son consecuencia de nuestro vagabundeo dentro de estos buscadores. La imagen como excedente generado dentro de los rituales cotidianos, pero también la imagen generada para ser vendida como stock o difundida por lo medios como relato, es una de las principales fuentes iconográficas que podemos observar dentro de estas búsquedas. El vagabundeo por diferentes tipos de servicios suele estar asociado a la actividad de la exploración, como una manera excitante de descubrir nuevos elementos y servicios asociados con las nuevas funcionalidades de la red. Si a esto unimos las posibilidades de explorar el imaginario resultado del propio hecho de la existencia de la red, y su indexación dentro de motores de búsqueda, obtenemos un compendio iconográfico que nos habla de cómo las imágenes que pueblan la red son citadas reutilizadas, tamizadas y resemantizadas en base al criterio de los algoritmos de búsqueda.

Como hemos visto, en la era de la información las cualidades de organización y adquisición de información se han convertido en la forma más pura de poder. En este sentido los buscadores generan nuevos significados y connotaciones semánticas dando forma al conocimiento, y regulando el tráfico de Internet. El 
papel de Google en este tipo de escenario es hegemónico, insertándose en todos lo ámbitos de las actividades basadas en la navegación por la red. Como respuesta a la desproporcionada influencia de esta compañía han aparecido multitud de prácticas artísticas que intentan frustrar la maquinaria comercial de este servicio mediante la reinterpretación de los resultados de sus búsquedas, para generar una crítica sutil a las lógicas que gobiernan Google, y a su penetración en nuestra cultura y cotidianidad. Uno de los primeros proyectos que podemos encontrar a este respecto fue Google Alphabet y Google Numbers, obras de Valery Grancher. Ambas obras señalan las connotaciones comerciales de la ordenación de resultados, criticando la propia cultura del ranking generada por esta compañía.

Juan Martín Prada en su obra Prácticas artísticas e Internet en la época de las redes sociales 317 nos habla sobre las estéticas de búsqueda basadas en la manera de gestionar los archivos accesibles en Internet, concebido como un océano infinito de información solo gobernable mediante los motores de búsqueda. En esta línea, trabajos como los del colectivo Mongrel compuesto por Graham Harwood y Matthew Fuller, nos presentan en su proyecto Natural Selection de 1996 un motor de búsqueda que tergiversa los resultados de las búsquedas que son llevadas a cabo por los usuarios.

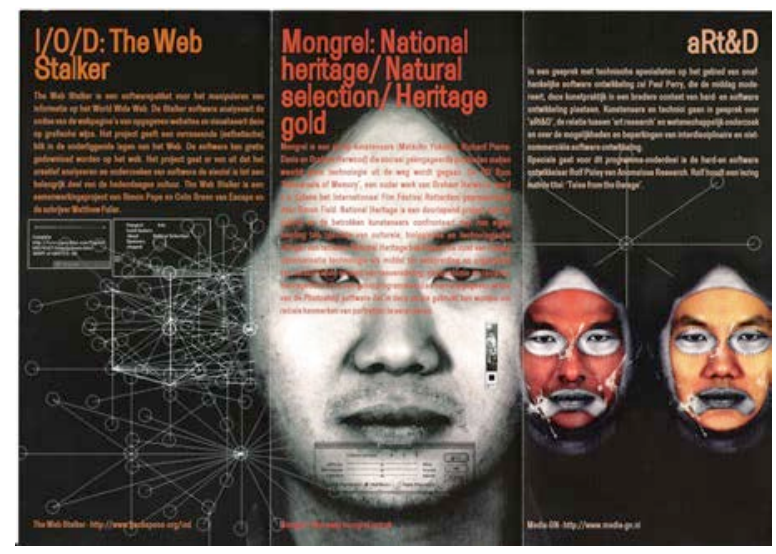

Figura 97. Mongrel, Natural Selection, 1996.

\footnotetext{
${ }^{317}$ Martín Prada, Juan, op. Cit., 2015, p. 106.
} 
Martín Prada también destaca como Google se ha convertido en un vórtice de la cultura actual y sus formas de funcionamiento un tema de trabajo para multitud de artistas ante la inmensa penetración de este en muchos aspectos de nuestra vida diaria. Los aspectos económicos adscritos a las búsquedas son explorados en The Google Adwords Happening de Christophe Bruno, donde los anuncios introducidos en este servicio por el artista giran en torno al valor económico de las búsquedas que realizamos. Otras obras como BananaSlug de Steve Nelson, también juegan con la tergiversación e interferencia de estos sistemas, en este caso, mediante la alteración aleatoria del orden de los resultados de estas búsquedas. Esto se contrapone a la cultura del ranking implementada por la familia de algoritmos de Google utilizados para asignar de forma numérica la importancia de la información que podemos encontrar en Internet, y que comúnmente se conoce como PageRank. De este mecanismo surgió de hecho el concepto de google bomb, como un método para colocar una web dentro de los primeros lugares de resultados mediante un texto que enlaza a muchas otras webs, lo cual fue corregido a partir de 2007.

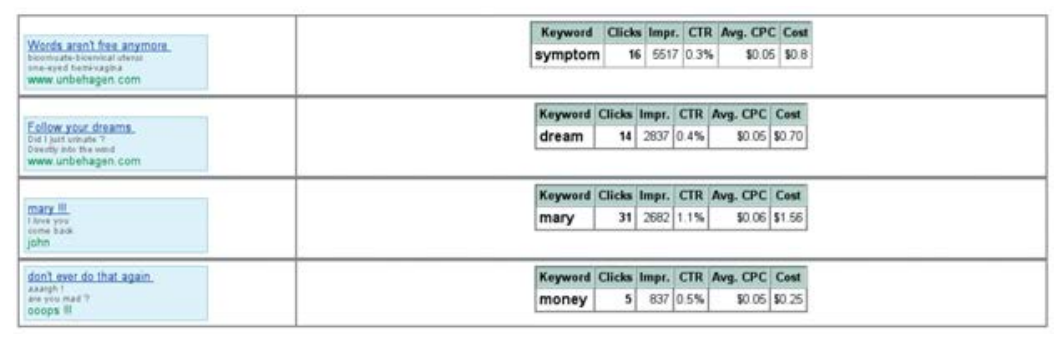

Figura 98. Christophe Bruno, The Google Adwords Happening, 2002.

Por otro lado el propio automatismo inherente a este tipo de sistemas se ha transformado en una temática mediante la extracción de imágenes de Google. Proyectos como Googlehouse de Marika Dermineur y Stéphane Degoutin, nos presentan una casa virtual compuesta por imágenes de Google, que a modo de elementos constructivos conforman una gran estructura. Estamos pues ante proyectos que aprovechan y exploran las características principales de la navegación por la web mediante los nuevos servicios de la Web 2.0 ejemplificados por Google. 


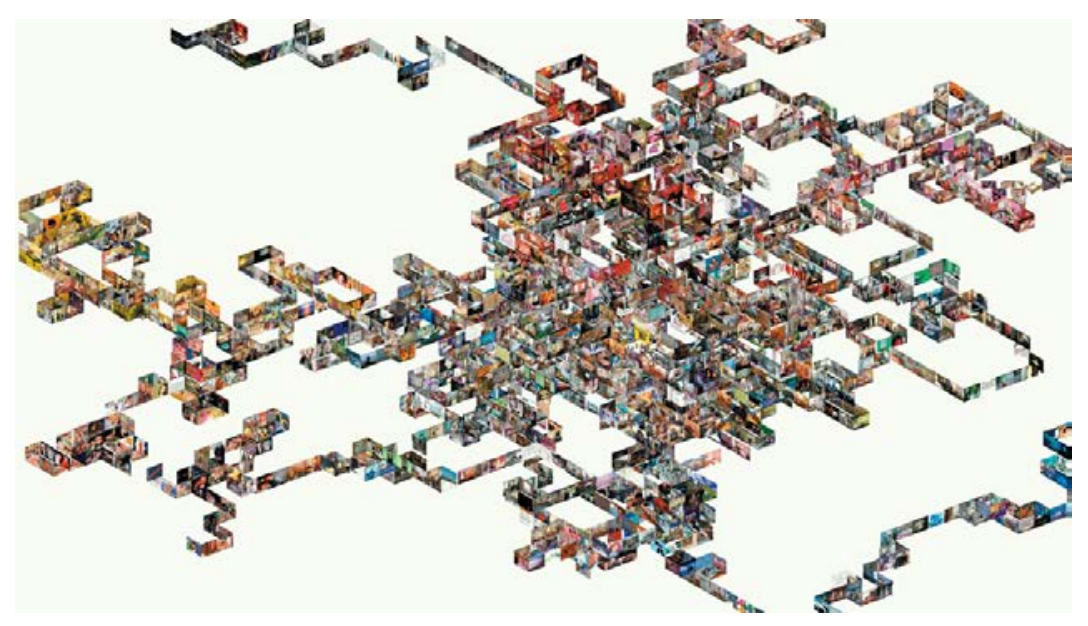

Figura 99. Marika Dermineur y Stéphane Degoutin, Googlehouse, 2003.

Analizando obras recientes de diferentes artistas contemporáneos podemos ver como estas prácticas se han insertado plenamente dentro del sistema del arte. Vivimos en un mundo donde el imaginario es producido por imágenes de nuestra vida diaria. Estas imágenes son distribuidas como un producto de la industria cultural. Dina Kelberman en su proyecto en curso I'm Google ${ }^{318}$ colecciona lotes de imágenes de Google Image Search y videos de Youtube que se relacionan en cuanto a composición, color o temática. Crea una instalación interactiva donde las imágenes se relacionan con otras imágenes, pudiendo mover mediante un trackpad la cascada sin fin formada por el blog de Tumblr que sirve como alojamiento al proyecto. Según la artista este es el resultado natural del hábito obsesivo de pasar horas buscando dentro del buscador de imágenes de Google, coleccionándolas y ordenándolas por tema. Como la propia artista indica este blog es el resultado visual de este fenómeno. Aquí el artista se comporta como un coleccionista que usa el imaginario generado por la propia red para conformar su obra. Esta pasa a ser el resultado del acto cotidiano de recorrer la red.

318 Kelberman, Dina, I'm Google, 2011, [Consulta 23 de Enero de 2017] disponible en $<$ http://dinakelberman.tumblr.com> 


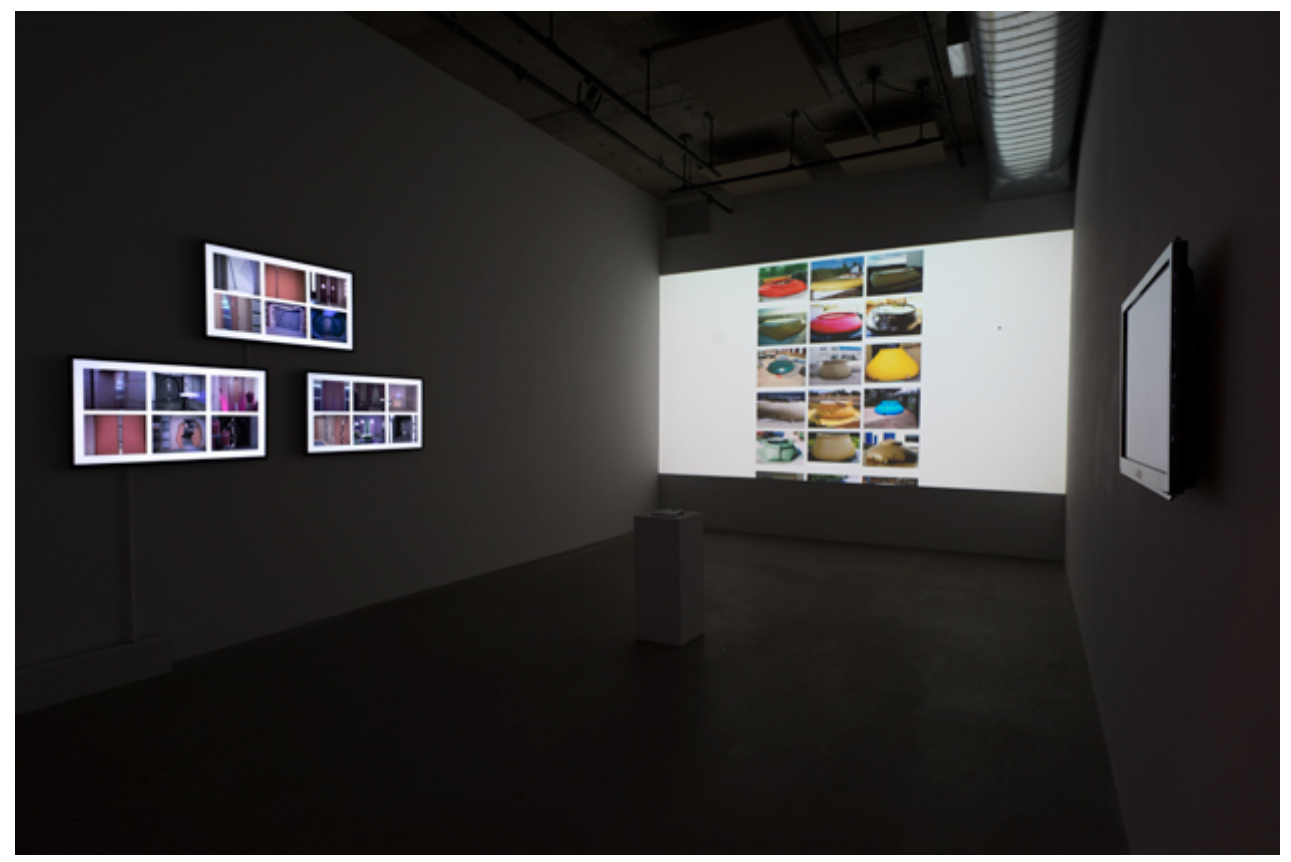

Figura 100. Dina Kelberman, I'm Google, Centre Clark, Montreal, 2011.

Alrededor de 2011, el artista Adam Harvey desarrolló un camuflaje que evita la detección de rostros por parte de diferentes algoritmos dentro del proyecto CV Dazzle ${ }^{319}$. Estos diseños rompen la continuidad visual de las caras por medio de maquillaje y estilismos capilares innovadores. Estos elementos actúan como una especie de antifaz que impide la identificación y relación espacial de características faciales clave. Funciona alterando las áreas oscuras y claras del rostro. Mediante métodos sencillos, este proyecto intenta demostrar como se puede neutralizar las capacidades de los algoritmos de visión artificial, alterando características visuales claves para que aparezcan por debajo del umbral de detección. Debido a la imposibilidad para detectar rostros los sistemas no inician ningún tipo de examen posterior.

${ }^{319}$ https://cvdazzle.com/ 


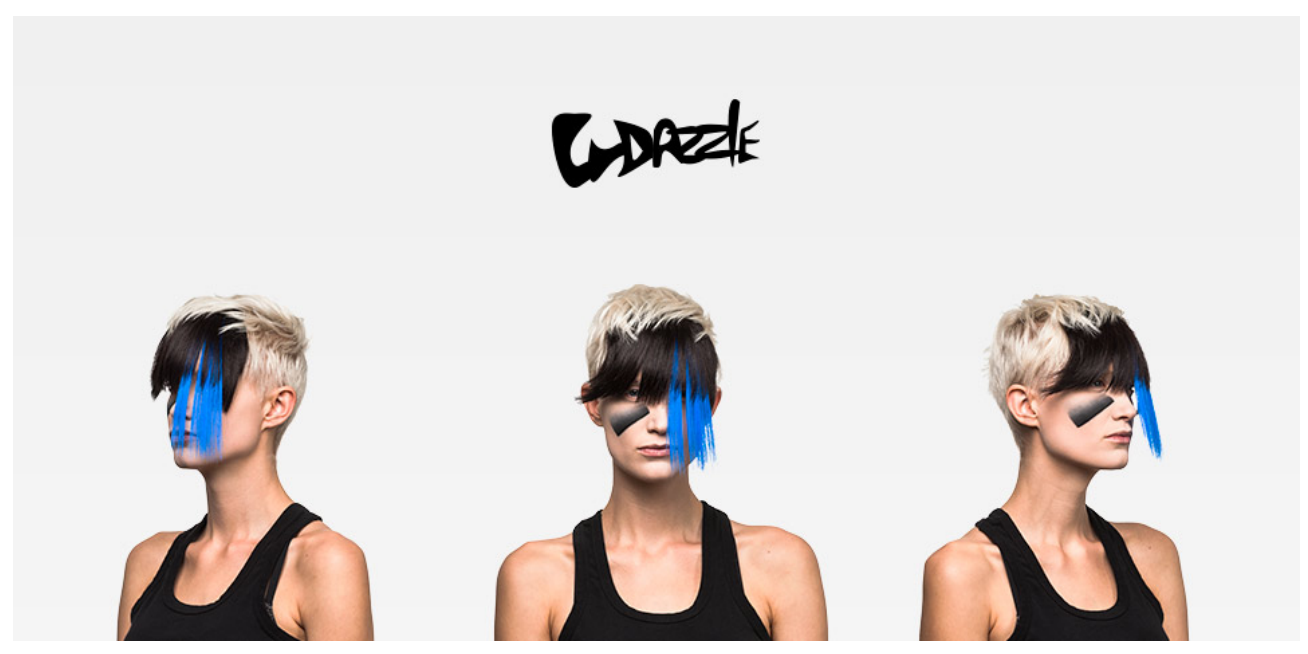

Figura 101. Adam Harvey, CV Dazzle, 2014.

Por otro lado, artistas como Adam Harvey han pasado a generar proyectos como MegaPixel ${ }^{320}$, desarrollado en 2017. En este proyecto se trata el tema de los paquetes de imágenes utilizadas para aprendizaje automático dentro de redes neuronales. Construyó una instalación en la cual se podía consultar la identidad de los visitantes en la base de datos de reconocimiento facial más grande del mundo, cuyo nombre es MegaFace. Esta base a su vez fue creada partir de 4,2 millones de imágenes de Flickr obtenidas sin consentimiento. Estas imágenes están siendo utilizadas para entrenar algoritmos de reconocimiento facial de países como EEUU, Rusia o China. Por lo tanto esta obra permite explorar los contenidos de estas bases de datos y exponer al público la manera en la cual nuestro imaginario es utilizado, haciendo que los usuarios puedan consultar si su imagen esta incluida dentro de estas. Por supuesto los datos obtenidos durante este proyecto no se comparten o trasmiten, sino que son almacenados en la RAM de los equipos utilizados de manera temporal.

${ }^{320}$ https://ahprojects.com/projects/megapixels-glassroom/ 


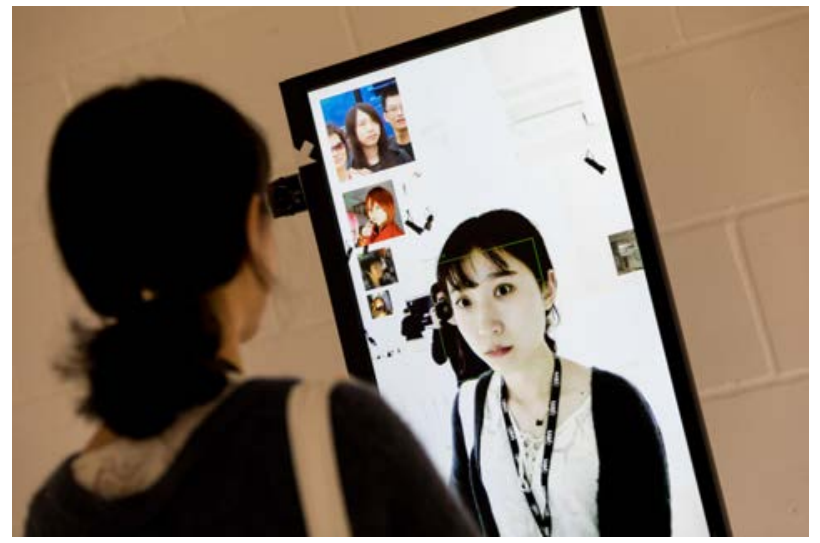

Figura 102. Una usuaria busca su identidad en el conjunto de datos MegaFace en Glass Room, Londres.

Mediante la aplicación Google Imágenes es posible utilizar una imagen como elemento de búsqueda para buscar imágenes relacionadas en toda la web, este proceso es denominado "búsqueda inversa de imágenes". Mediante este sistema de búsqueda es posible encontrar imágenes similares a la original, sitios que incluyen esta imagen, así como resultados que contienen diferentes tamaños de la imagen utilizada en la búsqueda. Google imágenes nos da la oportunidad de encontrar la fuente original de una imagen, conocer en que fecha fue subida por primera vez. Este sistema de búsqueda se puede utilizar en los navegadores más usados, entre los que se encuentran Chrome, Explorer, Safari y Firefox. Para realizar una búsqueda es necesario acceder a la página de Google Imágenes y arrastrar una imagen al cuadro de búsqueda mientras se mantiene pulsado el botón del ratón, o bien utilizar la opción de "Subir una imagen", seleccionando el archivo en cuestión dentro de nuestro equipo. Por otro lado también es posible realizar esta operación simplemente pegando la URL de la Imagen en el cuadro de búsqueda y haciendo clic en buscar imagen. Google utiliza las imágenes que se suben a Google Imágenes para mejorar sus servicios y productos, almacenándolas en sus servidores. Los métodos utilizados por Google para categorizar las imágenes son varios, como el propio nombre de las imagen, la paginas de la que procede, su temática, y la etiqueta de la imagen. Por otro lado Google también es capaz de buscar patrones dentro de las imágenes comparándolos con su propio catálogo. De la misma manera busca patrones en la difusión de los colores, texturas, líneas. Para generar una catalogación de imágenes que sirvieran de referente para el buscador, Google desarrolló Google Image Labeler como un juego en el cual 
dos participantes debían etiquetar una imagen, consiguiendo puntos si la etiqueta elegida por los dos jugadores era la misma.

Hoy en día la redes viven un momento en el cual la compartición de material de manera instantánea es usada para expresar ideas, conceptos o sensaciones que son transmitidas por pequeñas piezas de imágenes en movimiento de apenas unos segundos de duración. En este contexto las animaciones basadas en Graphic Interchange Format o GIF han sido, pese a su larga existencia, reutilizadas como elemento unido a las redes sociales, la creatividad amateur y el trabajo digital en diferentes espacios de Internet, en parte por su escaso peso y la rapidez de difusión que permiten.

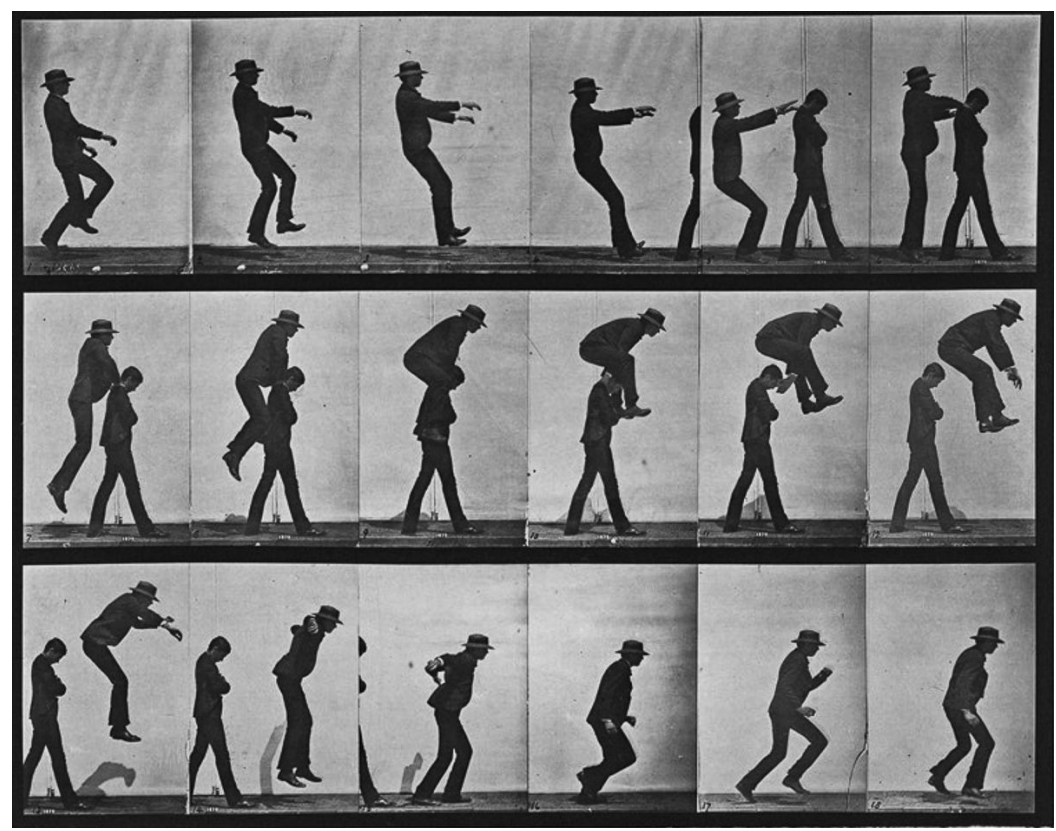

Figura 103. Estudio de movimiento de Eadweard Muybridge.

Tomando como base las propias técnicas de representación de estos espacios, nos dispusimos a generar un proyecto artístico que diera como resultado una imagen especular compuesta por las imágenes resultado de una búsqueda, en este caso utilizadas de la misma manera que Google, para confeccionar un doble virtual generado en base a los datos de esta búsqueda. Partiendo de un 
gesto sutil pretendiamos obtener un resultado inesperado y aleatorio. Utilizando nuestra propia imagen para realizar una búsqueda inversa obtuvimos una lista de imágenes que incluía las fotografías de diferentes personas que los algoritmos de Google procesaron como similares a mi propio retrato.

Por lo tanto al utilizar este tipo de imágenes estoy utilizando como material el resultado de una búsqueda que atañe a mi propia identidad. Al hacer que Google busque imágenes similares en realidad estamos interpelando a su algoritmo a construir, según sus propias lógicas, una pequeña base de datos, que es reformulada y reutilizada, para siguiendo el proceso inverso, generar una imagen que represente, gracias a esta búsqueda, un doble virtual generado en base a los datos obtenidos en Google Imágenes. Inspirándonos en la potencialidad de los datos como característica esencial de la virtualidad, decidimos producir una animación que generara este doble virtual compuesto por las imágenes que Google considera similares a nuestro propio retrato y por lo tanto como resultado de la gestión corporativa de estos datos. Como práctica artista desarrollada dentro de una espacio virtual hegemónico, utiliza las estructuras de poder, apropiándose, modificando y tergiversando sus signos y códigos. En este caso como nos diría Roland Barthes optamos por reformular y burlar estos códigos y funcionamiento en lugar de destruirlos.

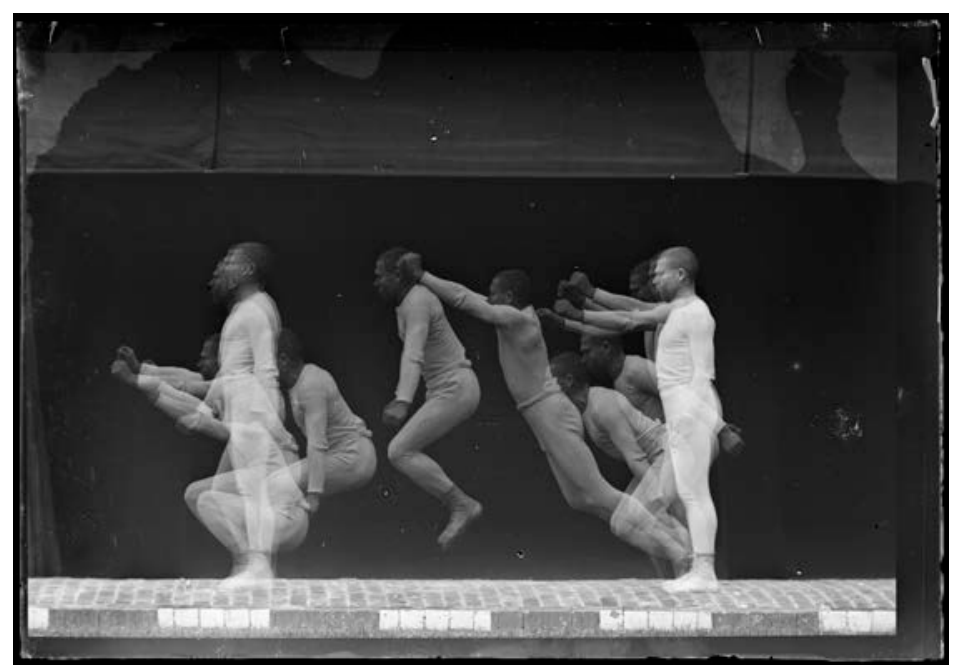

Figura 104. Étienne-Jules Marey, Cronofotografía de placa fija de un salto de longitud, 1882. 
La materialización de la pieza consiste en la aparición progresiva de cada una de las fotografías resultado de la búsqueda que al tener una opacidad baja se combinan y fusionan con las anteriores, las cuales permanecen en pantalla. La progresiva superposición de diferentes imágenes genera las sensación de movimiento y de cambio constante de un rostro que se va construyendo en base a el torrente de imágenes extraídas de esta búsqueda. El sueño de crear movimiento mediante diferentes imágenes ya comenzó con los primeros experimentos cronofotográficos de Étienne Jules Marey que a su vez inspiraron a investigadores coetáneos como Eadweard Muybridge y Leland Standford.

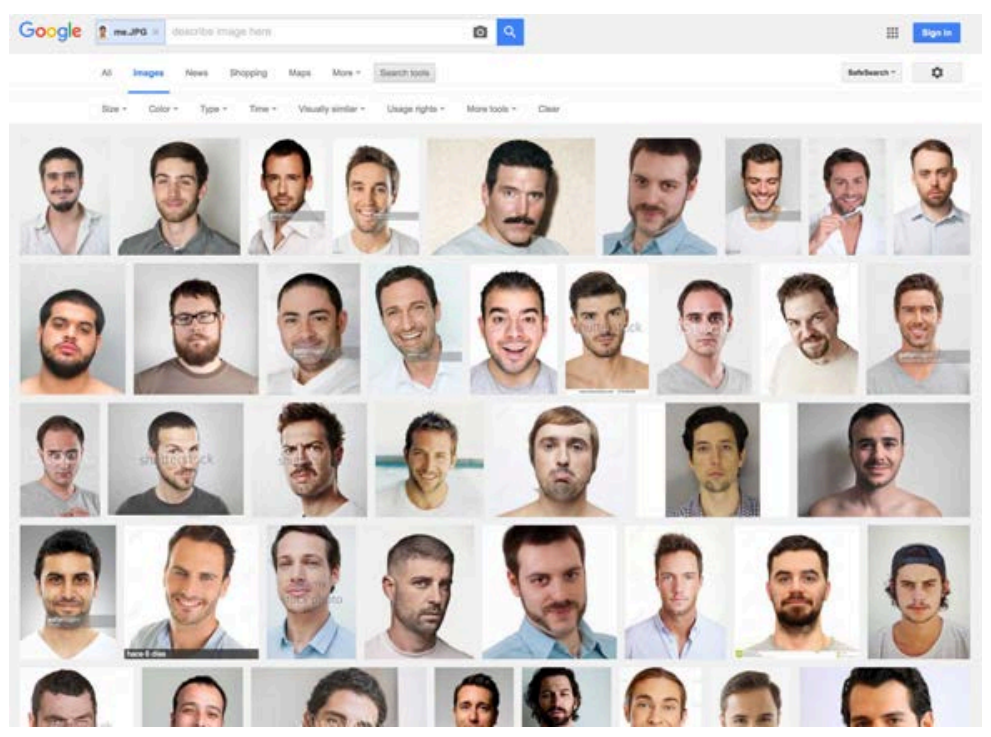

Figura 105. Parte de los resultados de la búsqueda inversa basada en mi propio retrato.

Los resultados de la búsqueda generan todo un catalogo de imágenes relativas a la información indexada por Google en el cual predominan imágenes de stock, resultados procedentes de noticias de sucesos donde los detenidos son mostrados en su ficha policial y diferentes actores que del mismo modo aparecen en noticias de Internet. Estos resultados nos muestran una interesante cultura visual que es el resultado de la búsqueda, y que se genera en base a los opacos procesos de los algoritmos de Google. 
Esta obra posiciona al artista como un explorador de los nuevos espacios mediáticos que mediante su práctica artística pretende discernir en que manera estos modelan nuestra percepción y cognición sobre nuestro entorno y nosotros mismos. En este caso, al reinterpretar los datos extraídos de una búsqueda inversa de mi propia imagen en Google Imágenes, estamos reutilizando este material para generar un doble virtual mediante las imágenes en movimiento. Esto produce una antropomorfización de esta búsqueda en forma de un doble virtual, en el sentido de que existe solo al ser reproducido y visualizado en un pantalla o proyección mediante imágenes en movimiento. Este doble virtual antropomorfizado es conformado como una cronofotografía digital que es en realidad una imagen especular de nosotros mismos generada en base a las imágenes que Google decide mostrarme como similares a mi.

En este caso usamos un técnica heredera del cine primitivo para visualizar la verdadera naturaleza de un nuevo medio, lo cual nos remite al concepto de anti-medio trazado por McLuhan. Por otro lado, al usar las propias herramientas de estos espacios mediáticos para visualizar los efectos de los mismos estamos generando una tergiversación cercana al detournement situacionista, ya que estamos tomando un producto cultural hegemónico para distorsionar su uso original con la intención de generar una visión contracultural sobre la manera en la cual esta traza nuestros movimientos, con la intención de generar patrones y perfiles en base a los datos que producimos. De hecho esta obra genera un paralelismo con la manera en la cual los cuerpos de datos son utilizados por las grandes compañías de Internet para trazar un retrato de quienes somos y que queremos. Así pues la materialización de todo ese material apropiado en forma de retrato tiene si cabe, un sentido más potente si tenemos en cuenta que estos cuerpos de datos nos retratan. Por otro lado, podríamos decir que esta obra genera cierto "distanciamiento". Como ya vimos, es entendido como una manera de crear cambios sutiles que sacan a la luz nuevos aspectos de nuestra realidad, o como podemos apreciar en este caso un uso inusual de un material que da como resultado una imagen virtual y antropomorfizada de la propia búsqueda, algo en principio ajeno a este tipo de motores de búsqueda. 


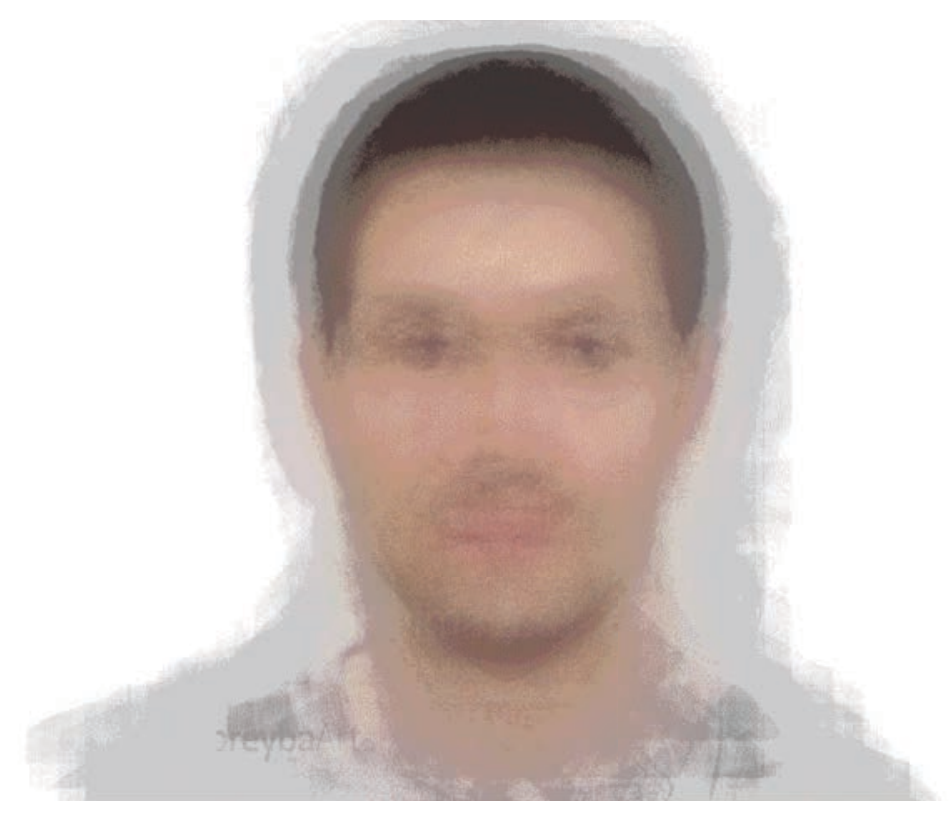

Figura 106. Still de la animación final.

Este tipo de aplicaciones que son capaces de regular nuestro dialogo con el mundo y construir nuestra realidad mediática, generan un seguimiento constante de nuestros patrones dentro de la red, conformando cuerpos de datos de acuerdo a nuestro actuar en Internet, generando una identidad virtual algorítmicamente asistida. En este punto podemos reflexionar sobre la manera en la cual este tipo de aplicaciones nos construyen en base al contenido de nuestras búsquedas. Para ello nos valemos de los resultados de una búsqueda inversa de nuestro propio retrato en el buscador de Google Imágenes, con la intención de confeccionar un supuesto retrato virtual mediante las imágenes extraídas de esta búsqueda. Estas imágenes, puestas en movimiento dentro de una animación que nos retrotrae al cine primitivo, generan la sensación de confeccionar un retrato cambiante y difuso, que nos plantea una vuelta a la conciencia sobre quienes somos realmente y como estas tecnologías nos condicionan en cuanto a nuestra percepción de nosotros mismos y de nuestro entorno. Sin duda nos encontramos ante una aplicación que ejemplifica el oligopolio de los servicios de Internet. Es por ello que decidí preguntarle quién era realmente mediante una búsqueda inversa basada en mi propio retrato. Para ello utilizamos nuestra propia imagen como material mediante el cual delimitar en que manera esta aplicación relaciona esta 
imagen con otras, así como diferentes tipos de paginas y contenidos, dando como resultado un interesante estudio de cómo funcionan este tipo de motores búsqueda y de la potencialidad artística de este tipo de aplicaciones.

Uno de los temas abordados de manera transversal son los fenómenos de virtualización y desterritorialización adjuntos a estas tecnologías como consecuencia del solapamiento, el de lo real y lo virtual. Mientras que por un lado gracias a las redes somos individuos disueltos y constituidos por información, estas herramientas son capaces de llevar nuestra percepción de la realidad y de nosotros mismos a un terreno artificial constituido por datos e imágenes, continuamente modificado por las propias herramientas dedicadas a constituir estas encarnaciones y representaciones.

Esta obra finalmente fue conformada bajo el título de Google Me, nombre que viene del habito de buscar información sobre uno mismo en Google, o en este caso, las propias imágenes generadas por esta búsqueda inversa en Google Imágenes. Esta búsqueda es puesta en movimiento para conformar una imagen especular mediante la combinación de estas imágenes. Aquí la potencialidad de los datos generados por la búsqueda es solidificada en un animación que muestra un individuo virtual, al estar compuesto de imágenes en movimiento de completos desconocidos. Es por ello que el proceso de esta obra ilustra el paso del propio retrato por el filtro de una herramienta virtual que interpreta esta misma imagen como gran numero de ítems similares. Mediante la transformación de las imágenes se convierte la potencialidad de esta información en virtualidad. Esta obra nos habla del paso de una identidad constituida en base al otro a una identidad generada en base a la interpretación que un algoritmo hace de quienes somos en base a nuestro actuar en la red. 


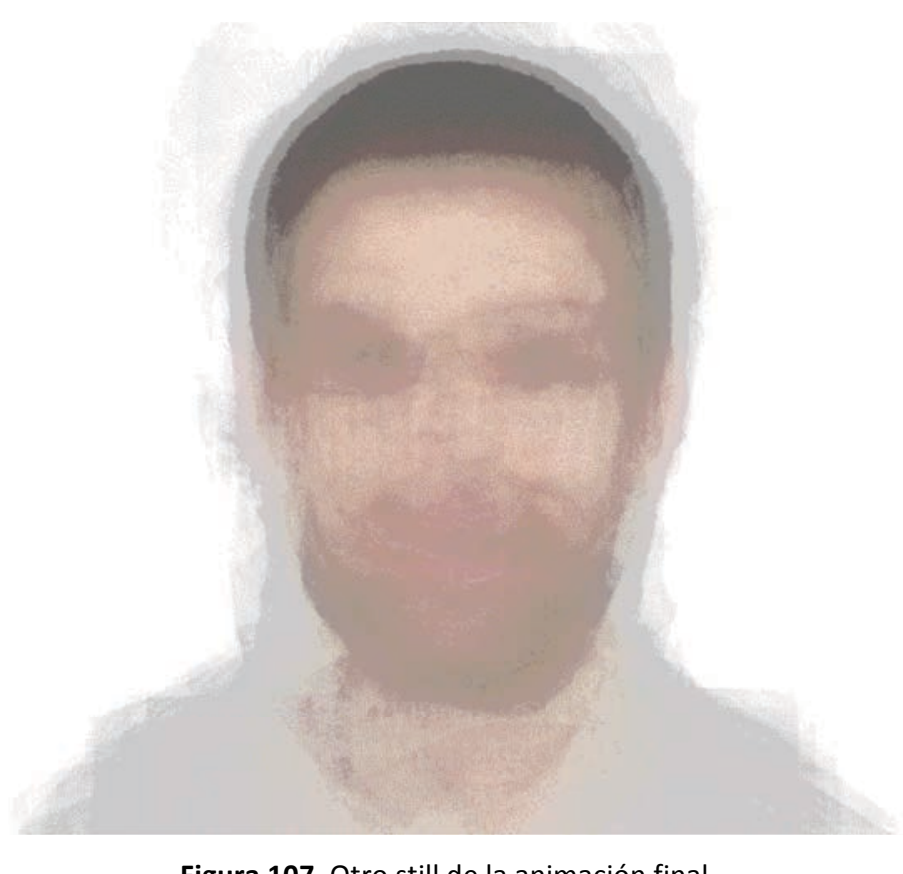

Figura 107. Otro still de la animación final.

En definitiva, como hemos podido comprobar mediante el análisis de nuestro propio comportamiento, Google puede predecir las búsquedas que responden de manera más fidedigna a nuestras propios intereses y por lo tanto retratarnos mediante sus propias herramientas algoritmicas. La búsqueda de imágenes en Google se ha convertido en un nuevo modo de exploración visual basado en los patrones básicos de las fotografías. Se trata pues, de imágenes que llaman e interpelan a otras imágenes gracias al algoritmo de Google, BackRub, el cual realiza su personal masaje sobre nuestro actuar.

Por otro lado, la acción de coleccionar imágenes en Internet, se ha convertido como consecuencia de este tipo de motores de búsqueda, moldeando nuestro tiempo libre, en base a nuestra necesidad de recolectar, archivar y preservar documentos que nos resultan atractivos, y que son el resultado de nuestro actuar como flâneur dentro de estos buscadores. La imagen como producto sobrante originada dentro de la cotidianidad, pero como no la imagen producida con el objetivo de ser comercializada como imagen de stock o publicada por las redes y sus servicios, es una de las principales fuentes iconográficas que podemos observar dentro de estas búsquedas. 


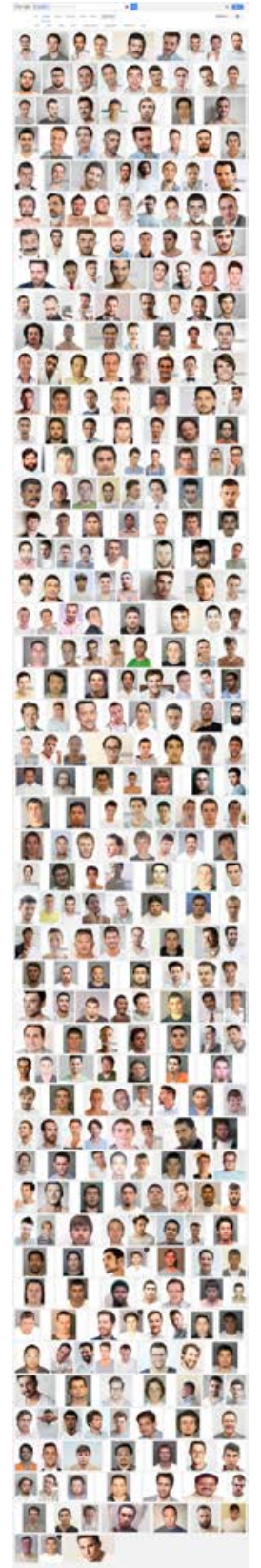

Figura 108. Captura final que aúna todos los resultados de búsqueda. 


\subsection{NEOGEOGRAFÍAS.}

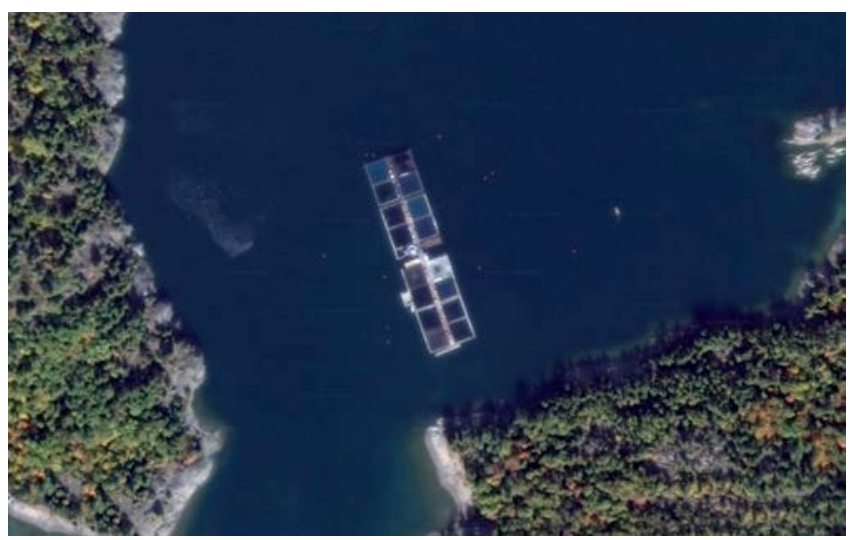

Figura 109. Imagen del satélite encontrado en Google Earth.

Hace unos años se hizo popular el enigma creado alrededor de una imagen captada en Google Earth en la cual podíamos observar lo que parecía un satélite sobrevolando unas islas situadas frente al Parque Estatal La Cloche en Ontario, Canadá. Rápidamente todo tipo de hipótesis esgrimidas por los autoproclamados teóricos de la conspiración llenaron las redes, sobre las cuales se impuso la idea de se trataba de un satélite espía que volaba a baja altura con la intención de hacer algún tipo de prospecciones en la zona. Sin embargo, nadie se percató de lo que posiblemente sea lo más fascinante, y es que en esta imagen un satélite fotografío fortuitamente a otro satélite, dejando patente la gran cantidad de estos aparatos que nos sobrevuelan con diferentes misiones entre las que se encuentran generar mapas navegables. Este solapamiento entre satélites es el hecho más visible de lo que podríamos denominar como un estrategia de control del espacio orbital para mantener la hegemonía y el dominio sobre el territorio.

Este tipo de tecnologías están transformando la superficie de cada país en parte de la propiedad intelectual de empresas como Google. En muchos casos las imágenes de países capturadas por estos satélites no son propiedad de estos países, sino que son recogidas por empresas estadounidenses de teledetección como Digital Globe o Geosat, para mediante su asociación con Google representar digitalmente la superficie terrestre como producto de su 
industria cultural. En este sentido todo el planeta se ha transformado en una base de datos digital que en muchos casos en generada violando la soberanía de muchos de estos territorios. De hecho la propia orbita terrestre se ha convertido en un espacio privatizado y del cual es difícil obtener información por la propia naturaleza privada de las actividades que tienen lugar allí. Hay más de 300 satélites comerciales funcionando en este momento, y cuando uno de ellos deja de funcionar o tiene problemas es movido a una orbita en la cual es aparcado junto al resto de la chatarra espacial, para hacer hueco a las nuevas generaciones de satélites. La gran cantidad de desechos que esta industria genera ha empezado a preocupar a estas empresas por el peligro público y medioambiental que conlleva el impacto de estos restos de satélites.

Alrededor de 2008 un nuevo complemento fue desarrollado por Google Earth $^{321}$, permitiendo a los usuarios visitar los más de 13.000 satélites activos e inactivos que orbitan alrededor de la tierra, seguir sus orbitas y comprobar lo concurrido que se encuentra nuestro cielo. El control de la denominada basura espacial se ha convertido en una actividad primordial para muchos gobiernos, ante el temor a lo que se denomina como el síndrome de Kessler, es decir la acumulación de una cantidad de basura tan abrumadora que acabe destruyendo los satélites activos, que irónicamente pasarían a formar parte así mismo de la basura espacial, dentro de una cadena de colisiones en cascada. Sin embargo, no podemos dar todo el merito de la realización de estas cartografías a los satélites de los respectivos gobiernos que ceden sus imágenes a Google, sino que la propia empresa utiliza una flota de coches para realizar entornos navegables a nivel de calle dentro de la funcionalidad de Google Earth, Google Street View. También es sorprendente el hecho de que esta compañía utiliza avionetas con la intención de mapear amplias zonas del planeta para generar entornos en tres dimensiones mucho más precisos y realistas.

\footnotetext{
${ }^{321}$ O'Neill, lan, Explore earth's satellites with Google Earth, Universe Today, [en línea], 2008, [consulta 6 de Marzo de 2018] disponible en <https://www.universetoday.com/17754/exploreearths-satellites-with-google-earth/>
} 


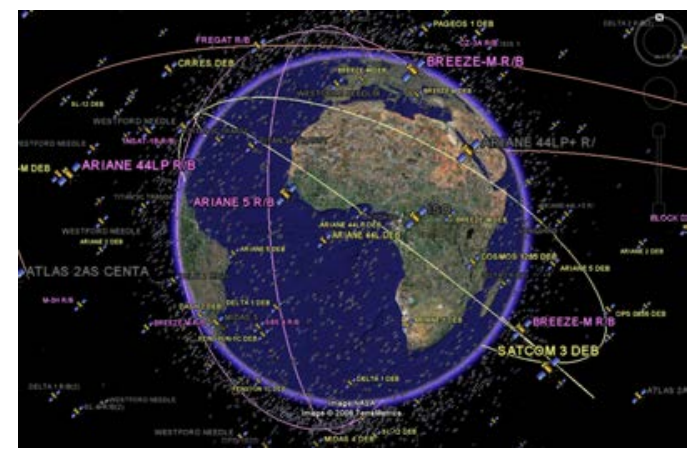

Figura 110. Satélites activos e inactivos que podemos observar a través de Google Earth.

Uno de los primeros deseos que aparecen en la mente de los usuarios al comenzar a usar aplicaciones como Google Earth, es el de explorar territorios en principio inaccesibles desde la comodidad de un gadget o periférico. Esta sensación de libertad y de poder se traduce en una búsqueda frenética de nuevos espacios mediante una visión cenital que históricamente ha sido considerada como patrimonio de los dioses.

Como vimos anteriormente, Google como compañía hegemónica tecnológica mundial ha pasado a responder nuestras preguntas, pero también a mostrarnos una realidad conformada como un gigantesca textura sobre una forma en tres dimensiones, regulando nuestro conocimiento del entorno y de lo que podemos considerar nuestra realidad exterior corporativamente construida. Sin duda, el punto de vista desde el cual observamos algo cambia totalmente la experiencia que podemos vivir como exploradores de nuestra realidad. Tal fue el caso de la experiencia dentro de la aplicación Google Earth. Una de los primeros deseos de todo usuario es explorar la infinitud de paisajes inabarcables como desiertos tanto cálidos como helados. La casualidad nos lleva a descubrir elementos que no esperamos encontrar dentro de un espacio tan basto, pero que obviamente no están tan deshabitados como cabría esperar. Fuimos capaces de encontrar por nosotros mismos elementos como el memorial a un vuelo que nunca llego a su destino ${ }^{322}$ construido mediante

\footnotetext{
322 Como posteriormente pude comprobar, este vuelo, el 772 de la compañía UTA, fue siniestrado el 19 de Septiembre de 1989, entre las poblaciones de Bilma y Tenéré en Niger, muriendo todos sus pasajeros y tripulantes. La investigación determinó que una bomba en el compartimento de equipaje fue la causante de tal catástrofe.
} 
los restos de esta catástrofe. Nos encontramos ante lo casual y aleatorio dentro de un entorno construido mediante fotografías realizadas automáticamente, sin ninguna intencionalidad concreta más que registrar un fragmento de la superficie terrestre para su posterior unión dentro de un gigantesco tapiz navegable.

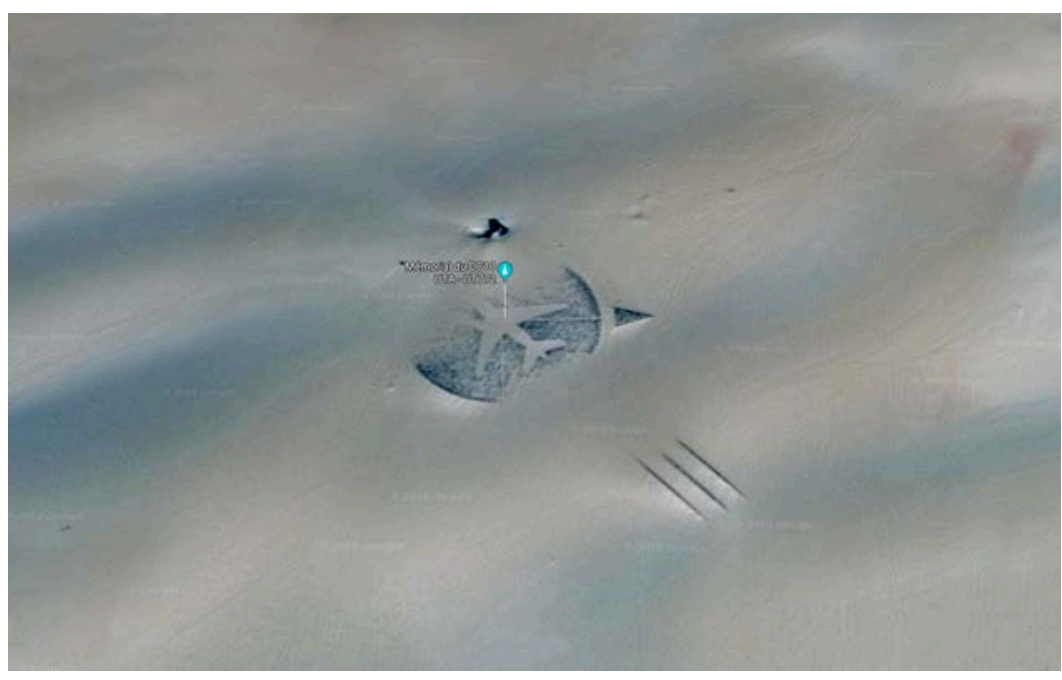

Figura 111. Memorial al accidente del vuelo 772 de la compañía UTA.

Otro de los hallazgos durante esta primera exploración fue un campo volcánico de basalto oscuro localizado en el centro geográfico del desierto del Sahara, que toma el nombre de Waw an Namus ${ }^{323}$. La visualización de este tipo de lugares desde una perspectiva inusual nos hace apreciar verdaderamente la inmensidad de estas localizaciones y lo importante del punto de vista para cambiar totalmente la percepción y la experiencia alrededor de un espacio.

Por otro lado, lo que puede ser visto como una simple anécdota en el ámbito de un mapa navegable, nos lleva a una visión y experiencia totalmente distinta al ampliar la información que tenemos sobre elementos que aparecen ante

323 Se trata de una caldera que contiene tres lagos de agua salada y vegetación que puede ser visto fácilmente desde el espacio, debido a su color oscuro y extensión de entre 10 y 20 kilómetros. 
nosotros mediante este tipo de collages. Esta actividad análoga a la exploración, parte de la interpretación de imágenes que en muchos casos son parte de lo fortuito y aleatorio de este tipo de sistemas de representación, que desarrollan collages de manera automatizada

Sin duda es destacable el papel de extensas comunidades de usuarios, entre los que nos encontramos inmersos, dedicados a observar este tipo de anomalías y a publicarlas como hallazgos asombrosos. La presumible exactitud de estas imágenes, resultado de las más altas cotas de la tecnología humana, y por lo tanto ejemplos irrefutables de la objetividad, es continuamente puesta en tela de juicio por parte de individuos dedicados a buscar lo insólito del fondo y la forma de muchas de estas imágenes entrelazadas entre si de manera incoherente, contenedores de escenas enigmáticas o realizadas en el momento preciso. Estos usuarios se comportan como coleccionistas de imágenes realizadas por máquinas de manera automática, que de manera inconsciente se asemeja a un modus operandi relacionado con el ready made duchampiano. Se trata pues de usuarios que desde su posición amateur realizan una actividad de búsqueda dentro de lo que ha sido realizado sin ninguna intencionalidad artística para encontrar retazos con cierto interés estético.

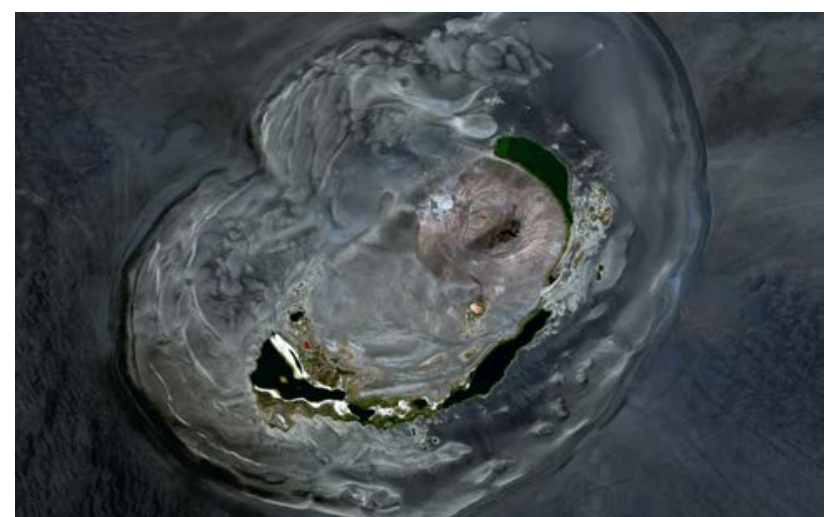

Figura 112. Caldera de Waw an Namus rodeada por la llanura de piedras de cobalto.

Pese a que estas aplicaciones emulan la propia experiencia de explorar nuestro planeta y recorrer su superficie en busca de hallazgos que nutran 
nuestra curiosidad y anhelo de caminar a través de nuevos espacios, se basa en fotografías realizadas por satélites que reflejan las limitaciones técnicas de este medio. Rápidamente pudimos observar como este tipo de fotografía tiene claras limitaciones basadas por un lado en entornos en constante cambio que devuelven imágenes cambiantes, o como no, de la propia rotación de la tierra sobre si misma que hace que la cantidad de luz que recibe un espacio cambie radicalmente durante su ciclo de 24 horas. Por lo tanto, una gran extensión es fotografiada mediante diferentes pasadas a diferentes horas del día o incluso días diferentes, lo que da como resultado una imagen iluminada de diferente modo. Estas imágenes al ser unidas entre si generan incoherencias claramente palpables.

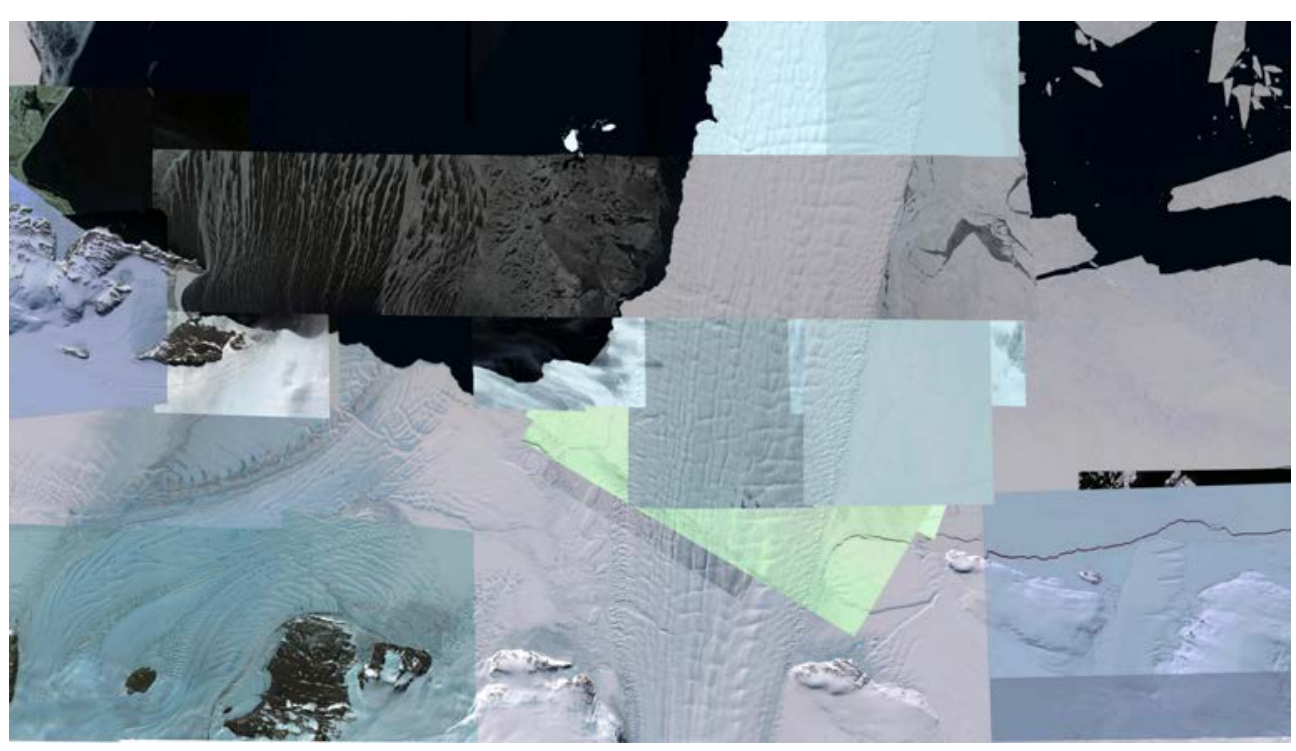

Figura 113. Ejemplo de espacio antártico lleno de incoherencias.

Por otro lado los propios espacios que estaba analizando, es decir, los desiertos tanto fríos como cálidos, por sus propias características cambian sustancialmente su topografía mediante tormentas de arena o desprendimientos de hielo, lo cual aumenta sustancialmente el tipo de incoherencias que podemos observar en estas imágenes. 


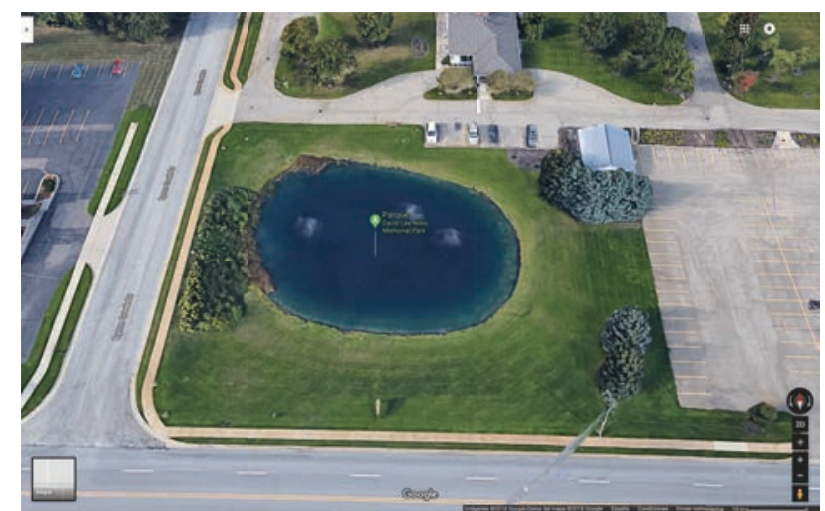

Figura 114. Zona de Bryon Township, en Michigan, donde se podía apreciar el coche sumergido de Davie Lee Niles, como vemos en la imagen hoy podemos ver un memorial en su nombre.

Esta experiencia se ha instalado como una manera de explorar nuestra realidad cercana, o lugares desconocidos, dándonos la posibilidad de encontrar elementos inusuales y situaciones que han pasado desapercibidos para el resto de usuarios, o que nunca antes habían sido analizadas. Sin duda, la red siempre ha sido un lugar donde vagabundear y alimentar nuestra curiosidad, pero los geonavegadores han dado un nuevo sentido a esta actividad heredera del propio flâneur de Charles Baudelaire.

Este tipo de hallazgos se han transformado en un tipo de noticias sensacionalistas que pueblan los informativos de diferentes medios de manera continuada desde hace años. Sin embargo, cuando se halló el cuerpo del anciano de 72 años Davie Lee Niles ${ }^{324}$ dentro de su coche en un estanque de Michigan en 2015, después de 10 años desaparecido, fue un vecino que adornaba su casa con luces de navidad el que se percató de que algo raro estaba cerca de la orilla de este pequeño lago. En base a esta noticia miles de usuarios comprobaron que el coche de este anciano siempre había podido ser visible desde Google Earth y Google Maps, pero que esta aplicación por si

\footnotetext{
${ }^{324}$ ABC Tecnología, La increíble historia del hombre desaparecido durante nueve años cuyo paradero solo Google Maps conocía, ABC Tecnología, [en línea], 2017 [consulta 6 de Marzo de 2018] disponible en <http://www.abc.es/tecnologia/redes/abci-increible-historia-hombre-desaparecidodurante-nueve-anos-solo-google-maps-conocia-201511161814_noticia.html>
} 
misma no analiza los datos que contiene, sino que son los usuarios lo que ponen en funcionamiento un sistema basado en la búsqueda de curiosidades y la navegación frenética, convirtiéndonos en flaneurs de estos mapas navegables. Tal es el caso de las competiciones entre usuarios llamadas Spot the Black Helicopter ${ }^{325}$, en las cuales se desarrolla la búsqueda de instalaciones militares con contenido delicado para el gobierno de Estados Unidos. En definitiva se trata de un tipo de aplicación que por un lado nos muestra la racionalización sobria de la tecnología que irónicamente es utilizada de manera lúdica por la comunidad de usuarios de este servicio gratuito.

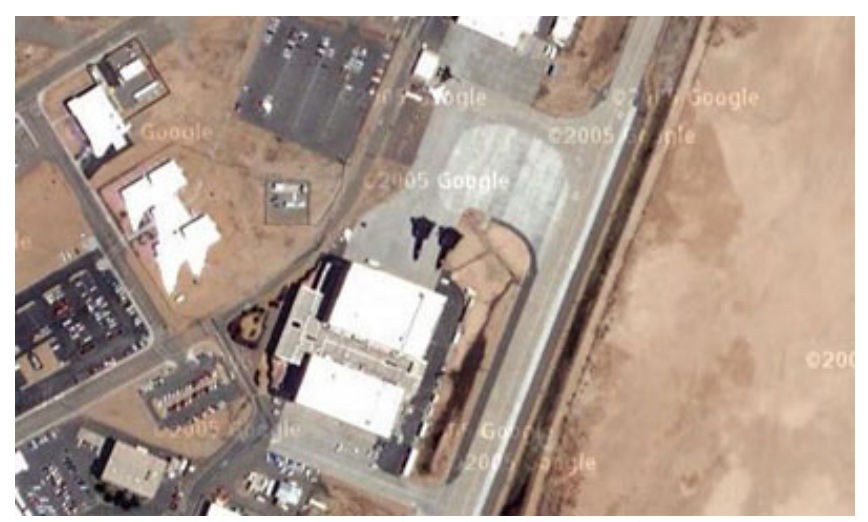

Figura 115. Aviones espía Lockheed SR-71 hallados durante una competición de Spot the Black Helicopter.

En una era en la cual el determinadas compañías muestran tener el poder de saber, ver y procesar todo lo que esta sobre la superficie terrestre, es necesario mantener una posición reflexiva respecto a tales imágenes, y usarlas precisamente para reconocer que algunas cosas no pueden simplemente ser registradas y puestas a disposición del gran público como un producto de lo que Adorno denominó industria cultural, sino que estamos ante un imaginario que contiene elementos de carácter impredecible que en muchos casos podríamos considerar en el ámbito de lo privado.

325 Tipo de competición desarrollada por usuarios de Google Earth, en la cual los participantes tratan de encontrar aeronaves o detalles comprometidos sobre instalaciones militares del gobierno de EEUU e incluso otros gobiernos. El termino helicópteros negros proviene de la teoría conspirativa desarrollada por movimientos de milicias de EEUU, que argumenta como helicópteros de este color sin matricular son usados por el gobierno para fines ocultos. 


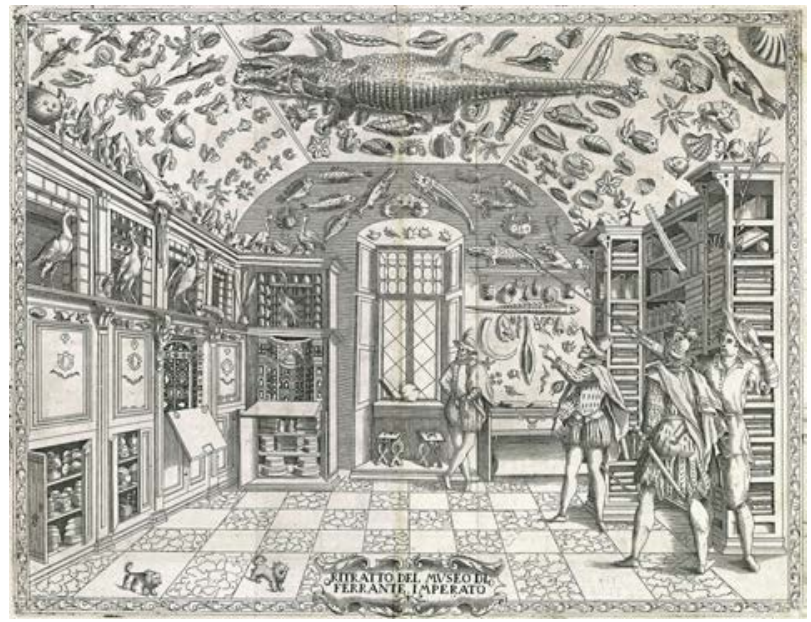

Figura 116. Ferrante Imperato, grabado de Dell'Historia Naturale, Nápoles 1599.

En el contexto de la Europa renacentista, debido a la falta de un marco clasificatorio adecuado, se generaron los gabinetes de curiosidades o cuartos de maravillas, como espacios donde se exponían objetos exóticos provenientes de todo el mundo para conformar un microcosmos o teatro del mundo, generalmente contenido en una misma habitación. Este tipo de colecciones era consideradas como ejemplos de magnificencia, así como lugares de retiro y contemplación, destinados a reflejar todo el cosmos en una escala en miniatura. Esto provoco un cambio de visión que a la postre favoreció un transición hacia una visión dinámica de la historia natural que contribuyo al desarrollo de una visión científica de la realidad.

Sin embargo, en la actualidad nuestra cosmovisión, como la percepción del mundo o el marco de ideas o creencias que conforman una descripción global mediante la cual los individuos observan o interpretan el mundo, ha pasado a estar mediada corporativamente mediante algoritmos que organizan la información que recibimos y la construcción de nuestra realidad exterior que tecnologías como Google Earth realizan. La visión cenital panóptica de los satélites ha implementado la aparición de estas aplicaciones las cuales están compuestas por un gran mosaico de imágenes que compone la totalidad de la superficie planetaria. Estamos ante un mundo fotografiado de manera automática, proponiendo, al igual que Man Ray y Moholy Nagy, una nueva 
definición de lo fotográfico marcada por su exactitud e impersonalidad. Hoy en día el hecho de cartografiar y fotografiar van unidos de la mano produciendo fotografías creadas sin ninguna intencionalidad expresiva, por parte de satélites que sobrevuelan nuestra orbita constantemente.

La horizontalidad ha sido asociada a la vieja idea ilustrada de fraternidad, aunque tiene anteriores precedentes en el cristianismo y el estoicismo, e incluso el renacimiento. Mediante esta horizontalidad los nexos de unión entre los individuos se basan en la colaboración y la ayuda mutua, una apertura y necesidad del otro. De hecho la necesidad del otro anunciada por Enmanuel Levinas ${ }^{326}$ es algo necesitamos para nuestra propia construcción, y de lo que Lacan también se percató mediante su estadio del espejo, y que mejor ámbito para ello que la igualdad y horizontalidad comunicativa.

La propia estructura de la red de Internet desde sus orígenes fue planteada como un espacio de intercambio de información horizontal inspirado en el la metodología investigadora. En los años 60 del siglo XX dentro de las universidades de EEUU interactuaron el desarrollo científico junto a las redes contraculturales, poniendo en contacto la cultura estudiantil con la gran ciencia, generando lo que para muchos fue una nueva herramienta de comunicación libre en red o incluso una herramienta emancipadora mediante la cual escapar del poder del Estado y la empresa.

Sin embargo, hoy día la aparición de unos gobernados que desconfían y se posicionan en rebelión contra el stablishment, ha dado lugar a fenómenos como el de la posverdad, que nos muestra la tensión entre los mass media como parte de la cultura hegemónica y las bases de la sociedad. La red tienen un papel importante en este fenómeno al potenciar, mediante la horizontalidad de este espacio, noticias, opiniones y hechos no contrastados que no responden al modelo unidireccional de los medios tradicionales. Este tipo de pensamiento o estado de opinión se refuerza mediante estas tecnologías, ya que gracias a sus algoritmos de búsqueda nos ofrecen información y productos en base a nuestro actuar en la red, mediante la recolección y análisis de datos y por lo tanto con lo que ya estamos de

\footnotetext{
${ }^{326}$ Lévinas, Enmanuel, Totalidad e infinito. Ensayo sobre la exterioridad, Sígueme, Salamanca, 1999.
} 
acuerdo, retroalimentando y fortaleciendo premisas que no tienen por qué responder a la verdad.

Como nos cuenta Hito Steyerl en su obra Los condenados de la pantalla ${ }^{327}$ citando a Eyal Weizman ${ }^{328}$, este relaciona política y arquitectura en base a poder que la verticalidad despliega mediante la soberanía y la vigilancia. Esto puede definirse como una soberanía vertical compuesta por capas horizontales superpuestas. Mediante aplicaciones como Google Maps generamos una visión de conjunto que nos posiciona como observadores distanciados y etéreos que supera el paradigma de la perspectiva lineal. Estamos pues ante un escenario donde las miradas son globales, omniscientes e intrusivas, pero también, desde esta verticalidad, se aprecia la ilusión de un control extremo de clase mediante las industrias militares y del entretenimiento.

Este ideal de lo horizontal surge como contrapunto a la verticalidad inspirada en una sociedad piramidal y fuertemente jerarquizada mediante lo que Bourdieu denominó "habitus"329, como el tipo de pautas y estilos culturales que caracterizan un estrato de la jerarquía. Ya Michel de Certeau 330 nos hablaba de cómo el conocimiento era producido desde las elites y distribuido verticalmente, es decir desde las clases dominantes hacia las clases dominadas, pero sin duda estos tenían la posibilidad de reformular esta cultura. Sin embargo no existe dialogo desde la verticalidad, se trata de una comunicación unidireccional similar a la de los clásicos medios de comunicación de masas, cumple un papel ideológico pero no dialógico. Por otro lado la verticalidad desplegada desde los geonavegadores puede ser contestada desde el punto de vista de los usuarios generando nuevos contenidos que insertar en estos mapas o poniendo en evidencia las incoherencias que estos albergan.

\footnotetext{
${ }^{327}$ Steyerl, Hito, Los condenados de la pantalla, Caja Negra Editora, Buenos Aires, 2014, p. 25.

${ }^{328}$ Weizman, Eyal, The politics of verticality, en Open Democracy, abril de 2002, en <http://www.opendemocracy.netjecology-politicsverticalityjarticle_801.jsp>

${ }^{329}$ Bourdieu, Pierre, La distinción. Criterio y bases sociales del gusto, Taurus, Madrid, 2000.

${ }^{330}$ De Certeau, Michel, op. Cit., 2000.
} 


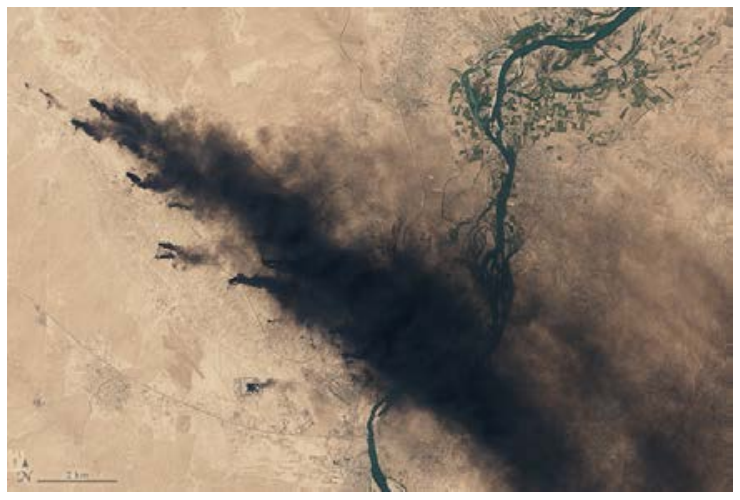

Figura 117. Imagen de la misión Landsat 8 durante la quema de pozos petrolíferos en Irak en Junio de 2016.

Como ya Paul Virilio nos anunciara en su obra Bunker Arqueology331, el espacio orbital militar es el factor determinante en los conflictos mediante las armas basadas en la comunicación como la detección a la larga distancia, el control del campo de batalla y el territorio, y los sistemas de navegación inercial. Por otro lado, como nos cuenta Lisa Parks en su ensayo Vertical Mediation: Geospatial Imagery and the US Wars in Afghanistan and Iraq ${ }^{332}$, a partir de los acontecimientos del 11 de Septiembre en Nueva York, el gobierno de Estados Unidos se lanzo en una carrera por el dominio del espacio orbital, o lo que Parks llama campo vertical, siendo clave en sus estrategias en la guerra contra el terrorismo y la invasión de Irak y Afganistán. Entre 2001 y 2003 la Oficina Nacional de Reconocimiento lanzó 24 satélites que se unieron a 6 más de iniciativa privada, que tenían como objetivo controlar el espacio existente entre la superficie de la Tierra y la estratosfera. Esto permitió que durante la invasión de Irak 6 satélites sobrevolaran el país cada hora. Como aclara Parks las estrategias de poder siempre tuvieron una forma vertical, y son este tipo de tecnologías las que se han incorporado al imaginario del poder priorizando el control de la atmosfera como un objetivo capital. En este contexto el uso de imágenes geoespaciales se ha transformado en parte de una microfísica del poder que permite el dominio militar, económico y político sobre el territorio.

\footnotetext{
${ }^{331}$ Virilio, Paul, Bunker Arqueology, Princeton Architectural Press, Nueva York, 1994, p. 202.

${ }^{332}$ V.V. A.A., Mediated Geographies and Geographies of Media, Springer Science+Business Media Dordrecht, 2015, p. 159-175.
} 
Paradójicamente, hoy en día uno de los principales motores de la hegemonía es la globalización, impulsada por las elites económicas y políticas de todo el mundo mediante la liberalización de los movimientos de capitales que la conectividad de las redes permite. Mediante la virtualización del territorio compañías como Google han generado un monopolio de la manera en la cual recorremos nuevos espacios, implementando un proceso de desterritorialización consistente en el abandono del territorio para concentrarnos en su exploración online. Como afirma Régis Debray en su obra Elogio de las fronteras ${ }^{333}$, quizá nosotros mismos deseemos y busquemos un planeta liso, despojado del otro y carente de enfrentamientos. Un territorio al cual se le ha practicado un lifting, de manera que toda conflictividad ha sido borrada al oponerse a la realidad de las fronteras y su aumento exponencial. En este sentido, la artista Carolina Caycedo nos muestra en su gran proyecto aun en curso Be Dammed, como las imágenes satelitales pueden mostrar, junto a geocoreografías y ensayos audiovisuales, como los ecosistemas fluviales están entrelazados con las comunidades, conjurando el agua como un bien común que puede ser privatizada mediante la construcción de presas y la destrucción del entorno.

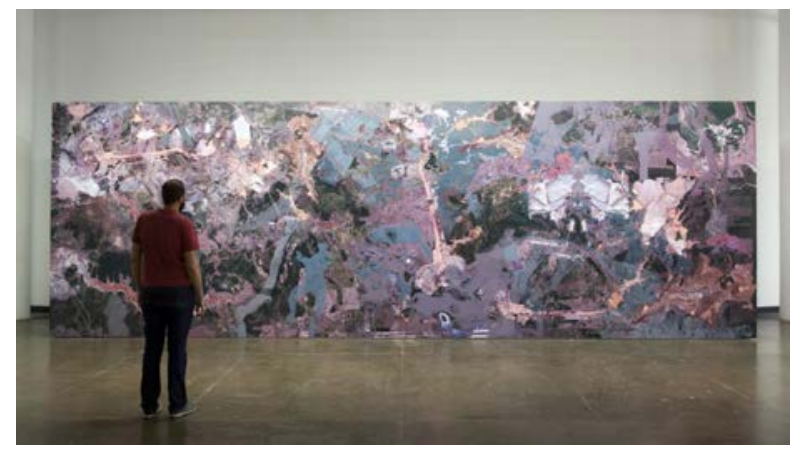

Figura 118. Carolina Caycedo, A gente Rio, 2016. Vista de instalación en la 32a Bienal de São Paulo.

Ya Deleuze y Giattari anunciaron sistemas maquínicos que atravesarían el territorio , así como sus estratificaciones materiales y mentales. Este tipo de movimiento tiene lugar en el plano de la tecnología, la producción y la cultura, entendiendo esta como los imaginarios colectivos globales. Se trata pues de

${ }^{333}$ Debray, Régis, Elogio de las fronteras, Gedisa, Barcelona, 2016. 
muestras transversales que tienen lugar al mismo tiempo, como la inclusión de la totalidad del planeta dentro de la economía global, no solo privatizando sus recursos, sino que incluyéndolos dentro de la cosmovisión hegemónica desarrollada por este tipo de tecnologías en forma de tapiz navegable en alta resolución. Si bien este tipo de aplicaciones son útiles en el ámbito de nuestra vida diaria, también generan una desmovilización al no ser necesario desplazarnos para contemplar un lugar, o en este caso su representación construida mediante imágenes y formas 3D.

Desde la puesta en marcha de la Web 2.0, los dispositivos relativos a la posición geográfica y datos espaciales, unidos a la aportación voluntaria de una masa de usuarios que disponen de un nivel de conocimientos cada vez más alto, han originado una nueva manera de explorar nuestro mundo basada en los mapas navegables combinados con formas 3D y fotografías a nivel de calle. Los geonavegadores como parte de la denominada web geoespacial han revolucionado la manera en la cual observamos nuestra realidad, generando un fenómeno con connotaciones dentro de lo sociológico, antropológico y filosófico. Sin duda este tipo de tecnologías era algo que ya existía dentro de los sistemas de información geográfica, pero fue su paso por el filtro de las lógicas de la Web 2.0 lo que los transformó en una nueva forma visual de navegación cartográfica con elementos sociales, que resemantizan la geografía de nuestro planeta mediante la vinculación de puntos de estos mapas navegables a materiales como fotos, videos, noticias, empresas, instituciones o paginas web. Este tipo de vinculación se nutre del trabajo digital de los usuarios como nuevos obreros de la geografía global, que ofrecen su mano de obra gratuita a cambio de resignificar, desde su punto de vista personal, la geografía de nuestra planeta en base a su actividad y producción de materiales, dentro de un proceso cultural de creación de significado vinculado a lo cotidiano y el consumo.

Por lo tanto, la intersección de la cartografía y las aplicaciones de la Web 2.0 han generado una nueva comunidad de geógrafos amateur que gracias a multitud de aplicaciones cartográficas, tanto de carácter abierto y gratuito como gestionadas corporativamente, pueden construir mapas y cartografías en base a sus propios intereses. El concepto de API o Application Programming Interfase, permite la mezcla y reciclaje de diferentes aplicaciones abiertas para generar lo que se denomina mashup. Este tipo de aplicaciones están orientadas a potenciar la participación y creatividad de los usuarios, 
posicionando lo geográfico como un elemento democratizado y liberalizado dentro del ámbito de la creatividad, el tiempo de ocio y lo cotidiano. Este fenómeno, que ha puesto en manos de los usuarios y desarrolladores complejas técnicas de cartografía y SIG334, ha venido a denominarse como neogeografía por varios autores, entre los que destaca Andrew J. Turner por su ensayo Introduction to Neogeography 335 realizado en 2006. Este termino ha sido ampliamente discutido desde el ámbito científico por las connotaciones del uso de contenido geográfico generado por los usuarios dentro de mapas que podemos encontrar en diferentes herramientas dentro y fuera de la web, ya que esto implicaría equiparar el trabajo científico a la información geográfica generada voluntariamente. Sin embargo, como veremos se trata de un tipo de actividad generada desde la individualidad, que responde a la subjetividad de los usuarios como una extensión de la geografía experta y por lo tanto realizada por los usuarios para los usuarios dentro de las redes.

Los mapas satelitales virtuales han puesto a nuestra disposición una visión nunca antes accesible de nuestro planeta, posicionándonos desde una mirada vertical sobre nuestro territorio que nos brinda un poder nunca antes imaginado sobre esta representación del planeta en el cual vivimos, ubicándonos como observadores y a la vez objetos de esta observación. Por otro lado las herramientas relacionadas con los archivos KML nos permiten intervenir sobre estos mapas navegables mediante diferentes tipos de objetos que se superponen al territorio como una capa de información generada por los usuarios como resultado de su actuar y experiencia fuera y dentro de estos mapas. Estos archivos KML pueden ser intercambiados, modificados y distribuidos libremente gracias a las comunidades virtuales de usuarios dedicadas a explorar y generar nuevos mapas alternativos. Esto ha abierto la posibilidad de generar mapas que no responden a motivaciones meramente cartográficas o relacionadas con la cotidianidad, sino que permiten construir nuestras propias versiones paralelas a las difundidas desde las aplicaciones hegemónicas corporativamente gestionadas. Aunque estas también incluyen en muchos casos estas funcionalidades, siempre prima la funcionalidad y veracidad sobre la creatividad de los usuarios.

\footnotetext{
${ }^{334}$ Siglas para Sistema de información geográfica, o por su nombre en ingles GIS siglas de geographic information system.

${ }^{335}$ Turner, Andrew J., Introduction to Neogeography, O’Really Media, San Francisco, 2006.
} 


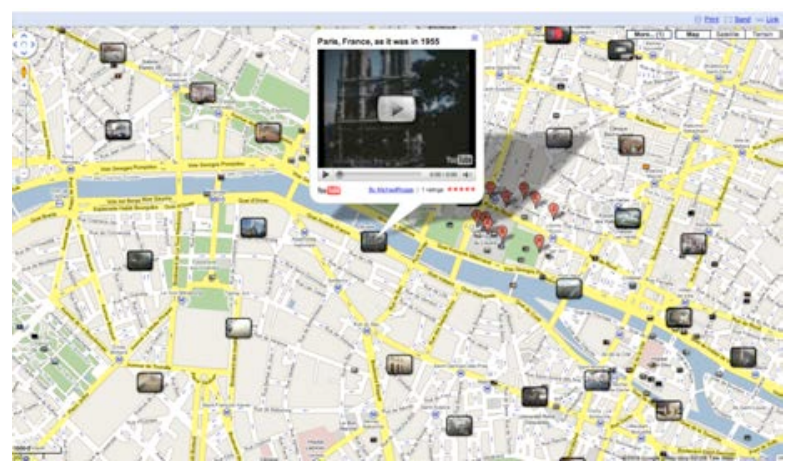

Figura 119. Ejemplo de las funcionalidades de Google Earth dentro de un archivo KML.

Por lo tanto la aparición de mapas navegables virtuales abiertos, o que permiten intervenir sobre ellos, ha hecho que se produzca un entrecruzamiento entre la horizontalidad de la red y el poder que otorga la visión hegemónica del territorio ejercida desde la verticalidad, lo cual, como consecuencia de su inserción dentro del gran público y la cotidianidad, ha generado la aparición de comunidades dedicadas a generar diferentes tipos de cartográficas y explorar este tipo de mapas navegables.

Gracias a estas herramientas los mapas son recorridos e interpretados desde la subjetividad del usuario, otorgando a este la posibilidad de explorar y sacar conclusiones sobre diferentes cartografías. Por lo tanto, se ha transformado en una cuestión relacionado con las diferentes motivaciones de los usuarios. La geografía no es una disciplina únicamente científica sino que se trata un ámbito también relacionada con lo mental y el paisaje. Tal y como tiempo atrás Deleuze y Guattari afirmaran "La geografía no se limita a proporcionar a la historia una materia y unos lugares variables. No sólo es física y humana, sino mental, como el paisaje. Desvincula la historia del culto de la necesidad para hacer valer la irreductibilidad de la contingencia... Finalmente desvincula la historia de sí misma, para descubrir los devenires"336.

\footnotetext{
${ }^{336}$ Deleuze, Gilles, Guattari, Felix, ¿Qué es la filosofía?, Anagrama, Barcelona, 1993, p. 96-97.
} 
El concepto de geosemántica introducido por el sociólogo chileno Diego Cerda Seguel en su artículo El mundo según Google337, sirve para designar la practica de generar y desarrollar territorios sobre mapas virtuales con la intención de que el resto de usuarios validen este tipo de territorios causando repercusión en el medio físico. Esta práctica ligada a lo utópico mediante la expresión libre de los usuarios materializada en anotaciones, imágenes, videos, formas vectoriales o en tres dimensiones, potencia una resemantización del territorio y de la conciencia del lugar.

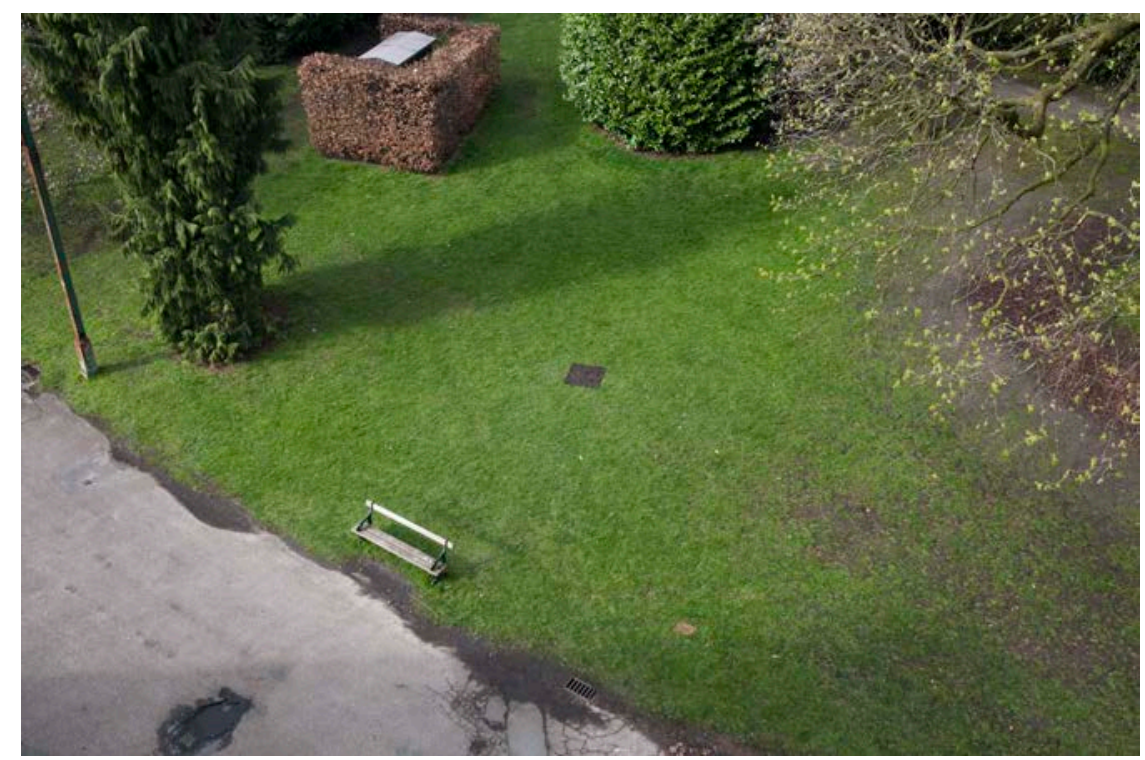

Figura 120. Helmut Smits, Dead pixel in Google Earth, 2008.

Precisamente será mediante la práctica artística como podremos resignificar y cambiar nuestra mirada sobre el territorio en base a el compromiso social, ecológico o político mediante acciones in-site como la obra de Helmut Smits, Dead pixel in Google Earth. Muchas de las prácticas artísticas giraran en torno a la relación entre las redes de comunicaciones con el espacio físico redefiniendo las interacciones que pueden darse en el. Lo que se ha venido a

\footnotetext{
${ }^{337}$ Diego Cerda Seguel, Diego, El Mundo Según Google. Google Earth y la Creación del Dispositivo Geosemántico Global, Escaner Cultural, 2006.
} 
llamar arte locativo es en realidad una reacción a la deslocalización globalizadora propia de las redes. Propiciando una convergencia entre datos y espacio físico en base a un lugar concreto. Muchas de las propuestas de arte locativo se basan en el vagabundeo, el trayecto, o la migración y son cartografías dinámicas y abiertas. De hecho, el nuevo auge de lo cartográfico como forma de expresión artística ha surgido como consecuencia de la aparición de los geonavegadores como cartografías dinámicas de código abierto.

Por otro lado, muchas obras que hacen uso de este tipos de tecnologías ensayan formas de contrarrestar la política de vigilancia que estas despliegan, convirtiéndolas en tecnologías para la crítica, el juego y la disensión. Se realizará una visión poética sobre la vigilancia a la cual estamos sometidos y la sutil señalización de los sistemas que la sustentan. Google Earth convertido en un ente productor de objetividad basada en la exactitud de la tecnología, ha generado una mirada omnisciente basada en el dominio sobre lo que se está observando, que transciende lo subjetivo para conformarse como un componente ideológico esencial del control y la hegemonía basado en su posición cenital respecto al territorio.

La enfermedad de la razón acuñada por Theodor Adorno y Max Horkeimer en su obra Dialéctica de la Ilustración ${ }^{338}$ de 1944, llevó a un proceso de racionalización que nos hizo abandonar el mito a favor del saber científico, lo cual se materializo en nuestro afán de control de la naturaleza. Para ellos la razón nace bajo el signo del dominio, un dominio que, gracias a la tecnología, también tiene la pretensión de ampliar su hegemonía mediante la construcción de un doble virtual, una imagen especular implementada mediante las tecnologías de mapas navegables virtuales y panorámicas a nivel de calle de 360 grados. Por otro lado Adorno estaba preocupado por el potencial distractor del arte de las masas, ejemplificado por la industria cultural, prefiriendo un arte individualista ante la disolución del yo que para Adorno el cine provocaba. Seguramente hoy en día describiría tecnologías como Google Earth buscando su origen en la vigilancia, la guerra, la invasión de la privacidad y el control de territorio mediante el control de la atmosfera terrestre y todo lo que contiene. Como contrapunto a esto tenemos a su amigo

${ }^{338}$ Adorno, Theodor, Horkheimer, Max, op. Cit., 1998. pág. 12. 
Walter Benjamin el cual estaría seguramente fascinado por las consecuencias que la creación de imágenes de manera automática e impersonal, carente de ninguna intencionalidad artística. Lo compararía con la capacidad de aislar elementos del cine y recomponerlos de otra forma, tal y como hacemos al centrar nuestra atención e incidir en un punto concreto del planeta, sumergiéndonos en el gran mosaico que llamamos Google Earth.

Como parte de esta investigación decidimos investigar las comunidades dedicadas a la exploración de este tipo de aplicaciones. Estas comunidades dedican una gran parte de su tiempo a recorrer estos mapas navegables buscando curiosidades, errores del propio geonavegador $\mathrm{y}$ aspectos llamativos de este tipo de cartografías. Los artistas como exploradores de los nuevos espacios de Internet no han dejado pasar la oportunidad de actuar como individuos insertos en el medio y generar nuevas formas de intervenir estos espacios desde el propio funcionamiento de estas aplicaciones en base a la actividad y relación de los usuarios con este tipo de espacios. En este sentido hay multitud de artistas que apuestan por explorar las características de estas tecnologías que revelan la manera en la cual funcionan, los límites en cuanto a su intento de representación de la realidad. Es aquí donde la recolección de fuentes automáticas de imágenes conformadas como grandes bases de datos generan la ilusión, en cambio hay imágenes que nos devuelven al propio proceso de construcción de estos espacios. Clement Valla realizó a obra Postcards from Google Earth en 2010, en la cual registra las anomalías que aparecen en Google Earth haciendonos reflexionar sobre el propio proceso de producción mecánica y en sus intentos de simplificación. Son texturas aplicadas sobre un modelo tridimensional. Alude al paso de la cultura digital que ha llevado a espacializar la imagen y hacer que sea navegable. Nos presenta un territorio que en definitiva es la unión de imágenes y formas en tres dimensiones, mostrándonos los procesos y tecnologías implicados en la confección de esta representación cartográfica de la realidad. 


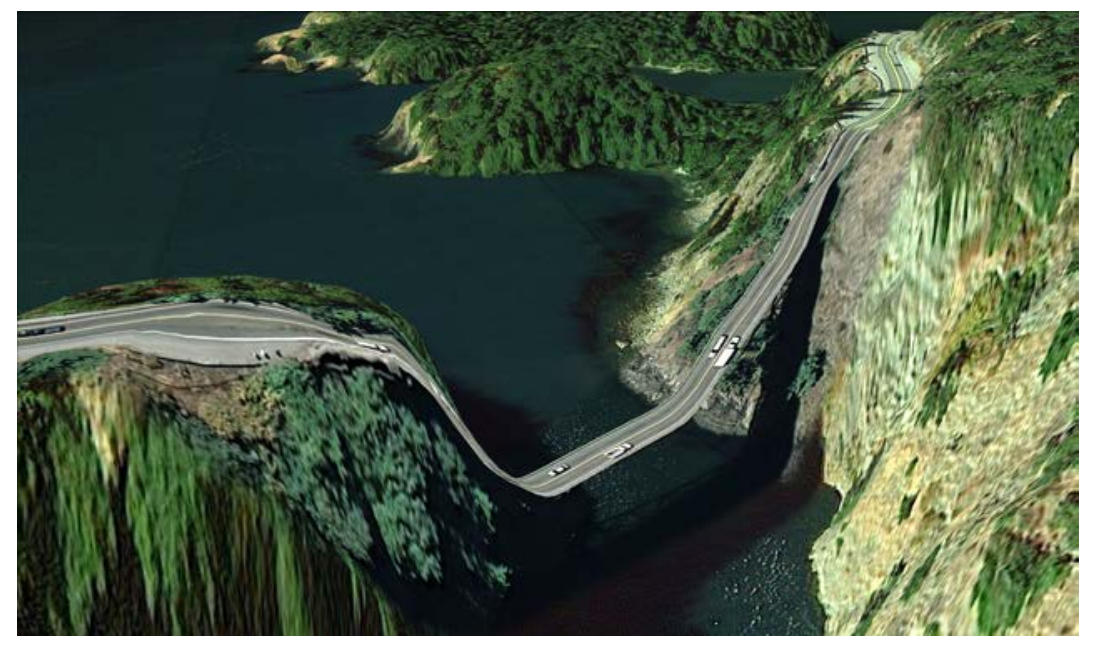

Figura 121. Clement Valla, Postcards from Google Earth, 2010.

Aplicaciones como Google Street View extendieron la idea de que la red podía contener una copia de nuestro medio físico capturada en imágenes. Esta aplicación que ofrece imágenes tomadas a nivel de calle de una gran cantidad de urbes y espacios colindantes, genera una imagen caleidoscópica mediante fundidos, que transmite la percepción de continuidad a modo de ilusión óptica que simula un entorno real en base a un modelo de tres dimensiones. Entre 2007 y 2011 el artista canadiense John Rafman realizó la serie The Nine Eyes of Google Street View, donde el artista se limita a seleccionar momentos decisivos dentro de esta aplicación, los cuales recupera buscando en lo ya fotografiado por parte de cámaras automáticas, que realizan imágenes no hechas por la mano del hombre. Son fotografías sin fotógrafo ya que el artista solo selecciona y se apropia de las imágenes. 


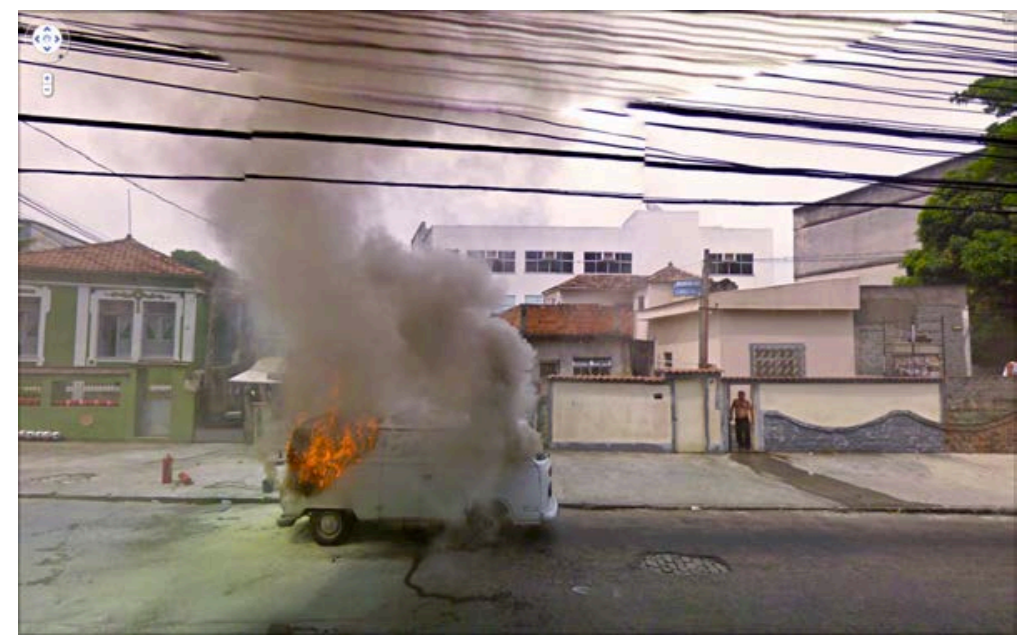

Figura 122. John Rafman, The Nine Eyes of Google Street View, 2007-2010.

Mediante este proyecto Rafman se acerca al ready made buscando la estética dentro de lo que no ha sido realizado sin intención artística. Gran parte de sus imágenes son encuentros con escenas surrealistas, o realidades sociales normalmente ocultas, pero que el ojo automático de la cámara no discrimina a la hora de registrar, lo que muchas veces no parece visibilizarse en otros medios. Sin duda se trata de un trabajo que tiene como referente la fotografía documental. En la misma línea fotógrafos como Michael Wolf se han incorporado a esta serie de prácticas, como en su obra A Serie of Unfortunate Events, donde recopila incidentes acaecidos dentro del espacio público y registrados fortuitamente por el automóvil, siempre en movimiento, de Google, dotado con una cámara 360 grados situada a tres metros de altura sobre este.

Del mismo modo que se ha creado toda una red de satélites que fotografían automáticamente la superficie de nuestro planeta, generando un espacio panóptico planetario, comunidades de usuarios recorren diariamente estos mapas navegables y panorámicas a nivel de calle buscando la serendipia, o encuentro no intencionado pero realmente afortunado, de diferentes elementos inusuales, curiosos o significativos. Este proceso de trabajo basado en la mirada del usuario y su interés por escrutar lo confeccionado automáticamente tiene como finalidad el propio reconocimiento ante la comunidad como recompensa de esta tarea vinculada con el ocio y lo 
cotidiano. Comunidades como en español como www.google-earth.es, se dedican a explorar y discutir sobre los diferentes encuentros, curiosidades y errores de la aplicación Google Earth o Google Maps, dentro de una extensa pagina con diferentes foros, noticias, artículos y manuales para la comunidad.

Artistas como Mishka Henner han transformado su práctica artística en una búsqueda de espacios censurados dentro de estas aplicaciones. Este es el caso de su serie Dutch Landscapes de 2011 , donde nos muestra zonas militarizadas de Países Bajos que han sido censuradas por este gobierno mediante polígonos irregulares que recuerdan a una pintura neoplasticista.

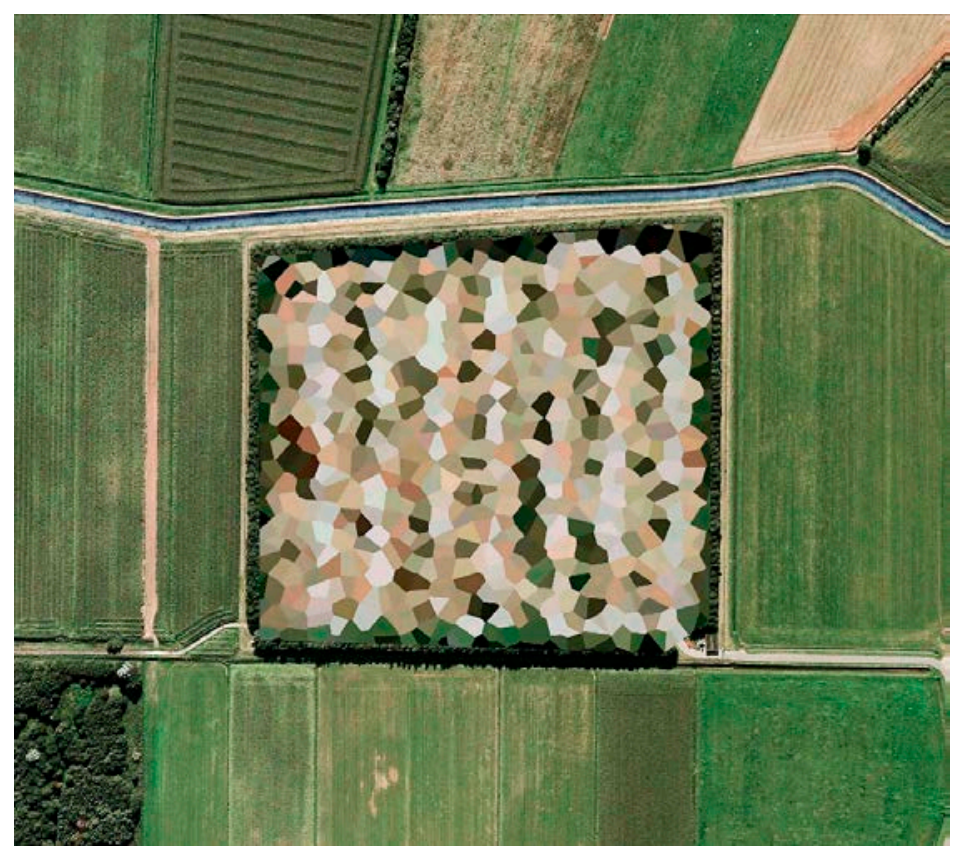

Figura 123. Mishka Henner, Dutch Landscapes, 2011.

Tras esta investigación inicial sobre el papel de estas aplicaciones dentro del ámbito de la creatividad amateur y el ocio online, y su repercusión dentro de la práctica artística, comencé a reflexionar sobre la relación entre la representación que estas aplicaciones realizan, y el referente original. ¿Hasta que punto este tipo de tecnologías realizan de manera automática una 
cartografía de nuestro planeta? ¿Pueden estar construcciones generar una visión realmente completa de los complejos procesos que se generan en nuestro planeta?

En base a estas preguntas y mi investigación sobre el funcionamiento de Google Maps y Google Earth nos percatamos sobre las diferentes imágenes que se pueden observar en base a la altura del suelo a la que se encuentre la aplicación. Por ello una vista que cubra una gran extensión de terreno se percibe como mucho mas homogénea que una que se encuentra a corta distancia del suelo. Aquí el propio proceso de toma de imágenes genera errores debido a la incapacidad de estos sistemas de fotografiar grandes áreas con la suficiente rapidez y exactitud. Esto provoca diferencias en cuanto a la iluminación, contraste y saturación en diferentes partes de estas cartografías navegables, ya que o bien estas imágenes fueron tomadas a diferentes horas del día o incluso diferentes épocas del año. Por lo tanto los propios procesos de nuestro planeta, como objeto en movimiento alrededor de nuestro sistema solar y sobre si mismo, generan multitud de incoherencias en las imágenes, las cuales parecen haber sido captadas en diferentes momentos.

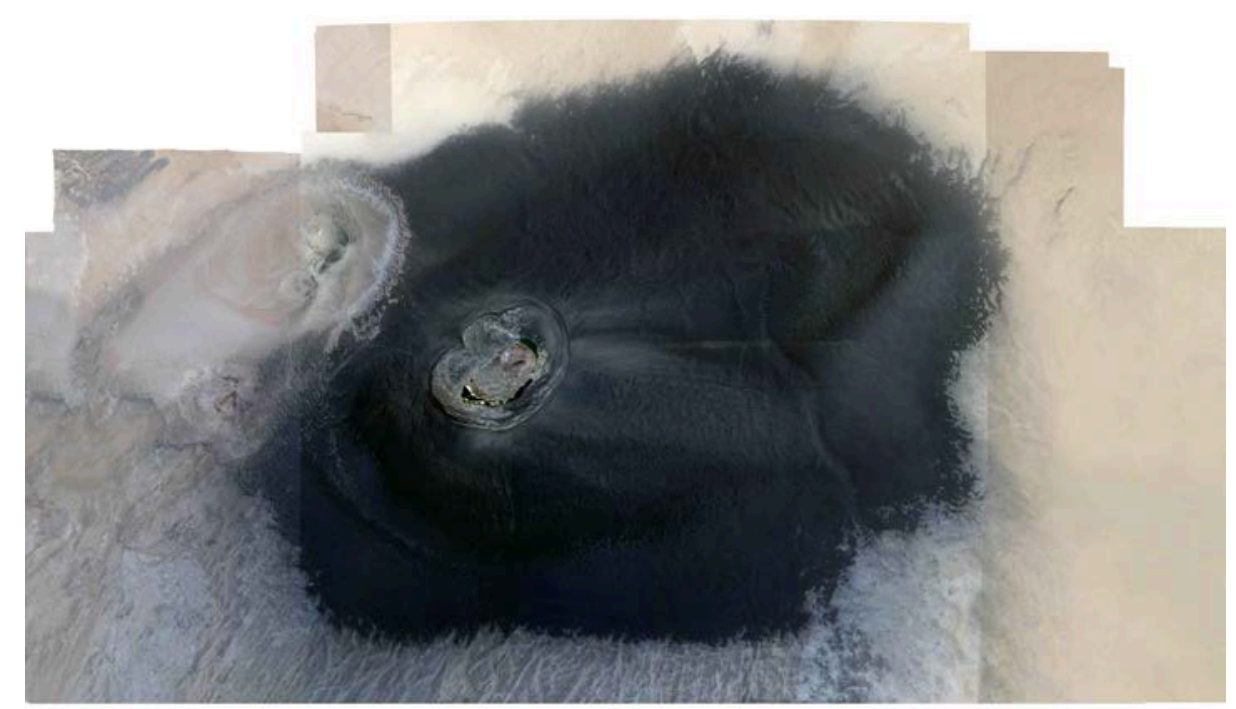

Figura 124. Imagen en proceso, ejemplo de la unión de multitud de imágenes en una sola. 
Por otro lado, cuando hacemos zoom en una zona obtenemos una imagen de mayor resolución, aunque no podemos ver el paisaje en su totalidad. Con la intención de reproducir grandes zonas en las cuales estos errores pueden ser observados, decidimos capturar pequeñas zonas de estos mapas y generar grandes imágenes mediante la fusión de estos pequeños retazos, generando un proceso inverso al que realizan Google Earth. Por lo tanto, podríamos hablar de una práctica artística basada en lo cotidiano en la red que imita los procesos de creación de mapas navegables, para visibilizar estos como una representación limitada técnicamente que no puede representar la complejidad de los procesos que tienen lugar en nuestro planeta. En gran medida por lo cambiante de estos, insertos en un contexto mucho mayor, pero que también se puede hacer extensible a la propia actividad humana. El terreno no es algo estático y fijado, sino que puede modificarse por los procesos de la naturaleza. La materialidad del territorio como terreno se relaciona con lo construido y el paisaje, y surge mediante su interrelación. Son estos procesos y relaciones los que nos muestran los procesos de producción mecánica revelando la manera en la cual estos mapas navegables son construidos. En este caso seleccioné cartografías de espacios naturales vacíos, como desiertos y paisajes antárticos para mostrar con mayor vehemencia la magnitud de estos cambios. Los desiertos antárticos, por los propios procesos asociados con el desprendimiento de hielos se ve modificado sustancialmente de manera muy rápida. Por otro lado los desiertos de arena cambian constantemente de morfología ante la acción del viento que hace a las dunas moverse constantemente. 


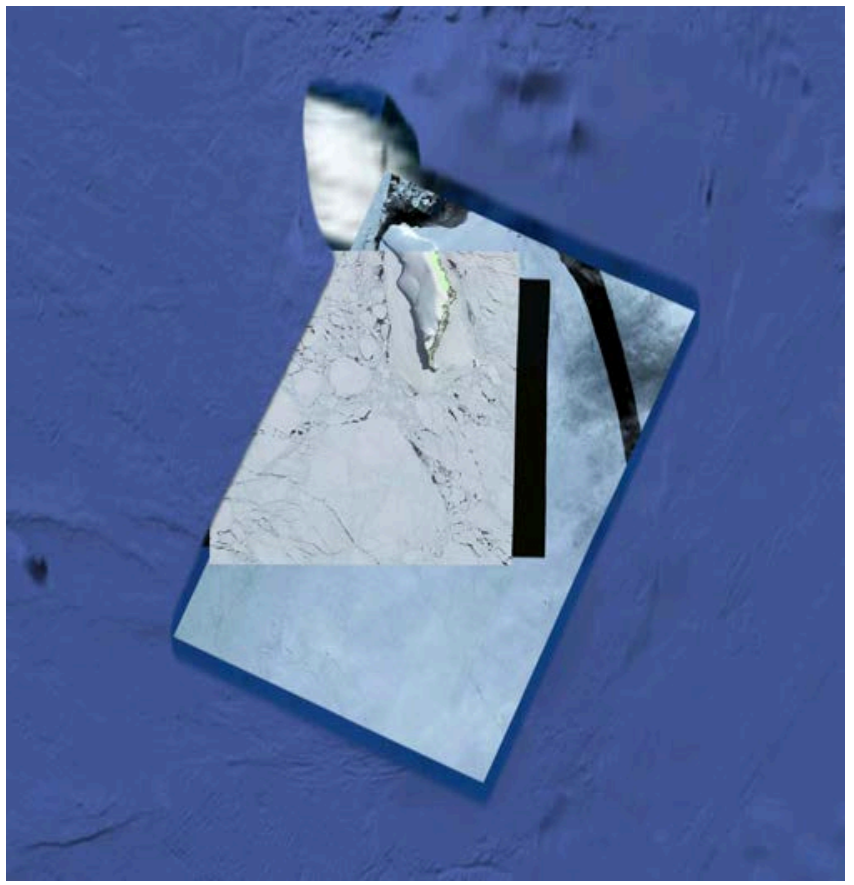

Figura 125. Ejemplo de imagen reconstruida mediante este proceso.

El uso de objetos cotidianos que no podemos considerar artísticos en si mismos, hunde sus raíces en el objeto encontrado y el collage ${ }^{339}$. Fue sin duda una de las técnicas que fueron usadas con mayor profusión por el movimiento dadaísta a principios del siglo $\mathrm{XX}$, dando lugar al assemblage o ensamblaje artístico. Esto genero así mismo una extensa clasificación de diferentes variantes, como objetos perturbados, preparados, encontrados, etc. Precisamente mediante esta practica desarrollada en Google Earth podemos apreciar como elementos de nuestra cotidianidad procedentes en este caso de los medios de masas son reutilizados y recontextualizados dentro de una práctica artística. Podemos afirmar que la abundancia de imágenes ha fascinado a toda una generación de artistas, que al igual que Marcel Duchamp quedó fascinado por los objetos manofacturados por la industria, se han posicionado como recicladores del imaginario de las redes.

${ }^{339}$ Duchamp, Marcel, op. Cit., 1978, p. 164. 


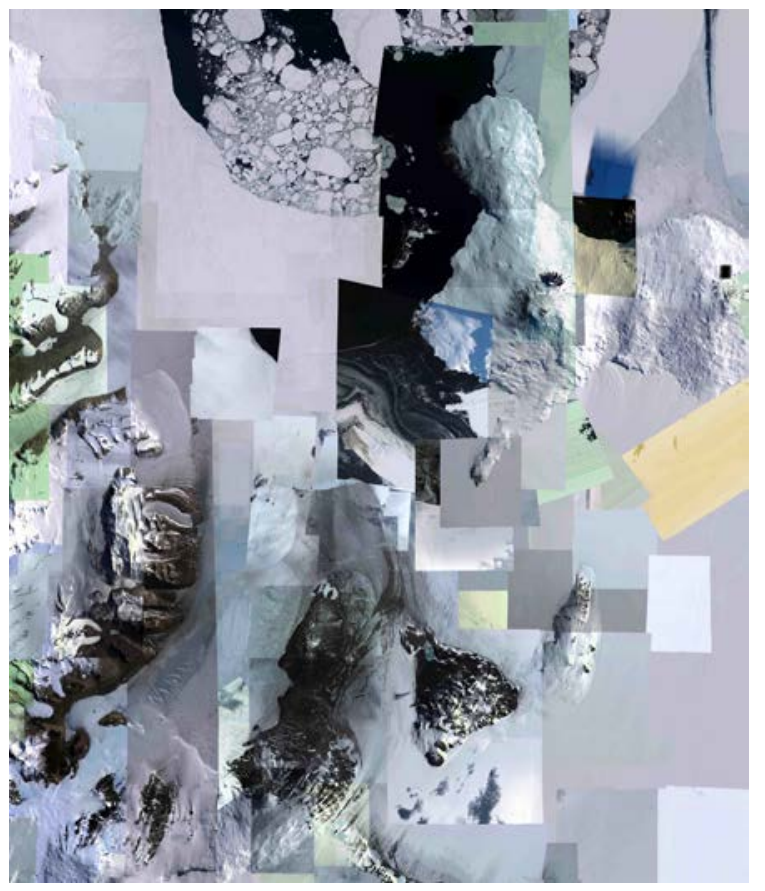

Figura 126. Reconstrucción de parte de la Isla de Ross localizada en la Antártida.

En este caso, la deconstrucción y posterior reconstrucción de imágenes mediante su ensamblaje nos lleva a reproducir un proceso análogo al de los satélites que componen estos grandes mapas navegables. Precisamente la implementación de este proceso saca a la luz aspectos relativos a la producción de estos mapas que permanecen ocultos al gran público, mostrándonos como este tipo de tecnologías generan imágenes incoherentes pese a su halo de exactitud y frialdad científica. Es precisamente esto lo que genera la distancia necesaria para crear una visión crítica sobre la manera en la cual estas tecnologías generan una visión hegemónica de nuestro entorno.

Al mismo tiempo este tipo de práctica nos posiciona dentro de una táctica apropiacionista que sirve para visibilizar la manera en la cual este tipo de empresas incorporan toda la superficie terrestre a su propia propiedad intelectual. Esta estructura mediática, como estructura de poder ejerce una visión hegemónica de nuestro entorno, apropiándose así mismo de un imaginario en muchos casos obtenido sin permiso o ante el vacío legal 
internacional. Por lo tanto, mediante este proceso de trabajo generamos una práctica que imita y repite las lógicas de esta aplicación de manera sutil para subvertirlas y mostrar su verdadera naturaleza, lo que nos hace preguntarnos ¿Quién es verdaderamente el propietario de estas imágenes y hasta que punto es licito su uso? Sin embargo no estamos intentando generar una sobreidentificación para con las lógicas de este sistema, sino que más bien una lectura crítica sobre las implicaciones del funcionamiento de estas estructuras mediáticas mediante un actuar basado en la exploración, reflexión y sutil tergiversación de estos entornos virtuales y su relación con sus referentes en el medio físico o real.

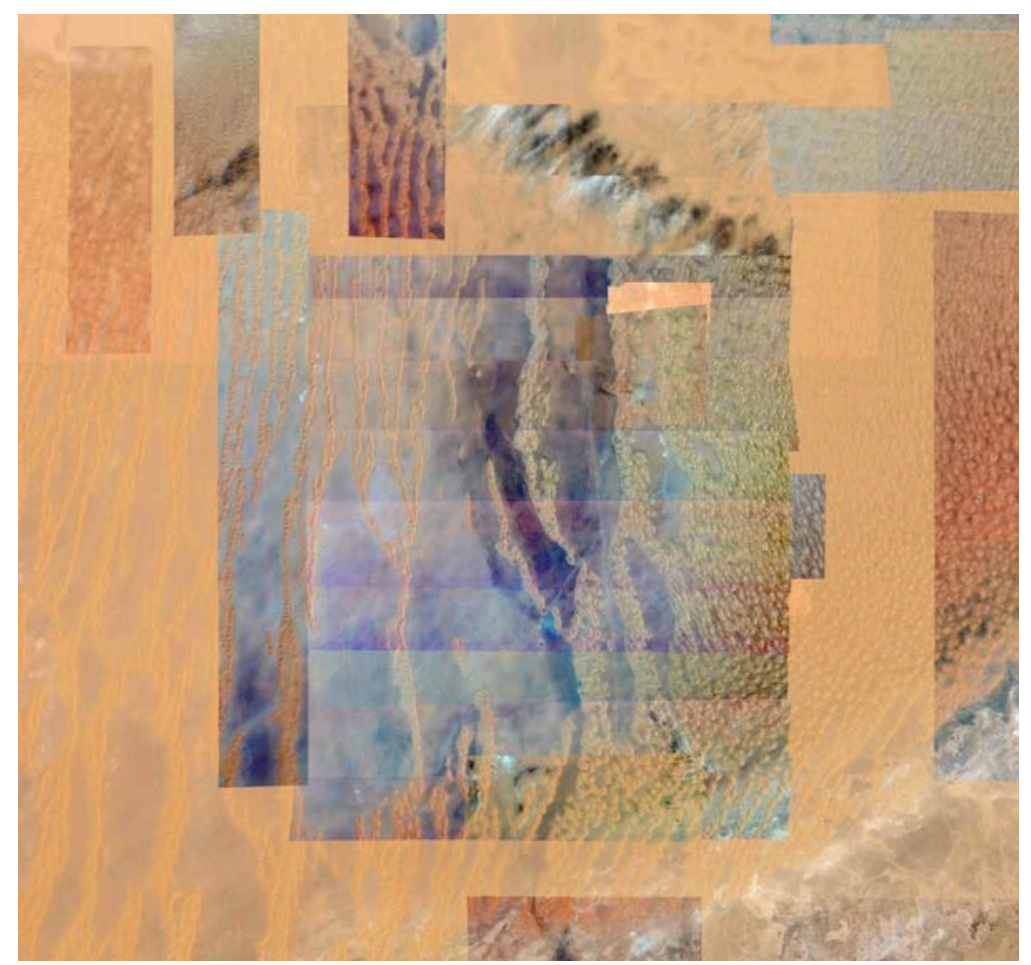

Figura 127. Imagen reconstruida perteneciente al desierto del Sahara.

Por lo tanto mediante este proyecto se pretende traer al espectador de vuelta la mundo real ante un escenario virtualizado, mostrando las incoherencias que este tipo de procesos genera. Nos encontramos en un momento en el cual muchas de las estrategias de las estructuras mediáticas hegemónicas 
implementadas por la Web 2.0 consisten en el concepto de la inmersión del usuario dentro de la virtualidad artificial. Sin embargo, lo que este proyecto pretende es generar el proceso opuesto mediante el cambio perceptivo sobre estas tecnologías que este proyecto pretende implementar en el espectador de manera sutil. Dentro de este contexto podemos considerar los medios digitales como una herramienta y vehículo para este tipo de pretensiones cercanas a la idea de cambio de cosmovisión o visión del mundo. Para ello, se trabaja con la manera en la cual se construye en el imaginario relativo a nuestro mundo exterior, y por lo tanto con como generamos una visión del mundo en base a imágenes procesadas y construidas como elementos veraces, cientifistas y totalmente objetivos respecto a cualquier componente político, social, ideológico o religioso. Sin duda estas empresas utilizan multitud de tecnologías encaminadas a construir una imagen que nuestro cerebro interprete como real mediante la sensación de estar recorriendo un territorio desde la posición cenital, históricamente asociada con el poder, y la inclusión de formas 3D que aporten mayor realismo volumétrico a la superficie observada.

Como parte de este proyecto realizamos un díptico videográfico en el cual combino elementos generados dentro de la propia red, en base a la creatividad de los usuarios, con los mapas que representan el tipo de espacios geográficos a los que pertenecen. En este caso he seleccionado por un lado un punto de la costa del continente Antártico y por otro una parte del desierto del Sahara. El material seleccionado alude de manera explicita a los propios procesos que tienen lugar en estos espacios y que se relacionan con el hielo, la arena y sus ciclos. De esta manera el artista se posiciona como un comisario que selecciona lo elementos de los cuales se apropia, generando una nueva conceptualización de la autoría basada en el reciclaje de material producido por otros usuarios como resultado de su pasión por crear y compartir dentro de la red. La disponibilidad de este tipo de material se presenta como una fuente interminable para el reciclaje y la remezcla, de manera que la propia idea de autoría parece carecer de sentido en este tipo de contextos. 


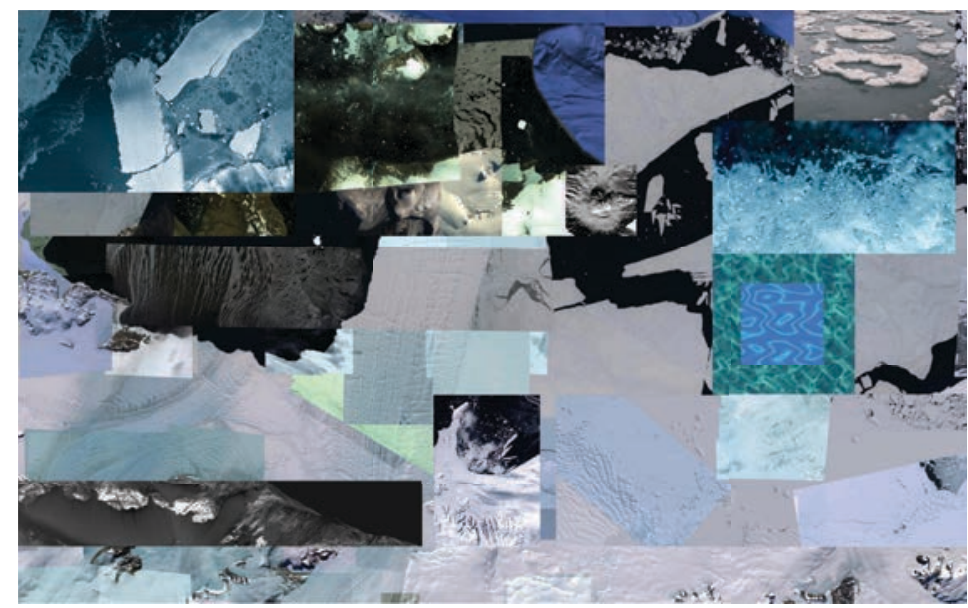

Figura 128. Primer video de la serie basado en un paisaje antártico.

Este tipo de adopción de imágenes, como diría Joan Fontcuberta, vienen a representar la elección de un valor determinado que es resignificado por un nuevo contexto y lectura que nosotros como creadores le otorgamos. Por lo tanto, al igual que las cartografías reconstruidas, este díptico se presenta como un tipo de obra deudora del ready made en la que toda creación a la vez es deudora de creaciones anteriores. El historial de artistas que han extraído material para volver a recontextualizarlo y resignificarlo dentro de otros contextos es interminable, desde el arte pop a el detournement situacionista o el pastiche posmoderno. Sin embargo, será gracias a las redes y las aplicaciones de la Web 2.0 cuando la apropiación y reciclaje implementaran fenómenos virales basados en una cadena interminable de versiones y reinterpretaciones.

Por otro lado, confeccionamos un díptico videográfico que pretende mostrar los procesos que tienen lugar en estos entornos sobre el propio territorio en el cual tienen lugar, los cuales son incapaces de ser captados por un mapa navegable. El territorio se transforma en lienzo sobre el cual presentar procesos, acciones sutiles e insignificantes, o por lo contrario movimientos colosales. Estas pequeñas animaciones nos distancian de la idea del mapa para llevarnos a un terreno que cambie nuestra percepción sobre estos espacios naturales. A la vez esto genera un cambio en nuestra percepción sobre la manera en la cual estos territorios quedan plasmados y establecidos como 
imágenes objetivas dentro de los geonavegadores. Sin duda la complejidad del mundo en el cual vivimos debe plantearnos otros modos de acercarnos a los diferentes territorios que lo componen.

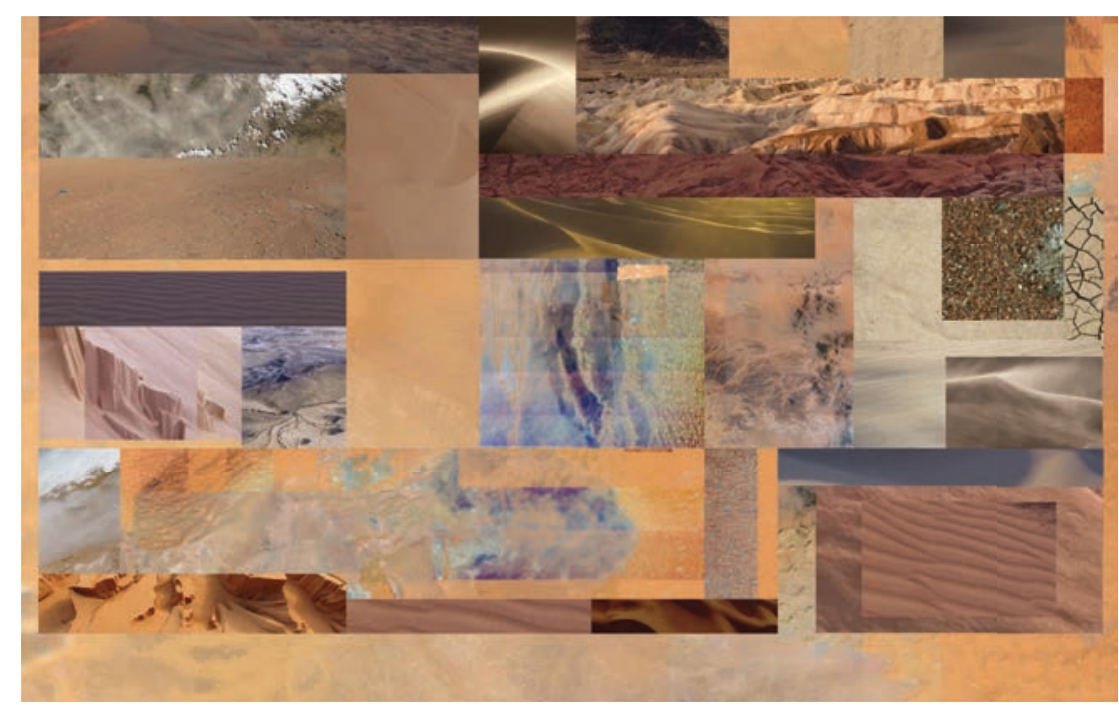

Figura 129. Segundo video de la serie basado en el desierto del Sahara.

Por otro lado, la combinación de formas 3D con mapas navegables ha originado auténticas reconstrucciones de grandes ciudades, como vimos en la obra de Clement Valla, nos remiten a las propias técnicas digitales de construcción de estas. Durante mi estancia en la ciudad de Nueva York el uso de este tipo de mapas se hizo indispensable para mi vida diaria, de manera que comencé a investigar sobre las características de este tipo de representaciones. En este caso Google Earth cuenta con un modelo 3D tremendamente detallado de la arquitectura de la ciudad, que pudiera ser el escenario de un metaverso o un juego multijugador online. Explorando las posibilidades de la aplicación Google Earth, observe la posibilidad de generar recorridos análogos a los que realizamos en el espacio físico o incluso que excedían las posibilidades materiales de un ser humano. 


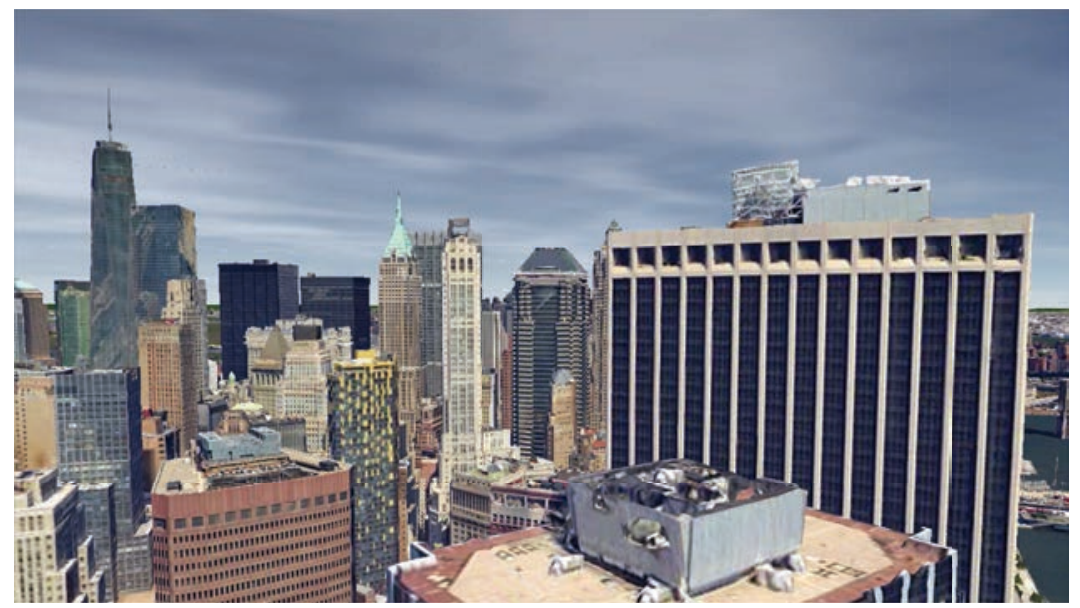

Figura 130. Still del video en el cual se producido un recorrido sobre Nueva York.

Es por ello que me dispuse a realizar diferentes recorridos que muestren la verdadera materialidad de esta representación en base a las funcionalidades de la aplicación Google Earth. Estos recorridos dieron como resultado una pieza videográfica en la cual la propia estructura generada por la forma 3D que compone la ciudad se ve atravesada y recorrida de un extremo a otro mostrándonos las características de este tipo de recreaciones.

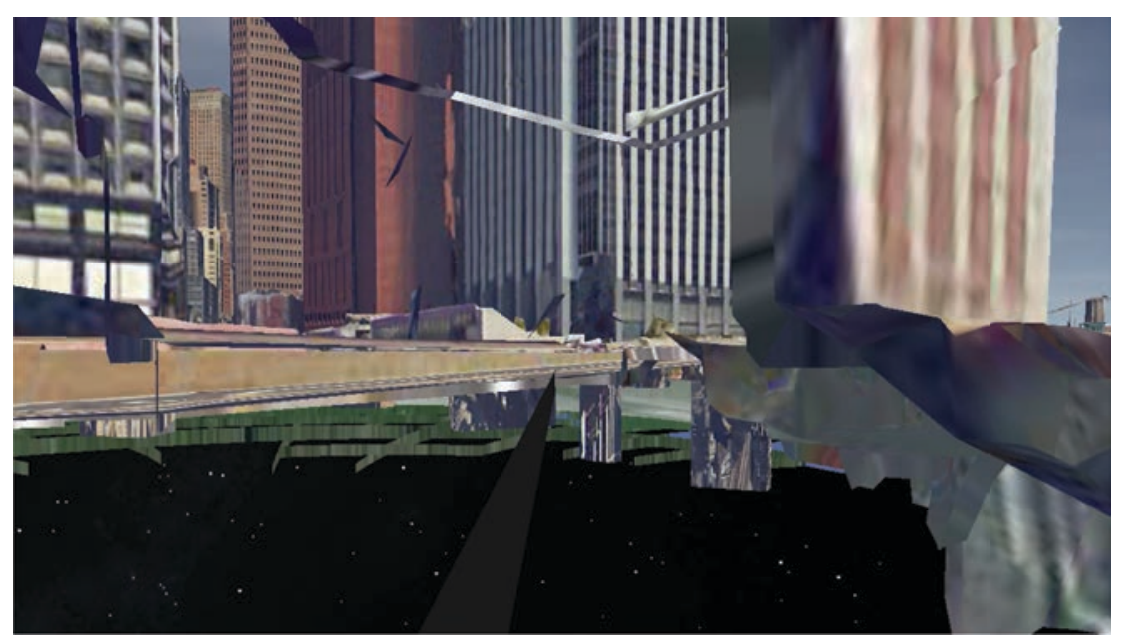

Figura 131. Still del recorrido por la ciudad de Nueva York. 
La propia materialidad de esta representación es puesta de relieve constantemente mediante este tipo de recorridos aleatorios, que atraviesan edificios, el subsuelo e incluso nos muestran que hay debajo de esta representación compuesta por una textura y una forma 3D. Por lo tanto estamos mostrando el verdadero funcionamiento y puesta en escena de esta aplicación mediante algo tan sutil como un paseo a través de la ciudad de Nuevas York.

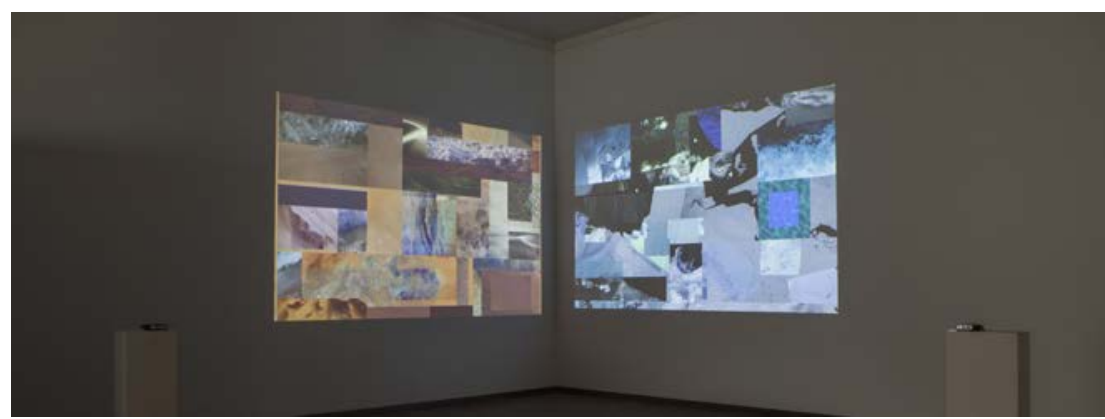

Figura 132. Fotografía de parte de la video instalación.

Toda este proyecto quedó materializado dentro de la exposición inaugurada el 29 de Septiembre de 2016 en el Espai Rambleta de la ciudad de Valencia. La amplitud del propio espacio permitió espacializar y cumplir uno de los objetivos de mi proyecto, al traer al medio físico la experiencia vivida dentro de este mapa navegable mediante una instalación audiovisual. La instalación se compuso de varios elementos distribuidos por este espacio que pretenden combinar tanto proyecciones de video como construcciones e imágenes.

Uno de los principales elementos de la instalación es una construcción realizada en madera cuyas paredes contienen las grandes reconstrucciones de paisajes realizadas durante el proyecto. Esto genera un recubrimiento análogo a la propia experiencia vivida en Google Earth, donde nos encontramos con elementos en tres dimensiones cubiertos por un gigantesco tapiz, mosaico o textura confeccionada mediante imágenes satélite. Al entrar al interior de esta estructura podemos encontrar el video anteriormente citado en el cual 
aparece un recorrido por la representación de la ciudad de Nueva York en Google Earth.

Como Olafur Eliasson argumenta en su obra Leer es respirar, es devenir ${ }^{340}$, al generar un espacio transitable activamos la presencia del espectador evitando una experiencia pasiva e inmersiva. Se trata pues de evitar la no presencia mediante un entorno reflexivo que nos trae de vuelta de lo virtual a lo real. Tras nuestra experiencia y exploración de estos entornos virtuales, y la posterior reflexión que materializamos en forma de práctica artística, nos propusimos que el espectador viviera esta experiencia mediante el hecho de atravesar esta estructura cubierta de imágenes satélite y contemplar el recorrido a través de Google Earth. Se trata de una toma de conciencia sobre las limitaciones, materialidad y verdadera naturaleza de estos espacios virtuales, que al igual que esta construcción se componen de una forma tridimensional cubierta por imágenes. Se trata pues de un artificio que deja ver a través de sus rendijas un espacio vacío al cual podemos acceder. Por otro lado, este tipo de espacio en su conjunto genera una recursividad evidente a contener en un solo lugar todos los elementos y procesos desarrollados durante esta investigación.

\footnotetext{
${ }^{340}$ Eliasson, Olafur, Leer es respirar, es devenir, Gustavo Gili, Barcelona, 2012, p. 17.
} 


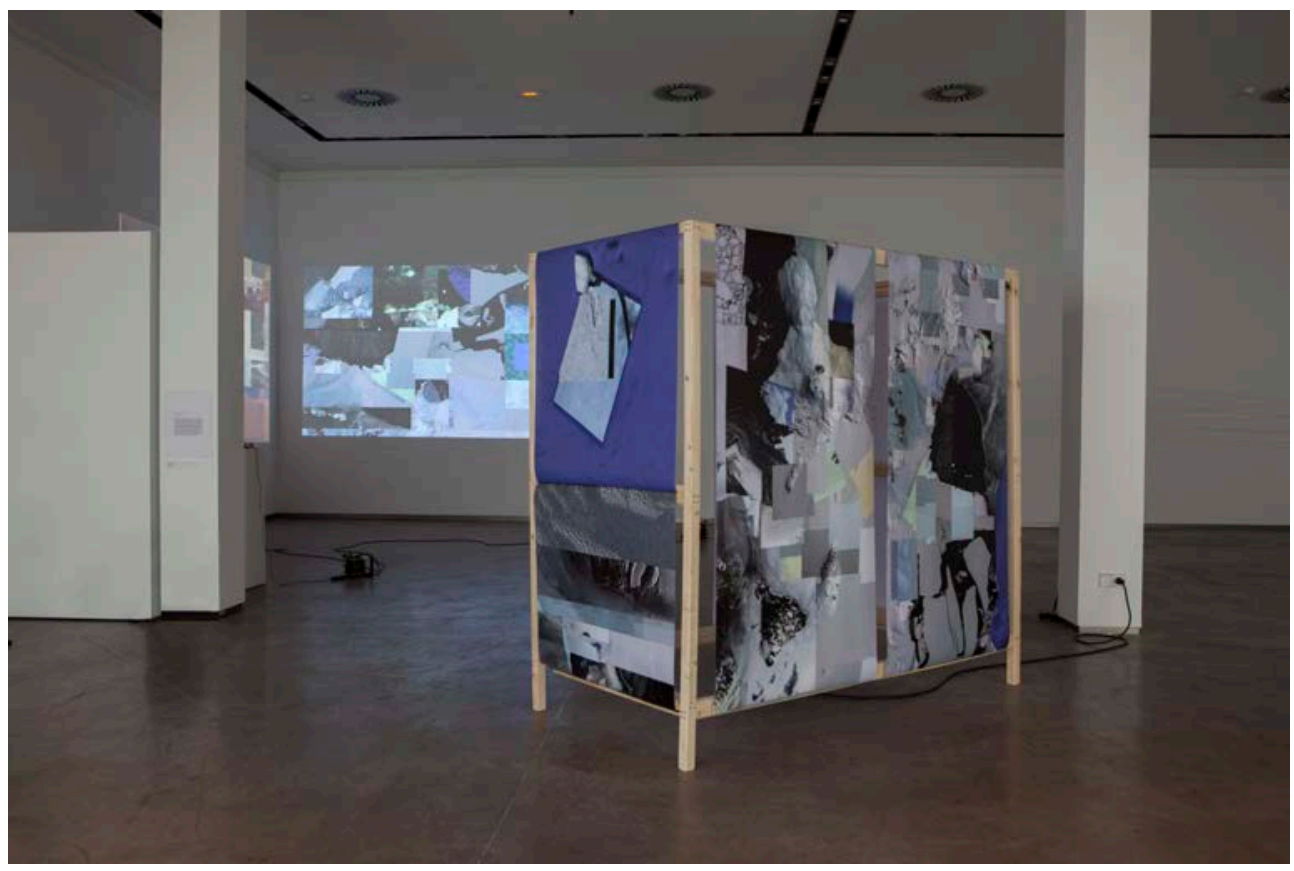

Figura 133. Vista de la instalación.

Implicarse en un entorno tiene como consecuencia la constitución de un espacio como tal, por lo cual mediante el hecho de atravesar la propia estructura estamos generando un proceso que nos lleva a romper una experiencia meramente contemplativa.

De esta manera, el observador se posiciona dentro de lo que observa, para mediante este video asimilar una nueva percepción alrededor de este tipo de representaciones que interpelan a nuestra experiencia en espacios virtuales. Por otro lado, mediante este video, se plantea una deconstrucción de la materialidad de esta representación al atravesarse de manera aleatoria la ciudad, mostrando el artificio en el cual consiste esta. Es por ello que este espacio requiere de un espectador implicado en el dialogo con las diferentes piezas que constituyen este espacio instalativo. Se trata pues de un espectador que pregunta y se pregunta, generando una experiencia artística más compleja. 
Mediante este conjunto de obras se produce una disolución entre los géneros de la fotografía, video y escultura con la misión de generar una propuesta global y unitaria. Esta característica de la propia instalación como hibrido, también incluye implícitamente los procesos que han dado origen a estas obras entre los cuales se incluyen las experiencias vividas dentro de estos espacios virtuales y cuyas conclusiones han dado origen a este cuerpo de obra.

En el video del interior de la instalación podemos observar un recorrido por la ciudad de Nueva York mediante la aplicación Google Maps que pone de manifiesto que nos encontramos simplemente ante texturas que se superponen a una forma 3D. Esto nos habla del paso dentro de la cultura digital a imágenes navegables. Nos ha servido también para cuestionar el papel de la imagen y la cartografía como representantes de la objetividad en un mundo con exceso de imágenes.

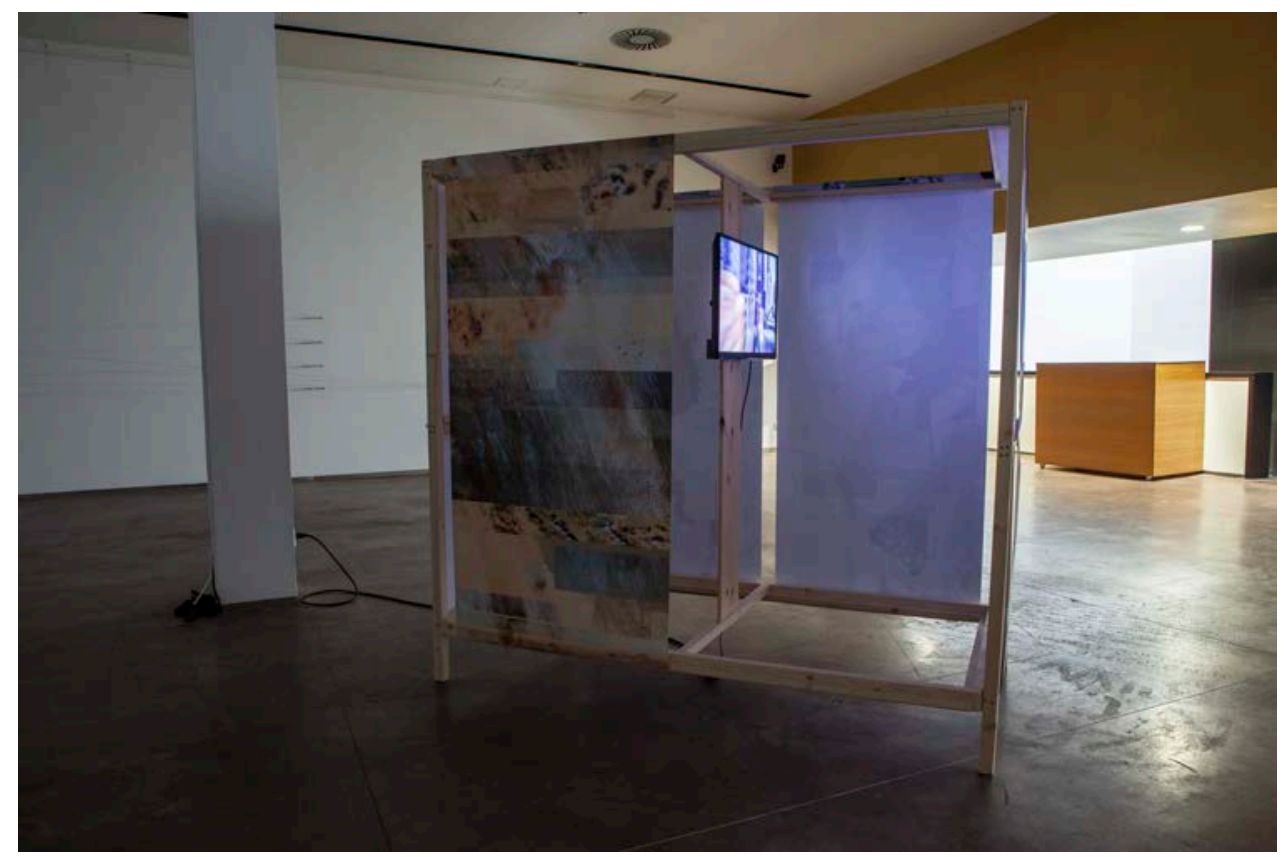

Figura 134. Vista de la instalación. 
La práctica de descomponer y volver a construir grandes cartografías es un modo de hacer que nos lleva a una práctica artística basada en la apropiación de imágenes de la red ante la sobreproducción de las mismas mediante una mirada anónima y literal, haciéndonos reflexionar sobre el propio proceso de producción mecánica y en sus intentos de simplificación. Se acerca al ready made buscando la estética dentro de lo que ha sido realizado sin intención artística. Se reubican físicamente materiales que se encuentran en línea dentro de estas cartografías virtuales. Estos grandes collages son texturas aplicadas sobre un modelo tridimensional. Alude al paso dentro de la cultura digital de los media que ha producido una espacialización de la imagen, haciendo que esta sea navegable. En este proyecto hemos trabajado, como en otras obras, sobre lo cotidiano en la red mas concretamente sobre los geonavegadores, que se han convertido en parte de nuestra vida diaria, y sustituido en parte la experiencia de transitar un espacio. Existen multitud de usuarios que se dedican a buscar los errores y las incoherencias que podemos encontrar en estas grandes collages navegables. Hemos adoptado este actuar en la red como metodología para mi proyecto. El proceso ha consistido en la deconstrucción y posterior reconstrucción de grandes áreas de estas cartografías que he espacializado dentro de esta instalación, dando un uso artístico a un objeto de uso cotidiano sin modificar su aspecto original. Rápidamente advertimos que eran los propios procesos naturales que tenían lugar en estos lugares los que causaban incoherencias, por lo cual decidimos realizar estos dos videos en los cuales se pone de manifiesto los ciclos mediante la apropiación de imágenes de la red. 
6.6. ECO.

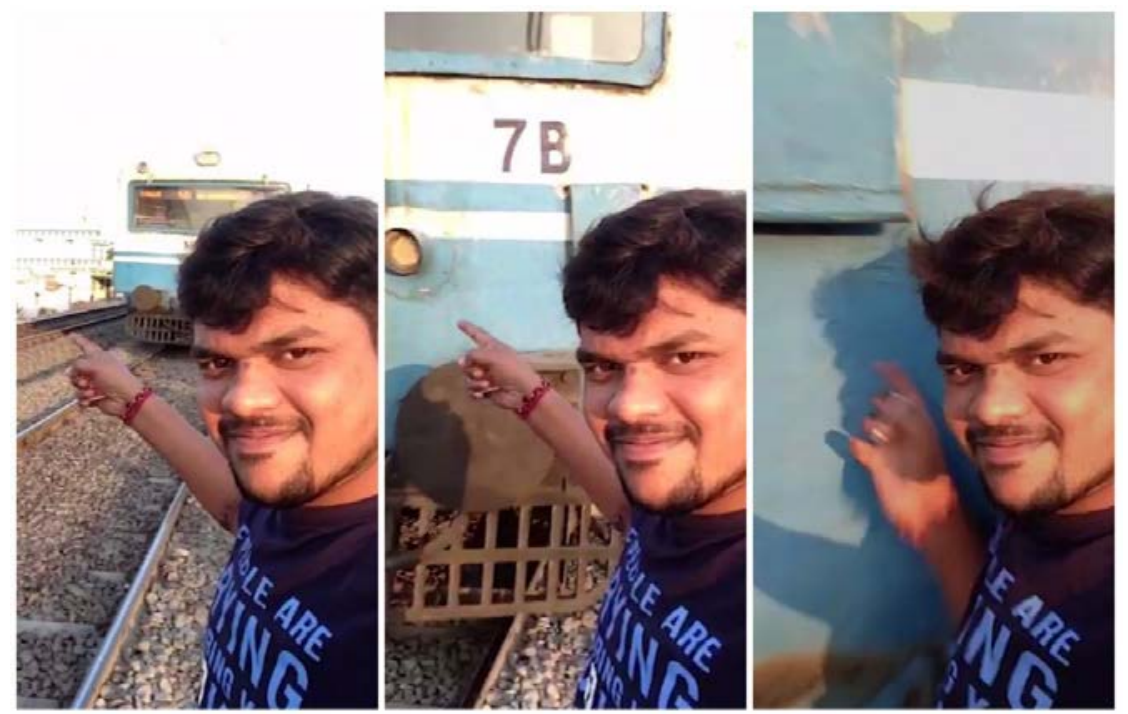

Figura 135. Secuencia de imágenes del accidente de Shiva.

En Enero de 2018 un joven que responde al nombre de Shiva decidió posar junto a las vías del tren en la localidad de Hyderabad, India ${ }^{341}$. El joven esboza una sonrisa mientras un tren se acercaba hacia el a gran velocidad. Como podemos ver incluso señala el objeto de su decidido intento de captar este instante efímero, sin embargo el no para de mirarse a sí mismo. El tren finalmente impacta contra el, pese a los denodados intentos del maquinista por avisarle. Afortunadamente Shiva solo resulta malherido y se recuperó de este fatal y previsible impacto. Podríamos ver el percance que Shiva sufrió como un simple accidente, consecuencia de factores como la búsqueda de popularidad en base a la imitación de una cultura de las celebrities, que ha llegado a transformar a individuos en productos de marca. Sin embargo, si profundizamos aún más en este acontecimiento podemos observar algo aún más revelador. Shiva utiliza su terminal móvil como espejo que le devuelve la imagen de un tren que se acerca, sin embargo, esto no parece alertar al joven,

341 Park, Victoria, Man hit by train in quest for perfect selfie, BBC News, [en línea], 2018, [consulta 25 de Enero de 2018] disponible en <http://www.bbc.com/news/world-asia-india-42815483> 
el cual parece estar tan cautivado por su propia imagen que no ve venir el peligro que avanza hacia el. Marshall McLuhan afirmaba que miramos el presente a través de un espejo retrovisor, mirando los nuevos entornos tecnológicos a través de los anteriores, generando una desorientación total en cuanto a las cualidades y características del nuevo. Sin duda un elemento tecnológico anterior como la videocámara era ajena a este tipo de prácticas y potenciaba un uso radicalmente diferente de la imagen, desconectada de la inmediatez y sociabilidad de las redes. Como decía McLuhan en su obra El medio es el masaje: "Miramos el presente en un espejo retrovisor. Entramos en el futuro retrocediendo. El suburbio vive imaginativamente en una tierra de bonanza" 342. Esto que parece un hecho aislado se ha convertido preocupantemente en una tendencia en la India, donde 76 personas murieron de esta manera durante el periodo comprendido entre 2014 y 2016 , el 60\% de las muertes a nivel mundial. Esto ha hecho que el gobierno de este país tome medidas estableciendo zonas peligrosas para este tipo de prácticas en diferentes ciudades ${ }^{343}$.

En EEUU es común la práctica de realizar selfies con diferentes tipos de armas de fuego. Esto ha provocado disparos accidentales que en algunos casos han costado la vida a ciudadanos de este país. Sin embargo, también ha ayudado a detener a delincuentes como Jules Bahler el cual publico su foto en Facebook portando un arma después de atracar un banco ${ }^{344}$.

\footnotetext{
342 McLuhan, Marshall, Fiore, Quentin, op. Cit., 1997, p. 75.

343 Coffey, Helen, India has the highest number of selfie deaths in the world, Independent, [en línea], 2017, [consulta 25 de Enero de 2018] disponible en

$<$ https://www.independent.co.uk/travel/news-and-advice/india-selfie-deaths-highestnumber-priti-pise-marine-drive-instagram-a7827486.html>

344 Coffey, Helen, The most dangerous selfies ever taken, from the Grand Canyon to an active volcano, Independent, en línea], 2017, [consulta 25 de Enero de 2018] disponible en $<$ https://www.independent.co.uk/travel/news-and-advice/most-dangerous-selfies-bearvolcano-grand-canyon-gun-christ-the-redeemer-a7678901.html>
} 


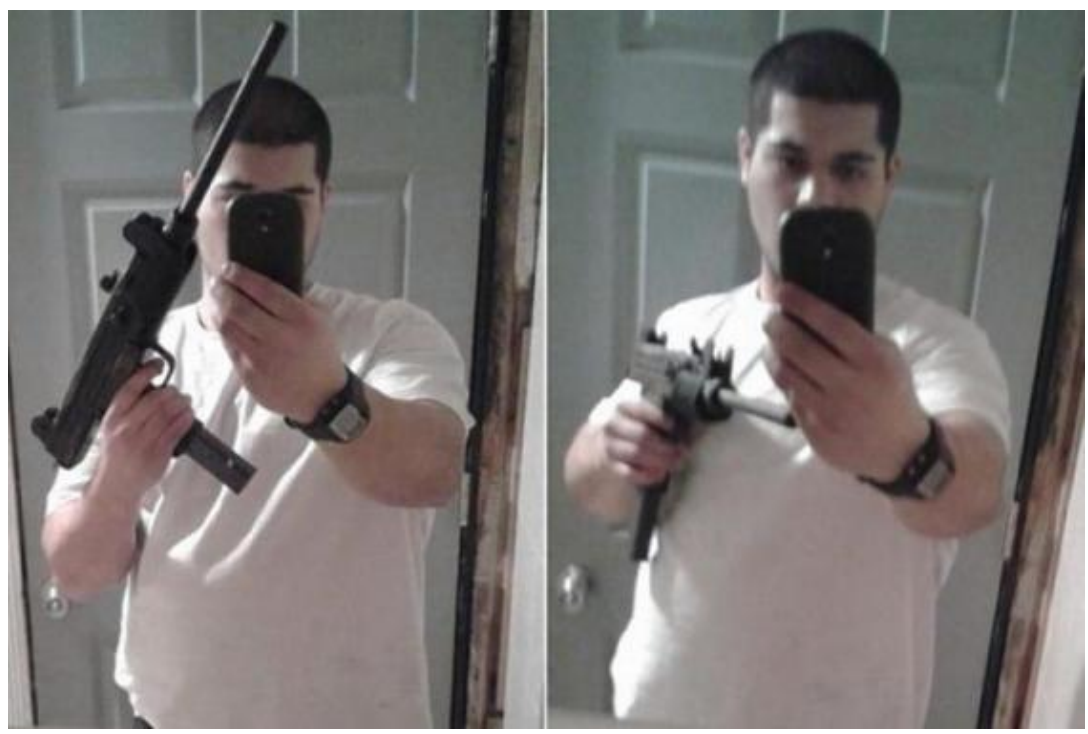

Figura 136. Foto publicada por Jules Bahler antes de su detención.

Otro caso bastante llamativo es la prohibición del conocido como palo selfie dentro de las plataformas de tren en Japón, ya que como las autoridades parecen argumentar, molesta a otros usuarios y puede generar multitud de situaciones peligrosas, como electrocuciones o choques con el propio tren. Por este motivo las autoridades recomiendan un uso convencional de los terminales móviles que no represente un peligro para el usuario, resto de público o las instalaciones mismas. Con este misión se ha popularizado una amplia gama de señalética que tiene la misión de alertar sobre el peligro que representa esta actividad.

No podemos hablar de las prótesis móviles como único factor, sino que son las aplicaciones de la Web 2.0 y la conexión permanente los vértices que conforman este tipo de comportamiento. Plataformas como Instagram, hace años, incentivaron mediante sus algoritmos de posicionamiento herederos de la cultura del ranking 345 que empresas como Google comenzaron, un tipo de sistema que selecciona las imágenes que aparecerán al consultar los nuevos feeds publicados, generando un caos respecto al anterior sistema cronológico. Esto hizo que los usuarios reclamaran una vuelta a este sistema que parece

345 Puig Punyet, Enric, op. Cit., 2017. 
haberse reinstaurado casi plenamente ${ }^{346}$. Actitudes y tipologías de imágenes son repetidas miméticamente por toda una horda de fotógrafos amateur. Estos medios generan la sensación artificialmente construida de que diferentes personalidades son realmente mucho más importantes de lo que realmente son, generando comportamientos narcisistas en la edad adulta que podríamos calificar como un desorden de personalidad. Esto se ha venido a denominar como "narcisismo situacional adquirido" 347.

Por lo tanto estamos generando toda una multitud de usuarios que han dejado de mirar a los demás para, como hemos podido apreciar, mirarse únicamente a si mismos, cautivados por el registro especular que les devuelve su terminal móvil en forma de su propia presencia, imágenes, publicaciones y historias que conforman una narrativa propia, las cual es generada como alimento de este tipo de estructuras mediáticas. Como hemos podido observar anteriormente, y Instagram no es una excepción, este tipo de redes sociales se valen de la actividad de los usuarios para generar el contenido que rellena este tipo de plataformas, las cuales de otro modo aparecerían vacías. Como diría Remedios Zafra 348 estas imágenes habituales y homogéneas parecen intentar parecerse a otros cuya imagen recorre nuestra mente, renunciando a nosotros mismos como sujetos a favor de la copia. Esto es lo que Zafra define como una suerte de diferentes coreografías, que nos intentan conducir a ser otros originales, pero que solo consiguen llegar a ser lo mismo. Estas imágenes no son una muestra de nuestro yo, el cual aparece oculto bajo un estereotipo que invisibiliza nuestra verdadera impronta y que queda registrado como registro especular. Este tipo de producción mediática es creada con la intención de ser difundida dentro de las redes, saliendo del tradicional ámbito privado de la fotografía.

\footnotetext{
346 Rus, Rebeca, Instagram recupera el feed cronológico (o casi) que tanto habíamos echado de menos, Trendencias.com, [en línea], 2018, [consulta 25 de Enero de 2018] disponible en $<$ https://www.trendencias.com/redes-sociales/instagram-recupera-el-feed-cronologico-o-casique-tanto-habiamos-echado-de-menos $>$

347 Crompton, Simon, All about me, HarperCollins, Londres, 2007, p. 171.

${ }^{348}$ Zafra, Remedios, op. Cit., 2015, p. 48.
} 
Por otro lado, autoras como Gemma San Cornelio ${ }^{349}$ apuestan por un distanciamiento de este discurso narcisista para recalcar las capacidades socializantes y narrativas de este tipo de autorretrato, basadas en su estatus de objetos comunicativos que construyen narrativas personales dentro de las redes. Este punto de vista no está basado en la propia imagen aislada, sino que debemos mirar más allá para poder observar un relato homogéneo, constituido por una serie de imágenes que en conjunto generan un relato unitario y coherente. Este tipo de cualidad narrativa ya fue relacionada con las propias características del desarrollo de la identidad personal en las redes por autoras como Sherry Turkle ${ }^{350}$ durante la primera época de la comercialización de Internet, generando uno de los primeros análisis sobre este tipo de fenómenos. Sin embargo podemos afirmar que no todo en Instagram son selfies, repetición, copia y narcisismo, pese a lo icónico y difundido de esta idea. Las narrativas generadas por lo usuarios incluyen todo tipo de elementos que contrastan con este uso espectacularizado de la imagen, generando narrativas personales basadas en todo tipo de elementos y lugares.

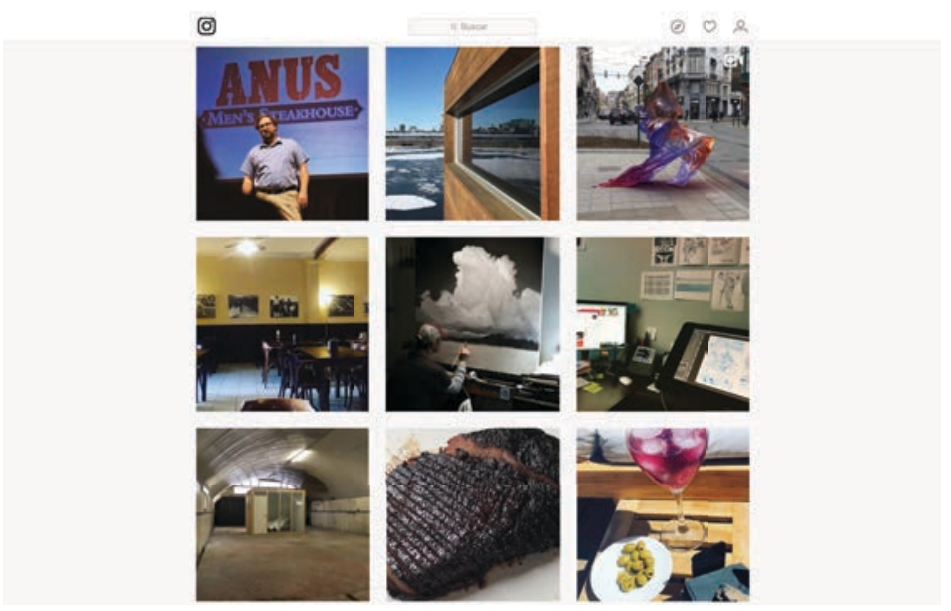

Figura 137. Imagen del feed de Instagram con imágenes publicadas por diferentes usuarios.

\footnotetext{
${ }^{349}$ San Cornelio, Gemma, Roig, Antoni, Ardevol, Elisenda, 2017, Selfies y eventos culturales: metodologías híbridas para el estudio del selfie en contexto, Josep Maria Carbonell, Reality and screen: a postmodern mirror IX International conference on communication and reality, Universidad Ramón Llull, Barcelona.

${ }^{350}$ Turkle, Sherry, op. Cit., 1997.
} 
Un claro ejemplo de este tipo de usos son los foodies o "comidistas", palabra que sirve para designar a los aficionados a la comida y la bebida, y para los cuales Instagram es el espacio perfecto donde publicar todo tipo de hallazgos y creaciones culinarias. Sin embargo, este tipo de usuarios no quedan exentos de la actitud competitiva heredera de la cultura del ranking que esta aplicación potencia. Del mismo modo se podrían categorizar multitud de tipologías de usuarios dentro de los amantes de los viajes, el deporte, los animales y la moda, entre otros. Todos ellos son fácilmente identificables, sin embargo también podemos observar como todos estos contenidos se hibridan y superponen en narrativas que presentan todo tipo de tipologías, en cuanto al contenido que nos presentan, generando una complejidad bastante mayor de la que podíamos esperar de una red social que tiende a generar estereotipos en base a la imagen mediática de la celebrities.

Sin duda todos estos elementos son tremendamente útiles para dar coherencia a uno de los patrimonios más valorados en este tipo de redes, que no es otro que la capacidad de llevar una crónica particular. Precisamente mediante la funcionalidad de "historias" es donde podemos apreciar que la narratividad adquiere un papel más preponderante, generando hilos narrativos en los cuales elementos como le tiempo, el lugar, los personajes o elementos aleatorios definen el tipo de historia que los usuarios pretenden desarrollar. Sin embargo los selfies o otras tipologías fotográficas no quedan fuera de esta intención comunicativa de los usuarios, que pueden funcionar como pequeñas historias a modo de fugaces pinceladas biográficas.

Explorando Instagram como ecosistema mediático podemos observar como muchas de las imágenes que encontramos responden a diferentes patrones bien establecidos dentro de la propia historia de esta plataforma, sin embargo, estas quedan oscurecidos ante el vendaval de nuevas funcionalidades que esta aplicación está empezando a desarrollar. Podemos observar nuevas publicaciones promocionadas y enlaces clicables en los contenidos, como elementos de pago dentro de esta red social. Por otro lado, la funcionalidad de shopping que permite etiquetar productos dentro de las imágenes, incluyendo su precio y nombre, también parece haber empezado a desarrollarse dentro de Instagram. 
Otra de las grandes metas de esta plataforma es transformarse en la home page de diferentes negocios, mediante una estetización constante de los contenidos publicados. Este tipo de uso de las redes sociales ha generado lo que se denomina como influencers, como usuarios que logran congregar a una gran cantidad de seguidores en torno a ellos, hasta el punto de que son contratados para promocionar productos o servicios dentro de su producción en esta aplicación. Este tipo de usuarios no son realmente famosos por que realicen algún tipo de actividad profesional destacable, sino que su propia presencia en las redes y su actividad dentro de ellas es la que ha generado su popularidad y éxito como lideres de opinión online.

Por otro lado, los micro-influencers son usuarios que pese a su no tan grande numero de seguidores resultan más confiables y cotidianos para estas comunidades. El hecho de la utilización comercial de este tipo de redes sociales ha generado una gran preocupación por los cambios en el algoritmo de Instagram, ya que de una comprensión adecuada de su funcionamiento depende el éxito de las estrategias de marketing digital desarrolladas dentro de esta red social.

Si anteriormente observamos como los medios construyen una visión hegemónica de nuestro entorno y de los conflictos que tienen lugar en el mediante la construcción de una mirada mediada por imágenes, también podemos afirmar que en la actualidad gracias a la consolidación de las redes sociales como espacios de exposición y construcción de un relato propio, es el individuo el que se afirma dentro de la expresión de un yo que demanda representarse a si mismo. Como vimos, nuestra mirada es capaz de intervenir sobre el mundo añadiendo y eliminando elementos, y creando relaciones que construyen nuevos significados. Mediante las herramientas de producción y difusión de las aplicaciones sociales y las tecnologías de la imagen, la creación de miradas está al alcance del público en general. Obras como Canal Gitano de Antoni Abad pusieron de manifiesto como la difusión de las tecnologías de la comunicación y la información han revolucionado mediante la imagen digital, la conectividad constante y las tecnologías móviles la manera mediante la cual podemos mantener el compromiso con la expresión de una perspectiva personal generadora de comunidad. 


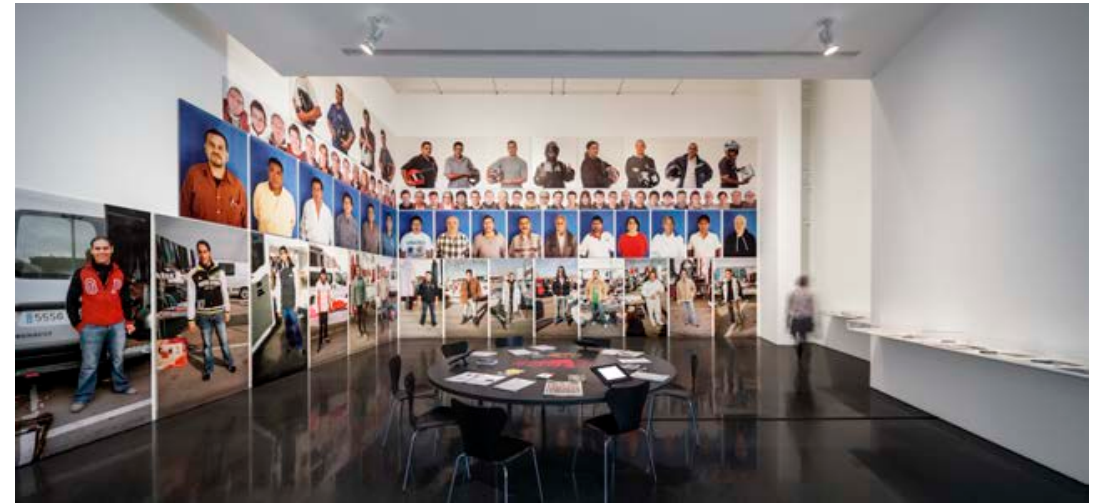

Figura 138. Antoni Abad, Canal Gitano en el MACBA de Barcelona, 2014.

Por otro lado, el espacio expositivo de la pantalla de nuestros terminales nos ha transformado en Narcisos, perplejos ante nuestra propia imagen especular conformada como un reflejo de nuestras pretensiones y construcción indentiraria, dentro del fluir comunicacional generado en la cotidianidad de millones de usuarios. Esta amplificación de nuestra presencia en forma de imágenes, videos y retrasmisiones en directo nos convierte en individuos inconscientes ante la manera en la cual estas tecnologías nos modelan en base a su funcionamiento. Pese a su gran importancia tendemos a centrarnos en el contenido de estos espacios y no en la propia estructura del mismo, obviando por lo tanto el poder de la misma sobre el tipo de narrativa e interacciones que desarrollamos. Es por ello que es especialmente necesario un redirección de nuestra mirada, no hacia el tipo de contenidos y narraciones que conforman este tipo de espacios, sino hacia la propia estructura en si.

Desde una perspectiva de genero podemos afirmar que el selfie parece condensar gran parte de la normatividad social e imaginario que producen estereotipos femeninos que dan poder a la autoridad patriarcal. Es aquí donde podemos apreciar el poder de las herramientas virtuales en base a la impronta que imprimieron sus creadores, normativizando el comportamiento de los usuarios, y en especial el de las mujeres jóvenes. Como ya vimos, la obra de la artista argentina Amalia Ulman titulada Excellences \& Perfections ${ }^{351}$, de 2014, fue desarrollada durante cuatro meses en la cuenta de Instagram de la artista.

${ }^{351}$ http://webenact.rhizome.org/excellences-and-perfections 


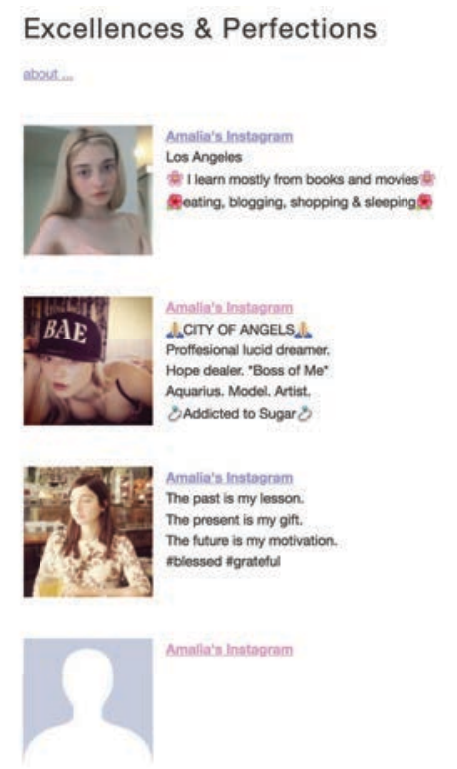

Figura 139. Web del proyecto Excellences \& Perfections, donde podemos ver sus diferentes partes.

En este proyecto Ulman fabricó un personaje ficticio cuya historia es desarrollada en tres episodios diferentes. Cada fase del proyecto se caracterizó por la interpretación de tres roles diferentes por parte de la artista, por un lado cute girl o chica bonita, sugar baby o joven mantenida por su amante, y life goddess o diosa de la vida. Ulman desarrolló estos tres personajes como reflejo de las tendencias más populares para representar a la mujer en la red. Durante los cuatro meses que duró este proyecto la artista desarrollo todo tipo de relatos truculentos a través de esta cuenta acumulando 88.906 seguidores al terminar este. Fingió haber aumentado su pecho publicando imágenes de ella en un hospital con bata. Posteriormente manipuló sus imágenes para que el público creyera esta historia. Mediante el uso de escenarios y ubicaciones muy cuidadas, este proyecto evocó un estilo de vida de fantasía basada en el consumismo más desaforado. Durante todo el proyecto Ulman generó todo un catalogo de imágenes donde aparecían flores cuidadosamente escogidas, elementos asociados al lujo, como vestidos y ropa interior cara. Estas imágenes son perfectamente creíbles y familiares pese al exceso, llevándonos a un terreno ampliamente desarrollado por multitud de usuarios privilegiados que construyen su propia marca. Este tipo de actividad 
hizo difícil distinguir, incluso a sus propios familiares y amigos, de que se trataba este tipo de nueva personalidad que la artista estaba desarrollando de manera inesperada en las redes, hasta el punto que gente del mundo del arte se preocupó por ella. Pese a que nos encontramos en un momento donde los medios tradicionales han visto disminuido su poder a favor de las redes, estas siguen reflejando y reproduciendo los valores culturales de las esferas del poder. En esta obra por tanto Ulman hizo que durante la duración del proyecto las redes le dijeran como debía mostrarse siendo objeto de proposiciones vulgares, comentarios ofensivos o criticas por promover estos estereotipos.

Podemos ver como Ulman trata sobre la identidad online y offline, mientras critica nociones como autenticidad y anonimato. Su intención era mostrar a la audiencia lo fácil que resulta manipular a una audiencia en base a contenido ficticio y arquetipos previamente asentados en la sociedad. Durante este proyecto Ulman muestra todo tipo de selfies tomados en hoteles de lujo y desayunos en habitaciones bellamente decoradas que interpelaban a una audiencia habida por ver este tipo de contenidos. Lo que no era tan evidente eran los marcados roles de genero presentados en este proyecto que del mismo modo se acomodaban a una heteronormatividad de la que las redes son también participes. Sin duda la gramática cultural, también presente en las redes, construye y mantiene roles de genero, también alrededor del tipo de representación que realizamos de nosotros mismos.

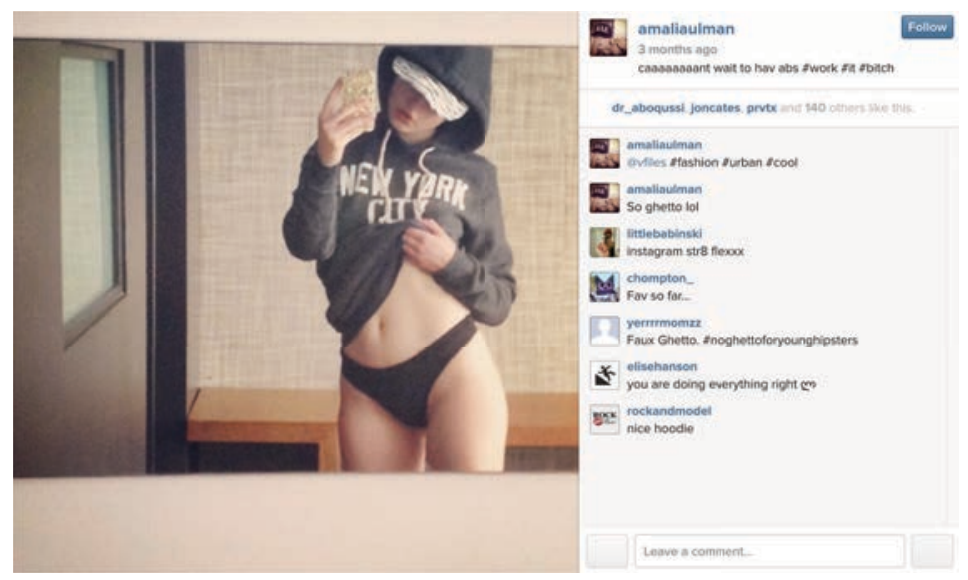

Figura 140. Imagen extraída de la cuenta de Instagram del proyecto Excellences \& Perfections. 
Esta materialidad esta basada en la virtualidad de estos espacios, donde somos permanentemente construidos por los flujos de información que nosotros mismos producimos y la potencialidad que los datos posibilitan. Estas imágenes son editables, transmisibles, disponibles permanentemente, fáciles de compartir y reutilizables. Estos son espacios de exposición en los cuales todos podemos acceder a las memorias personales de otros usuarios. Internet finalmente, debido a las herramientas hegemónicas de la Web 2.0, se ha convertido en una espacio que lo contiene todo, que promete encontrarlo todo y que lo archiva y preserva. Sin embargo como ya vimos, el último paso en esta evolución es imágenes que ya no son creadas por humanos y para humanos, sino que son leídas e interpretadas como mera información por maquinas mediante los algoritmos, los sistemas de reconocimiento automático y las tecnologías biométricas en incipiente desarrollo. La imagen desprendida de su capacidad de reflexión de la luz solo es legible por máquinas en forma de información que no necesita de ningún tipo de soporte para ser contemplada.

Sin embargo, los diferentes tipos de experiencias narrativas basadas en imágenes que podemos encontrar en la red han sido desarrolladas dentro de lo que denominamos capitalismo cognitivo, como una economía en la cual la producción y distribución de conocimiento es la principal apuesta del capital para genera valor añadido. Como pudimos ver, mediante la combinación del trabajo cognitivo cultural y tecnologías digitales se genera valor en base a nuestras prácticas cognitivas y afectivas mediante lo que Maurizio Lazzarato denominó trabajo inmaterial, las cuales quedan ampliamente representadas en el tipo de intercambios, narrativas y constructos generados en plataformas como Instagram. Por otro lado Michael Hardt y Antonio Negri352 ya nos hablaban mediante el concepto de affective labor, de nuevas formas de producción económica hegemónicas basadas en la mezcla de la tecnología y afectividad, que generan valor añadido en el campo de la relaciones sociales. Teóricos como Tiziana Terranova ${ }^{353}$, entre otros, elaborarán la formulación del concepto de digital labor o trabajo digital. Apunta hacia una fascinación por el atractivo y encanto que transmite este tipo de actuar, en base a una

\footnotetext{
352 Hardt, Michael, Negri, Antonio, op. Cit., 2004, p. 136.

353 Scholz, Trebor, op. Cit., 2013, p. 46.
} 
degradación del trabajo intelectual, algo que parece muy palpable si tenemos en cuenta la popularización de la cultura de las celebrities que los medios han alimentado y difundido para su propio beneficio, debido al rédito que esto les proporciona en forma de audiencia fiel y maleable.

Como hemos visto, la popularización de las celebrities dentro de las redes han convertido estas aplicaciones en espacios donde seguir la narrativa generada por este tipo de personalidades, lo que a su vez ha generado toda un cultura ampliamente imitada por una gran masa de usuarios. Sin embargo, no constituyen el grueso de la actividad en estos espacios, pese a su gran eco mediático. Como vimos las tecnologías de la Web 2.0 han puesto al alcance del gran público multitud de herramientas y aplicaciones que forman parte de nuestra cotidianidad al estar insertas en lo social.

Este tipo de practicas creativas han sido analizadas de manera crítica por Andrew Keen en su obra The cult of the amateur. En ella Keen hace un análisis de los procesos participativas generados por la Web 2.0, y de cómo estas afectan a diferentes áreas como la creatividad, economía e innovación. Keen pone el foco en la manera en la cual instituciones tradicionales como el cine, la prensa o la música, han sido reemplazadas por una ingente cantidad de producción gratuita. Sin duda, y tal como apunta Joan Fontcuberta vivimos en una cultura del exceso y la sobreproducción de imágenes, que las redes ponen en circulación a una velocidad nunca antes vista, pero que también tiene su origen en la omnipresencia de las cámaras que hipertrofian nuestro imaginario con millones de fotografías y videos que nos saturan, y precisamente por su exceso, nos impiden ver las imágenes que faltan, las de una memoria realmente necesaria por su poder para repensar nuestra mundo y a nosotros mismos.

Tal y como nos cuentan investigadores como Nicholas Carr en su obra Superficiales, el cerebro humano posee características plásticas que modulan las percepción de los estímulos del medio, dentro de lo que ha venido a definirse como plasticidad neuronal o neuroplasticidad. En este contexto Internet es "la última de una larga lista de herramientas que han ayudado a moldear la mente humana"354. Según Carr, las tecnologías de Internet hacen

${ }^{354}$ Carr, Nicholas, op. Cit., 2017, p. 150. 
que tendamos a analizar superficialmente la información debido a la perdida en nuestra capacidad de concentración, contemplación y reflexión, dentro de una disolución de la mente lineal que ya predijo McLuhan. Precisamente cuando este afirmaba que el medio es el mensaje estaba hablando del poder transformador de las nuevas tecnologías de la comunicación y del poder que ejercen sobre la sociedad a la vez que advertía sobre las consecuencias de estas tecnologías. Del mismo modo, entendió que la aparición de un nuevo medio hace que nos centremos en el contenido, en la propia información que suministra ese medio, mientras que este permanece invisible ante el fluir comunicativo del propio medio. Por lo tanto, lo que McLuhan logró vislumbrar en realidad es que a largo plazo, pese a la tremenda potencialidad que despliega en los campos de la comunicación y la creatividad, es el medio el que influye de manera más importante en nuestros pensamientos y actos, en el sentido que modela lo que vemos y la manera en la cual lo vemos, alterando de manera continuada nuestra percepción sin resistencia alguna por nuestra parte. En un mundo donde las pantallas han sustituido al papel como soporte, las nuevas aplicaciones sociales aniquilan nuestras dudas mediante la comodidad y las pequeñas recompensas que otorgan, haciendo que resulte desechable la idea de reflexionar sobre la manera en la que nos modelan, debido a lo placentero de nuestra actividad en las mismas.

Las estructuras mediáticas delimitan la manera en la cual realizamos una representación de nosotros mismos. Sin embargo, este tipo de aplicaciones tienen el poder se permanecer invisibles para el gran público redirigiendo nuestra mirada hacia la producción que nosotros mismos, como usuarios, realizamos. Como hemos visto la configuración de las formas de lo que vemos en la red depende en gran medida de la relación desarrollada entre "fondo y figura", es decir entre las estructuras mediáticas conformadas como ecosistema dentro de Internet, y por otro lado las figuras como los contenidos producidos por los usuarios de este medio. Generando un paralelismo con lo que nos cuenta William J. T. Mitchell en su libro Image Science 355 . En el caso de Instagram podemos apreciar como las diferencias de clase, la estratificación social y las relaciones de poder son elementos que quedan autorepresentados en base a la imitación de la estética de la clase media/alta.

\footnotetext{
355 Mitchell, William J. T., Image Science, The University of Chicago Press, London, 2015, p. 11.
} 
Como hemos podido comprobar, las tecnologías móviles han pasado a posicionarse como autenticas extensiones de nosotros mismos, conformando, gracias a la conectividad constante, una nueva dimensión de nuestra realidad. Del mismo modo, ha hecho posible un incremento de la producción de contenidos basada en la inmediatez, que a su vez ha modificado el rumbo del desarrollo tecnológico hacia funcionalidades y características que amplifican y potencian nuestras capacidades creativas, basadas en el potencial de lo audiovisual en el contexto de la producción mediática social. Esto ha generado centros de producción, edición y distribución que caben en la palma de nuestra mano, y que han cambiado el esquema comunicativo tradicional a favor de una gran masa de usuarios que intercambian todo tipo de contenidos constantemente.

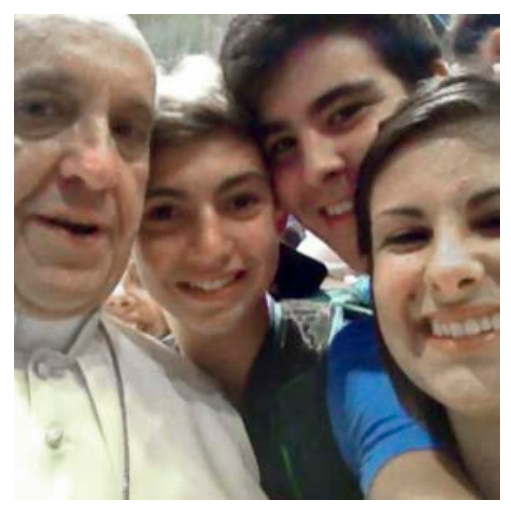

Figura 141. Su Santidad el Papa Francisco tomándose un selfie.

Como punto de partida de esta parte de la investigación se presenta la posibilidad de explorar las posibilidades expresivas de las propias aplicaciones de la Web 2.0, en este caso la red social Instagram, especializada en la publicación de fotografías tomadas generalmente mediante nuestro teléfono móvil. Esta aplicación se ha convertido en una herramienta hegemónica para la publicación de imágenes en la red, en parte por la generalización de su uso en segmentos de la sociedad muy activos en redes sociales y donde la cultura del autorretrato o selfie se ha convertido en una actividad relacionado con nuestra vida diaria y mediante la cual transmitir nuestra presencia. 
Como exploradores mediáticos nos dispusimos a experimentar el propio funcionamiento de la aplicación mediante un proceso de trabajo llevado a cabo, debido a la naturaleza de la propia aplicación, tanto dentro como fuera de las redes. El propio actuar del usuario dentro de las redes genera una visión panorámica de los procesos que tienen lugar dentro de esta aplicación y de cómo afectan a la imagen y el tipo de miradas que se producen. Mediante el entrecruzamiento de lo social, el software y la red se configuran estas estructuras mediáticas que causan un impacto considerable en lla vida de muchos de sus usuarios.

La producción de imágenes como parte constitutiva de nuestra vida diaria alimenta una "identidad narrativa" escenificada dentro de las redes sociales mediante conductas exhibicionistas que buscan una afectividad escenificada y artificial que se naturaliza como real dentro de Internet. La cultura de las celebrities han posicionado estas prácticas como un signo de estatus que legitima la pertenencia a una comunidad. Dentro de esta cultura de la acumulación y el exceso nos propusimos subvertir el propio valor cultural de estas imágenes mediante la apropiación de una fotografía realizada por una de estas celebridades, en este caso su santidad el Papa Francisco o Jorge Mario Bergoglio por su nombre secular. La fotografía en cuestión, tal y como recoge el artículo de Harriet Alexander para The Telegraph ${ }^{356}$, nos muestra el considerado como primer selfie tomado a un Papa de la Iglesia Católica. Este tuvo lugar en una audiencia privada con el pontífice cuando se encontraba rodeado de jóvenes. Más de quinientos de estos jóvenes realizaron una peregrinación desde las diócesis de Piacenza y Bobbio situadas a 80 kilómetros de Milán, con el fin de conocer al pontífice. La imagen se convirtió en viral a mediados de 2013 al ser difundida por diferentes medios de comunicación y redes sociales. Fue tomada por el smartphone de uno de los jóvenes extendiendo su brazo para encuadrar a todos los participantes en la instantánea, la cual fue inmediatamente publicada en redes sociales. Como curiosidad, podemos destacar que desde ese momento parece que esta práctica se convirtió en algo habitual, si tenemos en cuenta que años después el canal italiano RAI-3 preparó un documental para televisión titulado Un selfie con il Papa, en el cual las personas que tuvieron la oportunidad de

\footnotetext{
${ }^{356}$ Alexander, Harriet, Pope Francis and the first "papal selfie", The Telegraph [en línea], 2018, [consulta 25 de Enero de 2018] disponible en <http://www.telegraph.co.uk/news/worldnews/thepope/10277934/Pope-Francis-and-the-first-Papal-selfie.html>
} 
fotografiarse con el sumo pontífice podían subir sus fotografías y videos a la web de producción del documental, tras lo cual el material más destacado sería seleccionado para formar parte del montaje final.

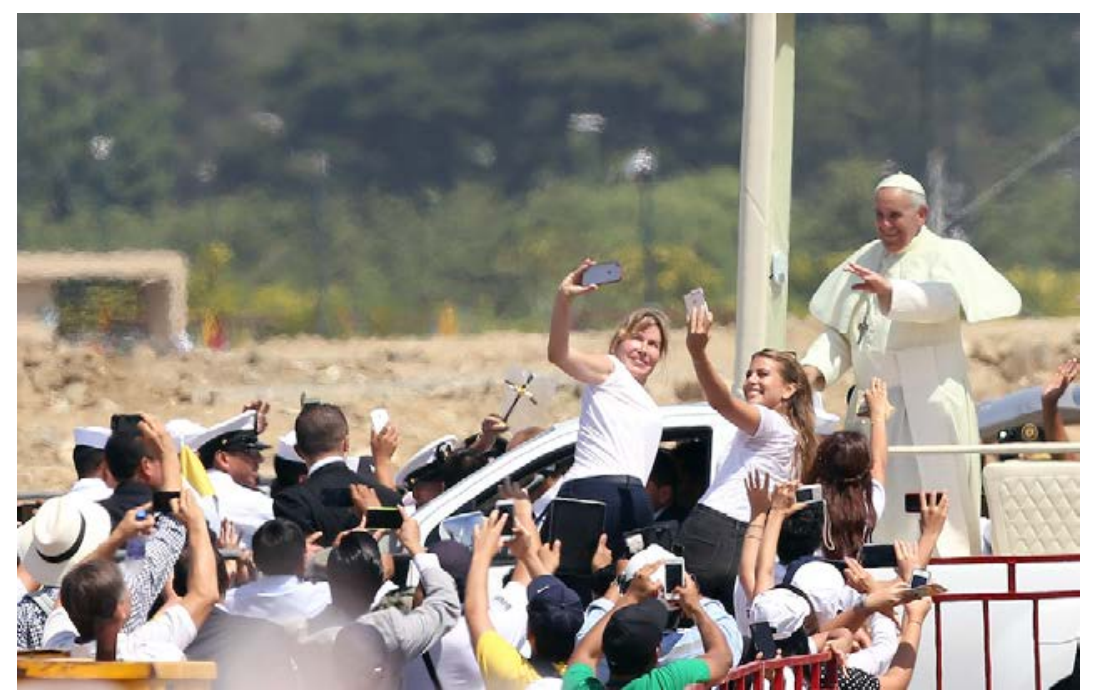

Figura 142. Multitud fotografiándose con su Santidad en Guayaquil, Ecuador, 2015.

Volviendo a la audiencia papal, el Papa realizó un discurso donde afirmaba "Ustedes son portadores de esperanza. Ustedes, de hecho, viven en el presente, pero miran hacia el futuro. Ustedes son los protagonistas del futuro, los artesanos del futuro". Seguramente el Papa Francisco no pensaba en el papel de la imagen y el estatus del trabajador digital dentro del capitalismo cognitivo, ni de cómo dentro de las redes la viralización y mutación de diferentes materiales que son transformados y reciclados por los artesanos de lo digital va a conformar nuevos significados e interpretaciones. Pero sin duda, podemos afirmar que dentro de las redes se ha gestado un nuevo tipo de artesanía asociada a la provisionalidad y temporalidad de materiales recogidos de la red, como productos del fluir comunicativo de las redes. Sin embargo, aquí la reutilización de esta imagen realizada por unos jóvenes nos plantea la reutilización de una fotografía producida y difundida desde los medios hegemónicos, que es sacada de su contexto para ser reubicada dentro de un proyecto artístico. De la misma manera que el détournement, usado por los situacionistas secuestraba objetos o imágenes producidas desde el capitalismo o el poder político dominante y hegemónico para distorsionar su 
significado, la apropiación de esta imagen plantea de manera implícita la posibilidad de otorgar un valor cultural a un producto de los medios hegemónicos cuya finalidad es la de dar fe de un hecho, de lo acaecido en un momento determinado dentro de la vida de un grupo de jóvenes, de aumentar la presencia de estos en la redes y de generar un relato asociado a un representante del poder político y religioso de gran importancia para millones de personas en todo el mundo.

Como hemos visto el actuar en la red se comporta como un elemento que vertebra nuestra experiencia dentro de las aplicaciones sociales más populares. Podríamos decir que las estructuras mediáticas modelan un determinado tipo de comportamiento e interacciones que revierten en la manera en la cual usamos y vivimos en los media, cambiando la manera mediante la cual nos representamos y relacionamos. Sin embargo los medios por su carácter ambiental tienden a ser difícilmente identificables y analizables en cuanto a sus efectos, dirigiendo nuestra atención hacia la gran producción de comunicacional que estos despliegan sobre la multitud y que esta despliega sobre si misma en base a el ansia por representarse y asumir una narrativa autobiográfica propia dentro de las redes.

Como consecuencia a toda esta investigación anterior, decidimos abrir una cuenta de Instagram ${ }^{357}$ seleccionar la imagen del Papa Francisco rodeado de jóvenes y realizar una primera publicación en la cual la imagen aparecía tal y como su autor original la publicó. Seguidamente nos dispusimos a trabajar sobre que tipo de intervención podía realizar en base a las posibilidades de este espacio. Sin duda se trataría de un táctica que desplegar para contrarrestar la propia estrategia que este espacio despliega sobre los usuarios. Michel de Certeau ${ }^{358}$ nos habla de un sistema donde la hegemonía de las elites como productoras de los medios de producción y la cultura despliegan estas sobre los ciudadanos. Sin embargo es el artista es el causante de los cambios en las dinámicas de los espacios en los cuales interviene, replanteando las relaciones de poder existentes y usando las propias herramientas mediáticas que emanan de las lógicas del sistema, como herramienta de cuestionamiento. Es por ello que decidimos revertir el

${ }^{357}$ https://www.instagram.com/luislisbona/

${ }^{358}$ De Certeau, Michel, op. Cit., 2000. 
funcionamiento de esta aplicación usándola de manera contraria a sus lógicas. Generando un proceso secuencial de desaparición de la imagen antes publicada, mediante la repetición de una acción que genera un proceso performativo basado en los propios mecanismos de producción de Instagram. Es decir, generar un efecto espejo infinito mediante el hecho de fotografiar la imagen subida y volver a subirla a esta red social.

Posteriormente, y como resultado inherente a este proceso, creamos una animación ${ }^{359}$ compuesta por las imágenes generadas por este proyecto. El bucle generado por este video nos habla de lo cíclico y repetitivo del los tipos de actuar generados en base a este tipo de aplicaciones, generando procesos repetitivos en base al comportamiento de las celebridades de Instagram. La fluidez de la red y el intercambio de imágenes e información esta relacionado con este tipo de animaciones GIF que pese a su larga historia dentro de Internet se han convertido en los últimos años en la lengua franca de muchos usuarios. Resulta interesante utilizar un tipo de tecnología reciclada y usada por la multitud para precisamente hablar de cómo la multitud se expresa y actúa en la red

\footnotetext{
${ }^{359}$ https://www.instagram.com/p/9jP6VFx9iU/?taken-by=luislisbona
} 

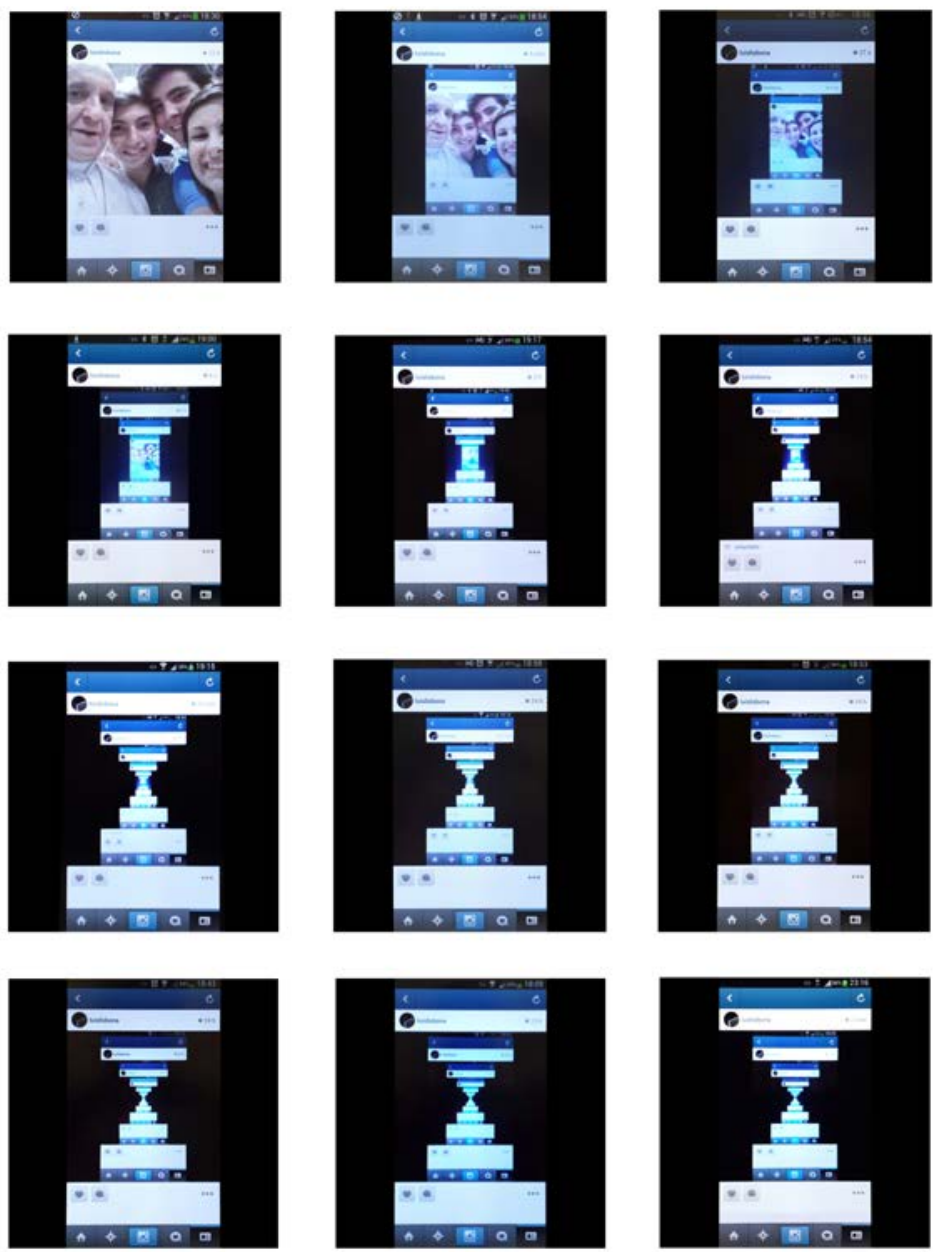

Figura 143. Secuencia que muestra toda la serie de imágenes realizadas durante el proyecto.

Esta obra muestra la evanescencia de las imágenes especulares que son publicadas diariamente en la redes, no como parte de un proceso químico o perdida de información sino como una práctica artística realizada desde el punto de vista del usuario y basado en la manera en la cual una determinada aplicación social vehiculiza nuestro actuar y participación en las redes. 
Este actuar basado en el secuestro y publicación de una imagen hegemónica, genera un proceso homologo al de los usuarios de esta aplicación. El objeto fotografiado, en este caso es la pantalla del ordenador que contiene la aplicación de Instagram con la fotografía apropiada anteriormente. Una vez ajustada y encajada mediante el propio software del teléfono móvil, esta vuelve a ser publicada. Vuelve nuevamente a ser fotografiada en la pantalla del ordenador y vuelta a publicar. Esto produce al realizarse repetidamente, la desaparición de la imagen, quedando como resultado la propia estructura mediática al desnudo, privada de contenidos personales y proyectada hasta el infinito dentro de un túnel constituido por la estructura de la aplicación de Instagram. Por lo tanto se trata de la propia desaparición de la imagen, como objeto en el cual proyectamos la construcción de nuestra identidad individual y como contenido generado para este tipo de aplicación. Esto hace posible visibilizar la estructura mediática que la condiciona.

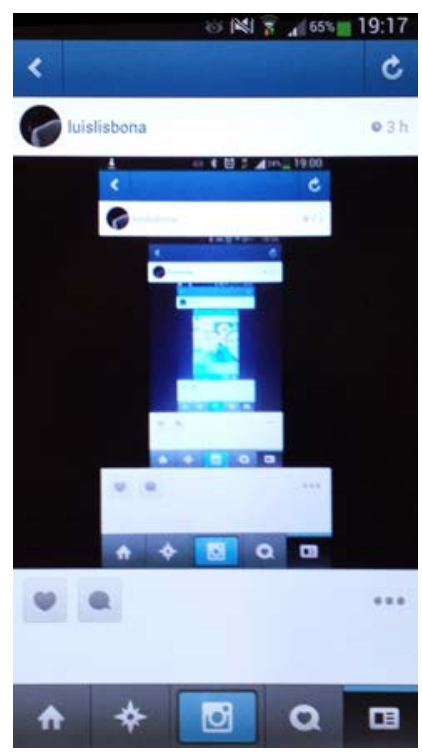

Figura 144. Una de las imágenes realizadas durante el proyecto.

El resultado estético es una imagen similar a la que podemos observar cuando ubicamos dos espejos enfrentados reflejando el uno al otro hasta el infinito ante la ausencia de ningún contenido o ser del cual generar una imagen especular. Como resultado de este proceso obtuvimos una serie de doce 
imágenes que ilustran este proceso de manera nítida. Sin embargo, utilizando los propios medios inherentes al intercambio y fluir comunicativo de las redes decidí generar una animación en forma de archivo GIF con esta serie, la cual se puede visualizar en la propia cuenta de Instagram en la cual se encuentra la serie de imágenes. El Graphics Interchange Format o GIF es un tipo de archivo utilizado ampliamente dentro de las redes, ya que sirve tanto para generar pequeñas animaciones en bucle como imágenes. La eficiencia de su algoritmo LZW le hizo ganar en popularidad a otros tipos de archivos ya en los años 80 del siglo XX. Es capaz de generar archivos de un tamaño reducido con una relativa perdida de calidad, y con hasta 256 colores que pueden soportar transparencias. Lo optimizado de su compresión lo convirtió en un tipo de archivo ideal para difundir rápidamente archivos en un momento en el cual la velocidad de conexión era mucho menor. Por otro lado, dentro de la primitiva Internet, tuvo un papel importante dentro del desarrollo de las primeras paginas web, al ser utilizado para la publicidad que podemos encontrar en los banners ya que es soportado por la mayoría de los navegadores. En los últimos años ha empezado a utilizarse como medio mediante el cual difundir rápidamente diferentes productos por sus características unidas a lo viral. Por otro lado las redes sociales han readaptado sus funcionalidades a este tipo de animaciones ante su gran difusión entre los usuarios, lo que ha provocado la aparición de repositorios y redes sociales exclusivamente dedicadas a este tipo de creaciones que se han posicionado como parte de la producción amateur que surge dentro de las principales aplicaciones de la Web 2.0, y que se ha instalado dentro de lo cotidiano como una de las formas de expresión relacionadas con la vida diaria, la viralidad y el reciclaje dentro de la red.

Sin embargo su papel dentro de la industria cultural no se limita a las redes sociales, ya que ha sido adoptado como un medio de expresión por multitud de artistas provenientes del arte dentro de la red, y que tras más de treinta años después de su creación como tecnología, lo han posicionado como un elemento tecnológico cercano a lo vintage. Desde mediados de la primera década del siglo XIX un gran número de artistas empezaron a reflexionar sobre las posibilidades de este recurso cinemático.

Michel de Certeau reconsideró mediante su obra el papel del consumidor dentro de la sociedad contemporánea, para ello reconceptualizó el papel del usuario, no como objeto pasivo y disciplinado, sino como individuo que mediante su habilidad para gestionar lo cotidiano, reelabora la relación entre 
producción y consumo. Realiza la búsqueda de intersticios mediante los cuales apropiarse del medio y poetizar sobre el orden dominante. Este es pues una "manera de hacer" e intervenir en la esfera de lo público que se vale de una producción invisible, silenciosa y astuta, para transformar los constructos propios de la industria cultural y la cultura de masas mediante su uso. Del mismo modo la posibilidad de reutilizar las aplicaciones de la Web 2.0 para cuestionar los efectos perceptivos de estas, se presenta como la oportunidad perfecta para elaborar una metodología que se valga del propio actuar del usuario de Instagram para generar una práctica artística que visibilice la estructura mediática de esta red social, lo que señala los efectos perceptivos y cognitivos que producen su evanescencia.

La inserción de las nuevas tecnologías como pilar fundamental de nuestra cotidianidad ha hecho posible que la virtualidad en la cual nos encontramos a diario sea uno de los aspectos más notables de nuestra actividad dentro de una supuesta esfera pública, que parece haber mutado alguna de sus características esenciales ante la omnipresencia de las redes. Esta es una actividad de la que nunca salimos debido a la conectividad constante. Podemos afirmar que vivimos con Internet, dentro de una relación imperecedera que nos conforma como individuos en base a nuestra actividad y el conjunto de relaciones que desplegamos dentro de nuestras redes, las cuales son valoradas cuantitativamente como un valor. La creatividad dentro de lo cotidiano impulsada por la Web 2.0. ha generado imágenes que ya no responden a las connotaciones ritualísticas del pasado, sino que debido a la versatilidad de lo digital y las redes se han posicionado como elementos que nos hablan de un presente sin memoria, ya que el fluir comunicativo borra todo recuerdo de lo publicado ayer. La cotidianidad de las imágenes las ha transformado en un medio de relacionarse con el presente inmediato. 


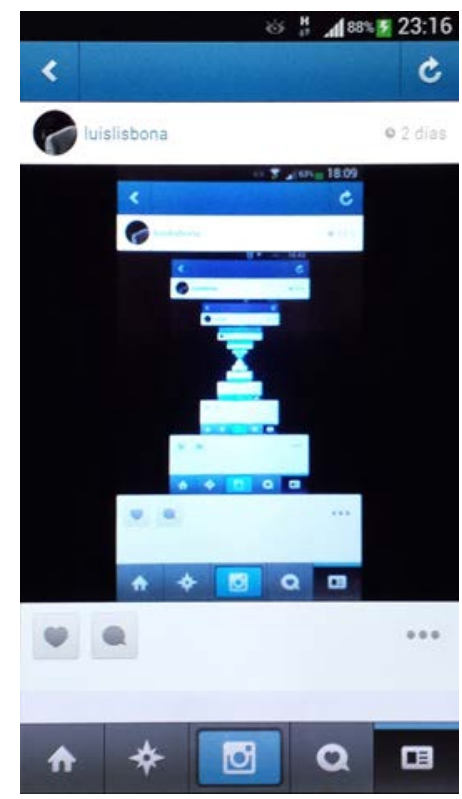

Figura 145. Última de las imágenes realizadas durante el proyecto.

Este actuar tiene como objetivo la visibilización de las propias estructuras mediáticas que modelan nuestro comportamiento y delimitan la manera en la cual nos representamos mediante imágenes, transformando la realidad en imágenes y las imágenes en realidad, lo que podríamos denominar un proceso de continuo self-branding como diría Gemma San Cornelio ${ }^{360}$ que tiene como meta la implementación de lo que Guy Debord definió como el espectáculo, algo que "no es un conjunto de imágenes, sino una relación social entre personas mediatizada por imágenes" 361 . Tras esas relaciones se esconden estructuras mediáticas que modelan este tipo de relaciones. Como resultado de esta acción vemos como una imagen anteriormente nítida se transforma en un reflejo fantasmal que redirige nuestra mirada hacia el elemento determinante en la génesis de este tipo de imaginario, recordándonos el poder que ostentan los medios y sus creadores sobre la manera en la cual se conforman tanto sesgos de genero y sociales como todo tipos de relaciones de poder.

\footnotetext{
${ }^{360}$ San Cornelio, Gemma, op. Cit., 2008, p. 8.

${ }^{361}$ Debord, Guy, op. Cit., 1999, p. 25.
} 


\subsection{PAISAJES SUBJETIVOS}

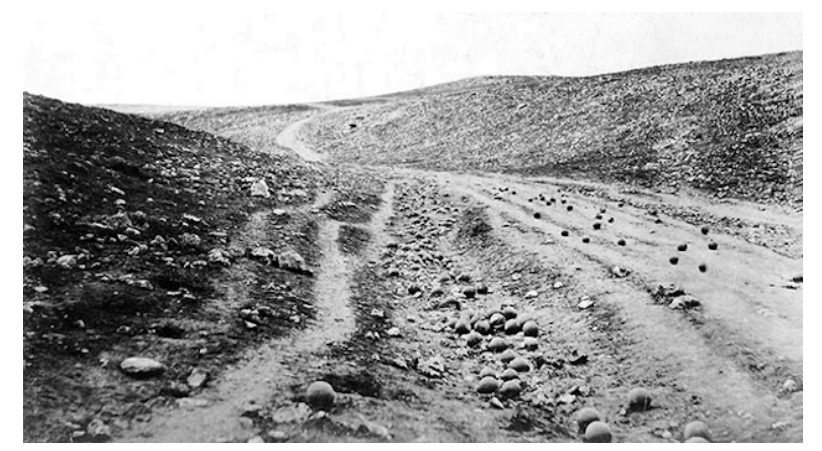

Figura 146. Roger Fenton, El valle de las sombras de la muerte, 1855.

En 1855 el fotógrafo Roger Fenton fue enviado al frente de la Guerra de Crimea, conflicto bélico que enfrentó a Rusia contra un conglomerado aliado formado por países como Turquía, Francia y Reino Unido, entre 1853 y 1856. Fenton es considerado el primer fotógrafo de guerra que fue enviado a un frente. Sin embargo como nos cuenta Susan Sontag en su obra Ante el dolor de los demás ${ }^{362}$, Fenton fue aleccionado por el gobierno del Reino Unido para no mostrar los aspectos más catastróficos del conflicto, con el animo de no generar malestar en las familias de los soldados británicos. Estos generó un tipo de documento edulcorado en el cual se plasmaban los momentos de ocio de la tropa y oficiales. De hecho las limitaciones técnicas y ambientales hacían imposible fotografiar cualquier tipo de acción que no fuera un posado o un paisaje. Es aquí donde surge una de las primeras y más famosas escenificaciones fotográficas de la historia, ya que Fenton fotografía dos tomas casi idénticas, pero en una de las dos se ha añadido un gran número de balas de cañón alrededor del camino que contiene la imagen.

Como afirma Susan Sontag lo más seguro es que estas fueran añadidas con posterioridad para generar un mayor dramatismo y significación alrededor de la imagen. Estudios posteriores de estas imágenes como el de Errol Morris

${ }^{362}$ Sontag, Susan, Ante el dolor de los demás, Alfaguara, Madrid, 2003. 
publicado en el New York ${ }^{363}$ Times han corroborado esta hipótesis en base al movimiento de ciertas piedras de un lado del camino a otro con la intención de hacer hueco a un gran numero de balas de cañón que seguramente fueron colocadas por Fenton y sus ayudantes alterando el paisaje in situ.

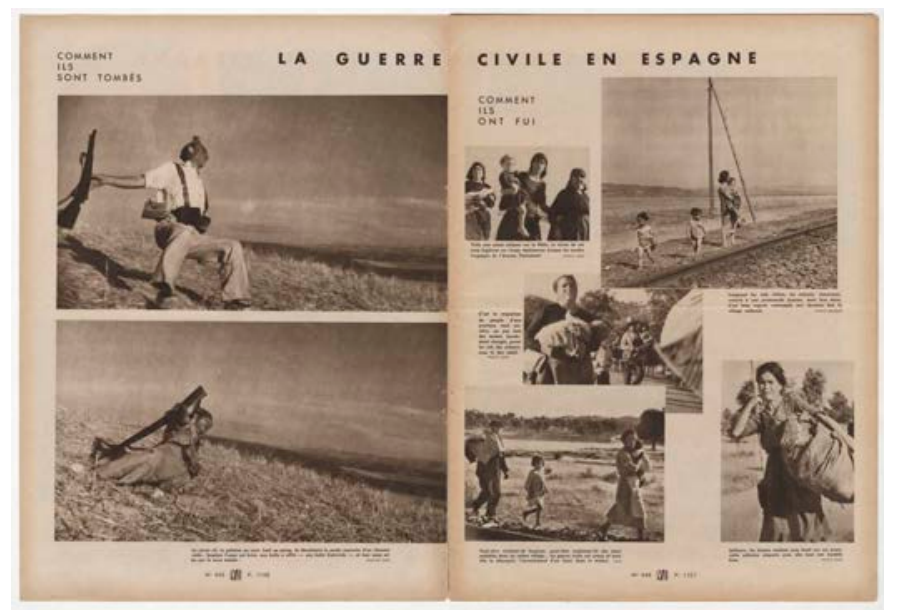

Figura 147. Páginas de la revista Vu con las dos fotografías realizadas en el mismo punto.

Del mismo modo, en 1936 Robert Capa realiza una icónica fotografía en el frente de Córdoba, en la que capta el instante justo en el cual el miliciano Federico Borrell es alcanzado por una bala. La fotografía que acabo titulándose Muerte de un miliciano es una de las fotografías más icónicas de la Guerra Civil Española y de todo el Siglo XX. Fue publicada por primera vez en la revista francesa Vu en Septiembre de 1936 junto a otras imágenes, y posteriormente en la revista LIFE en Julio de 1937. Precisamente en esta revista francesa podemos ver como este mismo tipo de imagen se repite con otro soldado que parece caer en el mismo lugar, a la misma hora y con el mismo encuadre, lo cual ha suscitado serias dudas sobre la veracidad de los acontecimientos que se pueden extraer de esta imagen. Según diferentes fotógrafos de guerra es extraordinariamente improbable de que dos

\footnotetext{
${ }^{363}$ Morris, Errol, Which Came First, the Chicken or the Egg? (Part One), The new York Times, [en línea], 2007, [consulta 25 de Enero de 2018] disponible en

$<$ https://opinionator.blogs.nytimes.com/2007/09/25/which-came-first-the-chicken-or-the-egg-partone/?_php=true\&_type=blogs\&_r=0>
} 
milicianos cayeran en el mismo punto y Capa pueda captar a los dos sin antes recoger el cuerpo del primero, a no ser que la fotografía estuviera escenificada. Pese a todas estas hipótesis Capa siempre argumentó que el soldado fue alcanzado por una bala inesperada del enemigo y que la imagen fue captada de manera fortuita.

La imagen no ha podido ser certificada como un hecho real pero tampoco como un hecho construido. El documental La sombra del Iceberg sostiene que el propio soldado no es quien se suponía que era, es decir Federico Borrell ${ }^{364}$. Una necrológica de la revista anarquista Ruta Confederal de 1937 desmiente que fuera abatido en campo abierto, en cambio un miliciano identificado con este nombre daba como resultado una imagen más mediática y comercial. Cuando se publico esta imagen en la revista LIFE bajo el titular Muerte en España. La guerra civil se ha cobrado medio millón de víctimas en un año, el miliciano paso a representar a todas las victimas de esta guerra, pasando esta anécdota a convertirse en símbolo de todas las victimas.

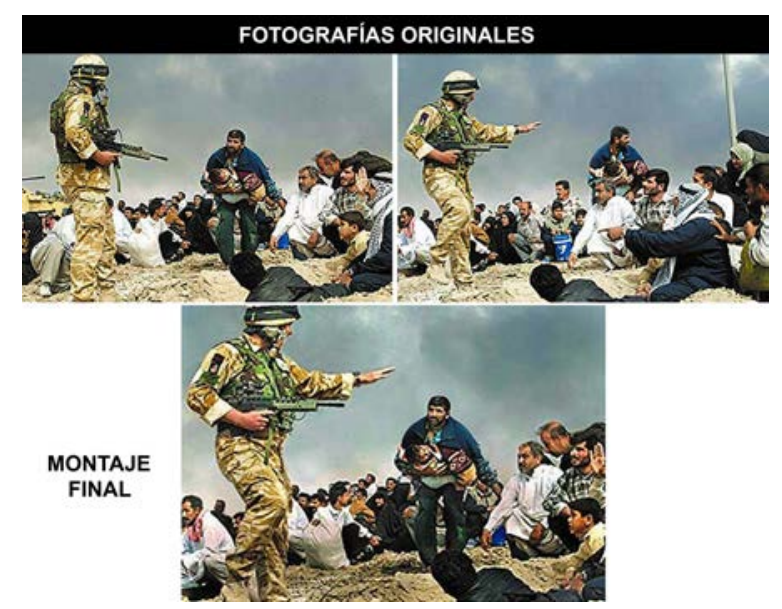

Figura 148. Montaje fotográfico de Brian Walski para Los Angeles Times en 2003.

\footnotetext{
${ }^{364}$ Villena, Miguel Ángel, Un documental desmonta el mito del miliciano de Robert Capa, El País, [en línea], 2008, [consulta 25 de Enero de 2018] disponible en <https://elpais.com/diario/2008/12/16/cultura/1229382004_850215.html>
} 
Brian Walski, un fotógrafo del periódico Los Angeles Times que trabajaba en Iraq, fue despedido el 1 de Abril de 2003 tras el descubrimiento 365 , por parte de sus editores, de la combinación de varias instantáneas con la finalidad de mejorar la composición de una fotografía. Al combinar dos imágenes, una en la cual un soldado británico gesticula a los civiles y otra en la cual un hombre con un niño en brazos parece implorar, Walski obtuvo un imagen mucho más impactante por su dramatismo, y por lo tanto capaz de copar la primera página de grandes periódicos. Obviamente, Walski combinó deliberadamente dos fotografías originales para generar una tercera mediante Photoshop, el programa de edición de imagen. Esto fue descubierto después de que algunos empleados notaran la duplicación de ciertos elementos dentro de la imagen. Sin embargo, como apunta el fotógrafo Pedro Meyer, cabria preguntarse hasta que punto la manipulación de Walski cambió los hechos objetivos. Más bien, se trata de un hecho que altera el factor que otorga valor a este tipo de actividad, es decir la credibilidad de los profesionales que generan el material que recibimos como noticias. Por otro lado, Meyer apunta a este tipo de polémicas como un tipo de información que oculta las verdaderas problemáticas de este tipo de conflictos, es decir la omisión real de hechos que desarman la narrativa generada desde los medios y el poder político. Mientras esta imagen era el centro de la polémica alrededor del trabajo de los reporteros gráficos, se obviaban elementos muchos más trascendentales de este conflicto y que afectaban de manera mucho más dramática a la propia población iraquí. Sin duda estamos en un punto en el cual la historia es sujeto de un espectáculo. Ver el mundo a través de imágenes genera un filtrado que se antepone a los hechos, ante la evanescencia de lo real y cierto. Irónicamente la ambición descriptiva de la fotografía se sirve de herramientas que falsean la realidad objetiva, algo que ha acompañado a la fotografía desde sus orígenes y que la fotografía digital simplemente se ha limitado a facilitar.

Ejemplos como la fotografía de Brian Walski son representativas de cómo las herramientas digitales son usadas para enfatizar, modificar y combinar elementos, de la misma manera que la fotografía analógica lo hace en el momento de la toma de la fotografía o el encaje de los elementos de la misma. Como nos explica Joan Fontcuberta en su obra La cámara de pandora ${ }^{366}$, la

\footnotetext{
${ }^{365}$ Van Riper, Frank, Manipulating Truth, Losing Credibility, The Washington Post [en línea], 2003, [consulta 25 de Enero de 2018] disponible en <http://www.washingtonpost.com/wpsrv/photo/essays/vanRiper/030409.htm>

${ }^{366}$ Foncuberta, Joan, op. Cit., 2011, p. 137.
} 
combinación de diferentes imágenes de la misma secuencia fotografiada por Walski dio como resultado una fotografía más dramática, en la que un soldado británico parece impedir el paso a un padre con su hijo en brazos en la ciudad iraquí de Basora, ante la mirada de una multitud de detenidos que permanecen sentados en el suelo. Sin embargo, no se debatió, como cuestión de fondo, si la imagen alteraba la esencia de los acontecimientos o si solo se trataba de una estetización de los mismos. Irónicamente el fotógrafo resulto despedido por el equivalente fotográfico de lo que realizan normalmente los medios de comunicación comerciales, es decir, modelar la forma en la cual los acontecimientos son contados sin modificar los hechos en si, enfocando y encuadrando los acontecimientos de manera subjetiva o parcialmente, lo que obviamente implica la construcción de una mirada particular modeladora de nuestra percepción de los acontecimientos.

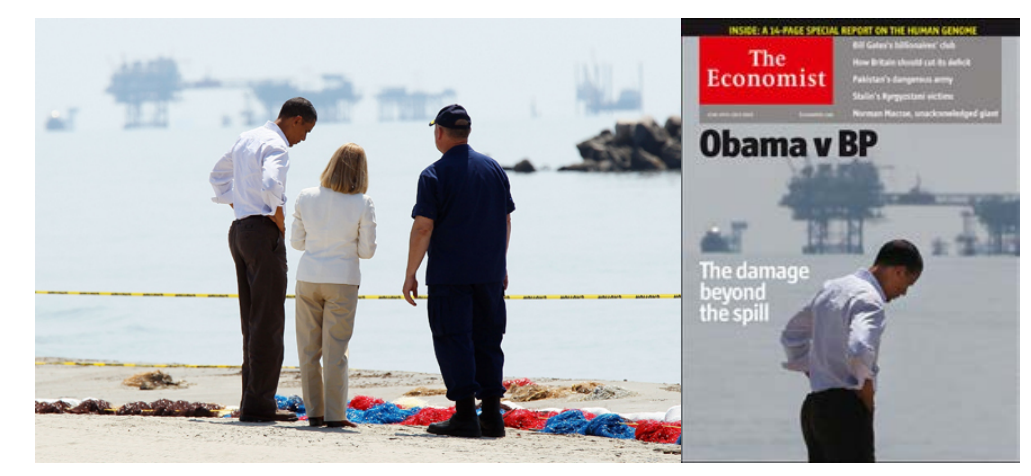

Figura 149. Fotografía de Barack Obama en Lousiana publicada por The Economist.

En la misma línea, en Julio de 2010 la fotografía de portada de The Economist fue manipulada para mostrar a un solitario Barack Obama que contempla la marea negra generada por el accidente en una plataforma de BP en el golfo de México. Esta actitud contemplativa y solitaria fue en realidad una construcción basada en una imagen en la que, el entonces presidente de EEUU, estaba junto a dos personas más, las cuales fueron bien borradas o recortadas para enfatizar el aspecto desolador del momento y la preocupación de Obama. Finalmente la editora de este medio Emma Duncan admitió que se había manipulado esta imagen con la intención de que el lector se centrara en la propia imagen de Obama, eliminando para ello otras distracciones que pudieran alterar esta atmosfera. Por lo tanto, estamos de nuevo ante la búsqueda de una imagen más estética y atrayente mediante modificaciones 
que generan una ficción que no altera sustancialmente los hechos, sino que más bien los adecua a la visión del fotógrafo sin perder la verosimilitud. Como podemos ver, la imagen fotográfica ha sufrido un gran cambio de rol en los últimos decenios debido a la aparición de la fotografía digital y los programas de edición fotográfica. De esta manera, las imágenes que vemos diariamente como ejemplos de objetividad son en realidad parte de una nueva tipología fotográfica en la cual el sentido y lectura de estas queda supeditado al punto de vista que el autor pretende imprimir.

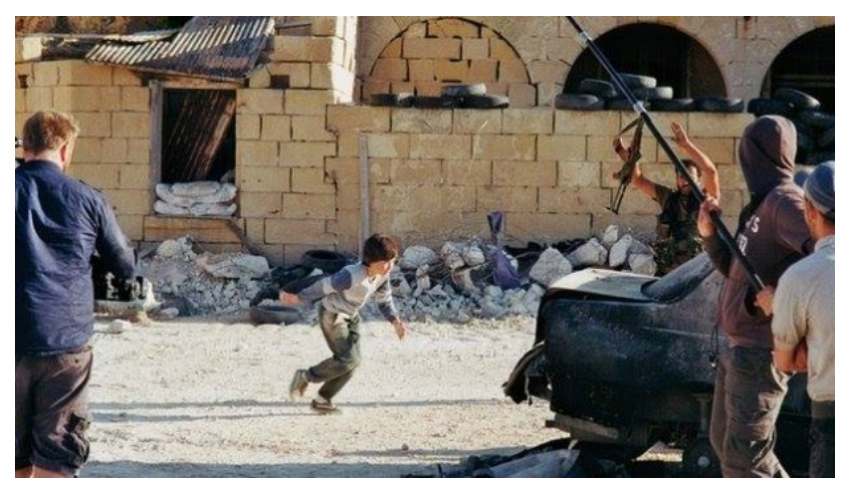

Figura 150. Escena del video Syrian Hero Boy.

En 2014 fu publicado un video donde un niño sirio rescata a una niña bajo una lluvia de balas, posteriormente el cineasta noruego Lars Klevberg reconoció que el video había sido rodado en Malta por un equipo profesional con la intención de crear conciencia sobre el conflicto. El video recibió millones de visitas en la plataforma Youtube, hasta que el propio director reconoció en Twitter la verdad. Sin embargo, la respuesta de la población siria fue de rechazo al entender que el director pretendía explotar esta guerra como una manera de ganar notoriedad, mediante la comercialización de estas imágenes.

Podemos ver como, durante el propio trascurso de este conflicto, las verdaderas imágenes de civiles han demostrado repetidamente ser de gran utilidad para identificar atrocidades cometidas por diferentes bandos, mientras por otro lado los videos adulterados o falsos han surgido del mismo modo como una manera de alimentar diferentes agendas políticas del conflicto. 
Sin duda las tecnologías asociadas a la red como las redes sociales, el blogging y el microblogging, la implementación de los medios de comunicación dentro de la red y consolidación de Internet como el macromedio de nuestro tiempo, ha producido formas de acceso más inmediatas y accesibles que han amplificado este tipo de prácticas de ficción documental. No podemos olvidar el aumento exponencial de la esfera blog, y el periodismo amateur, lo que ha propiciado la multiplicación de las voces alrededor de la actividad periodística y documental mediante publicaciones que reflejan un punto de vista alternativo respecto a los medios tradicionales y que en muchas ocasiones, como es el caso de Twitter, logran informar con mayor rapidez que los propios periódicos o medios digitales. Los reporteros internacionales se encuentran hace años con serias dificultades para discernir las noticias falsas de las reales, dentro de un escenario en el cual los fakes que intentan hacerse virales se han sumado a la propia propaganda gubernamental. Los medios tecnológicos al alcance de todos han hecho que tanto periodistas como ciudadanos anónimos generen todo tipo de material falseado desde la comodidad de su casa, y los propaguen sin ningún limite a través de la esfera blog.

Como nos recuerda Joan Foncuberta, aludiendo a el conocido como "síndrome de Hong Kong"367, la velocidad se ha impuesto sobre el trabajo profesionalizado y de calidad, optando por formulas que suplen a los profesionales para ceder nuevas herramientas de producción al propio público. La red por su parte, ha sido el epicentro de este tipo de generalización de las herramientas creativas. Sin duda estas encierran un tipo de cualidades que producen unos tipos de usos concretos. Antes de codificar el mensaje debemos comprender los códigos y los materiales mediante los cuales lo construimos.

Como ya vimos, en su obra Synsopleveder Figurer, Edgar Rubin usaba su afamada copa para describir la interesante relación perceptiva entre fondo y figura. Como nos cuenta William J. T. Mitchell en Image Science ${ }^{368}$, esto genera una excepcional metáfora sobre la relación de los medios con sus propios

\footnotetext{
${ }^{367}$ Fontcuberta, Joan, La furia de las imágenes. Notas sobre la postfotografía, Galaxia Gutenberg, Barcelona, 2016, p. 35.

${ }^{368}$ Mitchell, William J. T., op. Cit., 2015, p. 11.
} 
contenidos. Como afirmaba McLuhan, las cualidades ambientales de los medios, como entornos en los cuales permanecemos permanentemente sumergidos, y los cuales nos amplifican y extienden en cuanto a nuestras capacidades se refiere, generan una invisibilidad que imposibilita un fácil discernimiento sobre la manera el cual estos nos afectan y modelan en base a sus estructuras y características.

Precisamente, Walter Benjamin en su Tesis sobre la historia ${ }^{369}$ realiza una disección los procesos hegemónicos de construcción de relatos históricos que en muchos casos han fundamentado relaciones de poder y sometimiento. Para el la deconstrucción de la historia universal debe de dejar de lado la épica así como cualquier tipo de empatía con el vencedor. Como el mismo afirma "a la historia hay que cepillarla a contrapelo" mediante el materialismo histórico podríamos añadir. Apuesta por una reescritura de la historia desde el punto de vista de los marginados, desterrados y vencidos, es decir, las historias ocultas que la cultura hegemónica difumina sistemáticamente, y que representan la multiplicidad de voces que se ven sometidas por el poder. Benjamin apunta hacia la posibilidad de encontrar huecos e intersticios en los cuales insertar discursos no hegemónicos, y es aquí donde la red, gracias a sus características de horizontalidad e interactividad, amplificadas gracias a los nuevos espacios de la esfera blog y la redes sociales se transforma en un espacio donde implantar discursos individuales, que partiendo del yo y un punto de vista del usuario puedan cambiar la percepción del nosotros. Tal y como Remedios Zafra argumenta al hablar de las posibilidades de la esfera pública para generar conciencia dentro de la opinión pública, esto sería el paso del yo al nosotros.

Debido a la invisibilidad dentro de un entorno mediático durante su periodo de innovación el ser humano tan solo es consciente del entorno que lo precede. Un entorno se hace del todo visible cuando es reemplazado por otro entorno. Como nos cuenta William J. T. Mitchell en su obra The Reconfigured $E_{y} e^{370}$ de 1992 el automóvil fue visto como un carruaje sin caballos y la radio como un tipo de telegrafía inalámbrica. Pese a sus similitudes, una fotografía analógica difiere de una digital tanto como una analógica de una pintura. Esta

\footnotetext{
${ }^{369}$ Benjamin, Walter, Tesis sobre la historia y otros fragmentos, Itaca, México D. F., 2008.

${ }^{370}$ Mitchell, William J. T., The Reconfigured Eye, The MIT Press, Cambridge, 1992, p. 4.
} 
diferencia se basa según Mitchell en sus características físicas que provocan consecuencias lógicas y culturales de gran alcance dentro de nuestra cultura visual. Según José Luis Brea esta reorganización de los media generada en base al giro digital de principios de los años 90 del siglo XX tiene especial importancia "en lo que se refiere a los modos de producción, distribución y recepción de la experiencia artística"371. Por otro lado Lev Manovich completará este análisis con su texto The paradoxes of the digital photography ${ }^{372}$, donde pone sobre la mesa el nuevo estatus de la fotografía. Son por lo tanto tecnologías que generan la posibilidad de reconfigurar la esfera pública y los modos de distribución y exposición de estas prácticas.

Este primer estadio de análisis ha dado paso a la hipertecnificación de la sociedad contemporánea, donde la información y la imagen rodean nuestra existencia hasta el punto de vivir superados por la exacerbada y abundante producción de materiales creados desde diversos dispositivos, actualmente preponderantemente móviles. En muchos casos mantenemos una relación más estrecha con estos terminales que la que compartimos con muchos de nuestros congéneres. Esta segunda revolución digital se caracteriza por el papel destacado que juegan Internet, las redes sociales y las tecnologías móviles. Esto nos enfrenta a un escenario en el cual debemos gestionar los efectos sociales y políticos de la imágenes desplegadas dentro del entorno mediático. Las tecnologías de la sociedad red han amplificado una tendencia ya iniciada por los medios de comunicación de masas y la industria cultural. La imagen ha tomado un papel tan importante que es capaz de modificar nuestra percepción sobre la realidad que nos rodea y nosotros mismos de forma sutil. Es por ello que desde la práctica artística se ha implementado una nueva manera de trabajar sobre las imágenes, centrada en los efectos de estas al desplegarse dentro de la atmosfera comunicacional generada por Internet, como el medio hegemónico de nuestro tiempo. Las prácticas postfotográficas propuestas por primera vez por Mitchell en The Reconfigured Eye en 1992, han conseguido incorporar gran cantidad de elementos ajenos a la cultura fotográfica debido a la interacción de esta con la red de Internet y las características asociadas a ella. Esto ha generado nuevos discursos que se

\footnotetext{
${ }^{371}$ Brea, José Luis, La era postmedia. Acción comunicativa, prácticas (post) artísticas y dispositivos neomediales, Editorial CASA, Salamanca, 2002, p. 22.

${ }^{372}$ V.V.A.A., Photography After Photography: Memory and Representation in the Digital Age, G\&B Arts International, Amsterdam, 1997, p. 57.
} 
alejan de lo propiamente fotográfico para discutir sobre cuestiones como la propia materialidad de la obra de arte, la autoría, la apropiación, el papel del usuario como productor y el control de la información. Este tipo de acercamientos son próximos, en muchos casos, a lo que se conoció a mediados de los años 90 del siglo XX como net-art y hactivismo, opuestos al control de la información y la vigilancia masiva, mediante propuestas en principio ajenas al mercado del arte y concebidas para ser accesibles desde la red. Es aquí donde el potencial productor de la multitud interconectada se pone de manifiesto mediante usuarios capaces de generar y administrar sus propios medios, lo que da como resultado la confrontación entre usuarios y medios hegemónicos, algo que se puede ver tras la aparición de periodismo amateur, la esfera blog o la difusión de información en redes sociales.

La invención de la fotografía supuso la posibilidad de dilatar la sensación de presencia mediante la permanencia especular del objeto fotografiado. Ya no era necesario estar presente para poder ver algo que ha sucedido en otro momento y lugar. Sin embargo en su lenta evolución a lo largo del siglo XX, la fotografía va a pasar a ser algo que va más allá de una imagen especular de la realidad que todos conocemos, sino más bien se tratara de una mirada, y por lo tanto de algo que permite de manera subjetiva construir relaciones mediante los elementos que están presentes dentro de nuestra realidad cercana. Cuando tenemos delante una imagen, estamos como público consumiendo e interiorizando una visión que se construye desde un tercero, y por lo tanto interiorizando una visión delegada de la realidad que hoy en día tiene su principal fuente en los medios de comunicación de masas fuera y dentro de Internet, pero que a la vez ha sido puesta a disposición del público en general gracias a la implementación de las herramientas de las web 2.0. Precisamente este entorno mediático es el que reordena y gestiona estas miradas desde las líneas editoriales y corrección política de los medios de información profesionales, pero también dentro de las redes sociales y el propio trabajo inmaterial realizado por los usuarios de la red. Dentro de esta cultura digital la imagen ha pasado a ser algo que no solo esta mediado por la tecnología, sino que responde al discurso de un tercero que es cada vez más difícil de precisar debido a la ingente producción amateur. Como nos cuenta Joan Fontcuberta en su obra La furia de la imágenes "A pesar de que en el origen de toda imagen hay una intención, siempre es posible proyectar una segunda mirada, una mirada crítica que la resemantice y modifique su estatus inicial. Esta segunda mirada actúa, por tanto, con este valor prescriptor: 
descubre y pone de manifiesto factores que de otro modo pasarían inadvertidos"373.

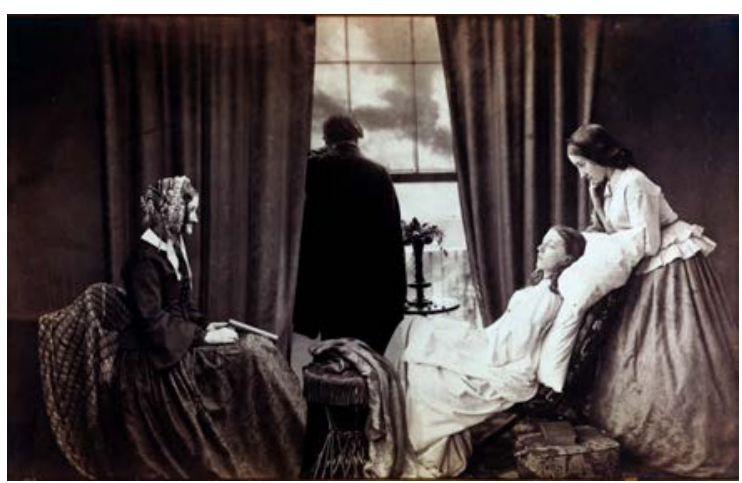

Figura 151. Henry Peach Robinson, Fading Away, 1887.

En cambio, como nos aclara William J. T. Mitchell en su ensayo Realismo $e$ Imagen Digital374, la manipulación siempre fue algo que ha sobrevolado la imagen, desde el primer fotomontaje Fading Away, pese a lo costoso de su materialización. Esta manipulación de la imagen se ha convertido hoy día en algo fácil de llevar a cabo y común dentro de nuestra vida diaria debido a la expansión de las herramientas digitales entre el gran público. Sin embargo, la verosimilitud de la imagen es algo que va más allá de su naturaleza analógica o digital. El realismo o la veracidad son términos que no están necesariamente adscritos a la ontología de ningún medio. Son independientes del carácter digital o analógico ya que su ontología no es algo que dependa de su materialidad sino de las prácticas sociales materiales que incorporan habilidades tradiciones, géneros, hábitos, etc. Por lo tanto, no solo se basa en las características físicas y materiales sino que más bien de las prácticas sociales y de los usos que se llevan a cabo a partir de esta materialidad. Como diría Kevin Robins ya en 1997 dentro de su ensayo ¿Nos seguirá conmoviendo una fotografía?, "la revolución visual y tecnológica asociada con las nuevas tecnologías se considera además como el verdadero centro de una revolución

\footnotetext{
${ }^{373}$ Fontcuberta, op. Cit., 2016, p. 55.

${ }^{374}$ Mitchell, William J. T., op. Cit., 2015, p. 49.
} 
cultural más amplia"375. Es aquí donde las practicas definidas como postfotográficas han roto los vínculos de la fotografía con la representación natural gracias al impulso del factor sociológico y los nuevos escenarios virtuales de creación y difusión de las imágenes, donde la profusión, la inmaterialidad, el intercambio y el reciclaje son las señas de identidad que han puesto en duda la perdurabilidad del concepto de autoría dentro de las redes.

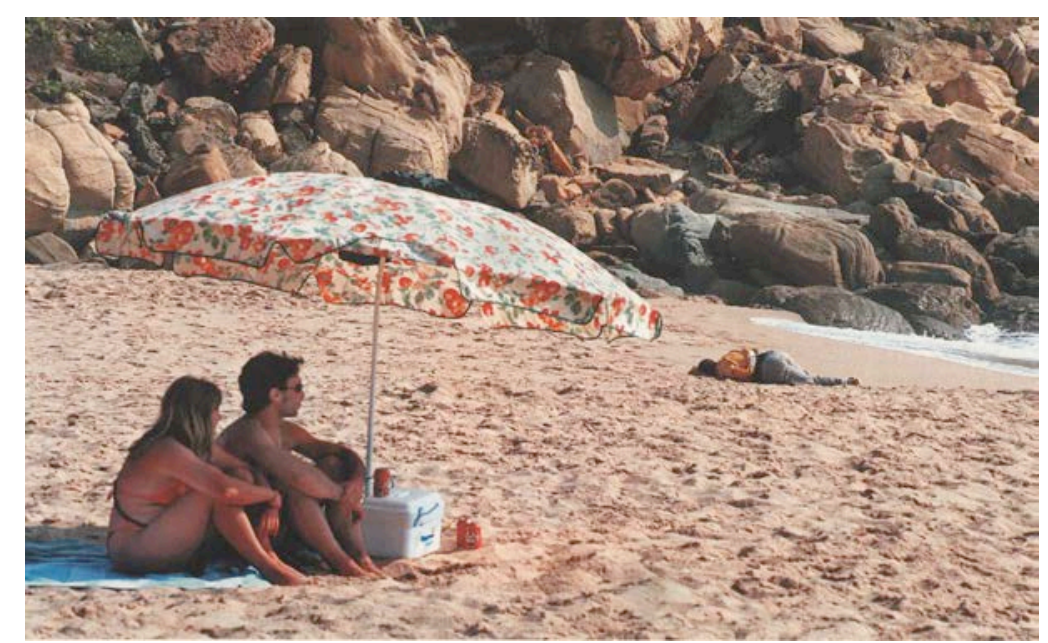

Figura 152. Javier Bauluz, Muerte a las puertas del paraíso, 2000.

El genero del reportaje fotográfico fue un tipo de categoría que ha dado paso a un modo de estetificación de los conflictos que tienen lugar dentro de nuestra realidad, ocultando y depreciando la verdadera dimensión de este tipo de problemáticas asociadas al territorio. Los medios hegemónicos, por lo general, despliegan sobre nosotros un tipo de pensamiento único que sustenta una mirada etnocentrista $\mathrm{y}$ hegemónica del mundo que nos rodea, posicionándonos como observadores distantes de fenómenos catastróficos desde el punto de vista humanitario, pero que apenas interfieren en nuestra vida diaria. Se trata pues, de fenómenos constantes pero normalizados mediante la propia acción del entorno mediático sobre nuestras mentes. Obras de fotoperiodistas como Javier Bauluz, ganador del Premio Pulitzer, el cual publicó en el año 2000 un reportaje fotográfico sobre la tragedia de los

${ }^{375}$ Lister, Martin, La imagen fotográfica en la cultura digital, Paidos, Barcelona, 1997, p. 51. 
inmigrantes en el estrecho de Gibraltar dotado de gran carga simbólica, han despertado siempre una encendida polémica sobre el valor informativo y posible manipulación de este tipo de imágenes. En este caso fue el periodista Arcadi Espada en el que mediante su libro Diarios ${ }^{376}$ galardonado con el Premio Espasa de Ensayo 2002, el que lideró la teoría de que la fotografía principal estaba alterada por el propio encuadre y distancia focal que el fotógrafo gestionó. Sin embargo esta imagen consiguió convertirse en un icono de una realidad que normalmente permanece soterrada, paralela a la nuestra, y redirigida por unos medios que prefieren conducir nuestra mirada en otra dirección. Sin bien esta construcción generó la visibilación de acontecimientos artificialmente separados de nuestra cotidianidad, por otro lado, este tipo de construcción del imaginario ha pasado a ser gracias a la herramientas digitales, una caja de pandora que no deja de levantar suspicacias respecto a la naturaleza digital de la imagen y por lo tanto a la supuesta modificación de la misma.

Más recientemente, el bombardeo constante de imágenes sobre la crisis de refugiados en el mar Mediterráneo, agudizada en 2015, nos hizo reflexionar sobre como la información es encajada y reubicada, mostrándonos un contenido concreto que obvia las causas materiales y las estructuras de poder que posibilitan y provocan este tipo de fenómenos. Es decir, el fondo de la cuestión y los acontecimientos que pese a permanecer visiblemente separados de esta catástrofe son en realidad los causantes. Según la Comisión Española de Ayuda al Refugiado 377 el contexto geopolítico actual y el carácter duradero de los conflictos y de las situaciones de violencia, hace necesario abordar las causas mediante soluciones perdurables y sostenibles. Sin embargo desde los medios de comunicación de masas rara vez se aborda de donde huyen estas personas y porqué. Tenemos la percepción de que este tipo de refugiados acuden masivamente a Europa, pero en realidad según ACNUR el 86\% de las personas refugiadas del mundo huyen a países de su entorno que son más pobres. Si bien el 53\% de estos refugiados son de Siria, Afganistán y Somalia, los principales países que los acogen son en realidad Jordania, Turquía. Pakistán, Irán, Líbano y Etiopía. Si ponemos datos al numero de refugiados por países veremos que de los 4 millones de refugiados Sirios, 1,9 millones se

\footnotetext{
${ }^{376}$ Espada, Arcadi, Diarios, Espasa-Calpe, Madrid, 2002.

${ }^{377}$ https://www.cear.es/15-preguntas-clave-para-entender-la-situacion-de-emergencia-de-lapersonas-refugiadas-en-europa/
} 
encuentra en Turquía, 1,1 millones en Líbano, 250.000 en Irak, 630.000 en Jordania y 150.000 en Egipto.

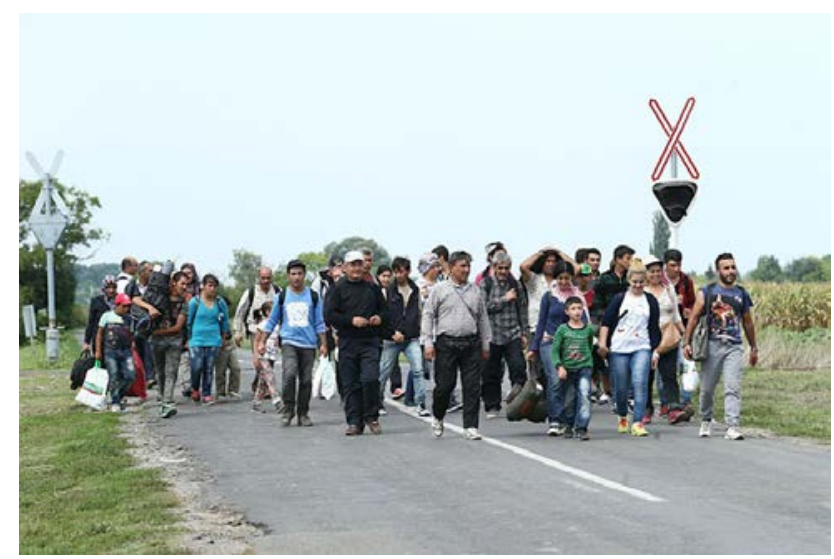

Figura 153. Refugiados cerca de la frontera con Serbia, en agosto de 2015.

Paradójicamente, el papel de la Unión Europea en este conflicto ha sido el de centrar sus esfuerzos en impedir la llegada de refugiados a sus fronteras externalizando el control de las mismas a terceros países. Estas personas provenientes de países en conflicto ven como existe una falta de vías legales para obtener protección, teniendo que emprender peligrosas rutas a través del mar Mediterráneo, recurriendo a las mafias ilegales para ello. Dentro de este escenario los medios de comunicación actúan sacando provecho de este tipo de crisis mediante el amarillismo con el cual se presenta esta tragedia humana, presentando el estatus de estas personas, no como refugiados provenientes de países en conflicto, sino como inmigrantes económicos. Al mismo tiempo redirigen nuestra atención del fondo al contendido, es decir, potenciando la fuerza estética de la propia crisis para desconectarla de su relación con acontecimientos transcendentales como la disolución del Estado Libio, la guerra civil en Siria o los regímenes dictatoriales del cuerno de África. Esto pone de manifiesto la falta de análisis estratégico de los países occidentales al apoyar y desarrollar conflictos que han dado como resultados guerras, estados fallidos y caos generalizado en gran parte de las regiones de origen de los refugiados. 
Las fronteras so solo pueden ser consideradas como barreras geográficas, políticas e históricas. Existen barreras y límites ocasionados por las relaciones de poder, criminalización y marginalidad que se generan por nuestro miedo al diferente. En este contexto las fronteras siempre han potenciado la segregación y exclusión de diferentes poblaciones. Mientras que la globalización, o aldea global, de la que nos hablaba McLuhan, facilitó el movimiento libre de capitales mediante las redes de telecomunicaciones que se estructuran globalmente. Nuestro planeta se ha llenado de nuevas fronteras que ya no responden a una necesidad política o defensa de la nación, sino que parece que algunos aspectos de esta globalización se encuentran en retroceso mientras otros siguen gozando de buena salud. El atrincheramiento de los estados nación ha supuesto un retorno a los nacionalismos, paradójicamente ante problemas que solo pueden ser resueltos desde lo global. En este sentido las redes solo han servido para visibilizar las diferencias entre diferentes partes del mundo, pero sin atacar a los problemas reales, buscar soluciones o encontrar formas de encontrarnos realmente con el otro.

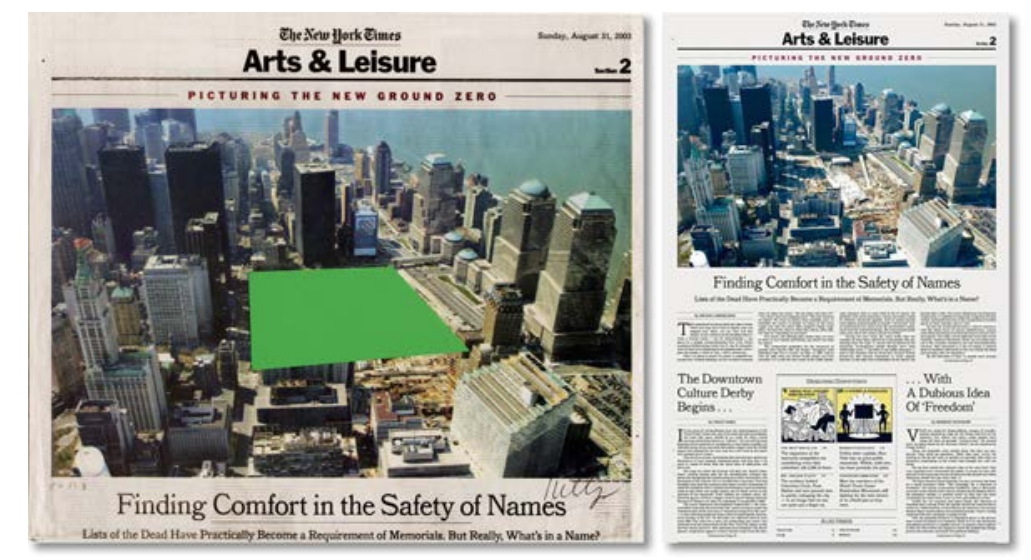

Figura 154. Ellsworth Kelly, Ground Zero, exposición 11 de Septiembre en MOMA PS1, 2003.

Dentro de este contexto, la práctica artística debe contrarrestar la manera en la cual los conflictos de nuestro entorno son presentados y sus victimas problematizadas. La difusión de una gran cantidad de imágenes de extrema crudeza sobre las travesías y naufragios de refugiados a lo largo del Mediterráneo, generan por lo general una actitud voyeurista y poca dada a un análisis en profundidad debido a su impacto. Como contrapunto a este tipo de enfoques podemos destacar propuestas como la de Hal Foster sobre la 
exposición September 11 realiza en el MOMA PS1 de Nueva York en 2012. Según el afamado crítico de arte, y tal y como se recoge en el número de Enero de 2012 de Artforum ${ }^{378}$, una de las principales premisas de la exposición fue desligar los acontecimientos del 11 de Septiembre de 2001 en Nueva York del impacto visual de esta catástrofe de dimensiones colosales mediante el no uso de imágenes de los acontecimientos. Al evitar las imágenes de este acontecimiento y las obras generadas directamente en respuesta a este se intento generar un marco subjetivo mediante el cual reflexionar sobre los ataques de Nueva York y sus repercusiones posteriores, sobre todo si tenemos en cuenta la manera en la cual experimentamos y nos relacionamos con el mundo en base a las consecuencias de estos hechos. Por otro lado, podemos recordar las graves consecuencias que han tenido las políticas de la denominada "guerra contra el terrorismo" para regiones cómo Oriente Medio o África, como podemos observar ante la generalización de los ataques "selectivos" con drones y las intervenciones militares en dichas regiones.

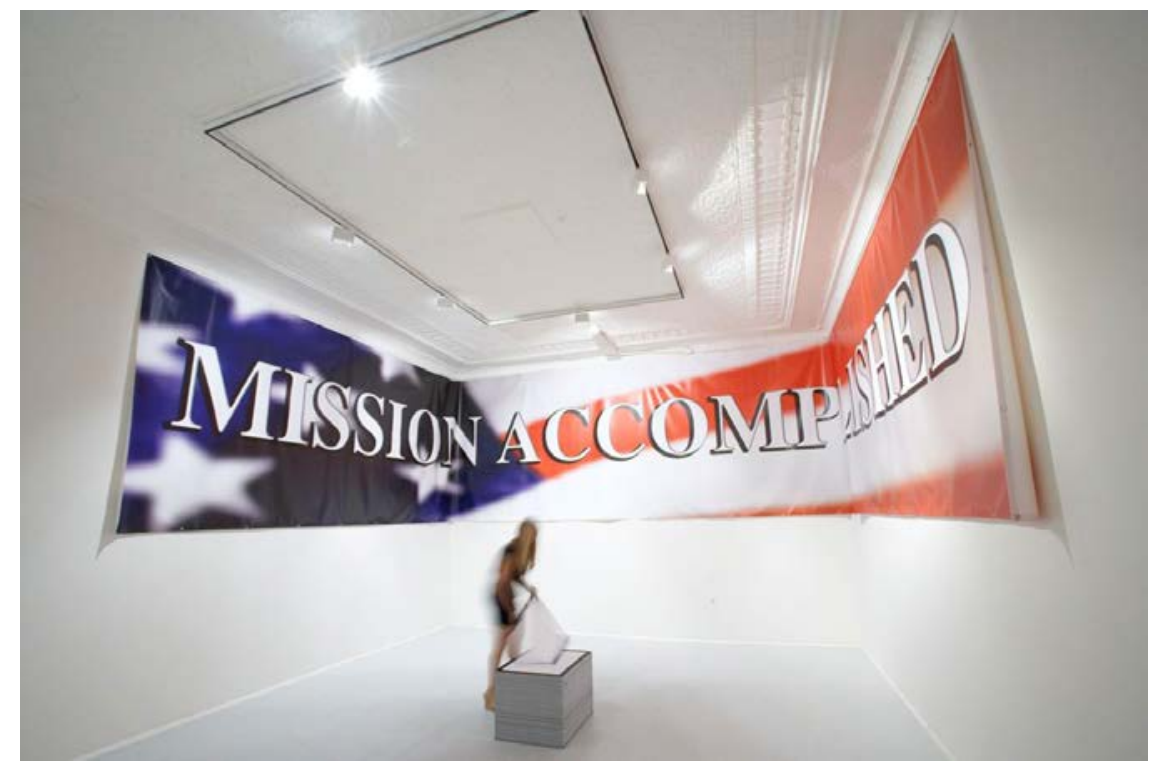

Figura 155. Una de las salas de la exposición 11 de Septiembre en MOMA PS1, Nueva York.

\footnotetext{
${ }^{378}$ Foster, Hal, September 11, Artforum, Enero de 2012, [en línea], [Consulta el 17 de Febrero de 2018], disponible en <https://www.artforum.com/print/reviews/201201/september-11-29803>
} 
En este sentido Foster aboga por una liberación del propio cautiverio causado por el shock de las imágenes de estos acontecimientos instrumentalizados como herramientas de terror. La manera de contrarrestar este tipo de imágenes que nos propone esta exposición es precisamente liberar nuestra percepción y cognición de estos impactos visuales, generando otras imágenes que nos saquen de la espectacularidad que nos golpea y paraliza diariamente. Esto debe hacernos reflexionar sobre la verdadera naturaleza y consecuencias de los conflictos globales y la manera en la cual los mass media enfocan y redirigen nuestra atención sobre estas cuestiones transcendentales, que apelan en último lugar a nuestra relación con el otro y la manera en la cual podemos gestionar este tipo de retos como sociedad.

Como hace años anunciaba Roland Barthes, el grado cero de la escritura ${ }^{379}$ se materializaría mediante un texto en el cual la ausencia del autor fuera la seña de identidad, y por lo tanto mostrara un estado puro e inalterable del documento. Irónicamente, en la actualidad debido a la implementación de la redes de comunicación y las posibilidades que los medios digitales nos ofrecen, el autor aparece camuflado dentro de nuevos modelos de autoría que replantean este mismo concepto desde la interactividad, el anonimato, la creación colaborativa y el intercambio, dentro de espacios donde la viralidad y el reciclaje de las imágenes forman parte de nuestra cotidianidad. Paradójicamente, gracias a la redes se ha logrado una disolución de la autoría que ha puesto en crisis la posibilidad de crear algo realmente original.

${ }^{379}$ Barthes, Roland, El grado cero de la escritura, Siglo XXI, México D.F, 1989. 


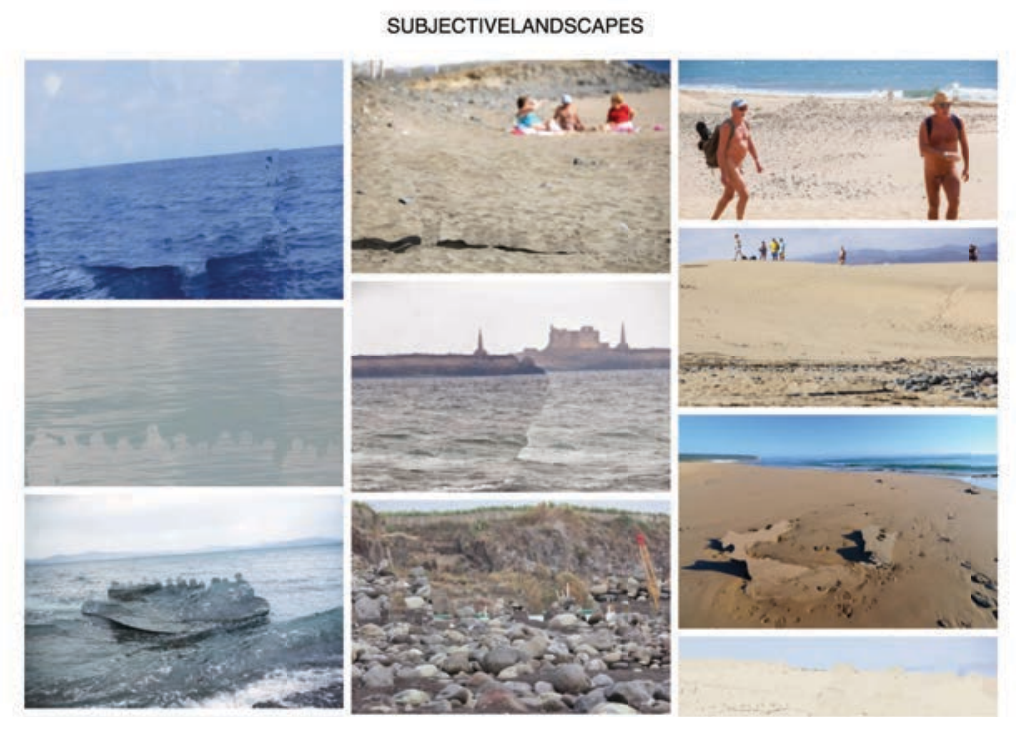

Figura 156. Blog del proyecto http://subjectivelandscapes.tumblr.com/.

En esta obra llamada Paisajes Subjetivos hemos trabajado mediante la selección, reciclaje, intervención y publicación de una colección de imágenes de prensa extraídas del buscador de imágenes de Google, y por otro lado la realización de una animación mediante estas imágenes. Según Juan Martín Prada ${ }^{380}$, como contraste a las estrategias de reubicación y descontextualización de la posmodernidad, el medio digital va a pasar a transformar diferentes materiales dentro de una integración y fusión de lo apropiado. Para ello va a usar conceptos provenientes de otros medios como remix, sample, mash-up o remake. Todos nos hablan del uso de elementos de otras piezas, la mezcla y transformación en una versión alternativa. Estas prácticas están asociadas a la provisionalidad y temporalidad de materiales recogidos de la red, tal y como el poeta estadounidense Kenneth Goldmisth afirma $^{381}$, estos son almacenados, moldeados y descartados con una rapidez proporcional a la de los flujos de información. Goldsmith defiende el plagiarismo como una estrategia creativa, creando dentro de sus clases en la Universidad de Pensilvania un completo decálogo de cómo perder el tiempo dentro de la red. Ante la avalancha de material que generamos diariamente

\footnotetext{
${ }^{380}$ Martín Prada, Juan op. Cit., 2012, pag. 187.

${ }^{381}$ Goldsmith, Kenneth, op. Cit., 2011, pag. 218.
} 
Goldsmisth aboga por la apropiación literal como acto creativo. Como ya vimos, obras como la de la artista estadounidense Dina Kelberman en su proyecto en curso I'm Google 382 , donde colecciona lotes de imágenes procedentes de Google Image Search que se relacionan en cuanto a composición, color o temática. Esto le sirve para crear una instalación interactiva donde las imágenes se relacionan con otras imágenes, pudiendo mover mediante un trackpad la cascada sin fin formada por el proyecto.

Volviendo al presente proyecto, podemos afirmar que el hecho de coleccionar imágenes se ha convertido en algo inherente a la propia actividad de navegar por la red. Es precisamente este coleccionismo lo que da lugar al propio imaginario que pone en funcionamiento el proyecto, y que como punto de partida delimita el propio resultado del mismo. Estas imágenes originalmente reflejan el drama que supone la inmigración ilegal a través del mar Mediterráneo, pero al ser intervenidas clonando partes del paisaje dentro de los protagonistas de estas, se genera una nueva imagen donde la figura se mimetiza con el fondo.

Esto invisibiliza los acontecimientos que tienen lugar en dicha escena, pero da la oportunidad al espectador de interpretar lo que realmente sucede en ese escenario. Del mismo modo, devuelve la mirada del espectador hacia el fondo, es decir la propia frontera que representa el mar Mediterráneo. Aquí, al igual que los medios de comunicación, es el artista el que prescribe un nuevo sentido a la propia imagen transformándola mediante las herramientas digitales y la manera en la cual se presenta, interpelando al espectador a crear su propia reflexión sobre las implicaciones de estos hechos. Como vimos en el concepto de la exposición September 11 en el MOMA PS1, las imágenes espectacularizadas que los medios distribuyen masivamente pueden liberarnos de este tipo de shocks mediante una táctica que nos devuelva a la realidad del espacio que estamos contemplando, el cual es llenado de significaciones ajenas a el.

\footnotetext{
${ }^{382}$ Kelberman, Dina, op. Cit., 2011, [Consulta 23 de Enero de 2017] disponible en $<$ http://dinakelberman.tumblr.com>
} 
La intervención de las imágenes como productos de los medios de comunicación de masas subvierte las nociones de originalidad y propiedad disolviendo en concepto de autoría a la par que tergiversa su uso a favor de la práctica artística y la visibilidad de un conflicto que, lejos de generar un discurso victimista, pretende dignificar a los protagonistas cuestionando la manera en la cual estas personas son presentadas al mundo. Enfoca la mirada hacia los espacios que realmente originan el conflicto, presentándolos como espacios neutros capaces tanto de unir como separar, enfatizando por tanto el modo en el cual los medios transforman nuestra mirada. Es aquí donde la obra plantea, mediante la subjetividad que la técnica permite, crear una reflexión sobre los espacios en los cuales estos hecho tienen lugar. Al despojarlos de las problemáticas de los refugiados aparece el mar y las playas ocupadas en muchos casos por turistas.

Estos archivos se comportan como un proceso que muestra fisuras, silencios y ausencias, aumentando el cuestionamiento de la autoría a favor de la cita, generada por la acción de recolectar por encima de la apropiación. Esto pretende cuestionar el ruido audiovisual presente en las redes para mostrarnos imágenes en las que la ausencia nos devuelve a una realidad de la cual los medios nos secuestran, respondiendo desde lo local e individual a este atmosfera comunicacional global.

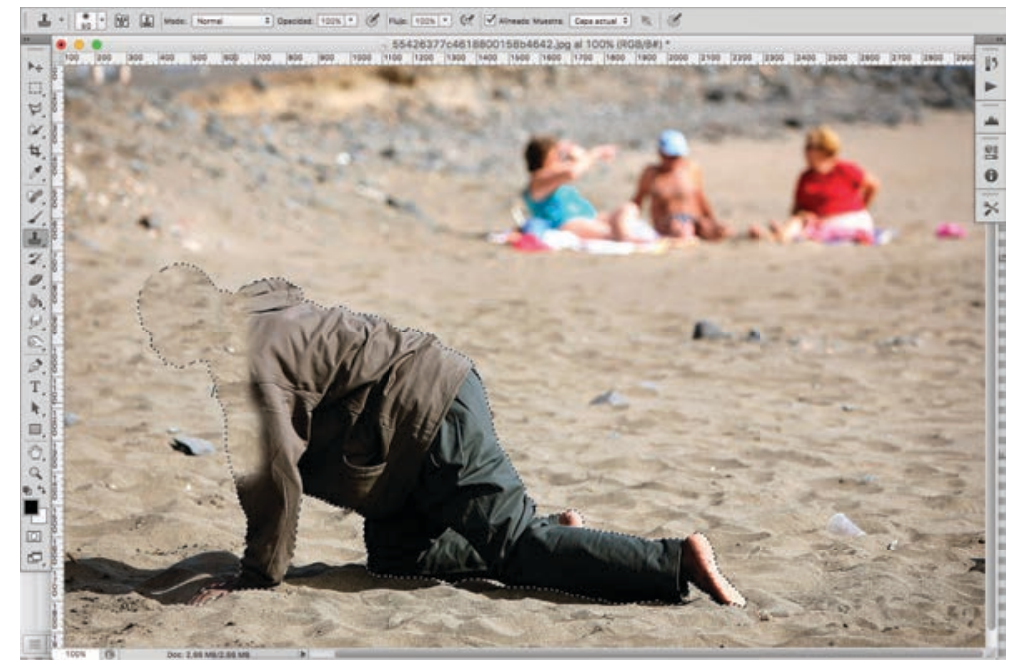

Figura 157. Imagen que muestra el proceso de trabajo en Photoshop. 
De hecho el mar Mediterráneo ha sido sin duda un punto de encuentro, un espacio donde encontrarse con el otro para generar nuestra propia identidad. Como argumenta el antropólogo francés Marc Auge desde hace años la idea de que la multiplicación de los contactos con el exterior es una amenaza contra la identidad, algo que se escucha a menudo es erróneo. No hay identidad sin la presencia de los otros. No hay identidad sin alteridad. Es por ello que esta obra intenta resemantizar nuestra visión sobre el mar Mediterráneo para cambiar su significación construida desde los media hacia la que se ajusta más a su papel histórico como nexo de unión entre culturas.

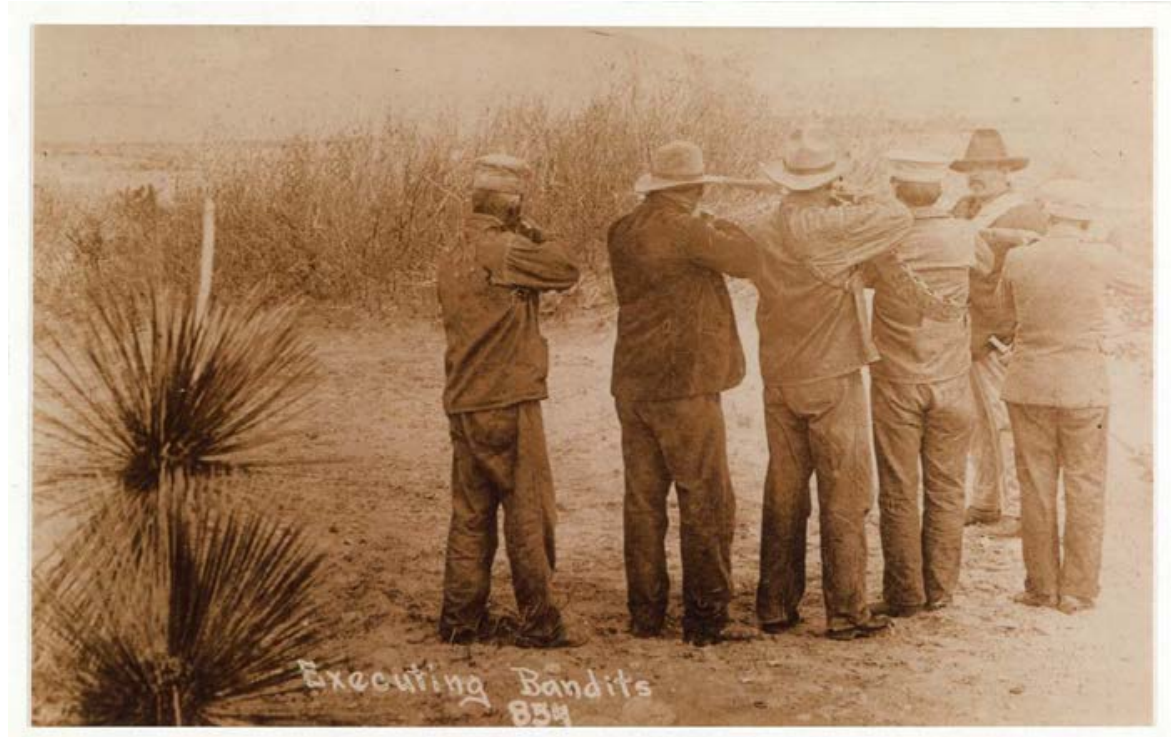

Figura 158. Una de las imágenes de Ken Gonzales-Day para Erased Lynching, 2005.

Obras como Erased Lynching de Ken Gonzales-Day, donde el artista colecciona fotografías y tarjetas postales en las cuales aparezcan linchamientos realizados en EEUU entre 1850 y 1935, para eliminar a las victimas y los artilugios mediante los cuales se ejercía la violencia para precisamente desviar la mirada hacia los autores y mecanismos de violencia estructural de la sociedad que llevó a cabo este tipo de actos atroces sobre las minorías étnicas de su país. Precisamente aquí Gonzales-Day hace mas evidente el marco o contexto social en el cual estos hechos fueron perpetrados mediante la 
invisibilización de los asesinados, destacando el fondo en cual acaecieron. Al igual que en este proyecto artístico no se pretende incentivar una censura sobre la realidad imanente de nuestro mundo pero si reconducir nuestra atención hacia los contextos en los cuales nuestra visión es manipulada y las verdaderas causas de estos desconectadas de las consecuencias.
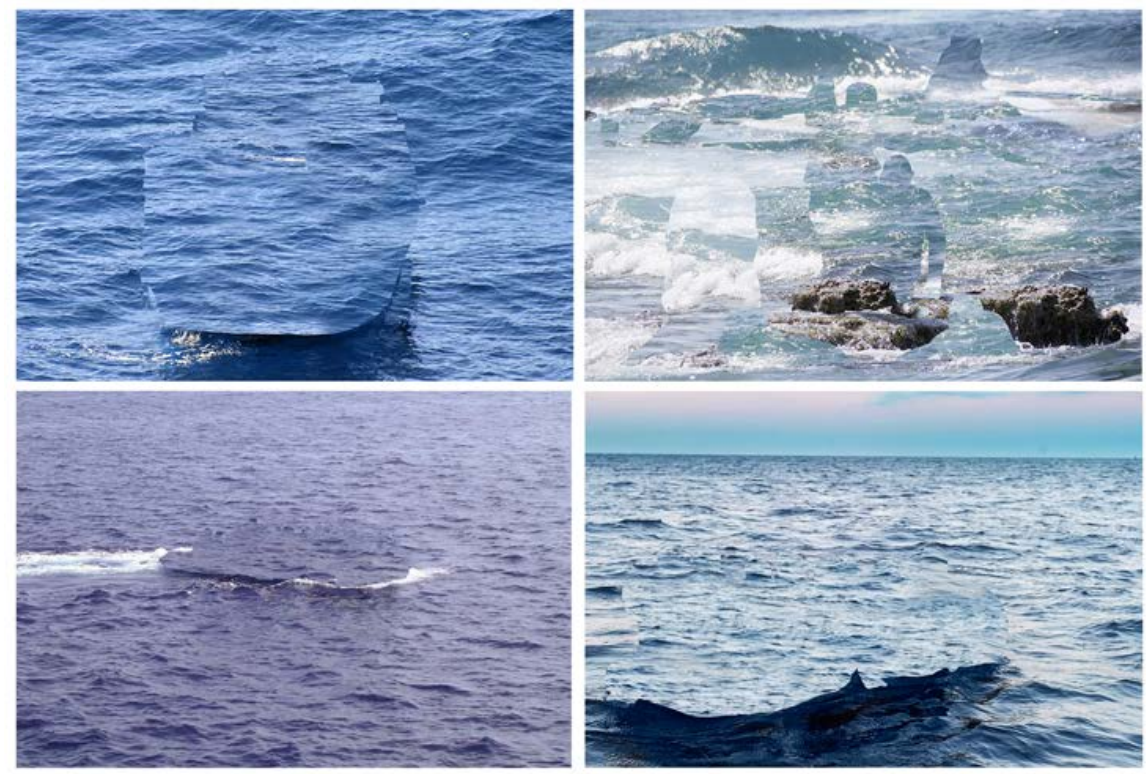

Figura 159. Cuatro imágenes elaboradas dentro del proyecto.

En este contexto se hace necesario que la práctica artística tome partido como elemento que hace posible la redirección de nuestras miradas hacia los elementos que se obvían dentro de los relatos generados desde los medios de comunicación de masas.

Por un lado el papel del artista como explorador mediático, nos presenta, tal y como Marshall McLuhan 383 argumentaba, la posibilidad de posicionarnos como descubridores de alteraciones y nuevos cambios en el entorno mediático. Esto se debe a la actividad inherente del artista como husmeador,

\footnotetext{
${ }^{383}$ Entrevista de Eric Norden a Marshall McLuhan publicada en el número de Marzo de 1969 de la revista Playboy.
} 
la cual le hace percatarse de los profundos cambios perceptivos y de los contornos invisibles de los entornos tecnológicos de la información y comunicación.

Por otro lado, esta colección reubica el papel del artista como un curador o coleccionista que selecciona material de la red para intervenir estas imágenes, de manera que transmitan un sentido diferente al del trabajo original. Por lo tanto, este tipo de apropiación y reciclaje dentro de un ecosistema mediático avasallado por la ingente producción de imágenes y datos, tiene como finalidad plantear implícitamente un tipo de conciencia sobre la sobreproducción de imágenes, de las cuales el buscador de Google es el epicentro en cuanto a su categorización y jerarquización. Como hemos podido observar, buscadores como Google se han convertido en la herramienta hegemónica que organiza la información generada en todo el mundo, sirviendo como intermediario entre el usuario y esta información, posicionándose por tanto como un narrador omnisciente que regula nuestro dialogo como el mundo.
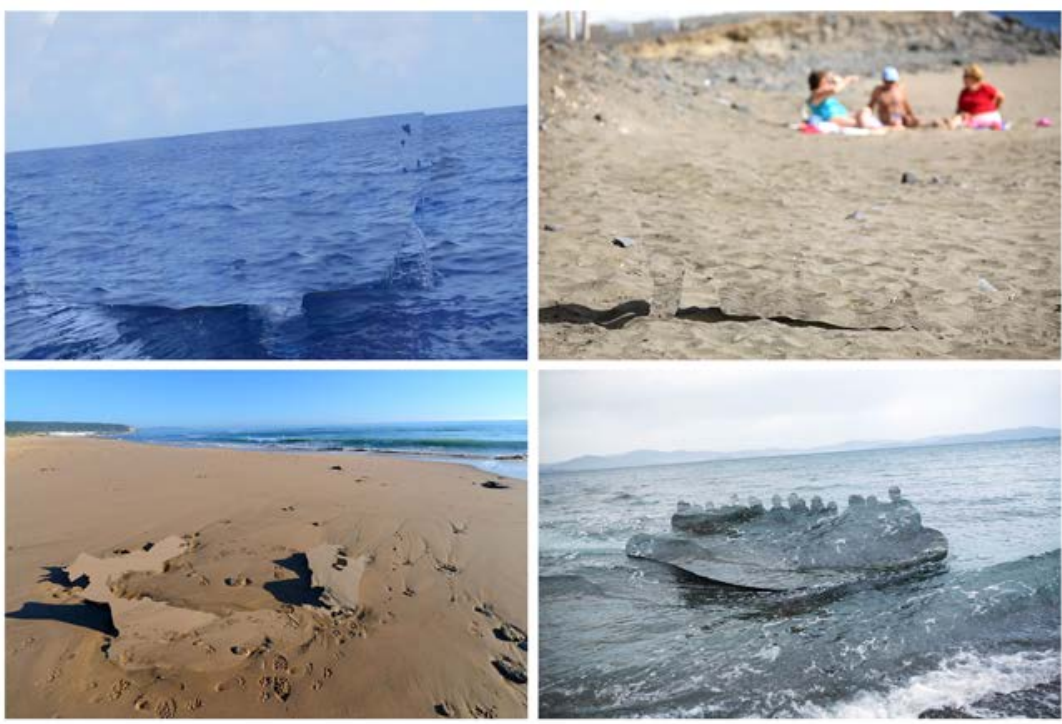

Figura 160. Cuatro imágenes elaboradas dentro del proyecto. 
Es aquí donde las actividad ligada a la exploración de la red y su análisis crítico replantean una reflexión sobre cuestiones como los discursos y narrativas planteadas desde los medios de comunicación, los mecanismo de distribución y consumo de la información, la imagen como constructo implementado desde la mirada, la apropiación de material dentro de la red, así como la posibilidad plantear proyectos artísticos que reflexionen sobre la capacidad de los medios para modificar nuestra percepción y visión de nuestro entorno.

Este tipo de planteamientos críticos son herederos de los discursos del net-art y el hactivismo, pero ampliando el campo de acción e interaccionando con otros intereses y disciplinas. El artista se comporta como un flaneur de Charles Baudelaire, que recorre la red intentando comprender como las estructuras mediáticas implementadas mediante software son desplegadas sobre los usuarios. Es por ello que en base a esta actividad de exploración es imprescindible generar una reflexión que posibilite la creación nuevos modos de actuar, usar los medios y los contenidos entre los cuales nos desenvolvemos a diario, usando para ello el espacio mediático sobre el cual queremos generar una nuevo tipo de planteamiento para reutilizarlo de diferente modo. Es por ello que el uso de la esfera blog para ubicar estas imágenes se platea como un tipo de uso no hegemónico de este tipo de espacios, normalmente usado para contener relatos autobiográficos.

Estas imágenes han sido tratadas para eliminar cualquier elemento espectacularizado del transito ilegal de refugiados, dejando sin embargo las huellas de esta intervención de manera palpable, al copiar sobre este espacio otras partes de la imagen. La herramienta de clonación de la aplicación de retoque Adobe Photoshop permite copiar partes de una imagen dentro de esa misma imagen, realizando una copia que adolece de cualquier tipo de suavizado. La herramienta imita a un pincel, produciendo cambios bruscos fácilmente detectables en cuanto a los patrones de clonación que se crean, ya que en ocasiones es fácil repetir varias veces la misma zona de la imagen. En muchos casos este tipo de errores han generado una estética propia que repercute en la obra de diferentes artistas.

También podemos considerar esta herramienta como uno de los pilares de la creación amateur instalada hoy día dentro de los cotidiano, lo que Lev 
Manovich ha venido a llamar el software de los medios ${ }^{384}$. Dentro de sus software studies, Manovich y sus coetáneos fueron inspirados por el enfoque de McLuhan sobre el papel de los medios en si mismos en lugar del contenido de las plataformas. Poniendo el foco ne la configuración de la cultura que estos realizan y de cómo estos modelan nuestros mundos y percepciones. Aquí Manovich destaca como las herramientas de este programa simulan sus equivalentes pre-digitales, relacionando las herramientas de este con herramientas analógicas previas. De la misma manera la mayoría de los filtros de este programa aluden a técnicas de manipulación y creación de imágenes anteriores a la era del software. Por lo tanto estamos ante simulaciones de medios físicos cuyas propiedades han sido traducidas y aumentadas mediante el software, en lo que Nicholas Negroponte director de MediaLab MIT definió en 1996 como "lo digital" en su obra Being Digital ${ }^{385}$ o El Mundo Digital por su titulo en español.

Posteriormente a su realización como serie, estas imágenes son vueltas a publicar en forma de blog de la plataforma Tumblr, que contiene toda la colección, generando un archivo que reordena la obra de acuerdo a las herramientas de la web 2.0 y la introduce de nuevo dentro de los caudales comunicativos corporativamente gestionados. Esto forma parte de la propia tergiversación de la producción mediática que no solo alcanza la producción material, sino que se centra también sobre la propia estructura mediática

\footnotetext{
${ }^{384}$ Manovich, Lev, op. Cit., 2013, p. 107.

${ }^{385}$ Negroponte, Nicholas, El mundo digital, Ediciones B, Barcelona, 1995.
} 


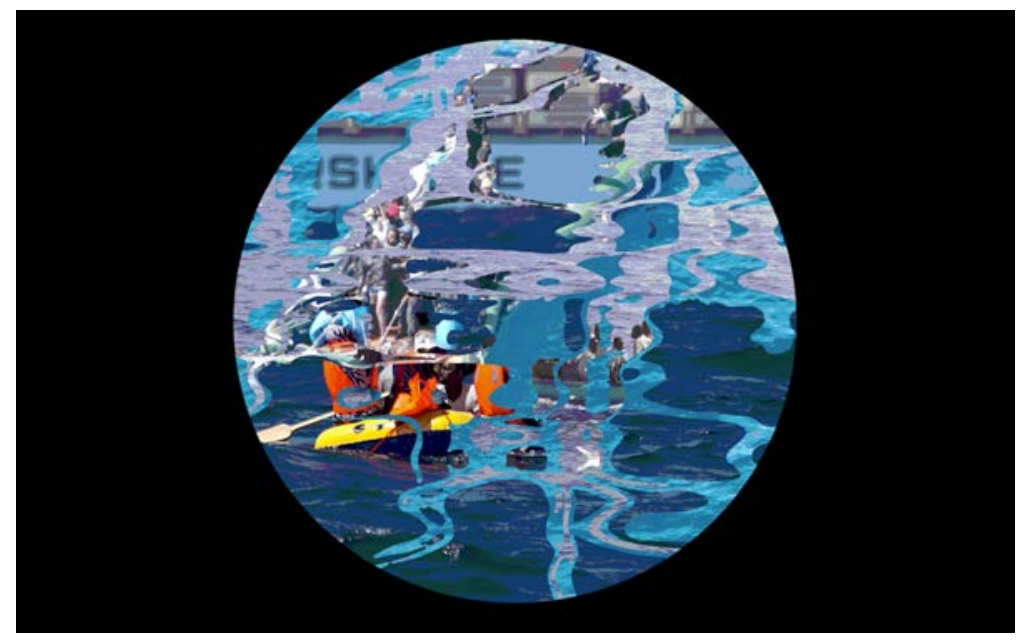

Figura 163. Video del proyecto https://www.youtube.com/watch?v=Cq1Xk|5cuAQ

Con posterioridad a esta colección de fotografías intervenidas realice una animación GIF en la cual los elementos que construyen la imagen a nivel cromático son sustituidos por diferentes imágenes de la colección, en este caso sin modificar. La corta animación reciclada para tal efecto es la de un mar que genera una leve ola en bucle. Precisamente, nos encontramos con elementos que son insertados dentro de una imagen en movimiento para producir la sensación de saturación, indescifrabilidad, y movimiento perpetuo de un mundo saturado icónicamente. Por otro lado, al poner las imágenes en movimiento se genera una imagen virtual.

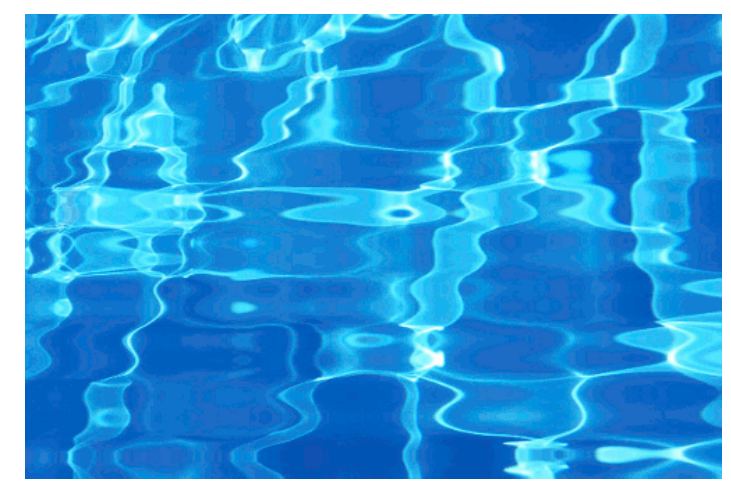

Figura 161. Animación gif original que sirvió de modelo para la animación del proyecto. 
Este movimiento perpetuo alude, mediante las posibilidades de esta animación GIF, a lo perenne y perdurable de los conflictos que han producido estas imágenes pero también a los grandes espacios en los que tiene lugar y las dinámicas que los rigen.

Por otro lado, podemos apreciar como no logramos salir de la atmosfera comunicacional implementada por las redes de comunicación y la conectividad constante, y es por ello que la colección y seriación cobra sentido mediante los propios criterios mediante lo cuales se realiza. La selección y posterior reutilización se opone diametralmente al bombardeo icónico que sufrimos permanentemente, al requerir una reflexión y búsqueda explicita de un determinado tipo de material que posteriormente pasa a ser transformado, reinterpretado y publicado de nuevo. Aquí nuevamente nuestro cerebro genera varias imágenes dependiendo de la relación de planos que capte nuestra atención. Por un lado puede doblegarse al impacto de las imágenes de los refugiados o por otro centrar su atención en contemplar la imagen de unas aguas en movimiento. Esta dualidad perceptiva transciende la clásica relación fondo figura ejemplificada por el vaso de Rubin, y nos plantea como diferentes planos pueden conformar una imagen virtual en movimiento, que transciende el propio contenido de la colección. Aquí es el fluir del mar el que queda configurado por los diferentes planos de imágenes y por la variaciones tonales entre estas. En cierto modo alude también a como el fluir comunicativo palidece ante la inmensidad del mar, el verdadero entorno en el cual suceden estos hechos, el cual queda marcado y señalado mediáticamente por estos acontecimientos como lugar de catástrofe y sufrimiento. 

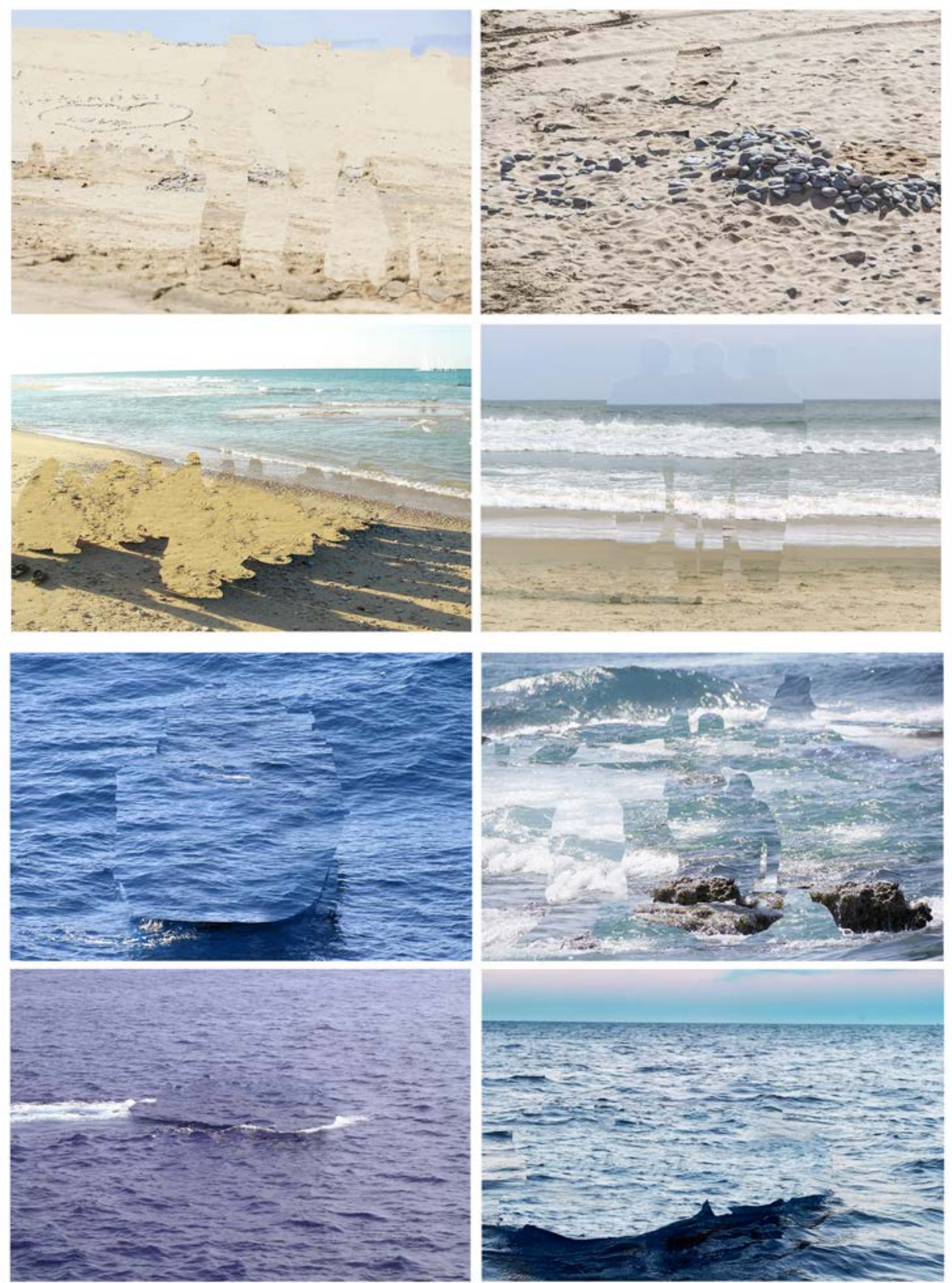

Figura 162. Parte de las imágenes desarrolladas durante el proyecto. 

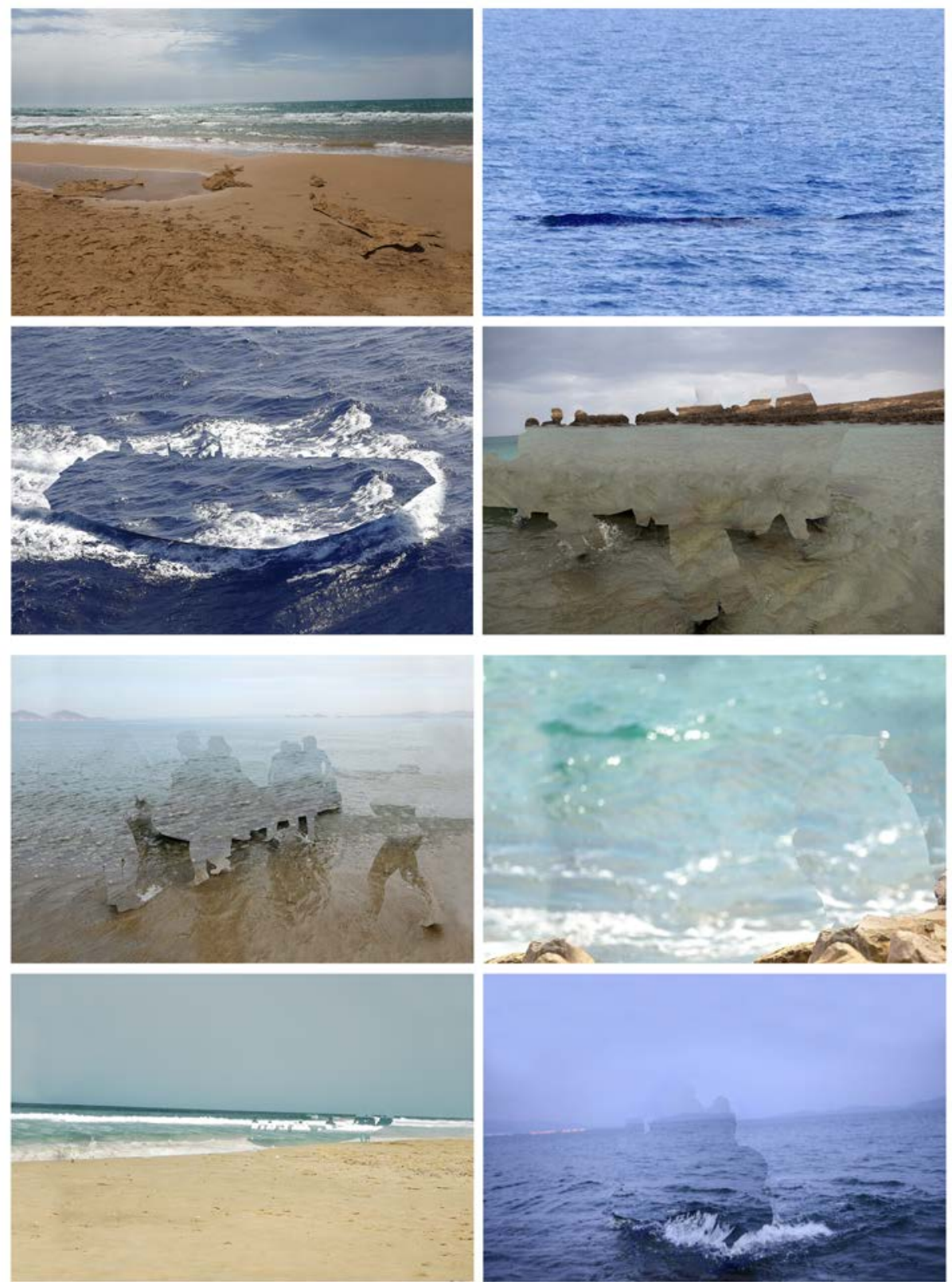

Figura 163. Parte de las imágenes desarrolladas durante el proyecto. 
CONCLUSIONES 


\section{Español:}

El papel del artista como explorador mediático, nos presenta la posibilidad de posicionarnos como descubridores de alteraciones y nuevos cambios en el entorno mediático. Esto se debe a la actividad inherente del artista como husmeador, la cual le hace percatarse de los profundos cambios perceptivos de los entornos tecnológicos de la información y comunicación. Es aquí donde su capacidad predictiva se hace patente, refiriéndonos a su habilidad perceptiva, en el sentido de leer el lenguaje del exterior y vincularlo al mundo interior. Como práctica artista desarrollada dentro de un espacio virtual hegemónico, utiliza las estructuras de poder, apropiándose, modificando y tergiversando sus signos y códigos. Por otro lado, al usar las propias herramientas de estos espacios mediáticos para visualizar estos efectos, estamos generando una tergiversación. El propio uso de las tecnologías asociadas a la Web 2.0., sin modificarlas, es decir, desde el punto de vista del usuario, se presenta como una respuesta al solucionismo tecnológico imperante. Este es un modo reposado que se contrapone a la aceleración constante que no nos permite reflexionar.

Como hemos podido comprobar, la práctica artística debe contrarrestar la manera en la cual los conflictos de nuestro entorno son presentados y sus victimas problematizadas. Debemos optar por una liberación del propio cautiverio causado por el shock de las imágenes de estos acontecimientos instrumentalizados como herramientas de terror. Los artistas, como exploradores de los nuevos espacios de Internet, no han dejado pasar la oportunidad de actuar como individuos insertos en el medio, para crear nuevas formas de intervenir estos espacios desde el propio funcionamiento de estas aplicaciones en base a la actividad de los usuarios con este tipo de entornos. Al mismo tiempo, este tipo de práctica nos hace posicionarnos dentro de una táctica apropiacionista, que sirve para visibilizar la manera en la cual este tipo de empresas incorporan nuestro trabajo cognitivo a su propia propiedad intelectual.

Gracias a las redes y las aplicaciones de la Web 2.0 la apropiación y reciclaje implementaran fenómenos virales basados en una cadena interminable de versiones y reinterpretaciones. La invisibilidad y sutileza empleadas en la prácticas artísticas desarrolladas durante la presente tesis doctoral se conforma como una respuesta al selfbranding constante en el cual vivimos. Este nos empuja a mostrarnos y dejar constancia de multitud de aspectos de 
nuestra vida diaria, en definitiva generar un relato alrededor de nosotros mismos mediante las herramientas que podemos encontrar dentro de las redes sociales o el microblogging.

En la actualidad, el autor aparece camuflado dentro de nuevos modelos de autoría que replantean este concepto desde la interactividad, el anonimato, la creación colaborativa y el intercambio, dentro de espacios donde la viralidad y el reciclaje de las imágenes forman parte de nuestra cotidianidad. La implementación de este proceso saca a la luz aspectos relativos a estas aplicaciones que permanecen ocultos al gran público. Es precisamente esto lo que nos da la distancia necesaria para crear una visión crítica sobre la manera en la cual estas tecnologías construyen una visión hegemónica de nuestro entorno.

La intervención de las imágenes, como productos de los medios de comunicación de masas, subvierte las nociones de originalidad y propiedad disolviendo el concepto de autoría a la par que tergiversa su uso a favor de la práctica artística. La producción de imágenes, como parte constitutiva de nuestra vida diaria, alimenta una "identidad narrativa" dentro de las redes sociales mediante conductas exhibicionistas que buscan una afectividad artificial que se naturaliza como real dentro de Internet. La creatividad dentro de lo cotidiano impulsada por las redes ha generado imágenes que ya no responden a las connotaciones ritualísticas del pasado, sino que debido a la versatilidad de lo digital y las redes se han posicionado como elementos que nos hablan de un presente sin memoria, ya que el fluir comunicativo borra todo recuerdo de lo publicado ayer.

La cotidianidad de las imágenes las ha transformado en un medio de relacionarse con el una realidad que nos oculta el presente inmediato y cercano. Mediante la práctica artística hemos podido desentrañar como estas tecnologías han alterado la percepción de nuestro entorno y de nosotros mismos. Dentro de este escenario el Manual de Guerrilla de la Comunicación se posiciona como una mirada al pasado de la práctica artística activista dentro de los medios, los modos de hacer y el concepto primigenio de esfera publica. Esta mirada resulta útil para repensar un futuro más humano, que se sitúa fuera del solucionismo tecnológico mediante prácticas que no conllevan la transformación directa de las tecnologías. 
Uno de los logros de esta investigación es haber conseguido establecer un recorrido metodológico mediante el cual desarrollar la práctica artística dentro de las aplicaciones de la Web 2.0, desde el punto de vista del usuario en base a las posibilidades que estas aplicaciones ofrecen. Esta método basado en la exploración y reflexión crítica, genera una intervención y materialización en forma de proyecto artístico. Construye un camino mediante el cual cambiar nuestra percepción sobre la manera en la cual estas tecnologías modelan y expropian nuestro tiempo y atención en base a nuestro trabajo y practicas cognitivas. Esto nos da la oportunidad de repensar y concebir nuevas formas de actuar en Internet.

Estamos ante un sentido de lo humano que se encuentra en disputa en base a una cultura explotada por lo que conocemos como capitalismo cognitivo, que ha dado como resultado el precariado cultural. Este es un momento en el cual hemos perdido el horizonte de progreso que la modernidad nos marcó, debido a la marcada servidumbre que la cultura protagoniza, teniendo la sensación de que no podemos intervenir en el cambio de las formas de vida que se desarrollan en nuestra sociedad. Sin embargo, desde estas prácticas artísticas se propone una reapropiación de nuestro tiempo. Tal y como Marina Garcés defiende, debemos trabajar sobre la apropiación del tiempo visible para aprender a trabajar mediante una alianza de saberes que exceden y se combinan con la práctica artística, para rehacer nuestro tiempo, nuestro mundo y la manera en la que lo contemplamos. No dejándonos arrastrar por lo que Garcés denomina la condición póstuma de nuestro tiempo, la incapacidad de los individuos para intervenir en su tiempo e historia cerrándose las posibilidades a nuevas formas de vida.

En esta investigación se han presentado formas de intervención dentro de las estructuras de comunicación social generadas alrededor de lo cotidiano, utilizando estas estructuras para modificar la manera en la que el artista como usuario las usa. Para ello se ha utilizado el concepto de gramática cultural, como las normas que generan un orden basado en las relaciones de poder existentes, y estas prácticas, como las herramientas que lo pueden modificar. Estamos pues, ante una deconstrucción del funcionamiento de unas estructuras de poder de carácter comunicacional. Se intenta generar una distancia crítica en el propio espectador, de manera que se generen lecturas 
no habituales, y por lo tanto la visibilización de las estructuras de poder, sus relaciones, situaciones y procesos de comunicación dentro de lo cotidiano.

En base al recorrido generado durante esta investigación hemos visto como estas prótesis comunicacionales modelan nuestra percepción, procesos cognitivas e identidad. Es por ello que el propio uso de la tergiversación, como método que nos saca de nuestro modo de hacer cotidiano y cambia la manera en la cual percibimos nuestro entorno mediático, resulta especialmente adecuado. Las aplicaciones de la Web 2.0 como medios de producción en base a nuestro trabajo cognitivo gratuito, pueden ser objeto de una resignificación a nivel visual y a nivel performativo, con la misión de deconstruir su función ideológica, la cual no es fácilmente identificable si observamos las redes sociales u otros servicios de Internet.

Hoy en día es Internet el medio que domina el paisaje mediático de nuestro tiempo, y por lo tanto mediante el cual interrogamos al mundo a la vez que recibimos respuestas y creamos contenidos. Es dentro de este escenario donde los servicios de la Web 2.0. reescriben las reglas y métodos mediante los cuales nos interrogamos. No es de extrañar que estos medios tomen el papel de la filosofía y la religión ya que la mezcla de un motor de búsqueda y la conexión inalámbrica da como resultado algo muy parecido a Dios, como narrador omnisciente e inmaterial. En la actualidad nuestra cosmovisión, como la percepción del mundo o el marco de ideas o creencias que conforman una descripción global mediante la cual los individuos observan o interpretan el mundo, ha pasado a estar mediada corporativamente mediante algoritmos que organizan la información que recibimos y la construcción de nuestra realidad exterior.

Se ha generando toda una multitud de usuarios que han dejado de mirar a los demás para, como hemos podido apreciar, mirarse únicamente a si mismos, cautivados por el registro especular que les devuelve su terminal móvil en forma de su propia presencia, imágenes, publicaciones y historias que conforman una narrativa propia, las cual es generada como alimento de este tipo de estructuras mediáticas. Mientras que por un lado somos individuos disueltos y constituidos por información, estas herramientas son capaces de llevar nuestra percepción de la realidad y de nosotros mismos a un terreno 
artificial constituido por datos e imágenes, continuamente modificado por herramientas dedicadas a constituir estas encarnaciones y representaciones.

Una de las señas de identidad de nuestro tiempo es el solapamiento de diferentes esferas, tales como la de lo público y lo privado, entre otras que hemos podido ver anteriormente, dando origen a lo que Marina Garcés define como universalismo individualista ${ }^{386}$, es decir un proceso de modernización en el cual tanto el universalismo como el individualismo son las dos caras de un mismo proceso. El papel clásico de los medios de comunicación de masas ha sido sobrepasado por la mediatización ${ }^{387}$ como proceso que reformula la relación entre lo público y lo privado, lo real y lo virtual y lo local y lo global, gracias a las redes sociales y otros servicios de la Web 2.0. Estas redes inauguraron un espacio de exposición y difusión de discursos y materiales individuales.

Mediante esta porosidad entre lo público y lo privado producida por la necesidad de producir y consumir podemos ver la intersección de ambas esferas dentro de un nuevo paradigma, en el cual por el contrario, como nos cuenta Remedios Zafra, el verdadero potencial político de la red se atisba cuando pasamos del "yo al nosotros" 388 , mediante relaciones humanas que logran movilizarnos en base a un vínculo comunitario. Sin embargo, estos espacios funcionan en su mayoría en base al yo y su experiencia vital cotidiana, solidificada mediante imágenes publicadas con el objetivo de sustentar una audiencia que se mantiene mediante la actualización constante de contenidos personales.

Sin embargo, el potencial de las redes para "pasar del yo al nosotros", sigue presente, como en el caso de las primaveras árabes, las caceroladas de Islandia, el movimiento Occupy Wall Street o el 11M en España. Los mecanismos de comunicación interpersonal fueron útiles para subvertir el

\footnotetext{
${ }^{386}$ Garcés Marina, Un mundo común, Ediciones Bellaterra, Barcelona, 2013, p. 24.

${ }^{387}$ En este caso nos referimos a un cambio en las dinámicas sociales, de consumo y culturales debido a la gran difusión de los medios, los cuales por otro lado aparecen cada vez más invisibles de cara al gran público.

${ }^{388}$ Zafra, Remedios, op. Cit., 2015, p. 122.
} 
estado de opinión creado por el gobierno, teniendo como consecuencia el fracaso de su estrategia de comunicación. Como nos cuenta Manuel Castells ${ }^{389}$, el uso de las redes fue fundamental para este tipo de movimientos. Hoy en cambio podríamos afirmar que lo que realmente delegamos son nuestras propias capacidades e inteligencia debido a la credulidad que producen las tecnologías de la información y la comunicación, encarnadas dentro de la red de Internet. Por lo tanto la nuestra es una inteligencia delegada que genera servidumbre.

Si bien, los discursos volcados dentro de Internet como parte de nuestra producción intelectual, opiniones o creación del general intellect, son componentes de discursos bidireccionales que son contestados por otros usuarios, las plataformas en las cuales estos discursos son desplegados, son creadas y gestionadas por grandes empresas que ofrecen un servicio, que a su vez permite obtener un público masivo sobre el cual insertar publicidad y obtener datos. Este actuar está compuesto por nuestro trabajo digital gratuito y amateurizado que a su vez en rentabilizado en forma de contenido e información gratuitas. Quizá la manera de hacernos más conscientes del modo en el que estos medios nos afectan y nos transforman sea hacer visibles los contornos de estos medios, revelando por tanto la propia naturaleza de estos paisaje mediáticos. Es aquí donde la práctica artística juega un papel importante al mostrar lo que a priori no parece ser visible por el grueso de la sociedad, poniendo el acento en la manera en la cual estos medios nos modelan. Por otro lado, desde el ámbito teórico, han aparecido posicionamientos extremadamente críticos con este tipo de tecnologías y su relación con la esfera pública. El peso del ego en las aplicaciones de nuestros días parece haber afectado de manera negativa las posibilidades de producción de dinámicas sociales dentro de los espacios hegemónicos de Internet.

Como el fundador de Facebook Mark Zuckerberg ha reconoce, entre las razones principales del éxito de su creación se encuentra el hecho de poder compartir con tus amigos en base a una identidad real. Aunque se han reducido drásticamente, ya que no entran dentro de las lógicas de la Web 2.0., hay otros sitios en Internet donde uno puede desarrollar una identidad

${ }^{389}$ Castells, Manuel, 2012, p. 212. 
ficticia. En cambio el éxito de Facebook se basa en el uso de identidades reales. Esto obviamente delimita y modela el tipo de interacciones que van a tener lugar en esta red social, implementando un tipo concreto de publicaciones y dinámicas sociales. Esta lógica propia de las reflexiones de Marshall McLuhan, nos lleva a plantearnos como nos convertimos en lo que contemplamos y como "modelamos nuestras herramientas y luego estas nos modelan a nosotros" 390 , siendo el medio el que modela la dimensión y la forma de la sociedad. Nos encontramos un tipo de entorno mediático que se adapta a las tendencias de los usuarios y cuyos contenidos regidos mediante la hipermediatez y la viralidad hacen posible conexiones entre diferentes materiales mediáticos y significados.

Como hemos podido observar, lo ambivalente de la realidad en la cual nos movemos se ha visto acentuada por la propia flexibilidad intrínseca de Internet, como un medio mediante el cual podemos generar todo tipo de imaginarios. Como nos cuenta Manuel Castells en su obra La Galaxia Internet. "La elasticidad de Internet hace que este media sea especialmente apropiado para acentuar las tendencias contradictorias de nuestra sociedad. Internet no es ni una utopía ni una distopía, es el medio en que nosotros nos expresamos mediante un código de comunicación especifico que debemos comprender si pretendemos cambiar nuestra realidad"391. Como apunta Castells es obvio que nos movemos en un medio con muchas aristas cuya incoherencia es construida por nuestra propia actividad en la red y los múltiples intereses e iniciativas, tanto privadas como públicas, que la gobiernan. Estamos ante un medio que genera una imagen especular de nosotros mismos, que muestra lo que realmente hemos creado y desarrollado.

Sin embargo, la percepción como un elemento inherentemente social, no responde únicamente a elementos visuales o hechos. Como nos cuenta el psicólogo social de origen holandés Sander van der Linden ${ }^{392}$, tendemos a prestar mayor atención a las informaciones con las que estamos de acuerdo e

\footnotetext{
${ }^{390}$ McLuhan, Marshall, op. Cit., 1996, p. 20.

${ }^{391}$ Castells, Manuel, op. Cit., 2001, p. 20.

${ }^{392}$ Van der Linden, Sander, Maibach, Edward, Leiserowitz, Anthony, Improving Public Engagement With Climate Change: Five "Best Practice" Insights From Psychological Science, Perspectives on Psychological Science Vol. 10, no 6, 2015, p. 758 - 763.
} 
ignorar las que nos parecen falsas, y es aquí donde las noticias falsas y la desinformación actúan haciéndonos responder con mayor atención a hechos que no responden a informaciones veraces. Los algoritmos de las redes sociales potencian las noticias sobre las que clicamos con mayor asiduidad, ofreciéndonos contenidos similares constantemente, alimentando nuestras opiniones con información con la que evidentemente ya estamos de acuerdo, y por lo tanto disminuyendo nuestra apertura de mente hacia otro tipo de opiniones, contenidos y noticias. Por lo tanto estamos hablando de algoritmos que polarizan los contenidos que consumimos en base a nuestra actividad.

Sin embargo, podemos afirmar que son las noticias falsas, distribuidas viralmente mediante las redes sociales, las que hacen posible la propagación de este tipo desinformación que neutraliza el poder de los hechos contrastados científicamente. Irónicamente, mediante la difusión en redes sociales de informaciones que desacreditan y ponen de manifiesto lo absurdo de este tipo de informaciones podemos revertir la efectividad de las noticias falsas. Vivimos en un medio en el cual todos nos movemos al unísono generando una coreografía mediante la cual delegamos nuestra opinión y nuestra crítica gracias a nuestra pasividad, creando un tipo de actividad que no genera experiencia pese a la gran cantidad de información que recibimos.

Si bien, el tipo de funcionamiento delimita el tipo de uso que le damos a diferentes aplicaciones, será por otro lado, el tipo de discursos que se crean dentro de estas lo que delimitara el nivel de utilidad comunicativa. Podemos utilizar un medio para debatir sobre una cuestión determinada, como hemos podido observar reiteradamente, no siempre la información actúa generando un debate racional, sino que más bien polariza el debate público. Incluso los puntos de discusión desacreditados por los hechos continúan usándose como slogans. Estos rasgos definen a la perfección el concepto de posverdad, el cual apunta hacia un tipo de sociedad en la cual la opinión pública se ve influencia en mayor medida por creencias o emociones que por los hechos probados en base investigaciones científicas.

Como ya indicamos la máxima "pienso luego existo" ha dado paso a la de "siento luego existo", como nos anunciaba Antonio Damasio en su obra El 
error de Descartes ${ }^{393}$. La opción de creer en el solucionismo que la tecnología nos ofrece se nos ha presentado como una herramienta esencial ante la nuestra imposibilidad de producir una sociedad mejor. Se trata de un tipo de público adulto que tiende a creer lo que mejor defiende sus intereses en cada ocasión, aceptando inconscientemente que ya somos incapaces de reflexionar sobre lo que esta sucediendo a nuestro alrededor.

Este tipo de actitudes han posibilitado la aparición de un posicionamiento crédulo que facilita y posibilita relaciones de dominación, que a su vez impide nuestra emancipación como individuos. Seguimos pensando que las tecnologías producen formas de liberación, como es el caso de las corrientes tecno-utópicas de los años 60 y 70 del siglo XX, sin embargo y como podemos comprobar a diario, las nuevas formas de liberación también pueden generar formas de dominación aún más poderosas.

Como hemos podido comprobar, la aparición de las aplicaciones de la web 2.0 como estructuras mediáticas hegemónicas corporativamente gestionadas, dieron un vuelco a nuestra concepción sobre la red como un espacio de libertad e intercambio. Empezamos a discernir la manera en la cual los medios afectan nuestro discernimiento y percepción de todo lo que nos rodea, así como también la manera en la cual nos exponemos al mundo. No para discernir ante los demás, sino para exteriorizar nuestra privacidad de manera continua y voluntaria en base a, como ya nos anunciaba Neil Postman citando la obra de Huxley Un mundo feliz, un mundo en el cual los individuos de una sociedad sacrifican sus derechos para conseguir una droga relacionada con la distracción.

Durante esta tesis doctoral hemos asistido al desarrollo, expansión, apogeo y juicio público de algunas de las aplicaciones paradigmáticas asociadas a la Web 2.0. Estamos ante un tipo de medios tecnológicos que aparecieron ante el auge de la denominada nueva economía de los años 90 del siglo XX, pero que alcanzaron si cenit en la siguiente década, constituyéndose como una tipología mediática propia, en base a sus características sociales de participación y creación. Sin embargo, desde la implementación del primer algoritmo de

${ }^{393}$ Damasio, Antonio, op. Cit., 1996. 
Google hasta nuestros días, este tipo de servicios han mutado del mismo modo que los proyectos y empresas que los acogieron, pasando a conformarse como modelos transnacionales de negocio, que utilizan muchas de sus nuevas funcionalidades y tecnologías para constituir una parte fundamental de la manera en la cual desarrollamos nuestra vida diaria.

Sin duda, el arco temporal que abarca desde la aparición de estas aplicaciones hasta nuestros días nos muestra diferentes conceptos que hemos estudiado durante esta investigación. Como pudimos observar la expectación y fascinación por un nuevo tipo de negocio incentivado desde el mundo de las finanzas y el emprendimiento, dio lugar a un tipo de extensiones tecnológicas de nosotros mismos por las cuales quedamos fascinados inmediatamente. Esto es algo que como pudimos ver Marshall McLuhan describe como narcosis narciso. Para el, todos los medios es un fase de innovación permanecen ocultos para los usuarios, actuando sobre nosotros con toda libertad. Factores como el hype, descrito como algo que el consumidor espera en base a la información externa recibida sobre un producto o servicio, se ha convertido en una de las herramientas desde las cuales se promocionan y expanden multitud de proyectos y modelos tecnológicos. Normalmente, este tipo de tendencia viene acompañada de supuestas virtudes o cualidades que este producto reviste, pero que difícilmente son comprobables. De este modo, estas son construidas en base a una imagen de marca tremendamente potente e innovadora. Podemos afirmar que el hype se fundamenta al igual que la posverdad es aspectos emocionales del ser humano, solo que en este caso en lugar de hacer creíble una información se construye artificialmente un interés sobre un tema concreto. Sin embargo, este tipo de estrategias de marketing pueden ser contraproducentes, ya que los propios usuarios pueden descubrir que las supuestas virtudes de un producto, son en realidad una elaborada construcción en su mente y generada en base a sus emociones.

Hemos dejado de creer en la necesidad de educarnos más allá de la simple adquisición de información para alcanzar una vida más plena, cediendo nuestro intelecto, tiempo y capacidades para conformar una credulidad desinformada, o lo que Marina Garcés denomina "analfabetismo ilustrado"394. Un tipo de estatus intelectual en el cual el acceso al

${ }^{394}$ Garcés, Marina, Nueva Ilustración Radical, Editorial Anagrama, Barcelona, 2017, p. 45. 
conocimiento no implica la solución a ningún problema, debido a nuestra incapacidad para generar formas de entender nuestra realidad, la manera de relacionarnos con el mundo que nos rodea y con nosotros mismos. Esta incesante acumulación de información neutraliza cualquier intento de crítica real, ya que tiende a saturar nuestra atención. Genera un lenguaje estandarizado, construyendo una hegemonía del solucionismo como respuesta a todos nuestros males. Este tipo de realidad que sobrepasa nuestras capacidades genera un tipo de actitud acrítica como consecuencia de una atención ahogada en multitud de informaciones, lo que nos transforma en ignorantes crédulos, que deciden delegar sus opiniones y criterios de manera pasiva a favor de todo tipo de servicios. Este tipo de práctica se ha conformado como un tipo de actividad incapaz de producir experiencia o comprensión real, pero si estandarización y segmentación que hace que nuestras habilidades y saberes estén incomunicados entre si.

Estamos en un momento en el cual la tecnología ha conseguido adquirir virtudes plenamente divinas, permitiéndonos interactuar sobre diferentes áreas problemáticas de nuestra vida y nuestra sociedad, delegando problemas complejos a estrategias digitales de cuantificación. Esto ha producido, como pudimos ver, lo que Evgeny Morozov denomina el solucionismo tecnológico, concepto que le sirve para debatir sobre las consecuencias morales de las nuevas tecnologías ante un mundo regido por la eficiencia que la tecnología nos ofrece. Morozov advierte sobre la vampirización llevada a cabo por parte de Silicon Valley sobre los intelectuales de los años 60 del Siglo XX para absorber el espíritu e ideas de esta época generando narrativas que ocupan el debate alrededor de la tecnología. Sin embargo, el alude a la importancia de la economía como único motor de estos proyectos emprendedores mediante el capital de riesgo, la nueva economía, la geopolítica y el imperialismo.

Morozov apunta hacia sistemas que han sido creados para crear dependencia, debido a que cimenta la propia rentabilidad de estos proyectos innovadores mediante un condicionamiento similar al de los perros de Paulov. Estamos hablando de modelos de negocio que se nutren de nuestra atención y trabajo cognitivo, manofacturando un tipo de dependencia que nos distrae constantemente. Por otro lado, la ansiedad de expresar nuestro yo, de posicionarnos dentro de la sociedad y actualizar quienes somos constantemente, mueve las aplicaciones sociales de la Web 2.0, explotando nuestras relaciones y amistades en beneficio de las empresas que las crean. A 
este respecto Morozov argumenta que Silicon Valley solo ofrece soluciones a los propios problemas que sus propias tecnologías crean mediante más tecnologías novedosas y penetrantes en nuestro ámbito cognitivo. Esto genera un tipo de medios mediante los cuales se genera movilidad social y la sensación ficticia de avance pero que en absoluto contribuyen a mejorar o desarrollar nuestro ámbito social y comunicativo. Más bien se trata de la mezcla de los privado y lo público, tal y como pudimos apreciar en el primer proyecto presentado en esta investigación y que tuvo lugar en la aplicación de videochat Chatroulette, donde por otro lado pudimos comprobar como un mayor numero ce conexiones no implica una mayor número de comunicaciones.

En los últimos años hemos visto como la aparición de multitud de aplicaciones que han cerrado tras tiempos de gran popularidad o algunas otras que no pudieron adaptarse a un entorno mediático altamente competitivo. Aplicaciones sociales como MySpace vieron como lo que antes fue una gran comunidad les abandonaba inexorablemente. Por otro lado proyectos como Google +, nunca pudieron contar con la confianza del gran publico. A todo esto hay que unir el gran número de usuarios que simplemente deciden abandonar y cerrar sus redes por convencimiento propio, unido a la necesidad de desaparecer de la burbuja mediática en la cual estamos inmersos. Quizá se basa en la necesidad de recuperar un reconocimiento de nosotros mismos no basado en el feedback obtenido en las redes. La monotonía de unas mecánicas claramente repetitivas, el paso de los años y la toma de conciencia sobre los efectos de estas aplicaciones han propiciado el abandono por parte de sectores concretos de la población. Este incesante goteo de abandonos, más o menos anónimos, que están sufriendo tanto Twitter como el resto de plataformas virtuales en estos últimos años es algo sobre lo cual reflexiona Enric Puig Punyet en su obra El Dorado 395 mediante el termino exconectados, el cual sirve para designar a personas que tras haber participado de las promesas de horizontalidad y de igualdad asociadas a la red han pasado a distanciarse de este sistema por el descredito y lo ilusorio de estos proyectos. Punyet los conceptualiza como una contrarrevolución que se comporta como un freno a la aceleración que la redes propician, ante el malestar generado por unas tecnologías que se contraponen al progreso social. Al igual que los luditas del S.XIX estos exconectados no se plantean una lucha contra la tecnología en

${ }^{395}$ Puig Punyet, Enric, op. Cit., 2017, p. 117. 
si misma, sino contra el control que una elite ejerce sobre estas y que garantiza y perpetua la hegemonía cultural y tecnológica de estas. Se trata pues de un cambio de orientación, en el sentido de redirigir una relación con la tecnología que deviene dominación.

Por otro lado, la vida de los influencers ha generado un modelo de negocio inédito hasta le momento, pero que ha aumentado la ansiedad que sentimos por compartir nuestro estilo de vida y compararnos con otros usuarios. No entendemos que no tenemos la necesidad de transformarnos en una imagen de marca. La insatisfacción con la clase vida que llevamos, o la baja autoestima han increnmentado la necesidad de obtener una aprobación exterior. Esta actividad se ha transformado en parte de un trabajo cognitivo gratuito que desarrollamos dentro de la red para beneficio de estas compañías. La búsqueda de la afectividad y relaciones desemboca en muchas ocasiones en un tipo de comportamiento que difícilmente puede suplir estas, pero que genera una adicción por el tipo de recompensas que este tipo de aplicaciones nos devuelven. Por otro lado, el uso profesional de estas redes en lo que podemos denominar economía afectiva, ha erosionado en muchos casos las barreras entre el trabajo y la vida privada, generando perfiles profesionales cada vez más precarizados y desprofesionalizados. Esto ha contribuido a la postre a una desinstitucionalización de las humanidades como colofón del proyecto cognitivo del capitalismo actual.

La toma de conciencia ante el funcionamiento de este tipo de tecnologías sociales ha puesto de manifiesto como estas se valen de nuestra información para construir su propio modelo de negocio, mediante la explotación de una gran masa de usuarios. El diseño de estas estructuras mediáticas esta pensado para manipular nuestro comportamiento mediante un gran número de elementos que nos hacen permanecer interconectados constantemente y nos obligan a interactuar de manera continua, produciendo hábitos rutinarios. Mediante nuestra atención se ha erigido un modelo de negocio que genera valor en base a nuestras prácticas cognitivas, las cuales son incentivadas mediante todo tipo de estrategias poco éticas, tales como actividad y mensajes que no se corresponden con interacciones reales o relevantes, pero que mantienen a los usuarios activos y perceptivamente en estado de alerta ante la avalancha de nuevas informaciones que recibimos. Este fluir comunicacional provoca estrés y sensación de inabarcabilidad, fragmentando nuestra atención 
pero manteniéndonos conectados y distraídos permanentemente, lo cual mina a la postre nuestra capacidad de atención.

Sin duda nos encontramos con un tipo de tecnologías que han empezado a ser visibles, en el sentido de atisbar claramente sus efectos, y por lo tanto, empiezan a adentrarse lentamente en un periodo de obsolescencia. Como podemos observar, algunos usuarios al menos, las abandonan por un tiempo o reducen considerablemente su uso. Este abandono, más que el fin de una moda pasajera, debe considerarse como el inicio de la toma de conciencia por parte de los usuarios de los efectos y verdadero alcance de estas tecnologías. La falta de un marco regulador que de confianza a los usuarios también ha minado la visión que tenemos sobre este tipo de tecnologías. Solo en EEUU existe un organismo, la Comisión Federal del Comercio, que regula de alguna manera las prácticas de las empresas de Internet. Sin duda, solo a través de una regulación que ofrezca garantías a los usuarios se podrá empezar a hablar de un tipo de tecnologías generadas a la medida de los usuarios como un servicio realmente trabaja en base a los intereses de estos.

Si tenemos en cuenta los casos de plataformas como Facebook y su escandalo Cambridge Analytica, donde su completo modelo de negocio ha sido puesto en tela de juicio, debido a la venta de datos, los términos y condiciones abusivos y las dinámicas sociales concebidas se acuerdo a sus propios creadores para generar adicción en los usuarios, podemos ver como la percepción sobre este tipo de aplicaciones ha cambiado sustancialmente dentro de la propia esfera mediática. Lo que hace una década era presentado como un innovador y exitoso modelo de negocio, al amparo de un creciente determinismo tecnológico, la nueva economía y su fondos de inversión de capital riesgo, y como no, el termino Web 2.0 convertido en un meme, ha terminado siendo cuestionado en muchos aspectos. A medida que hemos ido comprendiendo como sociedad la manera en la cual estos medios funcionan, hemos empezado a preguntarnos si es aconsejable o necesario el uso de estas redes.

Estamos pues ante tecnologías que generan un tipo de transformaciones, descritas desde el concepto de neuroplasticidad, que alteran la propia estructura de nuestra mente y la construcción biopolítica de nuestra actividad cognitiva, transformada en trabajo inmaterial, digital, amateurizado y gratuito. Debemos por tanto, generar conciencia como sociedad sobre la manera en la 
cual somos transformados por las propias tecnologías que creamos. Para ello de vemos cambiar nuestra visión del presente en base a tecnologías que miramos mediante los ojos del pasado, siendo incapaces de vislumbrar el verdadero funcionamiento de las mismas, condicionando a la postre nuestra percepción y subjetividad, y por lo tanto como nos vemos a nosotros mismos y como vemos el mundo exterior. Dentro de este campo de juego perceptivo es donde libra la pugna por la dominación de nuestro tiempo, visión y actuar.

Como hemos podido observar el proyecto cognitivo del capitalismo actual ha sido capaz de apropiarse de nuestra inteligencia como fuerza productiva, sin embargo ha amputado el uso de esta como potencia reflexiva y autónoma, desvinculando nuestras prácticas cognitivas de cualquier proyecto colectivo emancipatorio, más allá de canales alternativos que disgregan y segmentan nuestros esfuerzos en micromundos, imposibilitando por tanto una respuesta certera a un capitalismo cognitivo cada vez más poderoso. Vivimos en un momento en el cual hemos perdido el horizonte de progreso propugnado por la modernidad hace décadas, pero también la posibilidad de un posicionamiento crítico posmoderno, en el sentido de escrutar y examinar nuevas posibilidades en base al análisis del presente. Más allá de intentar restaurar un nuevo sentido de la historia basado en el pasado moderno necesitamos dar un nuevo sentido a nuestra temporalidad que trascienda el solucionismo tecnológico como respuesta hegemónica a las problemáticas de nuestro tiempo. Es aquí donde la práctica artística debe jugar un papel esencial a la hora de generar un puente entre diferentes saberes que cree una actitud incrédula ante la hegemonía ideológica producida por la tecnología, que precisamente crea una desactivación de nuestra subjetividad crítica mediante una inteligencia delegada e irreflexiva que no puede examinarse a si misma. Debemos, tal y como defiende Marina Garcés, volver a ubicar en la centralidad el estatuto de lo humano, reapropiándonos de esta condición asociada a una inteligencia reflexiva de unas humanidades en transición, es decir diversas, críticas, en transformación constante y mediante las cuales podamos elaborar el sentido de la experiencia humana.

Como podemos extraer del ensayo de Remedios Zafra El entusiasmo ${ }^{396}$, mediante la idea de emprender, el capitalismo ha conseguido esconder la

\footnotetext{
${ }^{396}$ Zafra Remedios, El entusiasmo. Precariedad y trabajo creativo en la era digital, Editorial Anagrama, Barcelona, 2017.
} 
manera en la cual se instrumentaliza nuestra motivación, como metodología mediante la cual rentabilizar nuestra hiperproducción. Esto es algo que podemos ver a diario en el ámbito de las redes sociales, objeto fundamental de análisis en esta investigación, pero que podría también servir para describir el estado de la cultura contemporánea y las artes visuales en particular. La velocidad surge del exceso como característica de nuestra cultura digital, mediante la cual todos los usuarios somos productores de conocimiento, opiniones e información, conformando una nueva forma de ceguera análoga a la hiperestimulación sensorial de la que nos hablaba McLuhan, en base al entumecimiento producido por nuestras extensiones tecnológicas.

Por otro lado, la precariedad esta convirtiéndose en una manera de romper el vinculo entre iguales en base a la tremenda competitividad desarrollada en el ámbito cultural, construyendo personas permanentemente conectadas pero solas. Este escenario está neutralizando a personas con grandes capacidades creativas en base a la obtención de méritos que configuran una vida aplazada, a la espera, previniendo un futuro cada vez más incierto y burocratizado que siempre se aplaza. Mediante la reflexión, examen y crítica se pretende generar una parada para pensar como estamos creando el presente y hacia donde apunta, papel que por otro lado la práctica artística siempre ha intentado desarrollar. La necesidad de una parada para intervenir activamente en el futuro, es en realidad la inversión en un tiempo para pensar nuestro momento, que haga posible un cambio en nuestros imaginarios y la transformación de nuestro mundo mediante la ruptura del ritmo que este sistema nos reclama mediante la prisa. Llenamos nuestras vidas de automatismos que delegan nuestra inteligencia y la posibilidad de frenar y tomar distancia mediante la reflexión, posibilitando la adopción de ideas preconcebidas, en lugar de formas creativas.

La adopción de formas de domesticación se ha tranformado en seres incapaces de percibir y pensar el presente, nos impide profundizar en nosotros mismos, tomar conciencia, discernir y construir quienes somos realmente. Nos ha transformado en seres resignados ante un mundo donde los medios generan un poder asimétrico gracias a su capacidad para dividirnos y sacar rédito de esta fragmentación. Es precisamente mediante los aspectos reflexivos asociados a la creatividad como podemos repensar el status quo en el cual desarrollamos nuestro tiempo de vida, optando por un tipo de creación que no tenga como finalidad la implementación de un sistema del arte 
gobernado por una industria cultural precarizada que demanda nuevos productos elaborados mediante el entusiasmo creativo de una gran masa de artistas precarizados y amateurizados. La diletancia como estado profesional perpetuo nos empuja a trabajar por un futuro que no llega, rodeados de una cultura producida de manera irreflexiva. Esto también tiene su reflejo en las redes mediante el supuesto uso profesional de plataformas que desprofesionalizan la cultura a través de la búsqueda de novedades y la interactividad que estos medios proporcionan, pero ocultando como al mismo tiempo generan nuevas formas de esclavitud y dependencia como contraprestación a una visibilidad que hace que existamos dentro de un mundo conectado. Estamos en un momento en el cual los argumentos individuales que triunfan deben de reunir a una multitud alrededor y por lo tanto despertar emotividad, radicalidad y dogmatismo. Esto contradice radicalmente lo que Habermas define como requisitos de la consolidación de un tipo de esfera pública racional entre iguales, como elemento transformador de la sociedad, como una manera de pasar del yo que las redes incentivan a un nosotros que verdaderamente conforme una colectividad despierta y asentada en un presente crítico, capaz de aprender del pasado y construir un futuro en base a esta reflexión. 


\section{English:}

The role of the artist as a media explorer, give us the possibility of positioning ourselves as discoverers of alterations and new changes in the media environment. This is due to the inherent activity of the artists as a sniffer, which makes him aware of the profound perceptive changes in the information and communication technological environments. It's here where their predictive capacity is evident, referring to their perceptive ability, in a certain way of reading the language of the outside and linking it to the inner world. As artistic practice developed within a hegemonic virtual space, the artist uses the structures of power, appropriating, modifying and distorting their signs and codes. On the other hand, by using the tools of these media spaces to visualize these effects, we are generating a distortion. The own use of the technologies associated with Web 2.0. without modifying them, that is to say, from the point of view of the user, it's presented as a response to the ruling technological solutionism. This is a restful mood that contrasts with the constant acceleration that doesn't allow us to reflect on.

As we have seen, the artistic practice must counteract the way in which the conflicts of our environment are presented and their victims problematized. We must opt for a liberation of the captivity caused by the shock of the images of these events exploited as tools of terror. Artists, as explorers of new Internet spaces, haven't missed the opportunity to act as individuals inserted into the environment, in order to create new ways of intervening these spaces from the own working of these applications, based on the activity of the users in this kind of environments. At the same time, this kind of practice makes us take a stance within an appropriationist tactic, that serves us to make visible the way in which this kind of companies incorporates our cognitive work into their own intellectual property.

Thanks to networks and applications of the Web 2.0, appropriation and recycling are implementing a viral phenomenon based on an endless chain of versions and reinterpretations. The invisibility and subtlety employed in the artistic practices developed during the present doctoral thesis is shaped as a response to the constant self-branding in which we live. This pushes us to show and record many aspects of our daily life, in short, generate a tale around ourselves through the tools we can find within social networks or microblogging. 
Currently, the creator appears camouflaged within new models of authorship that rethink this concept from point of view of the interactivity, anonymity, collaborative creation and exchange, within spaces where virality and recycling of images are part of our daily life. It is precisely this what gives us the necessary distance to create a critical vision of the way in which these technologies build a hegemonic vision of our environment.

The intervention of the images, as products of mass media, subverts the notions of originality and property, dissolving the concept of authorship while distorting their use in favor of the artistic practice. The production of images, as part of our daily life, feeds a "narrative identity" within the social networks through exhibitionistic behaviors that seek an artificial affectivity that is naturalized as real on the Internet. The creativity in every day on the Internet, has generated images that no longer respond to the ritualistic connotations of the past, but because of the versatility of the digital and networks, have positioned themselves as elements that speak of a present without memory, since the communicative flow erases all memory of what was published yesterday.

The everyday nature of the images transforms them into a way of connecting to this reality that hides the immediate and close. Through the artistic practice, we have been able to figure out how these technologies have altered the perception of our environment and ourselves. Within this scenario, the Communication Guerrilla Handbook is set as a look at the past of the activist artistic practice within the media, the ways of doing and the primal concept of the public sphere. This look is useful to rethink a more human future, through practices that do not involve the direct transformation of technologies.

One of the achievements of this research is to establish a methodological path through which to develop an artistic practice within Web 2.0 applications, from the user's point of view based on the possibilities offered by these applications. This method, based on exploration and critical reflection, generates an intervention and materialization in the form of an artistic project. It builds a path through which we can change our perception of the way in which these technologies models and expropriate our time and 
attention based on our work and cognitive practices. This gives us the opportunity to rethink and conceive new ways of acting on the Internet.

We are before a sense of the human that is in dispute based on a culture exploited by what we know as cognitive capitalism, which has resulted in a precarious culture. This is a moment in which we have lost the horizon of progress that modernity showed us, due to the marked servitude that culture plays, with the feeling that we can't take part in the change of the life forms that are developed in our society. However, from these artistic practices, an appropriation of our time is proposed. As Marina Garcés defends, we must work on the appropriation of the visible time, in order to learn to work through an alliance of knowledge that exceeds and combines with artistic practice, to re-make our time, our world and the way we contemplate it. Not letting ourselves be dragged by what Garcés calls the "posthumous condition" of our time, the inability of individuals to intervene in their time and history, closing their possibilities to new ways of life.

In this research, forms of intervention have been presented within the structures of social communication generated around every day, using these structures to modify the way in which the artist as the user uses them. To this end, the concept of cultural grammar has been used as the norms that generate an order based on existing power relations, and these practices as the tools that can modify it. We are therefore facing a deconstruction of the functioning of the power structures of communicative nature. We try to generate a critical distance in the viewer, so unusual readings are generated, and therefore the visibility of power structures, their relationships, situations and communication processes within the everyday.

Based on the journey generated during this research, we have seen how this communicational prosthesis shapes our perception, cognitive processes, and identity. That's why the very use of distortion, as a method that takes us out of our way of doing every day and changes the way we perceive our media environment, is especially appropriate. The applications of Web 2.0 as a media of production based on our free cognitive work, can be the object of a resignification at a visual and performative level, with the mission of deconstructing it's ideological function, which is not easily identifiable if we observe the social networks or other Internet services. 
Nowadays the Internet is the medium that dominates the media landscape of our time, and therefore through which we interrogate the world while we receive responses and create content. It's within this scenario where the services of the Web 2.0. rewrite the rules and methods by which we interrogate ourselves. It is not surprising that these media take on the role of philosophy and religion, since the combination of a search engine and the wireless connection results in something very similar to God, as an omniscient and immaterial narrator. Today our worldview, as the perception of the world or the framework of ideas or beliefs that make up a global description through which individuals observe or interpret the world, has become corporately mediated through algorithms that organize the information we receive and the construction of our external reality.

It has generated a multitude of users who have stopped looking at others too, as we have seen, only look at themselves, captivated by the mirror image that gives them back their mobile terminal in the form of their own presence, images, publications and stories that conform a narrative of their own, which is generated as food for this kind of media structures. While on the one hand, we are individuals dissolved and constituted by information, these tools are capable of taking our perception of reality and ourselves to an artificial terrain constituted by data and images, continuously modified by tools dedicated to built these incarnations and representations.

One of the hallmarks of our time is the overlapping of different spheres, such as public and private spheres, among others that we have seen previously, giving rise to what Marina Garcés defines as individualistic universalism ${ }^{397}$, that is, a process of modernization in which both universalism and individualism are two sides of the same process. The classic role of the mass media has been overtaken by the mediatization ${ }^{398}$ as a process that reformulates the relationship between the public and the private, the real and the virtual and the local and the global, thanks to the social networks and other social services related to the Web 2.0. These networks inaugurated a

\footnotetext{
${ }^{397}$ Garcés Marina, Un mundo común, Ediciones Bellaterra, Barcelona, 2013, p. 24.

${ }^{398}$ In this case we refer to a change in the consumption and cultural social dynamics due to the great diffusion of the media, which on the other hand appear increasingly invisible to the general public.
} 
space for the exhibition and dissemination of speeches and individual materials.

Through this porosity between the public and the private produced by the need of produce and consume, we can see the intersection of both spheres within a new paradigm, in which, on the contrary, as Remedios Zafra tells us, the true political potential of the network is seen when we move from "I to We"399, through human relationships that manage to move based on a community bond. However, these spaces function mostly based on the self and their daily life experience, solidified by images published with the aim of sustaining an audience that is maintained through the constant updating of personal contents.

However, the potential of the networks to "move from the I to the We" is still present, as in the case of the Arab Springs, the Icelandic pots, the Occupy Wall Street movement or the $11 \mathrm{M}$ in Spain. The mechanisms of inter-personal communication were useful to subvert the state of opinion created by our governments, having as a consequence the failure of its communication strategy. As Manuel Castells 400 tells us, the use of networks was fundamental for this kind of movement. Today we could say that what we really delegate is our own abilities and intelligence because of the credulity produced by the information and communication technologies, embodied within the Internet network. Therefore, ours is a delegated intelligence that generates servitude.

Although, the speeches dumped within the Internet as part of our intellectual production, opinions or creation of the general intellect, are components of bidirectional discourses that are answered by other users, the platforms in which these discourses are displayed, are created and managed by large companies that offer a service, which in turn allows them to obtain a mass audience on which to insert advertising and obtain data. This activity is made up for our free and motorized digital labor that in turn is profitable in the form of free content and information. Perhaps the way to become more aware of the way in which these media affect and transform us is to make visible the

\footnotetext{
${ }^{399}$ Zafra, Remedios, op. Cit., 2015, p. 122.

${ }^{400}$ Castells, Manuel, 2012, p. 212.
} 
contours of these media, thus revealing the very nature of these media landscape. This is where artistic practice plays an important role in showing what in advance does not seem to be visible by the majority of the society, with an emphasis on the way in which these media shapes us. On the other hand, from the theoretical field, extremely critical positions have appeared with this kind of technology and its relationship with the public sphere. The weight of the ego in today's applications seems to have adversely affected the possibilities of producing social dynamics within the hegemonic spaces of the Internet.

As the founder of Facebook Mark Zuckerberg has recognized, among the main reasons for the success of his creation is the fact of being able to share with your friends based on a real identity. Although they have been drastically reduced, since they do not fall within the logics of Web 2.0, there are other sites on the Internet where one can develop a fictitious identity. In contrast, the success of Facebook is based on the use of real identities. This obviously delimits and models the kind of interactions that will take place in this social network, implementing a specific kind of publications and social dynamics. This logic, typical of the reflections of Marshall McLuhan, leads us to consider how we become what we contemplate and how we "model our tools and then these model us" 401 , being the medium that models the dimension and form of society. We find a kind of media environment that adapts to the tendencies of the users and whose contents governed by hypermediation and virality make possible connections between different media materials and meanings.

As we have seen, the ambivalence of the reality in which we move has been accentuated by the intrinsic flexibility of the Internet, as a means by which we can generate all kinds of imaginaries. As Manuel Castells tells us in his work The Internet Galaxy. "The elasticity of the Internet makes this media, especially appropriate to accentuate the contradictory tendencies of our society. The Internet is neither a utopia nor a dystopia, it is the medium in which we express ourselves through a specific communication code that we must understand if we intend to change our reality"402. As Castells points out, it's obvious that we move in a medium with many edges whose incoherence is

\footnotetext{
${ }^{401}$ McLuhan, Marshall, op. Cit., 1996, p. 20.

${ }^{402}$ Castells, Manuel, op. Cit., 2001, p. 20.
} 
built by our own activity on the Internet and multiple interests and initiatives, both private and public, that govern it. We are facing a medium that generates a mirror image of ourselves, which shows what we have really created and developed.

However, perception as an inherently social element, does not respond only to visual elements or facts. As the Dutch social psychologist Sander van der Linden 403 tells us, we tend to pay more attention to the information we agree with and ignore what we think is false, and this is where fake news and misinformation act, making us respond with greater attention to facts that don't respond to accurate information. The algorithms of the social networks enhance the news about which we click with greater assiduity, offering similar content constantly, feeding our opinions with information with which we obviously agree, and therefore decreasing our openness of mind towards other types of opinions, contents and news. Therefore, we are talking about algorithms that polarize the content we consume based on our actions.

However, we can affirm that it is the fake news, distributed virally through social networks, which make possible the propagation of this kind of misinformation that neutralizes the power of scientifically contrasted facts. Ironically, through the dissemination in social networks of information that discredit and reveal the absurdity of this type of information, we can reverse the effect of fake news. We live in a medium in which we all move in lockstep, generating a choreography through which we delegate our opinion and our criticism thanks to our passivity, creating a type of activity that doesn't generate experience despite the large amount of information we receive.

Although, the kind of working process delimits the kind of use that we give to different applications, it will be on the other hand, the kind of discourses that are created within these, what will delimit the level of communicative utility. We can use a media to discuss a given issue, as we have repeatedly observed, not always the information acts generating a rational debate, but rather polarizes the public debate. Even points of discussion discredited by the facts

\footnotetext{
${ }^{403}$ Van der Linden, Sander, Maibach, Edward, Leiserowitz, Anthony, Improving Public Engagement With Climate Change: Five "Best Practice" Insights From Psychological Science, Perspectives on Psychological Science Vol. 10, no 6, 2015, p. $758-763$.
} 
continue to be used as slogans. These traits perfectly define the concept of post-truth, which points towards a kind of society in which public opinion is influenced to a greater extent by beliefs or emotions than by proven facts based on scientific research.

As we already indicated the maxim "I think therefore I am" has given way to "I feel therefore I am", as Antonio Damasio announced us in his work Descartes' Error: Emotion, Reason, and the Human Brain. The option to believe in the solution that technology offers us has been presented to us as an essential tool before our impossibility to produce a better society. It's a kind of adult public, that tends to believe what best defends their interests on each occasion, unconsciously accepting that we are unable to reflect on what is happening around us.

This kind of attitude has enabled the emergence of a credulous position that facilitates and enables relations of domination, which in turn prevents our emancipation as individuals. We continue thinking that technologies produce forms of liberation, as is the case of the techno-utopian trends of the $60 \mathrm{~s}$ and 70 s of the 20th century, however, as we can see on a daily basis, new forms of liberation can also generate forms of domination even more powerful.

As we have seen, the emergence of web 2.0 applications as comparatively managed media hegemonic structures, overturned our conception of the network as a space of freedom and exchange. We began to discern the way in which the media affect our discernment and perception of everything that surrounds us, as well as the way in which we expose ourselves to the world. Not to discern before others, but to exteriorize our privacy in a continuous and voluntary way based on, as Neil Postman announced to us quoting Huxley's work A Happy World, a world in which the individuals of a society sacrifice their rights to obtain a drug related to distraction.

During this doctoral thesis, we have assisted in the development, expansion, apogee and public judgment of some of the paradigmatic applications associated with Web 2.0. We are facing a type of technological media that appeared before the rise of the so-called new economy of the 90s of the twentieth century, but that reached its zenith in the next decade, constituting 
itself as a media typology of its own, based on its social characteristics of participation and creation. However, since the implementation of Google's first algorithm to this day, this type of services have changed in the same way as the projects and companies that hosted them, becoming established as transnational business models, which use many of their new functionalities and technologies to constitute a fundamental part of the way in which we develop our daily life.

Undoubtedly, the temporal arc that spans from the appearance of these applications to our days shows us different concepts that we have studied during this investigation. As we could see the expectation and fascination for a new type of business incentives from the world of finance and entrepreneurship, it gave rise to a kind of technological extensions of ourselves for which we were immediately fascinated. This is something that as we could see Marshall McLuhan described as narcocis narcissus. For him, all the media in phase of innovation remain hidden for the users, acting on us with all freedom. Factors such as the hype, described as something that the consumer expects based on external information received about a product or service, has become one of the tools from which many projects and technological models are promoted and expanded. Normally, this type of trend is accompanied by supposing virtues or qualities that this product has, but that are difficult to prove. In this way, they are built on the basis of a tremendously powerful and innovative brand image. We can say that the hype is based just, as the post-truth, is the emotional aspects of the human being, only that in this case instead of making credible information is artificially built an interest on a specific topic. However, this type of marketing strategies can be counterproductive, since the users themselves may discover that the supposed virtues of a product are actually an elaborate construction in their mind and generated based on their emotions.

We have stopped believing in the need to educate ourselves beyond the simple acquisition of information to achieve a fuller life, transfering our intellect, time and skills, forming a misinformed credulity, or what Marina Garcés calls "enlightened illiteracy" 404 . A kind of intellectual status in which access to knowledge does not imply a solution to any problem, due to our inability to

${ }^{404}$ Garcés, Marina, Nueva Ilustración Radical, Editorial Anagrama, Barcelona, 2017, p. 45. 
generate ways of understanding our reality, the way we relate to the world around us and to ourselves. This incessant accumulation of information neutralizes any attempt of real criticism, since it tends to saturate our attention. It generates a standardized language, building the hegemony of solutions in response to all our ills. This kind of reality that surpasses our skills, generates a kind of uncritical attitude as a consequence of a drowned attention in multitude of informations, which transforms us into credulous ignorant, who decide to delegate their opinions and criteria passively in favor of all kinds of Internet services. This kind of practice has been formed as a type of activity that is incapable of producing real experience or understanding, but rather standardization and segmentation that makes our skills and knowledge insolated each other.

We are at a time when technology has managed to acquire fully divine virtues, allowing us to interact on different problematic areas of our lives and our society, delegating complex problems to digital quantification strategies. This has produced, as we could see, what Evgeny Morozov calls the technological solutionism, a concept that serves to discuss the moral consequences of new technologies in a world governed by the efficiency that technology offers us. Morozov warns about the vampirization carried out by Silicon Valley over the intellectuals of the 60s of the 20th century to absorb the spirit and ideas of this era, generating narratives that occupy the debate around technology. However, he alludes to the importance of the economy as the only engine of these entrepreneurial projects through venture capital, the new economy, geopolitics and imperialism.

Morozov points to systems that have been created to create dependency, because it builds the profitability of these innovative projects through a condition similar to Paulov's dogs. We are talking about business models that feed our attention and cognitive work, manufacturing a kind of dependence that constantly distracts us. On the other hand, the anxiety to express our self, to position ourselves within society, and update who we are constantly, moves the social applications of Web 2.0, exploiting our relationships and friendships in benefit of the companies that create them. In this regard Morozov argues that Silicon Valley only offers solutions to the own problems that their own technologies create, through more innovative and penetrating technologies in our cognitive field. This generates a kind of media through which social 
mobility is generated and the fictitious sensation of progress, but which also doesn't contribute to improve or develop our social and communicative environment. Rather, it is the mixture of private and public, as we could see in the first project presented in this research, which took place in the Chatroulette video chat application, where on the other hand we could see ho more connections it doesn't imply a bigger number of communications.

In recent years we have seen the emergence of many applications that have closed after times of great popularity, or some others that could not adapt to a highly competitive media environment. Social applications such as MySpace saw how, what was once a large community, was abandoned inexorably. On the other hand projects like Google +, could never count with the confidence of the large public. We must also add the large number of users who simply decide to abandon and close their networks because of their own convictions, together with the need of disappearing from the media bubble in which we are immersed. Perhaps it is based on the need to recover recognition, not based on the feedback obtained in the networks. The monotony of clearly repetitive mechanics, the over time and awareness of the effects of these applications have led to the abandonment by specific sectors of the population. This incessant drip of abandonments, more or less anonymous, that Twitter and the other virtual platforms are suffering in recent years is something that Enric Puig Punyet reflects on in his work El Dorado 405 through the term "exconnectados", which is used to designate people who, after having participated in the promises of horizontality and equality associated with the network, have moved away from this system because of the discredit and the illusion of this projects. Punyet conceptualizes them as a counterrevolution that behaves as a brake on the acceleration that networks foster, in the face of the discomfort generated by technologies that are opposed to social progress. Like the Luddites of the 19th century, these outcasts do not consider a fight against technology in itself, but against the control that an elite exercises over them, which guarantees and perpetuates their cultural and technological hegemony. It is therefore a change of orientation, in the sense of redirecting a relationship with technology that becomes dominant.

${ }^{405}$ Puig Punyet, Enric, op. Cit., 2017, p. 117. 
On the other hand, the life of the influencers has generated an unprecedented business model until now, but it has increased the anxiety we feel about sharing our lifestyle and compare ourselves with other users. We don't understand that we do not need to transform ourselves into a brand image. The dissatisfaction with the kind of life we lead, or the low self-esteem has increased the need to obtain an external approval. This activity has become part of a free cognitive work that we develop within the network for the benefit of these companies. The search for affectivity and relationships often leads to a kind of behavior that can hardly supply these relationships, but that generates addiction because of the type of rewards that this type of application gives us back. On the other hand, the professional use of these networks in what we can call affective econnomy, has in many cases eroded the barriers between work and private life, generating professional profiles increasingly precarious and de-professionalized. This has contributed in the end, in a de-institutionalization of the humanities as the culmination of the cognitive project of the current capitalism.

The awareness of the operation of this type of social technologies has shown how they use our information to build their own business model, through the exploitation of a large mass of users. The design of these media structures is designed to manipulate our behavior through a large number of elements that make us constantly interconnect and force us to interact continuously, producing routine habits. Through our attention a business model has been erected that generates value based on our cognitive practices, which are incentivized through all kinds of unethical strategies, such as activity and messages that do not correspond with real or relevant interactions, but that maintain to the active users and perceptively in alert state, before the avalanche of new information that we receive. This communicative flow causes stress and sense of unattainability, fragmenting our attention, but keeping us permanently connected and distracted, which ultimately undermines our capacity for attention.

Undoubtedly we find a type of technologies that have begun to be visible, in the sense of clearly discerning their effects, and therefore, begin to slowly enter a period of obsolescence. As we can see, some users at least abandon them for a while or reduce their use considerably. This abandonment, rather than the end of a passing fad, should be considered as the beginning of awareness of the effects and true reach of these technologies. The lack of a 
regulatory framework that trusted users has also undermined our vision of this type of technology. Only in the US there is a body, the Federal Trade Commission, which in some way regulates the practices of Internet companies. Undoubtedly, only through a regulation that offers guarantees to users will it be possible to start talking about a type of technologies generated to the extent of the users as a service really works based on their interests.

If we keep in mind the cases of platforms like Facebook and its scandal Cambridge Analytica, where its complete business model has been questioned, due to the sale of data, abusive terms and conditions and social dynamics conceived according to its own creators to generate addiction in users, we can see how the perception of this type of applications has changed substantially within the media sphere itself. What a decade ago was presented as an innovative and successful business model, under the protection of a growing technological determinism, the new economy and its venture capital investment funds, and of course, the term Web 2.0 turned into a meme, has ended up being questioned in many ways. As we have understood, as society, the way in which these media work, we have begun to ask ourselves if it is advisable or necessary to use these networks.

We are therefore facing technologies that generate a type of transformations, described from the concept of neuroplasticity, that alter the very structure of our mind and the political construction of our cognitive activity, transformed into immaterial, digital, motorized and free work. We must, therefore, generate awareness as a society about the way in which we are transformed by the technologies we create. We must change our vision of the present based on technologies that we look through the eyes of the past, being unable to glimpse the true functioning of the same, ultimately conditioning our perception and subjectivity, and therefore how we see ourselves and how we see the outside world. Within this field of perceptual play is where it fights the struggle for the domination of our time, vision and action.

As we have seen, the cognitive project of current capitalism has been able to appropriate our intelligence as a productive force, however, it has amputated the use of this as a reflective and autonomous power, decoupling our cognitive practices from any collective emancipatory project, beyond alternative channels that disintegrate and segment our efforts into microworlds, thus preventing an accurate response to an increasingly powerful cognitive capitalism. We live in a moment in which we have lost the horizon of progress 
advocated by modernity decades ago, but also the possibility of a postmodern critical positioning, in the sense of scrutinizing and examining new possibilities based on the analysis of the present. Beyond trying to restore a new sense of history based on the modern past, we need to give a new meaning to our temporality that transcends technological solutions as a harmonic response to the problems of our time. This is where artistic practice must play an essential role when it comes to generating a bridge between different knowledge that creates an incredulous attitude towards the ideological hegemony produced by technology, which precisely creates a deactivation of our critical subjectivity through a delegated and unreflective intelligence that cannot examine itself. We must, as Marina Garcés defends, relocate in the centrality the status of the human, reappropriating this condition associated with a reflective intelligence of a human in transition, that is, diverse, critical, in constant transformation and through which we can elaborate the meaning of human experience.

As we can extract from Remedios Zafra's essay El Entusiasmo ${ }^{406}$, through the idea of undertaking, capitalism has managed to hide the way in which our motivation is instrumented, as a methodology through which our hyperproduction can become profit. This is something that we can see daily in the field of social networks, a fundamental object of analysis in this research, but that could also serve to describe the state of contemporary culture and the visual arts in particular. Speed arises from excess as a characteristic of our digital culture, through which all users are producers of knowledge, opinions and information, forming a new form of blindness analogous to the sensory hyperstimulation that McLuhan told us about, based on the numbness produced for our technological extensions.

On the other hand, precariousness is becoming a way to break the bond between equals based on the tremendous competitiveness developments in the cultural sphere, building people permanently connected but alone. This scenario is neutralizing people with great creative abilities based on obtaining merits that shape a life postponed, waiting, preventing an increasingly uncertain and bureaucratized future that is always postponed. Through

406 Zafra Remedios, El entusiasmo. Precariedad y trabajo creativo en la era digital, Editorial Anagrama, Barcelona, 2017. 
reflection, examination and criticism is intended to generate a stop to think how we are creating the present and where it points, a role that on the other hand the artistic practice has always tried to develop. The need for a stop to actively intervene in the future, is actually the investment in a time to think our moment, which makes possible a change in our imaginaries and the transformation of our world by breaking the pace that this system claims us through the hurry. We fill our lives with automatisms that delegate our intelligence and the possibility of slowing down and taking distance through reflection, making possible the adoption of preconceived ideas, instead of creative forms.

The adoption of forms of domestication has transformed into beings incapable of perceiving and thinking about the present, it prevents us from deepening ourselves, becoming aware, discerning and building who we really are. It has transformed us into resigned beings before a world where the media generate an Asymmetric power thanks to its ability to divide us and take advantage of this fragmentation. It is precisely through the reflexive aspects associated with creativity that we can rethink the status quo in which we develop our time of life, opting for a type of creation that does not have as its goal the implementation of an art system governed by a precarious culture industry, that it demands new products made through the creative enthusiasm of a great mass of precarious and motorized artists. Dilemma as a perpetual professional state pushes us to work for a future that does not come, surrounded by a culture produced in an unreflective manner. This also has its reflection in the networks through the supposed professional use of platforms that de-professionalize the culture through the search for novelties and the interactivity that these media provide, but concealing how at the same time they generate new forms of slavery and dependence as consideration to a visibility that makes us exist within a connected world. We are in a moment in which individual arguments that succeed must gather a crowd around and therefore awaken emotionalism, radicalism and dogmatism. This radically contradicts what Habermas defines as requirements of the consolidation of a type of rational public sphere among equals, as a transforming element of society, as a way of passing from the ego that networks encourage awe that truly conform a collective awakens and seated in a critical present, able to learn from the past and build a future based on this reflection. 
BIBLIOGRAFÍA 
$A B C$ Tecnología, La increíble historia del hombre desaparecido durante nueve años cuyo paradero solo Google Maps conocía, ABC Tecnología, [en línea], 2017 [consulta 6 de Marzo de 2018] disponible en <http://www.abc.es/tecnologia/redes/abci-increible-historia-hombre-desaparecidodurante-nueve-anos-solo-google-maps-conocia-201511161814_noticia.html>

Adams, Tim, How the internet created an age of rage, The Guardian, [en línea], 2010, [consulta 6 de Abril de 2013] disponible en <http://www.guardian.co.uk/technology/2011/jul/24/internetanonymity-trolling-tim-adams>

Adorno, Theodor, Horkheimer, Max, Dialéctica de la llustración. Fragmentos Filosóficos, Editorial Totta, 1998, p. 166.

Alexander, Harriet, Pope Francis and the first "papal selfie", The Telegraph [en línea], 2018, [consulta 25 de Enero de 2018] disponible en <http://www.telegraph.co.uk/news/worldnews/thepope/10277934/Pope-Francis-and-the-first-Papal-selfie.html>

Armitage, John, Virilio Live: Selectec Interwievs, Sage Publications, Londres, 2001.

Ashford, Doug, Ault, Julie, Locks, Sabrina, Show \& Tell: A Chronicle of Group Material, Londres, Four Corners Books, 2010.

Augé, Marc, Hay que amar la tecnología y saber controlarla", [en línea], 2005, La Nación, [consulta miércoles 22 de Febrero de 2017], disponible en < http://www.lanacion.com.ar/714868-marc-augehay-que-amar-la-tecnologia-y-saber-controlarla>

Barthes, Roland, El grado cero de la escritura, Siglo XXI, México D.F, 1989.

Barthes, Roland, El susurro del lenguaje, Paidós, Barcelona, 1994.

Baudrillard, Jean. La Agonía del Poder, Círculo de Bellas Artes, Madrid, 2006.

Baumgärtel, Tilman. Experimentelle software. Telepolis, 2001, [En línea], [consultado el 27 de Junio de 2016], disponible en <http://www.heise.de/tp/deutsch/inhalt/sa/9908/1.html>

Battelle, John, The Birth of Google, [En línea], [Consultado el 20 de Julio de 2017], disponible en <https://www.wired.com/2005/08/battelle/>

Baudelaire, Charles, El pintor de la vida moderna, Taurus, Madrid, 2013.

Benjamin, Walter, El libro de los pasajes, Akal, Madrid, 2005.

Benjamin, Walter, La Obra de Arte en la Época de la Reproductibilidad Técnica, Mexico D.F., Itaca, 2003.

Benjamin, Walter, Tesis sobre la historia y otros fragmentos, Itaca, México D. F., 2008.

Beuys, Joseph, Bodenmann-Ritter, Clara, Joseph Beuys: cada hombre, un artista: conversaciones en Documenta 5-1972, Editorial Visor, Madrid, 1995.

Berardi, Franco "Bifo", Fenomenología del Fin, Sensibilidad y Mutación Conectiva, Caja Negra Editora, Buenos Aires, 2017.

Berardi, Franco, La fabrica de la infelicidad, Traficantes de Sueños, Madrid, 2003.

Borges, Jorge Luis, Ficciones, Alianza Editorial, Madrid, 2006. 
Bourdieu, Pierre, Intelectuales, política y poder, Eudeba, Buenos Aires, 1999.

Bourdieu, Pierre, La distinción. Criterio y bases sociales del gusto, Taurus, Madrid, 2000.

Brea, José Luis, La era postmedia. Acción comunicativa, prácticas (post) artísticas y dispositivos neomediales, Editorial CASA, Salamanca, 2002.

Bulatovic, Peja, Nudity filter helps Chatroulette clean up, CBC News, [en línea], 2011, [consulta 6 de Marzo de 2017] disponible en <http://www.cbc.ca/news/technology/nudity-filter-helpschatroulette-clean-up-1.1094425>

Butler, Judith, El género en disputa. El feminismo y la subversión de la identidad, Paidos, Barcelona, 2007.

Cabanne, Pierre, Conversaciones con Marcell Duchamp, Editorial Anagrama, Barcelona, 1984.

Carlson, Nicholas, Here's THE Solution To Chatroulette's Penis Problem, [en línea], 2010, [consulta 19 de Junio de 2017] disponible en <http://www.businessinsider.com/chatroulette-penis-problemsolved-2010-04>

CARR, Nicholas, Superficiales: ¿Qué está haciendo Internet con nuestras mentes?, Taurus, Madrid, 2011.

Casacuberta, David, Reclaim the Backbone: Repensar Internet como espacio Público, [En línea], [Consultado el 20 de Julio de 2017], disponible en < http://www.ub.edu/imarte/investigacions/estudis-teorics/david-casacuberta/reclaim-thebackbone-repensar-internet-como-espacio-publico/>

Castells, Manuel, La Galaxia Internet, Plaza y Janes, Barcelona, 2001.

Castells, Manuel, La sociedad red, Alianza, Madrid, 1997.

Castells, Manuel, Redes de indignación y esperanza. Los movimientos sociales en la era de Internet, Alianza Editorial, Madrid, 2012

Chritophe, Bruno, The Google Adwords Happening, 2002, [Consulta 23 de Enero de 2017] disponible en <http://www.iterature.com/adwords>

Chul-Han, Byung, La Sociedad de la Transparencia, Herder, Barcelona, 2013.

Coffey, Helen, India has the highest number of selfie deaths in the world, Independent, [en línea], 2017, [consulta 25 de Enero de 2018] disponible en <https://www.independent.co.uk/travel/newsand-advice/india-selfie-deaths-highest-number-priti-pise-marine-drive-instagram-a7827486.html>

Colleman, Gabrielle, Las mil caras de Anonymous: hackers, activistas, espías y bromistas, Arpa editores, Barcelona, 2016.

Coffey, Helen, The most dangerous selfies ever taken, from the Grand Canyon to an active volcano, Independent, en línea], 2017, [consulta 25 de Enero de 2018] disponible en <https://www.independent.co.uk/travel/news-and-advice/most-dangerous-selfies-bear-volcanogrand-canyon-gun-christ-the-redeemer-a7678901.html>

Critical art ensemble, La desobediencia civil electrónica, la simulación y la esfera pública, [En línea], [consultado el 24 de Junio de 2016], disponible en <http://aleph-arts.org/pens/dec_simul.html> 
Crompton, Simon, All about me, HarperCollins, Londres, 2007.

Damasio, Antonio, El error de Descartes, Editorial Andrés Bello, Chile, 1996.

Debord, Guy, La Sociedad del Espectáculo, Pre-Textos, Madrid, 1999.

Debray, Régis, Elogio de las fronteras, Gedisa, Barcelona, 2016.

De Certeau, Michel, La Invención de los Cotidiano I. Artes de Hacer, Universidad Iberoamericana, México D.F., 2000.

Deleuze, Gilles, Guattari, Felix, ¿Qué es la filosofía?, Anagrama, Barcelona, 1993.

Delgado, Manuel, El animal público. Hacia una antropología de los espacios urbanos, Anagrama, Barcelona, 1999.

Diego Cerda Seguel, Diego, El Mundo Según Google. Google Earth y la Creación del Dispositivo Geosemántico Global, Escaner Cultural, 2006.

Donath, Judith S, Identidad y decepción en la comunidad virtual, en Smith, Marc A.; Kollock, Peter, Comunities in cyberspace, Londres, Routledge, 1999.

Dreyfus, Suelette, Underground, Seix Barral, Barcelona, 2011.

Duchamp, Marcell, Escritos. Duchamp du Signe, Editorial Gustavo Gili, Barcelona, 1978.

Espada, Arcadi, Diarios, Espasa-Calpe, Madrid, 2002.

Eliasson, Olafur, Leer es respirar, es devenir, Gustavo Gili, Barcelona, 2012.

Ellul, Jacques, La technique ou l'enjeu du siècle, Economica, París, 2008.

Ellul, Jacques, Propaganda. The Formation of Men's Attitudes, Vintage Books, Nueva York, 1973.

Elola, Joseba, Rebelión contra las redes sociales, El Pais, [Consulta el 17 de Febrero de 2018], disponible en <https://elpais.com/tecnologia/2018/02/16/actualidad/1518803440_033920.html> Fontcuberta, Joan, La cámara de Pandora, Gustavo Gili, Barcelona, 2011.

Fontcuberta, Joan, La furia de las imágenes. Notas sobre la postfotografía, Galaxia Gutenberg, Barcelona, 2016

Foster, Hal, September 11, Artforum, Enero de 2012, [en línea], [Consulta el 17 de Febrero de 2018], disponible en <https://www.artforum.com/print/reviews/201201/september-11-29803>

Foucault, Michel, El orden del discurso, Tusquets Editores, Barcelona, 1999.

Foucault, Michel, Historia de la sexualidad. Vol 1: La voluntad de saber, Siglo XXI, Madrid, 2009.

Foucault, Michel, La voluntad de saber, Siglo XXI, Madrid, 2009.

Foucault, Michel, Michel Foucault: Un diálogo sobre el poder y otras conversaciones, Alianza Editorial, Madrid, 2000.

Foucault, Michel, Nietzsche, la genealogía, la historia, Pre-Textos, Valencia, 1988. 
Friedman, Thomas L., Is Google God?, New York Times, 29 de Junio de 2003, [en línea], [consulta 16 de Febrero de 2017], disponible en <http://www.nytimes.com/2003/06/29/opinion/is-googlegod.html>.

Fuchs, Christian, Digital labour and Karl Marx, Routledge, Nueva York, 2014.

Gaiman, Neil, American Gods, Roca Editorial, Barcelona, 2012

Garcés, Marina, Nueva Ilustración Radical, Editorial Anagrama, Barcelona, 2017.

Garcés Marina, Un mundo común, Ediciones Bellaterra, Barcelona, 2013.

García, Dora, Y Masotta cometí un 'happening', El País, 2017, [En línea], [consultado el 27 de Junio de 2016], disponible en

<https://elpais.com/cultura/2017/10/09/babelia/1507542025_086590.html>

Gaunlett, David, Creative explorations: new approaches to identities and audiences, Routledge, New York, 2007.

Gaunlett, David, Making is connecting, Polity Press, Cambridge, 2011.

Gergen, Kenneth J., El yo saturado: dilemas de la identidad en el mundo contemporáneo, Paidos, Barcelona, 2006.

Giddens, Anthony, Modernidad e Identidad del Yo, Península, Barcelona, 1997.

Glass, Robert S., Facts and Fallacies of Software Engineering, Adisson-Wesley, Boston, 2004.

Goldsmith, Kenneth, Uncreative Writing, Columbia University Press, Nueva York, 2011

Gómez, Alfonso, El poema de Parménides, Editorial Universitaria, 2006.

Gopnik, Blake, Andy Warhol, Sleep (1963), [en línea], 2017, [consulta 19 de Octubre de 2017] disponible en <https://brooklynrail.org/2017/09/criticspage/Andy-Warhol-Sleep-1963>

Gottlob Schelle, Karl, El arte de pasear, Diaz \& Pons, Madrid, 2013.

Gramsci, Antonio, Cartas desde la cárcel, Nueva Editorial Argentina, Buenos Aires, 2006.

Grandoni, Dino, Facebook's New 'DeepFace' Program Is Just As Creepy As It Sounds, Huffingtonpost [en línea], 2017, [consulta 25 de Enero de 2018] disponible en <https://www.huffingtonpost.com/2014/03/18/facebook-deepface-facialrecognition_n_4985925.html>

Granés, Carlos, El puño invisible, arte revolución y un siglo de cambios culturales, Taurus Barcelona, 2012.

Greene, Rachel, Web Work a history of Internet Art, en Artforum Internacional, no 9 Mayo de 2000, pp. 162-167, 190, , [Consulta el 23 de Enero de 2016], disponible en <https://www.artforum.com/print/200005/web-work-a-history-of-internet-art-465>

Groys, Boris, Volverse Público, Caja Negra Editora, Buenos Aires, 2014.

Guattari, Félix, Psicoanálisis y transversalidad, Ediciones Siglo XXI, Buenos Aires, 1995.

Habermas, Jürgen, Historia y crítica de la opinión pública, Gustavo Gili, Barcelona 1981 
Han, Byung-Chul, En el Enjambre, Herder, Barcelona, 2014.

Hardt, Michael, Affective Labor, en boundary 2, Vol. 26, no 2, Duke University Press, 1999, p. 89.

Hardt, Michael, Negri, Antonio, Empire, Harvard University Press, Cambridge, 2000.

Hardt, Michael, Negri, Antonio, Multitud, guerra y democracia en la era del Imperio, Debate, Barcelona, 2004.

Havelock Eric, Preface to Plato, Harvard University Press, Cambridge, 1963.

Herring, Susan, Job-Sluder, Kirk, Scheckler, Rebecca, Barab, Sasha, Searching for Safety Online: Managing Trolling in a Feminist Forum, Rob Kling Center for Social Informatics, [en línea], 2002, [consulta 13 de Junio de 2013] disponible en <http://wwwbcf.usc.edu/ fulk/620overview_files/Herring.pdf>.

Hertz, Garnet, A Collection of Many Problems (In Memory of the Dead Media Handbook), Telharmonium Press, Toronto, 2009.

Hidell, Alek, Scientology Stiffs The Pizza Guy on a \$2,000 Bill, [En línea], [consulta 25 de Junio de 2016], disponible en <http://anonhq.com/scientology-stiffs-pizza-guy-2000-bill/>

Hinamen, Pekka, La ética hacker y el espíritu de la era de la información, Editorial Destino, 2002.

Honan, Mat, I liked everything i saw on facebook for two days. Here's what it did to me, Wired, 8 de Noviembre de 2014, , [Consulta el 23 de Enero de 2018], disponible en

$<$ https://www.wired.com/2014/08/i-liked-everything-i-saw-on-facebook-for-two-days-heres-whatit-did-to-me/>

Home, Stewart, Neoism, plagiarism \& praxis, AK Press, Edimburgo, 1995.

Huxley, Aldous, Un mundo feliz, Ediciones Cátedra, Madrid 2013.

Innis, Harold, Empire and Communications, Dunburn, Toronto, 2007.

Jameson, Fredric. El posmodernismo o la lógica cultural del capitalismo avanzado, Paidos, Buenos Aires 1991.

Jordan, Tim, Taylor, Paul, Hacktivism and ciberwars, rebels with a cause?, Routledge, Nueva York, 2004.

Jacoby, Roberto, El deseo nace del derrumbe, Ediciones de La Central, Barcelona, 2011.

Jansson, André, Christensen, Miyase, Media, surveillance and identity, Peter Lang, Nueva York, 2014.

Jiménez Barca, Antonio, Las revoluciones populares nos las hace Facebook, 25 de Mayo de 2011, EI País, [Consultado el 23 de Enero de 2016] disponible en <http://tecnologia.elpais.com/tecnologia/2011/05/25/actualidad/1306314067_850215.html>

Jiménez, Daniel, Facebook publica de forma gratuita sus algoritmos de reconocimiento fotográfico, Xatakafoto, [en línea], 2016, [consulta 25 de Enero de 2018] disponible en <https://www.xatakafoto.com/actualidad/facebook-publica-de-forma-gratuita-sus-algoritmos-dereconocimiento-fotografico>

Jordan, Tim, Taylor, Paul, Hacktivism and ciberwars, rebels with a cause?, Routledge, Nueva York, 2004 
Keen, Andrew, The cult of the amateur, Random House, Nueva York, 2007.

Kelberman, Dina, I'm Google, 2011, [Consulta 23 de Enero de 2017] disponible en <http://dinakelberman.tumblr.com>

Klein, Naomi, No Logo, Paidós, Barcelona, 2001.

Knabb, Ken, Situationist International Anthology, Bureau of Public Secrets, Berkeley, 2006.

Koolhaas, Rem, Espacio basura, Editorial Gustavo Gili, Barcelona, 2007.

Lacan, Jacques, Escritos I, Biblioteca Nueva, Madrid, 2013.

Lazzarato, Maurizio, Life and the Living in the Societies of Control, en Deleuze and the Social, Edinburgh University Press, Edimburgo, 2006.

Lazzarato, Maurizio, Marcel Duchamp y el rechazo del trabajo, Casus Belli, Madrid, 2017.

Lefebvre, Henri, La producción de espacio, Capitán Swing, Madrid, 2013.

Lessig, L., Code and other laws of cyberspace, New York, Basic Books, 1999.

Lévinas, Enmanuel, Totalidad e infinito. Ensayo sobre la exterioridad, Sígueme, Salamanca, 1999.

Lévy, Pierre, ¿Qué es lo virtual?, Paidós, Barcelona, 1999.

Levy, Steven, Hackers: Heroes of the Computer Revolution, Anchor Press/Doubleday, New York, 1984.

Lister, Martin, La imagen fotográfica en la cultura digital, Paidos, Barcelona, 1997.

Lloyd, Jan, Culture Jamming: Semiotic Banditry in the Streets [en línea], 2003, [consulta 1 de Febrero de 2013] disponible en <https://yesjanlloyd.wordpress.com/2014/05/12/culture-jamming-semioticbanditry-in-the-streets/>

Ludlow, Peter, Crypto Anarchy, Cyberstates and Pirate Utopias, MIT Press, Cambridge, 2001.

Luther, Blisset, Brünzels, Sonja, Manual de guerrilla de la comunicación, Virus Editorial, Barcelona, 2000.

Manen, Martí, Salir de la exposición (si es que alguna vez habíamos entrado), Barcelona, Consonni, 2012.

Maniaque-Benton, Caroline, French Encounters with the American Counterculture 1960-1980 Routledge, Nueva York, 2011.

Manovich, Lev, El software toma el mando, Editorial UOC, Barcelona, 2013.

Marcuse, Herbert, El hombre unidimensional, Planeta-De-Agostini, Barcelona, 1993.

Marcuse, Herbert, La dimensión estética, Biblioteca Nueva, Madrid, 2007.

Martín Prada, Juan, Otro tiempo para el arte, Sendemá Editorial, Valencia, 2012.

Martín Prada, Juan, Practicas Artísticas e Internet en la época de las Redes Sociales., Ediciones Akal, Madrid, 2015. 
Marx, Karl, Elementos fundamentales para la crítica de la economía política (Grundrisse) 1857-1858 Vol. 1, Siglo Veintiuno Editores, México D.F., 1971

Marx, Karl, Elementos fundamentales para la crítica de la economía política (Grundrisse) 1857-1858 Vol. 2, Siglo Veintiuno Editores, México D.F., 1972.

Masotta, Oscar, Revolución en el arte, Editorial Mansalva, Buenos Aires, 2017.

McLuhan, Marshall, Comprender los medios de comunicación, Paidós, Barcelona, 1996.

McLuhan, Marshall, Counterblast, Rapp and Whiting, Londres, 1970.

McLuhan, Marshall, Fiore, Quentin, El medio es el masaje, Paidós, Barcelona, 1997

McLuhan, Marshall, La cultura es nuestro negocio, Editorial Diana, México D.F. 1974.

McLuhan, Marshal, La Galaxia Gutenberg, Planeta-De Agostini, Barcelona, 1985.

McLuhan, Marshall, Letters of Marshall McLuhan, Oxford University Press, Nueva York, 1987.

McLuhan, Marshall, Marshall McLuhan Unbound Vol. 7, Gingko Press, California, 2005.

McLuhan, Marshall, Marshall McLuhan Unbound Vol. 12, Gingko Press, California, 2005

McLuhan, Marshall, Nevitt, Barrington, Take Today; The Executive as Dropout, Harcourt Brace Jovanovich, Cambridge, 1972.

McLuhan, Marshall, Parker, Harley, Through the Vanishing Point: Space in Poetry and Painting, Harper and Row, Nueva York, 1969.

Mcquire, Scott, The politics of public space in the media city, First Monday, [en línea] 2006 [consulta 6 de Marzo de 2017] disponible en <http://firstmonday.org/article/view/1544/1459>

Méndez, Lucia, La dopamina de las redes, El Mundo, [En línea], 2017[consulta 21 de Marzo de 2018], disponible en <http://www.elmundo.es/opinion/2017/12/16/5a342ccce5fdea97248b4626.html>

Mattes, Eva, Mattes, Franco, Darko Maver and fake news, [En línea], [consultado el 27 de Junio de 2016], disponible en <http://0100101110101101.org/darko-maver-and-fake-news/>

Miller, Henry, Big Sur y las naranjas del Bosco, Edhasa, Barcelona 2010.

Mitchell, William J., City of bits: space, place and the infobahn, MIT Press, Cambridge, 1996.

Mitchell, William J. T., Image Science, The University of Chicago Press, London, 2015.

Mitchell, William J. T., The Reconfigured Eye, The MIT Press, Cambridge, 1992.

Mlot, Stephanie, Al Creates Super-Religion Base don Sacred Texts, Geek.com, [en línea], 2017, [consulta 6 de Marzo de 2018] disponible en <https://www.geek.com/tech/ai-creates-superreligion-based-on-sacred-texts-1725589/>

Moore, Alan, Gibbons, Dave, Watchmen: Edición de lujo, ECC Ediciones, Barcelona, 2015.

Morozov, Evgeny, La locura del solucionismo tecnológico, Katz, Barcelona, 2015.

Morris, Errol, Which Came First, the Chicken or the Egg? (Part One), The new York Times, [en línea], 2007, [consulta 25 de Enero de 2018] disponible en 
$<$ https://opinionator.blogs.nytimes.com/2007/09/25/which-came-first-the-chicken-or-the-egg-partone/?_php=true\&_type=blogs\&_r=0>

Mumford, Lewis, Técnica y Civilización, Alianza Editorial, Madrid, 1992.

Negroponte, Nicholas, El mundo digital, Ediciones B, Barcelona, 1995.

Nietzsche, Friedrich, La voluntad de poder, Editorial EDAF, Madrid, 2000.

O’Neill, lan, Explore earth's satellites with Google Earth, Universe Today, [en línea], 2008, [consulta 6 de Marzo de 2018] disponible en <https://www.universetoday.com/17754/explore-earths-satelliteswith-google-earth/>

O'Reilly, Tim, What Is Web 2.0. Design Patterns and Business Models for the Next Generation of Software, 2005,

Consulta 23 de Enero de 2016] disponible en <http://www.oreilly.com/pub/a/web2/archive/whatis-web-20.html>

Orwell, George, 1984, Editorial Lumen, Barcelona, 2014

Parikka, Jussi, Arqueología de los medios: cuestionando lo nuevo en el arte medial, a-desk.org, 2017, [En línea], [consultado el 27 de Junio de 2016], disponible en <http://adesk.org/magazine/arqueologia-de-los-medios/>

Park, Victoria, Man hit by train in quest for perfect selfie, BBC News, [en línea], 2018, [consulta 25 de Enero de 2018] disponible en <http://www.bbc.com/news/world-asia-india-42815483>

Huhtamo, Erkki, Art in the Rear-View Mirror. The Media-Archeological Tradition in Art, en Paul, Christiane, A Companion to Digital Art, Joh Wiley-Blackwell, Nueva York, 2016.

Pérez Bes, Francisco, La publicidad comportamental online, Editorial UOC, Barcelona, 2012.

Pétonnet, Colette, L'observation flottante. L'exemple d'un cimetière parisien, L'Homme, París, 1982.

Poe, Edgar Allan, Poe: Cuentos 1, Alianza Editorial, Madrid, 2010.

Porter, David, Internet Culture, New York, Routledge, 1997.

Postman, Neil, Divertirse hasta morir. El discurso público en la era del "show bussines", Ediciones la Tempestad, Barcelona, 2001.

Postman, Neil, The Reformed English Curriculum, en Eurich , A. C. (ed.) High School 1980: The Shape of the Future in American Secondary Education, Pitman Publishing Corporation, Nueva York, 1970.

Postmes, Tom; Jetten, Jolanda, Individuality and the Group, Amsterdam, Sage Publications LTD, 2006.

Puig Punyet, Enric, El Dorado. Una historia crítica de internet, Clave Intelectual, Madrid, 2017.

Raymond, Eric S., The Cathedral \& the Bazaar, O'reilly Media, Sebastopol, 2008.

Ricoeur, Paul, Tiempo y narración III. El tiempo narrado, Siglo XXI Ediciones, Mexico D.F., 2009. 
Ritchel, Matt, A Silicon Valley school that doesnt't compute, New York times, 22/10/2011, Consulta 23 de Enero de 2016] disponible en <http://www.nytimes.com/2011/10/23/technology/at-waldorfschool-in-silicon-valley-technology-can-wait.html>

Rodríguez de las Heras, Antonio, Un nuevo y sugerente uso visual de la Red se está gestando, Bez.es, [en línea], 2016, [consulta 19 de Junio de 2017] disponible en <https://www.bez.es/546801274/Unnuevo-y-sugerente-uso-visual-de-la-Red-se-esta-gestando.html>

Rousseau, Jean-Jacques, Las ensoñaciones del paseante solitario, Alianza Editorial, Barcelona, 2016.

Rus, Rebeca, Instagram recupera el feed cronológico (o casi) que tanto habíamos echado de menos, Trendencias.com, [en línea], 2018, [consulta 25 de Enero de 2018] disponible en $<$ https://www.trendencias.com/redes-sociales/instagram-recupera-el-feed-cronologico-o-casi-quetanto-habiamos-echado-de-menos>

San Cornelio, Gemma, Arte e Identidad en Internet, Editorial UOC, Barcelona, 2008.

San Cornelio, Gemma, Roig, Antoni, Ardevol, Elisenda, 2017, Selfies y eventos culturales: metodologías hibridas para el estudio del selfie en contexto, Josep Maria Carbonell, Reality and screen: a postmodern mirror IX International conference on communication and reality, Universidad Ramón Llull, Barcelona.

Scholz, Trebor, Digital Labour. The Internet as Playground and Factory, Routledge, Nueva York, 2013.

Schwartz, Matatías, Los Trolls entre nosotros, The New York Times [en línea], 2008, [consulta 16 de Junio de 2013] disponible en <http://www.nytimes.com/2008/08/03/magazine/03trollst.html?_r=0>

Scolari, Carlos A., Ecología de los Medios, entornos, evoluciones e interpretaciones, Gedisa, Barcelona, 2015.

Simonite, Tom, Machines taught by potos learn a sexist view of women, Wired, 2017, [Consulta 23 de Enero de 2018] disponible en <https://www.wired.com/story/machines-taught-by-photos-learna-sexist-view-of-women/>

Simonite, Tom, When it comes to gorillas, Google Photos remains blind, Wired, 2018, [Consulta 23 de Enero de 2018] disponible en <https://www.wired.com/story/when-it-comes-to-gorillas-googlephotos-remains-blind/>

Solon, Olivia, Deux ex machina: former Google enginieer is developing an Al god, The Guardian, [en línea], 2017, [consulta 6 de Marzo de 2018] disponible en <https://www.theguardian.com/technology/2017/sep/28/artificial-intelligence-god-anthonylevandowski>

Sontag, Susan, Ante el dolor de los demás, Alfaguara, Madrid, 2003.

Sontag, Susan, Sobre la Fotografía, Debolsillo, Barcelona, 2008.

Suler, John, The Online Disinhibition Effect, en línea], 2004, [consulta 19 de Junio de 2017] disponible en <https://www.liebertpub.com/doi/abs/10.1089/1094931041291295>

Stein, Jake, Chatroulette Data: What Are The Odds Of Seeing A..., rjmetrics.com [en línea], 2010, [consulta 6 de Marzo de 2017] disponible en <https://blog.rjmetrics.com/2010/03/22/chatroulettedata-what-are-the-odds-of-seeing-a/> 
Steyerl, Hito, Los condenados de la pantalla, Caja Negra Editora, Buenos Aires, 2014.

Stone, Brad, Chatroulette's Creator, 17, Introduces Himself, New York Times, [en línea], 2010, [consulta 6 de Marzo de 2017] disponible en <https://bits.blogs.nytimes.com/2010/02/13/chatroulettes-founder-17-introduces-himself/>

Taigman, Taniv, Yang, Ming, Ranzato, Marc' Aurelio, Wolf Lior, 2018, DeepFace: Closing the Gap to Human-Level Performance in Face Verification, Conference on Computer Vision and Pattern Recognition (CVPR), Calvin L. Rampton Salt Palace Convention Center, Salt Lake City. $<$ https://research.fb.com/wp-content/uploads/2016/11/deepface-closing-the-gap-to-human-levelperformance-in-face-verification.pdf?>

Thoreau, Henry David, Un paseo invernal, Errata Naturae, Madrid, 2014.

Tomkins, Calvin, Duchamp, Anagrama, Barcelona, 1999.

Turkle, Sherry, La vida en la pantalla: la construcción de la identidad en la era de Internet, Editorial Paidos, Barcelona, 1997.

Turner, Andrew J., Introduction to Neogeography, O’Really Media, San Francisco, 2006.

Turner, Fred, From Counterculture to Cyberculture, Chicago Press, Chicago, 2006.

Unità di Crisi, ART: A Satellite Dérive for Harry Kipper, Observatory on Politics of Representation, [En línea], [consultado el 27 de Junio de 2016], disponible en <http://www.unitadicrisi.org/art-asatellite-derive-for-harry-kipper/>

Van der Akker, Robin, Vermeulen, Timotheus, Gibons, Alison, Metamodernism: Historicity, affect, depth after Postmodernism, Rowman \& Littlefield International, Washington, 2017.

Van der Linden, Sander, Maibach, Edward, Leiserowitz, Anthony, Improving Public Engagement With Climate Change: Five "Best Practice" Insights From Psychological Science, Perspectives on Psychological Science Vol. 10, no 6, 2015.

Van Riper, Frank, Manipulating Truth, Losing Credibility, The Washington Post [en línea], 2003, [consulta 25 de Enero de 2018] disponible en <http://www.washingtonpost.com/wpsrv/photo/essays/vanRiper/030409.htm>

Veloso, Moncho, El poder de Google desata una batalla entre Europa y EEUU, ABC, Madrid, 9 de Diciembre de 2014, [en línea], [consulta 16 de Febrero de 2017], disponible en <http://www.abc.es/economia/20141208/abci-poder-google-batalla-estados-201412052144.html>. Vila-Matas, Enrique, En un lugar solitario, Debolsillo, Barcelona, 2011.

Villena, Miguel Ángel, Un documental desmonta el mito del miliciano de Robert Capa, El País, [en línea], 2008, [consulta 25 de Enero de 2018] disponible en <https://elpais.com/diario/2008/12/16/cultura/1229382004_850215.html>

Viner, Katharine, How technology disrupted the truth, The Guardian, 12 de Julio de 2016, [en línea], [consulta 11 de Marzo de 2017], disponible en <https://www.theguardian.com/media/2016/jul/12/how-technology-disrupted-the-truth>

Virilio, Paul, Bunker Arqueology, Princeton Architectural Press, Nueva York, 1994

Virilio, Paul, Estética de la desaparición, Anagrama, Barcelona 1988. 
Virno, Paolo, Gramática de la multitud. Para un análisis de las formas de vida contemporáneas, Traficantes de Sueños, Madrid, 2003.

Virno Paolo, Hardt, Michael, Radical Thought in Italy. A Potential Politics, University of Minessota Press, Minneapolis, 1996.

Virno, Paolo, Virtuosismo y revolución. La acción política en la era del desencanto, Traficantes de Sueños, Madrid, 2003.

V.V.A.A., Capitalismo Cognitivo propiedad y creación colectiva, Traficantes de Sueños, Madrid, 2004.

V.V. A.A., Mediated Geographies and Geographies of Media, Springer Science+Business Media Dordrecht, 2015.

V.V.A.A., Modos de hacer, arte crítico, esfera pública y acción directa, Ediciones Universidad de Salamanca, Salamanca, 2001.

V.V.A.A., Photography After Photography: Memory and Representation in the Digital Age, G\&B Arts International, Amsterdam, 1997.

Weber, Max, La ética protestante y el espíritu del capitalismo, Fondo de Cultura Económica, México, 2011.

Weidenaar, Reynold, Magic Music from the Telharmonium, Scarecrow Press, Lanham, 1995.

Weizman, Eyal, The politics of verticality, en Open Democracy, abril de 2002, en $<$ http://www.opendemocracy.netjecology-politicsverticalityjarticle_801.jsp>

Woolf, Virginia, Orlando: una biografía, Alianza Editorial, Barcelona, 2012.

Worland, Justin, Microsoft Takes Chatbot Offline After It Starts Tweeting Racist Messages, Time, [en línea], 2016, [consulta 25 de Enero de 2018] disponible en <http://time.com/4270684/microsofttay-chatbot-racism/>

Wozniak, Steven, Smith, Gina, iWoz: From Computer Geek to Cult Icon: How I Invented the Personal Computer, Co-Founded Apple, and Had Fun Doing It, W.W Norton, 2006.

Zafra, Remedios, El instante invisible del Net Art, [Consulta el 23 de Enero de 2016], disponible en $<$ https://idus.us.es/xmlui/bitstream/handle/11441/26538/El instante invisible del net.pdf?sequence $=1>$

Zafra Remedios, El entusiasmo. Precariedad y trabajo creativo en la era digital, Editorial Anagrama, Barcelona, 2017.

Zafra, Remedios, Ojos y Capital, Consonni, Bilbao, 2015.

Zafra, Remedios, Un cuarto propio conectado, (Ciber)espacio y (auto)gestión del yo, Fórcola, Madrid, 2010. 
ÍNDICE DE FIGURAS 
Figura1. Mario Savio, dirigiendo una protesta en la Universidad de California, Berkeley, en 1964.

Figura 2. Tech Model Railroad Club, mediados años 50.

Figura 3. Mensaje del gusano WANK (Worms Against Nuclear Killers).

Figura4. Mapa mundial de los backbones de Internet, 2017. Fuente www.submarinecablemap.com.

Figura 5. Tim Berners-Lee muestra la World Wide Web a los delegados en la conferencia Hypertext 1991, San Antonio, Texas (Imagen: CERN).

Figura 6. Waldorf School en Silicon Valley, 2015, Fuente www.noodle.com.

Figura 7. Detalle de la instalación Wikipedia Art, 2099, Furtherfield Gallery, London.

Figura 8. Marshall McLuhan en la CBC de Toronto, 1966. Fotografía de Henri Dumain.

Figura 9. Neil Postman teórico de los medios.

Figura 10. Doble página de Watchmen.

Figura 11. Instalación de Étant Donnés de Marcel Duchamp.

Figura 12. Nota publicada en el diario El Mundo, Buenos Aires, 21 de Agosto de 1966.

Figura 13. Imagen del happening El helicóptero, de Oscar Masotta 1966.

Figura 14. Eva y Franco Mattes, Reenactment of Chris Burden's Shoot, 2007.

Figura 15. Diseño de Hackers \& Designers en base a la pintura Hatting Factory workers de Amy Katherine Browning.

Figura 16. Christof Wallner fue el primer propietario del nuevo iPad en Alemania, en Marzo de 2012.

Figura 17. Sophie Calle, Suite Venitienne, 1980.

Figura 18. Captura de la obra de Olia Lialina My boyfriend came back from the war de 1996.

Figura 19. Instalación de My boyfriend came back from the war.

Figura 20. Captura de la web del proyecto Distributing Martin de Pope L.

Figura 21. Página principal de la web mouchette.org.

Figura 22. Laís Pontes, Born Nowhere, 2011.

Figura 23. Fotografía del proyecto Intimidad Romero, 2011.

Figura 24. Amalia Ulman, Excellences \& Perfections, 2014.

Figura 25. Andy Bichlbaum como Jude Finisterra representante de Dow Chemical.

Figura 26. A Bioagreeable Music, Monty Cantsin, 1978.

Figura 27. Supuesto retrato de Luther Blisset.

Figura 28. Supuesta deriva del artista Harry Kipper alrededor de Europa.

Figura 29. Mark Zuckerberg ante el Senado de los EEUU. 
Figura 30. Eva y Franco Mattes, Synthetic Performances, 2007-2010.

Figura 31. Gregory Chachonsky, Peoples 2007

Figura 32. Petra Cortight, Vvebcam, 2007.

Figura 33. Daniela Ortiz, 97 empleadas domesticas, 2010.

Figura 34. Paul Gavarni, Le Flâneur, 1842.

Figura 35. Kenneth Goldsmith.

Figura 36. Jon Rafman, Mainsqueeze, 2014 (still).

Figura 37. Perros del Dr. Pavlov en el Instituto de Medicina Experimental. San Petersburgo, 1904.

Figura 38. Guy Debord, uno de los fundadores de la Internacional Situacionista.

Figura 39. Rainer Langhans y Fritz Teufel, Berlín, 1968.

Figura 40. Intervención de Culture Jamming de Jorge Rodriguez-Gerada.

Figura 41. Web de la Organización Mundial del Comercio creada por RTMark.

Figura 42. The Situationist Times \#3.

Figura 43. Capturas de retransmisiones de usuarios en Chatroulette.

Figura 44. Aspecto de la interfaz de Chatroulette en el momento de la investigación en 2013.

Figura 45. Imagen perteneciente a una prank de Steve Kardynal en Chatroulette.

Figura 46. Ratio de usuarios de Chatroulette por sexo.

Figura 47. Ratio de usuarios que ofrecen contenido inapropiado por países.

Figura 48. Aspecto actual de la interfaz de Chatroulette a principios de 2018.

Figura 49. Instalación de Sleep de Andy Warhol en el Instituto Suizo de Nueva York, 2017.

Figura 50. Usuario durmiendo durante su retransmisión a través de Chatroulette.

Figura 51. Still del trayecto Oslo-Bergen retrasmitido por la televisión estatal noruega.

Figura 52. Imagen de la galería durante la realización de Domestic Tension.

Figura 53. Michael Aniser y Isabel Walter, Danceroulette, 2011.

Figura 54. Eva y Franco Mattes, No Fun, 2010.

Figura 55. Joel Thompson, Chatroulnexter, 2010.

Figura 56. Imagen que los usuarios participantes en la obra podían ver en Chatroulette.

Figura 57. Still extraído del primer video del proyecto.

Figura 58. Still extraído del segundo video del proyecto.

Figura 59. Algunos de los usuarios que pude encontrar en Chatroulette.

Figura 60. Diseño original del Manual de Trolling. 
Figura 61. Algunos manuales plegados.

Figura 62. Vista frontal del espacio expositivo.

Figura 63. Uno de los retroproyectores con una de las transparencias.

Figura 64. Detalle de la instalación.

Figura 65. Vista lateral de la pieza.

Figura 66. El Manual de Trolling proyectado sobre la pared.

Figura 67. Contenido de la mesa durante la exposición.

Figura 68. Vista lateral de las proyecciones.

Figura 69. Vista general de las proyecciones.

Figura 70. Vista lateral de la pieza.

Figura 71. Vista de parte de la plaza de Times Square.

Figura 72. Intersección de la 7ạ Avenida con la calle 47 en Times Square.

Figura 73. Vista de Times Square con el edificio del Nasdaq al fondo.

Figura 74. Naked Cowboy, uno de los performers más populares de Times Square.

Figura 75. Visitantes de Times Square fotografiando la plaza.

Figura 76. Visitantes observando desde escalinatas de Times Square.

Figura 77. Pareja fotografiándose desde la escalinata.

Figura 78. Fotografía tomada en Times Square en 1988.

Figura 79. Vallas publicitaras anunciando alguno de los espectáculos de Broadway.

Figura 80. Edificio del Nasdaq en Times Square.

Figura 81. Jasper Elings, Flashings in the Mirror, 2009.

Figura 82. Still del video del proyecto.

Figura 83. Christopher Baker, Hello World! or: How I Learned to Stop Listening and Love the Noise, 2008.

Figura 84. Gráfico aproximado del esquema de la video instalación.

Figura 85. Natalie Bookchin, Mass Ornament, 2009.

Figura 86. Sede de Google en Mountain View, California.

Figura 87. Imagen de unas medusas antes y tras cincuenta iteraciones de DeepDream.

Figura 88. Última fase del procesado una fotografía realizado por DeepDream.

Figura 89. Tweet de Jacky Alciné en el que muestra como sus amigos son identificados como gorilas.

Figura 90. Ejemplo de la aplicación DeepFace para reconocer al actor Sylvester Stallone. 
Figura 91. Muestra de las 9 capas de procesamiento de Deepface.

Figura 92. Ejemplo del funcionamiento de DeepMask.

Figura 93. Imágenes generadas por Eigenface para diferenciar parejas adecuadas en Tinder.

Figura 94. Imagen obtenida con Eigenface.

Figura 95. Tweet de un usuario que recoge la evolución de Tay.

Figura 96. Aspecto del buscador de Google Imágenes en 2017.

Figura 97. Mongrel, Natural Selection, 1996.

Figura 98. Christophe Bruno, The Google Adwords Happening, 2002.

Figura 99. Marika Dermineur y Stéphane Degoutin, Googlehouse, 2003.

Figura 100. Dina Kelberman, I'm Google, Centre Clark, Montreal, 2011.

Figura 101. Adam Harvey, CV Dazzle, 2014.

Figura 102. Una usuaria busca su identidad en el conjunto de datos MegaFace en Glass Room, Londres.

Figura 103. Estudio de movimiento de Eadweard Muybridge.

Figura 104. Étienne-Jules Marey, Cronofotografía de placa fija de un salto de longitud, 1882.

Figura 105. Parte de los resultados de la búsqueda inversa basada en mi propio retrato.

Figura 106. Still de la animación final.

Figura 107. Otro still de la animación final.

Figura 108. Captura final que aúna todos los resultados de búsqueda.

Figura 109. Imagen del satélite encontrado en Google Earth.

Figura 110. Satélites activos e inactivos que podemos observar a través de Google Earth.

Figura 111. Memorial al accidente del vuelo 772 de la compañía UTA.

Figura 112. Caldera de Waw an Namus rodeada por la llanura de piedras de cobalto.

Figura 113. Ejemplo de espacio antártico lleno de incoherencias.

Figura 114. Zona de Bryon Township, en Michigan, donde se podía apreciar el coche sumergido de Davie Lee Niles, como vemos en la imagen hoy podemos ver un memorial en su nombre.

Figura 115. Aviones espía Lockheed SR-71 hallados durante una competición de Spot the Black Helicopter.

Figura 116. Ferrante Imperato, grabado de Dell'Historia Naturale, Nápoles 1599.

Figura 117. Imagen de la misión Landsat 8 durante la quema de pozos petrolíferos en Irak en Junio de 2016.

Figura 118. Carolina Caycedo, A gente Rio, 2016. Vista de instalación en la 32a Bienal de São Paulo. 
Figura 119. Ejemplo de las funcionalidades de Google Earth dentro de un archivo KML.

Figura 120. Helmut Smits, Dead pixel in Google Earth, 2008.

Figura 121. Clement Valla, Postcards from Google Earth, 2010.

Figura 122. John Rafman, The Nine Eyes of Google Street View, 2007-2010.

Figura 123. Mishka Henner, Dutch Landscapes, 2011.

Figura 124. Imagen en proceso, ejemplo de la unión de multitud de imágenes en una sola.

Figura 125. Ejemplo de imagen reconstruida mediante este proceso.

Figura 126. Reconstrucción de parte de la Isla de Ross localizada en la Antártida.

Figura 127. Imagen reconstruida perteneciente al desierto del Sahara.

Figura 128. Primer video de la serie basado en un paisaje antártico.

Figura 129. Segundo video de la serie basado en el desierto del Sahara.

Figura 130. Still del video en el cual se producido un recorrido sobre Nueva York.

Figura 131. Still del recorrido por la ciudad de Nueva York.

Figura 132. Fotografía de parte de la video instalación.

Figura 133. Vista de la instalación.

Figura 134. Vista de la instalación.

Figura 135. Secuencia de imágenes del accidente de Shiva.

Figura 136. Foto publicada por Jules Bahler antes de su detención.

Figura 137. Imagen del feed de Instagram con imágenes publicadas por diferentes usuarios.

Figura 138. Antoni Abad, Canal Gitano en el MACBA de Barcelona, 2014.

Figura 139. Web del proyecto Excellences \& Perfections, donde podemos ver sus diferentes partes.

Figura 140. Imagen extraída de la cuenta de Instagram del proyecto Excellences \& Perfections.

Figura 141. Su Santidad el Papa Francisco tomándose un selfie.

Figura 142. Multitud fotografiándose con su Santidad en Guayaquil, Ecuador, 2015.

Figura 143. Secuencia que muestra toda la serie de imágenes realizadas durante el proyecto.

Figura 144. Una de las imágenes realizadas durante el proyecto.

Figura 145. Última de las imágenes realizadas durante el proyecto.

Figura 146. Roger Fenton, El valle de las sombras de la muerte, 1855.

Figura 147. Páginas de la revista Vu con las dos fotografías realizadas en el mismo punto.

Figura 148. Montaje fotográfico de Brian Walski para Los Angeles Times en 2003.

Figura 149. Fotografía de Barack Obama en Lousiana publicada por The Economist. 
Figura 150. Escena del video Syrian Hero Boy.

Figura 151. Henry Peach Robinson, Fading Away, 1887.

Figura 152. Javier Bauluz, Muerte a las puertas del paraíso, 2000.

Figura 153. Refugiados cerca de la frontera con Serbia, en agosto de 2015.

Figura 154. Ellsworth Kelly, Ground Zero, exposición 11 de Septiembre en MOMA PS1, 2003.

Figura 155. Una de las salas de la exposición 11 de Septiembre en MOMA PS1, Nueva York.

Figura 156. Blog del proyecto http://subjectivelandscapes.tumblr.com/.

Figura 157. Imagen que muestra el proceso de trabajo en Photoshop.

Figura 158. Una de las imágenes de Ken Gonzales-Day para Erased Lynching, 2005.

Figura 159. Cuatro imágenes elaboradas dentro del proyecto.

Figura 160. Video del proyecto https://www.youtube.com/watch?v=Cq1Xkl5cuAQ

Figura 161. Animación gif original que sirvió de modelo para la animación del proyecto.

Figura 162. Parte de las imágenes desarrolladas durante el proyecto.

Figura 163. Parte de las imágenes desarrolladas durante el proyecto. 
